\title{
WRR
}

Huub Dijstelbloem, Paul den Hoed, Jan Willem Holtslag \& Steven Schouten (red.)

\section{Het gezicht van de publieke zaak} OPENBAAR BESTUUR ONDER OGEN 
Het gezicht van de publieke zaak 
De serie 'Verkenningen' omvat studies die in het kader van de werkzaamheden van de WRR tot stand zijn gekomen en naar zijn oordeel van zodanige kwaliteit en betekenis zijn dat publicatie gewenst is. De verantwoordelijkheid voor de inhoud en de ingenomen standpunten berust bij de auteurs.

Wetenschappelijke Raad voor het Regeringsbeleid

De WRR is gevestigd:

Lange Vijverberg 4-5

Postbus 20004

2500 EA 's-Gravenhage

Telefoon 070-35646 oo

Telefax 070-3564685

E-mailinfo@wrr.nl

Website http://www.wrr.nl 


\section{Het gezicht van de publieke zaak}

OPENBAAR BESTUUR ONDER OGEN

Huub Dijstelbloem, Paul den Hoed, Jan Willem Holtslag en Steven Schouten (red.) 
Omslagfoto: Overleg in 't Torentje 13 maart 2009, Roel Rozenburg/Den Haag Omslagontwerp: Studio Daniëls, Den Haag Vormgeving binnenwerk: Het Steen Typografie, Maarssen

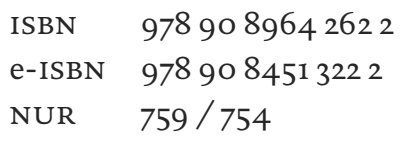

(C) WRR / Amsterdam University Press, Den Haag / Amsterdam 2010

Alle rechten voorbehouden. Niets uit deze uitgave mag worden verveelvoudigd, opgeslagen in een geautomatiseerd gegevensbestand, of openbaar gemaakt, in enige vorm of op enige wijze, hetzij elektronisch, mechanisch, door fotokopieën, opnamen of enige andere manier, zonder voorafgaande schriftelijke toestemming van de uitgever.

Voor zover het maken van kopieën uit deze uitgave is toegestaan op grond van artikel 16B Auteurswet $1912 j^{\circ}$ het Besluit van 20 juni 1974, Stb. 351, zoals gewijzigd bij het Besluit van 23 augustus 1985, Stb. 471 en artikel 17 Auteurswet 1912, dient men de daarvoor wettelijk verschuldigde vergoedingen te voldoen aan de Stichting Reprorecht (Postbus 3051, 2130 KB Hoofddorp). Voor het overnemen van gedeelte(n) uit deze uitgave in bloemlezingen, readers en andere compilatiewerken (artikel 16 Auteurswet 1912) dient men zich tot de uitgever te wenden. 


\section{INHOUDSOPGAVE}

Ten geleide

Woord van dank

1 De veranderende architectuur van het bestuur

Huub Dijstelbloem \& Jan Willem Holtslag

$\begin{array}{lll}1.1 & \text { Een constitutioneel probleem } & 15\end{array}$

$\begin{array}{ll}\text { 1.1.1 Functionalisering van bestuur } & 17\end{array}$

$\begin{array}{ll}\text { 1.1.2 Overal en nergens } & 18\end{array}$

1.1.3 Vragen voor het openbaar bestuur 21

1.2 Positie en kenmerken van het openbaar bestuur 23

1.2.1 Object, omgeving, perspectief 23

$\begin{array}{lll}\text { 1.2.2 Vier kenmerken } & 25\end{array}$

1.2.3 Bindend 28

1.2.4 Handelingsvermogend 29

1.2.5 Pluralistisch 30

1.2.6 Ter verantwoording te roepen en controleerbaar 31

1.3 Vier ontwikkelingen 33

1.3.1 Differentiatie van het bestuur 33

1.3.2 De verspreiding van het politieke $\quad 37$

$\begin{array}{ll}\text { 1.3.3 Fragmentering van het publiek } & 39\end{array}$

1.3.4 Bevraging van gezag 41

1.4 Pijnpunten in het bestuur 43

1.4.1 Coördineren of politiseren 43

1.4.2 Onzichtbare politiek, ongehoorde burgers 46

$\begin{array}{ll}\text { 1.4.3 Meerdere publieken dienen } & 48\end{array}$

1.4.4 Van legitimiteit naar (her)winnen van gezag 51

1.4.5 Bestuur uit het lood?

2 'De publieke zaak wil publiek worden behandeld': een blik op de ontwikkeling van het openbaar bestuur in Nederland sinds $\mathbf{1 8 4 8}$ Paul den Hoed $\&$ Steven Schouten

2.1 Het 'verbond' tussen staat en burgers en de 'wederzijdse doordringing' van staatsbestuur en publieke betrokkenheid, 1848-1917 57

2.1.1 De liberale scheiding van staat en maatschappij, 1848-1870 58

2.1.2 Burgerparticipatie en nieuwe politiek, 1870-1890 61

2.1.3 'Wederzijdse doordringing' van staat en maatschappij, 1890-1917 65

2.2 Moeizaam staatsbestuur en ambivalente publieke betrokkenheid,
1917-1945

2.2.1 Verzuiling, corporatisme en functionele decentralisatie, 1917-1929 71 
2.2.2 Centralisering van staatsbestuur en de zoektocht naar politieke vernieuwing, 1929-1945

2.3 Centraal staatsbestuur en de maakbaarheid van publieke betrokkenheid, 1945-1977

2.3.1 Consensus, overleg en een gecentraliseerde 'zuilenstaat', 1945-1959

2.3.2 Centraal staatsbestuur, beleid en 'burgerlijke ongehoorzaamheid', 1959-1977

2.4 Staatsbestuur en publieke betrokkenheid met een januskop, 1977-2010

2.4.1 Financieel beheer en institutionele liberalisering, 1977-2002

2.4.2 Integratievraagstuk en hernieuwd burgerschap, 2002-2010

2.5 Tot slot: enkele bevindingen

De internationalisering van beleid. Implicaties voor het openbaar bestuur

Kutsal Yesilkagit \& Sebastiaan Princen

3.1 Inleiding: bestuur en beleid over meerdere banden $\quad 105$

$\begin{array}{lll}3.2 & \text { Het spel tussen beleidsarena's } & 107\end{array}$

$\begin{array}{ll}\text { 3.2.1 Uploaden en downloaden } & 107\end{array}$

3.2.2 Uploaden en downloaden door de Nederlandse centrale overheid: enige empirische cijfers

3.3 Downloading: de EU als actor en arena 110

3.3.1 De invloed van de EU op Nederland 111

3.3.2 Van invloed naar interactie 116

3.3.3 De EU als alternatieve beleidsarena $\quad 118$

3.4 Uploading: de Nederlandse staat en de internationalisering van beleid $\quad 120$

3.4.1 De internationalisering van beleid en de fragmentatie van beleidsvorming

3.4.2 De internationalisering van beleid en de fragmentatie van de beleidsuitvoering

3.5 Transnationale overheidsnetwerken en Nederland

3.5.1 Dimensies en variëteit van transnationale overheidsnetwerken $\quad 125$

3.6 Implicaties voor het Nederlandse openbaar bestuur $\quad 130$

3.6.1 Stap 1: het stellen van prioriteiten en inventariseren van sterke/zwakke punten

3.6.2 Stap 2: een strategische keuze tussen beleidsarena's $\quad 134$

$\begin{array}{lll}3.7 & \text { Conclusie } & 139\end{array}$

4 Tussen tafel en tribune. Het handelingsvermogen van het Nederlandse openbaar bestuur in de Europese tussensfeer

Luuk van Middelaar

4.1 Inleiding

4.2 Geboorte en bestendiging van de Europese tussensfeer 144

4.2.1 Drie sferen van Europese politiek: buitensfeer, binnensfeer, tussensfeer 
4.2.2 Vervlechting van belangen: de crisis van de 'lege stoel' (1965-1966) en de dwang van de tafel

4.2.3 Druk van de buitenwereld: de val van de Berlijnse Muur (1989) en de Unie $\quad 148$

4.2.4 De Europese Raad van regeringsleiders $\quad 150$

4.3 Het Nederlandse onbehagen bij de tussensfeer $\quad 154$

4.3.1 Nederland in de Europese binnen- en buitensfeer $\quad 154$

4.3.2 Haagse huiver jegens de bestendiging van de tussensfeer $\quad 156$

4.4 Het spel aan tafel 160

4.4.1 Trek de conclusies uit het belang van de Europese Raad 161

4.4.2 Erken Europa als club van lidstaten $\quad 165$

$\begin{array}{lll}4.4 .3 & \text { Neem initiatief } & 166\end{array}$

4.5 Drie strategieën om publiek te winnen 168

4.5.1 Duitse strategie: identiteit, cultuur- en symboolpolitiek $\quad 169$

4.5.2 Romeinse strategie: klanten 173

4.5.3 Griekse strategie: de democratische arena $\quad 177$

4.5.4 Tribune \& tafel - concluderende opmerkingen $\quad 181$

$5 \quad$ Planologie extended. Naar een nieuwe toekomst van ruimtelijk $\begin{array}{ll}\text { openbaar bestuur } & 185\end{array}$

Luuk Boelens

$\begin{array}{ll}5.1 & \text { Planologie en openbaar bestuur } \\ 5.2 & 185\end{array}$

5.2 Planologie in een relationele ruimte $\quad 188$

$5.3 \quad$ Openbaar bestuur in een relationele ruimte $\quad 191$

5.4 Een delta-havenassociatie $\quad 195$

5.5 Ruimtelijk openbaar bestuur als een relationele complexiteit $\quad 199$

6 't Is maar wat je democratie noemt... 205

Will Tiemeijer

6.1 Wat we weten over de steun voor democratie? 206

6.2 Problemen met deze cijfers 211

6.3 Een gedeeld volk? $\quad 215$

6.4 Empirische gegevens 217

$\begin{array}{ll}6.4 .1 & \text { Wat is democratie? }\end{array}$

6.4.2 Meer directe democratie 219

6.4.3 Gedeeldheid 222

6.4.4 Oordeel over 'de Nederlandse democratie' 224

6.5 Beschouwing: onvrede als kennisprobleem 230

$\begin{array}{ll}\text { Bijlage } & 239\end{array}$

7 Nieuwe scheidslijnen en de turbulente relatie tussen politiek, media en burgers

Maud Adriaansen $\&$ Philip van Praag

7.1 Inleiding 
7.2 Veranderingen in de mediamarkt 243

7.2.1 De opkomst van de medialogica $\quad 245$

7.2.2 Groeiend wantrouwen tussen media en politiek 250

7.3 Nieuwe politieke scheidslijnen en de positie van de media 253

7.3.1 Veranderende burgers: zwevende kiezers en zappende kijkers 253

7.3.2 Een nieuwe politieke scheidslijn 255

7.3.3 De invloed van nieuwe scheidslijnen op de positie van de media $\quad 258$

7.3.4 De culturele dimensie en het mediagebruik van burgers 262

7.3.5 De aansluiting tussen media en burgers $\quad 264$

7.4 Gevolgen voor de intermediaire rol van de media 266

$\begin{array}{lll}7 \cdot 5 & \text { Conclusie } & 269\end{array}$

$8 \quad$ De producentenbenadering 273

Menno van der Veen, Susanne Sleenhoff \& Tanja Klop
8.1 Inleiding

8.1.1 Producenten versus consumenten 273

$\begin{array}{lll}\text { 8.1.2 Opbouw } & 274\end{array}$

$\begin{array}{lll}8.2 & \text { Consumenten } & 275\end{array}$

8.2.1 Consumentensamenleving 276

$\begin{array}{lll}8.2 .2 & \text { Sociale contracten } & 279\end{array}$

8.2.3 Wantrouwen 279

8.2.4 Consumentisme 2.0 281

8.3 Producenten $\quad 282$

8.3.1 Schets van producentensamenleving $\quad 282$

8.3.2 Het ambt burger $\quad 286$

8.3.3 Omgeving 288

8.3.4 Korte samenvatting 294

8.4 Evenementen en participatie 294

$\begin{array}{lll}\text { 8.4.1 Evenementen } & 294\end{array}$

$\begin{array}{lll}8.4 .2 & \text { Participatie } & 297\end{array}$

8.4.3 Reflectie op evenementen 300

$\begin{array}{lll}8.4 .4 & \text { Tot slot } & 302\end{array}$

9 Onvoorspelbare verantwoording. Meervoudige verantwoording en de nieuwsmedia

Thomas Schillemans

9.1 Inleiding

9.2 Voorspelbare publieke verantwoording 307

$\begin{array}{lll}\text { 9.2.1 Publieke verantwoording } & 307\end{array}$

9.2.2 Hiërarchie en voorspelbaarheid 309

9.3 Horizontaal en onvoorspelbaar bestuur 310

9.3.1 Horizontalisering beleidsuitvoering 310

9.3.2 Horizontalisering publieke verantwoording 311 
9.4 Verantwoording aan de media $\quad 314$

9.5 Verantwoording en onvoorspelbaarheid 319

9.5.1 Verantwoordingsregime: van hiërarchie naar redundantie 321

9.5.2 Verantwoordingmechanismen: van rechtmatigheid naar prestaties 323

9.5.3 Doel van verantwoording: van naleven naar verbeteren $\quad 326$

$\begin{array}{lll}9.6 & \text { Slot } & 327\end{array}$

10 Van ondergraving naar ondervraging. Over de vormgeving van gezag in een gemediatiseerde wereld

Wytske Versteeg $\mathbb{8}$ Maarten Hajer

10.1 Inleiding 333

10.2 De politiek is een drama: de dramaturgie van het politieke spel 333

10.3 Ouderwets gezag: de klassiek-modernistische orde 335

10.4 De stem(men) van het gezag: een alternatieve conceptualisering 338

10.5 Het meervoud van media? Representatie in veelvoud 341

10.6 Casus HPV-vaccinatiecampagne: tussen kernboodschap en kapperspraatje 345

10.7 De voorlichting voorbij: gezaghebbend spreken in een gemediatiseerde publieke sfeer

$\begin{array}{ll}\text { Over de auteurs } & 361\end{array}$

$\begin{array}{ll}\text { Literatuur } & 367\end{array}$ 



\section{TEN GELEIDE}

Het openbaar bestuur heeft de afgelopen jaren een steeds prominentere plaats gekregen in het politieke en wetenschappelijke debat. Was die discussie aanvankelijk nog beperkt tot kringen van bestuurskundigen, in betrekkelijk korte tijd is het een onderwerp geworden waarover door vele commentatoren wordt gepubliceerd. Uiteraard laten ook diverse adviesorganen, de WRR incluis, zich niet onbetuigd. De Raad heeft de afgelopen tien jaar al eerder aan de toekomst van het openbaar bestuur aandacht besteed. Te denken valt aan Lerende overheid (2006), Bewijzen van goede dienstverlening (2004) en Het borgen van publiek belang (2000).

Een lacune in dit debat is dat vaak wordt gesproken over het openbaar bestuur, maar dat zelden de aandacht wordt gericht op het openbare karakter van dat bestuur. Dat specifieke karakter uit zich in vier kenmerken: het is - ideaaltypisch bindend, handelingsvermogend, pluralistisch en controleerbaar. De afgelopen decennia is het accent vooral op het controlerende aspect komen te liggen. $\mathrm{Om}$ het openbare karakter van dat bestuur te waarborgen, behoeven het bindende, handelende en pluralistische aspect echter eveneens zorg. De vraag hoe dat moet, dus hoe beter zorg kan worden besteed aan het openbare karakter, verdient een centralere plaats op de bestuurlijke en wetenschappelijke agenda.

Uitgangspunt in deze Verkenning is dat het Nederlandse bestuur historisch gezien een sterke maatschappelijke oriëntatie kent. Die heeft het bestuur sterk verweven doen raken met diverse vormen van betrokkenheid van maatschappelijke groepen en organisaties. Het is die openbare oriëntatie die te weinig gehanteerd wordt als zoeklicht bij het overdenken van de toekomst van het bestuur.

Het bestuur heeft namelijk sinds de jaren tachtig en negentig van de twintigste eeuw een ander aanzien gekregen. De functies zijn in toenemende mate van de instituties ontkoppeld. Privatisering, verzelfstandiging en invoering van marktmechanismen - geïnspireerd door het zogeheten New Public Managementhebben van Nederland vooral een regulatieve staat gemaakt. Bestuur en politiek hebben binnen die regulatieve staat een nieuwe relatie ontwikkeld. De klassieke instituties zijn daarin ten gunste van de functies op de achtergrond geraakt.

Om een nieuwe invulling van de bestuurlijke verhoudingen van het openbaar bestuur kracht en vitaliteit te geven, is een hernieuwde doordenking van problemen en oplossingsrichtingen voor het huidige bestuurlijke stelsel van belang. Het zoeken is naar een nieuwe balans van de klassieke instituties van het bestuur met de huidige bestuurlijke en maatschappelijke realiteit. 
Op een viertal terreinen verdient dit in het bijzonder aandacht:

1 Institutionele differentiatie. Nederland is medevormgever van de Europese Unie. Het nieuwe Europese Unie Verdrag vergroot die betrokkenheid. Maar hoe kan het Nederlandse bestuur daaraan het beste zorg besteden, en hoe kan het bestuur eerder en adequater reageren op wat in Europa op de agenda staat, of zelf initiatief ontplooien?

2 Proliferatie van het bestuur. De functies van het bestuur zijn op afstand van de instituties komen te staan. Vooral bij het vraagstuk van de zelfstandige bestuursorganen (zBO's) en de verhouding ervan tot het parlementaire politieke stelsel is dat actueel. Hoe kan met behoud van de voordelen van verzelfstandiging het publieke karakter beter worden gewaarborgd?

3 Fragmentatie van de publieke sfeer. Burgers organiseren zich in de samenleving in wisselende samenstelling. Hoe kan het openbaar bestuur bindend blijven en toch de diversiteit in de samenleving recht doen?

4 Gezagsvorming in een gemediatiseerde wereld. De media kennen een eigen dynamiek om publieke kwesties in of buiten de schijnwerpers te zetten. De klassieke instituties van het bestuur strijden om zichtbaarheid. Hoe kan in het hedendaagse medialandschap het bestuur overtuigend naar het publiek optreden?

Gezien het belang van deze onderwerpen heeft de raad besloten bijgaande studies, die alle raken aan het openbare karakter van bestuur, in zijn serie Verkenningen uit te brengen. De Raad verwacht dat ze voeding bieden aan een geïnspireerd debat over de toekomst van het openbaar bestuur en het gezicht van de publieke zaak.

Prof.dr. J.A. Knottnerus

Voorzitter WRR 


\section{WOORD VAN DANK}

Deze verkenning is het resultaat van de interne projectgroep van de WRR 'Toekomst openbaar bestuur'. Voor de totstandkoming gaat dank uit naar de redacteuren: dr. Huub Dijstelbloem (coördinator van de projectgroep), dr. Paul den Hoed, drs. Jan Willem Holtslag (voorzitter van de projectgroep) en dr. Steven Schouten. Naast hen gaat dank uit naar drs. Maud Adriaansen, dr. Imrat Verhoeven en drs. Josje den Ridder die in een eerder stadium bij dit project waren betrokken. De laatste wordt in het bijzonder bedankt voor haar bijdragen aan de redactie en het onderzoek voor het eerste hoofdstuk. In een later stadium waren dr. Peter de Goede en ir. Martijn Vink bij het project betrokken. Zij worden zeer bedankt voor hun suggesties en hun commentaar bij de in deze verkenning opgenomen teksten.

Dank gaat uiteraard uit naar de auteurs die een geschreven bijdrage hebben geleverd aan deze verkenning. Daarnaast gaat dank uit naar allen die bereid waren via interviews of deelname aan bijeenkomsten een bijdrage aan de gedachtevorming te leveren: prof.dr. K. Aarts, prof.dr. F.R. Ankersmit, prof.dr. J.Th.J. van den Berg, prof.dr. L.F.M. Besselink, prof.dr. J.W. de Beus, prof.mr.dr. M.A.P. Bovens, mr.dr. A. van den Brink, prof.dr.ir. P.M.R.J.O. Dewilde, prof.dr. W.B.H.J. van de Donk, prof.mr.dr. W.T. Eijsbouts, prof.mr.dr. D.J. Elzinga, dr. J. G. van Erp, prof.dr. I. de Haan, mr. L. van Hasselt, prof.dr. A.C. Hemerijck, prof.dr. F. Hendriks, dr. M. van Keulen, dr. M.H. Klijnsma, prof.dr. F.L. Leeuw, dr. E. Mastenbroek, drs. B. Netelenbos, prof.dr. J.Q.Th. Rood, prof.dr. P. de Rooy, prof.dr. W.G.M. Salet, dr. J.W. Sap, prof.mr. M. Scheltema, prof.dr. M.P.C.M. van Schendelen, dr. A.J. Smullen, dr. S. van Thiel, prof.dr. J.J.A. Thomassen, prof.dr. H. te Velde, prof.mr. L.F.M. Verhey, dr. K. Verhoest, dr. G. Voerman, prof.dr. W.J.M. Voermans, prof.dr. B.F. van Waarden, prof.dr. E.A. van Zoonen, prof.mr.dr. S. Zouridis en prof.dr. A. Zuurmond. 



\title{
DE VERANDERENDE ARCHITECTUUR VAN HET BESTUUR
}

\author{
Huub Dijstelbloem en Jan Willem Holtslag
}

\subsection{EEN CONSTITUTIONEEL PROBLEEM}

In de media, het publieke debat en de wetenschappelijke literatuur staan de positie, de omvang en het takenpakket van het nationale bestuur veelvuldig ter discussie. Niet alleen de onontkoombare bezuinigingen, de onvrede over de prestaties van het bestuur en de fragiele vertrouwensband met de burger liggen aan die discussie ten grondslag, ook twijfels over de architectuur van het bestuur spelen een belangrijke rol: de functies van het gebouw, de verhouding tussen de onderdelen, de relatie met de gebruikers, de positie in de omgeving, het algehele ontwerp.

Een belangrijke reden hiervoor is dat het bestuur de afgelopen decennia heeft moeten leren leven met het lege-nestsyndroom (Van Thiel 2008). Veel van zijn oorspronkelijke taken en bevoegdheden zijn 'uitgevlogen'. De institutionele differentiatie, de europeanisering, de internationalisering en de liberaliserings- en verzelfstandigingsoperaties van de jaren negentig hebben van Nederland welhaast een regulatory state (Majone 1996) gemaakt, waarin veel oorspronkelijke taken en functies 'op afstand' zijn geplaatst. Het bestuur is daardoor niet alleen op en rond het Binnenhof, maar ook bij organen die minder duidelijke vertegenwoordigende fora kennen. De rise of the unelected (Vibert 2007) lijkt alomtegenwoordig. Het gevolg is dat het gezicht van de publieke zaak andere trekken krijgt.

Deze situatie roept vragen op over wat het nationale bestuur (nog) vermag. Wat is het handelingsvermogen van een bestuur dat veel taken heeft afgestoten? Hoe kunnen burgers zich mengen in het politieke debat? Hoe herkenbaar is het bestuur in publiek-private samenwerking? Wat is zijn rol in de horizontale relaties met burgers en maatschappelijke organisaties? Wat is zijn positie binnen de EU? Hoe verhoudt het nationale bestuur zich tot internationale en transnationale organisaties zoals de VN en de WTO? Volstaat het dat burgers zich slechts indirect via de nationale en Europese parlementen kunnen laten vertegenwoordigen? Of hebben deze parlementen feitelijk ook het nakijken? Kunnen burgers überhaupt nog wel betrokken worden bij het politieke proces? Of is de troon van de wetgever leeg geworden (Bijsterveld 2002)?

In theorie is het bestuur aan heldere nationale kaders opgehangen, bevindt het centrum zich in Den Haag, staat het 'huis' van de drie lagen van rijk, provincies en gemeentes recht overeind, is er een scheiding tussen publieke en private organisaties, een heldere toedeling van taken en verantwoordelijkheden mogelijk, bestaat 
er een 'kenbare' samenleving en zijn moderne burgers trouw aan legaal gezag. Het is echter zeer de vraag of dit klassieke beeld nog in alle opzichten met de werkelijkheid overeenstemt.

Ook binnen het bestuur zelf zijn vragen over de architectuur veelvuldig onderwerp van debat. Adviesorganen, ambtelijke werkgroepen en speciale commissies richten zich, zeker sinds de Commissie Interdepartementale Taakverdeling en Coördinatie ('commissie-Van Veen') die in 1969 door minister-president De Jong werd ingesteld, met enige regelmaat op zijn positie. De meer recente geschiedenis vanaf de jaren negentig van voorstellen door commissies en adviesorganen alsmede de rapportages vanaf die tijd die door de secretarissen-generaal zijn opgesteld, draaien telkens om dezelfde thema's en problemen: ontwikkeling van beleid voor de langere termijn; beleidsontwikkeling voor complexe problemen; ontkokering; sturing door politieke en ambtelijke leiding; de verbinding tussen beleid, uitvoering en toezicht; de bedrijfsvoering van de rijksdienst; de kwaliteit van de ambtelijke dienst; de omvang van de rijksdienst (Van Kuik 2009). In toenemende mate gaat de aandacht uit naar de vraag hoe de performance kan worden verbeterd: minder bureaucratie, meer efficiency, betere dienstverlening aan de burger, verlichting van de lastendruk, betere bedrijfsvoering, meer ontschotting en programmatisch werken, minder ambtenaren, enzovoorts.

Wat opvalt is dat de analyse-eenheid vaak niet zozeer het 'bestuur' is als wel 'de rijksdienst'. Het bestuur is echter breder dan de rijksdienst. Wie vragen stelt bij de positie van het bestuur raakt niet alleen aan de organisatie ervan, maar ook aan zijn positie binnen de constitutie, de staatsinrichting. Die constitutie betreft niet slechts de grondwet, maar de positie van het bestuur binnen de driehoek van polity, policy en politics: de politieke gemeenschap, het beleid en de politiek (Börzel en Risse 2000, 2003; Schmidt 2002; Mouffe 2005). Het is daar dat de vraag naar de architectuur in beeld komt.

Nemen we deze driehoek als heuristisch hulpmiddel om de plaats van het bestuur te duiden, dan is het constitutioneel te positioneren tussen:

1 de instituties die de politieke gemeenschap van de staat vormen;

2 het politieke (democratische) proces van machtsvorming en machtsuitoefening;

3 het beleid dat politiek vertaalt in interventies naar de markt en de samenleving.

Polity, politics en policy vormen aldus de scharnieren waaraan het bestuur is opgehangen. Hangt het bestuur daarbinnen in het lood, dan kan inderdaad de rijksdienst het juiste schaalniveau zijn om verbeteringen door te voeren. Hangt het bestuur echter uit het lood, dan is er een fundamentelere analyse nodig en moet de aard van het bestuur als zodanig opnieuw worden bezien. 


\subsubsection{FUNCTIONALISERING VAN BESTUUR}

Als er iets eigen is aan de aard van het bestuur in Nederland, dan is dat het openbare karakter. De actuele vragen naar de positie, de omvang en het takenpakket van het bestuur zijn, als het om de architectuur gaat, te herleiden tot vragen over de aard en dus tot vragen over het openbare karakter van het hedendaagse nationale bestuur.

Het openbaar bestuur is een historisch en staatsrechtelijk gegroeide 'eenheid van verscheidenheid'. De term 'openbaar bestuur' wordt vaak als synoniem voor 'de overheid' of 'de staat' gebruikt, maar duidt eigenlijk een hele bepaalde bestuursvorm aan die sterk maatschappelijk gepositioneerd is, verweven is met tal van andere partijen en zich van een 'publiek discours' bedient. Hierin onderscheidt het zich bijvoorbeeld van 'functioneel bestuur', dat minder op democratische inputlegitimiteit is gebaseerd en meer op de effectiviteit is gericht.

Het bestuur heeft de laatste decennia vooral in functionele herordeningen vorm gekregen. Het is in steeds complexere arrangementen opgenomen: Europese Unie (EU), transnationale organisaties, zelfstandige bestuursorganen (ZBO's), publiek-private samenwerking. Tegelijkertijd moet het onverminderd recht doen aan zijn openbare karakter. Zo moet het verantwoordelijkheid nemen voor tal van complexe maatschappelijke vraagstukken. De spanning tussen 'functionele herordening' en 'openbaar karakter' manoeuvreert het bestuur hiermee in een spagaat die het uiterste vergt van zijn vermogens.

Vrijwel alle Europese staten hebben sinds de vorige economische recessie in de jaren tachtig een vermageringskuur ondergaan. In Nederland leidden de stagnatie (Van Doorn en Schuyt 1978) en de kritiek op het functioneren van de verzorgingsstaat, mede als gevolg van de werkloosheid, maar vooral na de tweede oliecrisis van 1979, de noodzaak van herziening van de verzorgingsstaat in, eerst bij het aantreden van het kabinet-Van Agt in 1977, daarna in de periode van de kabinetten-Lubbers (1982-1994) en de daaropvolgende kabinetten-Kok (1994-2002).

Belangrijke delen van de verzorgingsstaat zijn op grotere afstand geplaatst. Collectieve voorzieningen en sociale beschermingsconstructies zijn afgeslankt. Daartegenover is de EU op steeds meer terreinen binnenlands beleid geworden. Mondiale problemen zoals rond voedsel, energie, klimaat en uiteraard de financiële economie, zijn geen 'ver van ons bed show', maar dringen diep door in het dagelijks bestaan, zonder dat duidelijk is wat een nationaal openbaar bestuur daarmee nog van doen heeft. Het openbaar bestuur heeft zich uit veel terreinen teruggetrokken, maar steeds meer problemen lijken paradoxaal genoeg een zaak te zijn van algemeen belang. 
Typerend voor deze periode is de toenemende ontkoppeling van de functies van traditioneel openbaar bestuur van de instituties van dat bestuur. Hoog op de politieke agenda in de jaren tachtig en negentig stonden decentralisering, deregulering, privatisering, verzelfstandiging en bevordering van marktwerking bij de uitvoering van publieke taken. Al deze ontwikkelingen hielden onderling verband met elkaar. Privatisering werd vooral ingezet in de nutssectoren, waaronder energie- en postvoorzieningen. Verzelfstandiging van de uitvoerende taken van het bestuur kreeg vooral vorm via een veelheid aan ZвO's, onder meer op het gebied van geschilbeslechting, kwaliteitsbeoordeling en toezicht. Private en semipublieke organisaties vielen niet langer ondubbelzinnig onder de ministeriële verantwoordelijkheid, maar werden zelfstandig of hadden binnen bepaalde kaders veel vrijheid om zelfstandig te opereren.

De privatisering en verzelfstandiging van uitvoerende taken werden gestimuleerd vanuit de Organisatie voor Europese Samenwerking en Ontwikkeling (OESO) die daarbij gebruikmaakte van de Angelsaksische managementfilosofie van New Public Management (NPM). De gedachte achter NPM was een scheiding aan te brengen tussen beleid en uitvoering. Door de uitvoering te delegeren aan degenen die dicht op de praktijk zitten, zou er een doelmatiger en effectiever uitvoering van publieke taken ontstaan. Bovendien zouden beleidsdiscussies weer over de doelen van die publieke taken kunnen gaan. Terwijl bestuurders beleidsdoelen formuleerden, werden maatschappelijke partijen en zво's belast met de uitvoering van publieke taken. De regulerende taken van het bestuur werden aan particulieren of semipublieke instellingen overgelaten. Hierdoor werd echter de parlementaire controle op de uitvoering van publieke taken bemoeilijkt. In de praktijk nam bovendien het aantal nieuwe regels aanzienlijk toe, en daarmee - paradoxaal - ook de regulerende taak van het bestuur. Zowel deregulering als privatisering had vervolgens ook een tegengesteld effect. Hoewel een helder onderscheid werd beoogd tussen het private en publieke domein, ontstonden meer hybride, publiek-private constructies met soms minder heldere taken en verantwoordelijkheden.

\subsubsection{OVERAL EN NERGENS}

Anno 2010 is het repertoire van stijlen waaruit het bestuur kan kiezen breed en wisselvallig. Het zijn vaak combinaties van lichte (monitoring, zelfregulering) en zware instrumenten (wettelijke sancties) en allerlei vormen ertussen in (bijv. coregulering). Burgers worden daarbij niet slechts als kiezer of 'gebruiker' benaderd, maar ook als medeverantwoordelijken met maatschappelijke burgerzin. De verhouding van bestuur en samenleving is bovendien verder gecompliceerd door de ongelijke mate van europeanisering van beleid en politiek. Door de groeiende betekenis en het gewicht van een interne Europese markt is dit verschil enkel sterker geworden. 
In het Nederlandse beleid wordt de invloed van 'Europa' op uiteenlopende manieren ingekaderd.

In de eerste plaats door toepassing van een reeks formele instrumenten. Een daarvan is de voorrang van het primaire recht in verdragen, richtlijnen (bijv. voor Interne Markt of de Dienstenrichtlijn), verordeningen en politieke kaderafspraken (bijv. het Stabiliteit en Groeipact, de Lissabon-doelstellingen, afspraken binnen de Justitie en Binnenlandse Zaken (JBZ)-ministerraad). Daarnaast vindt inkadering plaats door uitspraken van het Europese Hof, zoals op gebied van de gelijke behandeling bij pensioenen, de gemeentelijke plannen in verband met fijnstof, de ordening van de postmarkt of het aanbestedingsrecht.

In de tweede plaats zijn er tal van informele wegen waarop zich de invloed van de EU doet gelden. Zo zijn er bestuurlijke en ambtelijke werkwijzen gangbaar, zoals de zogenaamde open methode van coördinatie, die eerder op basis van overtuiging dan van (juridische) dwang 'Europa' verder vorm proberen te geven in de lidstaten. Daarnaast wordt via Europese agentschappen, die indicatoren en benchmarks ontwikkelen, de autonomie van beleid beïnvloed (Sabel en Zeitlin 2008). De europeanisering lijkt zich daarbij vooral te voltrekken op het niveau van het beleid. De integratie gaat veel minder ver in politieke zin, laat staan in het streven naar een politieke gemeenschap (Princen en Yesilkagit 2005).

De betekenis van de vraagstukken die behandeld worden in deze circuits is zeer groot. Het is daarom zaak voor een openbaar bestuur steeds te blijven zoeken naar manieren het publiek bij de politiek te betrekken, om te voorkomen dat deze niet in beleidsnetwerken uit het zicht verdwijnt. Dat op veel terreinen de afstand tussen publieke problemen en het openbaar bestuur eerder groter dan kleiner is geworden, geeft aanleiding tot zowel hele principiële als hele emotionele standpunten over de rol van het bestuur.

Vooral ook in Nederland wordt de discussie op een hoge temperatuur gevoerd. In de publieke opinie en in wetenschappelijke kring wordt het vermeende failliet van het bestuur dat geen grip meer op de samenleving zou hebben en van zijn burgers vervreemd zou zijn geraakt, breed uitgemeten. Boeken met titels als De grote kloof. Verhitte politiek in tijden van verwarring (Snels en Thijssen 2008), De vertrouwenscrisis. Over het krakend fundament van de samenleving (Knepper en Kotenray 2008), De tien plagen van de staat (Ankersmit en Klinkers 2008) en Niemand regeert. De privatisering van de Nederlandse politiek (Chavannes 2009) getuigen daarvan.

Tegelijkertijd zijn de eisen waarvoor het bestuur zich gesteld ziet misschien wel groter dan ooit. De verwachtingen ten aanzien van wat het vermag zijn immens: leefbaarheid en sociale cohesie bewerkstelligen, immigratie en integratie hanteer- 
baar maken, omgaan met klimaatverandering, duurzaamheid bevorderen, enzovoorts. Zonder te spreken van the return of the state of zelfs the revenge of the state na de kapitaalinjecties die overheden wereldwijd in de financiële sector en de economie hebben gedaan om een diepe crisis af te wenden, wijst alles erop dat de rol van het bestuur geenszins is uitgespeeld - dit in tegenstelling tot de vele aankondigingen van het einde van de (natie)staat die rond de laatste eeuwwisseling te horen waren.

Paradoxaal genoeg worden van het bestuur kolossale prestaties verwacht, maar is de architectuur van het bestuur de laatste decennia eerder op versnippering en verspreiding dan op concentratie en versterking van de bestuurskracht gericht geweest. Dat heeft ertoe geleid dat het openbaar bestuur vaak 'overal en nergens' is. Aan de ene kant is het alomtegenwoordig, omdat het zich op vrijwel alle delen van de samenleving begeeft. Zo doet het bestuur zich voelen middels wet- en regelgeving, collectieve voorzieningen, belastingheffing, orde en veiligheid, de vervulling van elementaire publieke taken, het faciliteren van maatschappelijke dienstverlening en de ordening van markten.

Aan de andere kant is het bestuur ogenschijnlijk nergens, omdat zijn rol en het effect van die rol in veel gevallen moeilijk tastbaar - laat staan: zichtbaar - is. Institutionele differentiatie heeft dit verschijnsel de laatste jaren versterkt. Om maatschappelijke problemen op te lossen zijn experts nodig, professionals in het veld en private partijen om de markt - of nieuw gecreëerde markten - in beweging te krijgen. Ook zijn burgers nodig om sociale actie te ondernemen. Het speelveld is bovendien internationaal. Wat de taak van het bestuur precies is, is voor burgers hierdoor lang niet altijd even duidelijk.

Deze onduidelijkheid over de plaats en zichtbaarheid van het hedendaagse bestuur zorgt ervoor dat dit bestuur in de samenleving vaak dubbele gevoelens oproept. Deze gevoelens worden versterkt door het intrinsiek maatschappelijke karakter van openbaar bestuur in Nederland. De vervlechting van bestuur met de samenleving heeft er niet enkel toe geleid dat dit bestuur tot diep in de 'leefwereld' van burgers is doorgedrongen, maar ook dat maatschappelijke groepen en organisaties tot diep in de 'systeemwereld' van bestuurders en de bestuurlijke realiteit zijn doorgedrongen.

Deze ontwikkeling gaat nog altijd voort. Hoewel het interventionisme in het beleid voor een belangrijk deel plaats heeft gemaakt voor een rol op afstand, zijn veel van de bestuurlijke touwen nog steeds in handen van de staat. Tegelijkertijd laat het verantwoordelijkheden aan burgers, die het bestuur echter wel degelijk verantwoordelijk blijven houden voor een veelheid aan publieke zaken. Ook al ziet men het bestuur niet altijd even duidelijk meer, men verwacht het wel te zien als er zich problemen voordoen. 


\subsubsection{VRAGEN VOOR HET OPENBAAR BESTUUR}

Waar beschouwingen over het openbaar bestuur veelal het vertrouwen van burgers, hun tevredenheid over de geleverde prestaties, de regeldruk, de efficiency en de organisatie en het takenpakket van het bestuur als startpunt nemen, zal deze Verkenning zoals gezegd zijn aanvang nemen bij een analyse van de aard van het openbare bestuur. De aandacht gaat daarbij uit naar het nationale openbaar bestuur. Om de staat daarvan te onderzoeken, worden in dit hoofdstuk, ter introductie op de bijdragen van de auteurs in de afzonderlijke hoofdstukken, zowel enkele kenmerken van het openbaar bestuur als enkele ontwikkelingen onderscheiden die dat openbare karakter in de kern raken.

De bedoeling van deze Verkenning is niet een nieuwe blauwdruk voor het bestuur op te stellen. De inzet is om na te gaan welke kenmerken van het bestuur door welke ontwikkelingen op de proef worden gesteld en te bezien of de huidige architectuur van het bestuur daartegen bestand is. Aanleiding daartoe is de veronderstelling dat er een kloof is ontstaan tussen 'beeld' en 'werkelijkheid' van het bestuur waarin de laatste vooruitloopt op de eerste. Om die veronderstelling te toetsen, worden de vragen en problemen die in de eerste paragrafen van dit hoofdstuk zijn opgeworpen, uitgewerkt tot (1) een analysekader, en tot (2) thematische beschouwingen. Resultaat daarvan is deze Verkenning. Het analysekader is opgenomen in het vervolg van dit hoofdstuk. De beschouwingen zijn opgesteld door verschillende auteurs en zijn als hoofdstukken in deze bundel opgenomen.

Allereerst wordt in dit hoofdstuk ingegaan op wat de positie van het openbaar bestuur is en wat de kenmerken ervan zijn (par. 1.2). Het 'openbare' van het bestuur is gebaseerd op een lange geschiedenis van maatschappelijke vervlechting. Dat openbare is niet alleen een feitelijke, maar ook een normatieve eigenschap. Dat komt tot uitdrukking, zo zal worden uiteengezet, in vier kenmerken. Een bestuur moet, om openbaar te zijn, bindend zijn, handelingsvermogend, pluralistisch en controleerbaar. Deze vier kenmerken worden gereconstrueerd uit zowel een historische als een conceptuele analyse van het openbaar bestuur.

Dat openbare karakter wordt echter op de proef gesteld door enkele ontwikkelingen die het bestuur doormaakt. In het bijzonder wordt ingegaan op de institutionele differentiatie, de verspreiding van het politieke, de fragmentering van het publiek en de bevraging van gezag (par. 1.3).

Met institutionele differentiatie wordt bedoeld dat de aard en de vorm van het openbaar bestuur de laatste decennia ingrijpende veranderingen hebben ondergaan. De uitbouw van de EU heeft een complete dimensie aan het bestuur toegevoegd. Internationale en transnationale gespecialiseerde organisaties als de VN en de WHO vormen een onontkoombare politieke en regulatieve orde. In eigen 
land hebben de processen van decentralisatie, deregulering, verzelfstandiging en liberalisering het aanzien van het bestuur veranderd en hele nieuwe bestuurlijke organen en toezichthoudende organen in het leven geroepen. De vraag is of en hoe deze ontwikkeling zich verhoudt tot de gebruikelijke beelden van het openbaar bestuur en de taken en bevoegdheden die daarbij horen.

Met de verspreiding van het politieke wordt bedoeld dat de afgelopen decennia de politiek niet alleen van karakter maar ook van plaats is veranderd. Dat betekent niet alleen dat er andere mechanismen van controle en verantwoording nodig zijn geworden, maar ook dat de mogelijkheden van burgers om zich te involveren met politieke en bestuurlijke fora beperkt zijn, omdat de 'nieuwe locaties van de politiek' minder goed zichtbaar zijn. Hoe kan men zich mengen in een discussie over intellectueel eigendomsrecht, standaardisering van internet of internationale richtlijnen voor het vliegverkeer? De 'normaalroute' (van burger naar parlement naar regering naar internationaal forum) lijkt hier door de ondoorzichtige samenstelling van deze organen, de geopolitieke machtsverhoudingen en de schimmige belangenverstrengelingen met de industrie nauwelijks op te gaan. Dat betekent dat onvoldoende recht dreigt te worden gedaan aan de mondigheid van burgers. Hen wordt minder stem geboden. De vraag is welke consequenties dat heeft voor het bestuur.

Met de fragmentering van het publiek wordt bedoeld dat de sociale segmentatie van de samenleving diepgaand gewijzigd is. Volstond het vroeger wellicht om burgers naar geslacht, opleiding, inkomen en religie in te delen in enkele hoofdcategorieën, tegenwoordig is het aantal deelverzamelingen van soorten burgers exponentieel toegenomen. Burgers clusteren zich rond issues, problemen en uitdagingen (Marres 2005). De publieke energie en de sociale actie die daaruit ontstaat laat zich veelal niet reduceren tot eenvoudige classificaties van de afzonderlijke individuen. De sociale orde is wispelturig met als gevolg dat de politieke orde meer volatiel wordt. De vraag is of en hoe het openbaar bestuur zich weet te verhouden tot een zo diverse samenleving met zovele mogelijke en reëel bestaande wisselende combinaties van meningen en belangen.

Met de bevraging van gezag wordt bedoeld dat het beroep op rationeel en legalistisch gezag steeds minder geschikt is om als legitimatiegrondslag van het bestuur te dienen. Van het gezag en van gezagsdragers wordt vaker geëist dat ze ook charismatisch zijn: bestuur moet inlevend zijn, emoties tonen, anders verliest het vandaag de dag het contact met het publiek. Een belangrijke rol is hierin weggelegd voor de media. Media zijn niet alleen een doorgeefluik tussen politiek en publiek, ze zoeken ook eigen niches op, verslaan gebeurtenissen op een publiekstrekkende wijze, werken met eigen formats om de wereld te duiden. Daarnaast werkt internet de zelfvoorziening van nieuwsgaring en informatieverspreiding in de hand. In een dergelijk medialandschap is het niet vanzelfsprekend dat de tradi- 
tionele rationele gezagslogica de meest geëigende manier is om verbindingen tussen publiek, politiek en bestuur te leggen of om issues geadresseerd te krijgen.

De pijnpunten die dat voor het bestuur oplevert en die de auteurs in hun bijdragen aan deze bundel zullen bespreken, worden ter afsluiting van dit hoofdstuk in een vooruitblik geïntroduceerd (par. 1.4). De vier ontwikkelingen wringen namelijk waar ze raken aan de vier kenmerken van het openbaar bestuur en aldus het openbare karakter ervan op de proef stellen. Kan het bindende karakter van het bestuur overeind blijven onder invloed van institutionele differentiatie? Hoe verhoudt het pluralistische karakter van het bestuur zich tot de fragmentering van het publiek? Blijft het handelingsvermogen van het bestuur onverminderd van kracht onder invloed van de verspreiding van het politieke? Is de controle daarop nog op eenzelfde wijze mogelijk in een tijd van continue bevraging van gezag? Meer algemeen: is de architectuur van het bestuur nog te begrijpen binnen het kader van polity, policy en politics? Met deze en andere vragen worden de bijdragen ingeluid die verder op deze thematiek ingaan.

\subsection{POSITIE EN KENMERKEN VAN HET OPENBAAR BESTUUR}

\subsubsection{OBJECT, OMGEVING, PERSPECTIEF}

Zo ongeveer ieder bestuurskundig leerboek opent met de stelling dat het openbaar bestuur als object van onderzoek niet of nauwelijks definieerbaar is, dat er vele omschrijvingen en afbakeningen in omloop zijn, en dat de keuze sterk afhankelijk is van het perspectief dat op het bestuur wordt ingenomen. Daarna volgt dan gebiedend dat dit uiteraard geen reden mag zijn om maar helemaal geen begripsomschrijving of objectafbakening te gebruiken en wordt toch een poging gedaan enige verheldering aan te brengen. Om tot een omschrijving van het bestuur te komen zijn idealiter drie zaken vereist: (1) een bepaling van het object; (2) een analyse van de relevante omgeving van het object (politiek, samenleving, rechterlijke macht); en (3) een disciplinair, multidisciplinair, interdisciplinair of zelfs transdisciplinair perspectief om de relaties tussen object en omgeving te onderzoeken.

Met alle voorbehoud dat daarbij hoort, kan er wel degelijk enige systematiek in de bepaling van het openbaar bestuur worden aangebracht. De literatuur biedt weliswaar slechts in beperkte mate sluitende antwoorden op deze vereisten, wel laat ze goed zien waarom het zo moeilijk is tot sluitende antwoorden te komen - en waarom het ontbreken daarvan niet eens altijd problematisch hoeft te zijn, bijvoorbeeld omdat onderkend wordt dat begripsmatige 'open grenzen' en 'gecontesteerde begrippen' van de bepaling deel kunnen uitmaken. Zouridis (2009) noemt de verschillende interpretaties van het openbaar bestuur niet voor niets 'concentrische cirkels', die in engere of ruimere zin een afbakening van het bestuur geven. 
Wat het object betreft, wordt de definitie van Rosenthal et al. (1996) vaak aangehaald, die het openbaar bestuur opvatten als "het geheel van organisaties en activiteiten die zijn gericht op de besturing van de maatschappij”. Deze definitie is (onder meer) terug te vinden bij Bovens et al. (2007). Er zijn echter publieke, semipublieke en ook private organisaties die zijn gericht op de besturing van de maatschappij. Laatstgenoemde auteurs onderkennen dat ook en onderscheiden daarom vier dimensies van het bestuur: de variëteit aan organisaties, de verscheidenheid aan activiteiten, de verschillende schaalniveaus en de diffuse grenzen tussen 'politiek', 'bestuur' en 'samenleving'. Breeman et al. (2008) zijn nog specifieker en dragen vijf criteria aan op grond waarvan de mate waarin een organisatie tot het openbaar bestuur behoort, beoordeeld kan worden. Zij hanteren als maatstaven de juridische grondslag (publiekrechtelijk, privaatrechtelijk), de wijze van financiering (publiek of privaat), de doelstelling, de verantwoordingswijze en de toegekende bevoegdheden. Ook deze criteria leveren geen sluitend systeem op maar wel een graduele weergave.

Die gradaties zijn van belang. In de eerste plaats omdat wat als publiek en wat als privaat geldt historisch gezien kan verschuiven en sterk afhankelijk is van het probleem waarnaar wordt gekeken (Geuss 2001). In de tweede plaats omdat de mate waarin taken als meer of minder publiek of privaat worden verondersteld, ook een krimp of groei van het bestuur met zich kan meebrengen. Het bestuur fluctueert dus met de eisen van de tijd.

Samenvattend wordt in al deze omschrijvingen het bestuur opgevat als een subsysteem van het politieke systeem, dat ten opzichte daarvan een bepaalde autonomie kent, en dat nauw gerelateerd is aan maar gescheiden van het maatschappelijke domein. Een strakke demarcatielijn van het bestuur is dus inderdaad niet te trekken en dat hoeft ook niet, maar een stippellijn is wel mogelijk.

Daarmee komen we bij de tweede vereiste, de relevante omgeving van het object. Nederland kent niet zoals Frankrijk of Engeland een sterke staatstraditie, maar heeft historisch gezien een maatschappijgericht bestuur dat niet 'van bovenaf' is opgelegd aan de samenleving, maar daarmee welhaast organisch vervlochten is geraakt.

Deze zienswijze relativeert stereotype beelden over het bestuur dat de laatste decennia van centraal veel meer decentraal georganiseerd zou zijn geraakt of dat van verticaal steeds meer horizontaal is geworden. Dat klopt wel, maar dat is geen ontwikkeling van gisteren. Hoewel er een stroomversnelling is waar te nemen vanaf eind jaren zestig, begin jaren zeventig, ligt de kiem van deze tendensen al lange tijd in de aard van het Nederlandse bestuur besloten. 
De bestudering van de relaties tussen bestuur en omgeving verlangt, de derde vereiste, een bepaald mono-, multi-, inter- of zelfs transdisciplinair perspectief. Dat hoeft niet noodzakelijk een strikt bestuurskundig of politicologisch perspectief te zijn. Geen enkele discipline heeft een monopolie op een domein, al kan dat lange tijd geclaimd worden (de economie als object van studie was tot voor kort voor de economen; nu blijken andere, sociologische, historische, antropologische perspectieven wenselijk).

Als startpunt van de analyse is er veel voor te zeggen 'het beste van meerdere werelden' te nemen. Redenerend vanuit de relaties tussen object en omgeving heeft een bestuurssociologische benadering die empirisch geïnformeerd is en het bestuur primair beschrijft vanuit de waargenomen stand van zaken, aantrekkelijke kanten. De bestuursjurist Van der Hoeven (1958) bedient zich reeds van zo'n perspectief. Het openbaar bestuur bestaat daarin uit de ambten en de instellingen die de empirische centra zijn van waaruit gezag wordt uitgeoefend. Vanuit dat ervaringsfeit komt hij tot de vaststelling dat het bestuur tegelijk structuur en gebeuren is: niet alleen de formeel juridische staatsstructuur, maar de configuratie en het functioneren van de instellingen (zoals Staten-Generaal, Raad van State, Provinciale Staten) bepalen het karakter en de betekenis van het staatsbestel. Het zijn de levende instellingen die het bestuur vormen.

Een dergelijk 'organisch' en historisch geïnformeerd perspectief stelt het vizier af op de beweeglijkheid van het bestuur. Niet alleen de instituties van het bestuur (de ambten en de instellingen) verdienen aandacht, maar vooral ook de wijze waarop openbaar besturen plaatsvindt. Dat betekent dat de aandacht niet alleen uitgaat naar de organisatorische en institutionele statica, maar ook naar de functies en de daarmee verbonden processen, de dynamica.

\subsubsection{VIER KENMERKEN}

$\mathrm{Nu}$ het openbaar bestuur als object, de omgeving ervan en het perspectief erop is verduidelijkt, rijst de vraag naar de inhoudelijke betekenis van het openbaar bestuur. Van groot belang daarbij is dat de term 'openbaar bestuur' niet zomaar een synoniem is voor 'de staat' of 'de overheid'. De opkomst van deze termen staat in een historische, chronologische lijn. In de negentiende eeuw lag het accent daarin aanvankelijk op het 'landsbestuur' en 'de staat' die het geweldsmonopolie draagt en een veilige economische en maatschappelijke orde waarborgt. Dat was het vroege liberale model van de postnapoleontische tijd met een beoogde heldere scheiding tussen het publieke en private. In de twintigste eeuw werd het gebruikelijk over de 'overheid' te spreken, die weliswaar 'boven ons staat' maar feitelijk meer gedecentraliseerd en gedifferentieerd is geraakt. Vanaf de jaren zeventig is het accent komen te liggen op een 'openbaar bestuur' dat een sterk maatschappelijke inbedding kent. 
Een dergelijk 'openbaar bestuur' is geen staatsmoloch, maar goed in staat om flexibel op veranderende omstandigheden te reageren. Processen waarin het bestuur gedifferentieerd raakt, meervoudig wordt en met andere, bijvoorbeeld private, actoren wordt aangevuld, zijn niet noodzakelijk trendbreuken door de uitbreiding van het bestuur met Fremdkörper, maar evengoed tekenen van een zich historisch uitgekristalliseerde lijn waarin het bestuur zich als een 'verzameling ambten' slim voegt naar en meebeweegt met de eisen van de tijd. In die lijn kunnen de functies van het bestuur, zoals de ordenende, de presterende, de sturende en de arbitrerende, op gevarieerde wijze organisatorisch vorm krijgen.

Kent een dergelijk maatschappelijk ingebed bestuur voordelen, nadelen zijn er ook. De scheidswand tussen bestuurlijke instellingen en private instellingen is poreus, intensieve structurele samenwerking met bedrijven, particulieren of maatschappelijke organisaties kan het bestuur raken en van aard doen veranderen. Voor buitenstaanders (maar ook bestuurders zelf) is dan niet altijd meer duidelijk waar hun ambt ophoudt en waar de taken en de verantwoordelijkheden van anderen beginnen.

Het bestuur is in Nederland nooit strikt gescheiden van 'de samenleving', maar schurkt daar dicht tegenaan. De sfeer van statelijke bestuurlijke discretie zoals door Weber (1919) beschreven, is in nauw contact gekomen met de maatschappelijke sfeer van openbaarheid en debat zoals Habermas (1996) die heeft opgetekend. De laatste kon al in de jaren zeventig van de vorige eeuw signaleren dat de strikt formele legale legitimiteit van het bestuur zijn uiterste houdbaarheidsdatum naderde toen het een openbaar bestuur werd en doordrong tot in de 'leefwereld' van burgers. Het werd van dichtbij geconfronteerd met burgerlijke ongehoorzaamheid, nieuwe vormen van activisme en maatschappelijk protest. Daarop volstaat het een bestuur zich niet langer te legitimeren door legalistische rationaliteit, maar groeit de behoefte aan communicatieve rationaliteit.

'Openbaar bestuur' typeert aldus een specifieke positie van het bestuur (niet strikt hiërarchisch maar maatschappelijk ingebed) en kent daar ook een specifieke kwalificatie aan toe (de waarde van openbaarheid). Met deze omschrijving wordt aldus een 'maatschappelijke' invulling aan het begrip 'openbaarheid' gegeven, die aansluit op de historische positie van het bestuur in Nederland, althans zijn positie vanaf het einde van de negentiende eeuw, toen het staatsgezag gaandeweg meer sociaal-maatschappelijk in plaats van politiek en staatkundig werd gelegitimeerd.

De term 'openbaar' laat zich op twee manieren begrijpen. In de eerste plaats staat openbaar voor 'collectief' en contrasteert het met 'individueel'. In de tweede plaats staat openbaar voor 'zichtbaar' en contrasteert het met 'afgeschermd' en 'besloten' (Weintraub 1997; Pesch 2008). In het eerste onderscheid staan bijvoorbeeld collectieve belangen tegenover individuele preferenties. In het tweede staan bijvoor- 
beeld de algemene bekendmakingen uit de Staatscourant (zelfs nu die niet langer op papier verschijnt) tegenover de (geheime) broncode van Microsofts Windows.

Wat zijn nu de kenmerken van een openbaar bestuur? Uit de geschiedenis van het openbaar bestuur in Nederland (die in hoofdstuk 2 van deze bundel aan de orde komt) vallen vier kenmerken af te leiden:

1 Het moet bindend zijn.

2 Het moet over handelingsvermogen beschikken.

3 Het moet pluralistisch zijn.

4 Het moet controleerbaar zijn.

Deze kenmerken, die in het vervolg zullen worden toegelicht, zijn niet alleen feitelijk van aard, maar ook normatief: ze zijn te reconstrueren uit de geschiedenis van het bestuur en vormen tegelijk de voorwaarden voor dat bestuur. Zonder aan deze voorwaarden te voldoen kan er wel sprake zijn van bestuur, het is dan alleen geen openbaar bestuur, maar eerder bijvoorbeeld functioneel bestuur.

Het is uiteraard niet de bedoeling van de betekenis van het 'openbaar bestuur' een scholastische studie te maken. Een analyse van het woord alleen kan nooit 'de kern' van dat bestuur definiëren. Wel kan een omschrijving in enkele kenmerken het bestuur van een vocabulaire voorzien dat het mogelijk maakt dat bestuur in zijn verschillende vormen te bespreken en te evalueren. Overigens vormen de kenmerken geen checklist waarmee het bestuur de maat kan worden genomen. Hoewel er uiteraard samenhang in schuilt, zijn ze ongelijksoortig en kennen ze in verschillende situaties een ongelijk relatief gewicht. Sterker nog, er zijn gevallen denkbaar waarin bepaalde eigenschappen tegenstrijdig of onderling uitsluitbaar zullen blijken te zijn. Voor die gevallen biedt het overzicht geen uitkomst. Wel is het nuttig als het erom gaat tot een wat algemener beeld te komen van wanneer een bestuur nu wel en wanneer het geen of te weinig openbaar karakter kent.

Omdat het om de verhouding van het bestuur tot de samenleving gaat, zijn bredere kenmerken dan bestuursrechtelijke, publiekrechtelijke en gewoonterechtelijke beginselen vereist om tot een adequate kwalificatie te komen. Een omschrijving van het gedachtegoed achter 'openbaar' vereist dat de gebruikte kwalificaties ook op hun historische en conceptuele betekenis worden onderzocht. In het nu volgende wordt daarom enige disciplinaire variëteit betracht, et naast de bestuurskunde de politieke wetenschappen, de politieke geschiedenis en de politieke filosofie als voornaamste bron van kennis. 


\subsubsection{BINDEND}

Een eerste belangrijk kenmerk van het openbaar bestuur is dat het bindend is. Het bestuur opereert op basis van democratisch gelegitimeerde wetgeving waaraan alle onderdanen onderworpen zijn. Die wetgeving bindt geregeerden aan elkaar en aan hun regeerders. In de rug wordt het openbaar bestuur aldus gedekt door wat Witteveen (2001) de 'fictie van het algemeen belang' noemt: het uiterst nuttige maar niet geheel met de werkelijkheid overeenstemmende idee dat er zoiets bestaat als het algemeen belang, dat tot uitdrukking kan worden gebracht via verkiezingen en overleg (representatie en deliberatie) en waarnaar kan worden gehandeld.

Een dergelijk beeld van een algemeen belang dat volk en regering bindt, lijkt inderdaad een (collectivistische) fictie. Meer in overeenstemming met de feiten is het om te spreken van een "door onderhandeling en overleg in een pluralistisch politiek spel tot stand gekomen idee van een tot op zekere hoogte gezamenlijk belang". Zeker in een land van minderheden zijn politiek en wetgeving het resultaat van concessies en compromissen tussen deelbelangen van verschillende groepen en individuen in de samenleving - van wisselende coalities dus.

De legitimatie van het bestuur mag dan door een pluralistisch proces op 'meervoudige' wijze tot stand komen, de uitwerking van het bestuur dient desalniettemin toch 'enkelvoudig' te zijn. De kracht van het algemeen bindend verklaren van wetten gaat verloren als burgers of groepen incidenteel of stelselmatig in een uitzonderingspositie worden geplaatst, of als er sprake is van willekeur of corruptie.

Daar staat tegenover dat door de binding van het bestuur iedere burger weliswaar gelijk is, maar er toch verschil in behandeling kan zijn: door de bijzondere aard van de situatie, de context, regionale verschillen, enzovoorts. Het bindende karakter van het bestuur staat niet gelijk aan de gelijke behandeling van burgers. Ook theoretisch valt dat te billijken: algemene regels bieden onvoldoende houvast om daar in verschillende situaties voor verschillende personen concrete handelingen op gelijke wijze van af te leiden (regulatieve onderbepaaldheid).

Wanneer in absolute zin wordt vast gehouden aan de wens dat het algemeen belang voorop dient te staan in het bestuur, is 'verschil' en zeker 'ongelijkheid' een problematisch gegeven. Bijvoorbeeld wanneer beleid zich inlaat met persoonlijke dienstverlening 'op maat'. Een servicegerichte staat, hoe breed gewaardeerd ook tegenwoordig, loopt in die visie het gevaar burgers als klanten te behandelen en laadt de verdenking op zich daarmee mensen 'op maat' (en dus als consument) in plaats van 'in het algemeen belang en volgens de wet' (en dus als burger) te behandelen (Ankersmit 2008). 
Dat het bestuur de afgelopen decennia sterk is gefunctionaliseerd, wil echter niet zeggen dat er een 'uitverkoop' van staatstaken heeft plaatsgevonden door de liberalisering, privatisering en verzelfstandiging daarvan vanaf de jaren negentig die dreigt uit te monden in een nieuw feodaal stelsel van een beperkt bestuur omringt met vele private uitbaters. Wel is het de vraag hoe het openbare karakter behouden kan blijven en vorm kan krijgen als het weliswaar grosso modo bindend is, maar in specifieke gevallen ook variatie toestaat, maatwerk, samenwerking, enzovoorts.

De binding van het bestuur en door het bestuur brengt in ieder geval als eis met zich mee dat beleid 'uit te leggen' moet zijn. Bestuur is moeilijk openbaar te noemen wanneer het geen 'verhaal' meer heeft te bieden over hoe nu het 'algemene' (als uitkomst van een pluralistisch politiek spel) gekoppeld is aan het 'particuliere'. Anders gezegd, het openbare karakter van het bestuur vereist dat er een verband is aan te geven tussen wat voor iedereen geldt en wat voor iemand geldt, waarom een maatregel of besluit dat op een particuliere situatie betrekking heeft, gezien moet worden in het grotere verband van het algemene bestuur.

\subsubsection{HANDELINGSVERMOGEND}

In de tweede plaats dient het openbaar bestuur over een relatief onafhankelijk handelingsvermogen te beschikken. Het bestuur moet de ruimte en de middelen bezitten om daadwerkelijk executief te kunnen zijn. Maar handelingsvermogen bezitten is niet hetzelfde als 'soeverein' zijn. De eerste vooronderstelt weliswaar de laatste maar is meer op de uitvoering gericht. De soevereiniteit van de staat is altijd een relatieve soevereiniteit, afhankelijk van onder meer de internationale politieke orde, verdragen, bevoegdheden en nationale democratische legitimiteit. Zo is ook handelingsvermogen een relatief begrip.

Handelingsvermogen betekent dat het bestuur op de terreinen waar zijn bevoegdheden liggen deze waar kan maken of waar kan laten maken. Het betekent niet dat een bestuur alles zelf moet kunnen. Het bestuur is ook niet gemandateerd om op alle terreinen te mogen ingrijpen. De mate waarin verschilt naarmate anders geoordeeld wordt over de rol van het bestuur en er andere middelen ter beschikking komen. Die rol kan op verschillende manieren vorm krijgen. Direct, door handhaving van wettelijke randvoorwaarden, uitoefening van toezicht en opleggen van sancties of in laatste instantie zelfs door de zwaardmacht aan te wenden. Of via budgettering door middelen ter beschikking te stellen. En indirect door overtuiging, overreding, een moreel appel te doen, informatie te verstrekken of door te faciliteren en te delegeren. Kortom, handelingsvermogen bestaat uit de bekende trits van de stok, de wortel en de preek. Het ontbreekt een bestuur dus aan handelingsvermogen wanneer het er niet in slaagt wetten te handhaven, budgetten volgens afspraak te verdelen of effectief uit te geven, of wanneer de communicatieve relatie met burgers, belangenorganisaties en bedrijven tekortschiet. 
Het ontbreekt het bestuur evenzeer aan handelingsvermogen wanneer het vasthoudt aan ondoelmatige bestuursparadigma's (centrale sturing, stringent law \& order beleid, te nationaal gerichte beleidsvoering) in situaties die zich daar niet toe lenen. Openbaarheid brengt ook met zich mee dat een bestuur zich bij tijd en wijle kan en wil laten verleiden om uit de sfeer van de discretie te treden en zich in te laten met maatschappelijke, bestuurlijke en politieke experimenten. En eens uit een ander bestuurlijk vat tapt om een probleem te lijf te gaan, bijvoorbeeld door te werken met alternatieve beleidsinstrumenten. Voorbeelden in de Nederlandse bestuurspraktijk lopen uiteen van het milieubeleid tot de volksgezondheid en van experimenten met inspraak en participatie op lokaal niveau over bijvoorbeeld ruimtelijke ordeningsvraagstukken tot natuurbeheer.

\subsubsection{PLURALISTISCH}

In de derde plaats moet het bestuur weliswaar voor iedereen gelijk zijn, maar ontbeert het een openbaar karakter als het burgers in een keurslijf dwingt en slechts één perspectief openlaat op waar het bestuur voor staat, welke maatschappelijke problemen er spelen of welke mogelijkheden om deze aan te pakken er voor handen zijn. Besturen in een pluralistische samenleving is geen eendimensionale bezigheid maar vereist 'meervoudigheid'. Dit aspect van 'publiek' is afgeleid van de betekenis die Arendt eraan geeft als ze de public sphere bespreekt (1958). Daarin vergelijkt ze de publieke ruimte met een tafel, die mensen bindt (we zitten er samen aan), maar ook afstand schept (we zitten naast of tegenover elkaar, niet bij elkaar op schoot). De publieke ruimte verenigt aldus verschillende mensen met verschillende inzichten en verschillende posities zonder dat het gedeelde karakter ervan verloren gaat.

Van belang is dat een 'openbaar bestuur' het respect voor deze meervoudigheid van de publieke sfeer laat doorklinken in zijn manier van afwegingen maken, burgers betrekken, partijen mobiliseren, ruimte geven, enzovoorts - een perspectief dat in Nederland en daarbuiten door onder meer Van Gunsteren is bepleit (1994; 1998).

Meer specifiek kan de betekenis van openbaarheid in de zin van de pluralistische publieke ruimte worden begrepen als het Duitse Öffentlichkeit zoals dat door Habermas (1991) wordt gebruikt om het liberale model van de publieke ruimte te kenmerken dat de laatste eeuwen in West-Europa is ontstaan. 'Openbaar bestuur' staat dan, analoog daaraan, voor een bestuursvorm die een dergelijk model van de publieke ruimte mede mogelijk maakt, voedt, beschermt, en zich daartoe verhoudt door er voor open te staan, zich responsief te tonen, er een afspiegeling van te zijn zonder hetzelfde te zijn. 
Om openbaar te zijn in deze zin moet een bestuur 'kennisintensief' te werk gaan. Besluiten dienen op feiten, of althans: op een aan onderzoek onderworpen beeld van de werkelijkheid te zijn gebaseerd. Daar ontbreekt het aan wanneer maatschappelijke problemen (illegaliteit) of infrastructurele projecten (Noord/Zuidlijn) onjuist begrepen of gepercipieerd worden omdat er onvoldoende gebruik wordt gemaakt van beschikbare kennis of nieuwe kennis niet ontwikkeld wordt om een probleem te lijf te gaan. Het bestuur onttrekt zich dan niet zozeer aan maatschappelijke waarden of belangen, maar aan kennis.

Deze lijn van denken kan worden gelezen in de pragmatische politieke theorie met als bron Dewey (1927) en hedendaagse pendanten onder meer in Cohen \& Sabel (1997) en Bohman (2004) die pleiten voor deliberatieve bestuursstructuren waarin centrale en decentrale organen aan elkaar gekoppeld worden via 'lerend' beleid dat verknoopt is met maatschappelijke informatiestromen en wetenschappelijk gegenereerde kennis (Dijstelbloem 2008).

In de kennisbehoefte van het bestuur wordt voorzien door onder meer de planbureaus en de adviesorganen, door parlementaire onderzoekscommissies, ingehuurde expertise, rapporten van speciale commissies en opdrachtverlening aan gespecialiseerde wetenschappers of adviesbureaus. Dergelijke kennisinput versterkt niet alleen de rationaliteit van beleid maar ook de transparantie ervan: door de inbreng van gecodificeerd advies is voor iedereen controleerbaar welke informatie en argumenten worden aangedragen en dus ook: wat het bestuur daarmee doet. Houdt een bestuur zich moedwillig 'doof' voor nieuwe inzichten of houdt het onwelgevallige inzichten buiten de deur, dan wordt niet alleen met de rationele onderbouwing van beleid gebroken, maar ook met het idee dat argumenten voor beleid publiekelijk ter discussie moeten kunnen staan om tot redelijke afwegingen en geïnformeerd overleg te komen.

\subsubsection{TER VERANTWOORDING TE ROEPEN EN CONTROLEERBAAR}

In de vierde plaats is bestuur niet openbaar als er geen verantwoording plaatsvindt, als het niet te controleren valt en als er onvoldoende informatie over aanwezig is.

Verantwoording afleggen is een essentieel onderdeel van een democratisch gelegitimeerd bestuur. Het democratische gehalte van een bestuur komt onder druk te staan wanneer bestuurders zich onvoldoende verantwoorden voor hun daden, bijvoorbeeld wanneer hun daadkracht is afgestaan aan andere instellingen die minder verantwoordingsmechanismen kennen. Als de macht het volk niet meer in het gezicht ziet, wordt ze anoniem en oncontroleerbaar. Het eerste forum waar verantwoording moet worden afgelegd is in de democratie het parlement. Daar bevraagt de volksvertegenwoordiging de uitvoerende macht. Bovens et al. (1995) hebben aangegeven dat naast het parlement vele andere formele fora zijn ontstaan, 
omdat 'de politiek' en 'het bestuur' verplaatst en verspreid zijn geraakt. In de tweede plaats moet dan gedacht worden aan verantwoording door bijvoorbeeld zelfstandig bestuursorganen (zBO's) via verslagen, media, aan maatschappelijke organisaties, gebruikerspanels, burgerjury's, enzovoorts.

Het bestuur verliest aan openbaarheid als er onvoldoende directe controle op kan worden uitgeoefend. Macht vereist tegenmacht en dient in de sceptische traditie van gerede twijfel aan autoriteiten met een gezagsclaim kritisch gevolgd te worden, ook buiten het parlement. Rosanvallon (2008) onderscheidt daartoe drie vormen van democratische controle buiten het parlement: door waakzaamheid, denunciatie en evaluatie.

Waakzaamheid betreft het monitoren van de macht door het volk, direct of indirect. Van origine werd deze 'controle van onderop' bestempeld als surveillance, paradoxaal genoeg tegenwoordig de term die voor 'controle van bovenaf' wordt gebruikt. Deze waakzaamheid buiten het parlement kan bijvoorbeeld in de vorm van toezicht plaatsvinden, door burgergroeperingen (watch-organisations) of door geïnstitutionaliseerd toezicht (Rekenkamer).

Denunciatie, 'verklikken' of wat positiever geformuleerd als 'aan de kaak stellen' is een vorm van controle die verbonden is aan publiciteit, via de media door journalisten maar ook door 'lekken' of 'klokkenluiders'. Hoewel om deze vorm de geur hangt van schandalen, kan denunciatie bijvoorbeeld in de vorm van onderzoeksjournalistiek, zelfs als het tot grote ophef leidt, bestaande normen en waarden opnieuw ter discussie stellen of lang getolereerde maar malafide praktijken (denk aan de bouwfraude) eindelijk aankaarten. Het mechanisme van denunciatie werkt voornamelijk via affaires die reputatieschade toebrengen en daardoor controle en verandering mogelijk maken.

Evaluatie is een meer geïnstitutionaliseerde vorm van controle die niet alleen iets aankaart, maar ook oproept tot verbeteren: fouten moeten aan het licht komen om ervan te leren.

Tenslotte is het bestuur niet openbaar als het niet voldoet aan de openbaarmaking van informatie. Die openbaarmaking als plicht van het bestuur is, in lijn met waar de commissie-Biesheuvel in 1970 voor pleitte, later uitgedrukt in de Wob (Wet openbaarheid van bestuur, vanaf 1980 in werking). In een wat bredere definitie van openbaarheid van informatie dient een openbaar bestuur duidelijk te maken wat het wil, waarom het dat wil, en hoe en wanneer het dat wil bereiken. Niet alleen om de Rekenkamer te plezieren of om 'woensdag gehaktdag', de jaarlijkse dag van de verantwoording, nog enig leven in te blazen; maar om op een heldere, controleerbare en (dat wordt niet altijd genoemd) overtuigende en bindende wijze burgers te informeren en ook te involveren in het beleid. 


\subsection{VIER ONTWIKKELINGEN}

Deze kenmerken van het bestuur markeren geen statisch, onveranderlijk openbaar bestuur, maar zijn eigenschappen waaraan het in verschillende tijden, op verschillende manieren, in verschillende vormen, kan voldoen. Het is dus niet zo dat deze eigenschappen per definitie beter passen bij een centraal of een decentraal bestuur, bij een kleine of een grote staat, of bij een bestuur met meer of minder 'lagen'; iedere vorm kan opnieuw beoordeeld worden op hoe aan deze eigenschappen invulling wordt gegeven. Het zijn dynamische kenmerken, geen statische, die geacht mogen worden mee te groeien met de tijd.

De vier kenmerken en daarmee het openbare karakter van het bestuur, hebben de afgelopen decennia moeten meebewegen met enkele ingrijpende ontwikkelingen. Deze zijn, in het kort, de volgende:

1 institutionele differentiatie;

2 verspreiding van het politieke;

3 fragmentering van het publiek;

4 bevraging van gezag.

In de eerste plaats is de ordening van het bestuur aangevuld, overgegaan en soms opgegaan in een Europese, internationale en transnationale werkelijkheid. In de tweede plaats is op nationaal niveau de klassieke structuur veranderd: verzelfstandiging, deregulering, privatisering en liberalisering hebben een ander landschap tevoorschijn getoverd met ZBO's, agentschappen, nieuwe regulatieve organen en toezichthouders. In de derde plaats zijn burgers, groepen en organisaties op een andere wijze tot het bestuur komen te staan via wisselende single-issue bewegingen en evenementgerichte campagnebureaus. In de vierde plaats is de druk op het openbaar bestuur verstevigd door kritische burgers (variërend van wantrouwig en cynisch tot assertief) en de razendsnel uitdijende mediaruimte van hypercommunicatie, beeldvorming, nieuwe maatschappelijke en politieke logica's.

Deze vier ontwikkelingen raken op cruciale onderdelen verschillende aspecten van het openbare van het bestuur (resumerend: dat het bindend en voor iedereen gelijk is, maar toch ook pluralistisch, dat het over handelingsvermogen beschikt en ter verantwoording is te roepen).

\subsubsection{DifFERENTIATIE VAN het BestuUR}

Institutionalisering en regulering hebben zich in de loop van de negentiende en twintigste eeuw ontwikkeld tot sleutelkenmerken van het openbare bestuur. Typerend is de groeiende reikwijdte van het takenpakket van het rijk en een tendens van centralisatie, al dan niet in trek-en-duwbewegingen met decentralisatie, en van een almaar voortgaande uitbreiding van het bestuur. Het gevolg is dat 
het zich op steeds meer maatschappelijke terreinen heeft begeven en zich daardoor ook voor een veelheid aan thema's verantwoordelijk is gaan houden. Tegenwoordig zijn de klassieke instituties en functies van bestuur echter losser van elkaar komen te staan. Beide blijven weliswaar essentieel voor het bestuur, maar zij vinden elkaar niet langer uitsluitend in de staat. Bestuur en beleid krijgen ook steeds meer vorm door actoren uit de maatschappij. Het bestuur beperkt zich daarbij veelal tot controle of toezicht op regulering, soms direct, soms indirect.

Deze differentiatie en de vraag naar de binding van het openbaar bestuur plaatst vraagtekens bij zijn handelingsvermogen in dit complexe bestuurlijke landschap. De 'wildgroei' aan private en semipublieke bestuurlijke instituties ligt ten grondslag aan de onoverzichtelijkheid omtrent onderlinge afstemming en coherentie van het hedendaagse bestuur en beleid in Nederland. Dat heeft geleid tot een ontkoppeling van functies van instituties. Daardoor dreigt een institutioneel gat te ontstaan. Veel adviezen die de afgelopen jaren zijn geschreven over de fragmentatie van bestuur pleiten voor 'meer en betere coördinatie' en daarmee ook voor minder 'verkokering' in het openbaar bestuur (deels een onbedoeld gevolg van de wens tot verdere specialisatie bij de staat).

Het kabinet-Balkenende IV heeft weliswaar gehoor gegeven aan dergelijke adviezen (Vernieuwing Rijksdienst), maar er zijn de laatste jaren minstens zoveel studies verschenen die laten zien, en waarschuwen, dat de bestuurlijke praktijk dit streven naar coherentie uiterst lastig maakt. Te denken valt aan gebrek aan collegialiteit en afstemming tussen de staat in Den Haag en die van gemeenten, al dan niet veroorzaakt door interbestuurlijk wantrouwen (De Ridder en Winter 2006) of door 'Haagse' arrogantie jegens 'lagere' overheden (Bekke et al. 20o9). Ook valt te denken aan de positie van de Nederlandse minister-president, die uit hoofde van zijn functie niet de macht heeft om 'integraliteit' tussen beleidsterreinen in de ministerraad af te dwingen of om deelbelangen te bundelen en verenigen (Engels et al. 2009).

Het handelingsvermogen van het 'nationale' bestuur wordt nog verder op de proef gesteld door de toenemende betekenis van de EU op en in nationale beleidsvorming. Net als in Nederland, is in de EU sprake van ontkoppeling van functies en instituties (Majone 1996). Beleid en uitvoering zijn gescheiden. Terwijl Brussel beleidslijnen uitzet, hebben EU-lidstaten, waaronder Nederland, de taak en verantwoordelijkheid om het EU-beleid naar 'binnen' te vertalen. Alhoewel Brussel daarbij tegenwoordig liever inzet op bestuurlijke methodes van 'overtuigen' dan van (juridische) 'dwang', is volgens velen onverminderd sprake van voortgaande en toenemende 'europeanisering' van het Nederlandse beleid (Princen en Yesilkagit 2005; Vos 2008). Op bepaalde beleidsterreinen, zoals landbouw en milieu, wordt het beleid in Nederland zelfs voornamelijk door 'Europa' bepaald (Vos 2008). 
Hierin verschilt Nederland overigens niet principieel van andere EU-lidstaten. Sinds enkele jaren worden in Brussel tevens pogingen gedaan om 'nationale' invloed op EU-beleid (verder) te beperken, zoals door 'europeanisering' van de kabinetten (d.w.z. samenstelling op basis van diverse nationaliteiten in plaats van die van de Commissaris alleen). Ook heeft de Commissie de laatste jaren onder leiding van haar huidige voorzitter, Barroso, gepoogd meer samenhang en coördinatie in haar beleid na te streven om 'verkokering' en departementale fragmentatie tegen te gaan, onder meer door versterking van het Secretariaat-Generaal (Schout 2009). Ook dit wekt de indruk dat 'nationale' input op Europese beleidsontwikkeling wordt ingeperkt door een 'Europeser' wordende EU.

Dit neemt echter niet weg dat de implementatie van het EU-beleid in Nederland niet zonder problemen verloopt. Voornaamste reden hiervoor is dat de implementatie van EU-beleid via Den Haag verloopt, dat voor de uitvoering van dat beleid bovenal afhankelijk is van lokale en provinciale overheden. Vaak loopt implementatie van EU-beleid daarbij stuk op gebrekkige communicatie en onvoldoende afstemming tussen de diverse overheden (en andere actoren) in Nederland, zoals recentelijk nog bleek uit een rapport over afvalverwerking in Nederland (EIPA 2009). Het openbaar bestuur in Nederland is aldus complexer geworden door interbestuurlijke vervlechting met de EU, maar loopt daardoor tevens niet zelden ook moeizaam in eigen land.

Differentiatie van het openbaar bestuur leidt niet enkel tot onduidelijkheid over bestuurlijke relaties en het handelingsvermogen van de Nederlandse staat, maar tevens tot onduidelijkheid over de plaats en betekenis van (ministeriële) verantwoordelijkheid en publieke verantwoording. Wie heeft nu precies waarover verantwoording af te leggen, en waar? Formele verantwoording is vooral verbonden met klassieke, verticale bestuurslijnen, maar die blijken in het huidige, bestuurlijke landschap niet langer dominant te zijn. In de huidige, complexe bestuurlijke realiteit neemt informele verantwoording (vaak via media) een centralere plaats in (Elzinga 1989; Bovens 2005; Schillemans 2007a, 2007b). Probleem daarbij is dat horizontale verantwoordingsstructuren vaak tot tegenstrijdige feedback kunnen leiden.

Als gevolg van de losgroei van instituties en functies van het nationale bestuur is ook minder duidelijk geworden welke instituties of organisaties met recht de vlag van 'het publieke' mogen dragen en welke niet. Het bestuur dreigt hierdoor minder herkenbaar te worden, en aan onderscheidend karakter te verliezen. Dit vestigt aandacht op de verhouding van 'openbaar' bestuur tot democratie en representativiteit. Differentiatie heeft immers geleid tot een verandering in de relatie van dat bestuur ten opzichte van 'het' publiek en de bredere politieke sfeer waarin dat traditioneel zijn representatie vond. Door meer nadruk op de output van bestuur te leggen, is tevens meer nadruk op de maatschappelijke bijdrage van het 
openbaar bestuur komen te liggen. Van burgers en bedrijven wordt verwacht dat ze hun steentje bijdragen. Zij hebben daarbij invloed gekregen op openbaar bestuur buiten het parlement om, en maken bovendien door onduidelijke besluitvorming en complexe bestuursstructuren soms ook eerder aanspraak op juridische dan politieke middelen om invloed op dat bestuur uit te oefenen (Rosanvallon 2008). Dit zet niet enkel vraagtekens bij het 'primaat van de politiek' (Witteveen 2001), maar ook bij de representativiteit van het parlement als waakhond en controlelichaam van democratisch en rechtvaardig bestuur. Als er al zoiets bestaat als een 'kloof' tussen burger en politiek, dan ligt de oorzaak daarvan wellicht deels in de toegenomen differentiatie van openbaar bestuur.

Verlies aan bestuurlijke herkenbaarheid en onduidelijkheid over verantwoordelijkheden, representativiteit en onderlinge verhoudingen in het openbaar bestuur hebben bovendien geleid tot vertekende beeldvorming over dat bestuur, met name door media die door al deze onduidelijkheden niet zelden een eigen beeld van 'het' openbaar bestuur en diens verantwoordelijkheden in de percepties van burgers tot leven brengen. Als gevolg daarvan is datzelfde bestuur nogal onzeker geworden. Deze onzekerheid neemt enkel toe door continue druk van diezelfde media om snel antwoord op een veelheid aan zaken te geven. Gezien de wens van huidige bestuurders om toch vooral responsief te zijn, en politieke eisen en verwachtingen waar te maken, wordt vaak overhaast of niet besloten met soms slepende problemen tot gevolg (de jeugdzorg). Niet zelden ontstaat hierdoor nog meer verwarring over verantwoordelijkheden in het bestuurlijke landschap in Nederland. Kenmerkend daarbij is dat media het bestuur verantwoording niet zo zeer, of per se, 'afdwingen'. Door verlies aan publiek draagvlak van het representatieve politieke stelsel neemt de behoefte almaar toe om burgers tevreden te stellen, ook als problemen soms eerder om overdenking vragen. Nadruk op afrekening (output) van bestuur gaat zo ten koste van de kwaliteit van dat bestuur, omdat problemen niet eerst grondig worden geanalyseerd. Dit is vooral het geval bij zogenaamde 'ongetemde' problemen die met grote feitelijke en normatieve onzekerheden zijn omringd en waarvan detectie en analyse nu eenmaal tijd kosten (WRR 2006).

Ook kan de behoefte aan responsiviteit aan het publiek uiteindelijk contraproductief zijn. Het verder 'openen van de ramen en deuren van openbaar bestuur', zoals Breeman en Timmermans dit mooi uitdrukken, vergroot immers de kans dat onvrede onder burgers op lange termijn toeneemt als beloftes niet (kunnen) worden nagekomen. Ook vergroot het de kans dat de samenhang tussen beleid, als ook tussen beleid en uitvoering, steeds verder afneemt (Breeman en Timmermans 2009). En het is juist die samenhang die gedifferentieerd bestuur volgens velen effectief zou kunnen maken (Bekke et al. 2009). 


\subsubsection{DE VERSPREIDING VAN HET POLITIEKE}

In het Nederlandse debat is het afgelopen decennium al veelvuldig stil gestaan bij de verspreiding van het politieke (zie Bovens et al. 1995; Duyvendak 1997; Bovens 2005) . Daar wordt in zijn algemeenheid onder verstaan dat de locaties waar politieke besluitvorming plaatsvindt niet meer alleen bestaan uit de bekende democratische fora, maar gaandeweg zijn uitgebreid met wat Majone (1996) non-majoritarian institutions noemt. Het politieke is in die zin verplaatst naar instituties zoals Zво's, transnationale overlegorganen, Europese directoraten en netwerken van overheden met bedrijven of ngo's, waarin zwaarwegende besluiten worden voorbereid, zodanig dat ze praktisch door parlementen worden overgenomen zonder grootschalig democratisch debat.

Deze ontwikkelingen worden zeer verschillend gewaardeerd, afhankelijk van het idee van 'democratie' waarmee ernaar wordt gekeken. Als democratie in een smalle betekenis wordt opgevat en zich beperkt tot de formele organen van de representatieve democratie waarop vertrouwde vormen van controle en verantwoording van toepassing zijn (government of the people), dan is de verplaatsing van de politiek, zonder een verplaatsing van belendende inspraak- en controlemechanismen, ongewenst. Wordt democratie breder opgevat als een systeem van 'input' en van 'output', van meer en minder democratische organen, van bredere checks and balances met daarbij ook meer op effectiviteit gebaseerde instituties (government for the people), dan verkleint het probleem.

Bovens (2005) wijst op de strategie om de centrale waarden achter de liberale democratie toe te passen op de nieuwe arena's van het politieke. Hij noemt daarbij vier democratische waarden die van groot belang zijn voor het openbare karakter van het bestuur. In de eerste plaats zou het beginsel van afspiegeling of representativiteit ook in de nieuwe arena's aan bod moeten komen. Alle betrokken publieken en relevante belangen zouden bij de beraadslaging moeten worden betrokken. In de tweede plaats is er het meerderheidsbeginsel, dat veronderstelt dat politieke besluitvorming terug te voeren moet zijn op de instemming van de meerderheid van de burgers. Een derde beginsel is dat van de publieke verantwoording, waarbij het gaat om de vraag of er in de nieuwe arena's verantwoording wordt afgelegd. Een vierde beginsel wordt door Bovens het transparantiebeginsel genoemd en heeft betrekking op het proces van beraadslaging. Dit proces moet helder en openbaar zijn, zodat iedereen kan zien waar en hoe de besluitvorming plaatsvindt. Dit beginsel is als het ware een voorwaarde voor representatie en publieke verantwoording. Wat Bovens in feite bepleit is dat ook in de nieuwe arena van het gedifferentieerde bestuur en de verplaatste politiek het openbare karakter van het bestuur met hernieuwd democratisch elan vorm krijgt. 
Het vormgeven aan deze centrale waarden van de democratie en het openbare karakter van het bestuur kan ook worden beoordeeld vanuit een gezichtspunt waarbij de emancipatoire consequenties van de verspreiding van het politieke centraal staan. 'Politiek', zeker democratische politiek, is traditioneel ook een manier om de emancipatie van burgers te bevorderen, in de zin dat mensen een 'stem' gegeven wordt en hun mondigheid in politieke zin tot uitdrukking komt. Klassieke politieke burgerrechten zoals de vrijheid van meningsuiting, het recht van vergadering en het recht om organisaties te vormen, zijn de uitdrukking en de waarborg van een vitale publieke sfeer. Het rood inkleuren van een hokje (nu Nederland het zonder stemcomputers moet doen) tijdens de verkiezingen is de weerslag hiervan, maar daaraan vooraf gaat een proces van afweging, meningsvorming en debat dat de mondigheid van burgers uitdrukt. Dat is niet alleen een proces van representatie maar ook van deliberatie.

Indien echter de plekken waar politiek daadwerkelijk bedreven wordt niet meer gekoppeld zijn aan de publieke deliberatie van burgers, of de democratische fora die wel toegankelijk zijn feitelijk eroderen omdat hun positie is uitgehold, dan stokt het politieke emancipatieproject. Dan dreigen de wensen van burgers niet meer gehoord te worden, omdat ze verstoken blijven van fora waarin naast hun eigen ook juist andere inzichten en meningen naar voren worden gebracht. Dat gevaar wordt versterkt door de professionalisering van de kaders van de klassieke maatschappelijke organisaties, zoals de kerken en de vakbonden. Waar deze ontwikkeling heeft bijgedragen aan de deskundigheid en de organisatiekracht, heeft ze soms minder mogelijkheden opengelaten voor burgers om zich op te werken in de maatschappelijke participatie. Het probleem is hier niet de afname van controle en verantwoording van de macht, maar het verlies aan mogelijkheden van burgers om bij pluralistische belangen- en kennisafwegingen georganiseerd betrokken te zijn. Ook dat leidt tot onmondigheid.

Die dreigende onmondigheid brengt twee risico's met zich mee. In de eerste plaats dat politieke fora steeds minder de plaatsen zijn waar het politieke debat plaatsvindt dat ertoe doet. In dat geval verliest het bestuur zichtbare plaatsen waar pluraliteit tot uitdrukking komt en tegengestelde opinies met elkaar in contact komen. In de tweede plaats dat burgers zich van de weeromstuit terugvinden in specifieke niches van bijvoorbeeld single-issue organisaties, mede mogelijk gemaakt door moderne communicatietechnologie. Daarmee staan mensen weliswaar in contact met elkaar, maar is (ten eerste) niet gezegd dat de veelheid aan meningen de verscheidenheid ten goede komt, en evenmin (ten tweede) dat de veelheid tot een collectief discours zal leiden in plaats van versnipperd te raken. 


\subsubsection{FRAGMENTERING VAN HET PUBLIEK}

Veranderingen in de politieke cultuur en de heterogeniteit in de samenleving hebben geleid tot een andere verhouding tussen openbaar bestuur en samenleving. Die verhouding kan worden geduid met de term 'fragmentering van het publiek'. Daarmee wordt bedoeld dat de manier waarop een samenleving tot het formuleren van een 'algemeen belang' komt, is veranderd door de meervoudigheid van actoren waarmee het openbaar bestuur te maken heeft (Rosanvallon 2006). 'De burger' vormt niet langer de enkelvoudige categorie waarop een bestuur gebaseerd kan worden.

Op zich zijn alle moderne complexe samenlevingen tot op zekere hoogte pluralistisch. Pluraliteit is volgens Van Gunsteren (1998) dan ook de kern van politiek: politiek houdt zich bezig met verschillen tussen met elkaar samenlevende mensen. Nederland is een verdeeld land, we kunnen de Nederlandse politiek begrijpen als een strijd tussen deelbelangen. Deze deelbelangen liepen het grootste deel van de twintigste eeuw langs de scheidslijnen van religie, wereldbeschouwing en sociale klasse (zie bijvoorbeeld Andeweg en Irwin 2009; Kriesi en Frey 2008). De collectiviteiten die op basis van deze scheidslijnen ontstonden werden in het politieke systeem geïntegreerd en gerepresenteerd in het parlement. Politieke elites brachten de deelbelangen samen en zetten ze door middel van samenwerking en compromissen om in politieke keuzes en beleid.

Als gevolg van ontzuiling en individualisering is het belang van deze klassieke scheidslijnen afgenomen. Het is de vraag of er nog zulke stabiele en homogene betekenisvolle collectieve identiteiten zijn die in het parlement of daarbuiten gerepresenteerd kunnen worden. Het algemeen belang en de samenhang tussen burgers moet tegenwoordig begrepen worden als het gedeeltelijk overlappen van achtergronden en behoeften. Anders dan in het midden van de twintigste eeuw wordt de eenheid tussen identiteiten niet meer bewaard door de grenzen van de natiestaat. Bovendien is er sprake van steeds wisselende coalities van belangen, welke identiteiten en belangen overlappen hangt af van de tijd en het onderwerp. De meervoudigheid van het publiek heeft daarom in de hedendaagse maatschappij een meer centrale en problematische rol gekregen. De maatschappelijke orde kenmerkt zich, om een eerdere term van Habermas (1985) te gebruiken, door een 'nieuwe onoverzichtelijkheid'.

Ook Hajer (2009) wijst erop dat er niet één samenhangend publiek is. Het publiek zit niet te wachten tot het wordt gehoord, maar wordt gevormd door de manier waarop het wordt betrokken of zichzelf betrekt bij het politieke proces. Zo ontstaan er verschillende publieken die rond verschillende vraagstukken actief kunnen worden. Elk publiek kan een maatschappelijk probleem anders waarnemen en beoordelen, waardoor er rond hetzelfde thema conflicterende waarnemin- 
gen en betekenissen kunnen ontstaan. De notie van verschillende publieken vereist een andere manier van denken over hoe het openbaar bestuur met burgers om zou moeten gaan en hoe zijn gezag tot stand komt. Hajer confronteert de fragmentering van publiek en bestuur met de meervoudigheid van de media. De concurrentie in het medialandschap is groot waardoor er veel aanbieders zijn, zelfs burgers dragen via internet en mobiele telefoon bij aan het maken van nieuws (Hajer 2009). De fragmentering van het publiek wordt weergegeven via deze gefragmenteerde media. Het publiek versnippert, het is niet op één plek terug te vinden, maar verspreidt zich over verschillende aanbieders en uitingsvormen en sluit zich soms ook af voor andere publieken.

De fragmentering van het publiek heeft gevolgen voor het openbaar bestuur. Het bestuur raakt zijn centrale positie kwijt, er is niet één politiek en bestuurlijk centrum. De meervoudigheid van het publiek raakt het openbaar bestuur direct (via eigen handelingen) en indirect (via de politiek). Niet alleen omdat er geen eenduidig publiek bestaat, ook omdat het publiek onder invloed van nieuwe problemen, maar ook onder invloed van nieuw beleid tot ontstaan komt. Beleid schept ook publieken: burgers bijvoorbeeld die als doelgroep of als probleemgroep worden aangemerkt.

De fragmentering heeft ook gevolgen voor de representatie via de politiek en daarmee voor de legitimiteit die via de politiek tot stand komt. De politiek zal moeten proberen de deelbelangen van burgers met elkaar te verbinden. Door individualisering is het moeilijk geworden alle mogelijke identiteiten te representeren. De politiek moet op zoek naar andere vormen van representatie (Andeweg 2003). De hoge volatiliteit bij verkiezingen maakt duidelijk dat behoeften en meningen van kiezers niet stabiel aan één partij verbonden zijn. De vermeende opkomst van een nieuwe scheidslijn rond het integratie- en migratievraagstuk sinds midden jaren negentig in de Nederlandse politiek verandert de politieke verhoudingen, omdat de deelbelangen van het electoraat op verschillende manieren kunnen worden opgesplitst (Manin 1997). Kiezers hebben een keuzeset van verschillende partijen waaruit ze bij elke verkiezing opnieuw een keuze maken. Afhankelijk van hun voorkeuren van dat moment bepalen ze welke partij uit hun keuzeset hun stem krijgt.

Het openbaar bestuur heeft echter niet alleen indirect met burgers te maken, maar heeft door de uitbreiding van de mogelijkheden tot participatie en invloed (bijv. via deliberatieve processen) steeds vaker direct met burgers van doen. Burgers zijn niet alleen afnemers van diensten, zij zijn ook betrokken bij de totstandkoming van beleid of kunnen zich verzetten tegen beleidskeuzes. Als reactie op de differentiatie van het bestuur en de meervoudigheid van het publiek zijn er nieuwe vormen van participatie en democratie ontstaan. Vraagstukken van representatie en de afweging tussen deelbelangen raken het openbaar bestuur dan ook vaker 
direct. Want: wie doen er mee, wie vertegenwoordigen zij en hoe moeten die belangen worden afgewogen? Fragmentering leidt ertoe, samen met de differentiatie van het bestuur en de verspreiding van de politiek, dat het eenduidig formuleren van problemen moeilijk is: er zijn verschillende publieken die niet per se samenvallen met territoriale eenheden (Urbinati en Warren 2008).

\subsubsection{BEVRAGING VAN GEZAG}

'Vertrouwen komt te voet en gaat te paard', zo luidt het gezegde. De worsteling die bestuurders moeten aangaan om hun gezag te herwinnen, te herstellen of te behouden getuigt daarvan. Het bestuur moet zich legitimeren, steeds opnieuw vorm en inhoud geven aan gezag dat allerminst als vanzelfsprekend wordt ervaren. Bestuur in het media- en informatietijdperk wordt in toenemende mate theater, met kritische toeschouwers die nog wel een voorstelling op toneel willen, maar geen genoegen meer nemen met de 'vierde wand' die hen van de spelers scheidt. De vraag is wat dit betekent voor het bestuur.

De discussie over gezag vindt veelal plaats onder de noemer van vragen naar 'legitimiteit'. Legitimiteit kan worden opgevat als de vrijwillige acceptatie van gezag. In sociaalwetenschappelijk onderzoek verschuift de aandacht van het statische begrip legitimiteit naar het meer dynamische legitimatie (Hurrelmann et al. 2007). Legitimatie is een proces en gaat over handelingen. De verschuiving van legitimiteit naar legitimatie gaat gepaard met een verschuiving van de invalshoek. Er wordt niet gekeken of er sprake is van legitiem gezag en in welke mate, maar hoe gezag wordt verworven en door wie.

De invloedrijke visie van Weber onderscheidt drie bronnen van gezag. De eerste is charismatisch gezag, waarbij gezag gebaseerd is op de persoonlijke kwaliteiten van de leider en de erkenning daarvan door zijn volgelingen. De tweede is traditioneel gezag waarbij de bron van het gezag in de afkomst van de gezagsdrager ligt: in troonopvolging of van God gegeven gezag. De derde is legaal gezag waarbij de bron van het gezag ligt in de formele positie die een gezagsdrager bekleedt.

In lijn hiermee is het gezag van het openbaar bestuur in de twintigste eeuw vooral begrepen in de betekenis van legaal gezag. Aangezien legitimiteit en gezag in alle machtsrelaties een rol spelen, zijn er veel verschillende soorten actoren die proberen gezag te verwerven. Het gaat hier echter niet om de relatie tussen bijvoorbeeld werknemers en werkgevers, maar over gezag in de bestuurlijke en politieke context, gezag waarin een belangrijke rol is weggelegd voor de staat. In deze context zijn gekozen en benoemde gezagsdragers de belangrijkste actoren. Wanneer het gaat om verplaatste politiek kunnen de gezagsdragers worden opgedeeld in verschillende actoren: politici, ministers, ambtenaren of directeuren van Zво's. Ook actoren van buiten het nationale openbaar bestuur proberen gezag te 
verwerven, denk bijvoorbeeld aan deskundigen of wetenschappelijke experts van planbureaus of adviesraden of van Europese en internationale instellingen.

Het object van gezag is meestal de gezagsdrager zelf. Hij probeert zijn eigen gezag te vestigen. Toch is het ook denkbaar dat hij niet alleen zijn eigen gezag probeert te vestigen, maar ook dat van de instelling waarvoor hij werkt. Zo kan een bestuurder van een Zво proberen het gezag van dat ZBO te vestigen en probeert een expert van het Rijksinstituut voor Volksgezondheid en Milieu (RIVM) te laten zien dat zijn instituut gezaghebbend is als het om bepaalde vraagstukken gaat.

Gezag wordt verworven in de ogen van een bepaald subject, publiek of forum. Gezag zullen ze vooral moeten verwerven in de ogen van anderen. Daarbij zijn te onderscheiden (a) het verwerven van gezag van verschillende actoren binnen het openbaar bestuur ten opzichte van zichzelf of elkaar en (b) het verwerven van gezag van actoren binnen het openbaar bestuur ten opzichte van burgers. Het kan gaan om een continu proces, waarbij een actor steeds moet laten zien dat hij gezaghebbend is. Er kunnen ook speciale momenten zijn waarop een actor gezag moet verwerven, bijvoorbeeld wanneer een actor zich moet verantwoorden ten opzichte van een bepaald publiek.

De belangrijkste vraag is echter hoe actoren proberen gezag te verwerven. Waarop baseren ze hun gezag? Waarom vinden bepaalde mensen de actor gezaghebbend? Het verwerven van gezag is in de huidige bestuurlijke en maatschappelijke context problematisch. Er is een ontwikkeling gaande die je zou kunnen aanduiden als de 'uitdaging' van gezag. Zo stelt Furedi (2009) dat westerse samenlevingen een problematische verhouding hebben gekregen met gezag. Gezag wordt niet meer zomaar geaccepteerd, maar wordt uitgedaagd. Hij signaleert een gebrek aan een positief gezagsverhaal en stelt dat dit verhaal wordt omzeild door het instellen van regels en procedures. Gezagsdragers binnen het openbaar bestuur proberen door het inschakelen van externe adviseurs, wetenschappers en adviesorganen hun gezag op peil te houden, maar ook het gezag van die externen wordt uitgedaagd.

Een goed voorbeeld hiervan zagen we rond de vaccinatie tegen baarmoederhalskanker. Het gezag van de minister van Volksgezondheid, de Gezondheidsraad en de directeur van het RIVM is niet vanzelfsprekend. Hun oproep aan risicogroepen om zich te laten vaccineren wordt niet zonder meer aanvaard, omdat die gebaseerd is op wetenschappelijk onderzoek of omdat de oproep afkomstig is van mensen met gezag. Burgers doen zelf 'onderzoek' op internet en vinden belangengroepen en websites net zo gezaghebbend als wetenschappelijke experts. Het openbaar bestuur heeft dus niet automatisch gezag, maar de actoren binnen het bestuur moeten hun gezag telkens weer verwerven en behouden. 


\subsection{PIJNPUNTEN IN HET BESTUUR}

Deze vier ontwikkelingen raken, ieder op een eigen manier, aan de kenmerken van het openbaar bestuur. Dat heeft een viertal pijnpunten tot gevolg:

1 coördineren of politiseren;

2 onzichtbare politiek, ongehoorde burgers;

3 meerdere publieken dienen;

4 van legitimiteit naar (her)winnen van gezag.

Deze punten zullen in het vervolg worden uitgewerkt. Daarmee wordt tevens een introductie op de bijdragen van de verschillende auteurs in deze Verkenning geboden. In plaats van de hoofdstukken stuk voor stuk te introduceren, worden ze aldus thematisch ingeleid.

\subsubsection{COÖRDINEREN OF POLITISEREN}

Het proces van differentiatie is onmiskenbaar een van de centrale thema's van deze bundel dat ook tot een eerste pijnpunt leidt: de keuze tussen coördineren of politiseren. Dat dilemma keert bij verschillende auteurs terug. Den Hoed en Schouten schetsen in hun bestuurshistorische en bestuurssociologische bijdrage de ontwikkeling van toenemende differentiatie van instituties en regulatie in het nationale openbaar bestuur vanaf 1848 . Zij laten zien dat de 'vermaatschappelijking' van bestuur in Nederland al veel langer dan een paar decennia gaande is. Die differentiatie is niet pas begonnen met de decentralisering, deregulering, privatisering, verzelfstandiging en bevordering van marktwerking van de afgelopen decennia. Anders dan vaak gedacht wordt liggen de wortels van deze ontwikkeling diep in het verleden. Wel is de maatschappelijke dimensie van het bestuur de laatste decennia in een stroomversnelling gekomen, met toenemende ontkoppeling van de functies van traditioneel openbaar bestuur van de instituties van dat bestuur. Dit gaat hand in hand met een verschuivende aandacht van verticale naar horizontale vormen van bestuur. Hiërarchie is daarmee zeker niet minder belangrijk, maar de aandacht van het bestuur ligt bovenal bij coördinatie en samenwerking in en met de samenleving, al dan niet gestimuleerd door aanwezigheid en doorwerking van traditioneel politiek en juridisch gezag.

Weliswaar heeft het publiek zich de afgelopen 150 jaar steeds meer toegang tot het bestuur verschaft, die toegang heeft niet tot gevolg gehad dat het bestuur systematisch is 'gedemocratiseerd', in de zin dat de mogelijkheden tot directe bemoeienis van burgers in alle opzichten zijn toegenomen. Het beeld is divers: op gemeentelijk niveau is er wel degelijk een groei van directe democratie te signaleren, landelijk en Europees echter veel minder. Veeleer is de mogelijkheid tot onderhandeling en overleg gegroeid, meestal op indirecte wijze via verenigingen, koepels en sectororganisaties en in het parlement via politieke partijen. 
Deze 'tweesporendemocratie' (politieke participatie via partijen in de formele democratie, maatschappelijke participatie via verenigingen enzovoorts in de informele democratie) behoeft echter voortdurend onderhoud en kan nooit in zijn bestaande vorm als een eindstation worden beschouwd. Publieke druk op politiek en bestuur is een continu proces dat zeker niet altijd tot systeemaanpassingen leidt, maar desalniettemin altijd om reactie vraagt.

Institutionele differentiatie is niet alleen een nationaal, maar vooral ook een internationaal proces. In de Europese beleidscontext laten Yesilkagit en Princen zien dat de discussie over de relatie van Nederland en de EU weinig wint met een debat in termen van 'meer of minder Brussel'. Dat is niet alleen een versimpeld, maar ook onjuist beeld van het proces van europeanisering. Als het (inter)nationale onderzoek naar europeanisering iets laat zien, dan is dat wel dat de waardering van de EU niet eenvoudigweg teruggebracht kan worden tot een nul-som (zero-sum) spel. Nederland en de EU zijn vooral complementair, en de beleidsvorming van de EU wordt niet zozeer aan Nederland opgelegd, dan wel (actief) door de laatste mede vormgegeven. Nederland en de EU staan ook niet los van elkaar, maar zijn met elkaar vergroeid, en de auteurs zijn van mening dat het openbaar bestuur in Nederland daar beter gebruik van zou kunnen maken.

Yesilkagit en Princen beschrijven de subtiele bewegingen waarmee staten internationaal en transnationaal manoeuvreren als een soort 'makelen en schakelen'. De Europese, internationale en transnationale beleidsnetwerken waarin Nederland is opgenomen, hebben het nationale openbaar bestuur echter niet 'gekaapt'. Veeleer zijn die beleidsnetwerken ook door de nationale staten zelf mede opgebouwd. Zo beschrijven Yesilkagit en Princen scherp dat hier een binnenlandse transformatie aan vooraf is gegaan, namelijk de verzelfstandiging van een grote hoeveelheid nationale en regionale publieke taken. Zoals beschreven is vanaf de jaren tachtig van de vorige eeuw menig organisatieonderdeel van de staat tot zelfstandig bestuursorgaan omgevormd. Op basis van de verkregen autonomie zijn deze zelfstandige bestuursorganen, mede vanwege de internationalisering van 'hun' beleidsterreinen, vergaande samenwerkingsverbanden met zusterinstellingen uit andere nationale staten en met inter- en (in de EU) supranationale instellingen aangegaan.

Volgens Yesilkagit en Princen is het resultaat van deze autonome processen

"een veelheid van transnationale netwerken op ieder denkbaar (internationaal) beleidsterrein. Waar ooit op nationaal niveau 'ijzeren driehoeken' of 'beleidsgemeenschappen' de vorming en uitvoering van beleid in nationaal omkaderde beleidssectoren monopoliseerden, worden belangrijke en vergaande beslissingen tegenwoordig (mede) voorbereid en uitgewerkt in internationale beleidsarena's." 
Ook Van Middelaar laat zien dat Nederland en de EU complementair zijn en dat Nederland via de Raad van Ministers actief vorm heeft gegeven en vormgeeft aan het beleid van de EU. Van Middelaar laat dat zien aan de hand van drie verschillende vertogen over de Europese eenwording, over het Europa van de staten, dat van de burgers en dat van de kantoren. Vanaf het allereerste begin hebben deze drie vertogen het streven naar gezamenlijkheid en institutionalisering in de Unie begeleid, zowel formeel politiek (in de verdragen en de bevoegdheden) als meer symbolisch (in het zoeken naar een Europese identiteit). Maar tegelijkertijd ontstond er juist door die drie vertogen discussie tussen lidstaten omtrent de invulling van instituties en functies van het project Europa, zodat beide in een 'tussensfeer' geleidelijk ook betekenis, vorm en invulling hebben gekregen. Van Middelaar kijkt daarbij naar de wijze waarop Nederland daarmee in het verleden om is gesprongen als ook naar de wijze waarop het daar tegenwoordig gebruik van zou kunnen maken om zijn vermogen te vergroten in het 'spel' aan de 'Europese handelingstafels', enerzijds, en in de verantwoording ten overstaan van het Nederlandse publiek op de tribune, anderzijds.

Anders dan Yesilkagit en Princen is Van Middelaar van mening dat het bestuur in de EU een ontwikkeling richting verticaliteit doormaakt, 'tegen de maatschappelijke trends in'. Dit verklaart ook waarom Nederland zou moeten inzetten op 'sterkere politieke regie top-down'. Dat vereist volgens hem echter wel een omslag van de bestuurlijke realiteit in Nederland, want de laatste heeft weliswaar 'een zeer goede ambtelijke coördinatie, maar die werkt bottom-up: vanuit het individuele dossier naar boven'. Van Middelaar is van mening dat Nederland meer dient in te zetten op een versterking van zijn positie in de Europese Raad: de machtspositie van de Raad neemt nog altijd in gewicht toe. Nederland heeft deze volgens hem ten langen leste onderkend.

Het probleem van de publieke representativiteit van nationaal bestuur komt terug in alle drie de hoofdstukken van Den Hoed en Schouten, Van Middelaar en Yesilkagit en Princen. Den Hoed en Schouten wijzen erop dat het publiek zich geleidelijk een sterkere plaats heeft weten te 'veroveren' in het nationale bestuur, en met name sinds de jaren zestig en zeventig, maar daarbij dient wel de kanttekening te worden gemaakt dat die plaats sinds de jaren tachtig tegelijkertijd ondoorzichtiger is geworden door nadruk op horizontalisering en output-legitimiteit.

Van Middelaar stelt dat de 'tribune', en daarmee de noodzaak tot publieke verantwoording van bestuur, belangrijker is geworden sinds 'Europa' als issue 'politieker' is geworden. In zijn bijdrage ligt de nadruk op performance van nationaal bestuur als middel om 'het' publiek op de 'tribune' te winnen, en tevens vast te houden. Hij bepleit de noodzaak van open communicatie om bewustzijn te creëren bij de bevolking over de interbestuurlijke vervlechting van Nederland en de EU. 
Van Middelaar ziet drie strategieën om burgers bij de EU te betrekken en te zorgen dat Europese besluiten 'onze' besluiten worden. De Duitse strategie zet in op de culturele en historische identiteit van gezagsdragers en geregeerden. De Romeinse strategie is gebaseerd op het voordeel dat de bevolking ontleent aan het functioneren van de democratie, het gaat om rechten en resultaten. De Griekse strategie berust op een democratische arena waarbij de bevolking via representatieve organen of direct meepraat over genomen beslissingen. Deze driedeling houdt verband met drie bronnen van legitimiteit, namelijk die van identiteit, output en democratische input (zie ook WRR 2006).

Voortbouwend op een wereld van interbestuurlijke vervlechting van 'beleidsarena's' in Nederland en de EU, benadrukken Yesilkagit en Princen in lijn met de eerder gememoreerde voorstellen van Bovens niet enkel het belang van onafhankelijkheid in het handelingsvermogen van Nederland, maar ook dat van de representativiteit daarvan. De auteurs verstaan onder dat laatste de mate waarin die 'arena's openstaan voor de inbreng van verschillende belangen'. Net als bij Van Middelaar, staat 'publiek' bij deze auteurs voor 'openbaarheid'; 'het' publiek zelf blijft daarmee echter vooral een verschijnsel zonder werkelijke vorm of gezicht.

\subsubsection{ONZICHTBARE POLITIEK, ONGEHOORDE BURGERS}

Nauw verbonden met de thematiek van de differentiatie is de verspreiding van het politieke en de betrokkenheid van burgers bij het politieke en bestuurlijke proces. Dat leidt tot het tweede pijnpunt: het gevaar van onzichtbare politiek en ongehoorde burgers.

Van Middelaar beschrijft de discussies over democratische input versus effectiviteit (output) in de context van de EU met behulp van de metafoor van de tafel en de tribune. De tafel staat voor het politieke spel dat in de sfeer van de discretie wordt gespeeld. De tribune voor het spel dat in openheid plaatsvindt. Op de tribune zetelt immers het publiek. Democratie is bij het spel aan tafel wegbezuinigd ten faveure van diplomatieke en politieke effectiviteit. Bij het spel voor de tribune daarentegen wordt het politieke bedrijf blootgesteld aan de goedkeuring of afkeuring van het publiek. Ontbreekt dat laatste en lukt het niet om duidelijk te maken dat de verhouding tussen bijvoorbeeld Nederland en Europa geen zero-sum game is maar dat die verhouding zelf een politiek moving target is, dan is verlies aan vertrouwen - en daardoor verlies aan legitimiteit - de prijs.

Een domein waar de bindende kracht van het bestuur verregaand wordt getest is de ruimtelijke ordening. Great Planning Disasters en een afwijzing van het na de Tweede Wereldoorlog zo succesvolle rationele en technocratisch planningsmodel hebben tot tal van nieuwe rollen van het bestuur geleid, waarvan de publiek- 
private samenwerking (met in de praktijk vaak een grotere 'p' voor de laatste dan voor de eerste) de voornaamste is.

In zijn bijdrage laat Boelens zien dat de zoektocht naar het 'publiek' in de ruimtelijke ordening nog een voortgaande queeste is. De ruimtelijke ordening is bij uitstek het domein van het 'maken'. Er ligt niet een samenleving vast waarover door verschillende belangengroepen wordt gesteggeld, de wereld is in constructie. Dat geldt niet alleen voor de materiële werkelijkheid (de gebouwen, de wegen, de stenen, het asfalt), maar ook voor de sociale en politieke werkelijkheid. Partijen die op een juiste wijze het juiste belang vertegenwoordigen in grote infrastructurele projecten moeten worden gezocht (en desnoods gemaakt) met behulp van stichtingen, bv's, maar ook door middel van contractuele beleidsfiguren zoals het afspreken van inspanningen, al dan niet begeleid door subsidies. Terecht merkt Boelens op dat de ruimte zich tot de ordening verhoudt als de openbaarheid tot het bestuur: het is niet iets wat vastligt maar iets wat gecreëerd en gereproduceerd moet worden. De jongste loot aan de stam bestaat uit de toenadering tussen de 'associatieve democratie' enerzijds en de 'actor-netwerken' binnen de ruimtelijke ordening anderzijds. Of deze toenadering zich praktisch even goed als theoretisch laat uitwerken kan alleen de ervaring uit gaan wijzen.

Schillemans besteedt expliciet aandacht aan het thema van publieke verantwoording in het openbaar bestuur. Uitgaande van een overwegende horizontale bestuursrealiteit laat hij zien dat differentiatie van het openbaar bestuur heeft geleid tot toename van informele publieke verantwoording. Hij legt daarbij een verband met onvoorspelbaarheid, dat in horizontale verantwoordingssituaties is toegenomen. Ook wijst hij erop dat differentiatie heeft geleid tot meerdere, overlappende verantwoordingsfora, met als gevolg meervoudige, dikwijls tegenstrijdige verantwoording. Horizontalisering van het bestuur heeft volgens de auteur het stelsel van publieke verantwoording door concurrentie en gebrek aan redundantie ondermijnd. Onzekerheid over potentiële verantwoording in de media kan negatief uitpakken, maar heeft volgens hem ook voordelen omdat het bestuurders dwingt tot bredere overdenking en afweging van keuzen.

Toch mogen hier geen al te hooggespannen verwachtingen aan worden verbonden. Burgers verschillen zoals mensen verschillen, en dat heeft gevolgen voor de bindende werking van bestuur. Temeer daar het verre van zeker is dat de beelden over het bestuur in de samenleving wel allemaal hetzelfde zijn. Eerder is het tegendeel het geval. Tiemeijer wijst er in zijn bijdrage op dat het een illusie is om te denken dat het beeld van een onderhandelend bestuur ook daadwerkelijk beklijft 'in de hoofden' van de burgers. Hij betwijfelt of alle burgers onder 'democratie' precies hetzelfde verstaan. 
Aan de hand van een kritische doorlichting van opinieonderzoek naar de waardering van de 'democratie' door burgers betoogt hij dat mensen hele andere beelden hanteren bij dat begrip dan de vragenstellers vaak in gedachten hebben. Een belangrijke groep burgers denkt bij democratie eerder aan vrijheid en een vorm van directe agendering van de kwesties die hun zorgen baren dan aan het onderhandelingsspel van geven en nemen dat nu eenmaal eigen is aan een coalitieland. Dat heeft als belangrijke consequentie dat het politieke spel tussen partijen om onderwerpen door de Kamer te krijgen dreigt te worden misverstaan. Onderhandeling, ja: het hele politieke spel, wordt dan als een onwenselijke in plaats van als een noodzakelijke praktijk gepercipieerd. Burgers die verwachten dat met hun stem ook hun mening direct in passende maatregelen zal worden omgezet, worden onvermijdelijk teleurgesteld.

Met die 'cognitieve dissonantie' tussen bestuur en burger hoeft echter geen genoegen te worden genomen. Indien bepaalde groepen burgers een zekere 'democratische ongeletterdheid' kennen, kan dat net als andere vormen van ongeletterdheid te lijf worden gegaan via scholing, in het onderwijs of in de media. Maar wellicht kan ook het openbaar bestuur zelf een voorbeeldfunctie vervullen.

\subsubsection{MEERDERE PUBLIEKEN DIENEN}

De binding van het bestuur met het publiek luidt een derde pijnpunt in: de relatie tot het gefragmenteerde publiek. Van der Veen, Sleenhoff en Klop sluiten aan bij de behoefte van het openbaar bestuur om greep te krijgen op het meervoudige publiek. In hun bijdrage vragen zij zich af hoe het bestuur het publiek in beeld kan krijgen en wat het kan doen om bij burgers een gedragsverandering teweeg te brengen.

Wanneer het bestuur probeert greep te krijgen op burgers doet het dit vaak door te zoeken naar homogene groepen met dezelfde belangen en identiteiten. Dit kan door te werken met groepsindelingen van burgers (zie rapport Toekomst Overheidscommunicatie) en door te denken in 'burgerrollen'. Het is echter de vraag of de 'zoektocht naar de burger' die vanuit het bestuur is ingeslagen via opiniepeilingen, focusgroepen, indelingen in burgercategorieën, doelgroepenbeleid, participatie, enzovoorts daarvoor de oplossing is. Statistieken hunnen wel degelijk helpen het sociale en economische beleid in te richten, als middel om burgers democratisch te bedienen loopt het tegen zijn eigen grenzen aan. 'De burger' bestaat namelijk helemaal niet. Niet alleen omdat er te veel soorten burgers zijn (dat is genoegzaam bekend), maar omdat de burger pas vorm krijgt in relatie tot het openbaar bestuur.

Sinds de jaren negentig is het beeld van de burger als 'consument' in opkomst, omdat dit de gemene deler is waarop het grootste deel van de burgers aan te spreken is. Het is, zo stellen Van der Veen et al., eigenlijk de enige overgebleven collec- 
tiviteit. Van der Veen et al. laten zien dat het denken in termen van de burger als consument niet productief is: het vergroot het wantrouwen van burgers in het bestuur en past niet goed in de cultuur van Nederland. Zij betogen dat het bestuur de burger juist zou moeten zien als een producent die actief verantwoordelijkheid draagt voor zijn eigen keuzes en invloed heeft op zijn eigen omgeving.

Wanneer het bestuur er echter steeds minder in slaagt burgers aan de publieke zaak te binden, kan het een optie zijn initiatieven te ontplooien die burgers meer aan elkaar binden. Dat wil natuurlijk niet zeggen dat het bestuur een terugkeer naar de zuilenmaatschappij van weleer moet aanmoedigen, of dat het bestuur verantwoordelijk wordt voor de sociale cohesie van en tussen groepen in de samenleving. Wel betekent het dat burgers meer vanuit hun eigen belevingswereld door het bestuur bereikt moeten worden. Beleid dat gedragsveranderingen wil afdwingen, zal pas succesvol zijn wanneer het mensen aanspreekt op wat binnen hun omgeving waardevol is.

Adriaansen en Van Praag brengen in hun bijdrage de turbulente relatie tussen politiek, media en burgers in beeld, en verbinden deze met de nieuwe scheidslijnen in de Nederlandse politiek. De multiculturalisering en mondialisering leiden in de context van een gepluraliseerd publiek tot een herschikking van uitgangsposities en zorgen voor nieuwe coalities en andere deelbelangen in de samenleving (zie Rosanvallon 2006). Een aantal auteurs (o.a. Pellikaan et al. 2007; Pellikaan et al. 2003; zie ook Aarts en Thomassen 2008) wijst er in het verlengde daarvan op dat er een nieuwe breuklijn of scheidslijn is ontstaan in Nederland die samenhangt met thema's over de integratie van allochtonen en Europese integratie.

Adriaansen en Van Praag bekijken de gevolgen van deze scheidslijn voor de relatie tussen politiek en media. Ze laten zien dat media en politiek concurrerende logica's volgen en vragen zich af in hoeverre media en politiek erin slagen burgers te representeren op de nieuwe culturele scheidslijn. Niet alle politieke partijen passen zich snel aan deze scheidslijn aan. Media zijn wellicht door de ontwikkelingen van de afgelopen decennia beter in staat deze nieuwe scheidslijn te agenderen. Tegelijkertijd is het ook voor de media moeilijk om het gedifferentieerde publiek te vatten in een tijd van hevige concurrentie op de mediamarkt. Daarbij bestaat het gevaar dat het segment van de bevolking dat zich juist voelt aangesproken door issues die samenhangen met de nieuwe scheidslijn nauwelijks nog naar nieuwsprogramma's kijkt. Dat is problematisch vanuit het perspectief dat enige kennis over hoe politieke partijen en kandidaten denken over maatschappelijke vraagstukken nodig is om een geïnformeerde stem te kunnen uitbrengen bij verkiezingen.

Adriaansen en Van Praag maken duidelijk dat de marktlogica die onvermijdelijk door de media wordt gevolgd, de creatie van specifieke niches tot gevolg heeft. 
Daarin signaleren ze een gevaar: collectieve nieuwsvoorziening wordt ingeruild voor 'nieuws op maat'. Zoals er verschillende politieke partijen bestaan, ontstaan er ook verschillende nieuwspartijen. Het grote verschil is dat er voor de laatste geen parlement bestaat waarin ze allemaal nog samenkomen.

Politieke partijen en derhalve ook parlementariërs kunnen zowel om praktische als principiële redenen in hun agendering nooit een zelfde doorloopsnelheid halen. Praktisch omdat de mediaruimte vele malen sneller en groter is dan de politieke ruimte: radio, televisie en internet en de diverse technologische media die daaraan gekoppeld zijn hebben een schier onoverzichtelijk landschap geschapen. Principieel omdat partijen altijd maar een beperkte en daardoor ook vaak trage manoeuvreerruimte hebben binnen hun eigen ideologische kaders. Het zijn geen marktpartijen op zoek naar consumenten, maar leden- en kiezerspartijen met een eigen programma op zoek naar de achterban. Media en politiek volgen zo bezien niet alleen twee verschillende logica's; ze bewegen zich ook met verschillende snelheden.

De fragmentering van het publiek heeft zodoende invloed op het openbare karakter van het bestuur. Veel kenmerken van het publieke karakter (denk aan het pluralisme, de verantwoordingsmogelijkheden en de controleerbaarheid) zijn gebaseerd op het verbinden van verschillende publieke belangen. Het idee van bestuur dat collectief bindende wetgeving uitvaardigt op basis van het idee van één algemeen belang is steeds meer een fictie zoals we hebben gezien. Verschillende auteurs wijzen erop dat dé burger niet bestaat (zie bijv. Van den Brink 2002). Het duurzaam verbinden van het publiek, haar identiteiten en belangen is zowel voor de politiek als voor het bestuur een moeilijke opgave geworden. Het dilemma tussen bindende besluiten die voor iedereen hetzelfde gelden en dienstverlening op maat speelt in een gepluraliseerde context een nadrukkelijke rol. Van der Veen et al. spreken zich niet uit tegen maatwerk, maar waarschuwen wel voor de gevolgen van het benaderen van de burger als consument.

Het wordt voor het openbaar bestuur moeilijk zijn handelingsvermogen vorm te geven, juist door het toegenomen pluralistische karakter van het openbaar bestuur. Door de fragmentering van het publiek is het voor zowel politiek als bestuur moeilijker geworden om alle belangen en perspectieven te verenigen. Dat komt ook doordat bestuur en politiek als hoeder van het algemeen belang niet onomstreden zijn. Een deel van de burgers is cynisch over politiek en denkt dat politici vooral uit zijn op eigen belang in plaats van het algemeen belang te dienen. De methodes van de politiek en het openbaar bestuur om met pluraliteit om te gaan, kunnen niet altijd op steun van burgers rekenen. Het openbaar bestuur bevindt zich in een permanente zoektocht naar belangen van burgers en de manier om daarmee om te gaan. Manieren om het handelingsvermogen te versterken worden meestal gezocht in het vroegtijdig verwerven van steun door burgers bij het tot stand komen van beleid. Er is al vaak op gewezen dat die participatie wel 
betekenisvol moet zijn: het gaat niet alleen om meepraten, maar er moet ook daadwerkelijk invloed uit te oefenen zijn (zie bijv. Ulbig 2008; Verhoeven 2009).

\subsubsection{VAN LEGITIMITEIT NAAR (HER)WINNEN VAN GEZAG}

De totstandkoming van gezag is een vierde terugkerend thema dat het laatste pijnpunt markeert. Zowel Versteeg en Hajer als Schillemans laten in hun bijdragen zien dat de manier waarop gezag tot stand komt is veranderd. In hun bijdragen staan twee ontwikkelingen centraal, te weten de centrale rol van de media en de onvoorspelbaarheid waarmee het openbaar bestuur te maken heeft.

Schillemans richt zich op een specifieke manier om gezag en legitimiteit te verwerven, namelijk publieke verantwoording. Publieke verantwoording is een communicatierelatie waarbij een actor verplicht is of zich zo voelt om een andere persoon of instantie inzicht te geven in zijn handelen en indien nodig de handelingen te rechtvaardigen. Door de horizontalisering van verantwoording en het toegenomen belang van de media is de onvoorspelbaarheid van publieke verantwoording gegroeid. Die onvoorspelbaarheid kan leiden tot problemen met de kwaliteit van het bestuur. Schillemans gaat na hoe het bestuur om kan gaan met deze onvoorspelbare verantwoording. Zijn conclusie is dat het bestuur (zowel centraal als decentraal) onzekerheid en complexiteit moet accepteren en moet zoeken naar manieren om de aandacht binnen verantwoordingsprocessen te leggen op de kwaliteit van het bestuur en een proces van permanente en gestage verbetering.

Versteeg en Hajer bespreken de totstandkoming van gezag in een gemediatiseerde wereld. De klassiek modernistische opvatting van gezag (waarbij de nadruk ligt op formele gezagsposities en passieve acceptatie) is, zo stellen Versteeg en Hajer, beduidend minder effectief in de nieuwe complexe werkgebieden van het openbaar bestuur en laat bovendien onvoldoende zien hoe gezag in het huidige openbaar bestuur tot stand komt. Versteeg en Hajer stellen dat gezag niet alleen moet worden opgevat als een te bekleden positie, maar ook als een al dan niet aanwezige kwaliteit van communicatie. Versteeg en Hajer vullen de klassieke modernistische opvatting over gezag aan met discursief en dramaturgisch gezag. Discursief gezag is gebaseerd op te ondervragen betekenisgeving. Het houdt in dat het bestuur zichzelf op verschillende podia moet laten zien en dat het proces van betekenisgeving steeds doorloopt. Dramaturgisch gezag is gebaseerd op vormgeving, waarbij de persoon van de gezagsdrager centraal staat en hij gezag moet verwerven in gevestigde rituelen of onvoorspelbare situaties. Het openbaar bestuur is misschien wel in formeel opzicht gezaghebbend, maar mist discursief en dramaturgisch gezag. Dit wordt zichtbaar door een aantal veranderingen in het mediapolitieke landschap die de voorwaarden waaronder gezag tot stand komt, hebben veranderd en bemoeilijkt. 
Zij laten dit zien aan de hand van een casus over de vaccinatiecampagne tegen het humaan papilloma virus (HPV, ook bekend als de vaccinatie tegen baarmoederhalskanker). Zij gaan daarbij vooral in op het beeld dat is ontstaan via de media. Als reactie op het heftige verzet tegen de vaccinatie reageert het RIVM op een klassiek modernistische manier waarbij het zich beroept op de kennis van de wetenschap en het gezag van instituties. Versteeg en Hajer concluderen dat een combinatie van verschillende gezagsgenres nodig is om gezaghebbend te spreken in een gemediatiseerde wereld. Dat het RIVM die les ook heeft getrokken, mag blijken uit de nieuwe website over HPV-inenting www.prikkenbescherm.nl die niet alleen informatie biedt maar communicatief ook zeer dicht op de huid van de doelgroep zit.

Gezagsdragers moeten logos (argumentatie), ethos (hun waarden, normen en deugden) en pathos (emotie) met elkaar verbinden om in elke context opnieuw hun gezag te vestigen. Een beroep op rationeel en legalistisch gezag is niet meer voldoende. Zij stellen dat

"het openbaar bestuur niet langer [beschikt] over de vanzelfsprekende formele autoriteit die in staat was om burgers een verhaal op te leggen. In plaats daarvan zal het moeten streven naar contextuele geloofwaardigheid; iedere politieke uitspraak of handeling moet passen binnen het script en de logica van het gegeven podium, door het doelpubliek gericht aan te spreken en zonder daarbij een ander publiek geweld aan te doen."

Een vorm van overtuigend en inlevend charisma zal nodig zijn om de voordelen en nadelen van bepaalde ingrepen (zoals vaccinaties) vanuit de leefwereld inzichtelijk te maken. Vooropgesteld natuurlijk dat de informatie waarop het bestuur zich baseert wel valide is en dat over de onzekerheid waarmee die eventueel is omgeven, helder wordt gecommuniceerd.

De bijdragen van Schillemans, en Versteeg en Hajer benadrukken het communicatieve aspect van het tot stand komen van gezag. De auteurs laten zien dat er veranderingen zijn opgetreden in de manieren waarop gezag tot stand komt. Door de sterke rol van de media is het subject of forum van gezag veranderd: media zijn niet alleen een intermediair. Schillemans laat zien dat de media ook een forum zijn geworden waaraan verantwoording moet worden afgelegd. Versteeg en Hajer maken in hun casus duidelijk dat de media het gezag van een bewindspersoon keer op keer in twijfel trekken en dat een gezagsdrager juist in die context verschillende manieren moet gebruiken om gezag te verwerven en te behouden. Door de toegenomen onvoorspelbaarheid staat niet altijd vast waar en wanneer iemand zijn gezag moet legitimeren. Er zijn vaste momenten, maar Schillemans laat zien dat de onvoorspelbaarheid is toegenomen (en dat dit gevolgen kan hebben voor de kwaliteit van het bestuur). Versteeg en Hajer betogen dat gezag niet alleen in vaste rituelen tot stand komt, maar zich veel vaker ad hoc voordoet. Er kan op elk moment 
iets gebeuren waarop een gezagsdrager op de juiste manier moet reageren. Een goede reactie kan zijn gezag versterken, bij een verkeerde ligt gezagsverlies op de loer.

Niet alleen bij de actoren die gezag verwerven doen zich veranderingen voor, ook de bronnen van gezag verschuiven. Was het beroepen op een goddelijke oorsprong of het 'leeftijdsargument' al lange tijd minder in zwang, nu lijkt ook de rationele-legale bron van gezag minder zwaarwegend te zijn. Versteeg en Hajer laten zien dat alleen het formeel hebben van gezag (logos) onvoldoende is en dat daarnaast pathos en ethos nodig zijn. Ook lijkt er een ontwikkeling te zijn richting personalisering, waarbij de persoon van de gezagsdrager centraler is komen te staan en de bron van zijn gezag ook meer in zijn persoonlijk optreden ligt dan in de functie die hij bekleed.

De bevraging van het gezag zorgt voor onzekerheid bij het openbaar bestuur. Bestuurders voelen zich niet als vanzelfsprekend aanvaard, maar moeten dit constant bewijzen. Schillemans laat zien dat deze onvoorspelbaarheid ook positieve effecten heeft: anticipatie en zelfkritiek kunnen ook zorgen voor betere verantwoording. De auteurs signaleren echter ook problemen. Versteeg en Hajer signaleren dat een te eenzijdige focus op formeel gezag kan leiden tot problemen met de legitimiteit, stabiliteit en het lerend vermogen van het bestuur.

Schillemans stelt dat onvoorspelbare verantwoording negatieve gevolgen kan hebben voor de kwaliteit van bestuur.

De manier waarop het bestuur ter verantwoording wordt geroepen of wordt gecontroleerd verandert. Dat het bestuur openbaar is wanneer het zich beroept op kennis en feiten is niet onomstreden, zo laten Versteeg en Hajer zien. Ook kennis en diegene die deze kennis presenteren, moeten gezag verwerven. Het handelingsvermogen van het openbaar bestuur hangt in deze context niet alleen af van de mate waarin het presteert (output-legitimiteit), maar ook van de zichtbaarheid en uitlegbaarheid van zowel het proces van besturen als de uitkomsten er van. De zichtbaarheid en uitlegbaarheid zelf zijn een graadmeter geworden voor de beoordeling van het bestuur. Het belang van de uitlegbaarheid, van het grote verhaal over het hoe en waarom van politiek en bestuur is toegenomen. Het openbaar bestuur zal zijn gezag steeds opnieuw moeten verwerven. Het zal moeten laten zien dat het inderdaad openbaar is en dat het zijn burgers dient op een wijze die bindend, handelingsvermogend, pluralistisch en controleerbaar is.

\subsubsection{BESTUUR UIT HET LOOD?}

Dit eerste hoofdstuk begon met de veronderstelling dat er een schreefgroei is opgetreden tussen 'beeld' en 'werkelijkheid' van het openbaar bestuur. Waar het 'beeld' zich nog beroept op nationale kaders, het epicentrum in Den Haag, de drie 
lagen van Rijk, Provincies en Gemeentes, een scheiding tussen publieke en private organisaties, duidelijke toedeling van taken en verantwoordelijkheden, een 'kenbare' samenleving, moderne burgers en trouw aan legaal gezag, is de 'werkelijkheid' heel wat diffuser. Institutionele en vooral functionele differentiatie (in de EU en in eigen land), verspreiding van de politiek, 'verdamping' van vertrouwde collectieven van burgers maar ook 'versmelting' tot nieuwe publieken en een continue bevraging van gezag, leiden ertoe dat de vanzelfsprekendheid van de positie van het bestuur, in het bijzonder zijn positie als openbaar bestuur, ter discussie staat. Het gezicht van de publieke zaak is veranderd.

Dat blijkt op verschillende manieren. Het bindende karakter van het bestuur staat onder druk. Zijn handelingsvermogen wordt op de proef gesteld. Zijn pluralistische gehalte moet moeite doen overeind te blijven. Van de weeromstuit lijkt alle verbeterdrang zich te richten op de omvang en efficiëntie van de rijksdienst en op de verantwoording van het bestuur, om de publieke controle te behouden.

Met die nadruk op controle wordt echter slechts in een beperkte betekenis recht gedaan aan het 'openbare' van het bestuur. Openbaarheid dreigt te worden gereduceerd tot transparantie en afrekenbaarheid, en wel in die mate dat het niet anders dan tot teleurstellingen zal leiden. Controle en verantwoording zijn wenselijk en noodzakelijk, maar de eenzijdige nadruk daarop gaat ten koste van andere aspecten van de openbaarheid van het bestuur die evenzeer (en misschien wel meer) de nodige herstelwerkzaamheden behoeven.

Belangrijke reden daarvoor is dat het openbare karakter van het bestuur en het publieke gezicht ervan een zaak is van constitutionele proporties. Aan het begin van dit hoofdstuk is reeds gesteld dat het openbaar bestuur in Nederland is te positioneren in relatie tot polity, politics en policy. Wat de verschillende bijdragen duidelijk maken, is dat deze 'ophanging' echter niet compleet is als onvoldoende recht wordt gedaan aan de verhouding van het bestuur tot de publics. Voor een openbaar bestuur vormen naast polity, politics en policy de publics het kader. Voor de verhouding tot het publiek is controle en verantwoording onmisbaar, maar niet zonder dat recht is gedaan aan het bindende, handelende en pluralistische karakter van het bestuur. 


\title{
2 'DE PUBLIEKE ZAAK WIL PUBLIEK WORDEN BEHANDELD': EEN BLIK OP DE ONTWIKKELING VAN HET OPENBAAR BESTUUR IN NEDERLAND SINDS $1848^{1}$
}

\author{
Paul den Hoed en Steven Schouten
}

Staatsbestuur heeft een publiek nodig om zich legitimiteit en vanzelfsprekendheid te geven. J.R. Thorbecke (1798-1872), 'geestelijk vader' van het hedendaagse Nederlandse bestuurlijke stelsel, was zich daarvan bewust. In het verslag van de grondwetscommissie van 1848 schreef hij: "De publieke zaak wil publiek worden behandeld” (Hooykaas en Santegoets 1996: 520). De zin gaf uitdrukking aan de wenselijkheid van publieke controle en betrokkenheid bij de behandeling - lees: bespreking, regulering, ordening - van de 'publieke zaak'. Via het parlement, aldus de liberale jurist, kon een dergelijke publieke dimensie bij die behandeling worden versterkt. Thorbecke was echter geen voorstander van vergaande democratisering, en publieke betrokkenheid via brede vormen van maatschappelijke 'inspraak' was zeker niet waaraan hij dacht. Vertegenwoordigers van de 'natie' dienden selectief te worden gekozen, en moesten onafhankelijk van de mening van diezelfde 'natie' tot weloverwogen en 'rationeel' bestuur komen. Voor Thorbecke had staatsbestuur wel een publiek nodig, maar een klein publiek was voldoende om dat bestuur van legitimiteit en vanzelfsprekendheid te voorzien.

Ondanks deze beperkte opvatting van publieke betrokkenheid bij staatsbestuur is door het credo van Thorbecke (en zijn pleidooi voor openbaarheid bij behandeling van de publieke zaak) een publieke dimensie bij staatsbestuur in Nederland niet meer weg te denken. In deze bijdrage staat de ontwikkeling en variëteit van die dimensie centraal. Ontdaan van de normatieve en voluntaristische betekenis van Thorbeckes woorden (e.g. 'de publieke zaak wil publiek worden behandeld'), gaat het hoofdzakelijk om de weergave van de ontwikkeling van de praktijk(en) van het Nederlandse openbaar bestuur sinds 1848 .

Bij de ontwikkeling van de publieke kanten van staatsbestuur gaat het om niets anders dan een voortdurende en dynamische compositie- en vormverandering van de relatie tussen staat en burgers bij behandeling van de publieke zaak. Vooral sinds 1848 zijn staat en burgers bij de praktijk(en) van staatsbestuur steeds meer en op steeds andere wijzen met elkaar vervlochten geraakt in een almaar dynamischere en complexere compositie. Daarbij is sprake geweest van een continue herdefiniëring van de relatie tussen (delen van de) staat en maatschappij en tevens van permanente hervorming van de bestuurlijke werkelijkheid. 
Deze bijdrage biedt geen volledig historisch overzicht. Het is eerder een schets van de ontwikkeling van de publieke kanten van staatsbestuur in Nederland sinds 1848. Uitgaande van een ontleding van het bovengenoemde credo van Thorbecke keren telkens vier centrale elementen terug. Behalve het bovengenoemde (impliciete) normatieve element in dit credo ('de publieke zaak wil publiek worden behandeld'), waarop we in de conclusie zullen terugkomen, gaat het daarbij om de volgende drie elementen:

1 De publieke zaak en definiëring daarvan: zoals wij zullen zien, verschilden interpretaties van dit begrip en van wat daar nu precies toe gerekend zou moeten worden.

2 De behandeling van die publieke zaak. Dit heeft betrekking op de praktijk van het staatsbestuur sinds 1848 , waarbij een onderscheid gemaakt kan worden tussen methoden van besturen (regulering, wetgeving, subsidiëring, ordening enz.) en institutionele vormgeving (verhouding bestuur en politiek, rol van parlement versus regering, positie van gemeentelijk zelfbestuur, positie van zelfstandige bestuurorganen enz.).

3 De publieke dimensie bij die behandeling van de publieke zaak, waarbij het in deze bijdrage vooral gaat om publieke betrokkenheid bij bestuurlijke praktijken. Daarbij gaat het niet enkel om betrokkenheid via een versterking van het parlement, maar om een veel ruimere interpretatie van een dergelijke publieke betrokkenheid. In brede zin gaat het om toegang van personen of groepen uit de samenleving tot het staatsbestuur van Nederland. Deze toegang kent raakvlakken met een traditie van democratisering, maar valt er niet mee samen. Sommige vormen van publieke betrokkenheid vertonen verwantschap met wat we tegenwoordig ook wel typeren als associatieve en deliberatieve vormen van publieke betrokkenheid, waarbij (deels naast het parlementaire proces) publieke betrokkenheid door participatie en inspraak wordt vormgegeven. ${ }^{2} \mathrm{De}$ publieke basis van deze associatieve (ook wel: corporatistische) of deliberatieve betrokkenheid was tot aan de Tweede Wereldoorlog niet erg breed, maar wel permanent aanwezig. Soms, en vooral sinds 1917, werd daarbij tevens gezocht naar wegen om behandeling van de publieke zaak (deels) buiten het parlement van onderop te versterken, zoals door P.J. Troelstra (1860-1930) (SDAP) in het interbellum. Maar doorgaans werd zo'n versterking door bestuurders vooral gezocht via toenadering tot een 'elite' van 'experts' of 'stakeholders' (en met name 'hoge lieden' uit het bedrijfs- en wetenschapsleven). Hoewel van een brede, democratische basis van openbaar bestuur niet altijd sprake was, ontwikkelde datzelfde bestuur (vooral) sinds 1848 dus wel een eigen verhouding tot delen van het publiek.

Er is gekozen voor een tussenweg tussen een chronologische en thematische benadering van de ontwikkeling van het openbaar bestuur. Daarbij wordt dit ruime tijdsbestek (1848-heden) in vier periodes ingedeeld en gelet op verbindende thema's van het openbaar bestuur. Wij onderscheiden achtereenvolgens de perio- 
de van 1848 tot 1917; die van 1917 tot 1945; die van 1945 tot 1977; en die van 1977 tot heden. Deze aanpak dwingt echter om selectief te zijn: de perioden worden daarom opgehangen aan een aantal cruciale 'breukpunten' uit elk van deze vier perioden. Bepaalde historische kennis en feitelijk materiaal blijven zo onderbelicht, maar het zoeklicht kan daarmee wel des te meer op de publieke kanten van het staatsbestuur vanaf 1848 worden gezet.

In chronologische volgorde onderscheiden wij de volgende vier thematische hoofdlijnen:

1 Toenemende publieke betrokkenheid bij staatsbestuur door juridische verankering van een bestuurlijke relatie tussen staat en maatschappij in een parlementaire democratie, enerzijds, en toenemende vervlechting of "wederzijdse doordringing” (Romein 1976) van de maatschappij en het staatsbestuur, anderzijds (1848-1919).

2 Versterking van 'elitair-associatieve' vormen van staatsbestuur en een impasse in de institutionele vervlechting van staat en maatschappij en in de ontwikkeling van het parlementaire stelsel (1917-1945).

3 Institutionele verdichting van de sfeer tussen staat en maatschappij en maakbaarheid van de maatschappij met nadruk op inspanningsverplichtingen aan de 'voorkant' van het bestuursproces (dus bij de voorbereidingen en zogeheten inspraak vooraf) (1945-1977).

4 Zoektocht van zowel het verstatelijkte particulier initiatief als de oude en nieuwe verzelfstandigde publieke diensten naar een nieuwe balans tussen staat en samenleving, met nadruk op resultaten en resultaatverbintenissen van staatsbestuur en dus lettend op vooral de 'achterkant' van het bestuursproces (1977-2010).

\subsection{HET 'VERBOND' TUSSEN STAAT EN BURGERS EN DE 'WEDERZIJDSE DOORDRINGING' VAN STAATSBESTUUR EN PUBLIEKE BETROKKENHEID, 1848-1917}

Openbaar bestuur, in de zin van staatsbestuur met een intrinsieke publieke connotatie, kreeg in Nederland in formele zin pas vorm vanaf 1848. Vóór die tijd was 'de' maatschappij wel betrokken geweest bij de vormgeving en uitvoering van staatsbestuur, maar van juridische verankering van publieke betrokkenheid was geenszins sprake. Staatsbestuur was een aangelegenheid van elitenetwerken, toegankelijk voor 'hoge heren' (Aerts 2009a) uit kringen van regenten en adel die qua levensstijl en mentaliteit niet wezenlijk van elkaar verschilden. In geografisch en cultureel opzicht was Nederland een lappendeken, waarbij elke streek haar eigen gewoonten, dialecten en regelingen cultiveerde (Leerssen 2006). Het land was 'leeg' en 's winters waren plaatsen onderling moeilijk bereikbaar door een moerassig landschap (Van der Woud 1987). Tot omstreeks 1850 bestond de Nederlandse bevolking nog voor de helft uit ongeschoolde boeren, die allen van staatsbestuur 
waren uitgesloten. Het staatsbestuur richtte zich bovendien ook minder op de maatschappij en meer op de koloniën, defensie en het buitenlandse beleid. Onder koning Willem I (1813-1840) kende dit bestuur een sterk centralistisch karakter, waarmee ook een stevige impuls aan de inrichting van het land werd gegeven, zoals door aanleg van waterwegen en stimulering van de industrie. De vorst zocht daarbij overigens vaak samenwerking met ondernemers, maar liet het parlement veelal links liggen. Er was sinds 1814 immers een parlement met twee kamers, de Staten-Generaal, maar deze had feitelijk nauwelijks invloed op het autocratische bewind van Willem I. Koninklijke Besluiten hadden tot 1830 uit zichzelf kracht van wet, en de koning beschikte over een eigen budget waarmee hij veel buiten het parlement om kon realiseren.

Daarin kwam verandering toen het optreden van Willem I steeds meer onvrede opriep, en het parlement zijn constitutionele positie als geïnstitutionaliseerde oppositie steeds meer ging benutten. Daarbij maakte het gebruik van zijn recht van inspraak over staatsfinanciën. Via een grondwetswijziging werd in 1840 besloten dat de koning de verantwoordelijkheid van bestuur voortaan deelde met zijn ministers, ook al stonden die ministers nog altijd niet in relatie tot het parlement. Daardoor ontstond een impasse tussen koning en parlement, die in 1848 werd doorbroken via een herziening van de grondwet (Aerts 1999b: 85-92; Oud en Bosmans 1990: 15).

\section{DE LIBERALE SCHEIDING VAN STAAT EN MAATSCHAPPIJ, 1848-1870}

De vernieuwing van de grondwet van 1848 kwam onder druk van revolutionaire dreiging uit het buitenland tot stand. Willem II (1840-1849), die zijn vader in 1840 was opgevolgd en nu naar eigen zeggen "in één nacht" van "zeer conservatief, zeer liberaal" was geworden, gaf Thorbecke opdracht om met een ontwerp van een nieuwe grondwet te komen. De grondwet, die nog datzelfde jaar werd aangenomen, doorsneed het daarvoor dominante verbond van God, vaderland en koning, en introduceerde grondrechten en andere kenmerken van een klassieke rechtstaat (waaronder scheiding van machten en onafhankelijke rechtspraak). Het legde de vrijheid van drukpers, onderwijs, vereniging, vergadering en godsdienst vast, en bevestigde de definitieve scheiding van kerk en staat. Verder bepaalde de grondwet ook dat de vrijheid van onderwijs nader geregeld zou moeten worden. Uitgangspunt van de grondwet, die onder meer was bedoeld om revolutie te voorkomen, was bovenal de idee dat burgers niet langer als 'onderdanen' dienden te worden beschouwd, maar als 'staatsburgers'. De soevereiniteit van de 'natie', die reeds sinds 1813 in het hart van het Nederlandse bestuurlijke stelsel was gezet, kreeg zo reële betekenis en kwam versterkt naar voren in de constitutie (Te Velde 2010: 80). Hoewel burgerschap vooralsnog in zeer beperkte en enge zin werd begrepen, smeedde het principe van staatsburgerschap zo een (stilzwijgend) verbond tussen staat en maatschappij. Formeel ging de grondwet - volgens doctrinair liberale 
principes à la Thorbecke - weliswaar sterk uit van een scheiding van beide domeinen, maar de idee van staatsburgerschap bevestigde ook hun onderlinge relatie en afhankelijkheid. Daarmee lag staatsburgerschap ten grondslag aan datgene dat zich tijdens de negentiende en twintigste eeuw in de sfeer tussen staat en burger aan instituties en praktijken kon ontwikkelen, waaronder het openbaar bestuur.

De grondwetsherziening van 1848, die met steun van koning Willem II in het parlement werd aangenomen, voorzag bovendien in een herziening van de positie van ministers, parlement en koning. De koning werd 'onschendbaar' verklaard; ministers werden volledig verantwoordelijk voor het bestuur van de regering en de koning diende voortaan meer zelfstandigheid voor dit bestuur te laten aan de ministers (art. 42, lid $2 \mathrm{GW}$ ). Het beginsel van ministeriële verantwoordelijkheid werd zo scherper neergezet dan in 1840, ook al duurde het nog tot 1866-1868 voordat bovendien duidelijk werd dat ministers daarbij niet langer konden volstaan met het vertrouwen van de vorst, maar ook daadwerkelijk het vertrouwen van het parlement dienden te hebben. Daarmee lag de macht uiteindelijk bij het parlement.

Deze versterking van de publieke dimensie bij staatsbestuur werd nog verder kracht bijgezet door een wijziging van de organisatie en verkiezing van de StatenGeneraal, waarvan de principes eveneens in de grondwet van 1848 waren vastgelegd. Uitgewerkt in een Kieswet (1850), die moest bijdragen aan een toename van de parlementaire controle op het landsbestuur, werd de Eerste Kamer (39 leden) nu niet meer benoemd door de koning, zoals vastgelegd in de grondwet van 1814, maar gekozen door de Provinciale Staten op basis van belasting betalende burgers in de betreffende provincie. De leden van de Tweede Kamer werden direct verkozen op grond van een meerderheidsstelsel in districten. Gemeenteraden, Provinciale Staten en de Tweede Kamer kwamen allemaal tot stand via een censuskiesrecht, oftewel een kiesrecht op basis van de hoogte van de belastingaanslag. Het actief en passief kiesrecht werd daarbij toegekend aan 'zelfstandige' burgers, oftewel mannen van 23 jaar en ouder met eigen inkomen van een zekere hoogte. Daarnaast kreeg het parlement het recht van amendement en enquête, waardoor niet enkel een actievere rol bij wetgeving en controle op bestuur verder mogelijk zou worden gemaakt (Van Deth en Vis 1995: 32-33), maar ook de mogelijkheid werd gecreëerd voor zelfstandig parlementair onderzoek buiten de Kamer. Het laat zien dat versterking van de publieke dimensie bij bestuur in de geest van die tijd dus onlosmakelijk verbonden was met de idee van een functieverandering van het parlement.

De liberale bestuurders in het tijdsvak tussen 1848 en 1870 zochten naar wegen om de invloed van de vorst op staatsbestuur te beperken, maar hoopten tevens op een compromis tussen dat staatsbestuur en lokale of maatschappelijke vormen van "zelfbestuur" (De Haan 1993). ${ }^{3}$ In de doctrinair liberale opvatting waren 
wetgeving en staatsinrichting vooral instrumenten om via wettelijke kaders het maatschappelijk en economische leven te bevorderen, en dan met name via wat Thorbecke "gemeentelijke zelfregulering" noemde (De Haan 1993: 34). Dit idee vond zijn weerslag in de Provinciale wet (1850) en de Gemeentewet (1851), die het Nederlandse bestuurlijke stelsel de vorm gaven van een gedecentraliseerde eenheidsstaat (Van Deth en Vis 1995: 32). Daarbij ontstond echter ook een bestuurlijke paradox tussen centralisme (door een door de staat opgelegde bestuursstructuur) enerzijds, en decentralisme (door behandeling van de publieke zaak op lokaal niveau invulling te laten geven door 'zelfregulering') anderzijds. Ter versterking van het staatsbestuur werd de burgemeester voortaan door de staat benoemd; ter bevordering van 'gemeentelijke zelfregulering' gaf de Gemeentewet een omschrijving van de gemeentelijke bevoegdheden en verkiezingen op lokaal niveau om zo de traditionele invloed van lokale patriciërs terug te dringen. In dit laatste opzicht was de Gemeentewet in zekere zin het lokale equivalent van de ministeriële verantwoordelijkheid (Te Velde 1999: 103-104).

Ondanks deze versterking van burgerlijke betrokkenheid via parlement en lokaal zelfbestuur bleven bestuur en politiek ook na 1848 een zaak voor 'hoge heren' (gegoede burgerij, patriciërs en adel). ${ }^{4}$ Dat gold voor bestuur op staatsniveau, maar ook op provinciaal en gemeentelijk niveau. Het censuskiesrecht, gekoppeld aan de bijdrage van directe belastingen van mannen van 23 jaar en ouder, versterkte de band met deze kleine sociale bovenlaag des te meer. Het kiesrecht was toegekend aan ruim 80.000 Nederlanders op een bevolking van 3 miljoen in 1851 (Blok 1987: 250, 275; Te Velde 1999: 103; Loots 2004), ofwel een krappe 4 procent van de totale Nederlandse bevolking. 5 In de loop van de jaren 1850 en 1860 nam dit percentage enigszins toe, maar het aandeel van het 'volk' bij behandeling van de publieke zaak bleef tot omstreeks 1870 gering. Politiek, zo was de liberale gedachte, was voorbehouden aan een 'aristocratie van het verstand', en des te meer omdat politiek - in de dominante liberale terminologie - een zaak voor 'het nut van 't algemeen belang' was. Volksvertegenwoordigers dienden onafhankelijk van een achterban of volksinvloed 'rationele' afwegingen en werkelijke 'vrije' keuzes te maken. Hoffelijkheid en 'fatsoen', kenmerken van de gegoede burgerlijke levens- en gedragsstijl, stonden centraal in het parlementaire debat. H. te Velde typeert dit debat dan ook als een "beschaafd herengesprek" (Te Velde 1999: 109).

Toch legde de grondwet van 1848 de kiem van een veel bredere - en in liberale ogen: onbeschaafde - publieke betrokkenheid bij staatsbestuur en de instituties van het Huis van Thorbecke. Burgerlijke gelijkberechtiging en andere grondrechten boden de ingang van een bredere publieke behandeling van de publieke zaak. Aan katholieken, die reeds vóór 1848 hun godsdienst vrij konden uitoefenen, was het voorheen door een verbod op de benoeming van bisschoppen niet toegestaan hun kerk te organiseren volgens kerkelijke hiërarchie. Het principe van staatsburgerschap, waarin de staat zich opstelde als beschermer van 'nationale' burgerrech- 
ten, gaf echter voor het eerst reële betekenis aan de (formeel) gelijke rechten van geloofsgemeenschappen. Bovendien maakte de scheiding van kerk en staat een einde aan de bevoorrechte positie van de Nederlandse Hervormde Kerk. In april 1853 maakte de paus van die situatie gebruik door te besluiten tot een bisschoppelijke herindeling van Nederland, waarbij de Katholieke Kerk onder het gezag van Rome werd geplaatst. De zetel van de aartsbisschop kwam in Utrecht. Aangezien Utrecht een bolwerk van orthodox protestantisme was, provoceerde dit vooral orthodoxe protestanten, die zich nu openlijk mobiliseerden en een petitie indienden bij de koning. Het effect was matiging van de invoering van doctrinair liberale staatsopvattingen en behoud van (religieus) zelfbestuur buiten de staat om.

Terwijl Thorbecke de armenzorg aanvankelijk had willen onttrekken aan de kerken om een zakelijke regeling door de staat - lees: gemeenten - mogelijk te maken, besloot het kabinet-Van Hall (1853-1856) via de Armenwet van 1854 de armenzorg vooralsnog voorbehouden te laten aan de kerk; gemeenten dienden slechts aanvullend op te treden. Achteraf beschouwd werd hier een basis gelegd voor de latere 'pacificatie' tussen confessionelen en liberalen.

Ondanks matiging van de liberale - 'neutrale' - claim op het publieke domein begonnen protestanten, bewust van de implicaties van de liberale grondwet, zich sterker te organiseren. Zij maakten daarbij ook gebruik van nieuwe grondrechten. Hier was met name het recht van vereniging en vergadering van 1854 van belang. Daarnaast bevorderde het recht van vrijheid van geloofsuitoefening door zelfstandig opererende predikanten en leken, vastgelegd in 1848, de ontwikkeling van een beweging van gelovigen buiten die (Hervormde) kerk om. Deze beweging, grotendeels afkomstig uit de gelederen van 'kleine luyden' (oftewel de middenstand en 'gewone' of 'lagere' burgerij), versterkten door zending en evangelisatie een orthodox-protestantse opleving in Nederland (Houkes 2009). In de loop van de jaren 1850 en 1860 ontstond zo een zeer gevarieerde en dynamische beweging van orthodox-protestantse signatuur, die de strijd aanging met het 'neutrale' liberale staatsbestuur van de publieke zaak en de religieuze claim bij behandeling daarvan boven die van de staat stelde. Katholieken, geschrokken na de ophef rondom de bisschoppelijke herindeling, deden het wat rustiger aan, maar volgden op termijn het voorbeeld van de antiliberale protestanten.

\subsubsection{BURGERPARTICIPATIE EN NIEUWE POLITIEK, 1870-1890}

De publieke bewustwording van diverse kringen in de maatschappij, die in de jaren 1850 en 186 o buiten het parlement begon te ontwaken, organiseerde zich aanvankelijk als apolitieke beweging. Om de strijd omwille van de publieke zaak kracht bij te zetten, kwam zij (tegen de wens van een meerderheid van protestanten in) echter steeds meer in een politiek vaarwater terecht. A. Kuyper (18371920), de "klokkenluider der kleine luyden" (Romein 1947) speelde daarbij een 


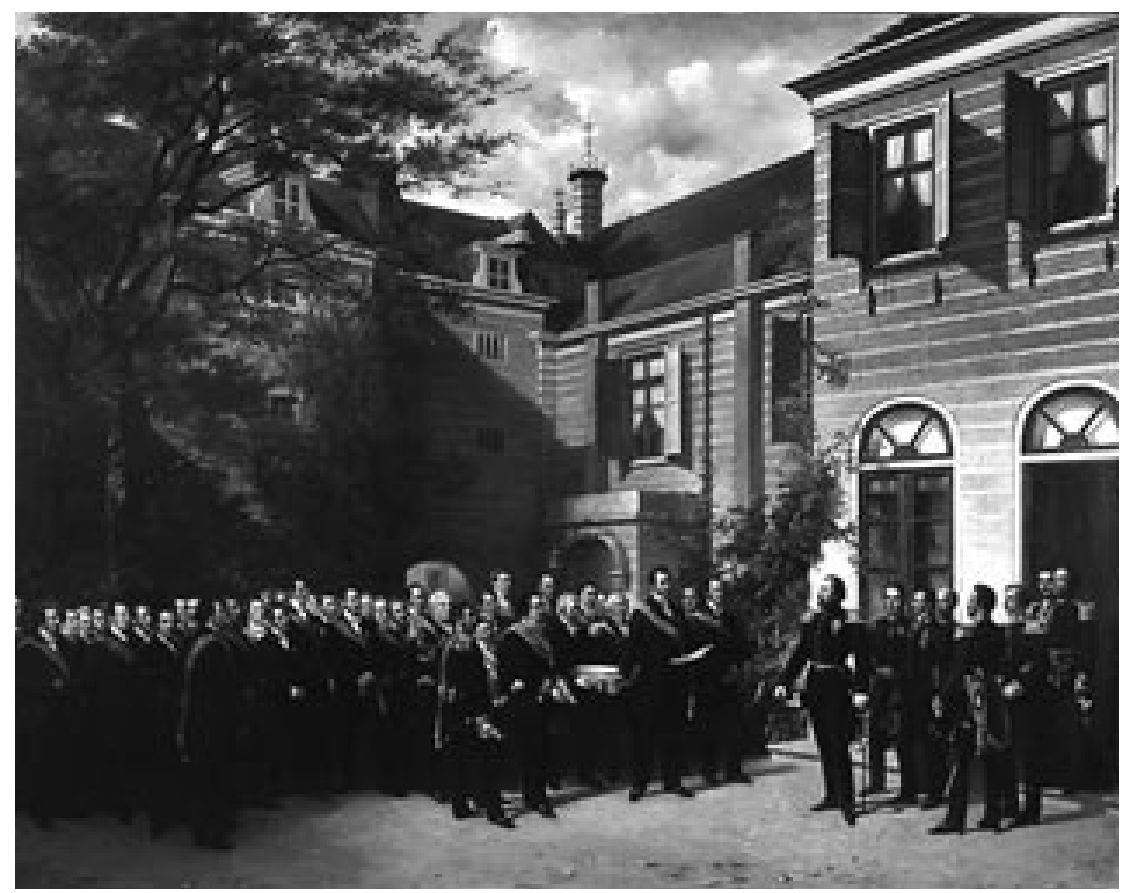

'Aanbieding van een adres aan koning Willem III op de binnenplaats van Paushuize Utrecht', Schilderij van N. Pieneman (1856)

In maart en april 1853 overhandigden besturen van diverse Nederlands Hervormde gemeentes petities aan koning Willem III met in totaal 200.000 ondertekenaars. Een van die besturen, namelijk dat uit Utrecht, bood zijn petitie op 13 maart 1853 aan. Dat is op dit schilderij afgebeeld. Het grondwettelijke recht van petitie bestond sinds 1814 en gaf burgers een middel om de publieke zaak te ondersteunen via de koning. In de loop van de tijd was dit recht niet zelden succesvol. Zo behielden de Nederlandse Hervormde gemeenten via dit recht zelfbestuur op het terrein van zorg en armoedebestrijding. In 1878 garandeerde vervolgens een petitie van 450.00o handtekeningen (op circa 3,5 miljoen inwoners) de vrijheid van (bijzonder) onderwijs. In 1985, ten slotte, had een volkspetitionnement van het Interkerkelijk Vredesberaad (IKV) van bijna 4 miljoen handtekeningen (op 14,5 miljoen inwoners) tegen plaatsing van kernwapens minder succes; wel gaf premier Lubbers aan gehoor te willen geven aan de wensen van het IKV.

(C) Centraal Museum Utrecht

doorslaggevende rol. In reactie op de liberale lager-onderwijswet van 1878, waarmee minister J. Kappeyne van de Coppello (1822-1895) de kwaliteit van het lager onderwijs, maar ook de greep van de staat daarop, wilde vergroten, organiseerde Kuyper een grootscheeps volkspetitionnement. Hij introduceerde daarmee een vorm van extraparlementaire politiek om publieke betrokkenheid bij de behandeling van de publieke zaak te versterken. Kuyper verzette zich tegen het 'neutrale' onderwijs en de beperkingen op het 'bijzonder' onderwijs, die volgden uit de lager-onderwijswet. Door steun van de katholieken leverde het volkspetitionnement maar liefst 450.000 handtekeningen op (op ca. 3,5 miljoen inwoners). 
Aangemoedigd door dit succes richtte Kuyper in 1879 de Antirevolutionaire Partij (ARP) op, die de eerste moderne politieke partij in Nederland werd. Om de band met de achterban te versterken begon hij die achterban nu ook verder te definiëren en af te bakenen, en besloot hij onder meer tot oprichting van de Vrije Universiteit (vU) in 1880. Daarbij formuleerde hij de idee van soevereiniteit in eigen kring, volgens welke de staat zich diende te onthouden van ingrijpen in kringen van het maatschappelijk leven die zelfstandig konden functioneren, zoals het gezin, maar ook de geloofsgemeenschap. In de kiem werd daarmee de basis van de latere verzuiling gelegd.

De nieuwe politiek van Kuyper bracht het parlementaire systeem - en daarmee het bestuur - naar de samenleving, en de samenleving vond zo ook ingang in dat systeem. De nadruk verschoof van persoonlijke politiek naar beginselpolitiek, hetgeen zijn weerslag vond in de vorming van partijen. In het verlengde van deze ontwikkeling begonnen ook andere groepen hun belangen beter te organiseren. Dit gold met name voor de arbeidersbeweging, die als gevolg van economische groei en industrialisatie (die pas werkelijk doorzette in de jaren 189o) zich sterker als maatschappelijke groepering begon te profileren. Onder leiding van F. Domela Nieuwenhuis (1846-1919), die zich met zijn Sociaal Democratische Bond (SDB) (1881) nog meer dan Kuyper op de publieke mobilisatie richtte, verplaatste de poli-

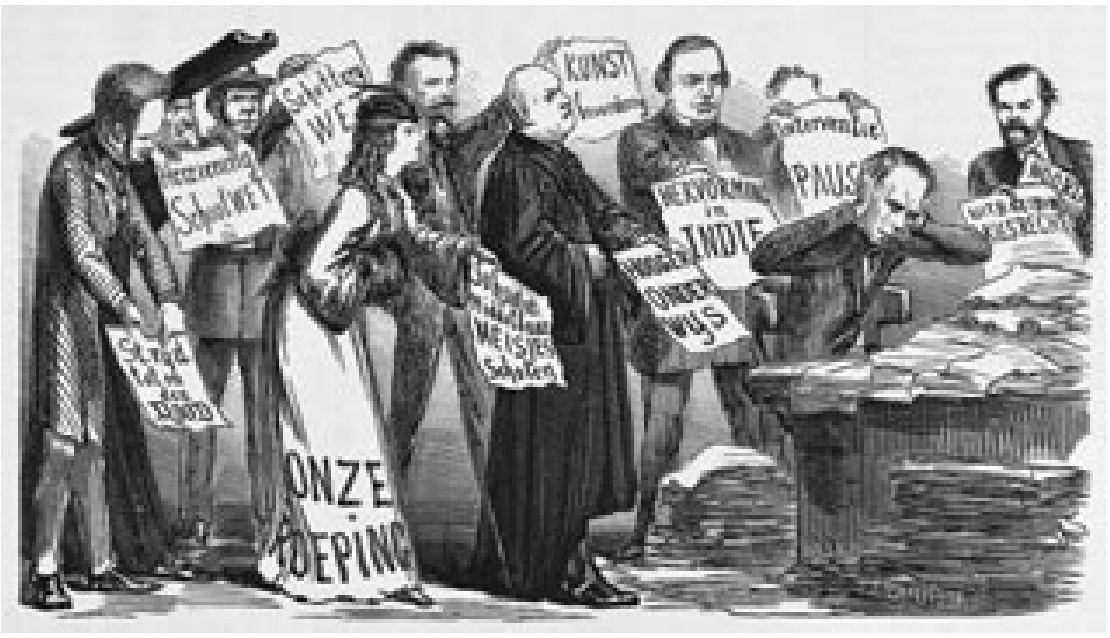

Thorbecke achter zijn bureau, Spotprent uit de Uilenspiegel (1871)

De bestuurlijke hervormingen van Thorbecke leidden tot een uitbreiding van het aantal taken van de overheid en van datgene dat tot de publieke zaak werd gerekend. Reeds vanaf de jaren 1870 vroegen de maatschappij en sociale bewegingen op tal van terreinen om nieuwe wetgeving. Ook andere vormen van staatsbestuur (subsidies, plannen, voorlichting) werden wenselijk. In de loop van de 2oste eeuw doordrongen staat en maatschappij elkaar steeds meer. 
tiek zich (letterlijk) naar de straat (Te Velde 1999: 143). Meer dan Kuyper gebruikte hij daarbij agitatie en opruiing, dat qua tactiek mijlenver van de 'deftige' liberale politiek af stond. Net als Kuyper profiteerde hij van toenemende maatschappelijke mobiliteit, alfabetisering, betere informatieverschaffing, en schaalvergroting in de economie na het midden van de negentiende eeuw.

De aldus ontstane nieuwe politiek introduceerde klasse en religie als criteria voor publieke betrokkenheid bij staatsbestuur. Anders dan voorheen raakte het standsverschil op de achtergrond en begon men in te zien dat een uitbreiding van het kiesrecht noodzakelijk was om de legitimiteit van bestuur en politiek te vergroten. Sinds de jaren 1870 was het kiesrecht een permanent onderwerp in het politieke en parlementaire debat geweest, en onderdeel van politieke strategieën van deelgroeperingen. In 1887 werd uiteindelijk besloten om de censusbepalingen uit de grondwet te schrappen. De grondwetswijziging vroeg vervolgens om uitwerking in een afzonderlijke kieswet, waartoe de links liberale minister J. Tak van Poortvliet (1839-1904) een voorstel presenteerde, dat echter grote polarisatie opleverde, en een scheuring dwars door de confessionele en liberale scheidslijn veroorzaakte. Tak wilde de mogelijkheden van de nieuwe grondwet zover uitbuiten dat bijna algemeen mannenkiesrecht zou worden bereikt, wat de behoudende partijen veel te ver ging (Te Velde 1999: 151; Loots 2004). Uiteindelijk kwam er onder het kabinet-Roëll (1894-1897) een kieswet tot stand, die beperkter was, maar wel een forse uitbreiding van mannelijke kiezers bewerkstelligde. Het aantal kiesgerechtigden verdubbelde bijna van ongeveer 300.000 in 1894 tot ongeveer 600.000 in 1897 (op een bevolking van zo'n 5 miljoen. De wet was bovendien zo geformuleerd dat met toename van de welvaart ook het aantal kiesgerechtigden zou stijgen, zodat er in 1913 bijna één miljoen kiezers was, iets meer dan tweederde van de mannen boven de 25 jaar tegen ruim de helft in 1897 . Verkiezingen veranderden door de uitbreiding definitief van persoonlijke naar collectieve strijd (Te Velde 1999: 153).

De uitbreiding van het kiesrecht leidde tot scheuringen binnen het liberale kamp enerzijds, en het antirevolutionaire kamp anderzijds. Een groep 'deftige' antirevolutionairen onder leiding van A. de Savornin Lohman (1837-1924) scheidde zich af, hetgeen in 1908 tot oprichting van de Christelijk-Historische Unie (CHU) leidde. Bij de liberalen, die in 1885 moeizaam met de Liberale Unie een aanvang van nationale organisatie waren begonnen, scheiden progressieven zich van behoudenden. De laatsten richtten in 1906 de Bond van Vrije Liberalen (BVL) op. Linkse liberalen en radicalen vormden in 1901 tezamen de Vrijzinnig Democratische Bond (VDB). Daarnaast verloor de SDB van Domela Nieuwenhuis zijn veerkracht en werd in 1894 de Sociaal-Democratische Arbeiderspartij (SDAP) opgericht. De partij legde het revolutionaire beginsel naast zich neer, en zette in op sociale hervorming. ${ }^{6}$ 
De versplintering in politiek en maatschappij versterkte een verlangen naar eenheid. Het (culturele) nationalisme fungeerde daarbij als bindende factor tussen groepen. Ook het symbool van de koning, Willem III, maar vooral dat van zijn dochter, prinses Wilhelmina (1880-1962), dat in deze jaren werd gecultiveerd, fungeerde als een bindend element. Nu het 'zelfbestuur' van de monarchie was ingeperkt, leek het aanzien daarvan toe te nemen. Deelgroeperingen zochten ieder op eigen wijze deelgenoot te worden van de cultus van het monarchale gevoel, en deze te combineren met een verdere cultivering van de eigen deelbelangen en identiteit. De spanning tussen dit verlangen naar eenheid enerzijds, en versterking van deelbelangen anderzijds, was in zekere zin de maatschappelijke equivalent van die tussen staatsbestuur en (lokaal) zelfbestuur in de gedecentraliseerde eenheidsstaat.

\section{'WEDERZIJDSE DOORDRINGING' VAN STAAT EN MAATSCHAPPIJ, 1890-1917}

De staat had zich sinds 1848 met diverse aspecten van de inrichting van het publieke domein beziggehouden. Handel en economie vroegen om regulering en inrichting van netwerken van transport en communicatie. Na 189o, toen de 'uitwassen' van de economische ontwikkeling en industrialisatie van de voorgaande jaren sterker op het maatschappelijke leven begonnen te drukken, nam de invloed van de staat verder toe. Daarbij verbreedde hij zijn invloed op terreinen die in het midden van de negentiende eeuw nog vrijwel uitsluitend tot het particuliere en (kerkelijke) initiatief hadden behoord, zoals sociale zorg, arbeid en armoedebestrijding. Die ontwikkeling werd versterkt door dreiging van maatschappelijke onrust, voornamelijk in snel uitdijende arbeiderswijken in Amsterdam. In 1885 , toen de economische stagnatie toenam, vond die ontwikkeling een uitlaatklep in het zogenaamde Palingoproer, waarbij de bevolking zich keerde tegen de Amsterdamse politie, die sinds jaren had geprobeerd socialistische manifestaties tegen te gaan (Kossmann 1986: 261-262). De zaak was aanleiding tot een parlementaire enquête. De Kamer maakte daarmee niet enkel gebruik van het recht dat haar in 1850 was toegekend, maar nam tevens afstand van haar eenzijdige focus op de regering en ging (actief) op zoek naar 'kennis' uit de samenleving. Zij verplaatste daarmee haar aandacht van discussie binnen de Kamer naar discussie buiten die Kamer. Toen deze enquête met behulp van statistieken in 1886 beter inzicht gaf in de erbarmelijke arbeidsomstandigheden, werd het sociale probleem voor bestuurders en politici bovendien ook tastbaarder - en een probleem in de publieke opinie. De opkomst van massamedia door technische vooruitgang en alfabetisering versterkte dat effect. Door zich te beroepen op statistieken nam vervolgens ook de 'objectieve' kennis van de bestuurders en politici toe, zodat het openbare debat zakelijker en rationeler werd (De Haan en Te Velde 1996: 194). Deze zakelijkheid stak scherp af tegen de nieuwe partijpolitiek, waarin juist een nieuwe emotionaliteit de 'oude' rationele (liberale) politiek domineerde. 
Sinds 1890 ging de staat zich nadrukkelijker met het sociale 'probleem' bemoeien. Daar waar kiesrechtuitbreiding en buitenparlementaire partijvorming, vooral van de ARP en later de SDAP, de greep van de maatschappij op de staat vergrootte, leidde sociale wetgeving tot een toename van het ingrijpen van de staat in de maatschappij (Te Velde 1999: 155). Dat ingrijpen had in de eerste plaats een wettelijk karakter, waarbij kaders werden geschapen voor maatschappelijk gedrag. Typerend zijn de sociale wetten die het maatschappelijke leven vanaf die tijd dienden te reguleren, zoals de veiligheidswet (1895), de leerplichtwet (1900), de ongevallenwet (1901), de woningwet (1901) en de invaliditeitswet (1913). Kinderwetten maakten bovendien een begin met bescherming van kinderen. Ouders liepen daarbij zelfs kans uit de ouderlijke macht te worden ontheven. De staat eigende zich zo de bevoegdheid toe om voortaan in te grijpen in het 'soevereine' domein van particuliere kringen.

Door zijn oog voor sociale problematiek raakte de staat bovendien betrokken bij particuliere initiatieven van "sociaal burgerschap” (De Rooy 1999b), die sinds de jaren 1880 probeerden om de maatschappelijke deugdzaamheid in organisatorisch verband te verbeteren. Aangezien sociale problematiek vaak als morele problematiek werd gezien, waren tal van verenigingen opgericht met het doel van morele hervorming om prostitutie, alcoholisme en schoolverzuim tegen te gaan (Janse 2007). Vaak zocht men versterking van 'fatsoenlijk' gedrag door 'volkse' activiteiten te koppelen aan 'nationale' en 'burgerlijke' kaders. Deels zijn deze groepen te zien als voortzetting van de protestants-orthodoxe zendingsbewegingen, maar ook socialisten en liberalen organiseerden zich in toenemende mate op vergelijkbare wijze. De staat, die met de groei van sociale problematiek steeds meer belang kreeg bij sociaal-culturele disciplinering en 'beschaving', stelde zich in toenemende mate open voor een zedelijke vorm van bestuur, waardoor veel terreinen van het sociale leven aan het begin van de twintigste eeuw in de woorden van P. de Rooy: “op zijn minst een element van dwang, voorschrift, toestemming of toezicht van wet en overheid" bevatten. De staat werd zo niet langer enkel handhaver van de wet, maar tevens regisseur, inspecteur, controleur, en zelfs "scheidsrechter" bij de publieke zaak (1999b: 6o-61).

Uitbreiding van het aantal overheidstaken vertaalde zich naar uitbreiding van het ambtelijke apparaat. Hoewel dat apparaat al sinds het midden van de negentiende eeuw in omvang was toegenomen, zette deze uitbreiding zich vooral na 1890 door. Naast de bestaande departementen op het gebied van binnenlandse zaken, buitenlandse zaken, oorlog (marine), financiën, justitie en koloniën, kwamen er tussen 1900 en 1918 vier afzonderlijke departementen bij: Waterstaat, Arbeid, Onderwijs, en Landbouw, Handel en Nijverheid. Hoewel de omvang en reikwijdte van de staat naar huidige maatstaven uiterst bescheiden bleef, nam tussen 1880 en 1910 het aantal rijksambtenaren toe van 12.000 tot 30.000 (De Jonge 1988: 246). Deze groei ging gepaard met een verdere professionalisering van het ambtelijke appa- 
raat. Ambtenaren hadden omstreeks 1900 wel nog steeds vooral een juridische (en technische) achtergrond, en dat gold ook voor de meeste Kamerleden (Te Velde 1999: 155), maar zij werkten niet langer halve dagen en vonden in hun werk steeds meer een volledige baan. Ook maakten zij zich nu een ambtelijk taalgebruik eigen, dat het openbare debat steeds meer kleurde (Te Velde 1999: 196; Van IJsselmuiden 1988: 150 e.v.). Daarnaast nam het burgerlijke karakter van het ambtelijke leven toe - en daarmee het burgerlijke karakter van de staat - door relatief sterkere uitbreiding van het aantal burgerlijke ambtenaren ten opzichte van het militaire deel van de staat (Krabbe 1883).

In het kader van deze professionalisering van het ambtelijke apparaat zag het staatsbestuur zich in deze tijd ook steeds vaker omringd door diverse nationale raden en commissies. Het aantal 'vaste colleges van advies en bijstand' (zoals ze vanaf de grondwetswijziging van 1922 zouden gaan heten) steeg van circa 5 naar 20. Statistiek, dat sinds de jaren 188o veel invloed op het regeringsbeleid zou krijgen, waaronder dat van de arbeidswetgeving, nam daarbij een zware positie in (Randeraad 2006). In 1899 werd besloten tot oprichting van een Centraal Bureau voor de Statistiek (CBS), en in 1892 tot oprichting van een Centrale Commissie voor de Statistiek (CCS) (De Haan en Te Velde 1996: 193). De CCS, opgericht door N.G. Pierson (1839-1909) en Tak van Poortvliet, hield toezicht op het verzamelen van statistieken, maar schreef ook adviesrapporten voor de regering, waarmee statistiek een vaste plaats kreeg in de onderbouwing en vormgeving van het 'regeringsbeleid'. Vanaf de oprichting van het CBS was het verzamelen van gegevens bovendien niet langer iets waarover gemeenten, provincies en andere departementen dan dat van Binnenlandse Zaken naar eigen inzicht konden beslissen. Het bureau werd het verzamelpunt van statistische kennis, waarnaar andere bestuurslagen zich in toenemende mate dienden te richten (Kuijlaars 1999). Het CBS was zo exemplarisch voor de explosieve groei van de overheidsadministratie in de jaren rondom de eeuwwisseling en voor een nieuwe infrastructuur van de overheid (De Haan en Te Velde 1996: 196). Statistiek lag tevens aan de basis voor verdere overheidsinterventie, niet slechts op landelijk niveau, maar vooral ook op lokaal niveau, waar gemeenten hun eigen kennisinstellingen ontwikkelden. ${ }^{7}$ Zo liep de oprichting van het CCS parallel met die van het Gemeentelijk bureau voor statistiek in Amsterdam, dat een rol diende te spelen bij het opzetten van een werkloosheidsverzekering en arbeidsbemiddeling.

De uitbouw van het staatsbestuur ging tevens gepaard met een groeiend aantal activiteiten op lokaal niveau (De Haan en Te Velde 1996: 196). Volgens liberaal beginsel was lokaal zelfbestuur vrij om zelf invulling te geven aan de wijze waarop dat gebeurde. Met het oog op de toegenomen complexiteit van de samenleving en de groeiende sociale problematiek, droegen lokale besturen in toenemende mate zorg voor kwaliteitsverbetering van openbare voorzieningen, zoals water, gas en transport, en de ontwikkeling van sociale voorzieningen, zoals 
werkverschaffing en huisvesting. Vaak namen gemeenten het initiatief in de bestuurlijke inrichting van Nederland, zoals in Amsterdam waar door 'radicale' liberale bestuurders vele sociale voorzieningen en nutsbedrijven in gemeentelijke handen vielen. Het gevolg was echter wel een toenemende groei van bepalingen en verordeningen per gemeente. Een toenemend verkeer tussen gemeenten ondervond echter steeds meer hinder van verschillen in regelingen (Knippenberg en De Pater 1988; Van der Woud 2006). Druk vanuit de staat om tot uniforme normen te komen en lokale regelingen en initiatieven op elkaar af te stemmen creëerde interne spanningen in de gedecentraliseerde eenheidsstaat. Tot een oplossing kwam het voorlopig niet, maar tijdens het interbellum zou deze uiteindelijk geboden worden door een sterker centraal staatsbestuur, ook al bleef dat bestuur uiteindelijk beperkt ten behoeve van het behoud van gemeentelijk bestuur.

Hoewel het staatsbestuur zeker niet onomstreden was, begon men de staat aan het begin van de twintigste eeuw in toenemende mate verantwoordelijk te stellen voor maatschappelijke ordening. Dit had, sinds de jaren 189o, al geleid tot sterke intensivering van het overheidsbeleid op allerlei terreinen. Maar naarmate de staat zich met meer maatschappelijke ordening moest bezighouden, raakte hij ook meer vervlochten met allerlei belangen. Om belangen te behartigen kon men steeds minder om de staat heen, terwijl de staat voor effectief bestuur steeds vaker was aangewezen op de belanghebbenden. Politieke macht verschoof daarbij van het parlement naar een veelvormig overleg tussen de staat en allerlei belangenbehartigers; "het parlement", dat zo opnieuw aan een verandering van functie(s) onderhevig was, "werd meer de plaats waar moeizaam bereikte compromissen werden gelegitimeerd” (De Rooy 1999a: 180). Politieke partijen zochten op vergelijkbare wijze vooral het compromis om de interne eenheid te behouden of versterken.

Daarbij nam paradoxaal genoeg de waardering voor politici af naarmate politiek een echt beroep werd. Aan het begin van de twintigste eeuw werd het parlement door burgers steeds meer gezien als een praatcollege, dat weinig tot stand bracht (De Rooy 1999b: 6o-61). In deze context nam ook de politieke betekenis van het staatshoofd verder toe (De Rooy 1999a: 181), terwijl 'hoge heren' uit de samenleving steeds vaker ingang zochten tot het staatsbestuur buiten het parlement om, door rechtstreekse contacten met de uitvoerende macht. Door het toegenomen belang van de economie nam de invloed van vertegenwoordigers van bedrijven ook steeds meer toe. Dit alles vond een hoogtepunt tijdens de Eerste Wereldoorlog. 


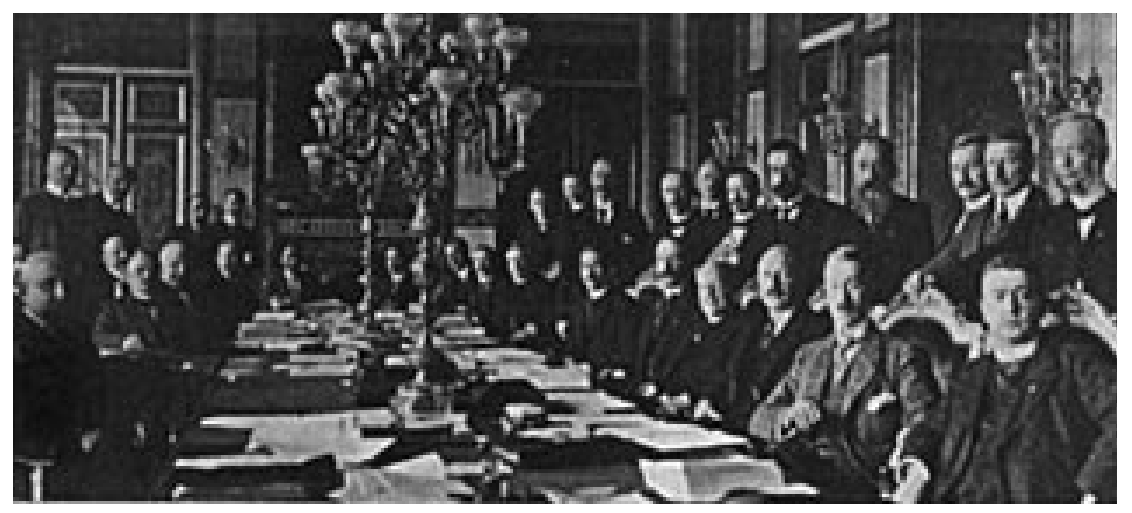

Staatscommissie tegen de werkloosheid (1914) (Beeldmateriaal: Albarda, J.W., Beeldmateriaal IISG) (foto uit De Prins, 11-07-1914)

Rond 1900 speelden staatscommissies en andere adviesinstellingen voor de regering een rol bij de voorbereiding van (sociale) maatregelen. Diverse maatschappelijke spelers - en vooral notabelen (en ook professoren) - werden op die manier bij staatsbestuur betrokken. Zo bestond de hier afgebeelde staatscommissie uit een variëteit van personen uit het kerkelijke, economische, politieke en wetenschappelijke leven, onder wie P.J.M. Aalberse, J.W. Albarda, M.W.F. Treub en J.Th. de Visser. Hoewel de SDAP in 1939 pas voor het eerst in de regering kwam, hadden socialisten via dergelijke commissies al eerder toegang tot de uitvoerende macht. Hier is dat zichtbaar in de persoon van Albarda (SDAP).
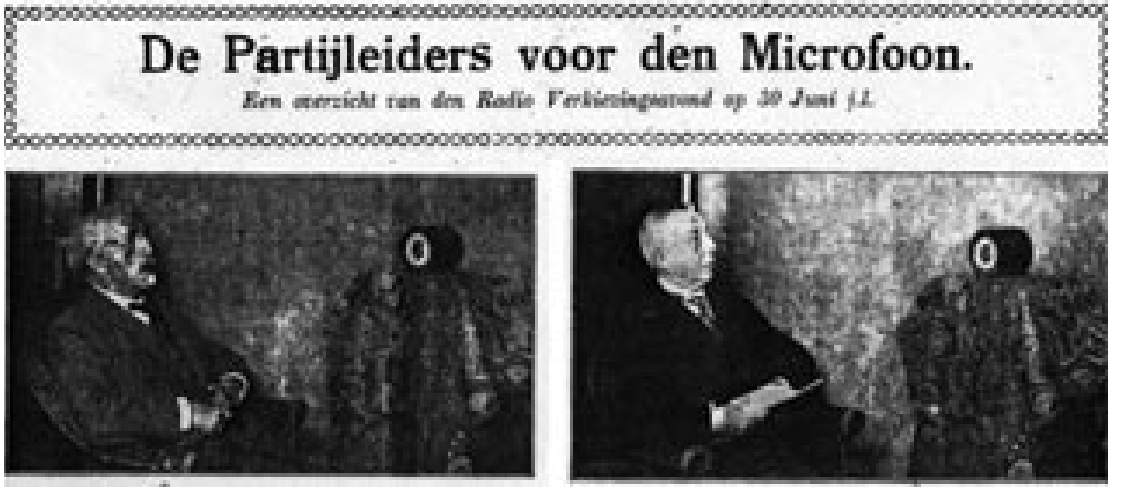

'Partijleiders voor den Microfoon' (1925) (uit: Radio Luistergids, 03 juli 1925)

Deze foto toont ARP-voorman en minister van Financiën H. Colijn en SDAP-voorman F.M. Wibaut op de eerste Radio Verkiezingsavond van 30 juni 1925. Wat begon met het eenvoudig gebruik van de microfoon als technisch hulpmiddel was de voorbode van een veel meer indringende en omvattende mediawerkelijkheid (televisie, internet enzovoorts) in politiek en bestuur. Microfoon werd megafoon. 


\subsection{MOEIZAAM STAATSBESTUUR EN AMBIVALENTE PUBLIEKE BETROKKENHEID, 1917-1945}

Nederland bleef neutraal tijdens de Eerste Wereldoorlog (1914-1918), maar de verscheurende werking van die oorlog ging zeker niet aan Nederland voorbij. In een tijd waarin nationale economieën door vrijhandel en specialisatie al intensief met elkaar vervlochten waren, betekende oorlog een ernstige aanslag op het functioneren van de Nederlandse economie, en daarmee van het maatschappelijk systeem. Om het krediet en de geldcirculatie (1914) overeind te houden, maar ook om leverantie van voedsel en brandstoffen te garanderen, was de 'staat' genoodzaakt actie te ondernemen. Crisismaatregelen in het leverantieen distributiesysteem van voedsel en steenkolen en de oprichting van het Koninklijk Nationaal Steuncomité onder leiding van koningin Wilhelmina (als overkoepeling van verenigingen, (vak)bonden en gemeentelijke instellingen om werkloosheid en armoede het hoofd te bieden), versterkten de rol van diezelfde staat bij ordening en regulering van het sociaaleconomische leven (Wolffram 2003: 30; Moeyes 2005; Von der Dunk 1988: 348-376; De Rooy 1999a: 188-190). Door de werklozenzorg nam de staat bovendien een rol als 'zorgdrager' van burgers op zich; wat - hoewel tijdelijk - een kentering in het denken over staatsbestuur inhield, zelfs al waren de gemeenten uiteindelijk voor de uitvoering daarvan verantwoordelijk (Wolffram 2003:30). ${ }^{8}$

Hand in hand met deze verdergaande tendens naar centraal staatsbestuur ging een verdere bestuurlijke vervlechting van staat en economie. De neutraliteitspolitiek, waarmee de regering hoopte buiten de oorlog te blijven, verlegde het accent voor bestuur van het politiek-militaire terrein naar dat van handel en economie. Om het risico van een schending van de neutraliteit (en daarmee van oorlog) te voorkomen onthield de staat zich voor de voorziening van voedsel en brandstoffen van (direct) contact met Engeland enerzijds en Duitsland anderzijds, en kreeg het bedrijfsleven daartoe een bepalende invloed op de behandeling van de publieke zaak. 'Hoge heren' (notabelen) uit het bedrijfsleven verzorgden de economische regulering en controle door de oprichting van de Nederlandsche Overzee Trustmaatschappij (NOT), die Engeland de garantie gaf Duitsland niet te voorzien van allerlei 'contrabande' goederen, maar die tevens berustte in een vaak goed georganiseerde en omvangrijke smokkelhandel op Duitsland. De NOT nam de vorm aan van een "soort staat binnen een staat", waarbij vergaande politieke bevoegdheden aan 'hoge heren' uit het Nederlandse bedrijfsleven toekwamen, die overigens niet vrij waren van (economisch) eigenbelang (De Rooy 1999a: 190). Zo versterkte de verstrengeling van bestuur en economie een vervlechting van publiek en eigen belang. Hoewel burgers in deze jaren dus afhankelijk werden van de staat om in hun levensbehoeften te voorzien, werd diezelfde staat omwille van datzelfde doel afhankelijk van het (vrijwel particuliere) bestuur van deze "mannen van de daad" (Houwink ten Cate 1995). 


\subsubsection{VERZUILING, CORPORATISME EN FUNCTIONELE DECENTRALISATIE,} 1917-1929

Reeds voor 1914 was het bewustzijn van bestuurders en politici toegenomen dat uitbreiding van het maatschappelijke draagvlak van openbaar bestuur noodzakelijk was. Hoewel het kiesrecht in 1913 al beschikbaar was voor tweederde van de mannelijke bevolking, waren de lagere sociale klassen nog altijd van (indirecte) participatie in het parlementaire systeem buitengesloten. De populariteit van de SDAP, en de daarmee verbonden dreiging van politieke organisatie van de arbeidersklasse voor het bestuurlijke establishment, vergrootten de druk op een verdere uitbreiding van het kiesrecht. De oorlog versnelde daarbij door 'pacificatie' tussen confessionelen en liberalen de weg naar de toekenning van het algemeen mannelijk kiesrecht, dat in 1917 een feit werd (door een directe koppeling van deze regeling aan de financiering van openbaar en bijzonder onderwijs op gelijke voet). Twee jaar later werd dit recht uitgebreid met algemeen kiesrecht voor vrouwen. ${ }^{9}$ Daarmee was sprake van een formele inbedding van alle (meerderjarige) burgers in het staatsrechterlijke systeem van 1848 .

De uitbreiding van het kiesrecht ging gepaard met introductie van een stelsel van evenredige vertegenwoordiging. Hoewel dit uitdrukking was van verdergaande democratisering, haalde dit tevens de veerkracht uit het parlement. Door de lage kiesdrempel bij de verkiezingen van 1918 waren er 32 lijsten ingediend, waaronder zich vele nieuwe en doorgaans ook kleine partijen bevonden. Hiertoe behoorde de Economisch Bond, die vooral tegen partijpolitiek zelf was gekeerd en zich uitsprak voor een zakelijke, economisch georiënteerde politiek (Vossen 2003). Nieuw in de verkiezing was bovendien de Rooms-Katholieke Staatspartij (RKSP; die vanaf 1926 zo zou heten), die met 30 van de 100 zetels de grootste partij in de Kamer werd. Samen met de ARP en de CHU won de partij met 50 van de 100 zetels de verkiezingen (De Rooy 1999a: 192). De drie vormden daarop een coalitie, die tot de Tweede Wereldoorlog vrijwel onveranderd stand hield. Deze coalitie werd aangevuld met liberalen van diverse snit.

De versplintering van het partijenstelsel versterkte fragmentatie van publieke representatie in het parlement, enerzijds, en verzwakte de kracht van dat parlement als instrument om invloed uit te oefenen op de bestuurlijke werkelijkheid, anderzijds (Woltjer 1992). Daarbij kwam dat de Eerste Wereldoorlog de geloofwaardigheid van (partij)politiek ernstig had aangetast. Het primaat van de economie stond, zeker in de jaren twintig en de eerste helft van de jaren dertig, voorop. Bepaalde terreinen van het publieke leven - handel, economie en buitenlandse zaken - waren volgens velen ook veel te belangrijk geworden en konden beter aan een elite van ondernemers worden overgelaten, zelfs al waren dit deels belanghebbenden. Het protest tegen partijpolitiek, en de neiging om belangrijke delen van het overheidsbeleid aan openbare controle te onttrekken, was "als ondertoon" van 
het debat over bestuur voortdurend aanwezig (De Rooy 1999a). Daarnaast was er een poging om democratie te versterken via institutionalisering van maatschappelijke vormen van democratie. Zo ontwierp Troelstra een nieuw systeem, waarin arbeidersbelangen beter tot hun recht konden komen via een speciale Arbeidskamer voor sociaaleconomisch kwesties.

Openbaar bestuur in het interbellum werd gekenmerkt door ideologische fragmentatie. De 'verzuiling', gecodificeerd en bevestigd door de onderwijspacificatie van 1917, speelde daarbij een centrale rol. Hoewel men sinds het einde van de negentiende eeuw indirect ook meer van de overheid was gaan verwachten, verlangden protestanten, katholieken, socialisten en andere groeperingen toch vooral 'autonomie' in eigen kring. Elke zuil had zo haar eigen opvatting over de morele invulling van de samenleving, en dat ging in het interbellum gepaard met een versterking van de gedachte en het gevoel tot een specifieke gemeenschap te behoren. De nadruk op een specifieke identiteit leidde tot sterke integratie van opvattingen over diverse domeinen van het leven. De band tussen religie en politiek werd bovendien ook sterker, en vervlochten met het economische en sociale leven, uitgedrukt in een dicht geweven netwerk van stichtingen, verenigingen en organisaties. Het radiozendtijdbesluit van 1930, dat zendtijd per zuil verdeelde, verhief de verzuiling tot officiële norm en stimuleerde een ontwikkeling om andere verdelingskwesties op vergelijkbare wijze te behandelen (De Rooy 1999a: 199-200).

Ondanks de wenselijkheid van zelfbestuur, was er bewustzijn bij de verschillende zuilen dat een zekere vorm van maatschappelijke 'ordening' van staatswege noodzakelijk was. Reeds aan het eind van de negentiende eeuw waren liberalen zich bewust dat de economische ontwikkelingen om 'ordening' vroegen. In de jaren twintig en dertig nam dat bewustzijn bij gereformeerden, maar vooral bij katholieken toe. De voorkeur ging daarbij uit naar decentrale vormen van zelfbestuur. Socialisten waren al lange tijd voorstander van een sterker optreden van de staat geweest. Katholieken en socialisten raakten elkaar vooral in de gedachte om in bedrijven via medebeheer en winstdeling samenwerking tussen werkgevers en werknemers te ontwikkelen. Dit zou moeten worden geïnstitutionaliseerd via delegatie van overheidsbevoegdheden aan bedrijfsorganisaties, waarin zowel arbeiders als ondernemers vertegenwoordigd waren. Het ging hier om functionele decentralisatie, een equivalent van territoriale decentralisatie (via de 'gedecentraliseerde eenheidsstaat' zoals bevestigd door de Provinciewet van 1850 en de Gemeentewet van 1851). Socialisten streefden daarbij vooral naar bedrijfsorganisaties onder leiding van de overheid. De overheid diende in deze organisaties tevens de doorslag te geven. Katholieken verwierpen die opvatting en propageerden zelfstandige bedrijfsorganisaties, waarin belangengroepen zelfstandig en op vrijwillige basis zouden opereren. Hoewel katholieken - anders dan gereformeerden - staat en maatschappij in een 'subsidiair' verband zagen, 
en voorstander waren van een zekere betrokkenheid en sturing van de overheid, propageerden zij toch vooral zelfstandigheid en ieders eigen positie en verantwoordelijkheid. Tot een oplossing van dit debat kwam het pas na 1945 (De Liagre Böhl 1999: 279-280). ${ }^{10}$

De spanning tussen staatsbestuur en gemeentelijk zelfbestuur profileerde zich eveneens in de bestuurlijke realiteit. Onafhankelijk van de discussies over 'ordening' verdiepten en versterkten feitelijke vormen van lokaal bestuur zich, en werden zij ook ingewikkelder door toename van economisch verkeer en regelingen. Net als voor de Eerste Wereldoorlog vergrootten zowel staat als gemeente hun claim op de behandeling van de publieke zaak. Doorgaans liet de staat gemeenten hun eigen beleid en bestuur vormgeven, maar juist dit creëerde problemen, omdat gemeenten ieder hun eigen regelingen troffen, waarvan de hoeveelheid en omvang in het interbellum toenam. Om de afstemming en aansluiting tussen gemeenten te vergroten, doorbrak de staat deze spanning in 1929 door gemeenten en provincies in hun autonomie op financieel terrein te beperken. De staat kende voortaan via het uit rijksbelastingen gevoede Gemeentefonds en het Provinciefonds algemene uitkeringen toe aan decentrale eenheden. Dit was een ruk naar centralisatie, dat door een groot deel van lokale bestuurders met afkeuring gade werd geslagen.

Dat neemt niet weg dat de maatschappij - en ook de staat - in het interbellum ambivalent bleef over centraal staatsbestuur. Maatschappelijk wantrouwen tegenover de overheid, maar ook culturele en 'morele' percepties bepaalden de wens om het sociaaleconomische en culturele leven zoveel mogelijk zelf te willen inrichten. Soms wilde de staat wel centraliseren, maar hij kreeg daartoe slechts beperkt de kans. De minister van Arbeid, P.J.M. Aalberse (1871-1948), riep in 1919 de Hoge Raad van Arbeid bijeen als een forum waar de leiders van werkgevers en werknemers op centraal niveau bij elkaar kwamen voor onderling overleg en advies. Ondanks de wens van de regering om deze raad te regisseren, lukt dat maar gedeeltelijk. Soms vonden werkgevers en werknemers elkaar zelfs in een gezamenlijk verweer tegen overheidsinmenging in het sociaaleconomische leven, zoals tijdens het ontwerp van een ziektewet in 1921 door bovengenoemde Aalberse (De Rooy 1999a: 195). De staat was soms bij conflict wel gewenst, maar doorgaans zagen de maatschappelijke partijen hem liever niet.

Ten aanzien van de publieke betrokkenheid bij openbaar bestuur in deze periode was opmerkelijk dat zowel het centrale staatsbestuur als lokaal zelfbestuur zocht naar wegen om diverse actoren bij de besluitvorming en de meer praktische vormgeving en uitvoering van bestuur te betrekken. De (kwalitatieve) toename van deelnemers bij de behandeling van de publieke zaak was deels een gevolg van de toegenomen betekenis van sociaaleconomische factoren en complexiteit in de 
maatschappij. Dit vroeg om meer specifieke kennis en expertise. Op lokaal niveau betekende dit doorgaans toenadering tot 'stakeholders', veelal 'hoge heren' uit het (lokale) bedrijfsleven (De Klerk 1998, 2008). Op staatsniveau betekende dit ook een uitbreiding van het aantal commissies en adviesraden. Daarin zaten veel vertegenwoordigers van grote bedrijven, die door het toegenomen belang van de economie en een verzwakt parlement hun gezag (en tevens hun invloed) in de jaren twintig en dertig grotendeels behielden, en grote invloed hadden op de internationale handelspolitiek van Nederland (Fennema en Rhijnsburger 2007: 66-102).

Dat neemt echter niet weg dat dergelijke 'colleges van advies en bijstand' bij wet - en dus met instemming van het parlement - dienden te worden ingesteld, zoals was geregeld via een grondwetsamendement van Troelstra uit 1922. Ondanks haar verzwakte status bleef de Tweede Kamer daarmee van cruciaal belang bij de vormgeving van alternatieve vormen van publieke betrokkenheid bij het staatsbestuur.

\subsubsection{CENTRALISERING VAN STAATSBESTUUR EN DE ZOEKTOCHT NAAR POLITIEKE VERNIEUWING, 1929-1945}

In de loop van de jaren dertig nam de wens in de richting van centraal bestuur toe. De financiële crisis van 1929 en de nasleep ervan in de tweede helft van het interbellum speelde daarin een doorslaggevende rol. Vooral op het gebied van zorg, armoede, volkshuisvesting, en arbeidsvoorziening nam de wens tot centralisatie toe. In 1933 stonden de verkiezingen in het teken van het thema 'krachtig staatsbestuur'. ARP-voorman H. Colijn (1869-1944) werd nu gezien als de man van de daad die Nederland uit de ellende kon helpen. Colijn, die in de jaren dertig het bestuur domineerde, vormde een crisiskabinet dat - zonder de SDAP - alle partijen omvatte. Met die steun ging hij aarzelend over tot een aantal steunmaatregelen, dat in wezen neerkwam op het afschermen van de Nederlandse markt. Formeel werd weliswaar nog altijd beweerd dat het vrijhandelssysteem intact was, maar geleidelijk werden nu inbreuken op dat systeem gemaakt. Al snel bloeide er een aantal crisisinstellingen op. Een landbouwcrisiswet uit 1933 fungeerde als raamwet voor verschillende regelingen en steunoperaties. Dit breidde zich uit naar steun voor noodlijdende bedrijven in de landbouw, handel- en nijverheidssector. Er kwamen ook steunregelingen voor werklozen en net als in de Eerste Wereldoorlog werd er een nationaal steuncomité opgericht, het Nationaal Crisis Comité, dat ditmaal onder bescherming kwam te staan van prinses Juliana (1909-2004) (De Rooy 1999a: 200-212). Ondanks reserves was er sprake van een toenemend centraal staatsbestuur van de publieke zaak. Wel trad de overheid doorgaans zeer terughoudend op. Zo werd in 1936 aarzelend een begin gemaakt met overheidsbemoeienis bij de lonen door invoering van een algemeen verbindend verklaring van collectieve arbeidsovereenkomsten (cao's) (De Rooy 1999a: 213). De staat creëerde zo voor zichzelf weliswaar een rol als regisseur in loonzaken, maar 
(her)bevestigde ook het primaat van de maatschappelijke partners bij behandeling van de publieke zaak.

De SDAP, buitenspel gezet door Colijn (en de RKSP), greep de ontwikkeling naar toenemend staatsbestuur in het sociaaleconomische leven aan om te pleiten voor een sterkere en structurelere rol voor de overheid bij de publieke zaak. In september 1935 presenteerde zij een moderne visie om de economie op gang te krijgen door overheidsinvesteringen, uitgewerkt in het Plan van de Arbeid van J. Tinbergen (1903-1994), destijds werkzaam bij het CBS. Om herhaling van de crisis te voorkomen zou dit gepaard moeten gaan met verdere versterking van de greep van de staat op de economie.

Het Plan van de Arbeid was onderdeel van een politiek vernieuwingsproces van de SDAP, die in toenemende mate afscheid nam van het historische materialisme.

Ook was het onderdeel van een zoektocht naar een bredere publieke representatie, waarbij de SDAP zich steeds meer van een arbeiderspartij naar een volkspartij wenste om te vormen (De Rooy 1999a: 215-216). De zoektocht naar een publieke dimensie voorbij de 'hokjes' van de verzuiling paste bovendien in een algemene herwaardering van het parlementair democratische bestel. Van cruciale betekenis in dat proces was de opkomst van de Nationaal-Socialistische Beweging (NSB), die door de economische crisis aan aanhang won. In 1935, toen de NSB bijna 8 procent van de stemmen bij de landelijke verkiezingen haalde, nam de publieke veroordeling van de beweging toe. In juni 1935 werd de Nederlandsche Beweging voor Eenheid door Democratie (EDD) opgericht, dat vooral liberalen en socialisten samenbracht en een aantal van 30.000 leden verwierf. Onder druk van de opkomst van de NSB, maar vooral door die van nazi-Duitsland, leek het aanzien van de parlementaire democratie weer enigszins toe te nemen. ${ }^{11}$ In de strijd tegen nazi-Duitsland werd behoud van 'democratie' steeds meer het symbool van de nationale vrijheid. Volgens P. de Rooy zou kritiek op de parlementaire democratie zich nu vooral gaan hullen in kritiek op de verzuiling, die door zijn "schotjesgeest" als belemmering werd gezien voor het ideaal van gemeenschap in de maatschappij (De Rooy 1999a: 129).

De zoektocht naar een gemeenschap voorbij de verzuilde hokjesgeest beïnvloedde koningin Wilhelmina (regeerperiode 189o-1948), die tijdens de Tweede Wereldoorlog in ballingschap op zoek ging naar wegen om die gedachte verder uit te bouwen. Ook in het bezette Nederland, van 1940 tot 1945, werden pogingen ondernomen om het versplinterde en verzuilde politieke stelsel te hervormen in de richting van politieke eenheid. Een eerste aanzet was de (omstreden) Nederlandsche Unie, die hervorming van dat stelsel zocht tijdens de bezetting (Ten Have 1999). Daarnaast - en in een geheel ander klimaat - werd er ook nagedacht over invulling van het politieke bestel in Nederland voor na de bezetting. Om de publieke representatie en eenheid te vernieuwen lanceerde een aantal vooraan- 
staande gijzelaars in Sint-Michielsgestel de idee van oprichting van een nieuwe eenheidsbeweging, de Nederlandse Volksbeweging (NVB), waarin sociaalpolitieke vernieuwingsdrang nauw verbonden was met de idee van een morele nationale regeneratie (De Rooy 2005a: 204-206). De beweging, die op de steun van koningin Wilhelmina kon rekenen, kreeg in 1946 uiteindelijk vorm als een politieke partij door de oprichting van de Partij van de Arbeid (PvdA). De SDAP ging volledig op in deze partij (samen met enkele liberalen); daarmee nestelde zich tevens de wens tot een sterker centraal staatsbestuur in een belangrijk deel van de politieke vernieuwingsbeweging na 1945. Ook bij andere (deels reeds bestaande) partijen ontstond nu de behoefte aan een sterker centraal staatsbestuur, zij het dat dit vooral staatsbestuur zou moeten zijn om feitelijke economische ontwikkelingen te begeleiden en niet om deze ontwikkelingen van bovenaf in te richten.

\subsection{CENTRAAL STAATSBESTUUR EN DE MAAKBAARHEID VAN PUBLIEKE BETROKKENHEID, 1945-1977}

Anders dan na de Eerste Wereldoorlog was Nederland na 1945 ontwricht en verwoest. Het accent lag daarom op de wederopbouw van Nederland. Staatsbestuur, dat sinds de late jaren dertig op een bredere publieke steun kon rekenen, werd als instrument tot maatschappelijke ordening vooralsnog nauwelijks omarmd. Er was echter wel algemene acceptatie dat de staat gewenst was en een sterkere-lees: sturende - rol zou kunnen spelen. Met de Marshallhulp, waardoor Nederland sinds 1948 financiële steun van de Verenigde Staten kreeg, verbeterde de economische toestand. Rond 1950 was de oorlogsschade grotendeels hersteld, waarna - na vrije prijsontwikkeling en opheffing van importbeperkingen en rantsoeneringen - twee decennia van ongekende economische groei volgden; achteraf niet door velen verwacht, die zich toen fixeerden op de gevolgen van het verlies van Indië.

Geleidelijk ontstond in dit klimaat ook meer aandacht voor de toekomst, waarbij de idee dat 'vooruitkijken' een rol zou moeten spelen in bestuur een structurele uitwerking kreeg in de jaren zestig en zeventig (Schuyt en Taverne 200o). Een sterk geloof in de maakbaarheid van de samenleving bepaalde het karakter van het naoorlogse beleid. Dit geloof was onlosmakelijk verbonden met een nieuwe opvatting over democratie, die uitging van de idee dat mensen recht hadden op bestaanszekerheid. Beïnvloed door Britse en Duitse beleidsopvattingen stelde een regeringscommissie - de reeds tijdens de oorlog in Londen ingestelde commissieVan Rhijn - kort na de bevrijding officieel vast dat elke burger recht had op sociale zekerheid, en dat het de plicht was van de staat dat recht te garanderen (Kappelhof 2007; Rigter, Van den Bosch, Van der Veen en Hemerijck 1995: 141-197). Daarmee kreeg het verbond van 1848 tussen staat en burgers een nieuwe dimensie, die zijn weerslag vond in de bestuurlijke vormgeving sinds 1945. Opmerkelijk was het 
uitgesproken paternalistische karakter van deze democratisering; de bevolking werd niets gevraagd. Publieke betrokkenheid bij bestuur was ook zeer beperkt. Dit veranderde vanaf de jaren zestig, toen burgers steeds meer door staat en maatschappij bij bestuur werden betrokken (Kennedy 1995).

2.3.1 CONSENSUS, OVERLEG EN EEN GECENTRALISEERDE 'ZUILENSTAAT', 1945-1959

$\mathrm{Na}$ de oorlog keerde men weliswaar niet volledig terug naar het oude partijenstelsel, maar van een radicale vernieuwing of 'doorbraak' was geen sprake. Wel was waardering voor het parlementaire stelsel toegenomen. Bovendien zochten de vooroorlogse partijen nu ook naar grotere publieke betrokkenheid. Behalve de SDAP, die opging in de PvdA, besloot de RKSP zich om te vormen tot een Katholieke Volkspartij (KVP). In navolging van de SDAP stelde deze zich zo open voor de gehele Nederlandse samenleving, ook al was de KVP toch vooral een katholieke partij. Beginselen werden aangevuld met partijprogramma's, waardoor de politiek 'praktischer' werd en een weg zocht voorbij de ideologische patstellingen van voor de oorlog. De eerste verkiezingen sinds de oorlog vonden plaats in 1946, waarbij de 'doorbraak'-partij PvdA (slechts) 28 procent van de stemmen haalde. De KVP en

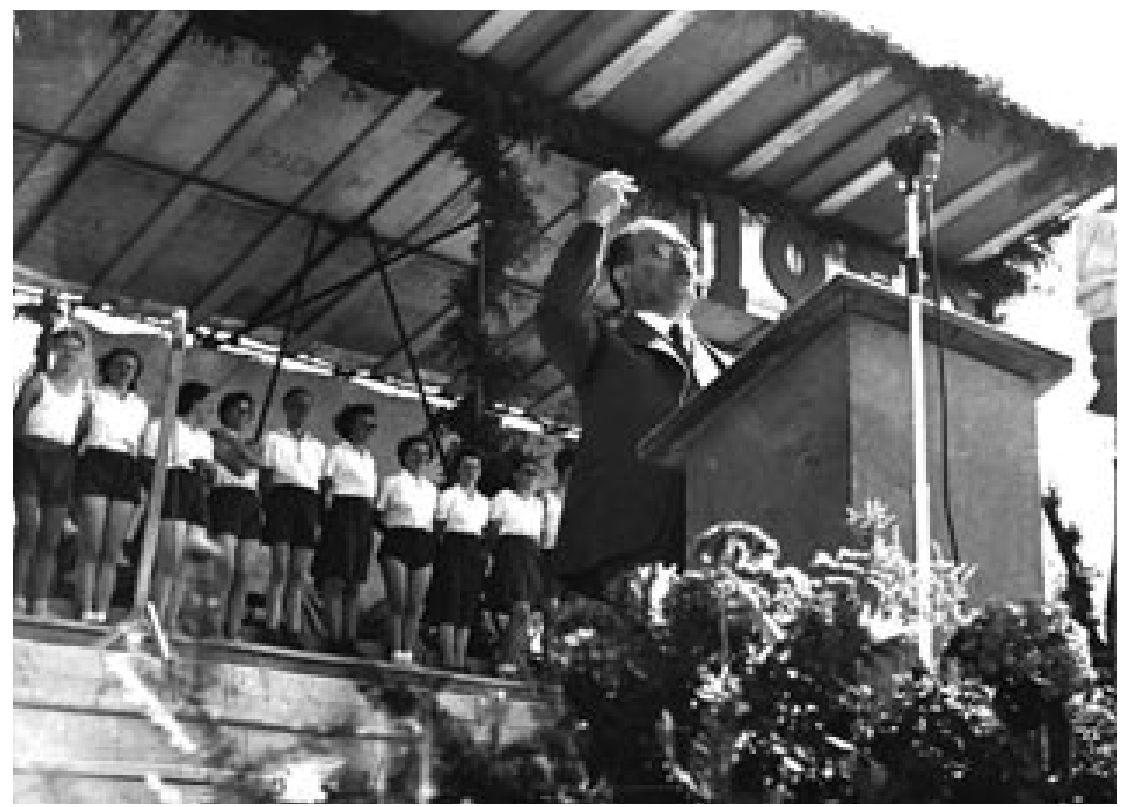

Na de Tweede Wereldoorlog bloeide het verzuilde verenigingsleven van voor de oorlog weer snel op. Verzuilde organisaties vormden schakels tussen burgers en de voormannen van de zuilen. Op deze foto spreekt premier Drees op 11 juni 1950 70.0oo leden van de vARA toe ter gelegenheid van haar zilveren jubileum in het Sportpark te Hilversum. 
ARP kregen respectievelijk 31 procent en 13 procent. Onder leiding van premier W. Drees (1886-1988) (PvdA) ontstonden er vanaf 1946 vier brede coalities, waarbij zowel confessionelen als socialisten betrokken waren, maar soms ook liberalen. Gemiddeld werden deze 'rooms-rode' coalities gesteund door maar liefst 80 procent van de zetels in de Kamer, waarmee er een breed draagvlak was om over te gaan tot 'herstel en wederopbouw' van Nederland (De Liagre Böhl 1999: 276).

Het karakter van staatsbestuur na 1946 was zakelijk. De basisgedachte was dat wederopbouw samenwerking en saamhorigheid vereiste, wat werd vergemakkelijkt door de Koude Oorlog en een anticommunistische stemming. Om het bestuurlijke handelingsvermogen te vergroten ging men verdere ideologische twisten uit de weg. De elite van het maatschappelijke middenveld wist zo een opmerkelijke consensus te bereiken. Om concessies te doen in (ideologisch) belangwekkende kwesties, opereerde zij als onafhankelijke intermediair van en naar de 'verzuilde' achterban. Communisten, politiek georganiseerd in de Communistische Partij Nederland (CPN) (1935) en in de Eenheidsvakcentrale (EVC), werden buitengesloten. Een hiërarchisch besef sloot vervolgens ook openbaarheid van bestuur naar de media uit. Het is opmerkelijk dat sommige parlementariërs er zelfs bij de regering op aandrongen om ten gunste van de vrijheid van regeren niet al te veel adviezen openbaar te maken (Den Hoed 2007: 79).

Deze zakelijke en pragmatische aanpak van het openbaar bestuur stak scherp af tegen de gelijktijdige 'morele' versterking van de zuilen. Ondanks de vooroorlogse kritiek nam de verzuiling na 1945 sterk toe. Katholieken, die met de KVP weliswaar publieke verbreding zochten, liepen daarin voorop. In 1954 werden zij in een mandement van Nederlandse bisschoppen, De Katholiek in het openbare leven van deze tijd, opgeroepen om hun geloofsgemeenschap te versterken, onder meer door verbod op lidmaatschap van linkse organisaties, zoals het Nederlandse Verbond van Vakverenigingen (NVv) (1906) en de omroepvereniging VARA. Op korte termijn zag de KVP daarmee haar ledental stijgen van 270.000 in 1954 tot 430.000 in 1955 (De Liagre Böhl 1999: 277-278). Ook de gereformeerden werden sterker aan hun zuil gebonden. Midden jaren vijftig gaf maar liefst 82 procent van hen de voorkeur aan de ARP als politieke partij (Lijphart 1968: 60-61; De Liagre Böhl 1999: 278).

Tot 1959, met het aantreden van het kabinet-De Quay (1959-1963) ${ }^{12}$, overheerste een sterke behoefte om de collectiviteiten (de werknemers en de werkgevers) toch vooral zelf haar zaken te laten regelen. Zelfstandigheid op collectief niveau stond daarin centraal, zij het met meer positieve aandacht voor de overheid. Anders dan voorheen kreeg de overheid bij maatschappelijke 'ordening' een coördinerende rol, ook al bleven de sociale partijen uiteindelijk vrij om te bepalen in hoeverre en wanneer de overheid gewenst was. Het streven naar 'ordening' met vergaande bevoegdheden voor de staat, zoals socialisten wensten, sneuvelde al in 1946, toen 
de PvdA de discussie in een dergelijke richting hoopte te kunnen sturen. In de praktijk leken vooral katholieken hun stempel op het naoorlogse ordeningsprincipe te drukken. De wet op de Bedrijfsorganisatie (1950), die 'ordening' liet verlopen via door het bedrijfsleven opgezette autonome organisaties van werkgevers en werknemers, was doortrokken van de subsidiariteitsdoctrine. De staat kreeg volgens die wet weliswaar de directe coördinatie toegewezen in een Sociaal Economische Raad (SER), maar de sociale partners - die zitting kregen in die raad waren uiteindelijk vrij om te bepalen of overheidsinvloed wenselijk was. De SER was vooral een compromis tussen een centraler staatsbestuur enerzijds en een verdere uitbouw van maatschappelijk zelfbestuur anderzijds.

Desalniettemin trad de staat steeds meer op als een krachtige regisseur van de publieke zaak. Het aarzelende ingrijpen in loonvorming van de jaren dertig werd omgezet in grootschalige interventie bij het loon- en prijsbeleid. Via het Buitengewoon Besluit Arbeidsverhoudingen van oktober 1945 - een erfenis uit de bezettingstijd - werd de bevoegdheid om op landelijk niveau het loonpeil vast te stellen toegewezen aan het College van Rijksbemiddelaars, een ambtelijk verlengstuk van het ministerie van Sociale Zaken (voorheen: ministerie van Arbeid). Dit College was verplicht om advies te vragen aan de Stichting van de Arbeid (SvA) (1945), waarin werkgevers, vakbonden, landbouw- en middenstandsorganisaties samenwerkten (Van Bottenburg 1995). Aangezien het College zelden adviezen van de SVA in de wind sloeg, verzekerde de regering zich van instemming van de maatschappelijke groepen en hield ze tegelijk de regie. Dit 'overlegmodel' maakte scherpe loon- en prijsafspraken mogelijk, omdat de vakbeweging de achterban onder controle hield en staking beperkt werd ingezet. De lage lonen schiepen ruimte voor de opbouw van een omvangrijk stelsel van sociale voorzieningen, waardoor werknemers het voordeel kregen van een hele reeks sociale wetten, inclusief de Werkloosheidswet (ww) van 1949 en de Algemene Ouderdomswet (AOW) van 1957 (die door verplichte verzekering van werknemers de mogelijkheid creëerde voor de opbouw van een staatspensioen vanaf 65 jaar). Met het in 1952 opgerichte ministerie van Maatschappelijk Werk breidde de staat bovendien ook zijn bevoegdheden uit naar een terrein dat tot dan toe uitsluitend aan het lokale particuliere initiatief had toebehoord: de maatschappelijke dienstverlening. Om het verzuilde stelsel daarbinnen te doorbreken gaf het daarbij talrijke subsidies aan koepelorganisaties voor welzijns- en zorginstellingen. De staat versterkte daarmee tevens een verdere professionalisering van de zorgsector en zijn toezicht op de uitvoering van de Armenwet (vanaf 1963 de Algemene Bijstandswet). Net als aan de overlegtafel hanteerde de staat via subsidie een sterkere, maar indirecte manier van sturing.

De oprichting van de bovengenoemde SER (1950) en SVA (1945) als centrale organen voor advies en overleg paste in een ontwikkeling van verdere uitbouw van raden en adviescolleges, die sinds 1945 een grotere impact kregen op openbaar 
bestuur. Toonaangevend in deze jaren waren de nieuwe rekenmeesters van het Centraal Planbureau ( $\mathrm{CPB})$, dat in 1945 werd opgericht om de bevolking door structurele planning te beschermen tegen 'uitwassen' van de vrije (internationale) markt. Ook het CBS, dat al bestond, nam in betekenis toe. Anders dan in de jaren dertig was het parlement tot midden jaren vijftig opvallend positief over deze bureaus, raden en stichtingen. De Tweede Kamer zag ze als complementair voor het werk van de Kamer en als middel om de groei van de staat te beperken in omvang en reikwijdte. De SER bood bovendien het model van een overleg- en adviesraad dat nu ook voor andere terreinen werd gekopieerd (bouwnijverheid, ruimtelijke ordening, sociale zekerheid en zorg).

Daarnaast kenmerken deze jaren zich door de opkomst van particuliere stichtingsen bedrijfsvormen - de nv's - bij de overheid. Het gebruik van privaatrechtelijke middelen sloot aan bij een bredere, uit de Verenigde Staten overgewaaide ontwikkeling om concepten uit het bedrijfsleven en bedrijfskunde toe te passen op de overheid. Het paste in de lijn van toenemende vervlechting van staat en economie sinds 1890 .

\subsubsection{CENTRAAL STAATSBESTUUR, BELEID EN 'BURGERLIJKE ONGEHOORZAAMHEID', 1959-1977}

De jaren zestig vormden een omslag in het denken over staat en maatschappij, en daarmee over de invulling van het openbaar bestuur. In plaats van nadruk op functionele decentralisatie of invoering van nieuwe bedrijfskundige concepten en modellen of om bestuurlijke efficiency te bevorderen, werd de nadruk nu gelegd op centralisatie en - vooral - centrale planning. De staat, die zich een sterkere rol ging toe-eigenen, klampte zich vast aan de maakbaarheid van de maatschappij vanuit één centraal punt: de overheid. Met een goed kompas en verrekijker kon de overheid in principe ver vooruitzien, zo dacht men, en preventieve maatregelen treffen om crises en tegenslag in de toekomst te voorkomen. Beleid, een centraal begrip sinds deze tijd, werd iets wat je kon 'maken', iets wat je kon plannen. Een dergelijke benadering ging uit van een sterk optimisme en vertrouwen in de toekomst. De oplossing van sociale problemen leek door kennis en beleid niet langer ondenkbaar (Nelson 1977).

Deze omslag, vooral voelbaar sinds het kabinet-Marijnen (1963-1965), was een reactie op de zakelijke, materiële periode van economische wederopbouw en hestel. Het succes van die opbouw leidde tot een betere levensstandaard en hogere verwachtingen over andere onderdelen van de maatschappij dan alleen de economie. Er was behoefte aan een inhaalslag op immateriële gebieden. Daarbij was de gedachte dat niet 'welvaart', maar ook 'welzijn' zou moeten worden verhoogd. Terreinen die direct na de oorlog wel even konden wachten met nieuw beleid, zoals rechtsbescherming, sociale grondrechten, immateriële arbeidsvoorwaarden 
en ethisch kwesties (abortus, euthanasie) kwamen nu centraal te staan. Bovendien creëerde ook de welvaart zelf behoefte aan nieuwe wetgeving en bestuurlijke maatregelen. In partijpolitieke kaders werd verhoging van het welzijn en maatschappelijke geluk bovendien een nieuw doel. De PvdA wierp zich daarbij op als voortrekster. In 1963 liet zij een beroemd rapport verschijnen, Om de kwaliteit van het bestaan, dat voor een belangrijk deel was geschreven door J.M. den Uyl (19191987). Het rapport bepleitte een planmatige welvaartsontwikkeling. De regering moest hiervoor zorgdragen; zij moest nivellerend optreden door middel van inkomenssubsidies en de toegang tot belangrijke voorzieningen aan alle burgers garanderen. Daarmee wenste het rapport tegemoet te komen aan de toegenomen loonsverschillen in Nederland sinds de loonafspraken van de jaren vijftig.

De PvdA, en met name het kabinet-Den Uyl (1973-1977), zette dit ideaal van een uitbouw van de zorg van de staat voor burgers sterk in, ook al kreeg deze uitbouw van de 'verzorgingsstaat' uiteindelijk de voornaamste impuls door deelname aan de regering van confessionelen - en met name van de KVP - en liberalen. De belangrijkste sociale verzekeringswetten uit deze jaren waren: de Algemene Kinderbijslagwet (1963), de (herziene) Ziektewet (1967), de Wet Arbeidsongeschiktheidsverzekering (1967), en de Algemene Wet Bijzondere Ziektekosten (1967). De kroon op deze tendens was echter de Algemene Bijstandswet (1963), die iedere burger een bestaansminimum garandeerde. Daarmee ging het minimumloon, bij wet ingevoerd in 1969, een centrale rol spelen bij sociale zekerheid (De Liagre Böhl 1999: 294).

De uitbouw van de verzorgingsstaat ging gepaard met bevordering van maatschappelijke 'inspraak' en transparantie. De inrichting van de staat moest niet enkel planmatiger, maar vooral ook 'communicatiever' en 'democratischer' worden. Democratisering had niet enkel betrekking op verdere ontwikkeling van het constitutionele parlementaire stelsel, maar werd opgevat als een breed proces dat zich niet beperkte tot de staat, maar alle maatschappelijke instellingen en kringen betrof, inclusief kerken, scholen, stichtingen en verenigingen. Vaak liep de politieke leiding in dat proces om inspraak te bevorderen voorop, zoals bij beleid om verenigingen en stichtingen democratischer te maken. Ook wilden bestuurders burgers leren om meer gebruik te maken van hun individuele en groepsrechten, zoals consumentenrechten en recht op gratis rechtshulp. Burgers werden daarbij niet langer alleen aangesproken als werknemers (en werkgevers), maar vooral ook als consumenten (en producenten). Vervolgens legden 'moderne' bestuurders de 'autocratische' stijl van hun voorgangers naast zich neer. Bij het kabinet-Den Uyl bereikte dit een (voorlopig) hoogtepunt met het onderling tutoyeren en het soms aanspreken van het staatshoofd als 'Mevrouw' (Van Dam 2009: 123-124). Bij dit alles ging het om een bewuste stijlverandering en vorming van 'publiek' bestuur. De maakbaarheid van publieke betrokkenheid liep zo parallel aan de maakbaarheid van beleid en openbaar bestuur. 
Daarmee kwam democratisering voor een belangrijk deel van bovenaf (Kennedy 1995). Dat neemt niet weg dat de roep om participatie en publieke betrokkenheid bij openbaar bestuur ook toenam in de samenleving zelf. Nadruk op efficiency en deskundigheid matigde reeds in de jaren vijftig de ideologische standpunten in het middenkader van de zuilenorganisaties zelf. Vooral bij de PvdA, maar ook bij de ARP - en dan vooral bij de Nederlandse Hervormde Kerk - sloeg dit al vroeg om in een relativering van de verzuiling. In de jaren zestig zette dit door. Burgers individualiseerden steeds meer, en maakten zich los van de zuilen. Tegelijkertijd werden nieuwe sociale en intellectuele verbanden gelegd, dwars door (en voorbij) de verticale scheidslijnen van de 'oude' zuilen. De opkomst van spontane bewegingen en bevlogen actiegroepen, waaronder Provo, zette het (verzuilde) verenigingswezen onder druk. Daarbij nam ook de voor de verzuiling zo kenmerkende sociale controle op gedrag sterk af, deels omdat jongeren nu op grotere afstand van hun ouders en hun milieu leefden. Burgers lieten nu ook steeds meer van zich horen, soms in combinatie met geweld en protest, zoals tijdens de huwelijksvoltrekking van koningin Beatrix en prins Claus in maart 1966. Studenten, die van 1950 tot 1970 in aantal toenamen van ruim 28.000 tot 103.000, eisten directe zeggenschap in de opzet en uitvoering van onderwijs. De opkomst van televisie droeg - in combinatie met een hogere scholingsgraad - sterk bij aan de groei van meer en meer 'mondige' burgers. De pers stapte over van gezagsgetrouwe naar gezagskritische journalistieke beroepsstijl (Wijfjes 2004). Universiteiten ontpopten zich tot kweekvijvers voor vernieuwing en radicalisme, waardoor traditioneel bestuur verder aan gezag inboette.

Naar de politiek vertaalde zich deze tendens in het bijzonder door de oprichting van D'66, dat in deze jaren onder leiding van ex-journalist H.A.F.M.O. van Mierlo (1931-2010) naar een vernieuwing van het partijenstelsel en een vergroting van openbaarheid in bestuur zocht. De partij zocht naar een functionalisering en verzakelijking van politiek en bestuur met centrale aandacht voor een bevordering van burgerlijke participatie en inspraak. Om de afstand van het bestuur tot de burger te verkleinen bepleitte D'66 zowel een gekozen minister-president als een gekozen burgermeester. Dergelijke ideeën werden rond diezelfde tijd ook aangekaart in een rapport van de Staatscommissie voor advies inzake de grondwet en de Kieswet (ofwel de commissie-Cals/Donner) uit 1967, maar maakten uiteindelijk geen kans. Het kabinet-De Jong (1967-1971), dat de commissie-Cals/Donner weliswaar zelf had ingesteld, weigerde dit rapport ter discussie voor te leggen aan de Tweede Kamer. Op geheel andere wijze zocht Nieuw Links, een vernieuwingsbeweging binnen de PvdA, naar bestuurlijke vernieuwing en grotere politieke betrokkenheid van burgers door (ideologische) polarisatie in de politiek.

Ondanks de toenemende kritiek op het bestuurlijke stelsel en het technocratische karakter van de overheid bouwde de laatste haar planningsysteem uit. Niet de toppen van de zuilen, maar overheidsdepartementen en -instellingen ( $\mathrm{CPB}, \mathrm{SCP}$ ) 
kregen centrale rollen toebedeeld. Het aantal departementen nam qua functies en personeel snel in omvang toe. Ook groeide de rivaliteit tussen deze departementen (en directoraten-generaal) door wat later wel 'verkokering' is genoemd (Commissie Hoofdstructuur Rijksdienst 1980). Departementen ontwikkelden zich tot verticale kolommen, met eigen wetten en eigen velden van (gesubsidieerde) organisaties (Van Poelje 1977: 53-56). Aan de top van deze sterk georganiseerde organisaties ontstonden bovendien veel nieuwe onderraden van de (centrale) ministerraad, ondersteund door evenzovele ambtelijke voorportalen. Op hun beurt werden zij alle 'geassisteerd' door planbureaus en adviesorganen. Centralisatie ging daarbij vooral ten koste van lokaal bestuur en particuliere autonomie. Gemeenten werden bovendien nu ook geacht onderling meer samen te werken en intergemeentelijk bestuur te ontwikkelen. Het gevolg was schaalvergroting van gemeenten enerzijds en een roep naar wijkraden met eigen bestuursbevoegdheden binnen die gemeenten anderzijds (waardoor de landelijke tendens naar bestuurlijke verticalisering zich op lokaal niveau ging weerspiegelen).

De nadruk op beleidsplanning gaf tevens vorm aan de geboorte van het nieuwe beroep van beleidsmedewerker. De door hem of haar geschreven nota's speelden in deze jaren een centrale rol in het openbare bestuur. Aanvankelijk was een nota niet veel meer dan een wat ruim uitgevallen voorstadium voor het maken van een memorie van toelichting bij een wetsontwerp, maar op den duur werden nota's steeds meer eigenstandige producten die in de plaats konden komen van wetten (Rosenthal en Ringeling 1976). De regering trad ook met haar nota's naar buiten en organiseerde er - in lijn van de bovengenoemde democratisering - inspraak omheen. Anders dan bij wetgeving in de voorgaande jaren, ging het bij beleid dus niet om structuur en 'ordening' in verhoudingen, maar om planning van de toekomst en om veranderingen in de samenleving. De maatschappij diende door beleidsplanning in beweging te worden gebracht (Van Gunsteren 1976; Den Hoed et al. 1983). Beleidsplanning zocht daarmee aansluiting bij sociaal burgerschap, dat niet enkel probeerde om de maatschappij verder aan de staat te binden, zoals sinds de jaren 1890 het geval was geweest, maar ook om die staat sterker aan de maatschappij te binden.

Om dat doel naderbij te brengen werd veel verwacht van de sociale wetenschappen. Kennis en expertise bij bestuur en (vooral) totstandkoming van beleid stegen in aanzien. Hierdoor nam het aantal planbureaus en adviesorganen verder toe, ook al bleven 'oudere' organen als SCP, CBS en СPB een spil in dit verder uitdijende advies- en overlegweb. Professoren in het bijzonder werden geroepen om ministers bij te staan in beleidsvoorbereiding en kregen zitting in commissies. Vertrouwen in het vermogen van wetenschappelijk advies om vorm te geven aan 'ruimtelijke ordening' leidde onder meer tot instelling van de Raad van Advies voor Ruimtelijke Ordening. In het verlengde van het streven naar openbaarheid, versterkt door het in 1970 verschenen Rapport van de commissie heroriëntatie 
overheidsvoorlichting (waarin een wet op de openbaarheid werd ontworpen), werden nota's van dergelijke raden doorgaans openbaar gemaakt om open gedachtewisseling met de maatschappij te stimuleren. In de Raad van Advies voor Ruimtelijke Ordening waren niet alleen vergaderingen openbaar, maar was ook sprake van uitgebreide raadplegingsprocedures, die burgers toegang gaven tot (mede)vormgeving van advies en overleg (Van Putten 1977).

Ondanks dit toenemende publieke karakter van adviesraden en commissies nam de zorg en het wantrouwen ten aanzien van deze instellingen in de jaren zeventig toe. Deels had dit te maken met de 'wildgroei' aan raden en commissies; omstreeks 1970 waren er zo'n 350 raden, mede als gevolg van competitie tussen beleidsterreinen, experts en een uitbreiding van de overheidssubsidies. Kenmerkend voor het parlementaire debat was echter vooral de vrees dat adviesraden de positie van de representatieve democratie zouden verzwakken. Anders dan in de jaren vijftig werden zij nu eerder als ondermijning van het werk van de Tweede Kamer gezien, des te meer omdat zij (oncontroleerbare) invloed wonnen aan de voorkant van het beleidsproces, dat dus sterk in betekenis was toegenomen.

Sommige parlementariërs zagen adviesraden als een soort vijfde macht, die naast de 'vierde macht' van ambtenaren (Crince Le Roy 1971) bijdroeg aan een ongewenste versterking van de regeringsmacht tegenover het parlement.

Het parlement zocht in deze jaren naar versterking van het primaat van de politiek bij openbaar bestuur enerzijds en van publieke betrokkenheid via parlementaire democratie anderzijds. Het koesterde daarbij vooral de institutionele situatie zoals die sinds Thorbecke tot stand was gekomen, ook al stelde het zich steeds meer open voor enkele structurele veranderingen in het openbaar bestuur. Om grip te krijgen op het toegenomen belang van beleid, sprak het parlement zich bijvoorbeeld steeds meer uit over beleidsnota's, waarbij de aandacht enigszins verschoof van wetgeving naar beleidsvorming. In de geest van dit proces constateerde T. Koopmans een overgang van 'codificatie' naar 'modificatie' (1970), wat door velen als een normatief wenselijke ontwikkeling werd gezien. Een probleem bij die verschuiving was echter dat niet precies duidelijk was wat de Kamer nu wel over dergelijke nota's te zeggen had, en wat niet. De parlementaire onzekerheid in de feitelijke vormgeving van het openbaar bestuur werd in deze jaren bovendien nog vergroot door het ontstaan van een pluriformer, mondiger en ook actiever geworden publiek. Steeds vaker gaf het publiek vorm aan het ideaal van een (bewuste) 'politieke natie' buiten dat parlement, bijvoorbeeld in actiegroepen en nieuwe sociale bewegingen, waarbij het parlement slechts in beperkte mate grip op de ontwikkelingen kon krijgen.

Met andere woorden: er was nu dan wel sprake van grotere publieke betrokkenheid bij de politiek, maar deze betrokkenheid creëerde nu tevens problemen omtrent de representatie daarvan via het traditionele parlementaire stelsel. Politieke partijen ondervonden daardoor steeds meer moeite om een brug te slaan naar de achterban en maatschappij, en met name na de jaren zeventig. 


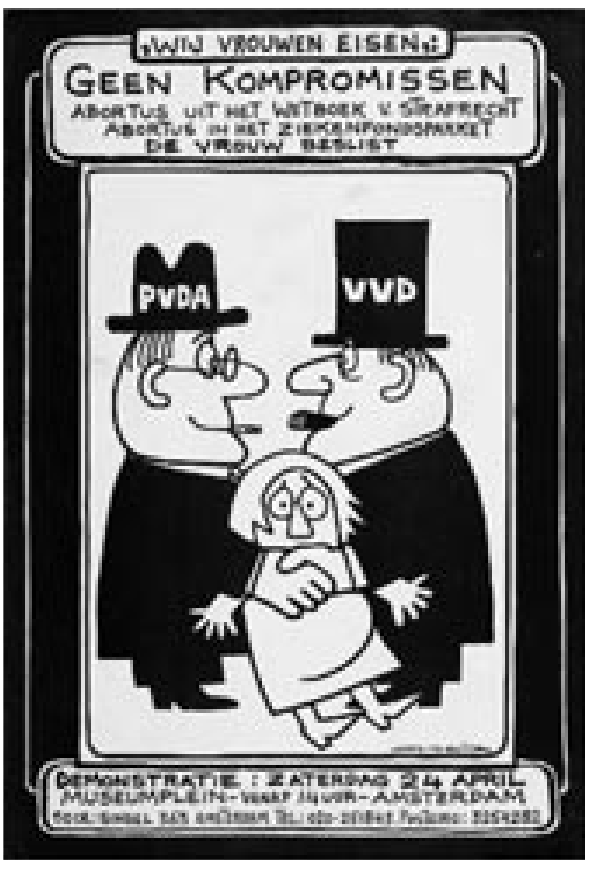

Affiche "Wij vrouwen eisen" ten behoeve van demonstratie op 24 april 1975, Museumplein, Amsterdam

Demonstraties en buitenparlementaire actie kwamen sterk op in de jaren zestig en zeventig van de twintigste eeuw. De ontzuiling leidde tot ontmanteling van de macht van de verzuilde - en (hoofdzakelijk) mannelijke - elite van het openbaar bestuur. In het hier afgebeelde affiche wordt opgeroepen tot deelname aan de demonstratie tegen de 'abortus-initiatiefwet' (1975) van PvdA en vvD. Vrouwen, die deze wet van de 'hoge heren' uit de conventionele politiek niet ver genoeg vonden gaan, wilden "geen kompromissen”. Zij lieten (evenals veel andere nieuwe sociale groepen) hun stem duidelijker horen en eisten nieuwe rechten, waaronder invoering van het recht van de vrouw om zelf te beslissen over abortus en opname van abortus in het ziekenfondspakket.

Internationaal Informatiecentrum en Archief voor de Vrouwenbeweging

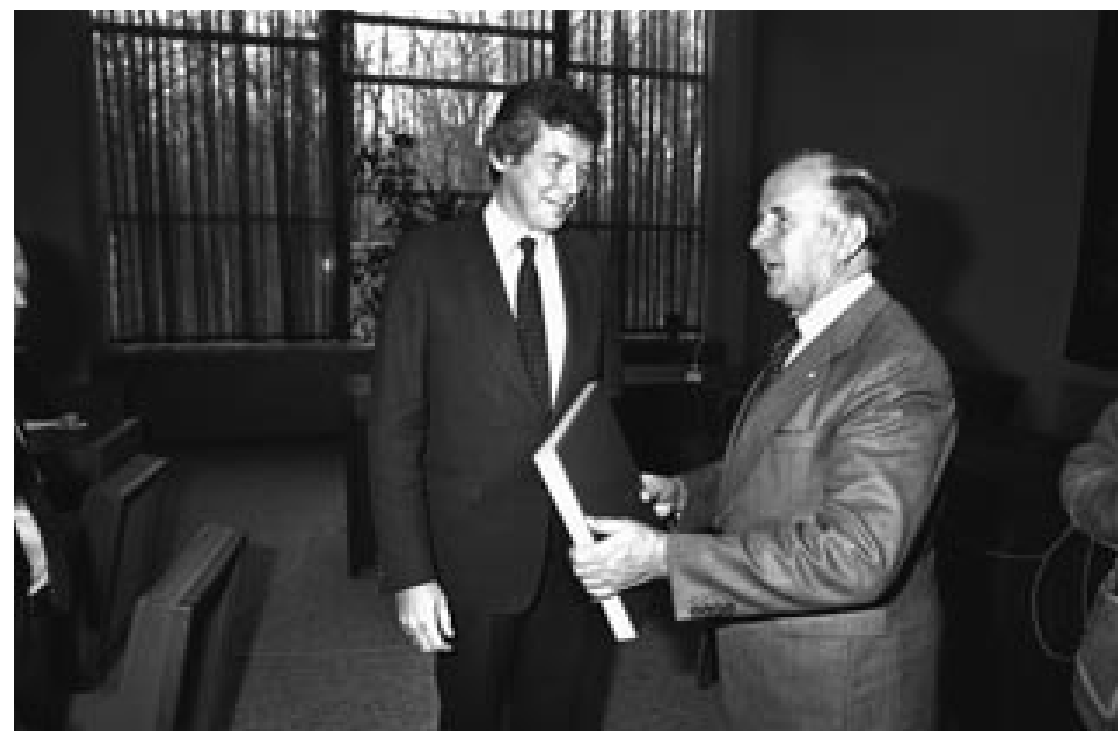

Kok en Van Veen (1982), met W. Kok namens de werknemers (links) en C. van Veen namens de werkgevers (rechts)

Op 24 november 1982 sloten de leiders van werkgevers en werknemers een sociale vrede in de privaatrechtelijke Stichting van de Arbeid. Dit zogeheten Akkoord van Wassenaar is illustratief voor de totstandkoming van afspraken tussen sociale partners buiten de regering om. Deze vorm van samenwerking werd later internationaal beroemd als 'poldermodel'. 


\subsection{STAATSBESTUUR EN PUBLIEKE BETROKKENHEID MET EEN JANUSKOP, 1977-2010}

Aan het einde van de jaren zeventig voltrok zich een grootscheepse transformatie van het openbaar bestuur. De verzorgingsstaat kwam onder druk te staan door een economische recessie, die vanaf 1973 inzette. In Nederland ontbrandde er een felle discussie over de verzorgingsstaat, waarvan de toekomst nu niet enkel onzeker leek te zijn geworden, maar die tevens vaak mede verantwoordelijk werd gehouden voor de economische recessie als gevolg van de hoge lasten die de verzorgingsstaat met zich meebracht. Vooral vanaf 1979, toen een tweede oliecrisis inzette en de vrees toenam dat de economische recessie niet van korte duur zou zijn, nam de kritiek toe. ${ }^{13}$ Hoewel dit in wezen geen afbreuk deed aan de idee dat burgers recht op sociale zekerheid hebben, nam wel de kritiek op staatsinmenging bij de publieke zaak toe. Volgens critici van de verzorgingsstaat had de overheid in de jaren zestig en zeventig veel te veel willen regelen en plannen, wat tot een gebrek aan efficiency en wettelijke en bestuurlijke onoverzichtelijkheid had geleid. Vanaf het begin van de jaren tachtig verruilde het ideaal van de jaren zestig zich voor een veel zakelijker optreden van de overheid, waarin financiën en bezuinigen centraal kwamen te staan en ideologische twisten naar de achtergrond verdwenen. De staat werd steeds meer gezien als regisseur op afstand, die de maatschappelijke partijen weer zelf het werk moest laten doen. Daarbij dienden nu niet zozeer de toppen van het maatschappelijk middenveld, zoals in de jaren vijftig, noch die van de departementen, zoals in de jaren zeventig, maar bovenal (individuele) burgers meer bij te dragen aan het bestuur. Door de ontzuiling was openbaar bestuur nu aangewezen op een zelfstandiger, zij het ietwat "verweesde samenleving” (Fortuyn 2002a).

Openbaar bestuur kreeg daarbij een wat paradoxaal ogende januskop, zowel omwille van de vorm en het karakter van het staatsbestuur als omwille van dat van publieke betrokkenheid. Zo voltrok zich een proces van een versterking van het staatsbestuur via centrale regie en aansturing enerzijds en van een beperking van staatsbestuur door privatisering, liberalisering en verzelfstandiging anderzijds. Burgers werden daarin gestimuleerd om een grotere (en actievere) rol te spelen bij het openbaar bestuur, maar veel van die betrokkenheid geschiedde buiten het traditionele en transparante parlementaire proces om. Ook bracht de Europese Unie (EU), die een almaar dominantere rol ging spelen bij de vorming van het Nederlandse beleid, een nieuwe dimensie teweeg, die het karakter van deze dubbele januskop nog verder compliceerde. Om het bestuur in Nederland af te stemmen op het bestuur van de EU, onthield de regering in Den Haag het publiek (al dan niet met opzet) steeds vaker van openbaarheid van zaken. Ook stond de Tweede Kamer niet in (duidelijke) relatie tot deze 'vierde laag' bij de controle van het staatsbestuur. In de loop van de jaren tachtig en negentig kenmerkte het staatsbestuur zich weliswaar door meer openbaarheid dan ooit tevoren, maar datzelfde bestuur kwam zo ook terecht in nieuwe en ongekende vormen van publieke duisternis. 
2.4.1 FINANCIEEL BEHEER EN INSTITUTIONELE LIBERALISERING, 1977-200214

De kritiek op de verzorgingsstaat, en de wenselijkheid tot een gematigder staatsbestuur, vond weerklank bij de verkiezingen van 1977. Hoewel deze verkiezingen vooral ook winst opleverden voor de PvdA, was de spanning - mede door de ingezette polarisatiestrategie van Nieuw Links - met de oppositie toegenomen, waardoor samenwerking metandere partijen moeilijk werd. De confessionelen (ARP, KVP en $\mathrm{CHU}$ ), die aan succes hadden ingeboet in de jaren zeventig, hadden zich sinds 1975 verenigd in een federatie, welke zich in 1980 formeel zou omzetten in het ChristenDemocratisch Appèl (CDA). Het CDA profileerde zich als een partij van het midden en mede dankzij een succesvolle lancering in de media wist het ononderbroken een positie te veroveren in het hart van de regeringscoalities tot 1994. De liberalen, georganiseerd in de VVD (1948), ervoeren tevens een flinke groei. Sinds 1945 waren liberalen weliswaar niet altijd even kritisch geweest ten aanzien van de uitbouw van de verzorgingsstaat, maar nu die staat onder vuur kwam te liggen, namen liberalen het voortouw om te pleiten voor beperking van overheidstaken. Voor het eerst sinds 1918 wisten liberalen zich daarbij tot een volkspartij te ontwikkelen. Samen met het CDA vormde de partij in 1977 een coalitie onder leiding van A.A.M. van Agt (KVP). Dit kabinet stelde herziening van de verzorgingsstaat centraal, maar daar kwam uiteindelijk niet veel van terecht. In een tweede kabinet onder Van Agt (1981-1982) probeerde het CDA met de Pvd A een akkoord op te stellen, maar dit liep spaak op het te voeren sociaal en financieel-economisch beleid, zodat deze 'vechterscoalitie' reeds snel zijn ontslag aanbod. Het was vooral tijdens de kabinetten-Lubbers (1982-1994), waarin het CDA tweemaal met de VVD en eenmaal met de Pvd A regeerde, dat deze herziening van de grond kon komen.

Premier R.F.M. Lubbers gaf vanaf 1982 vorm aan een nieuwe beleidsfilosofie, die was gericht op het terugdringen van het financieringstekort, een verlaging van de werkloosheid, en een bevordering en verbetering van de vermogenspositie van bedrijven en van de ruimte om meer te kunnen investeren ('het economisch realisme'). Dit beleid, dat in veel opzichten voortborduurde op de plannen van het kabinet-Van Agt I (1977-1981), ging gepaard met een terugdringing van de collectieve sector en staatsbemoeienis bij behandeling van de publieke zaak. In het verlengde van de jaren zeventig stelde Lubbers daarbij vertrouwen in de inzichten van adviesorganen, zoals de Wetenschappelijke Raad voor het Regeringsbeleid (WRR), dat in 1980 met een invloedrijk rapport, Plaats en toekomst van de Nederlandse industrie, naar buiten trad en een versterking van de industrie en het primaat van de economie bepleitte (na jarenlange relativering daarvan ten gunste van 'welzijn' en nadruk op consumenten in plaats van productenten). Ook stelde Lubbers vertrouwen in het rapport van een adviescommissie onder leiding van oud-Shell-voorman G. Wagner, Een nieuw industrieel elan, dat bovengenoemde WRR-studie in neoliberale richting operationaliseerde en pleitte voor 'marktconform' staatsoptreden. 
Lubbers besloot direct na zijn aantreden tot een hervorming van het staatsapparaat. Hij deed dat zonder raadpleging van de sociale partners. De (publiekrechtelijke) SER, die de regering wettelijk verplicht was te consulteren, was sinds het loslaten van het overlegmodel uit de jaren vijftig en de politisering van de jaren zeventig min of meer verlamd geraakt. Opmerkelijk was dat de Kamer en de sociale partners de koers van Lubbers steunden. Pragmatisch ingesteld door de noodzaak een einde te maken aan de recessie keerde - na een periode van polarisatie en contestatie aan het eind van de jaren zeventig - een maatschappelijke consensus terug. Geheel buiten de staat om zochten werkgevers en werknemers in het kader van de SVA ook weer contact met elkaar, wat resulteerde in het akkoord van Wassenaar van november 1982. In ruil voor arbeidstijdverkorting werd loonmatiging gerealiseerd. De overheid stimuleerde dit pad naar maatschappelijke, privaatrechtelijke zelfstandigheid en zelfbestuur. Hoewel de ontzuiling en een toenemende maatschappelijke complexiteit eensgezindheid tussen sociale partners in de jaren tachtig bemoeilijkte, ontstond zo toch een hernieuwde grondslag voor maatschappelijke samenwerking, die in de loop van de jaren negentig steeds meer onder het predicaat 'poldermodel' door het leven ging. Dit 'model', dat gepaard ging met een opleving van neoliberalisme, kenmerkte zich door afwezigheid van publiek, geheim overleg en achterkamertjes (Te Velde 2010: 220); het was zo allesbehalve openbaar in de geest van het credo van Thorbecke en de democratiseringsbeweging van de jaren zestig.

De aanpak van Lubbers was zakelijk en was onderdeel van een gematigde, 'nononsense'-ideologie. Ideologische deeltwisten werden ondergeschikt gemaakt aan oplossingsgericht en efficiënt bestuur. Deze aanpak werkte door op allerlei fronten van politiek en bestuur. In de politiek was dit niet enkel voelbaar bij het CDA en de VVD, maar ook bij de PvdA, die vanaf het begin van de jaren tachtig langzaam afstand nam van de erfenis van Den Uyl en de polarisatiestrategie van Nieuw Links. Typerend was een publicatie van Paul Kalma, De illusie van de democratische staat (1982), waarin afstand werd genomen van de idee dat de staat de oplossing kon bieden aan alle maatschappelijke problemen. W. Kok (geb. 1938), minister van financiën in Lubbers III (1989-1994), zette deze weg naar verzakelijking en pragmatisme voort. Onder zijn leiding verschoof de aandacht van de PvdA naar het neoliberalisme, waardoor de partij dichter bij CDA en VVD kwam te staan. In 1994 vond deze weg een hoogtepunt in de vorming van een 'paarse' coalitie tussen PvdA, vvD en D'66 onder leiding van bovengenoemde Kok, waarin liberalen en socialisten voor het eerst in de geschiedenis met elkaar samenwerkten in een regeringscoalitie. Het was een kroon op het streven van D'66 naar een politiek pragmatisme voorbij de traditioneel ideologische 'kloof' tussen 'links' en 'rechts'.

De no-nonsensementaliteit van de jaren tachtig en negentig verruilde het primaat van de politiek voor dat van de economie. Niet de politiek, maar het bedrijfsleven - en daarmee bedrijfskundige modellen en theorieën - vervulde steeds vaker een 
voorbeeldfunctie voor de maatschappij. De regering speelde daarin een belangrijke en stimulerende rol door het bedrijfsleven te volgen qua managementstijl en door privatisering en verzelfstandiging van overheidsonderdelen en door algehele bevordering van marktwerking. Vergaderingen waren zakelijk (Smit-Kroes 1991: 270) en ministers behoefden niet langer 'thuis' te zijn op het terrein van hun ministerie, maar vooral managementcapaciteiten te hebben. Vooral in de kabinetten-Kok (1994-2002) was laatste idee sterk aanwezig. Centraal stond de aandacht voor financieel staatsbestuur en de invoering van - uit het bedrijfsleven ingevoerde - prikkels voor een efficiëntere uitvoering van beleid. Prestatiecontracten en resultaatgerichte afrekeningssystemen speelden daarbij een rol. Door de nadruk op financieel beheer werd de minister van Financiën veruit de belangrijkste minister ten aanzien van de collectieve uitgaven, die onder de verantwoordelijkheid vielen van zogeheten sectorministers (ofwel 'uitgavenministeries', zoals Sociale Zaken, Gezondheidszorg, Onderwijs en Volkshuisvesting, Ruimtelijke Ordening en Milieu). De zogeheten Zalmnorm uit het kabinet-Kok I, volgens welke extra inkomsten nog uitsluitend werden gebruikt voor een verlaging van het financieringstekort, vergrootte de beheersing van de overheidsuitgaven en versterkte het aanzien van die minister. Ook nam de invloed van het bedrijfsleven op het bestuur toe door directe advisering aan de regering door vooraanstaande managers. Die toename was ook zichtbaar op het Binnenhof door een gelijktijdige toename van limousines, waarmee (overheids)managers en hun vervangers zich naar het regeringscentrum lieten rijden (Mertens 2005).

De privatisering en verzelfstandiging van de uitvoerende taken van openbaar bestuur werden gestimuleerd vanuit de Angelsaksische managementfilosofie van New Public Management (NPM). De gedachte achter NPM was om een scheiding aan te brengen tussen beleid en uitvoering (OECD 1995). Door uitvoering te delegeren aan diegenen die dicht op de praktijk zitten, zou er doelmatiger en effectiever uitvoering van publieke taken ontstaan. Terwijl beleidsdoelen door bestuurders dienden te blijven worden geformuleerd, zouden maatschappelijke partijen en Zво's belast kunnen worden met de uitvoering van publieke taken. Om dat doel dichterbij te brengen zette de overheid tevens in op de privatisering en verzelfstandiging van staatsbedrijven, zoals het loodswezen en de NS, en besloot het tot de opsplitsing van de PTT en verkoop van zowel de Postbank als KPN. Daarbij werd een begin gemaakt met het afstoten van nutsbedrijven, die sinds het einde van de negentiende eeuw geleidelijk in handen van de gemeenten en vervolgens van de staat waren gekomen. Ook werd de economische verzelfstandiging bevorderd van de woningbouwverenigingen en de arbeidsvoorziening. De invoering van marktwerking bij de uitvoerende taken van de overheid kreeg een sterke stimulans door technologische ontwikkelingen die meer manieren van uitvoering en dus concurrentie mogelijk maakten (cf. telecom) en daarnaast door de val van de Berlijnse Muur in 1989, waardoor een einde werd gemaakt aan de Koude Oorlog. Zeker sinds het 'failliet' van het communisme stond weinig meer in de weg van de 
markt als succesformule voor de toekomst. Dit vertrouwen werd nog versterkt door de totstandkoming van een Europese interne markt in 199o. Nederland nam ten aanzien van de Europese marktregels en beginselen een betrekkelijk kritiekloze houding aan. Tijdens de kabinetten-Kok (1994-2002) ontstonden veel plannen tot invoering van marktwerking en liberalisering in Nederland, onder meer in telecom, openbaar vervoer, energie- en zorgsector, die tot aan de jaren tachtig nog vrijwel uitsluitend in handen van de staat hadden gelegen.

Dat neemt niet weg dat Nederland aanvankelijk vrij gematigd bleef in het afstoten van overheidstaken aan de markt. Anders dan in het Verenigd Koninkrijk of de Verenigde Staten pakte Nederland de privatisering milder en minder ideologisch aan. ${ }^{15}$ De meerderheid van de vernieuwingen was op de interne organisatie van het staatsbestuur gericht. Ter bevordering van de samenhang en doeltreffendheid van de staat werd er in de jaren tachtig en negentig naar gestreefd om de groei van het overheidsapparaat onder controle te houden. Daarbij werd er tevens naar gestreefd om overlapping van beleid en bestuurslagen te beperken. Nadruk lag op de 'ontvlechting' van de onderlinge relaties tussen ministeries, zoals door opheffing van coördinatieorganen tussen en binnen departementen. Ook lag er nadruk op de invoering van 'zelfbeheer' bij ministeries, zoals door overheveling van functies op het gebied van personeelsbeleid naar zelfstandige delen van de overheid. Er werd bovendien begonnen met de regionalisering en verzelfstandiging van de politie en met de afslanking van het militaire apparaat door de invoering van een beroepsleger. Ten slotte was er sprake van een stelselmatige overdracht van veel uitvoerende rijkstaken aan lagere overheden. Voor het eerst sinds 1945 stonden gemeenten en hun taken weer centraal. Met name in grote steden was sprake van decentralisatie, uitbesteding of privatisering, zoals op het gebied van welzijn en zorg. Bij grote projecten werden steeds meer (private) actoren betrokken. Daarbij nam het aantal regels om al deze processen te begeleiden toe. Ondanks het afstoten van functies op staats- en gemeentelijk niveau, resulteerde dit paradoxaal genoeg eerder in toename van 'regulerend' staatsbestuur (dan in afname daarvan) (Majone 1996).

Van cruciaal belang in deze periode was het aanscherpen van de voorwaarden en regels van de verzorgingsstaat. Zoals gezegd, stond daarbij niet zozeer een beperking van de sociale voorzieningen dan wel van de condities voor toekenning daarvan centraal. Tijdens de recessie hadden bedrijven en bonden exorbitant gebruikgemaakt van WAO-regelingen om er werklozen in onder te brengen. "Nederland is ziek", aldus Lubbers na een sterke stijging tot bijna 1 miljoen WAO'ers in 1990. Dit leidde tot een aanscherping van de keuringseisen en pogingen om de vervroegde uittreding van oudere werknemers te beperken. Ook werd benadrukt dat uitkeringsrechten ook arbeidsplichten impliceerden. Na een lange strijd en een voorstel van de - als gevolg van een parlementaire enquête ingestelde - commissie-Buurmeijer verloren de sociale partners uiteindelijk hun medeverantwoordelijkheid bij de organisatie van de uitvoering van WAO-uitkeringen door de oprich- 
ting van het Uitvoeringsinstituut Werknemersverzekeringen (UWV) in 2002, waarmee de staat het eigen beheer van de uitvoering van die uitkeringen weer wilde vergroten.

Daar stond tegenover dat er in deze periode tevens een versterking van sociale rechten werd doorgevoerd. In 1983 werd de grondwet gewijzigd en uitgebreid met sociale grondrechten, die inspanningsverplichtingen inhielden voor de overheid bij sociale voorzieningen en huisvestiging. Voorts werd een nationale ombudsman ingesteld bij wie burgers klachten konden indienen over onjuist overheidsoptreden. Na invoering van een zelfstandige bestuursrechtspraak eind jaren zeventig was het beroep op de bestuursrechter exponentieel toegenomen. Mede door uitspraken van die rechter ontwikkelde zich tevens jurisprudentie over beginselen van behoorlijk bestuur, die een versterking betekende van bescherming van burgers en samenleving in bestuurlijke aangelegenheden (Van Deth en Vis 1995). Ook kwam er een Wet openbaarheid van bestuur (1980), voortvloeiend uit de werkzaamheden van de bovengenoemde Commissie heroriëntatie overheidsvoorlichting, die regels bevatte over het (actief) openbaar maken van overheidsinformatie en (passief) toegang geven aan burgers bij verzoek om overheidsinformatie. ${ }^{16}$ Zo werden de adviezen van de Raad van State openbaar gemaakt. Burgers werden zo beter waarborgen geboden tegen de macht van een zelfstandiger bestuur. Het was een belangrijke versterking van het 'verbond' tussen staat en burgers sinds 1848 en een verlate - en destijds vrijwel onopgemerkte - uitwerking van behoeftes uit vorige decennia, vooral de jaren zestig (Te Velde 2010: 68; Van Dam 2009: 132).

Deze versterking van de rechtstatelijke positie van burgers ten opzichte van het bestuur liep parallel met een toegenomen betekenis van de media in bestuurlijke aangelegenheden. Zoals wij reeds zagen, stelden die media zich sinds de jaren zestig steeds minder gezagsgetrouw op. Nu werd die ontwikkeling nog versterkt door commercialisering en de introductie van marktwerking (De Goede 1999; Wijfjes 2004). Burgers leverden via de media - en vooral de televisie - steeds vaker kritiek op openbaar bestuur en wisten zo ook problemen bij bestuur voor het voetlicht te brengen. Programma's als Ook datnog, Netwerk en Nova maakten in de jaren negentig gebreken van het bestuur voor burgers tevens inzichtelijk. De toenemende invloed van de media veranderde ook de stijl van dat bestuur zelf. Anders dan voorheen boden media fora waar conflicten binnen dat bestuur in de openbaarheid werden uitgevochten. Bekend is het voorbeeld van hoofdcommissaris van politie E. Nordholt van Amsterdam, die in een Nova-uitzending van november 1993 openlijk kritiek leverde op de minister van Binnenlandse Zaken. Behandeling van de publieke zaak nam zo dus buiten het parlement om in omvang toe. Het parlement en de politieke partijen reageerden daarbij vaak zelf ook via de media om een band met de publieke 'achterban' te behouden, verkrijgen of versterken. 
Toch slaagde diezelfde politiek er steeds minder in om een brug naar de samenleving te slaan. Kritischer en mondiger geworden bepaalden burgers steeds vaker de agenda van sociale problemen. Minder ideologisch gebonden werd hun stemgedrag (en zo ook de positie van politieke partijen) in deze jaren veel minder stabiel. Partijen hadden moeite grip te krijgen op een samenleving die steeds pluriformer en 'ongekender' leek te worden (Van Gunsteren en Van Ruyven 1995) en het gezicht van het 'volk' steeds lastiger te bepalen was (Rosanvallon 1998). Deze afstand werd ook duidelijk door een toename van buitenparlementaire acties van burgers. Bekend is het volkspetitionnement van de interkerkelijke vredesbeweging (IKV) tegen de plaatsing van kernwapens in 1985, dat 3,7 miljoen handtekeningen opleverde (op een bevolking van circa 14,5 miljoen), wat de regering er overigens niet volledig van weerhield om plaatsing van kernwapens toe te laten. Burgers verenigden zich steeds vaker in actiegroepen of zogeheten sociale bewegingen, zoals de Stichting Natuur en Milieu (1972) of Greenpeace (1971-1979), ${ }^{17}$ waarin natuur en milieu bindende thema's waren. Anders dan voorheen organiseerden burgers zich zo steeds minder vaak langs de scheidslijnen van klasse of religie (Van Deth en Vis 1995: 43). Een partij als D'66 had in de jaren zestig al gepoogd deze scheidslijnen te doorbreken, maar de sociale bewegingen van de jaren tachtig en negentig zochten niet zozeer naar partijvorming, maar naar vormen van directe invloed op (uitvoerend) bestuur (al dan niet met steun van politieke partijen, zoals tevens het geval was geweest bij het IKV). Veel van deze acties hadden een lokaal karakter, waarbij vooral de wijk, straat of school de bindende gemeenschap werd.

Het parlement zocht naar wegen om zijn rol te herwinnen en versterken. In een poging het primaat van de politiek te versterken, nam vooral de kritiek op adviesen overlegorganen toe. In 1993 verscheen een rapport van de in 1991 door de Kamer ingestelde commissie-De Jong (Raad op Maat) met het advies om in beginsel alle adviesorganen op te heffen, uitmondend in de zogeheten Woestijnwet (wet van 3 juli 1996, Stb. 377), waarbij zij (ondanks verzet van het kabinet) in principe allemaal werden opgeheven en vervangen door één college voor strategische advisering per ministerie. Dit laatste gebeurde met de Kaderwet Adviesorganen (1996), die de onafhankelijke adviesraden meer wilde onderschikken aan de uitvoering van het regeerakkoord en het beleid van de departementen. Ook wilde ze samenstelling van adviesraden louter op basis van deskundigheid en niet meer op basis van vertegenwoordiging van maatschappelijke belangen. In het jaar ervoor had het parlement bovendien de wettelijke plicht geschrapt om advies bij de SER in te winnen. Het betekende een verzwakking van het (publiekrechtelijke) neocorporatisme en het accent kwam meer te liggen op het (privaatrechtelijke) overleg tussen maatschappelijke partners. De maatregelen bevestigden een bredere verschuiving in het advieslandschap, waarbij het kabinet ook meer ging werken met ad-hoccolleges met telkens andere samenstelling. Daarnaast ontstond er een uitgebreide praktijk van directe ondersteuning en advisering aan het kabinet en ministers, via uitbesteding van onderzoek aan universiteiten en verstrekking 
van adviesopdrachten aan commerciële bureaus (vgl. Werkgroep Sint 1994; Den Hoed 2007: 128-138).

Ondanks de poging om zijn positie te versterken ondervond het parlement door de bestuurlijke veranderingen van de afgelopen decennia ook problemen in zijn traditionele rol van controleur. Uitbesteding van beleid en regulering aan particuliere of semipublieke instellingen creëerde door toenemende omvang en complexiteit van bevoegdheden steeds vaker onduidelijkheid over bestuurlijke verantwoordelijkheden en problemen rondom politieke en bestuurlijke verantwoording. Parlementaire klachten erover deden wel eens vergeten dat Zво's in leven waren geroepen bij wet en dus met medeverantwoordelijkheid van het parlement. Dergelijke problemen werden nog versterkt door de invloed van de Europese Unie (EU) op een toenemend aantal beleidsterreinen, waar het parlement (maar ook de politieke partijen) zich (uiteindelijk) maar beperkt bewust van was of waarde aan toe dichtte (Van Rooyen 2009).

Ook was er sprake van een verlegging van parlementaire aandacht binnen het bestuurlijke proces. In de jaren negentig was er een exponentiële toename van het aantal moties te bespeuren (Van Deth en Vis 1995: 84), waarin een oordeel werd uitgesproken over het bestuur van de regering. De Kamer nam niet het initiatief tot wetgeving (Van Deth en Vis 1995: 84), maar oriënteerde zich meer op de regering dan voorheen en volgde daarbij de bovengenoemde weg van 'codificatie' naar 'modificatie'. ${ }^{18}$ Kenmerkend was ook de herontdekking van de parlementaire enquête. De oorzaak van die herontdekking lag niet enkel in de wens om de band met een door het parlement en de politieke partijen steeds minder 'gekende' maatschappij te versterken, maar tevens in een trend om bestuur achteraf te evalueren (Rosanvallon 2008). Deels is de verschuiving van controle van de voor- naar de achterkant van het bestuurlijke proces te verklaren door toegenomen specialisatie bij ambtenaren enerzijds en bij advies- en overlegorganen anderzijds. De leden van de Kamer ontwikkelden vanaf de jaren zestig een relatief steeds groter tekort aan gespecialiseerde (juridische) kennis en raakten zo 'inhoudelijk' achterop. Ook richtten zij zich zo meer op oordeelsvorming (achteraf) over elders geformuleerd beleid of wetgeving. Kenmerkend in die ontwikkeling was een toenemende mate van reactief meebesturen, terwijl burgers juist op zoek bleken te zijn - tot grote verrassing van vele Kamerleden - naar een meer proactieve vorm van politiek. Anders dan politici en bestuurders van de conventionele politiek dachten, voelden veel burgers afstand tot het Binnenhof en verlangden zij naar directere vormen van betrokkenheid.

\subsubsection{INTEGRATIEVRAAGSTUK EN HERNIEUWD BURGERSCHAP, 2002-2010}

Lange tijd was er geen sprake van debat over een 'kloof' tussen burgers en politiek, noch over een dergelijke 'kloof' tussen burgers en bestuur. Evenmin was sinds de 
Tweede Wereldoorlog sprake geweest van een 'crisis' van het parlementaire stelsel. Integendeel, het parlement werd na die oorlog gezien als de vorm van democratie en publieke representativiteit. Des te groter was de ontnuchtering aan het begin van de eenentwintigste eeuw, toen er plotseling sprake was van een dergelijke 'kloof' en 'crisis' in het publieke debat, die veelvuldig werden besproken en geanalyseerd.

'Ontevreden' of 'boze' burgers kwamen daarmee in het middelpunt van de belangstelling van het openbaar bestuur te staan. "Veel burgers (hebben) onbehagen over ontwikkelingen in onze samenleving", aldus koningin Beatrix in de troonrede van september 2002 (Koningin Beatrix 2002). Een deel van dat onbehagen richtte zich direct tegen het openbaar bestuur. Politici werd verweten niet te weten wat er nu precies bij burgers omging. Bestuur zou zich in toenemende mate van burgers hebben vervreemd door 'beslotenheid' en warrigheid van de bestuurlijk situatie sinds 1977. Terwijl bestuurders en politici minder grip kregen op het 'profiel' van 'de' burger na de ontzuiling sinds de jaren zestig, wisten burgers eigenlijk ook steeds minder wat nu precies 'de staat' was en waar die staat zich sinds de bestuurlijke hervormingen van de jaren tachtig en negentig in het bestuurlijke landschap precies bevond. Vaak was de staat door 'deregulering' of 'privatisering' formeel niet langer verantwoordelijk voor bepaalde zaken, wat echter niet wegnam dat burgers diezelfde staat voor veel van die zaken nog steeds verantwoordelijk en aansprakelijk bleven houden. Dat laatste werd vergemakkelijkt, doordat de overheid zijn rol van toezichthouder versterkte en meer ging werken met de figuur van de onafhankelijke toezichtautoriteit; het wekte de indruk dat diezelfde overheid via toezicht voor van alles in de samenleving de eindverantwoordelijke was, ook al bleef onduidelijk hoe die verantwoordelijkheden nu precies verdeeld waren. ${ }^{19}$ Problemen in de zorg, maar ook bij het treinverkeer kwamen zo niet zelden bij bestuur en politiek terecht, terwijl zij daar in wezen geen verantwoordelijkheid meer hadden liggen.

De relatie tussen de overheid en de EU was een ander voorbeeld van deze door burgers ervaren bestuurlijke schimmigheid. Bestuurders (en met hen 'reactieve' politici) hadden de bevolking lange tijd 'buitengesloten' van betrokkenheid bij (en volwaardige inspraak in) 'Europa'. Dit Europa was echter vanaf het begin van de eenentwintigste eeuw sterk aanwezig in de binnenlandse realiteit. Vooral door introductie van de euro in 2000, waarmee de gulden in een wereld van herinnering en nostalgie verdween, werd 'Europa' voor burgers een veel sterker ervaren onderdeel van een reëel bestaand, groter institutioneel geheel. Burgers bleken echter weinig op te hebben met de 'abstracte' EU, ook al wisten zij niet altijd precies wat deze EU was (Van Rooyen 2009; WRR 2007). De nadruk die daarmee kwam te liggen op het nationaal 'eigene' vond bovendien een 'intern' equivalent in de aanwezigheid van 'buitenlanders' in Nederland, die sinds 2001 in toenemende mate als 'probleem' voor 'nationale' cultuur en maatschappij werden gezien. 
De aanzet tot bewustwording van deze transformatie in de relatie tussen bestuur en publiek werd vooral gegeven door W.S.P. Fortuyn (1948-2002). Deze politicus, die zich (in grote mate) buiten het bestuurlijke en politieke establishment om profileerde, wist in te spelen op wat hij noemde de "ongeloofwaardigheid van het openbaar bestuur" (Fortuyn 2002b), vooral door effectief gebruik te maken van de dominante rol van de media. Voortbouwend op toegenomen publieke 'ontevredenheid' legde hij de basis voor een 'nieuwe' vorm van politiek, die populistisch en (deels) extraparlementair van aard was. Anders dan Kuyper of Domela Nieuwenhuis in de jaren 1870 zocht Fortuyn ondersteuning bij een zeer brede achterban over maatschappelijke scheidslijnen heen. Het succes van het nieuwe populisme (Te Velde 2010: 256-262) berustte voor een groot deel op de beperkingen van een bestuurlijke realiteit, waarin pragmatisme, zakelijkheid en het primaat van de economie het 'welzijn' van de burger leken te hebben verwaarloosd. Zonder dat dit begrip 'welzijn' zijn rentree maakte had Fortuyn aandacht voor de sociaal-psychologische staat van het publiek. Reeds in 1995 had hij erop gewezen dat de burgers zonder aanspreekpunt ietwat 'verweesd' waren achtergelaten door ontzuiling en het verdwijnen van de traditionele institutionele kaders en sociale scheidslijnen (Fortuyn 2002a). Het bestuur had burgers bovendien ook in grote mate zelflos willen maken om zelfstandigheid en eigen verantwoordelijkheden te creëren. Burgers werden gestimuleerd om zich berekenender op te stellen in de relatie met de overheid en om te individualiseren, maar zochten daardoor ook naar nieuwe vormen van maatschappelijke binding. Vergelijkbaar met de jaren 1890 en in de jaren dertig van de twintigste eeuw voedde het primaat van de economie en de zakelijkheid van paars een gemeenschapsdenken voorbij sociaal-culturele versnippering en sociaalpsychologische 'onzekerheid'. Daarbij was - anders dan voorheen - sprake van een wisselende mix van algemene en individuele belangen en groeide er kritiek op immigranten vanuit niet-westerse landen (die vanaf circa 1990 alloch-tonen genoemd werden). Het ging hier bovendien ook niet langer om emancipatie of bescherming van gedrags- en leefregels van zuilen of individuen, maar meer gezamenlijke leef- en gedragsregels voor de gehele Nederlandse samenleving, die door de staat bijvoorbeeld via een "Handvest verantwoordelijk burgerschap" zouden moeten worden bevorderd (ministerie van BZK 2009).

Veel van de kritiek over de 'multiculturele samenleving' had zijn wortels reeds in de jaren tachtig en vooral in de jaren negentig. Turken en Marokkanen hadden zich in Nederland gevestigd, ${ }^{20}$ maar gaandeweg werd duidelijk dat hun komst niet van tijdelijke aard zou zijn. Omdat zij vaak aan de 'onderkant' van de samenleving terechtkwamen, was een deel van het 'AOw-probleem' in de vroege jaren negentig ook sterk verbonden met het 'integratieprobleem'. Veel allochtonen maakten namelijk gebruik van die sociale voorzieningen. Dit zette kwaad bloed bij diverse burgers, die (versterkt) het gevoel kregen dat misbruik werd gemaakt van de sociale rechten in Nederland. ${ }^{21}$ Mede in reactie hierop werd gepleit voor opheffing van het gesignaleerde taboe rondom de sociale problematiek bij allochtonen en werd 
opgeroepen om de "maatschappelijke vrede" te bewaren (Scheffer 200o); daarnaast zou het 'gevaar' van "islamisering" tevens omwille van het 'behoud' van 'de' nationale identiteit tijdig moeten worden onderkend (Fortuyn 1997).

Met de komst van Fortuyn als politicus kreeg de discussie over integratie in 2001 echter een krachtigere dimensie. Er leek sprake van een 'doorbraak' van een anti-islamitische stemming in Nederland na de aanslag door Al-Qaida op de Twin Towers in New York in 2001, waarbij de dreiging van terrorisme in kringen van radicale islamieten (of islamisten) het gepercipieerde gevaar van islam in radicaler daglicht stelde. Daarbij vermengde het integratiedebat zich bovendien met veiligheidsvraagstukken, wat het onbehagen van burgers in de samenleving vergrootte. Het droeg al met al bij aan de intensivering van het gesprek in politiek en samenleving over religieuze gedrags- en leefregels, waarbij 'hoofddoekjes' en een eventueel verbod op boerka's onderdeel werden van het publieke debat. Ten slotte speelden ook films om burgers keerzijden van de islam te tonen, een rol bij de opkomst van de behandeling van de islam als een publieke zaak. De moord op Fortuyn (door een dierenactivist) in 2002 en die op filmmaker T. van Gogh (1957-2004) (door een islamist) in 2004 droegen aan de versterking van deze ontwikkeling bij.

In het verlengde van deze cultureel nationalistisch getinte opleving kozen het staatsbestuur en de gevestigde politiek voor een andere koers, waarin de nadruk meer en meer kwam te liggen op de plichten die burgers aan elkaar en aan de staat bonden. Het CDA, dat tijdens de verkiezingen in de nasleep op de moord op Fortuyn in 2002 de grootste partij werd, nam daarbij een leidende rol. Reeds ingezet in de jaren tachtig en negentig vertaalde de weg van burgerrechten naar burgerplichten zich naar een verschuiving van nadruk op burgerschap naar nadruk op burgerzin. Hoewel de kabinetten-Balkenende (2002-2010) de weg van 'paars' grotendeels voortzette, inclusief het pad van bestuurlijke liberalisatie (en met nadruk op verdere uitbouw van Zво's en de reeds genoemde toezichthouders), kwamen 'normen en waarden' in het publieke debat en beleid centraal te staan. Deze leken een bijna ongeschreven (achteraf opgelegde) 'extra' voorwaarde te worden voor staatsburgerschap en dus voor het 'verbond' tussen staat en burgers.

Typerend voor deze jaren was de poging van het staatsbestuur om binnen de samenleving de (sociale en culturele) band tussen burgers te willen herstellen. Dit was het spiegelbeeld van het 'fatsoenlijke' liberale principe uit de negentiende eeuw, dat burgers juist zelf vorm wilde laten geven aan het maatschappelijk leven. Daarnaast was het een breuk met het confessionele principe van de soevereiniteit in eigen kring, dat in wezen toch dicht bij de gereformeerde basis van premier J.P. Balkenende (geb. 1956) stond. Hoewel de staat zich sinds de jaren 1890 (formeel) het recht had toegeëigend om in het 'autonome' leven van burgers in te grijpen, was echter nog nooit sprake geweest van een dusdanig sterke wens tot 'ingrijpen' 
in het gedrag en vooral de mentaliteit van burgers. ${ }^{22}$ Niet voor niets ontmoette premier Balkenende kritiek toen hij de discussie over normen en waarden op de politieke agenda wilde zetten. Desalniettemin is het opmerkelijk hoeveel lof zijn wens tot ingrijpen in het culturele leven van burgers feitelijk onder burgers heeft gekregen (zij het vaak stilzwijgend). De introductie van een historische canon op scholen, waarbij kinderen (weer) een vast stramien van kennis over de 'vaderlandse geschiedenis' kregen, is daar een uitstekend voorbeeld van. Ook bedachten gemeentes, zoals Gouda, 'regels' als een soort convenant met burgers (1o gouden regels, 2002). Daarnaast kan worden gedacht aan de zogeheten inburgeringscursus voor allochtonen bij vestiging in Nederland.

Een ander kenmerk van deze jaren was de door de staat 'geleide' en toegenomen tendens om steeds meer in termen van uniforme typen burgers te spreken; het succes van de discussie over autochtonen en allochtonen is daarvan een kenmerkend voorbeeld. In dergelijke typeringen schuilt de wens om meer grip te krijgen op een in wezen steeds 'onvindbaar(der) volk' (Rosanvallon 1998). Het is de uitdrukking van een spanning tussen een geïndividualiseerde samenleving en een roep om eenheid en binding ten behoeve van overzicht en structuur in een 'verweesde samenleving'.

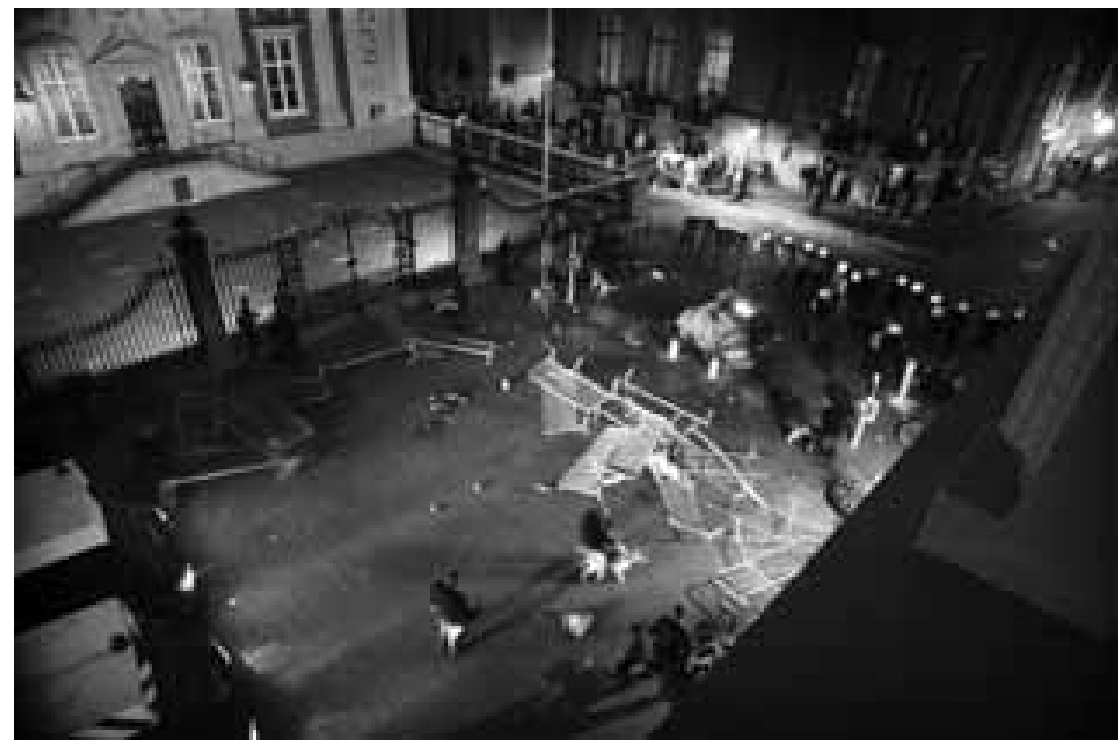

Grimmige sfeer rond 't Torentje (2002)

Foto: Roel Rozenburg

Begin eenentwintigste eeuw speelden 'ontevreden' of 'boze' burgers een steeds grotere rol op het politieke toneel. Na de moord op Pim Fortuyn op 6 mei 2002, die volgens opiniepeilingen in de aanloop naar de parlementsverkiezingen van ruim een week later kon rekenen op een zeer grote overwinning, verzamelden zij zich aan de poorten van het Binnenhof. 


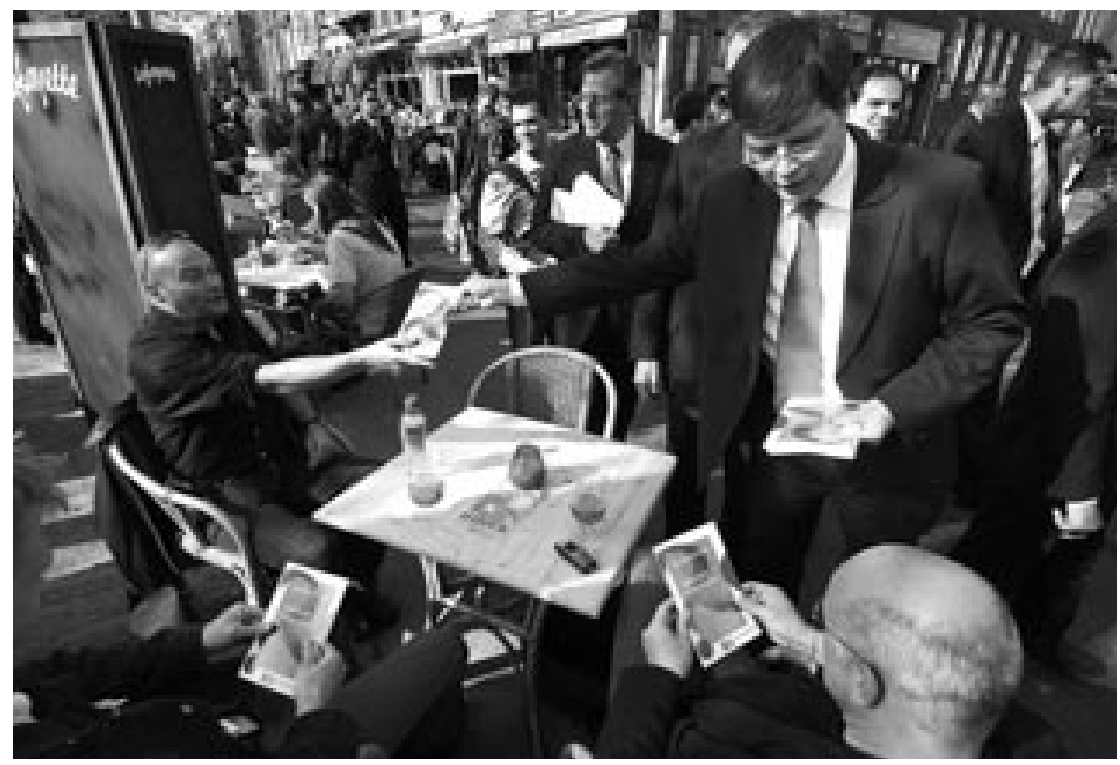

Uitdelen folder over Europese grondwet op het Plein in Den Haag (2005) Foto: Roel Rozenburg (2009)

Bestuur en publiek zijn in Nederland sterk met elkaar vervlochten geweest. Terwijl het publiek in eerste instantie vooral zelf zijn weg moest vinden naar het staatsbestuur, zocht dat bestuur sinds de jaren zestig van de twintigste eeuw steeds vaker naar wegen om dat publiek voor het openbaar bestuur te interesseren en daarbij betrokken te houden. Op 22 april 2005 ging het zelfs actief de straat op om publieke steun te verwerven voor invoering van een Europese grondwet. Zij deed dat in haar hoedanigheid van 'medeontwerper' van een 'nieuwe' EU aan het einde van een langlopend besluitvormingsproces daarover. Publieke legitimiteit van dat proces werd zo in wezen achteraf gezocht.

De kabinetten-Balkenende I-IV markeren een keerpunt in de wijze waarop staatsbestuur met de betrokkenheid van burgers te maken heeft gehad. Hoewel na de jaren zestig sprake was van een sterke toenadering van het bestuur tot de maatschappij, trad in het eerste decennium van de eenentwintigste eeuw een breuk op tussen 'mondigere/moeilijkere' burgers (Van den Brink 2002) en een gedifferentieerder publiek enerzijds, en bestuurders en Balkenende als het gezicht van het openbaar bestuur anderzijds. Hoewel ook hij heeft geprobeerd om het 'volk' te bereiken, zoals in het geval van steun voor een Europese grondwet in 2005, sprak het antwoord van datzelfde 'volk' op die poging tot steun boekdelen over de wijze waarop het zijn vertrouwen in het openbaar bestuur had verloren. De 'afstraffing' van het Nederlandse staatsbestuur door een 'nee' tegen een Europese grondwet in het referendum daarover in 2005 was typerend voor een bestuur dat aan het begin van de eenentwintigste eeuw in zekere zin vervreemd geraakt is van 'mondigere en bozere' burgers die tegenwoordig eerst nog eens goed nadenken voordat zij-lang na 1848 - een nieuw verbond afsluiten, waarvan de aard voor velen (nog) niet duidelijk is. 


\subsection{TOT SLOT: ENKELE BEVINDINGEN}

Ter afsluiting van deze bijdrage schetsen wij enkele algemene bevindingen over de ontwikkeling van het openbaar bestuur in Nederland sinds 1848. Uitgaande van Thorbeckes credo ('de publieke zaak wil publiek worden behandeld') legden wij die ontwikkeling in deze bijdrage - zij het impliciet - langs de lijn van de elementen uit dat credo: de publieke zaak; de vormen en manieren van behandeling ervan; en de publieke dimensie bij de behandeling van de publieke zaak. We voegen er in dit slotwoord nog een bevinding aan toe over het normatieve woordje 'wil' in het credo.

We komen tot de volgende bevindingen over de beschreven ontwikkelingen.

1 De publieke zaak en de definiëring daarvan. Sinds 1848 verschilden interpretaties over dit begrip. Ook de reikwijdte daarvan verschilde per moment. Toch lijkt er sprake te zijn van een geleidelijk 'oprekken' van de praktische betekenis van dit begrip en van datgene wat volgens staat en samenleving tot die zaak gerekend kan of zou moeten worden. Dit is een schoksgewijs proces geweest, met soms wat meer, soms wat minder behoefte tot 'oprekken' van de (praktische) definitie van de publieke zaak.

De relatie tussen staat en maatschappij is telkens bepalend geweest voor de wijze waarop die publieke zaak de facto invulling kreeg. Rond 1848 en de eerste decennia erna deed zich een andere situatie voor dan na 189o. In die eerste tijd werd de invulling van de publieke zaak sterk beheerst door constitutionele en organiekrechtelijke vraagstukken (over de soevereiniteit van de staat en over de positie van de koning, het parlement, de gemeente, enzovoorts). Die periode verschilde met die erna, als feitelijke materiële problemen van de maatschappij steeds meer doordrongen tot in de 'binnenkamers' van de staat en de staat zich 'gedwongen' zag om zichtbaarder te opereren ten opzichte van een maatschappij, die tot dan toe ver van die staat afstond. Achteraf gezien is de periode na 1890 een funderende periode geweest. Ze bleek het begin van een trend tot 'wederzijdse doordringing' en vervlechting van staat en maatschappij die zich in de twintigste eeuw heeft voortgezet. Hoewel er juist na (grofweg) 1977 ook vaak sprake lijkt te zijn van 'ontvlechting' van de relatie tussen staat en maatschappij, lijkt zich toch eerder dat proces van 'wederzijdse doordringing' door te zetten. De vele reguleringen en extra wetten sinds het proces van institutionele liberalisatie wekken wellicht de indruk van 'ontvlechting', maar zij versterkten in wezen juist de greep van de staat op het maatschappelijke leven. De weg naar meer 'toezicht' vanaf de late twintigste eeuw en het ontstaan van een "regulatory state" (Majone 1996) vereiste bovendien de medewerking van steeds meer maatschappelijke actoren, die zelf vorm konden geven aan de invulling van het bestuur. Ook dit impliceert dat het staatsbestuur en de samenleving steeds meer met elkaar vervlochten raken. 
Parallel aan dit proces is ook een vervaging van de 'private' en 'publieke' zaak uit het maatschappelijke leven tot stand gekomen. In 1848 gingen liberalen (formeel) uit van een strikte scheiding tussen het 'private' en het 'publieke', maar dit onderscheid bleek in de praktijk van (vooral) de jaren 189 o niet langer houdbaar. De 'sociale kwestie' aan het einde van de negentiende eeuw maakte een bredere opvatting van de reikwijdte van de publieke zaak (en daarmee van de functies van de staat) gewenst. Hoewel de staat tot ver in de jaren zestig van de twintigste eeuw bovenal voorzichtig en terughoudend optrad, eigende hij zich vanaf het einde van de negentiende eeuw echter wel het recht toe om voortaan in het private en maatschappelijke leven van burgers in te grijpen. De jaren zestig vergrootten die laatstgenoemde tendens, maar nu om actief het 'welzijn' en de zelfstandigheid van burgers te bevorderen en te stimuleren. Maar het was pas aan het einde van de twintigste eeuw dat de staat ook werkelijk de claim op het 'private' domein van burgers vergrootte. Discussies over 'normen en waarden', vermengd met veiligheidsissues, versterkten een tendens om de verantwoordelijkheden, maar ook de mentaliteit van maatschappelijke kringen en individuele burgers beter te begeleiden of te sturen. Anno 2010 lijkt vrijwel het gehele maatschappelijke leven tot de publieke zaak te zijn gaan behoren, inclusief elementen uit de intieme sfeer van het 'private' domein. Daarbij valt niet enkel te denken aan aspecten van het geestelijk of religieuze leven, zoals in par. 2.4.2 is aangegeven, maar ook aan het lichaam, dat door vingerafdrukken bij de aanschaf van paspoorten opgenomen wordt in de systemen van de staat of door bodyscans op luchthavens, die burgers onderwerpen aan de publieke zaak in de naam van veiligheid. Het geldt ook voor het ingrijpen in het gezins- en familieleven.

2 De behandeling van de publieke zaak. Een variëteit aan methoden en institutionele vormen bepaalden de praktijk van het openbaar bestuur door de tijd heen. Het repertoire van methoden en vormen is in de loop van de tijd verbreed: naast wetten zijn contracten, convenanten, communicatiemethodes en prikkels opgekomen; soms als aanvullingen, maar vaak ook als instrumentele alternatieven. Ook het repertoire van concrete organisatievormen voor realisatie van taken van het staatsbestuur is aanzienlijk verruimd: naast gemeentelijke taakuitoefening is er een breed scala van andere institutionele vormen van taakuitoefening ontstaan, zoals privaatrechtelijke organen met een wettelijke taak, zво's en agentschappen, al dan niet tevens in Europees verband. De laatstgenoemde veranderingen zijn tevens uitdrukking van een voortgaande institutionele liberalisatie van de bestuurlijke werkelijkheid, die overigens door de EU wordt bevorderd.

Door al die ontwikkelingen is de bestuurlijke werkelijkheid complexer geworden. De wens om via wetten het maatschappelijk leven te stimuleren en om burgers zelf vorm te laten geven aan de invulling van dat leven, zoals de doctrinaire liberalen à la Thorbecke voor ogen stond, is na 1848 te eenzijdig en ook niet haalbaar gebleken. Een van de meest wezenlijke transformaties van de bestuurlijke realiteit 
is wellicht de verschuiving geweest van de betekenis en invloed van de voor-naar de achterkant van het bestuursproces. In een tijd van institutionele verdichting van de sfeer tussen staat en maatschappij heeft bestuur in de feitelijke praktijk een sterk reactief karakter gekregen. Terwijl het in 1848 vooral proactief was, bedoeld om (wettelijke) 'kaders' voor een bestuurlijke werkelijkheid te creëren, voltrok zich in de loop van de tijd - en versneld sinds de jaren zeventig van de twintigste eeuw een verschuiving van een meer wettelijke en staatsrechtelijke naar een meer bestuurlijke en bestuurskundige vormgeving van de publieke zaak. De omslag van die ontwikkeling lag vooral in de jaren zestig van de vorige eeuw, toen beleid de proactieve vormgeving van bestuur door wetgeving verving door bestuur door nota's, die uiteindelijk ver afstonden van de handelingswerkelijkheid. Wetgeving bleef wel van belang, maar eerder als instrument van de bestuurders en van burgers, die met name via bestuursrecht een versterking van de eigen positie ten opzichte van de staat verwierven. Het parlement, dat zich steeds meer op nota's of door de regering aangedragen wetsontwerpen richtte, werd typerend voor een systeem van institutionele oppositie met een verhoogd reactief bestuurlijk karakter. Dat neemt niet weg dat datzelfde systeem tegelijkertijd ook (actief) vorm bleef geven aan de bepaling en behandeling van de publieke zaak, zoals door agendering van diverse sociale onderwerpen.

3 De publieke dimensie bij behandeling van de publieke zaak. Sinds 1848 was deze dimensie op diverse manieren vrijwel onafgebroken actueel, zoals bij verantwoordingsprocedures en bij het zoeken van aansluiting bij maatschappelijke verscheidenheid. Ook publieke betrokkenheid bij bestuurlijke praktijken en de behandeling daarvan is een permanent onderdeel van de ontwikkeling van het openbaar bestuur sinds 1848. Daarbij is geen sprake van een lineaire, toenemende ontwikkeling van die betrokkenheid, ook al is deze in bepaalde opzichten wel democratischer geworden (vooral vanaf de jaren zestig). Eerder is er sprake geweest van gevarieerde en afwisselende vormen van publieke betrokkenheid. In deze bijdrage is veelvuldig verwezen naar de verschillende vormen van die betrokkenheid sinds 1848, die hier nu niet herhaald zullen worden. Wel kan worden opgemerkt dat deze betrokkenheid altijd verbonden was met (ervaringen uit) een variëteit van leefwerelden, zoals die van het recht, het bedrijfsleven, de media, politieke partijen, belangengroeperingen, wetenschappelijke bureaus en diverse advies- en overlegorganen.

4 Met het oog op de normatieve dimensie van het credo van Thorbecke kan, tot slot, de volgende hypothese worden geformuleerd: daar waar Thorbecke vooral de wenselijkheid van publieke betrokkenheid (in de zin van 'openbaarheid') bij bestuur voor ogen had, lijkt tegenwoordig die wenselijkheid in noodzakelijkheid te zijn vertaald (of althans zo dienen te worden vertaald). Het voorbeeld van het referendum over een Europese grondwet in 2005, waarmee wij paragraaf 2.4.2 afsloten, is illustratief voor een openbaar bestuur dat een tweede 'verbond' tussen 
staat en burgers niet (langer) over de hoofden heen van een verscheidenheid aan publieken kan nemen, maar bovenal reacties uit de gevarieerde samenleving nodig heeft. Om legitimiteit en vanzelfsprekendheid te verkrijgen heeft het staatsbestuur een publiek nodig. Daarbij wil de publieke zaak tegenwoordig niet enkel (alleen) publiek worden behandeld, maar dient het dat ook. 


\section{NOTEN}

Deze bijdrage is in eerdere versies gelezen door en besproken met diverse personen; wij danken Wendy Asbeek Brusse, Huub Dijstelbloem, Peter de Goede, Herman van Gunsteren, Luuk van Middelaar en Erik Schrijvers. Bijzondere dank gaat uit naar Jan Willem Holtslag voor zijn betrokkenheid, suggesties en aanvullingen.

Voor connotaties met en onderscheid tussen, de begrippen 'associatief' en 'deliberatief' (waar de begrippen - anders dan in onze bijdrage - aan democratie worden gelinkt), zie: WRR 2004a.

Het begrip 'zelfbestuur' komt van I. de Haan; hoewel dit begrip wordt overgenomen in deze bijdrage, maken wij echter geen gebruik van de tegenstelling - en contrast - die deze auteur maakt tussen 'staatsbeheer' en dit 'zelfbestuur' (De Haan 1993). De Haan signaleert een permanente spanning in de geschiedenis van de Nederlandse bestuurlijke en politieke realiteit tussen deze twee vormen van bestuur als gevolg van de claim die beiden maken op de vormgeving van de publieke zaak. Wij maken gebruik van het begrip 'staatsbestuur', niet van 'staatsbeheer'. 'Zelfbestuur' dient in deze bijdrage vooral als analytische kapstok om diverse vormen van niet zuiver statelijk bestuur aan te duiden, inclusief particulier of kerkelijk bestuur en regionaal of gemeentelijk bestuur.

$4 \quad$ Tussen 1848 en 1877 waren "van de honderd ministers maar liefst 81 van adellijke of patricische afkomst; zeventien kwamen uit de hogere burgerij en slechts twee uit de lagere burgerij” (De Rooy 2005: 58-59).

Deze krappe 4 procent kwam overeen met ruim 11 procent van de totale mannelijke bevolking van 23 jaar en ouder (Oud en Bosmans 1990: 31; Van Deth en Vis 1995: 35).

Die weg bracht de SDAP echter in conflict met een interne groep revolutionaire marxisten, die zich in 1909 afsplitsten en de Sociaal-Democratische Partij ( SDP) oprichtte. In 1918 heette de SDP de Communistische Partij Holland (sinds 1935 Communistische Partij van Nederland, CPN). Dat de samenhang van bestuur en statistiek ook perverse gevolgen kan hebben maakt J.C. Scott (1998) met tal van voorbeelden duidelijk.

Gemeenten hadden autonome en medebewindstaken; de oorlog gaf een sterke impuls in de richting van de medebewindstaken, welke in de loop van de twintigste eeuw enkel in betekenis toenamen.

9 Sinds 1919 gold algemeen (actief en passief) kiesrecht voor mannen en vrouwen vanaf 23 jaar; dit werd in 1965 voor zowel mannen als vrouwen verlaagd naar 21 jaar, en in 1971 naar 18 jaar.

o Voor een belangrijk deel werd die oplossing ook geboden door de bereidheid van de katholieken om na 1945 hun afkeer van samenwerking met socialisten te laten varen. In het interbellum gold vooral het leerstuk van samenwerking met socialisten 'alleen bij uiterste noodzaak' (Nolens), wat er in de praktijk op neerkwam dat 
er van samenwerking tussen socialisten en katholieken geen sprake was. Dit neemt niet weg dat kritiek op het parlementaire stelsel ook aanhield tot in de eerste bezettingsjaren. Wij kiezen hier het aantreden van het kabinet-De Quay, omdat er dan andere prioriteiten worden gesteld door de nadruk op individuele bezitsvorming (hypotheekrenteaftrek) en aanvaarding van grotere sociale verschillen. De aanduiding 'verzorgingsstaat' kwam eigenlijk toen pas werkelijk goed in zwang.

Het gaat hier over een lange periode. Wellicht dat later zal blijken - als het stof van de geschiedenis wat meer is neergedaald - dat er een voorkeur is voor opsplitsing in twee tijdvakken; een voor de jaren tachtig en een voor de jaren negentig (vanaf het einde van de Koude Oorlog). Het doorlopen van veel institutionele veranderingen door deze decennia heen heeft ons echter doen besluiten om de behandelde tijd als één gehele periode te behandelen en de cesuur pas te leggen in 2002. De regering voerde ook niet altijd Europese regelgeving in eigen land door; zeker waar het om het verbod op kartelvorming ging. Deze regels bevatten overigens wel veel uitzonderingsbepalingen.

17 De eerste Greenpeace-actie vond plaats in Canada in 1971; in Nederland groepeerden zich actievoerders in 1978, waarna zij zich in 1979 omvormden tot de Stichting Greenpeace Nederland; in datzelfde jaar werd Greenpeace International opgericht. Het parlement wist niet hoe met het opkomende verschijnsel van nota's over beleid om te gaan; het recht van amendement geldt bijvoorbeeld slechts voor wetten en niet voor nota's. Daarop vond de Tweede Kamer in de loop van de tijd de 'amenderingsmotie' uit. De Tweede Kamer ging bovendien zelf om nieuwe nota's vragen en meedoen aan beleidsvorming en holde zo zijn eigen bevoegdheden uit (Klinkers 2006: 15-16). De bestuurlijk-juridische logica van de interne markt van de EU bevorderde de opkomst van onafhankelijke toezichtautoriteiten, die zich soms bovendien autonoom opstelden tegenover de nationale overheid. Turken en Marrokkanen waren overigens niet de enige 'etnische minderheden' die naar Nederland waren gekomen na de Tweede Wereldoorlog, maar de discussie spitste zich - deels door het verband met de islam - vooral op deze groeperingen toe in de jaren negentig en later. Wel dient hier benadrukt te worden dat het 'WAO-probleem' ontstond in de jaren zeventig en tachtig door het gemak dat Nederlandse bedrijven en bonden zelf hadden gemaakt van die regeling om zo ontslagenen - doorgaans uit de lagere sociale kringen - te 'parkeren'. Het hierbij betrokken beheersingsmotief vertoont verwantschap met dat van planning van de samenleving uit de jaren zestig en zeventig. 


\title{
3 DE INTERNATIONALISERING VAN BELEID. IMPLICATIES VOOR HET OPENBAAR BESTUUR
}

\author{
Kutsal Yesilkagit en Sebastiaan Princen
}

\subsection{INLEIDING: BESTUUR EN BELEID OVER MEERDERE BANDEN}

Raymond Ceulemans was er een meester in: biljartballen over verschillende banden laten spelen en doel treffen. Internationale beleidsprocessen zijn vanaf de jaren zeventig van de vorige eeuw meer gaan lijken op een driebandenspel. De banden in het internationale beleidsproces zijn publieke en private internationale en supranationale organisaties met hun vele fora die plaats bieden aan deliberaties en onderhandelingen tussen publieke en private actoren en de locus zijn waar multilaterale beslissingen worden genomen. Met de internationalisering van voorheen overwegend nationale beleidsterreinen zijn nationale overheden gedwongen om hun beleidsvoorkeuren via een of meerdere banden te spelen.

De internationalisering van de beleidsvorming heeft verschillende oorzaken, die elkaar verder versterken. Ten eerste zijn op veel terreinen markten over grenzen heen vervlochten geraakt. Dit raakt direct aan beleid en beleidsvorming, omdat maatregelen in één land invloed hebben op producten en bedrijven in andere landen. Omdat medicijnen over grenzen heen verhandeld worden, kan de goedkeuring en regulering van nieuwe medicijnen niet meer effectief en praktisch door afzonderlijke landen worden geregeld. Rond dit onderwerp zijn dan ook Europese (en vaak mondiale) normen afgesproken. De kredietcrisis heeft nogmaals pijnlijk duidelijk gemaakt dat financiële markten zo verweven zijn geraakt dat ze alleen op internationaal niveau effectief kunnen worden gereguleerd.

Daarnaast zijn veel risico's grensoverschrijdend en vragen ze daarmee om een internationale aanpak. Een goed voorbeeld is het broeikaseffect, dat zowel in zijn oorzaken als gevolgen niet tot één of enkele landen beperkt is. Maar ook recente uitbraken van (dier)ziekten als de varkenspest en de Mexicaanse griep betreffen risico's die zich weinig van de grenzen tussen landen aantrekken. Een effectieve aanpak van deze risico's is dan ook alleen in internationaal verband mogelijk.

Ten slotte laten veel beleidsterreinen een beweging zien naar het formuleren van een gezamenlijke consensus rond gezamenlijke waarden en uitgangspunten. Het meest fundamenteel is dit zichtbaar in verdragen over internationale mensenrechten en de oprichting van internationale tribunalen om oorlogsmisdaden te berechten. Maar ook binnen specifieke beleidsterreinen worden gezamenlijke uitgangspunten vastgelegd, bijvoorbeeld rond sociaal beleid in de Internationale 
Arbeidsorganisatie (International Labour Organization - ILO) of rond het rookbeleid in de Wereldgezondheidsorganisatie (World Health Organization - wHO).

Het praktisch belang van deze internationale afspraken verschilt per terrein en onderwerp. Bij elkaar heeft dit internationale meerbandenspel echter grote veranderingen meegebracht voor de manier waarop beleid wordt gemaakt en daarmee voor het speelveld waarin Nederlandse overheidsorganisaties zich bevinden. Deze bijdrage brengt daarom twee dingen in kaart:

1 Welke gevolgen heeft de internationalisering van economische en sociale vraagstukken op de handelings- en interventieruimte van het Nederlandse openbaar bestuur?

2 Welke mogelijkheden heeft het Nederlandse openbaar bestuur om zich aan te passen aan of in te spelen op processen van internationalisering?

De kern van onze argumentatie laat zich daarbij als volgt samenvatten. Ten eerste betogen wij dat de internationale omgeving van het Nederlandse openbaar bestuur hoofdzakelijk wordt bepaald door de wijze waarop de EU zich als actor op het internationale toneel en als beleidsarena binnen Europa ontwikkelt. Daarnaast worden, als tweede punt, de handelingsperspectieven en -mogelijkheden van het Nederlandse openbaar bestuur voor een belangrijk deel bepaald door de (gefragmenteerde) structuur en inrichting van het Nederlandse openbaar bestuur. Tezamen leiden deze twee observaties tot een derde constatering, namelijk van het groeiende belang van transnationale overheidsnetwerken in beleidsvorming en regulering. De wijze waarop de EU zich heeft ontwikkeld, heeft deze netwerkstructuren mogelijk gemaakt. De fragmentatie van het Nederlandse openbaar bestuur, zoals die de afgelopen decennia vanwege de verplaatsing van het bestuur is gegroeid, maakt het mogelijk dat organisaties in het openbaar bestuur makkelijker zelfstandig in Europa en daarbuiten kunnen opereren. De belangrijkste implicatie hiervan, tot slot, is dat politici en beleidsmakers zich (verder) moeten bekwamen in het strategisch managen en aansturen van transnationale overheidsnetwerken.

In de rest van deze bijdrage zullen wij deze argumentatie verder onderbouwen en uitwerken. We doen dit aan de hand van een kritische synthese van onderzoek dat op dit gebied is verricht. De volgende paragraaf introduceert de termen 'downloading' en 'uploading', waarmee grip kan worden gekregen op de relaties tussen verschillende arena's in de internationale beleidsvorming. Vervolgens gaan we in op het proces van 'downloading', dat wil zeggen de invloed van internationaal beleid op Nederland. Aan de hand van recent empirisch onderzoek laten we zien hoe, waar en in welke mate deze invloed zich heeft laten gelden. De vierde paragraaf richt zich op het andere deelproces, 'uploading', waarbij Nederlandse actoren proberen de beleidsvorming in internationale fora te beïnvloeden. Op basis hiervan volgt in de vijfde paragraaf een nadere beschouwing van de ontwikkeling en 
rol van transnationale beleidsnetwerken. In paragraaf 3.6 worden de implicaties van onze analyse voor het Nederlandse openbaar bestuur belicht, waarna een korte conclusie volgt.

\subsection{HET SPEL TUSSEN BELEIDSARENA'S}

\subsubsection{UPLOADEN EN DOWNLOADEN}

De Nederlandse staat, de Europese Unie (EU) en andere internationale organisaties kunnen worden getypeerd als 'beleidsarena's' - of beter nog, als verzamelingen van beleidsarena's. In hun inleiding in de bestuurskunde omschrijven Bovens, 't Hart en Van Twist beleidsarena's als “plaatsen waar beleid wordt gemaakt en geconstrueerd” (Bovens et al. 2007: 143). Arena’s zijn dus de institutionele plaatsen waar (politieke) actoren elkaar ontmoeten om beleid te ontwikkelen en daarover beslissingen te nemen. Internationalisering van beleid houdt dan in dat beleid niet (langer) alleen in nationale beleidsarena's wordt gemaakt, maar ook in beleidsarena's binnen de EU of op mondiaal niveau. Figuur 3.1 Schematische weergave van internationale beleidsprocessen: uploaden en
downloaden

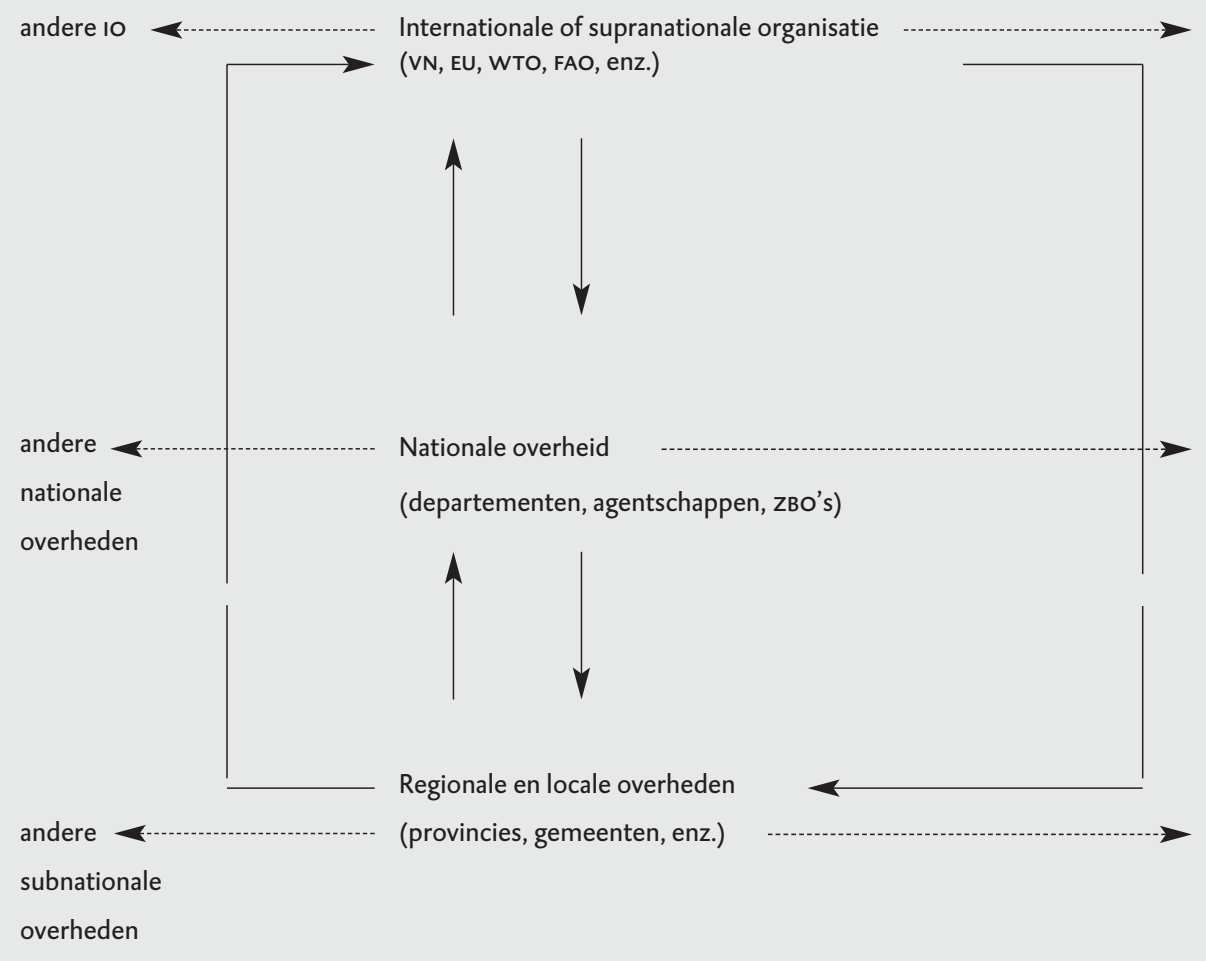


De relaties tussen nationale en internationale beleidsarena's kunnen worden geanalyseerd met de termen 'uploaden' en 'downloaden'. Bij 'uploaden' proberen nationale actoren hun eigen beleid(svoorkeuren) in internationale beleidsarena's geaccepteerd te krijgen. Bij 'downloading' verloopt het proces de andere kant op en worden beslissingen van internationale organisaties overgenomen en geïmplementeerd in de nationale beleidspraktijk. Deze processen zijn grafisch weergegeven in figuur 3.1.

De doorgetrokken pijlen naar boven staan voor het proces van uploaden. Uploading kan plaatsvinden in het formele deel van de besluitvorming, wanneer Nederland als staat een standpunt in moet nemen over een voorstel van, bijvoorbeeld, de Europese Commissie (zie bijv. Van Keulen 2006). Voorafgaand aan de formulering van een nationaal standpunt vinden echter vaak ook al informele pogingen plaats om de beleidsvorming in internationale fora te beïnvloeden, door het schrijven van papers, lobbyen bij collega's uit andere landen of het detacheren van nationale experts (vgl. Geuijen et al. 2008: 51 e.v.)

De pijlen naar beneden geven processen van downloaden aan. We maken hier onderscheid tussen twee soorten beslissingen die worden gedownload. De eerste soort zijn voor de nationale staten bindende verdragen en formele wetten en regels (verordeningen en richtlijnen in de EU). De tweede soort zijn niet-bindende standaarden die al dan niet in de vorm van aanbevelingen of opinies door internationale organisaties worden uitgebracht. Onder internationaal juristen wordt het onderscheid tussen beide vormen gemaakt in termen van 'hard law' en 'soft law'. De laatste categorie is gebaseerd op de eerste categorie. Bijvoorbeeld: de standaarden voor de bescherming van persoonlijke en medische gegevens van patiënten in een elektronisch patiëntendossier zijn een uitwerking van artikel 8 van de Privacy Richtlijn (95/46/EC) die een algemene bepaling over de bescherming van gevoelige gegevens bevat.

De routes waarlangs 'hard' en 'soft law' een staat binnenkomen verschillen. Verdragen dienen te worden geratificeerd door het nationale parlement. Europese regelgeving wordt getransponeerd door omzetting in nationale formele of secundaire wetgeving. Over de transpositie van Europese wetgeving in Nederland en andere landen is veel bekend (Mastenbroek 2003; Bovens \& Yesilkagit 2005; Steunenberg 2005). Het downloaden van niet-bindende standaarden en normen verloopt langs veel informelere wegen en er is maar weinig bekend over hoe dit proces precies verloopt. Binnen de EU vormen transnationale overheidsnetwerken van toezichthouders een belangrijke arena waarbinnen de interpretatie van open normen plaatsvindt. De zojuist aangestipte standaarden voor persoonsgegevensbescherming in elektronische patiëntdossiers zijn geformuleerd door de Groep Gegevensbescherming Artikel 29 die door de Privacy Richtlijn is ingesteld en waar alle privacyautoriteiten binnen de Eu lid van zijn. Dergelijke soft law wordt in 
opinies, aanbevelingen of werkdocumenten verwoord. Het is de bedoeling dat vervolgens de aangesloten autoriteiten deze normen transponeren in hun eigen nationale toezichtpraktijk.

\subsubsection{UPLOADEN EN DOWNLOADEN DOOR DE NEDERLANDSE CENTRALE OVERHEID: ENIGE EMPIRISCHE CIJFERS}

We kunnen een idee krijgen van het relatieve belang van uploaden en downloaden door de Nederlandse rijksoverheid door twee enquêtes die gehouden zijn onder respectievelijk rijksambtenaren (Geuijen et al. 2008) en bij (semi)zelfstandige organisaties in de publieke sector (Van Thiel en Yesilkagit 2006). De eerste enquête is in 2006 afgenomen onder 4500 individuele ambtenaren werkzaam bij departementen en daarmee verbonden uitvoeringsinstanties als Rijkswaterstaat en de Belastingdienst. De tweede enquête is gehouden onder leidinggevenden van ruim 600 organisaties in de publieke sector buiten de departementen. In beide enquêtes is gevraagd of respondenten zich in hun werk bezighielden met EU-gerelateerde werkzaamheden en, zo ja, hoe 'belangrijk' verschillende vormen van uploading en downloading dan waren.

Omdat de selectie van respondenten verschillend was, kunnen de absolute cijfers in de twee enquêtes niet direct worden vergeleken. De hogere absolute percentages in de enquête onder (semi)zelfstandige organisaties zijn waarschijnlijk deels

Tabel 3.1

$$
\begin{aligned}
& \text { Belang van verschillende aspecten van Eu beleid voor het werk van } \\
& \text { departementsambtenaren en (semi-)zelfstandige diensten }
\end{aligned}
$$

\begin{tabular}{|c|c|c|c|c|}
\hline & \multicolumn{2}{|r|}{ Ministeries } & \multicolumn{2}{|c|}{ Publieke sector organisaties } \\
\hline & Belangrijk & $\begin{array}{l}\mathrm{N} \text { (individuele } \\
\text { ambtenaren) }\end{array}$ & Belangrijk & $\begin{array}{c}\mathrm{N} \text { (individuele } \\
\text { organisaties) }\end{array}$ \\
\hline Voorbereiding besprekingen & $9 \%$ & 1270 & $18 \%$ & 147 \\
\hline Deelname Commissiewerkgroepen & $7 \%$ & 1257 & $10 \%$ & 148 \\
\hline Deelname Raadswerkgroepen & $5 \%$ & 1259 & $8 \%$ & 146 \\
\hline Bilateraal overleg & $9 \%$ & 1263 & $32 \%$ & 148 \\
\hline Transpositie & $12 \%$ & 1256 & $16 \%$ & 147 \\
\hline Implementatie & $19 \%$ & 1269 & $26 \%$ & 148 \\
\hline Rekening houden met EU regelgeving & $14 \%$ & 1269 & $45 \%$ & 146 \\
\hline \multicolumn{3}{|c|}{ Bron: Geuijen e.a. 2008} & \multicolumn{2}{|c|}{ Bron: Van Thiel en Yesilkagit 2006} \\
\hline
\end{tabular}


het gevolg van het feit dat in die enquête één persoon antwoord gaf voor de hele organisatie. Aangezien de vraagstelling identiek was, kunnen de uitkomsten echter wel worden gebruikt om de verhouding tussen upload- en downloadactiviteiten binnen de twee enquêtes te vergelijken. Dan blijkt dat het patroon hetzelfde is. Activiteiten die te maken hebben met 'downloaden' (de onderste drie regels in tabel 3.1) spelen een grotere rol in het werk van ambtenaren en overheidsorganisaties dan activiteiten die te maken hebben met 'uploaden' (de bovenste drie regels in tabel 3.1). De categorie 'bilateraal overleg' hebben we tussen upload en download gezet, omdat de vraagstelling in de enquêtes niet expliciet vroeg naar de fase waarin respondenten bilaterale contacten onderhielden. De antwoorden kunnen dus zowel op de upload-als op de downloadfase betrekking hebben.

Deze cijfers laten zien dat EU-beleid voor de meeste ambtenaren en (semi)zelfstandige organisaties meer iets is wat zij 'ontvangen' dan iets waar zij actief aan meewerken. Dat gezegd hebbende is het van belang preciezer zicht te krijgen op de omvang en vormen van downloaden en uploaden in en door het Nederlandse openbaar bestuur. In de volgende twee paragrafen zullen wij dit nader uitwerken aan de hand van beschikbaar empirisch onderzoek.

\subsection{DOWNLOADING: DE EU ALS ACTOR EN ARENA}

In het publieke en politieke debat over de EU is de 'Europese superstaat' een dominant beeld geworden. De gedachte hierbij is dat de ruimte die Nederland heeft voor eigen beleid en eigen keuzes steeds kleiner is geworden door de opkomst van de EU als beleidscentrum. De vrees voor een (nog) sterkere EU wordt vaak genoemd als belangrijke verklaring voor de afwijzing van het Grondwettelijk Verdrag in het Nederlandse referendum van 2005 en dit thema speelde ook een grote rol bij de laatste verkiezingen voor het Europees Parlement.

Bij een nadere beschouwing van dit beeld van de invloed van de EU op Nederland kunnen twee vragen worden gesteld. De eerste vraag is empirisch: in hoeverre heeft de EU invloed op Nederlands beleid en het Nederlandse openbaar bestuur? De afgelopen jaren is veel onderzoek verricht dat hier meer licht op kan werpen. De tweede vraag is conceptueel van aard. Het beeld van een Europese superstaat veronderstelt een eenzijdige verhouding, waarbij beleid vanuit 'Brussel' komt en 'Den Haag' daar slechts op kan reageren. In hoeverre is dit een zinvolle manier om de relatie tussen de EU en Nederland te begrijpen? In de volgende twee subparagrafen zullen we deze twee vragen bespreken. Vervolgens presenteren we een alternatieve conceptualisering van de EU als arena tussen andere arena's. 


\subsubsection{DE INVLOED VAN DE EU OP NEDERLAND}

Als we de invloed van de EU op Nederland willen vaststellen, is het zinvol eerst nader te bepalen op welke manieren de Eu invloed uit kan oefenen en op welke aspecten van het openbaar bestuur zij die invloed uitoefent. In beide gevallen kunnen drie elementen worden onderscheiden.

Bij de invloedskanalen (de manieren waarop de EU invloed kan uitoefenen) bieden de Duitse politicologen Christoph Knill en Dirk Lehmkuhl (2002) een nuttig analysekader. Zij onderscheiden een directe vorm van beïnvloeding door de EU en twee indirecte vormen. De directe vorm van beïnvloeding (door hen 'institutional compliance' genoemd) treedt op wanneer op EU-niveau wetgeving wordt aangenomen die bindend is voor de lidstaten. Voorbeelden hiervan zijn richtlijnen, die in nationale wetgeving moeten worden omgezet, en verordeningen, die direct werken binnen de lidstaten.

Daarnaast zijn er ook twee indirecte vormen van beïnvloeding door de EU. Ten eerste kan regelgeving op EU-niveau de politieke machtsverhoudingen op nationaal niveau veranderen ('changing domestic opportunity structures' in de terminologie van Knill en Lehmkuhl). Dit kan vervolgens leiden tot ander nationaal beleid, ook al wordt dat beleid niet direct door EU-wetgeving voorgeschreven. Een voorbeeld hiervan is het feit dat het voor veel bedrijven gemakkelijker is geworden zich in andere lidstaten van de EU te vestigen. Voor regeringen is dit een gegeven waar rekening mee moet worden gehouden bij het vaststellen van beleid, bijvoorbeeld door belastingen op bedrijven te verlagen. Hoewel deze beleidsveranderingen niet door de EU worden voorgeschreven, draagt het proces van Europese integratie daar wel aan bij.

De tweede vorm van indirecte beïnvloeding vindt plaats door de verspreiding van modellen en 'best practices' op Europees niveau. In de woorden van Knill en Lehmkuhl heeft de Eu dan invloed via de 'framing of domestic beliefs and expectations'. Hierdoor verandert de manier waarop in de lidstaten tegen politieke en beleidsmatige vraagstukken wordt aangekeken. Ook kunnen politici, ambtenaren en belangengroepen Europese 'modellen' gebruiken om hun eigen standpunt kracht bij te zetten. Een mooi voorbeeld daarvan wordt beschreven door Markus Haverland (2005) in het geval van de liberalisering van de spoorwegen in Nederland. Vanaf eind jaren tachtig propageerde de Europese Commissie een model waarbij infrastructuur (het beheer van de rails) en operationele diensten (het laten rijden van treinen) organisatorisch van elkaar zouden worden gescheiden. Omdat veel lidstaten op dit terrein geen bindende afspraken wilden maken, bevatte de richtlijn die in 1991 over dit onderwerp werd aangenomen echter alleen de verplichting infrastructuur en operationele diensten apart in de begroting van spoorwegen op te nemen. Desondanks werd in Nederland het Europese 'spoor- 
wegmodel' aangegrepen om over te gaan tot een splitsing van de NS in meerdere bedrijven. Dit was een verandering die niet direct voortvloeide uit EU-wetgeving, maar betrokken actoren (als het ministerie van Verkeer \& Waterstaat (v\&W) en de vakbonden) verwezen met graagte naar het Europese beleid om de splitsing te legitimeren (Haverland 2005: 30; zie ook Knill en Lehmkuhl 2002: 273).

Naast de drie invloedskanalen kunnen ook drie aspecten van het openbaar bestuur worden onderscheiden waarop de EU invloed uit kan oefenen. In het Engels worden deze vaak samengevat als 'policies, politics and polities' (Börzel en Risse 2003). 'Policies' betreffen het beleid dat in de lidstaten wordt gevoerd, zoals het spoorwegbeleid in het voorbeeld hierboven. 'Politics' is de manier waarop politiek wordt bedreven en beleid wordt gemaakt. 'Polities', ten slotte, omvatten de organisatie en institutionele vormgeving van het openbaar bestuur. Op elk van deze drie elementen kan de EU potentieel invloed uitoefenen.

Deze twee driedelingen bieden een nuttig kader om de invloed van de EU te analyseren, omdat zij laten zien dat de EU, naast directe invloed via wetgeving, ook indirect het openbaar bestuur in de lidstaten kan beïnvloeden en dat de invloed van de EU niet beperkt is tot beleid en wetgeving, maar zich ook uit kan strekken tot de manier waarop de politiek functioneert en het openbaar bestuur is georganiseerd. Een volledige empirische analyse van de invloed van de EU op Nederland zou dan ook alle vormen van beïnvloeding moeten bekijken. Tabel 3.2 bevat een schetsmatig overzicht van de uitkomsten die zo'n exercitie zou opleveren. De kolommen geven de drie aspecten van het openbaar bestuur weer waarop de EU invloed kan hebben, de drie rijen bevatten de drie invloedskanalen.

\section{Tabel 3.2} Mate van EU-invloed op Nederland

\begin{tabular}{|l|l|l|l}
\hline $\begin{array}{l}\text { Europese wetgeving } \\
\text { ('Institutional } \\
\text { compliance') }\end{array}$ & $\begin{array}{l}\text { Beleid } \\
\text { Veleidsterrein, van } \\
\text { verwaarloosbaar } \\
\text { tot aanzienlijk }\end{array}$ & Niet of nauwelijks & Organisaties \\
\hline $\begin{array}{l}\text { Politieke verhoudin- } \\
\text { gen ('Opportunity } \\
\text { structures') }\end{array}$ & $\begin{array}{l}\text { Op bepaalde } \\
\text { terreinen belangrijk }\end{array}$ & $\begin{array}{l}\text { Draagt bij tot } \\
\text { verschuivende } \\
\text { politieke 'praktijken' }\end{array}$ & $\begin{array}{l}\text { zowel tussen als } \\
\text { binnen organisaties }\end{array}$ \\
\hline $\begin{array}{l}\text { Europese modellen } \\
\text { en best practices } \\
\text { ('Framing domestic } \\
\text { beliefs') }\end{array}$ & $\begin{array}{l}\text { Op bepaalde } \\
\text { terreinen belangrijk }\end{array}$ & Niet of nauwelijks & Niet of nauwelijks \\
\hline
\end{tabular}


Verreweg het meeste onderzoek is gedaan naar de cel linksboven: de directe invloed van de EU op nationaal beleid (inclusief wet- en regelgeving). Sinds Jacques Delors begin jaren negentig de verwachting uitsprak dat 70 procent van alle nationale wetgeving op termijn vanuit 'Brussel' zou komen, is dit cijfer een eigen leven gaan leiden en wordt het vaak aangehaald als constatering van een bestaand feit. Systematisch onderzoek hiernaar laat een genuanceerder beeld zien. Zo zijn Bovens en Yesilkagit (2005) nagegaan welk deel van Nederlandse wetten, AMVB's en ministeriële regelingen is gebaseerd op Europese richtlijnen. Over alle beleidsterreinen bezien komen zij uit op een percentage van zo'n 12,5 procent. Deze uitkomsten zijn vrijwel gelijk aan die van vergelijkbare onderzoeken in andere EU-lidstaten (Page 1998; Blom-Hansen en Christensen 2004; Müller et al. te verschijnen) en lijken dus een breder patroon van EU-invloed weer te geven. Binnen dit algehele percentage zitten wel grote verschillen tussen beleidsterreinen. Tabel 3.3 laat dit zien.

Tabel 3.3 Aandeel en verdeling van omzettingsregels per ministerie, 31 juli 2003 (Bovens en Yesilkagit 2005)

\begin{tabular}{|c|c|c|c|c|c|c|c|c|}
\hline & \multicolumn{2}{|c|}{ Wetten } & \multicolumn{2}{|c|}{$\begin{array}{r}\text { Algemene } \\
\text { maatregelen } \\
\text { van bestuur }\end{array}$} & \multicolumn{2}{|c|}{$\begin{array}{r}\text { Ministeriële } \\
\text { besluiten }\end{array}$} & \multicolumn{2}{|c|}{ Totaal } \\
\hline Ministerie & EU \% & $100 \%$ & EU \% & $100 \%$ & EU \% & $=100 \%$ & EU \% & $y=100 \%$ \\
\hline Algemene Zaken & 2 & 44 & 0,00 & 135 & 0,00 & 46 & 0,4 & 225 \\
\hline Buitenlandse Zaken & 0 & 89 & 2,9 & 35 & 0,7 & 138 & 0,8 & 262 \\
\hline $\begin{array}{l}\text { Binnenlandse Zaken en Koninkrijks- } \\
\text { relaties }\end{array}$ & 2 & 230 & 2,9 & 309 & 1,3 & 553 & 1,9 & 1092 \\
\hline Defensie & 0 & 37 & 0,7 & 148 & 0,00 & 105 & 0,3 & 290 \\
\hline Economische Zaken & 17 & 81 & 33,3 & 135 & 16,1 & 434 & 19,9 & 650 \\
\hline Financiën & 15 & 231 & 9,1 & 154 & 12,2 & 410 & 12,5 & 795 \\
\hline Justitie & 10 & 360 & 5,4 & 294 & 5,4 & 636 & 6,6 & 1290 \\
\hline Landbouw, Natuurbeheer en Visserij* & 29 & 58 & 39,5 & 190 & 18,5 & 1122 & 21,9 & 1370 \\
\hline Onderwijs, Cultuur en Wetenschap & 4 & 144 & 2,6 & 233 & 0,4 & 1013 & 1,1 & 1390 \\
\hline Sociale Zaken en Werkgelegenheid & 12 & 165 & 9,8 & 236 & 6,0 & 586 & 7,9 & 987 \\
\hline Verkeer en Waterstaat & 20 & 133 & 25,5 & 255 & 9,7 & 1098 & 13,4 & 1486 \\
\hline Volksgezondheid, Welzijn en Sport & 10 & 110 & 30,0 & 313 & 18,4 & 852 & 20,6 & 1275 \\
\hline $\begin{array}{l}\text { Volkshuisvesting, Ruimtelijke } \\
\text { Ordening en Milieu }\end{array}$ & 14,1 & 99 & 28,7 & 223 & 14,9 & 551 & 18,3 & 873 \\
\hline
\end{tabular}


De ministeries van Landbouw, Natuurbeheer en Voedselkwaliteit (LNV), Verkeer en Waterstaat (V\&W) en Economische Zaken (EZ) behoren tot de meest geëuropeaniseerde ministeries. De hoge score van Volksgezondheid, Welzijn en Sport (vWs) is met name toe te schrijven aan de relatief grote hoeveelheid voedselveiligheidsrichtlijnen die dit ministerie moet omzetten. Hier is vws samen met LNV verantwoordelijk voor: terwijl LNV de aspecten diergezondheid en dierenwelzijn voor zijn rekening neemt, legt vws zich toe op de volksgezondheidsaspecten van voedselveiligheid. Tot slot zien we dat ook het ministerie van Volkshuisvesting, Ruimtelijke Ordening en Milieu (VROM) tot een van de meest geëuropeaniseerde ministeries behoort. Hiervoor zijn met name het grote aantal milieurichtlijnen die het directoraat-generaal Milieu omzet verantwoordelijk. Deze tabel (3.3) laat ook goed zien dat het ministerie van Buitenlandse Zaken (BuZa) weinig richtlijnen omzet, wat uiteraard niet wil zeggen dat BuZa geen belangrijke actor is in Europese beleidsvorming. De bevindingen in deze tabel laten in ieder geval goed zien dat verschillende departementen een eigen Europese omgeving hebben. De staat is gefragmenteerd, niet alleen verticaal door de instelling van overheden op afstand, maar ook horizontaal tussen departementen als het op hun internationale omgeving aankomt.

Bij deze cijfers moet worden aangetekend dat de keuze om alleen te kijken naar wet- en regelgeving die direct is gebaseerd op Europese richtlijnen een onderschatting van de invloed van de EU oplevert. De EU oefent immers ook invloed uit via verordeningen, die niet hoeven te worden omgezet in nationale wetgeving, via de EU-verdragen en via uitspraken van het Hof van Justitie. Onderzoekers van het T.M.C. Asser Instituut hebben daarom geprobeerd een meer omvattende maatstaf voor de invloed van de EU op nationale wet- en regelgeving te ontwikkelen (Douma et al. 2007). Daarbij werd een verwijzing naar Europees recht of Europese rechtspraak in de wetstekst of begeleidende stukken als de Memorie van Toelichting, de Kamerstukken en de Staatscourant opgevat als een indicatie van beïnvloeding door de EU. Bij toepassing op twee beleidsterreinen liet deze methode zien dat ongeveer 6 procent van de onderwijswetgeving en 66 procent van de milieuwetgeving in Nederland is beïnvloed door de EU.

Hoewel deze kwantitatieve gegevens slechts een indicatie geven en niet als opzichzelfstaande 'feiten' moeten worden opgevat, laten ze wel zien dat geen sprake is van een 'overname' van Nederlands beleid door de EU. Voor zover de EU een grote invloed heeft, bevindt deze zich in bepaalde, sterk geëuropeaniseerde beleidsterreinen als milieu en landbouw. Op veel andere gebieden worden de meeste beslissingen gewoon in Nederland genomen.

De invloed van de EU op politieke processen in Nederland is veel moeilijker vast te stellen, al was het maar omdat op dit terrein geen Europese wet- en regelgeving bestaat. Voor zover er invloed is vanuit de EU verloopt deze dus op indirecte wijze. 
Op dit punt zijn er echter wel degelijk aanwijzingen dat het bestaan van de EU tot verschuivingen in de Nederlandse constitutionele verhoudingen heeft geleid. Zo betoogt Leonard Besselink (2005) dat het proces van Europese integratie heeft geleid tot een versterking van de regering en de rechterlijke macht ten opzicht van het parlement. De sterkere rol van de regering komt voort uit het feit dat ministers direct actief zijn in de Europese besluitvorming via de Raad van Ministers, terwijl het parlement slechts op afstand kan toekijken. De positie van de rechterlijke macht is versterkt, doordat ze zich in uitspraken kan beroepen op Europees recht en rechtstreeks, zonder tussenkomst van regering of parlement, vragen kan voorleggen aan het Europese Hof van Justitie. Aan deze analyse kan worden toegevoegd dat de positie van de minister-president binnen de regering is versterkt door zijn prominente rol in de Europese Raad, terwijl de rijksoverheid met een beroep op de EU op punten het toezicht op lagere overheden heeft versterkt. Problematisch bij het waarderen van elk van deze processen is dat zij niet alleen door de EU of het proces van Europese integratie zijn veroorzaakt. De versterking van de positie van de regering en de minister-president, de centralisering van macht tussen bestuurslagen en de juridisering van de samenleving zijn processen die al langer dan een eeuw plaatsvinden en hun wortels hebben in maatschappelijke ontwikkelingen buiten de EU om. Het is daarom moeilijk de bijdrage van de EU op deze punten te isoleren van andere invloeden, hoewel het aannemelijk is dat de EU de langer bestaande tendensen heeft versterkt.

Wat betreft de organisatie van het openbaar bestuur, ten slotte, laat onderzoek naar de werkpatronen van ambtenaren zien dat het dominante patroon er een is van intensieve beïnvloeding op onderdelen naast grote delen die niet of nauwelijks worden beïnvloed (Geuijen et al. 20o8; Mastenbroek en Princen te verschijnen). In een grootschalige enquête onder Nederlandse rijksambtenaren gaf circa 30 procent van de respondenten aan in zijn of haar werk met de EU te maken te hebben. Meer dan de helft van deze 30 procent besteedde gemiddeld echter twee uur of minder per week aan EU-gerelateerde werkzaamheden. Daartegenover staat een kleinere groep van ambtenaren die vrijwel de gehele werkweek besteden aan werkzaamheden die met de EU te maken hebben. Ook hier waren er grote verschillen tussen ministeries. Bij de ministeries van Landbouw, Buitenlandse Zaken, Verkeer \& Waterstaat en Economische Zaken had meer dan de helft van alle respondenten met de EU te maken, tegen minder dan 20 procent in ministeries als Onderwijs, Cultuur \& Wetenschappen (OCW) en Justitie. Deze uitkomsten zijn vergelijkbaar met die van eerdere enquêtes in andere landen (Egeberg en Trondal 1999; Wessels 1997; zie Mastenbroek en Princen te verschijnen).

Al met al laat bestaand empirisch onderzoek dus een gedifferentieerd beeld zien. Er vindt wel degelijk belangrijke beïnvloeding plaats vanuit de EU, maar de Europese invloed is niet compleet. Bovendien verschilt de invloed van de EU sterk tussen beleidsterreinen en organisaties binnen het openbaar bestuur. Op sommige 
terreinen en voor sommige organisaties is de EU een belangrijk centrum van beleids- en organisatorische ontwikkelingen; op andere terreinen is de Europese invloed nog heel beperkt en vooral voer voor EU-specialisten.

\subsubsection{VAN INVLOED NAAR INTERACTIE}

In de vorige subparagraaf hebben we gekeken naar de invloed van de EU op Nederland. Het is echter ook belangrijk kritisch te kijken naar de veronderstellingen achter de vraag naar de invloed van de EU op het Nederlandse openbaar bestuur. Impliciet in het debat over de invloed van de Eu en de notie van een 'Europese superstaat' zijn twee veronderstellingen. De eerste is dat de EU iets is wat zich buiten Nederland bevindt. Er is dus sprake van invloed die van buiten op Nederland afkomt. Deze beïnvloedingsrelatie is eenzijdig: hij verloopt van de EU naar Nederland. De tweede veronderstelling is dat beïnvloeding van Nederland door de EU een 'zero-sum game' is: als de EU meer invloed krijgt, dan krijgt Nederland minder invloed (lees: minder beleidsruimte). Beide veronderstellingen zijn discutabel, hetgeen we zullen betogen aan de hand van onderzoek naar Europese beleidsvorming.

De eerste veronderstelling, dat de EU een invloed is die van buiten op Nederland afkomt, ligt (veelal impliciet) achter de berichtgeving in de media over de EU. Daarin is er vaak sprake van dat 'de EU', 'Europa' of 'Brussel' iets heeft besloten. Dit gaat eraan voorbij dat EU-beleid en EU-besluiten zelf grotendeels het product zijn van de inbreng van lidstaten. Formeel is dat het geval, omdat regeringen van lidstaten met vrijwel alle EU-besluiten in moeten stemmen, hetzij in de Raad van Ministers hetzij op ambtelijk niveau in werkgroepen of het comité van permanente vertegenwoordigers. Informeel speelt dit nog sterker, omdat veel van de ideeën voor Europees beleid worden ingebracht door nationale politici, ambtenaren en belangengroepen.

Soms kan dit zelfs een bewuste strategie zijn om binnenlandse politieke tegenstand te omzeilen. Virginie Guiraudon (200o) heeft bijvoorbeeld laten zien dat beleidsmakers uit Duitsland, Frankrijk en Nederland in de jaren tachtig en negentig de EU gebruikten om een restrictiever immigratiebeleid tot stand te brengen. Zij konden dat doen, omdat zij op Europees niveau niet werden gehinderd door ministeries en belangengroepen in eigen land die een ruimhartiger beleid voorstonden. Het Europese beleid kon vervolgens weer worden gebruikt om het beleid in eigen land aan te passen. In de context van sociale bewegingen op mondiaal niveau, is deze strategie door Margaret Keck and Kathryn Sikkink (1998) het 'boemerangeffect' genoemd: door op internationaal (hier: Europees) niveau iets aan te kaarten, hoop je veranderingen in eigen land tot stand te brengen.

Ook wanneer het doel niet is om de binnenlandse oppositie te omzeilen, doen regeringen vaak verwoede pogingen het eigen beleid naar het EU-niveau te expor- 
teren. Hier kunnen verschillende redenen voor zijn. Zo zijn veel regeringen beducht voor concurrentienadelen die ondernemingen in eigen land ondervinden van relatief strenge regelgeving. Wanneer het lukt die regelgeving aangenomen te krijgen als EU-wetgeving, worden de strengere normen (en daarmee de hogere kosten) 'geëxporteerd' naar alle andere lidstaten. Bijgevolg zijn regeringen op sommige beleidsterreinen verwikkeld in een strijd om het eigen beleid te 'uploaden' (Geuijen et al. 2008: 55; Héritier et al. 1996). Daarnaast spelen soms ook 'missionaire' motieven een rol. Zo is de Ierse minister van Volksgezondheid die in eigen land het rookverbod invoerde ook actief geweest om dit onderwerp binnen de EU op de agenda te krijgen (Princen 2009: 157). Anders dan het debat over de invloed van de EU op Nederland doet vermoeden, is dus sprake van een tweezijdige relatie, waarbij niet alleen beleid vanuit de EU zich doet voelen in de lidstaten (waaronder Nederland), maar organisaties en individuen in deze lidstaten actief proberen bepaalde vormen van Europees beleid tot stand te brengen.

Ook de tweede veronderstelling achter het debat over de invloed van de EU op Nederland, dat er sprake zou zijn van communicerende vaten tussen Europese en nationale invloed, houdt bij nadere beschouwing geen stand. Europees beleid wordt niet passief 'ontvangen', maar wordt onderdeel van lopende binnenlandse politieke debatten en daarin actief gebruikt. Daarmee voegt de EU juist iets toe aan het beleid in Nederland en kan zij de aanjager zijn van nieuw (nationaal) beleid. Dit geldt voor elk van de drie hierboven besproken kanalen via welke de EU invloed kan hebben op Nederland.

Bij het directe kanaal van beïnvloeding via 'institutional compliance' geldt dat, hoewel EU-richtlijnen moeten worden omgezet in nationale wetgeving, zij lidstaten vaak nog de nodige ruimte bieden om dit op een eigen manier te doen. De richtlijnen bieden dan wel een kader waarbinnen nationaal beleid zich moet bevinden, maar zij leggen dit beleid niet helemaal vast. Daarnaast wordt de omzetting van richtlijnen vaak aangegrepen door nationale ministeries en/of belangengroepen om aanvullende wensen in de wetgeving te laten opnemen, een praktijk die bekendstaat als 'goldplating'. Een mooi voorbeeld hiervan is de omzetting van de EU-richtlijn over luchtkwaliteit in nationaal recht. Daarbij kozen verschillende lidstaten voor verschillende benaderingen, waarbij de Nederlandse wet- en regelgeving in eerste instantie veel verderging dan door de Europese richtlijn was voorgeschreven (Backes 2006). Toen de Raad van State een reeks bouwvergunningen voor grote projecten vernietigde wegens strijd met de luchtkwaliteitsnormen, was dit minstens evenzeer het gevolg van Nederlandse keuzes in de omzetting als van de Europese richtlijnen op zich. De inhoud van het pakket aan maatregelen dat de Nederlandse regering vervolgens heeft opgesteld om de luchtkwaliteit in Nederland te verbeteren, is ook niet door de EU opgelegd. Het is eerder zo dat de Europese eisen Nederlandse beleidsmakers dwongen te zoeken naar nieuwe oplossingen. Daarmee heeft het Europese beleid niet geleid tot minder maar juist tot meer 
Nederlands beleid. Het Europese beleid kwam niet in plaats van het Nederlandse beleid, maar voegde er elementen aan toe.

Het samenspel van Europese en binnenlandse beleidskeuzes is nog duidelijker wanneer we kijken naar de indirecte vormen van beïnvloeding. Veranderende 'domestic opportunity structures' als gevolg van Europese integratie kunnen leiden tot veranderingen op nationaal niveau, maar zij geven zelden een eenduidige richting aan. Het ligt bijvoorbeeld voor de hand dat de grotere mobiliteit van bedrijven ertoe leidt dat regeringen voorzichtiger worden met het verhogen van de winstbelasting of dat zij zelfs actief belastingen verlagen om bedrijven te trekken (denk aan Ierland). Maar dat is nooit de enige overweging. In de afgelopen decennia is (in Nederland en daarbuiten) sowieso veel veranderd in het denken over de rol van de overheid in de economie, hetgeen onder andere geleid heeft tot een streven naar lagere belastingen. Dit is een verandering die zich voor een groot deel los van het Europese integratieproces heeft afgespeeld en die dus niet door de EU is gedetermineerd. Ook hier is sprake van een combinatie van Europese en binnenlandse processen die tot een bepaalde beleidsuitkomst leiden. Dat de EU of het proces van Europese integratie daarin niet doorslaggevend is, blijkt alleen al uit de grote diversiteit in belasting- en verzorgingsstaatregimes in Europa. Blijkbaar kan op dezelfde invloed vanuit de EU op veel verschillende manieren worden gereageerd, afhankelijk van binnenlandse omstandigheden en prioriteiten.

Datzelfde geldt voor de invloed van de EU via modellen en 'best practices'. In de vorige paragraaf gaven we het voorbeeld van de splitsing van de NS. Ook hier geldt dat de EU wel een rol heeft gespeeld in het proces, maar dat de splitsing uiteindelijk een Nederlands besluit was op grond van ideeën en overwegingen bij Nederlandse beleidsmakers. In dit geval lijkt het er vooral op dat het Europese beleid is gebruikt door het ministerie om de eigen ideeën kracht bij te zetten en door de vakbonden om moeilijke veranderingen te verkopen aan de eigen achterban. De EU heeft ook hier dus niet de Nederlandse beleidsruimte verkleind, maar bepaalde spelers in het veld een extra argument in handen gegeven in een lopend binnenlands politiek spel.

\subsubsection{DE EU ALS ALTERNATIEVE BELEIDSARENA}

Als het idee van een eenzijdige beïnvloedingsrelatie van de EU naar Nederland betwistbaar is, noopt dat tot een andere conceptualisering van de verhouding tussen de EU en Nederland. Meer productief is het volgens ons om deze verhouding te zien als een systeem met meerdere beleidsarena's waarin spelers uit politiek, openbaar bestuur en belangengroepen actief zijn. Naast de Nederlandse beleidsarena (die op zich al weer uit verschillende nationale en lokale arena's bestaat) heeft de EU geleid tot het ontstaan van een Europese beleidsarena (die zelf weer uit meerdere arena's is opgebouwd). Daarnaast zijn er diverse beleidsarena's 
'voorbij de EU', zoals de Raad van Europa, de NAVo en de onderdelen van de Verenigde Naties. Tussen deze andere Europese en mondiale arena's en de EU bestaan vergelijkbare relaties van wederzijdse beïnvloeding als tussen de EU en haar lidstaten (zie bijv. Dostal 2004 voor de relatie EU-OECD in sociaal beleid; Rhinard 2002 voor de relatie EU-OECD rond biotechnologie; Princen 2009 voor de relatie EU-WHO in volksgezondheidsbeleid en EU-CBD in visserijbeleid). De verhouding tussen deze beleidsarena's vertoont een aantal kenmerken die in de literatuur bekend zijn onder de term 'multilevel governance' (vgl. Bache en Flinders 2004; Hooghe en Marks 2001, 2003).

- Beleidsarena's op verschillende niveaus houden zich met dezelfde onderwerpen bezig. Er is dus geen scherpe scheiding tussen onderwerpen die op nationaal en onderwerpen die op Europees (of internationaal) niveau worden besproken.

- Dezelfde spelers zijn actief in meerdere beleidsarena's. Nationale beleidsvormers participeren ook in Europese en internationale beleidsvormingsprocessen en omgekeerd. Daarmee kunnen zij ook 'springen' tussen beleidsarena's, op zoek naar de arena die het meest ontvankelijk is voor hun ideeën en wensen (Princen 2009: 27-28).

- Er is geen hiërarchische verhouding tussen de verschillende beleidsarena's. Beïnvloeding kan zowel 'van boven naar beneden' (d.w.z. van de EU naar de lidstaten) als 'van beneden naar boven' (van lidstaten naar de EU) verlopen. In veel gevallen is sprake van interactie tussen de beleidsarena's, waarbij sprake is van wederzijdse beïnvloeding en moeilijk een eenduidig begin- of eindpunt is aan te wijzen.

Deze conceptualisering impliceert een verschuiving in perspectief waarbij de EU niet langer wordt gezien als een actor, die handelt ten opzichte van Nederland, maar als een beleidsarena naast andere beleidsarena's, die actoren kunnen gebruiken om beleid te maken en te beïnvloeden. Daarmee wordt aan de twee conceptuele kritiekpunten van de vorige paragraaf tegemoetgekomen. Om te beginnen kan een beleidsarenabenadering beter verklaren waarom sprake is van interactie tussen de EU en Nederland in plaats van een eenzijdige beïnvloedingsrelatie. Omdat actoren heen en weer kunnen springen tussen beleidsarena's op nationaal, Europees en internationaal niveau en er geen vaststaande hiërarchie tussen deze niveaus bestaat, verloopt de beïnvloeding in meerdere richtingen. Daarnaast laat deze benadering ook beter zien dat beleidsuitkomsten op nationaal niveau een samenloop zijn van Europese en binnenlandse invloeden. Doordat Europees beleid onderdeel wordt van lopende processen in binnenlandse beleidsarena's, is zelden sprake van het eenvoudigweg overnemen van Europees beleid, maar wordt het Europese beleid door politieke actoren gebruikt binnen een nationale context.

Dit heeft ook implicaties voor het denken over het Nederlandse openbaar bestuur. In plaats van een focus op 'externe' internationale factoren die de Nederlandse 
beleidsruimte beïnvloeden, komt de nadruk te liggen op de manier waarop actoren in het Nederlandse openbaar bestuur vormgeven aan en omgaan met de Europese en internationale beleidsarena's die hun ter beschikking staan. Dit vraagt om een nadere beschouwing van de manieren waarop beleid wordt geüpload naar Europese (en mondiale) beleidsarena's. In de volgende paragraaf zullen wij dit verder uitwerken.

\subsection{UPLOADING: DE NEDERLANDSE STAAT EN DE INTERNATIONALISERING VAN BELEID}

In de vorige paragraaf stelden wij dat om de invloed van internationalisering op het Nederlandse openbaar bestuur te begrijpen we in de eerste plaats de EU als een verzameling beleidsarena's dienen te beschouwen. In deze paragraaf laten we zien dat het ontstaan van verschillende Europese beleidsarena's consequenties heeft gehad voor de organisatie en structuur van beleidsvorming en -uitvoeringsfuncties in Nederland. We laten zien dat met de internationalisering en europeanisering van beleid - dat wil zeggen de opkomst van meerdere inter- en supranationale beleidsarena's - de Nederlandse overheid gefragmenteerd is geraakt op zowel het niveau van ministeries als op het niveau van uitvoerende diensten. Internationalisering van beleid en het ontstaan van beleidsarena's voor vrijwel ieder grensoverschrijdend beleidsvraagstuk heeft ertoe geleid dat (onderdelen van) ministeries en uitvoerende diensten die zich met grensoverschrijdende vraagstukken bezighouden eigen beleidsarena's hebben gevonden.

\subsubsection{DE INTERNATIONALISERING VAN BELEID EN DE FRAGMENTATIE VAN BELEIDSVORMING}

'Vroeger' bestond er een overzichtelijke situatie. Er was een unitaire staat die soeverein de arena van internationale betrekkingen met andere soevereine staten betrad en daarin handelde. Binnen een staat bestond ook een heldere en strikte taakverdeling. Internationale betrekkingen waren het exclusieve domein van de diplomatieke dienst. Het ministerie van Buitenlandse Zaken bezat het monopolie over de buitenlandse handel en wandel van de nationale staat. Diplomaten waren de ogen, oren en mond van de nationale staat. De diplomatieke dienst bestond uit een strak hiërarchisch georganiseerd corps dat zich sterk onderscheidde van de rest van de nationale bureaucratie (zie bijv. Coolsaet 1998; Hamilton en Langhorne 1995; Melissen 2006). Deze strikte scheiding in taken uitte zich ook in jurisdicties: nationale dossiers die internationaal werden, werden door diplomaten overgenomen en in internationale fora behandeld. Milieuambtenaren waren belast met het voeren en ontwikkelen van nationaal milieubeleid en diplomaten waren belast met het voeren van internationale onderhandelingen over milieubeleid. 
Dit klassieke model heeft inmiddels plaats moeten maken voor een model waarbij Buitenlandse Zaken niet langer het exclusieve domein van diplomaten zijn (vgl. Berridge 2002; Coolsaet 1998; Kennan 1997). De internationalisering van beleid als gevolg van de toegenomen vervlechting van nationale economieën, cultuur, technologische vooruitgang en migratie - ofwel: globalisering - maakt het monopolie van ministeries van Buitenlandse Zaken op internationale betrekkingen onhoudbaar. Ten eerste kunnen onderhandelingen en besprekingen over internationale beleidsproblemen zoals het milieu, financiële markten en voedselveiligheid niet meer op adequate wijze gevoerd worden zonder de kennis en expertise van ambtenaren binnen ministeries van milieu, financiën en voedselveiligheid. Diplomaten zijn generalisten en ontberen de kennis om op technisch detailniveau besprekingen over deze onderwerpen te voeren. Ten tweede vereist de aard van veel geïnternationaliseerde problemen korte lijnen tussen betrokken landen en ministeries. De uitbraak van vogelgriep en de crisis op de financiële markten vragen om snelle en directe contacten tussen de bevoegde en competente ambtenaren en hun departementen.

De internationalisering van beleid vereist een nieuwe manier van organiseren van de internationale vertegenwoordiging van nationale overheden. In de eerste plaats heeft de internationalisering van beleid ertoe geleid dat de internationale omgeving van een staat een integraal onderdeel van het beleidsdomein is gaan uitmaken. In klassieke modellen van overheidsbeleid bestaat de directe omgeving van een ministerie uit andere ministeries, maatschappelijke (koepel)organisaties, hun doelgroep(en), lokale overheden en adviesorganen. De beleidssector kon een gesloten beleidsgemeenschap of 'ijzeren driehoek' vormen en zich genesteld hebben binnen een niche van de nationale staat. In een globaliserende wereld worden gesloten sectoren opengebroken en/of getransponeerd naar een internationale omgeving. In deze internationale omgeving maken alle actoren in het beleidsnetwerk onderdeel uit van grotere internationale verbanden en zijn zij deel van of worden medeoprichters van internationale associaties en koepelorganisaties. In de tweede plaats zien we dat monopolies op internationale betrekkingen worden opgeheven of sterk uitgekleed. De strakke hiërarchie waarmee de diplomatieke diensten de internationale betrekkingen in en uit naam van de nationale staat voeren wordt opgebroken en wordt verspreid over verschillende departementen. Er ontstaan weliswaar weer monopolies maar deze omvatten alleen een specifiek domein van overheidsbeleid. Slaughter (2000, 2004) spreekt in dit verband van de disaggregatie van de staat. 'De' soevereine staat spreekt niet langer door één spreekbuis; de soevereine staat heeft verschillende spreekbuizen.

De ontwikkeling van de EU als beleidsarena heeft een belangrijk aandeel in deze ontwikkeling gehad. De EU is de enige supranationale organisatie met regelgevende bevoegdheden die langs vergelijkbare beleidssectoren is georganiseerd als de centrale overheidsministeries binnen lidstaten. De verschillende directoraten- 
generaal van de Europese Commissie hebben daarmee eenzelfde structurele invloed op de organisatie van maatschappelijke vraagstukken als die ministeries. De organisatie van de EU heeft een constituerende invloed op de vorming van Europese beleidsnetwerken. In die netwerken is geen plaats en rol weggelegd voor nationale ministeries van Buitenlandse Zaken volgens het klassieke model. Binnen de EU beleidsarena is buitenlands beleid binnenlands geworden en is binnenlands beleid ook buitenlands beleid geworden. Verschillende studies laten de vervlechting tussen Europees beleid en binnenlands bestuur en de afname van de centrale rol van Buitenlandse Zaken duidelijk zien (Egeberg et al. 2003; Laegreid et al. 2004; Geuijen et al. 2008). Egeberg en collega's (2003: 36) laten met behulp van hun survey uit 1997 onder 218 nationale ambtenaren (onder wie ambtenaren van Buitenlandse Zaken) van 14 lidstaten zien dat slechts 20 procent van de respondenten die naar commissiewerkgroepen gaan hun positie vooraf afstemmen met hun ministerie van Buitenlandse Zaken.

Concluderend kan gesteld worden dat de internationalisering van beleid zowel de internationale omgeving van nationale overheden als de wijze waarop nationale staten op het internationale toneel opereren significant heeft veranderd. Beleidsvraagstukken hebben vanwege de globalisering van de wereldeconomie en technologische ontwikkelingen een grensoverschrijdend karakter gekregen. De internationale aanpak van dergelijke vraagstukken heeft mede door hun complexiteit en urgentie geleid tot de integratie van voorheen gesloten nationale beleidssectoren en beleidsdepartementen in transnationale beleidsnetwerken. Ministeries van Buitenlandse Zaken hebben nog altijd een belangrijke rol op het internationale toneel, maar moeten de beleidspecialisten van andere departementen bij internationale overleggen naast zich dulden.

\subsubsection{DE INTERNATIONALISERING VAN BELEID EN DE FRAGMENTATIE VAN DE BELEIDSUITVOERING}

Internationalisering en europeanisering hebben niet alleen invloed gehad op de organisatie en structuur van ministeries. Ook zijn de structuur en organisatie van de uitvoering van beleid sterk veranderd. De omwentelingen die zich op het vlak van de beleidsuitvoering hebben voorgedaan zijn wellicht radicaler dan op het terrein van de beleidsvorming. De internationalisering van maatschappelijke vraagstukken heeft hierbij uiteraard ook een belangrijke rol gespeeld. Daarnaast zijn echter ook twee andere factoren te noemen die van groot belang zijn geweest. De eerste factor zijn de verzelfstandigingsoperaties. Onderzoek naar de relatie tussen autonomie en de internationalisering van de beleidsuitvoering bevindt zich nog in de kinderschoenen, maar studies die tot nu toe verricht zijn geven sterke aanwijzingen voor een causaal verband tussen verzelfstandiging en de internationalisering van beleidsuitvoering (Whytock 2005). Dit mag opmerkelijk heten, want de verzelfstandigingoperaties van de jaren tachtig en negentig hielden geen 
enkel direct verband met internationalisering van beleid (De Vries \& Yesilkagit 1999). Internationalisering was het laatste waar nationale beleidsmakers aan dachten toen zij menig onderdeel van de nationale overheid verzelfstandigden. De motieven voor verzelfstandiging zijn genoegzaam bekend: het deskundigenmotief, participatiemotief en het doelmatigheidsmotief (Van Thiel 2001). Hoe verhoudt verzelfstandiging zich dan tot internationalisering van de beleidsuitvoering?

Hier zijn weer twee factoren van belang. De eerste is de formele onafhankelijkheid van (semi)zelfstandige organisaties. Formele onafhankelijkheid heeft aan deze organisaties een vrije beleids- en managementruimte gegeven die deze organisaties naar eigen inzichten en hun (verzelfstandigde) belangen konden invullen. Studies naar verzelfstandiging (Carpenter 2001; Yesilkagit 2004;) laten zien dat toename van formele autonomie de handelingsvrijheid van publieke organisaties sterk vergroot. Het leiderschap van autonome publieke organisaties kan zelfstandig beslissingen van strategisch belang nemen. Indien autonome publieke organisaties op beleidsterreinen met een internationale dimensie moeten opereren, dan is het aangaan van netwerken en verbanden met zusterorganisaties een welhaast logische stap. In de tweede plaats heeft verzelfstandiging ruimte geboden aan verdere specialisering en professionalisering. Verzelfstandigde organisaties hebben de vrijheid gekregen zich te specialiseren en expertise op te doen (Christensen \& Laegreid 2006). Zij hebben zich in relatief korte tijd tot expertisecentra op specifieke terreinen (privacy, discriminatie, energietoezicht, zorg, enzovoorts) ontwikkeld. Terwijl ministeriële departementen zich meer toeleggen op de grotere beleidsvraagstukken - en dan voornamelijk op die vraagstukken die op de agenda van de minister prijken - hebben verzelfstandigde organisaties zich meer en meer in de technische verfijningen van beleidsinstrumenten gespecialiseerd en hebben ze de oorzaken en gevolgen van 'hun' beleidsvraagstukken beter leren doorgronden dan hun collega's op het ministerie. De studie van Abraham Newman (2008) naar het ontstaan van het netwerk van privacyautoriteiten illustreert deze punten (zie Tekstbox 3.1)

Een tweede factor die van invloed is geweest op de internationalisering van de beleidsuitvoering zijn de doelbewuste pogingen van de Europese Commissie om formele transnationale overheidsnetwerken in het leven te roepen. Zoals ook in paragraaf 3.2 beschreven is, is de EU een 'networked governance' gemeenschap. Bestuurlijke en beleidsnetwerken in de EU zijn uit noodzaak geboren. De lidstaten hebben de Europese Commissie weliswaar het initiatief van wetgeving gegeven, maar de bestuurlijke capaciteit om de regelgeving uit te voeren hebben de lidstaten haar onthouden. De EU heeft, zo heeft menig auteur al geschreven, een 'governance dilemma' (Dehousse 1997; Eberlein \& Newman 2008; Coen \& Thatcher 2008). De Europese Commissie heeft eenvoudigweg niet het ambtelijk apparaat om zelf binnen de lidstaten Europese regels uit te voeren. Vindingrijk- 
heid in het ontwerpen van alternatieve governance-arrangementen kan de Commissie echter niet ontzegd worden. Om haar bestuurlijk tekort te compenseren zijn verscheidene arrangementen, variërend van comitologie, de open methode van coördinatie tot Europese agentschappen gecreëerd. Europese netwerken van nationale toezichthouders kunnen tot de jongste loot van bestuurlijke innovaties in het domein van Europees governance gerekend worden. Zij vormen op veel gebieden belangrijke beleidsarena's in de zin dat de ontwikkeling van en zelfs besluitvorming over Europees beleid in deze netwerken plaatsvindt. Om die reden zullen we in de volgende paragraaf hun verschijningsvormen en activiteiten nader in kaart brengen.

\section{Box 3.1 Samenwerking tussen Europese privacyautoriteiten: de rol van autonomie en expertise}

In zijn studie laat Newman zien dat het aannemen van de Europese Privacy Richtlijn (95/46/ec) hoofdzakelijk toe te schrijven is aan de proactieve wijze waarop autonome nationale Europese privacytoezichthouders met elkaar in internationaal netwerkverband hebben samengewerkt. De opkomst van moderne communicatietechnologieën maakten de aanscherping van privacyregels in de ogen van privacy-instanties, deskundigen en activistische juristen hard nodig. Tegen de richtlijn was echter veel verzet en het heeft ook decennia geduurd voordat de Eu deze wet aannam.

Privacyregels leggen administratieve lasten op aan bedrijven, juridische beperkingen aan opsporingsinstanties en zijn moeilijk te handhaven. De omslag in het beleidsproces kwam pas na het begin van de jaren tachtig. Vanaf dit moment werden in verschillende Europese landen onafhankelijke privacyautoriteiten opgericht (in Nederland was dit de Registratiekamer, de voorloper van het College Bescherming Persoonsgegevens). In 1976 had alleen Zweden een onafhankelijke privacyautoriteit; in 1988 waren er al elf autoriteiten, waarvan zeven in landen die lid waren van de Europese Gemeenschap. Voorheen bestonden de voorstanders van privacyregelgeving uit een informeel netwerk van individuele privacydeskundigen. Met de groei van het aantal onafhankelijke privacyautoriteiten groeide ook de transnationale samenwerking tussen deze autoriteiten. De privacyautoriteiten ontwikkelden gezamenlijke initiatieven, produceerden kennis over privacy en deelden kennis met elkaar. Uit dit informatienetwerk groeide gaandeweg een harmonisatienetwerk. Vanaf 1989 schreef dit netwerk ontwerpen voor een Europese privacyrichtlijn en zette het de Commissie en de lidstaten onder druk om een privacyrichtlijn uit te vaardigen. De formele autonomie van de privacyautoriteiten, ten slotte, gaf de uiteindelijke doorslag. De privacyautoriteiten dreigden de Commissie en de lidstaten met het gebruik van hun bevoegdheid om interstatelijk verkeer in gegevens te blokkeren - door gegevensoverdracht aan derde landen niet goed te keuren - en daarmee het economisch verkeer en de handel tussen verschillende landen en sectoren nagenoeg stil te leggen (Newman 2008: 114 e..). In de woorden van Newman "data privacy authorities used their domestically delegated authority to change the preference calculation of actors at other levels" (Newman 2008: 116). 


\section{3 -5 TRANSNATIONALE OVERHEIDSNETWERKEN EN NEDERLAND}

De ontwikkelingen die we hierboven beschreven hebben - de ontwikkeling van de EU als beleidsarena en de fragmentatie van de nationale staat als gevolg van internationalisering van nationale beleidsvormings- en -uitvoeringsarena's - hebben ertoe geleid dat een nieuwe supranationale ruimte is ontstaan. Deze nieuwe ruimte wordt bevolkt door de transnationale netwerken. Deze netwerken zijn te omschrijven als 'transnationaal' in plaats van 'internationaal', omdat zij actoren van verschillende bestuurslagen bijeenbrengen: regulatoren en ambtenaren uit de EU-lidstaten, vertegenwoordigers van de Europese Commissie en soms ook vertegenwoordigers van buiten de EU.

Nadat we in de voorgaande paragrafen de factoren die tot de opkomst van deze netwerken hebben geleid hebben besproken, gaan we in deze paragraaf in op verschillende typen transnationale overheidsnetwerken. We zullen later laten zien dat een heldere categorisering van transnationale overheidsnetwerken het mogelijk maakt om verschillende patronen van strategisch handelen in kaart te brengen. We laten ook een aantal transnationale netwerken de revue passeren waarin onderdelen van het Nederlandse openbaar bestuur vertegenwoordigd zijn. Hiermee proberen we de praktijk van overheidsnetwerken inzichtelijk te maken.

\subsubsection{DIMENSIES EN VARIËTEIT VAN TRANSNATIONALE OVERHEIDSNETWERKEN}

In het afgelopen decennium is het aantal transnationale overheidsnetwerken binnen de EU sterk gegroeid. Een algemeen geaccepteerd kader voor de ordening en categorisering van transnationale netwerken is echter in de literatuur niet voorhanden. De vraag is of dat er ooit nog gaat komen. De verscheidenheid tussen verschillende netwerken, die zich momenteel op vrijwel alle (internationale) beleidsterreinen ontwikkelen, is daarvoor te groot. Toch hebben verschillende auteurs getracht enige ordening aan te brengen.

De typologie van Slaughter (2004) is gebaseerd op de verschillende functies die transnationale overheidsnetwerken kunnen uitoefenen. Informatienetwerken zijn overheidsnetwerken waarin het primaire proces uit - de naam zegt het al - het uitwisselen van informatie bestaat. Er bestaan echter verschillende soorten informatie. Tijdens bijeenkomsten van ambtelijke experts op het gebied van bijvoorbeeld voedselveiligheid zullen deelnemers spontaan (recente) ervaringen uitwisselen over hun praktijken. Dit is kosteloze informatie, omdat ze vrijelijk wordt uitgewisseld. Dit wordt anders wanneer netwerken zich primair toeleggen op het vergaren van informatie die voorheen niet bestond. Het formuleren van standaarden voor bescherming van privacygevoelige data die door een nieuwe technologie als het RFID in het geding raken vereist dat privacyautoriteiten zich verdiepen in de technologie en de privacyaspecten daarvan begrijpen. Reputatie is een cruciaal 
attribuut binnen netwerken die informatieverwerking en -productie als primaire doel hebben. Tijdens bijeenkomsten wordt de kracht van de deelnemende nationale overheden gemeten aan de relevante kennis die zij in huis hebben.

Een tweede type netwerk dat Slaughter onderscheidt zijn handhavingsnetwerken. Handhavingsnetwerken hebben als primaire doel de bevordering van de internationale samenwerking tussen nationale overheden bij de implementatie van nationale wet- en regelgeving en het toezicht op de naleving daarop. Georganiseerde misdaadbestrijding en economische mededinging zijn twee terreinen die bij uitstek vragen om handhavingsnetwerken. Grote criminele organisaties bewegen zich net als multinationals over de grenzen van nationale staten en kunnen uit handen van nationale opsporingsapparaten blijven, zolang deze niet effectief met elkaar grensoverschrijdend kunnen samenwerken. Internationale netwerken zoals Interpol en het justitieel handhavingsnetwerk van de EU, Trevi genaamd, zijn pogingen om deze grensoverschrijdende samenwerking bij de handhaving te institutionaliseren. Hetzelfde geldt ook voor nationale mededingingsautoriteiten die misbruik van dominante marktposities of kartelvorming bij landen omspannende multinationals willen tegengaan. In 2004 heeft de Europese Commissie op dit terrein een belangrijke stap gezet door het Europees Mededingings Netwerk (European Competition Network) in te stellen.

Een derde type transnationaal overheidsnetwerk dat Slaughter onderscheidt zijn harmonisatienetwerken. Harmonisatienetwerken trachten het aannemen van internationale standaarden door twee of meer landen te bewerkstelligen. De belangrijkste doelstelling van overheden die binnen een harmonisatienetwerk opereren is dus het creëren van een gelijk speelveld op specifieke beleidsterreinen op internationaal niveau. Harmonisatienetwerken 'hangen' niet zelden onder internationale verdragen en supranationale regelgeving. Deze verdragen zijn het product van bi- of multilaterale onderhandelingen tussen regeringen en bevatten vaak open normen en vage clausules. Onderhandelaars van nationale regeringen hebben die vaak opengelaten vanwege de technische complexiteit of de snelheid waarmee ontwikkelingen op de betreffende terreinen verlopen. De invulling van de verschillende normen komt in deze gevallen voor rekening van de ambtelijke experts van nationale overheden. Het Committee of Experts on Securities Regulation (CESR) bestaat uit tal van werkgroepen die de open normen in de Europese wetgeving van financieel toezicht moeten specificeren. De Prospectus Richtlijn (2003/71/EG) vermeldt niet precies waaraan de brochures die financiële instellingen uitgeven bij hun financiële producten moeten voldoen. Ook is uit de Wet op het financieel toezicht, die verschillende Europese richtlijnen die financiële markten reguleren omzet, niet op te maken wat precies onder 'verantwoorde kredietverlening' moeten worden verstaan. Vanwege het grensoverschrijdend karakter van handel in aandelen is er een taak voor financiële markttoezichthouders weggelegd om Europees maar ook wereldwijd (via de International Organization of 
Securities Commissions - IOsCO) een gelijk speelveld voor financiële consumenten en aanbieders van financiële producten te creëren.

Naast deze functionele indeling van Slaughter bestaat in de literatuur ook een indeling naar hardheid van bevoegdheden. Coen en Thatcher (2008) delen een aantal transnationale overheidsnetwerken in op een dimensie die van 'zacht' naar 'hard' verloopt. Voor alle duidelijkheid dienen we op te merken dat Coen en Thatcher zich in hun studie beperken tot transnationale netwerken van markttoezichthouders. Dit laat onverlet dat hun typologie ook toepasbaar is op publieke organisaties met sociale, algemeen-juridische en dienstverlenende taken.

Figuur 3.2 hieronder geeft deze dimensie grafisch weer.

Figuur 3.2 Indeling van typen transnationale overheidsnetwerken naar hardheid van bevoegdheden volgens Coen \& Thatcher (2008)

EU-netwerken van toezichthouders met formele juridische basis en functies

Transnationale netwerken van toezichthouders zonder juridische basis van de EU en geen secretariaat binnen de EU

Fora voor het samenbrengen van publieke en private actoren

Transnationale overheidsnetwerken buiten de EU

Helemaal onderaan bij het begin van de pijl plaatsen zij internationale netwerken van regulatoren van buiten de EU. Het betreft netwerken die ook geen formele bevoegdheden hebben en zelfs niet op grond van een verdrag zijn ingesteld. In deze categorie valt bijvoorbeeld de International Organization for Securities Commissions en de International Telecommunications Union (ITU). In het algemeen zijn dit informele netwerkorganisaties waar, om de termen van Slaughter te gebruiken, hoofdzakelijk informatie wordt uitgewisseld. ${ }^{2}$ Tekstbox 3.2 belicht een voorbeeld van een dergelijk netwerk, het Europese netwerk van publieke organisaties van gelijke behandeling. Een stap hoger in deze hiërarchie staan fora van nationale toezichthouders en private actoren. De bekendste fora zijn het zogenaamde Florence Forum op het gebied van elektriciteit en het Madrid Forum voor toezichthouders en private partijen op het gebied van gas. Deze fora dienen als een alternatief voor door de EU zelf ingestelde transnationale netwerken (die in figuur 3.2 bovenaan staan). Hierin kunnen ideeën uitgewisseld worden, proefballonnen worden opgelaten, en de agenda op het gebied van elektriciteit, respectievelijk, gas kunnen worden afgestemd zonder dat de Europese Commissie op grond van de formele instellingsgronden een vergaande invloed kan uitoefenen. Een voorbeeld van een door de EU ingesteld netwerk is het 
Committee of European Securities Regulators (CESR). Tekstbox 3.3 geeft meer achtergrond over dit netwerk.

Tussen formele door de EU ingestelde transnationale overheidsnetwerken en de informele netwerken waar toezichthouders en sectorvertegenwoordigers in participeren bevinden zich netwerken die informeel doch besloten zijn. Hierin hebben zich alleen de nationale toezichthouders verenigd. Ze staan in de schaduw van de officiële netwerken, maar hebben het voordeel dat ze onderling zonder aanwezigheid van de Commissie kunnen bijeenkomen. Bovenaan, tot slot, staan de bewust door de Europese Commissie zelf ingestelde netwerken. In lijn met de observatie van Dehousse (1997) van een aantal jaren geleden, vormen deze netwerken een bewuste poging van de Europese Commissie om het gebrek aan bestuurlijke capaciteit op het niveau van de lidstaten op te vullen. De verschillende vormen van transnationale overheidsnetwerken overziend concluderen Coen en Thatcher dat de lappendeken van netwerken binnen een en dezelfde sector naast elkaar bestaan als een uiting van het arenakarakter van de EU op die terreinen. De netwerken kunnen strategisch worden gebruikt voor het beïnvloeden van agenda's en het vormen van consensus over de vorming van standaarden. Daarmee spelen ze een belangrijke rol in de vormen van indirecte beïnvloeding (via 'changing opportunity structures' en 'framing domestic beliefs') die Knill en Lehmkuhl onderscheiden.

\section{Box 3.2 Informatie- \& harmonisatienetwerk - soft law: Equinet/ Commissie Gelijke Behandeling}

Het Europese netwerk van publieke organisaties voor gelijke behandeling (Equinet) is een voorbeeld van een informeel transnationaal overheidsnetwerk dat is ontstaan uit de samenwerking tussen instellingen van gelijke behandeling in Europa en niet op grond van een formele beslissing van de Europese Commissie. Equinet is in 2003 ontstaan uit een los samenwerkingsproject tussen een aantal West-Europese publieke instellingen voor gelijke behandeling. In vijf jaar tijd is het samenwerkingsproject uitgegroeid tot een georganiseerd netwerk van Europese (ook niet-EU) instellingen van gelijke behandeling. In 2009 telt Equinet 29 leden uit 26 landen. ${ }^{3}$ In 2007 is dit netwerk formeel tot Equinet gedoopt; in 2008 is een secretariaat in Brussel geopend. Het secretariaat is ingesteld naar Belgisch privaatrecht. Hoewel het overgrote deel van de leden instellingen zijn die in de lidstaten zijn gevestigd zijn ook instellingen van niet-EU-landen lid van Equinet (Noorwegen en Kroatië).

Ofschoon Equinet niet is ingesteld door de Europese Commissie, heeft de EU toch een sterke invloed op het ontstaan van dit netwerk gehad. Dit komt door de aanname van Rasrichtlijn 2000/43. In deze richtlijn (Art. 13, lid 1) is voor het eerst in de Europese wetgeving voor gelijke behandeling de eis opgenomen dat voor de uitvoering van gelijkebehandelingswetgeving 
onafhankelijk opererende en specialistische instellingen dienen te worden ingesteld. Voor deze tijd hadden slechts enkele landen van de EU een instelling voor gelijke behandeling. Nadat de richtlijn is aangenomen hebben praktisch alle lidstaten, op een aantal late omzetters zoals Spanje en Tsjechië na, een orgaan voor gelijke behandeling ingesteld. Aldus ontstond een fijnmazig transnationaal horizontaal netwerk van onafhankelijke instellingen voor gelijke-behandelingszaken. Dit bracht een proces van uitwisseling van ideeën en inzichten teweeg (Bell 2002).

Equinet is een typisch informatienetwerk. De belangrijkste doelstellingen van Equinet zijn het bevorderen van samenwerking tussen de leden; de uitwisseling en het delen van ervaringen en 'best practices'; wederzijdse ondersteuning; het geven van trainingen aan stafleden en het versterken van capaciteit; en het organiseren en onderhouden van een dialoog met nationale en internationale antidiscriminatiebelangengroepen. De Europese Commissie maakt geen deel uit van Equinet, maar subsidieert het netwerk via het EC Progress programma. Het secretariaat en het bestuur van Equinet, dat bestaat uit de door de leden gekozen vertegenwoordigers van nationale instellingen voor gelijke behandeling, onderhoudt wel nauwe contacten met directoraat-generaal voor Werkgelegenheid, Sociale Zaken en Gelijke Kansen. Nederland is vertegenwoordigd door de Commissie Gelijke Behandeling.

\section{Box 3.3 Harmonisatie \& handhaving - hard law: Committee of European Securities Regulators (CESR)/Autoriteit Financiële Markten}

CESR is in 2001 op advies van de Commissie van Wijze Mannen voor de regulering van financiële markten in Europa (de zogenaamde Lamfalussy-commissie) ingesteld door Commissiebesluit 2001/527/EC van 6 juni 2001. In het Lamfalussy-rapport werd eind jaren negentig geconcludeerd dat financiële markten een beter toezichtregime nodig hadden. Van CESR zijn alle financiële marktautoriteiten in de EU lid. ${ }^{26}$ De belangrijkste doelstellingen van CESR zijn het verbeteren van de coördinatie tussen financiële marktautoriteiten; het fungeren als een adviesgroep voor de Commissie wanneer deze nieuwe wetgeving voorbereidt; en het erop toezien dat eu-regelgeving tijdig en correct wordt geïmplementeerd door de lidstaten. Deze laatste doelstelling is verwoord in de Stockholm Resolutie die de Europese Raad op 23 maart 2001 tijdens de top in Stockholm heeft genomen. Hiertoe heeft CESR in 2003 het Review Panel ingesteld dat belast is met het monitoren van de voortgang van de implementatie van Europese financiële marktwetgeving in de lidstaten. Anders dan bijvoorbeeld Equinet heeft CESR enkele bevoegdheden gekregen van de Commissie. De eerste bevoegdheid is het gevraagd en ongevraagd adviseren van de Commissie (Art. 2 2001/527/EC). Daarnaast heeft CESR zichzelf een aantal bevoegdheden toegekend. Deze zijn het maken van aanbevelingen en opinies; het maken van reviews van en het rapporteren over praktijken van regulering in de verschillende lidstaten; en het vormgeven van een operationeel netwerk voor de uitwisseling van informatie. Verder is op basis van een convenant tussen CESR-leden afgesproken dat nationale financiële marktautoriteiten elkaar zoveel mogelijk moeten assisteren bij de handhaving van financiële marktregels in elkaars landen (CESR 05-335). Hieronder wordt verstaan de uitwisseling van relevante informatie in het kader van handhaving en het verlenen van diensten 
voor zover dat mogelijk is binnen de kaders van de wet. De afspraken zijn tussen de autoriteiten zelf gemaakt en bekrachtigd in een multilateraal memorandum. In de preambule van het memorandum wordt gesteld dat de handhavingsactiviteiten logischerwijze volgen uit de bedoeling van de Europese richtlijnen die stellen dat bij de implementatie van Europese financiële marktrichtlijnen nationale toezichthouders zo goed mogelijk dienen samen te werken. Met andere woorden, formeel is CESR een harmonisatienetwerk, maar het voorziet ook in grensoverschrijdende handhavingactiviteiten.

\subsection{IMPLICATIES VOOR HET NEDERLANDSE OPENBAAR BESTUUR}

We zijn nu aanbeland bij de vraag welke implicaties de internationalisering van bestuur en beleid heeft voor het Nederlandse openbaar bestuur. We willen deze verkenning hier dan ook voortzetten met het doordenken van enkele strategische en tactische handelingsmogelijkheden. Voor de duidelijkheid dienen we op te merken dat de hieronder beschreven weergave van handelingsmogelijkheden eerder van ideaaltypische dan van prescriptieve aard is. De grote variëteit aan organisaties, beleid en belangen in het openbaar bestuur maakt het onmogelijk om precieze adviezen te geven over hoe er in internationaliserende beleidsarena's het beste te opereren valt. Veel eerder schetsen wij hieronder handelingscenario's die als heuristisch instrument kunnen dienen bij de oriëntaties van Nederlandse openbare instellingen op het handelen in internationale beleidsarena's.

\subsubsection{STAP 1: HET STELLEN VAN PRIORITEITEN EN INVENTARISEREN VAN STERKE/ZWAKKE PUNTEN}

De Nederlandse overheid is in internationaal opzicht sterk gefragmenteerd. Bijna ieder ministerie en (semi)onafhankelijke publieke organisatie heeft zijn eigen internationale omgeving. Gegeven deze nieuwe werkelijkheid is een eerste (denk)stap die actoren binnen het Nederlandse openbaar bestuur zouden moeten zetten het onderkennen van het feit dat de EU en andere internationale beleidsarena's geen locaties zijn waarop enkel een 'nul-som' strijd tussen staten onderling of tussen supranationale instellingen en nationale staten wordt geleverd, maar beleidsarena's zijn waar ook een 'positieve som' samenwerking kan plaatsvinden. Dit kan men onderkennen door de arbeidsdeling tussen landen die vaak als gevolg van een decennialange specialisatie in verschillende sectoren van de maatschappij en de economie is gegroeid op hun waarde te schatten. Om een voorbeeld te geven: Nederland heeft in Europa een sterke positie als het gaat over kennis op het gebied van voedselproductie en veterinaire ziekten. In de tijd dat de vogelgriep uitbrak kreeg Nederland vanzelfsprekend internationaal een leidende positie bij het vormen van crisismaatregelen en toekomstig beleid om de uitbraak van dierziekten te beteugelen. Zo kon het gebeuren dat het crisisteam bij de FAO voor een groot deel uit Nederlandse ambtenaren bestond: onder andere twee ambtenaren 
van LNV en een Nederlandse ambtenaar die door LNV bij de FAO was gedetacheerd. Het punt hier is dat op een substantieel aantal terreinen verschillende lidstaten een specifieke expertise hebben die hen onderscheidt van andere landen. Het is evident dat op momenten waarop specifieke expertise hard nodig is, de Commissie of andere internationale organisaties te rade zullen gaan bij landen en overheidsinstellingen daarbinnen die de nodige expertise in huis hebben.

Een eerste stap die Nederlandse beleidsmakers zouden moeten zetten is het inventariseren en monitoren van kennisposities van verschillende sectoren binnen Nederland. Deze kennisposities zouden bij voorkeur internationaal vergeleken moeten worden om de relatieve kennispositie van Nederland op relevante beleidsterreinen vast te stellen. Uiteraard zal dat vanwege industriegevoelige informatie niet altijd transparant vast te stellen zijn. Een monitor van de Nederlandse kennisposities kan verschillende doelen dienen. In de eerste plaats kunnen die terreinen worden aangewezen waar Nederland een sterke kennispositie heeft, waarmee betrokken overheden binnen internationale beleidsarena's potentieel een sterke positie kunnen ontwikkelen. Een vergelijkende monitor laat in de tweede plaats zien welke overheden in andere landen potentiële concurrenten of coalitiegenoten zijn. Concurrentie zal ontstaan tussen landen die een sterke kennispositie hebben op een specifiek terrein, bijvoorbeeld financiële markten, maar andere standaarden voorstaan. Een ander voorbeeld: een bestaand nationaal spoorwegennet vertegenwoordigt aanzienlijke 'sunk costs' van eerdere infrastructurele investeringen. De Franse kennispositie op het gebied van spoorwegtechnologie is de sterkste in Europa. Nederland en andere landen zullen zich bij besprekingen over een trans-Europees spoorwegennet moeten verhouden tot de sterke Franse kennispositie op dit gebied. In de derde plaats kan van een monitor een leereffect uitgaan. Een monitor geeft namelijk naast inzicht in de relatieve kennispositie van Nederland ook inzicht in de absolute kennispositie van andere landen. Een sterke kennispositie van een land op een bepaald beleidsterrein is een signaal dat dat land tegen relatief minder kosten kennis kan leveren en de rol van beleidsproducent op dat beleidsterrein kan vervullen. Dit kan inhouden dat een lidstaat met een zwakkere kennispositie beleid 'van de plank koopt' en geld bespaart door niet te investeren in beleidsvorming op een terrein waar een ander land de kennis en de bereidheid heeft om die te 'exporteren'.

Hier komen we bij onze belangrijkste stelling in deze subsectie. Nederlandse overheden dienen zich te bezinnen op de vraag wanneer het nodig is om Nederlands beleid te 'exporteren' en wanneer het opportuun is om beleid te 'importeren'. Internationale beleidsprocessen zoals we die in paragraaf 3.3 hebben beschreven lenen zich hier goed voor. Uploaden en downloaden zijn neutrale termen voor beleidstransfers, beleidsdiffusie en beleidsleren (Dolowitz en Marsh 200o). Politiek gesproken kan dit betekenen dat de aanpassingskosten van beleidsimport lager uitvallen dan de baten die het nationaal oplevert. Aanpassingskosten zullen 
er altijd zijn, leren verschillende studies. Aanpassingskosten zijn het hoogst wanneer kernwaarden in stijl en structuur van beleid fundamenteel moeten worden herzien en hervormd (Knill 2001). Wanneer de aanpassingskosten van beleidsimport te hoog worden, dan kan het opportuun worden om de bestaande structuren en kanalen voor uploaden te gebruiken om nationaal beleid te exporteren en aanpassingskosten (i.c. aanpassing aan de Nederlandse status-quo) aan andere landen op te leggen.

Dat dit niet makkelijk gaat laat ons de casus van de Hygiëneverordening zien. Deze verordening regelt de hygiëne van slachthuizen in Europa. De eerste aanzet voor deze verordening is gegeven door een bij dg Sanco (het directoraat-generaal voor Volksgezondheid en Consumentenbescherming van de Europese Commissie) gedetacheerde Nederlandse ambtenaar van LNV. Er was Nederland veel aan gelegen om het onderdeel toezicht uit deze verordening op Nederlandse toezichtleest te schoeien. De Nederlandse toezichtvisie, ook vastgelegd in de regeringsnota Kaderstellende visie op toezicht (2005), bestond uit systeemtoezicht. Dit hield in dat de vleesverwerkende sector op brancheniveau zijn eigen toezicht zou regelen en dat de Nederlandse overheid alleen toezicht op afstand zou houden. De export van systeemtoezicht via de Hygiëneverordening mislukte echter. Het Italiaanse ministerie van Landbouw en een (voormalig Oost-)Duitse rapporteur van het Europees Parlement blokkeerden dit en zwakten dit onderdeel af. De uiteindelijke tekst laat echter voldoende ruimte over voor het handhaven van systeemtoezicht; hiermee had Nederland de eigen status-quo overeind weten te houden, maar slaagde het er niet in om systeemtoezicht te exporteren naar andere lidstaten.

Met andere woorden, door de begrippen 'exporteren' en 'importeren' expliciet te gebruiken stellen we dat Nederlandse overheden preciezer voor ogen moeten krijgen welke uitkomsten zij in internationale beleidsarena's willen en kunnen behalen. Het is daarvoor verstandig om te inventariseren welke kennispositie Nederland inneemt in verschillende sectoren. Op deze wijze kunnen actoren in het openbaar bestuur beter prioriteren en voor zich vaststellen op welke terreinen zij voor beleidsexport dan wel import van beleid willen ijveren. Afhankelijk van de aanpassingskosten kan het voor sommige beleidssectoren zeer opportuun zijn om energie te besteden aan de import van buitenlandse beleidspraktijken of, wanneer aanpassingskosten van internationaal beleid te hoog zijn, deze te blokkeren. De casus van de Hygiëneverordening laat zien dat internationale beleidsarena's de loci voor het blokkeren en afzwakken van pogingen tot beleidsexport van andere landen zijn en tegelijkertijd cruciale plaatsen voor het ongehavend doorvoeren van nationale beleidsvoorkeuren.

Kortom, we stellen dat de strategische afwegingen die de verschillende geïnternationaliseerde segmenten van het Nederlandse openbaar bestuur dienen te maken afhankelijk zijn van de volgende twee factoren: (1) het belang dat Nederland 
toekent aan de vraagstukken die binnen een arena centraal staan en (2) de kennispositie van Nederland met betrekking tot die vraagstukken. 'Belang' is een diffuus begrip en op verscheidene wijzen uit te leggen. In dit hoofdstuk definiëren we belang als een functie van aanpassingskosten die een Nederlandse sector moet maken als gevolg van de aanname van nieuwe standaarden door een internationale beleidsarena (cf. Knill 2001). Wanneer die kosten hoger zijn, is het Nederlandse belang groter. Onder 'kennispositie' verstaan we de hoeveelheid (geïnstitutionaliseerde) expertise die in een specifieke sector aanwezig is. Op sommige terreinen is Nederland internationaal koploper in termen van kennis en expertise, op andere terreinen is dat minder het geval. Belang en kennispositie zullen vaak positief met elkaar correleren. Maar het is voor het analytisch onderscheid goed om deze apart te behandelen. Tabel 3.4 geeft schematisch weer welke de inzet van Nederland kan zijn wanneer slechts het belang en de kennispositie bij de strategische afweging voor keuzen tussen arena's worden genomen. De tabel laat zien dat de inzet van overheden in Nederland 'neutraal', 'dienend', 'defensief' en 'offensief' kan zijn, afhankelijk van het relatieve belang dat een Nederlandse overheidsorganisatie aan een vraagstuk hecht en de kennispositie van die organisatie betreffende het vraagstuk.

Tabel 3.4 Strategische afwegingen bij de Nederlandse inzet in internationale beleidsarena's

\begin{tabular}{|c|c|c|c|}
\hline \multirow{4}{*}{$\begin{array}{l}\text { 吕 } \\
\frac{\sigma}{0} \\
\infty\end{array}$} & & \multicolumn{2}{|c|}{ Kennispositie } \\
\hline & & Laag & Hoog \\
\hline & Klein & Neutraal & Dienend \\
\hline & Groot & Defensief & Offensief \\
\hline
\end{tabular}

Onder een neutrale inzet verstaan we een situatie waarin een Nederlandse overheidsorganisatie noch een uitgesproken belang, noch de benodigde expertise heeft. Een voorbeeld is de regulering van bestanddelen van wijnen. Een dienende inzet doet zich voor bij vraagstukken die na aanpassing van geldende internationale standaarden tot weinig of geen aanpassingskosten zullen leiden, maar waarover binnen het Nederlandse openbaar bestuur veel kennis aanwezig is. Een voorbeeld is het internationale beleid voor schuldhulpverlening aan arme landen. Verandering van het beleid - bijvoorbeeld de condities waaronder schuldhulpverlening plaatsvindt - zal tot weinig aanpassingskosten in Nederland leiden - afgezien van wellicht strategische beleidskeuzen binnen het Nederlandse internationale samenwerkingsbeleid -, maar hierover is veel expertise aanwezig in Nederland. Net als bij een neutrale inzet is de noodzaak voor een strategische keuze voor een arena gering. De strategische keuze voor een beleidsarena krijgt substantieel meer gewicht wanneer de Nederlandse inzet defensief of offensief 
wordt. Een defensieve inzet doet zich voor in situaties waarin een aanpassing van vigerende standaarden en/of wetgeving tot substantiële aanpassingskosten voor Nederland zou leiden en Nederland relatief gezien het benodigde arsenaal aan expertise ontbeert om een invloedrijke rol tijdens de primaire processen binnen de arena te vervullen (denk aan de financiële markt). Een Nederlandse overheidsorganisatie kan zich tot slot een offensieve inzet veroorloven wanneer zowel het belang dat Nederland hecht aan verandering (of geen verandering) van de statusquo in de eigen sector als de expertise over het betreffende terrein hoog is. Een voorbeeld is de al genoemde Hygiëneverordening, maar we kunnen ook denken aan het Nederlandse softdrugsbeleid.

\subsubsection{STAP 2: EEN STRATEGISCHE KEUZE TUSSEN BELEIDSARENA'S}

$\mathrm{Nu}$ de inzet van Nederlandse overheden binnen internationale beleidsarena's schematisch is weergegeven, komen we toe aan overwegingen die een rol kunnen spelen bij de keuze voor een beleidsarena. Gebruikmakend van de typologie van Abbott en Snidal (2009) kunnen we beleidsarena's met behulp van twee van de vier door hen genoemde kenmerken onderscheiden: onafhankelijkheid en representativiteit. Onder 'onafhankelijkheid' verstaan deze auteurs de mate waarin een beleidsarena niet onder invloed staat van of gedomineerd wordt door een selecte groep van actoren. Het Internationaal Monetair Fonds, bijvoorbeeld, kan vanwege het aanzienlijke aandeelhouderschap van de Verenigde Staten niet als een onafhankelijke beleidsarena voor de regulering van schuldhulpverlening worden aangeduid. Landen die met regelmaat een beroep moeten doen op het IMF vanwege een grote financiële crisis, zoals Argentinië en Turkije, beschouwen het IMF als een verlengstuk van de Amerikaanse buitenlandse politiek. Het Basel Comité kan ook niet als een onafhankelijke beleidsarena worden beschouwd, omdat het Comité door internationale banken is opgericht en wordt bestuurd. De Algemene Vergadering van de Verenigde Naties, de Wereld Handels Organisatie, en de Europese supranationale instituties kunnen alle als onafhankelijke beleidsarena worden gekwalificeerd, omdat, hoewel ieder verschillend is, ze niet onder een zichtbare invloed van een selecte groep van actoren staat.

'Representativiteit' is het tweede kenmerk van een arena. Hieronder verstaan Abbott en Snidal de mate waarin beleidsarena's openstaan voor de inbreng van verschillende belangen. Representativiteit heeft betrekking op de procedure waarmee binnen beleidsarena's agenda's worden bepaald, onderhandelingen worden gevoerd en besluitvorming plaatsvindt. Op deze dimensie vinden aan de ene kant het 'club'-model van een arena die door geslotenheid wordt gekenmerkt (Keohane 2002). Het aantal deelnemers is beperkt en buitenstaanders worden niet of nauwelijks toegelaten. Het zijn de 'ijzeren driehoeken' van het internationaal beleidscircuit. Wellicht de meest bekende beleidsarena met clubkarakter is de G-8 waarin de acht meest geïndustrialiseerde landen ter wereld zitting hebben. Het clubkarakter 
is ook duidelijk aanwezig bij de G-20-variant waarin naast de meest geïndustrialiseerde landen ter wereld ook de opkomende markten zitting hebben; Nederland mocht onlangs op voorspraak van de Franse voorzitter als toehoorder bij dit gezelschap aanschuiven. Gesloten beleidsarena's kunnen zich ook manifesteren binnen voor het overige open arena's. Zo telt de Veiligheidsraad slechts vijf permanente leden. Binnen het IOSCO, de internationale organisatie van ruim 150 financiëlemarktautoriteiten, wordt de vijftienkoppige Technische Commissie, waarin ook de AFM zitting heeft, als een besloten club van landen met de meest ontwikkelde financiële markten beschouwd. De mate van openheid kan op procedurele wijze worden vastgelegd. Consultatieprocedures, momenten waarop zienswijzen kunnen worden ingediend, hoor- en wederhoorprocedures en heroverwegingsprocedures zijn de meest voorkomende procedures waarmee representativiteit van de uitkomsten van beleidsprocessen binnen beleidsarena's kan worden bewerkstelligd. De Groep Gegevensbescherming Artikel 29, waar alle nationale privacyautoriteiten en de EU-privacyautoriteit lid van zijn, publiceert haar voorlopige besluiten (opinies en aanbevelingen) als conceptopinies en -aanbevelingen. De werkdocumenten van dit netwerk worden bekendgemaakt aan een zo breed mogelijke groep van belanghebbenden die binnen een gestelde termijn hun zienswijze op het werkdocument kunnen geven. De Artikel 29 Groep is verplicht deze zienswijzen bij de definitieve vaststelling van zijn opinie mee in overweging te nemen. Behalve deze werkgroep hanteren vrijwel alle Europese transnationale overheidsnetwerken die bevoegdheden hebben tot het uitvaardigen van opinies en aanbevelingen een dergelijke consultatieprocedure.

Tabel 3.5 geeft schematisch vier typen van beleidsarena's weer. Beleidsarena's die open en onafhankelijk (cel rechtsonder) zijn laten veel actoren toe tot de primaire

\section{Tabel $3.5 \quad$ Vier typen beleidsarena's}

\begin{tabular}{|l|l|l|l}
\hline \multirow{1}{*}{ | } & \multicolumn{2}{|c}{ Representativiteit } \\
\cline { 2 - 4 } Onafhan- & Afhankelijk & $\begin{array}{l}\text { Aantal actoren zeer beperkt. } \\
\text { Een van de actoren is hegemoon. } \\
\text { Overige actoren spelen secundaire } \\
\text { rol (Invasie in Irak, de vs in } \\
\text { financiële markten voor opkomst } \\
\text { Londen) }\end{array}$ & $\begin{array}{l}\text { Aantal actoren in arena is groot, } \\
\text { maar hun inzet legt beperkt } \\
\text { gewicht in de schaal vanwege } \\
\text { aanwezigheid dominante actor } \\
\text { (Wereldbank, IMF) }\end{array}$ \\
\cline { 2 - 4 } & Onafhankelijk & $\begin{array}{l}\text { Clubmodel waarin een beperkt } \\
\text { aantal actoren elkaar als gelijken } \\
\text { bejegenen (transnationale } \\
\text { overheidsnetwerken) }\end{array}$ & $\begin{array}{l}\text { Aantal actoren in arena is groot en } \\
\text { uitkomsten worden als bindend } \\
\text { ervaren (EHJ, Europees Parlement) }\end{array}$ \\
\hline
\end{tabular}


processen die zich binnen de beleidsarena's afspelen (agendavorming, onderhandeling of besluitvorming). Dergelijke beleidsarena's bieden veel voordelen aan kleine landen die gemiddelde kennisposities innemen. De twee belangrijkste zijn dat deze landen dergelijke beleidsarena's relatief eenvoudig kunnen betreden.

Noch speelt de aard van het vraagstuk een rol, noch de kennispositie. De aard van deze beleidsarena's kan echter wel zeer verschillend zijn. Het Europees Hof voor Justitie of arbitrage bij de WHO zijn rechterlijke instanties die zowel open als onafhankelijk zijn. Dit geldt ook voor het Europees Parlement en de Algemene Vergadering van de Verenigde naties. De openheid en onafhankelijkheid van deze beleidsarena's heeft echter ook een prijs. Ten eerste betekent het dat individuele landen geen of weinig invloed hebben op het verloop van primaire processen binnen dergelijke beleidsarena's. Bij arbitrerende en/of rechterlijke beleidsarena's staan het verloop en de uitkomst van de besluitvorming geheel los van de betrokken landen. Daarbij komt dat rechterlijke beslissingen, voor zover er geanticipeerd op kan worden, een voor partijen onverwachte uitkomst kunnen hebben. De rechterlijke beslissing, tot slot, kan vrij eenduidig in het voor- of nadeel van een van de procespartijen zijn. Bij vertegenwoordigende beleidsarena's zijn het verloop en de uitkomsten van besluitvormingsprocessen vaak, afgezien van eventuele beslisregels, een functie van onderhandelingen en compromisvorming. Voor partijen die aan de onderhandelingen meedoen is het proces zo transparant als er informatie over de belangen en voorkeuren van andere actoren aanwezig is. Met een toenemend aantal deelnemers wordt het minder transparant. De uitkomst van dergelijke processen is niet zo scherp als bij rechterlijke beleidsarena's, maar is vaak bot vanwege de compromisvorming.

Tegenover open en onafhankelijke beleidsarena's staan beleidsarena's die een beperkt lidmaatschap kennen en waarbinnen vaak een actor de dominante speler is (de hegemoon). Deze bevinden zich in tabel 3.5 in de cel linksboven. In dergelijke beleidsarena's heeft de hegemoon wat Abbott en Snidal 'GIAP' noemen: 'Going It Alone Power'. Op vele terreinen in de wereld van na de val van de Muur, zijn het de Verenigde Staten die een dergelijke macht bezitten. Voor de invasie van Irak hadden de vs de Britten en andere Europese bondgenoten meer nodig om de legitimiteit van de unilaterale beslissing om Irak binnen te vallen dan vanwege het gebrek aan militaire vuurkracht. De presentatie van de toenmalige Amerikaanse minister van Buitenlandse Zaken Colin Powell die met gefingeerde bewijsstukken bij de Algemene Vergadering van de Verenigde Naties een resolutie voor de invasie probeerde te verkrijgen moet in dit licht worden gezien. Een ander voorbeeld van dit type beleidsarena is de rol die de Amerikaanse financiële marktautoriteit, de Securities and Exchange Commission (SEC), voor de opkomst van Londen eind jaren tachtig en jaren negentig als het financiële centrum van de wereldeconomie speelde. Gedurende deze periode dicteerde de SEC feitelijk de belangrijkste standaarden voor de financiële markten en legde deze eenzijdig op aan andere (opkomende) markten. Onderdeel van deze hegemone positie vormde het uitgebreide 
trainings- en opleidingspakket dat de SEC bij buitenlandse financiële toezichthouders bezorgde. De toezichthouders in Afrika, Azië en Latijns-Amerika namen zo de Amerikaanse standaarden voor hun financiële markten over. Voor landen met weinig economisch gewicht of een zwakke kennispositie zijn dergelijke arena's van weinig waarde. De hegemoon is leidend en het hoogst haalbare voor zwakkere landen is het beïnvloeden van de voorkeuren van de hegemoon, iets wat ook met een sterke kennispositie een moeilijke opgave is.

De kansen voor beïnvloeding door kleine landen wordt groter, naarmate een beleidsarena opener en/of onafhankelijker wordt, maar niet zo open en zo onafhankelijk dat de stem van individuele actoren verloren gaat in de massa of dat de onafhankelijkheid van een beleidsarena feitelijk abdicatie van enige invloed op de uitkomst van het beleidsproces binnen de arena impliceert. De cel linksonder van tabel 3.5 geeft gestileerd de situatie weer waarin de meerderheid van transnationale overheidsnetwerken zich bevinden. Een transnationaal overheidsnetwerk is als onafhankelijk te kwalificeren vanwege het gegeven dat de primaire beleidsprocessen binnen de beleidsarena (agendavorming, deliberatie/onderhandelingen en besluitvorming) niet gedomineerd worden door één actor. Transnationale overheidsnetwerken zijn daarmee beleidsarena's waarvan alle autoriteiten van lidstaten qualitate qua lid zijn. Dit gegeven maakt transnationale overheidsnetwerken ook gesloten: alleen de expliciet tot het netwerk toegelaten overheden zijn vertegenwoordigd. Deze netwerken sluiten daarmee niet alleen non-gouvernmentele organisaties uit, maar ook overheden wier lidmaatschap niet bij wet is geregeld. Dit leidt in de praktijk tot competentiestrijd, ofwel een letterlijke 'stoelendans': de vraag wie er namens Nederland de stoel achter de microfoon zal bezetten (Geuijen et al. 2008). Transnationale netwerken worden bevolkt door de gespecialiseerde vertegenwoordigers van nationale en/of op afstand geplaatste overheden. De bulk van het werk binnen dergelijke netwerken vindt plaats in gespecialiseerde subwerkgroepen en -commissies; dit geeft de leden van transnationale netwerken het aanzien van professionals onder elkaar die, bijeengekomen rondom een specifiek agendapunt, met elkaar trachten een concreet vraagstuk op te lossen. Meestal gebeurt dit in de vorm van een opinie of aanbeveling. Uiteraard is er ook binnen transnationale netwerken sprake van differentiatie in kennisposities en in belangen. In ieder geval in de periode van voor de uitbraak van de financiële crisis bezette bijvoorbeeld de Financial Services Authority, de Britse financiële marktautoriteit, een spilpositie in de CESR, het netwerk van Europese financiële marktautoriteiten, vanwege de vooraanstaande positie van de Londense City op de internationale financiële markten. De Nederlandse AFM en de marktautoriteiten van de met Londen concurrerende financiële markten dienen voortdurend alert te zijn op de positie en handelingen van de FSA. Als de AFM en andere marktautoriteiten niets zouden doen, dan zou de FSA vrij spel hebben in het exporteren van Britse standaarden voor het toezicht op de financiële markten. Het voorbeeld van de FSA/CESR is uitzonderlijk, omdat het de positie van Londen als financiële markt in 
de wereld uniek is. Vaker is het zo dat er rondom specifieke thema's binnen transnationale overheidsnetwerken zich 'clubs' ontwikkelen. Binnen het Europees netwerk rondom de EFSA, de Europese Voedsel en Waren Autoriteit, trekt de Nederlandse vwA bij onderwerpen die het Nederlandse belang raken (variërend van controles bij douane (i.c. de Rotterdamse haven) tot bestrijding van dierziekten), gezamenlijk op met autoriteiten die dezelfde belangen delen. Tot het min of meer vaste clubje van de vwA behoren in dit verband de autoriteiten van België, Luxemburg, Denemarken, Ierland en Duitsland.

Tot slot, in de cel rechtsboven in tabel 3.5 treffen we beleidsarena's aan die qua representativiteit hoog, maar qua onafhankelijkheid laag scoren. Dit betekent dat het lidmaatschap van beleidsarena's die zich in deze cel bevinden openstaat voor een grote hoeveelheid actoren, maar dat de leden niet gelijkwaardig aan elkaar zijn als het gaat om de uitoefening van invloed op de primaire processen binnen de arena. Het Internationaal Monetair Fonds is een voorbeeld van een institutie waarbinnen dit speelt. Van het bestuur van het IMF zijn 186 landen lid, maar de stemverhoudingen worden bepaald door het relatieve aandeel van die landen in de wereldeconomie. Dit systeem van 'quotering' leidt er in de praktijk toe dat de stem van geïndustrialiseerde westerse landen een veel groter gewicht heeft dan die van ontwikkelingslanden. De rijke westerse landen met de vs aan kop oefenen hierdoor een onevenredig grote invloed uit op de schuldposities en de hieraan gekoppelde schuldhulpverlenings- en economische stimuleringsprogramma's van minder ontwikkelde landen. In 2006 is het IMF begonnen om de quota's te herzien en is aan de opkomende landen (China, Korea en India voorop) een groter stemgewicht toebedeeld. Naast deze formele praktijk van quoteringen en stemverdelingen is er de informele afspraak tussen de vs en de EU dat de voorzitter van het IMF een door de EU naar voren geschoven Europeaan moet zijn. Het voorzitterschap van de Wereldbank, die grosso modo dezelfde bestuurs- en lidmaatschapsstructuur kent als het IMF, wordt volgens deze afspraak 'gegeven' aan een door de Amerikaanse president benoemde Amerikaan. Deze praktijken staan onder druk nu de politieke leiders van de opkomende staten, de Braziliaanse president Lula voorop, toenemende kritiek hebben op de in hun ogen achterhaalde verhoudingen in de wereldeconomie. Vanuit het perspectief van Nederland bieden dergelijke beleidsarena's kansen zolang het aandeel van de Nederlandse economie op de wereldmarkt op niveau blijft.

Wij betogen nu dat de inzet leidend dient te zijn bij de strategische afweging die Nederlandse overheden maken in internationale beleidsprocessen. Als we ons beperken tot de onderste rij van tabel 3.4 (met resp. een defensieve en een offensieve inzet), wordt dit schematisch weergegeven in figuur 3.3 Bij een defensieve inzet is de keuze voor een open en onafhankelijke beleidsarena opportuun, omdat dit vanuit Nederlands perspectief meer mogelijkheden biedt om de sterke preferenties van invloedrijkere landen af te zwakken. In open en onafhankelijke 
beleidsarena's zijn de mogelijkheden voor GIAP het kleinst en zullen de uitkomsten van beleidsprocessen vrije interpretatieruimte voor betrokken landen laten. $\mathrm{Bij}$ een offensieve inzet is de keuze voor een onafhankelijke en gesloten beleidsarena meer opportuun. Bij een offensieve inzet wil Nederland immers iets winnen: de export van het eigen beleid naar andere landen. Het gesloten karakter weert tegenstanders die roet in het eten kunnen gooien. Een zekere coördinatie zal bestaan, omdat het Nederland - hoe groot de belangen en de kennispositie ook mag zijn - niet zal lukken om de eigen inzet te verdedigen in gesloten en afhankelijke (lees: door Nederland gedomineerde) beleidsarena's. In het geval van Nederland is onafhankelijkheid van een beleidsarena ook essentieel: indien de uitkomst in het verlengde van de Nederlandse voorkeur ligt, dan wint de uitkomst ook aan legitimiteit, omdat de beleidsarena niet wordt vereenzelvigd met de beperkte belangen van een enkele speler.

\section{Figuur 3.3 Inzet en strategie}

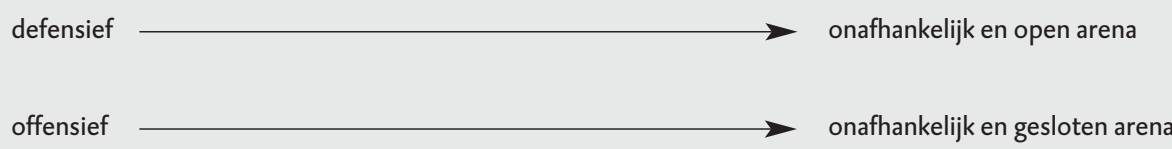

\subsection{CONCLUSIE}

In dit hoofdstuk stonden implicaties van de internationalisering van maatschappelijke vraagstukken - en als gevolg hiervan beleidsprocessen - voor de structuur en het functioneren van het Nederlandse openbaar bestuur centraal. De internationalisering van beleidsprocessen heeft ertoe geleid dat het traditionele monopolie van diplomaten en het ministerie van Buitenlandse Zaken op de vertegenwoordiging van Nederlandse belangen in het buitenland is doorbroken. Ergo, op vele maatschappelijke domeinen is het 'buitenland' binnenland geworden, net zo goed als het binnenland tot het buitenland is gaan behoren. Enerzijds heeft deze ontwikkeling ertoe geleid dat binnenlandse bestuurders van menig beleidsterrein vaker gedwongen worden om de belangen van hun sector in internationale beleidsarena's uit te dragen en te verdedigen. Anderzijds heeft deze ontwikkeling ertoe geleid dat binnenlandse bestuurders het nationale beleid in internationale beleidsarena's in overleg en onderhandeling met hun evenknieën uit andere landen zijn gaan vormen. Het onderscheid tussen buitenlandse en binnenlandse politiek en beleid is per saldo vager geworden.

Behalve de internationalisering van maatschappelijke vraagstukken, op gebieden variërend van milieu tot terrorisme en energie, heeft zich ook een transformatieproces binnen nationale staten afgespeeld dat sterk heeft bijgedragen aan de inter- 
nationalisering van beleidsprocessen. Dit interne transformatieproces is de verzelfstandiging van een grote hoeveelheid nationale en regionale publieke taken geweest. Vanaf ongeveer halverwege de jaren tachtig van de vorige eeuw is onder de noemer van privatisering, decentralisatie en 'op afstand plaatsing' menig organisatieonderdeel van de rijksoverheid tot zelfstandig bestuursorgaan omgevormd. Op basis van de verkregen autonomie zijn deze zelfstandige bestuursorganen, mede vanwege de internationalisering van 'hun' beleidsterreinen, vergaande samenwerkingsverbanden met zusterinstellingen uit andere nationale staten en met inter- en (in de EU) supranationale instellingen aangegaan. Het resultaat van deze autonome processen, die zich vaak buiten het zicht van de nationale vertegenwoordigende instellingen afspeelden, is een veelheid van transnationale overheidsnetwerken op ieder denkbaar (internationaal) beleidsterrein. Waar ooit op nationaal niveau 'ijzeren driehoeken' of 'beleidsgemeenschappen' de vorming en uitvoering van beleid in nationaal omkaderde beleidssectoren monopoliseerden, worden belangrijke en vergaande beslissingen tegenwoordig (mede) voorbereid en uitgewerkt in internationale beleidsarena's.

Wij hebben in dit hoofdstuk betoogd dat deze ontwikkelingen geen bedreiging hoeven te vormen voor de nationale soevereiniteit. In tegenstelling tot wat vaak in maatschappelijke debatten over de 'superstaat EU' wordt gezegd, hebben we in deze bijdrage willen betogen dat internationalisering van beleid niet zozeer als een 'nul-som spel' moet worden benaderd, maar hebben we de 'positieve som' aspecten van internationalisering benadrukt. Hiervoor is het nodig om te onderkennen dat internationalisering van beleid en het ontstaan van internationale beleidsarena's aan nationale overheden mogelijkheden bieden om te profiteren van de internationale specialisatie en arbeidsdeling die tussen landen en daarbinnen tussen bestuurlijke organisaties bestaan. Het ontstaan van internationale beleidsarena's opent voor actoren binnen het Nederlandse openbaar bestuur mogelijkheden om eigen beleid te exporteren en beproefde beleidsprogramma's ('best practices') te importeren. Zo bezien vormen supra- en internationale beleidsarena's vehikels voor het 'uploaden' en 'downloaden' van beleid.

Echter, het zou verkeerd zijn om de implicaties van internationalisering uitsluitend in economisch of marktefficiënt licht te bezien. Het exporteren of importeren van beleid vindt niet langs de principes van een 'onzichtbare hand' plaats, waarbij er voortdurend een Pareto efficiënte uitruil van beleid tussen staten en beleidssectoren daarbinnen plaatsvindt. De macht in de wereldeconomie is nog altijd ongelijk verdeeld en dit uit zich in de hoeveelheid en institutionele vormgeving van beleidsarena's. Deze variëren van beleidsarena's waar een hegemoon heer en meester is tot beleidsarena's waar de anarchie en daarmee onzekerheid en onvoorspelbaarheid van beleidsuitkomsten troef is. Voor een militair en politiek zwakke maar economisch sterke staat zoals Nederland is het daarom van groot belang strategische keuzen te maken met betrekking tot de beleidsarena's waar Nederlandse 
beleidsprioriteiten via hetzij beleidsexport hetzij via beleidsimport kunnen worden gerealiseerd. Kleine, gesloten beleidsarena's zijn ongeschikt, omdat Nederland daarbinnen de macht om beleidsprioriteiten te verwezenlijken mist. Tegelijkertijd zijn volledig open en representatieve beleidsarena's in beginsel ook ongeschikt, omdat daar het geringe stemgewicht van Nederland Nederlandse vertegenwoordigers tot coalities en compromisvorming met andere staten dwingt. In dit licht betogen wij dat gemiddeld genomen de Nederlandse belangen in internationale beleidsarena's het best gediend zijn met een defensieve inzet in onafhankelijke en open arena's en met een offensieve inzet in onafhankelijke en gesloten arena's. 


\section{NOTEN}

In beide enquêtes is ambtenaren gevraagd aan te geven hoeveel uur zij in totaal per week besteedden aan EU-gerelateerde werkzaamheden en hoe belangrijk de verschillende in de tabel opgesomde activiteiten waren in hun werk (op een vijfpuntsschaal van 'helemaal niet belangrijk' tot 'heel belangrijk'). Een uitzondering hierop vormt de Technische Commissie van IOsCo. Deze commissie, waarin de financiële toezichtautoriteiten van de landen met de meest ontwikkelde financiële markten zitting in hebben, fungeert wel als een belangrijk informatie- en deels harmonisatienetwerk tussen toezichthouders in de EU en de vs.

In een land kunnen meerdere gelijke behandelingsinstellingen bestaan; bijvoorbeeld een voor discriminatiegrond geslacht en een voor de grond racisme en/of alle andere mogelijke gronden.

4 In sommige lidstaten is de centrale bank lid van CESR. Dit hangt samen met het al dan niet bestaan van het zogenaamde twin peaks model van toezicht. In twin peaks landen is het prudentiële toezicht op banken gescheiden van het toezicht op financiële markten. In dit geval is de autoriteit die belast is met het toezicht op financiële markten lid van CESR. 


\title{
4 TUSSEN TAFEL EN TRIBUNE. HET HANDELINGS- VERMOGEN VAN HET NEDERLANDSE OPENBAAR BESTUUR IN DE EUROPESE TUSSENSFEER
}

\author{
Luukvan Middelaar
}

\subsection{INLEIDING ${ }^{1}$}

De Europese Unie (EU) schijnt in de hoofden van Haagse politici en ambtenaren te leven als een buitenlandse bezettingsmacht. Dit ervaart men in details. Neem de parlementaire achteloosheid jegens Europese besluiten. 'Jullie besluiten', kan men Tweede Kamerleden verwijtend horen zeggen tegen hun partijgenoten uit het Straatsburgse parlement. En dat moet natuurlijk onze zijn, aangezien de verantwoordelijkheid voor zulke besluiten evenzeer ligt bij de Nederlandse regering, die zij zelf dienen te controleren.

Het Nederlandse openbare bestuur worstelt met de spanning tussen de sterke dwang van de Europese onderhandelingstafels en de eis de gezamenlijk genomen besluiten te verdedigen ten overstaan van een tegelijk veeleisend en terughoudend publiek. Het is geen specifiek Nederlands probleem, maar neemt bij ons geprononceerde vormen aan. Dit heeft te maken met de inflatoire eurotaal die decennialang is gebruikt en die het publiek argwanend heeft gemaakt. Het heeft evenzeer te maken met een fundamentele wijziging in de aard van de Europese politiek, dus in de vorm van de Unie, die zich onder druk van geopolitieke breuken als '1989' en '2001' heeft voorgedaan en die Den Haag zeer heeft onderschat. Beide kwesties raken het Nederlandse openbaar bestuur zowel in het handelingsvermogen aan Brusselse tafels als in de performance voor de eigen publieke tribune. Op beide punten zijn aanmerkelijke verbeteringen mogelijk.

Deze bijdrage opent, vanuit Europees perspectief, met de schets van een model om de feitelijke dynamiek in zestig jaar Europese ontwikkelingen op nieuwe wijze te duiden. Dit gebeurt met een onderscheid tussen drie sferen waarin de Europese staten hun onderlinge betrekkingen hebben ondergebracht; de sleutel ligt in de onvermoede, onzichtbare en juridisch moeilijke grijpbare ontwikkeling van een 'tussensfeer' van reactie en initiatief, van onderhandeling en compromis, van dubbelrollen en deals (par. 4.2). Vervolgens richt deze bijdrage zich specifiek op het Nederlandse openbare bestuur in zijn optreden in en omgang met deze tussensfeer. Er is een historische terugblik op het Haagse onbehagen bij de Europese tussensfeer, teneinde de huidige moeilijkheden in te kaderen (par. 4.3). Vervolgens gaat de blik vooruit naar de mogelijkheden het Nederlandse handelingsvermogen te vergroten zowel in het spel aan de Europese handelingstafels (par. 4.4) als in de verantwoording ten overstaan van het publiek (par.4.5). 
Twee opmerkingen vooraf nog. Ten eerste, buiten de EU zijn voor Nederland uiteraard meer internationale organisaties van belang, de NAVO en de Verenigde Naties voorop, maar ook het IMF, de WTO of de prille G2O. Toch is er een kwalitatief verschil. De 'gewone' internationale organisaties zijn veelal gespecialiseerde organen en agentschappen, ten dienste van en zich richtend tot de staten. Daarentegen richt de Unie zich met rechten en plichten én een verhaal over de politieke toekomst niet alleen tot de lidstaten maar ook tot hun burgers. Voor de staten wordt ze daarmee in plaats van een dienstbare organisatie deels een concurrent. Ze raakt aan ieders constitutionele grondslagen. Vandaar dat bij nationale politici en bevolkingen de vrees kon ontstaan dat hun land in Europa zou 'smelten als een suikerklontje in de koffie' (de Tsjechische premier Klaus) of dat lidmaatschap het einde zou betekenen van 'a thousand years of history' (de Britse oppositieleider Gaitskell). ${ }^{2}$ Geen mens heeft ooit gedacht dat toetreding van zijn land tot, zeg, de Wereldgezondheidsorganisatie eenzelfde effect zou hebben. Bij het nadenken over de speelruimte voor het openbaar bestuur is het zaak dit verschil in publieke ervaring, de specifiek aan Europa gelieerde emoties en schrikbeelden, serieus te nemen.

Tweede opmerking vooraf: 'Europa' is een betwist begrip, zoals de meeste politieke woorden. De taal zelf is onderdeel van de politieke strijd. Een voorbeeld vormen de woorden waarmee de Europese ontwikkelingen sinds 1945 worden aangeduid. Onder meer de begrippen Europese 'integratie', 'constructie', 'eenwording' en 'samenwerking' zijn in omloop. Ze doen zich als beschrijvend voor, maar hebben elk een eigen klank en dwang. Integratie verwijst naar een schokvrij quasichemisch proces dat eindigt in totale vermenging; constructie doet denken aan een bouwproject op een lege plek; eenwording laat open of ze vrijwillig of met geweld plaatsvindt; en samenwerking benadrukt de blijvende zelfstandigheid van de (lid)staten. Elke term ontwaart én vormt een andere wereld. Het is dus betekenisvol dat de Nederlandse regering, die jarenlang de 'Europese integratie' voorstond, na het debacle van het referendum van 2005 in haar formele communicatie is overgeschakeld op 'Europese samenwerking', terwijl de Franse regering ook na het non uit dat jaar vasthoudt aan 'Europese constructie'. Deze politieke slag om de woorden heeft, gewild of ongewild, repercussies voor de wetenschappelijke beschrijvingen en analyses. ${ }^{3}$

\subsection{GEBOORTE EN BESTENDIGING VAN DE EUROPESE TUSSENSFEER}

4.2.1 DRIE SFEREN VAN EUROPESE POLITIEK: BUITENSFEER, BINNENSFEER, TUSSENSFEER

De analyse van de Europese ontwikkelingen sinds 1945 is gebaat bij een onderscheid tussen de sferen waarin de Europese staten hun verkeer hebben georganiseerd. Het zijn er drie. Ze omvatten elkaar als concentrische bollen. Elke sfeer heeft 
eigen principes van beweging en ordening. Elk heeft eigen regels en omgangsvormen, aflopend op de geweldsschaal van oorlog en dreiging met geweld tot veto en stemming bij meerderheid. Elk kenmerkt zich door een zelfbeeld en een publiek.

Ten eerste de buitenste sfeer. Deze vindt haar (onscherpe) afbakening in geografie en geschiedenis. Ze bevat het voltallige gezelschap van soevereine staten op het continent en stond eeuwenlang bekend als het 'Europese concert'. Beweging komt hier uit het najagen van eigenbelang door de staten; ordening vooral uit een machtsbalans en territoriale grenzen. De machtsbalans was de dragende ongeschreven regel van het stelsel. Deze werd door elke oorlog of oorlogsdreiging doorbroken en diende dan dankzij onderhandelingen, concessies en compromissen op een vredescongres à la Wenen 1814-1815 te worden herschikt. Territoriale grenzen vormden er een zichtbare uitdrukking van. Tot op heden spelen de verhoudingen tussen de staten op het Europese continent zich voor een deel af in dit puur politieke milieu van machtsbalans, oorlog en grensconflict. Men denke aan het conflict tussen Kroatië en Slovenië over toegang tot de Adriatische Zee of de recente spanningen tussen Nederland en België over de Westerschelde oftewel de toegang van Antwerpen tot de Noordzee: actueel sinds 1585. Het recht heeft in de buitensfeer een plaats als volkenrecht, dat niet in de laatste plaats het recht van oorlog en vrede omvat.

Ten tweede de binnenste sfeer. Deze is het product van een stichtingsakte uit 1951. Ze doopte zichzelf Gemeenschap. Ze bestrijkt een juridisch afgegrensd maar zich steeds uitbreidend handelingsterrein van de deelnemende staten. Haar interne bewegingsprincipe is een idee van de toekomst, het 'Europese project'. Ordening en houvast komen van een tussen de staten gesloten verdrag, het stichtingspact. Het hoofddoel van de oprichters was een radicale breuk met de machtspolitiek $\grave{a}$ l'ancienne. De gedachte aan Europese vrede werd verbonden met het indammen van de diplomatie. Men oordeelde dat Europa niet kon ontstaan uit een botsing van nationale belangen; deze waren stellig te hevig, de wonden van de laatste oorlog te rauw. Dus plaatste men zich zo goed mogelijk buiten de wereld van de nationale staten. In onderscheid met eerdere vredesverdragen voorzag het stichtingspact daartoe in onafhankelijke Europese instellingen, een Hoge Autoriteit (later: Commissie) en een Hof. Deze konden slechts handelen onder aanroepen van formele bevoegdheden in het verdrag.

Ten derde de tussensfeer. Deze ontstond bij de stichting van de Gemeenschap, onmiddellijk en onverwacht, tussen beide andere in. Deze tussenwereld bleef lang ongezien en is niet goed in juridische termen te vatten. Vandaar wellicht dat ze geen naam heeft gekregen. Toch is ze cruciaal. Het is de tussensfeer van de lidstaten samen. De landen die lid werden van de Gemeenschap ontdekten gaandeweg dat ze een eigen club waren in de wereld, dat ze belangen deelden, dat ze soms tegen heug en meug samen moesten optrekken. Het sterkste ordeningsprincipe in 
deze sfeer is het lidmaatschap, maar ook de machtsbalans en het recht spelen een rol. Beweging ontstaat hier (net als in de buitensfeer) uit ieders najagen van het nationaal belang, maar ook (daar zit de verrassing) uit een groeiend besef van gezamenlijke belangen. Deze sfeer is een tussenwereld naar eigenschappen, nu eens overlappend met buiten, dan weer met binnen. Het is ook een tussenwereld naar functie; haar rol is te verbinden, relaties leggen, gebeurtenissen op te vangen, overgangen te maken.

Waarom is die tussensfeer niet gezien? Een mogelijke verklaring is de kracht van de heersende denkschema's. Sinds 1950 doortrekt de tweedeling supranationaal (of: communautair) versus intergouvernementeel het denken over Europese politiek, zeker ook in Nederland. De intellectuele sympathie van deze beide ligt ruwweg bij het zelfbeeld van de binnensfeer en bij de machts- en belangenstrijd in de buitensfeer. Het supranationalisme, ideologische weerslag van de Brusselse alliantie tussen Commissie en Parlement, produceert een enorme hoeveelheid tekst: verdragen, verordeningen, richtlijnen, commentaren, maar ook een onvermoeibaar eromheen zoemende duiding en rechtvaardiging van methode en doel van het Europese project. Het intergouvernementalisme daarentegen volstaat liefst met een superieure ironie, met de gespeelde achteloosheid van 'sinds Bismarck in Europa niets nieuws onder de zon'. In dit getiktak vond de tussensfeer, die steeds met de ene en de andere sfeer kon overlappen en pas mettertijd haar zelfstandigheid verwierf, geen houvast. Er waren geen woorden voor over.

De tussensfeer toonde en toont haar zelfstandigheid en eigen aard op momenten van crisis. Ook om die reden is deze zeer politieke sfeer moeilijk grijpbaar en onzichtbaar gebleven; ze neemt een specifieke plaats in de tijd in, oplichtend en weer verdwijnend. In crisismomenten, wanneer er buiten de regels van het verdrag om moet worden gehandeld, wordt zichtbaar dat gezag over de Unie niet bij de binnensfeer ligt, maar bij de gezamenlijke regeringen van de lidstaten.

Twee breukmomenten mogen dit illustreren; een interne crisis en een externe schok. Ze tonen de beide aandrijvers van de tussensfeer: de vervlechting van belangen aan tafel (subpar. 4.2.2) en de druk van de buitenwereld (subpar. 4.2.3). Het resultaat: een verticalisering van het Europese bestuur, tegen de maatschappelijke trends in. De Brusselse bestuurspiramide - met haar basis van werkgroepen, daarbovenop de ambassadeurs, dan vakministers - krijgt in 1974 een top: de gezamenlijke regeringsleiders, oftewel de niet in het stichtingspact voorziene Europese Raad. Zeer recent krijgt die top bovendien een eigen piek: de vaste voorzitter van de Europese Raad (subpar. 4.2.4). Deze nieuwe functie alleen al duidt erop dat de tussensfeer geen tijdelijk verschijnsel is dat onherroepelijk in de binnensfeer zal opgaan, maar zich heeft bestendigd en een toekomst heeft. 


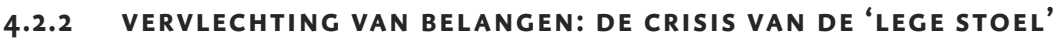 (1965-1966) EN DE DWANG VAN DE TAFEL}

Het stichtingsverdrag van Rome bevatte meerderheidsbepalingen die pas na acht jaar zouden ingaan. Deze kwestie leidde tot een ongekend zware politieke crisis. Vanwege het gevaar dat het op vitale onderwerpen zou kunnen worden overstemd bleef Frankrijk vanaf juli 1965 weg uit de Raad van Ministers ('lege stoel'). Tijdgenoten waren ontzet; de Nederlandse landbouwcommissaris Mansholt sprak van "de grootste ramp sinds Hitler" (Mansholt in Merriënboer 2005: 327). Pas in januari 1966 kwam Parijs met de andere vijf lidstaten tot een akkoord: het Compromis van Luxemburg. Dit behelst dat er in zulke gevallen wordt vergaderd tot ieder met het resultaat kan instemmen. Dit akkoord is in de EU-literatuur verguisd als obstructiepolitiek of het begin van twee decennia stagnatie. Het is echter een cruciaal passagemoment, de bestaansbevestiging van de tussensfeer. Frankrijk erkende de blijvende werking van het verdrag. De 'Vijf' erkenden dat zware nationale belangen niet konden worden overstemd. Het Compromis dwingt die beide werelden zich tot elkaar te verhouden binnen de tussensfeer van de Zes. Buiten de verdragssfeer gaven de Zes zich een gezamenlijke grondregel, een levensverzekering tegen meerderheidsheerschappij. Tot op heden hangt deze ongeschreven regel boven de Brusselse onderhandelingstafel.

Waarom viel de Gemeenschap in deze weergaloze crisis niet uiteen? Omdat de economische belangen al te sterk waren vervlochten. Dit ervoer met name Frankrijk. De Gaulle wilde het spel hard spelen, maar werd tijdens de presidentsverkiezingen van december 1965 terechtgewezen door de boeren. Deze vertegenwoordigden nog bijna eenvijfde van het electoraat; zij vreesden dat in de crisis het Europese landbouwbeleid - en dus hun inkomen - op het spel stond, stapten over naar een uit het niets opgekomen pro-Europese kandidaat en onthielden de Generaal zo de absolute meerderheid in de eerste ronde. Na deze terechtwijzing stemde Parijs in met een gesprek met de partners over een oplossing. Maar ook de andere Vijf wilden niet met de Fransen breken; de markt in aanbouw was een zegen voor het bedrijfsleven en consumenten en vergrootte ieders welvaart, gezamenlijk optreden in de internationale handelspolitiek (Kennedy-ronde) werd zeer gewaardeerd door de Amerikanen. Sinds die eerste 'lege stoel' is nooit meer iemand van tafel gestapt. Het lidmaatschap overtroeft het verdrag.

Wezenlijk is dat het Luxemburgse akkoord aldus de behoefte aan gezag in de Europese orde ingebracht. Erkenning hiervan speelde vermoedelijk een rol bij de stilzwijgende instemming van de Vijf met de Franse eis van een ultiem veto. Regeringen weten dat de uitvaardiging van een besluit nog niet garandeert dat de bevolking het aanvaardt. Om naleving af te dwingen kan een nationale overheid jegens zijn burgers desnoods geweld gebruiken. Dit zou evenwel tot een lastige situatie leiden wanneer de bevolking protesteerde tegen een Europees besluit 
waarop de betreffende staat was overstemd. Tegen een Franse afgevaardigde die over de landbouwprijzen mopperde, zeggend dat deze toch bij meerderheid werden vastgesteld, zei de Franse minister Couve de Murville: "Denkt u werkelijk dat het mogelijk is tegen, zeg, Duitsland te beslissen over de prijs van het graan? Wie zou dan opdraaien voor de opstand van de Duitse boeren waarop het kan uitlopen, de Commissie of de lidstaten?” (Couve de Murville 1971: 298). Ook de regeringen van de Vijf waren - beter dan hun parlementen - van dit dilemma doordrongen. Het is niet uitgesloten dat zij binnenskamers opgelucht waren blijvend over een veto te beschikken. De Gemeenschap beschikte niet over de middelen om naleving van een gezamenlijk besluit tegen de zin van de betreffende regering af te dwingen. De Gaulle dwong de anderen te erkennen dat de autoriteit van een Europees besluit rust op de staten. Ook deze politieke les geldt onverkort anno 2010.

Aldus heeft het Compromis van Luxemburg de Europese en de nationale ordes onontwarbaar verweven en versterkt. De regeringen zijn de schakel; zij komen in een dubbelrol. Tevoren biedt het hun een verzekering dat een gezamenlijk besluit niet tégen zwaarwegende nationale belangen in zal gaan. Tijdens de onderhandelingen functioneert het, behalve als recht, tevens als plicht de tijd te nemen om tot een gezamenlijk besluit te komen. Na afloop vraagt het 'Luxemburgse veto', precies in zoverre het niet is ingeroepen, verantwoordelijkheid te nemen voor het genomen besluit ten opzichte van de eigen bevolking.

De grote moeilijkheid is de dwang van deze tafel, waar het altijd schipperen en geven en nemen is, te doen voelen aan de eigen bevolking zonder in de beeldvorming als zwak over te komen. Vergelijk de Unie in dit opzicht met een coalitieregering met 27 partijen, waarbij elke partij steun zoekt voor de besluiten op eigen partijcongressen en de afwezigheid van een oppositie maakt dat het dragen van regeringsverantwoordelijkheid (en de prijs die daarvoor wordt betaald) niet iets is om trots op te zijn.

\subsubsection{DRUK VAN DE BUITENWERELD: DE VAL VAN DE BERLIJNSE MUUR (1989) EN DE UNIE}

In een buitenlandse politiek was in het verdrag van Rome niet voorzien. Deze scheen de meeste staten mogelijk, wenselijk noch noodzakelijk. De Europese instellingen hielden zich in beginsel bezig met low politics - hoofdzakelijk economische regelgeving. Voor de high politics verlieten de Zes zich alle op de Amerikaanse paraplu. Het gevaar van een nieuwe Frans-Duitse oorlog scheen te wijken, de NAvo hield de Russen buiten. In de statische wereld van de Koude Oorlog was men weinig alert op nieuwe gedaanten van historisch onheil. 
Groot en onverwacht was de schok van de val van de Muur (1989), toen Duitsland plotseling herenigd terugkeerde in het statengezelschap en de oostelijke helft van het continent zich in de Europese wachtkamer meldde. Deze schok is tot op heden nauwelijks verwerkt. De verhouding tussen het continent als geheel en hun kring dwong de lidstaten tot een politisering van hun verband. Sommige lidstaten deden met tegenzin mee, maar ze ontkwamen er niet aan. In Maastricht werd besloten tot Europese buitenlandse politiek en justitiebeleid. Hiertoe achtte men het strakke korset van de regels van de Gemeenschap niet geschikt; derhalve richtte men een Unie op, een losser verband.

Waarom kon men het beproefde communautaire model voor de markt niet gebruiken voor een gezamenlijke buitenlandse politiek? Omdat buitenlandse politiek geen kwestie is van juridische bevoegdheden overhevelen van de nationale staten naar 'Brussel', zoals de watertandende Commissie en Parlement graag zouden zien. Deze instellingen zijn niet in staat de verantwoordelijkheid te dragen voor zulke leven en dood rakende besluiten als het uitzenden van soldaten. Ook voor het zeker stellen van de energietoevoer in een dialoog met Rusland heeft een Commissievoorzitter onvoldoende gewicht om in het Kremlin indruk te maken (zoals opnieuw bleek in de gascrisis van januari 2009 met Oekraïne, die bejaarden in Bulgarije in de kou zette). En benadrukt moet worden: dit onvermogen is er niet omdat de huidige man Barroso een zwak politicus zou zijn, zoals zijn critici zeggen, maar qualitate qua. De Brusselse binnensfeer kan de geopolitieke jungle niet de baas. Daarom zoeken de lidstaten andere manieren om, buiten de institutionele binnensfeer om, als Europa te worden gehoord en de belangen van hun Unie te waarborgen.

Men kan dit verschil tussen de Gemeenschap van voor 1989 en de Unie van na 1992 ook anders benoemen. Tot 1989 ging het om het scheppen van een podium ('gelijk speelveld') waarop de economische actoren optreden. De spelers zijn bedrijven, consumenten, werkgevers, werknemers, maar niet de staten zelf. De Gemeenschap heeft de rol van marktmeester en een beetje van terreinknecht; het stelsel van regels en rechten van de Gemeenschap betekent voor de lidstaten vooral zelfbinding, bijvoorbeeld omdat ze hun industrie niet onvoorwaardelijk staatssteun mogen geven of met Europese aanbestedingsregels te maken krijgen. In de Unie daarentegen, zoals in 1992 vooral vanwege de buitenlandse politiek ontstaan, gaat het ook om het organiseren van verantwoordelijkheden. Cruciaal is dat de gezamenlijke lidstaten zélf de speler zijn op het politieke toneel van de orde verstorende gebeurtenissen. De handeling bij het zeker stellen van binnenlandse of buitenlandse veiligheid kan alleen van de staten uitgaan. Daartoe zijn die staten ooit ontstaan. Zij hebben de soldaten, diplomaten, agenten die ervoor nodig zijn. De fundamentele vernieuwing van de Unie is dat de lidstaten deze verantwoordelijkheid formeel gezamenlijk dragen. (Overigens blijven de oude taken bestaan!) 


\subsubsection{DE EUROPESE RAAD VAN REGERINGSLEIDERS}

Deze beide ontwikkelingen, de economische vervlechting en de druk van de buitenwereld, hebben geleid tot een verticalisering van het Europese bestuur. De gezamenlijke regeringsleiders hebben de macht gegrepen. Het sleutelmoment vond in 1974 plaats met de oprichting van de Europese Raad van regeringsleiders. Het dubbele doel was een forum dat in laatste instantie knopen kon doorhakken waar de vakministers in de sectorale raden niet uitkwamen én een forum dat namens de gezamenlijke lidstaten met gezag tot de buitenwereld kon spreken.

\section{Ontwikkeling en formalisering Europese Raad}

Sinds de oprichting in 1974 heeft de Europese Raad van regeringsleiders zich steeds sterker gemanifesteerd (Bulmer \& Wessels 1987; Werts 2008). Voor scherpzinnige waarnemers was al meteen duidelijk dat hij zou uitgroeien tot de meest gezaghebbende Europese instelling (Noël 1976). Na een twistrijke periode in de vroege Thatcher-jaren vanaf 1979, kan men midden jaren tachtig de omslag zien: op de top van Fontainebleau (juni 1984) werd een akkoord bereikt in een slepend conflict over het budget en een jaar later, op de top van Milaan (juni 1985) besloten de regeringsleiders tot de eerste ingrijpende verdragswijziging sinds het verdrag van Rome. Sindsdien is de Europese Raad niet meer uit het centrum van de Europese politiek verdwenen. Hij neemt alle besluiten over het budget, over verdragswijziging en grote inhoudelijke vernieuwingen, over de buitenlandse politiek. De geopolitieke ontwikkelingen na 1989 hebben zijn rol onontkoombaar gemaakt. Wegens verzet van de Commissie en de Benelux werd de Europese Raad bij oprichting in 1974 formeel geen 'Gemeenschapsinstelling'. Het lichaam paste niet in het communautaire denken. Een voormalig Nederlands diplomaat sprak van een 'koekoeksjong in het Gemeenschapsnest' (Linthorst Homan in Werts 2008: 17); deze metafoor onthult en passant hoe sterk het onderscheid tussen de sferen werd beleefd. Formeel namen de regeringsleiders geen besluiten. Politieke akkoorden kregen pas na afloop, op het niveau van de Raad van Ministers, juridisch bindende kracht. De ideologen van het supranationale burgerkantorenvertoog vonden dit geruststellend; nog recent kon men in Brussel horen beweren dat de Europese Raad 'geen instelling' was of mocht worden. Toch hielden zij zich enigszins voor de gek. De tafel van de regeringsleiders stelde zich aan de top van een Brusselse piramide die inmiddels was ontstaan. Onderop de talloze ambtenarencomités, dan de wekelijkse vergadertafels van de ambassadeurs van de lidstaten en hun plaatsvervangers, dan de maandelijkse vergadertafel van de ministers van Buitenlandse Zaken plus die van de vakministers (Economische Zaken, Landbouw, enz.) - het geheel elke paar maanden afgesloten door de regeringsleiders. Dit betekent dat het allergrootste deel van de Europese besluiten ('policy') nooit op deze tafel terechtkomt, maar tegelijk dat het altijd wel kan gebeuren, wanneer men op onderliggende niveaus het probleem als te heikel naar boven door blijft sturen. Zo bogen de regeringsleiders zich in 2002 over Italiaanse boetes inzake 
melkquota. In die zin is de grens tussen 'policy' en 'politics' niet hard; in het onbenulligste dossier kan de (nationale, partijpolitieke, enz.) politisering toeslaan. De Europese Raad is in de Unie de plaats waarvan de Amerikaanse president Truman ooit zei "the buck stops here". Als deze politieke arena er niet uitkomt, volgt geen antwoord.

Men kan deze politieke opmars ook in formele, verdragsrechtelijke zin volgen, als een 'innesteling' van de Europese Raad in de Gemeenschapsstructuur (Eijsbouts 200o). In de Europese Akte van 1987 - de eerste inhoudelijke wijziging van het stichtingspact - werd deze voor het eerst genoemd. In het verdrag van Maastricht (1992), dat de regeringsleiders zelf uitonderhandelden, gaven zij de Europese Raad de verantwoordelijkheid voor de richtinggevende besluiten op het gebied van de buitenlandse politiek (1992). In het verdrag van Lissabon (2007) neemt de Europese Raad de richtinggevende besluiten op alle beleidsterreinen. Tevens is in dat verdrag de veelbesproken instelling van een vaste voorzitter voorzien.

\section{Dubbelrollen}

De publieke kracht van de Europese Raad - en van de tussensfeer meer in het algemeen - ligt in de dubbelrol die zijn leden vervullen. Ieder aan tafel zit er uit hoofde van een nationaal kiezersmandaat. (Met uitzondering van de commissievoorzitter en sinds kort van de vaste voorzitter.) Aldus vertegenwoordigt de Nederlandse premier de Nederlandse regering en bij uitbreiding het parlement en de bevolking op het Europese vlak. De crux zit in de terugvertegenwoordiging die zich voordoet.

Zo heeft de Nederlandse minister-president voor hij afreist naar de vergadering met collega-regeringsleiders een overleg met de Tweede Kamer. Daar kan hij de inzet van de regering uitleggen, horen wat de wensen of eisen van het parlement zijn. Na afloop brengt de premier verslag uit. Als regeringsleider legt hij verantwoording af over de onderhandelingen: namens Nederland heb $i k$ hard gevochten om punt $\mathrm{X}$ binnen te halen, terwijl om reden zus of zo de slag om $\mathrm{Y}$ is verloren. Als lid van de Europese Raad neemt hij de verantwoordelijkheid voor het resultaat: namens de Unie hebben wij dit zo besloten. Zo dwingt de minister-president voor een Uniebesluit een parlementaire meerderheid af.

Aan deze verantwoordelijkheid kan men zich niet onttrekken, op straffe van teleurstelling of hoon van de collega's. Deze druk is sterk voelbaar bij ingrijpende politieke akkoorden, zoals verdragswijziging. De regeringsleider die voor het gezamenlijke Uniebesluit geen nationale meerderheid haalt, bijvoorbeeld door een referendum te verliezen, verliest zijn gezag bij de andere leden van de Europese Raad ("He didn't deliver his voters"). Dit is pijnlijk voor de politicus in kwestie, maar ook schadelijk voor de positie van zijn lidstaat. 


\section{Vooruitzichten Europese Raad}

De positie van de Europese Raad zal de komende jaren denkelijk versterken. De instelling van een vaste voorzitter is er een teken van. Dit zal vooral ten koste gaan van de Europese Commissie en haar voorzitter. Het is in journalistieke commentaren gebruikelijk de nadruk bij dergelijke analyses te leggen op de kracht of zwakte van individuele persoonlijkheden. Dan vermaant men bijvoorbeeld de huidige commissievoorzitter Barroso dat hij zelfstandiger moet opereren ten opzichte van de grote lidstaten of wenst men hem geluk met de keuze van de 'zwakke' Herman van Rompuy als eerste Raadsvoorzitter. Deze focus op de 'poppetjes' gaat voorbij aan de onderliggende dynamiek. Beslissend is dat in de huidige mondiale constellatie 'binnenlandse' en 'buitenlandse' politiek ook voor de Unie als geheel steeds minder goed te scheiden zijn. Beide aandrijvers van de opmars van de Europese Raad, de vervlechting van de belangen en de druk van de buitenwereld, raken elkaar. Brusselse bezweringsformules als 'institutioneel evenwicht' (i.e., tussen Commissie, Parlement en Raad) of 'communautaire methode' kunnen daar niet tegenop. De Europese Raad blijft het powerhouse van de Unie.

Voor de interne markt heeft de voorzitter van de Commissie de sterkste positie; deze is in zekere zin de 'baas van de binnensfeer' en waakt over de handhaving en toepassing van de economische regels tussen de lidstaten. Voor de Europese buitenlandse politiek is er sinds kort de Hoge Vertegenwoordiger nieuwe stijl (Catherine Ashton); zij zal zich denkelijk, de camouflagenaam van de functie niet te na gesproken, ontwikkelen tot een Europese minister van Buitenlandse Zaken en aanspreekpunt in crisissituaties.

Binnen en buiten raken echter steeds meer verknoopt. De oorzaken zijn legio; simpel gezegd betekent het feit dat de macht van het Westen afneemt ten opzichte van met name Azië, alsmede dat binnen dat 'Westen' de Europeanen de Amerikaanse beschutting verliezen, dat de druk van buiten zich binnen sterker doet voelen. Concreet: men kan niet het succes van de euro garanderen als de Unie geen gesprekspartner is van de Amerikanen en de Chinezen; een te hoge wisselkoers heeft directe consequenties voor de Europese export en dus werkgelegenheid. Men kan geen serieuze klimaat- en energiepolitiek voeren zonder positie te bepalen jegens Rusland, waarvan meerdere lidstaten geheel afhankelijk zijn voor de verwarming in de winter. Men kan geen immigratiepolitiek hebben zonder relaties met Noord-Afrika.

Het overleg tussen de regeringsleiders is bij uitstek de plaats waar én geopolitieke ontwikkelingen én het interne Europese geregel over tafel gaan. Dus zelfs als de vaste voorzitter van de Europese Raad zich zou beperken tot vergaderingen leiden over intern beleid, zal hij of zij onafwendbaar een grote buitenlandse rol krijgen. 
Overigens is er ook intern een steeds sterkere verwevenheid van beleidsdossiers. Denk aan de ambitieuze klimaatdoelen per 2020, van 20 procent minder $\mathrm{CO}_{2}{ }^{-}$ uitstoot, 20 procent schone energie, 20 procent zuiniger gebruik. Deze ingrijpende doelstellingen raken aan economie en werkgelegenheid, aan milieu, aan landbouw, aan research, onderwerpen die in dit verband dus in noodzakelijke samenhang moeten worden besproken. Dit betekent dat de sectorale vakraden - de 'gewone' ministerraden - steeds meer tot voorportalen worden van de besluitvorming, in plaats van het eindstation. De zogenaamde Raad Algemene Zaken en Extern Beleid, die tussen vakraden en Europese Raad als buffer zou moeten werken, functioneert steeds minder, omdat de daar aanwezige ministers van Buitenlandse Zaken zich liever over de tweede dan over de eerste helft van de in de naam vervatte taak buigen; oftewel, zij geven liever verklaringen over het Midden-Oosten uit dan zich over $\mathrm{CO}_{2}$-uitstoot te buigen. Niet toevallig heeft de Europese Raad zich in december 2008, bij de uitwerking van de klimaatdoelen, tot in ongekend detail met de wetgeving bemoeid, en is hij feitelijk als wetgever opgetreden (Smulders 2009).

\section{Tafel en konvooi}

De tussensfeer is geen overgangsfase tussen buiten en binnen, maar formaliseert zich steeds sterker. Dit is een uitdrukking van het dubbele feit dat de lidstaten niet verdwijnen, maar er evenmin onderuit kunnen in gezamenlijkheid hun Unie te besturen. Zo zal in Europa de moeilijk grijpbare spanning tussen één en veel, tussen het geheel en de delen, blijven bestaan. Het cliché van de Europese superstaat waarin de lidstaten verschrompelen tot deelstaten voldoet niet. Maar evenmin het cliché van de soeverein samenwerkende staten die hun handen geheel vrij hebben.

Twee metaforen kunnen de verhoudingen wellicht beter vangen. Voor de interne onderhandelingsdynamiek is dat het reeds gebruikte beeld van de tafel: de plaats waar allen samenkomen, zakendoen en vanwege de gelijktijdigheid van allerlei deelonderhandelingen en de reeds onderling vervlochten belangen niet van tafel kunnen stappen zonder daarvoor een hoge (economische en politieke) prijs te betalen. Belangrijker dan de formele besluitvormingsregels (veto of meerderheid?) is het gegeven dat men samen aan een tafel zit waar de dingen, vanwege de band van het verdrag, tot gedeeld probleem worden gemaakt en het vinden van een oplossing een gezamenlijke verantwoordelijkheid wordt. Onder druk komt er, welke formele procedure ook, altijd een besluit uit. Hoe dat gaat - het getrek en geduw, de kaarten tegen de borst, de kladjes met voorstellen, de deals tijdens schorsingen - dat is een ander verhaal...

Voor de plaats van de Unie in de wereld kan men de metafoor gebruiken van een konvooi, een konvooi van 27 schepen dat zijn weg zoekt op de geopolitieke baren. ${ }^{4}$ Je ziet de 27 schepen voor je, alle met een nationale én een Europese vlag in top. Je voelt hoe ze soms door de wind uiteen worden geblazen, soms dezelfde koers 
inslaan. Je beseft dat er een verschil is tussen grote en kleine boten, tussen schepen aan de binnen- of de buitenzijde van het konvooi en hun gevoeligheid voor de wind. En wat het publiek niet ziet, maar wat de 27 nationale kapiteins annex regeringen vanwege hun stoel aan de tafel goed weten, is dat hun schepen onder water economisch en monetair stevig met elkaar verbonden zijn.

Een eigen stoel aan een grote tafel, een schip in een flink konvooi: de afzonderlijke lidstaten zijn en blijven constitutief voor het geheel en tegelijk is hun rol minder heroïsch dan ze het graag zouden voorstellen. Dit stelt een formidabele opdracht aan de gezamenlijke én de afzonderlijke regeringen hun bevolkingen met een geloofwaardig verhaal bij de Europese politiek te betrekken. Voor sommige regeringen blijkt die opdracht extra moeilijk.

\subsection{HET NEDERLANDSE ONBEHAGEN BIJ DE TUSSENSFEER}

Een onderzoek naar het handelingsvermogen van het Nederlandse openbaar bestuur in de EU vereist om te beginnen een onderscheid tussen (1) het Nederlandse belang bij Europees handelingsvermogen als zodanig en (2) het handelingsvermogen van Nederland in Europa zoals het bestaat (à traité constant, zoals juristen dat noemen). Het eerste gaat erom of Europa een (be)stuur heeft; het tweede of en hoe lidstaat Nederland de richting meebepaalt. De focus ligt hier op de tweede vraag. Toch moet men zich realiseren dat de eerste vraag niet zal verdwijnen. De metavraag wat de Unie wel of niet zou moeten doen, maakt immers permanent deel uit van het politieke gesprek tussen lidstaten en instellingen. Dit blijft zo, ook wanneer men met het zojuist ingetreden Lissabon-verdrag institutioneel decennia vooruit zou kunnen. Bovendien toont de geschiedenis dat op tal van momenten nieuwe Europese institutionele vormen en beleidsterreinen gestalte kregen doordat een of meerdere lidstaten hun eigen, nationale belang geloofwaardig wisten te verpakken als een Europese zaak.

\subsubsection{NEDERLAND IN DE EUROPESE BINNEN- EN BUITENSFEER}

Het geschetste onderscheid in drie Europese handelingssferen - de institutionele binnensfeer, de geografische buitensfeer, de politieke tussensfeer - helpt lange lijnen in de Nederlandse Europapolitiek te ontwaren. Veel verwachtte men van Europa voor de welvaart, weinig voor de veiligheid. Dat leidde op termijn tot spanning.

Stichterstaat Nederland ontpopte zich al vanaf de jaren vijftig tot kampioen van de binnensfeer. Niet als initiatiefnemer - in 1950 schoof Den Haag aarzelend aan de oprichtingstafel van de mijnbouwgemeenschap tussen de Zes aan -, maar al snel onderkende men de kansen. Sterke Europese instellingen betekende een demping van de (Europese) machtspolitiek en dus meer speelruimte voor de kleinere 
landen. Zulke instellingen lieten zich niet realiseren voor de buitenlandse politiek en gezamenlijke veiligheid (high politics), zo was in 1954 gebleken toen de Franse Assemblée de vergaande plannen voor een Europese Defensie Gemeenschap afwees. Maar wel voor de economische ordening en welvaart (low politics). Het immense economische belang voor Nederland bij intensiever handelsverkeer met de buurlanden bracht juist de Nederlandse minister J.W. Beyen in 1955 tot het lanceren van de plannen voor een gemeenschappelijke markt, die in twee jaar tot het verdrag van Rome zouden leiden en zo het Europese project een beslissende tweede impuls gaf. Deze constellatie vanaf 1957 was voor Nederland een buitenkans: er waren de Amerikanen en de NAVO voor de veiligheid, de Europese Gemeenschap (alleen) voor de welvaart.

Het belang van de institutionele binnensfeer werd terdege onderkend. Te beginnen met de Commissie. Den Haag zond vanaf het begin sterke eurocommissarissen naar Brussel, op belangrijke beleidsterreinen. Commissaris Mansholt was van 1958 tot 1972 de drijvende kracht achter de inrichting van de Europese landbouwpolitiek, veruit het belangrijkst beleidsterrein in die jaren; hij handelde uit een gezamenlijk belang vanzelfsprekend, maar het beleid maakte Nederland tot in de jaren 1990 netto-ontvanger van Europese gelden. Belangrijke economische posten waren er nadien voor Andriessen (handel), Bolkestein (interne markt) en Kroes (mededinging), terwijl Van den Broek namens de Commissie meesprak over de uitbreiding met de landen achter het IJzeren Gordijn. Dit gaf Nederland steeds bovengemiddeld invloed in de Commissie.

Ook het politieke belang van een stabiele Europese rechtsorde werd door Den Haag hoog geschat. Sinds A.M. Donner, in 1958 de eerste president van het nieuwe Hof van Justitie van de Gemeenschappen, heeft ons land veel gezaghebbende leden van het Hof gekend (Th. Koopman, P.J.G. Kapteyn, C.W.A. Timmermans). In de Raad van Ministers konden de Nederlandse vakministers leunen op lang zittende, gezaghebbende permanente vertegenwoordigers, zoals Spierenburg en Rutten of recenter Bot en De Bruijn. Ook op lager ambtelijk niveau werden de Nederlandse belangen in Brussel uitstekend verdedigd.

In het Europese Parlement, waar de macht van het (bevolkings)getal zich qualitate qua meer doet gelden, was die relatieve Nederlandse invloed geringer. In de jaren tot 1979, toen de Straatsburgse vergadering nog bestond uit nationale parlementariërs, was er omgekeerd - dankzij mensen als Van der Goes van Naters - wel een grote invloed van dit groepje afgevaardigden op de stemming van de Tweede Kamer in Den Haag als geheel.

In zekere zin bestond er van de jaren vijftig tot tachtig een soort rolverdeling, waarbij de regering en ambtenaren de harde economische Nederlandse belangen in Brussel waarborgden (de 'koopman'), terwijl in de Tweede Kamer het meer idea- 
listische vertoog over de Europese eenwording levend werd gehouden (de 'dominee'). Men kon tot aan de val van de Muur de indruk krijgen dat de Tweede Kamer het daadwerkelijk meende als zij de Commissie liefst zag uitgroeien tot een Europese regering en de Straatsburgse vergadering tot Europese wetgever, terwijl de regering de wens van een politieke opwekking van de binnensfeer slechts met de mond beleed. Deze spanning bleef onzichtbaar zolang de Koude Oorlog duurde.

De Europese buitensfeer van machtspolitiek is met de samenwerking tussen lidstaten niet verdwenen. Ook na oprichting van de Europese Gemeenschap hielden de leden hun plaats op het continent en in de wereld. Vier van de zes lidstaten uit 1957 hadden koloniën. Dankzij de steeds hechtere economische vervlechting en het overkoepelende Amerikaanse gezag werd een oorlog tussen de West-Europese partners steeds minder waarschijnlijk. Bilaterale relaties met de Europese niet-lidstaten én met de lidstaten blijven fundamenteel voor de Nederlandse diplomatie, zowel binnen als buiten het verband van de Unie (zie ook subpar. 4.4.2).

\subsubsection{HAAGSE HUIVER JEGENS DE BESTENDIGING VAN DE TUSSENSFEER}

Het Nederlandse openbare bestuur, dat ijverde - of in de Tweede Kamer beweerde te ijveren - voor de opwekking van de Brusselse binnensfeer, wist zich geen raad met de groei van de tussensfeer van de verzamelde lidstaten. Dat was de plaats waar Europa in de ogen van met name Parijs 'politiek' kon worden. Daar kon men behalve over melkprijs of boterberg ook over het Midden-Oosten of de Koude Oorlog gaan praten. Juist tegen die politisering bestond huiver. Het was een constante in de periode 1951-1989, die verklaart waarom Den Haag na de breuk van 1989 de omslag naar de Unie (met alles wat deze behelsde) zo moeizaam maakte.

\section{Realpolitiek en rechtsdenken}

Twee vaste elementen zaten er in het wantrouwen jegens de door Parijs en Bonn gedreven politisering. Ten eerste werd het gezien als een ondermijning van ons veiligheidsanker Amerika en de centrale positie van de NAVO in de buitenlandse politiek. Hier speelde de angst om net als voor 1945 terecht te komen in een Europese ruimte waar de kleinen door de groten, i.e. Frankrijk en Duitsland, zouden worden vertrapt. Dit was het realpolitieke element. Ten tweede werd de vorm waarop deze politisering gestalte kreeg (of dreigde te krijgen) gezien als verraad van de Europese supranationale zaak. Men wilde een terugkeer naar het diplomatieke spel à l'ancienne vermijden en was gehecht geraakt aan de vastigheid van het Verdrag en zijn instellingen, alsmede aan de belofte die ervan uitging. Dit was een meer juridisch en/of idealistisch element. 
Beide elementen gingen lange tijd uitstekend samen, maar kenden een eigen discours. Op het ministerie van Buitenlandse Zaken vertaalde deze gespletenheid van de Europese politiek zich in die tussen de directoraten-generaal Politieke Zaken (DGPZ) en Europese Samenwerking (DGES). Het gebruikelijke onderscheid is 'Atlantisch' versus 'Europees', maar daarbij lijkt het slechts om beleidsopties te gaan. Feitelijk waren het twee denkwerelden: realpolitiek vertrouwen op Amerika als European balancer versus juridisch vertrouwen op de kracht van de Europese regels en instellingen. En dus ook: een redenering in de oude categorieën van de machtspolitieke, continentale buitensfeer (met Amerika in de rol die Groot-Brittannië tot 1939 vervulde) versus een identificatie met de belofte van de Brusselse binnensfeer. Beide buitenlandspolitieke wereldbeelden deelden daarmee een (geveinsd?) onbegrip voor de gezamenlijke dwang op de lidstaten, die malgré eux en buiten het Verdrag om een politiek blok vormden en hun samenzijn ook in een eigen sfeer gestalte wilden geven. Al vanaf de jaren vijftig heette dit 'Unie'.

\section{Op de rem / Nederland versus Frankrijk (1960-2003)}

Deze constellatie leidde tot een serie diplomatieke twisten tussen (met name) Parijs en (met name) Den Haag vanaf de jaren zestig tot op heden.

Bekend zijn de zogenaamde Fouchet-plannen uit 1960-1962. President De Gaulle, die de instemming van bondskanselier Adenauer verwierf, wilde buiten het economische gemeenschapskader een politieke samenwerking tussen de lidstaten ontwikkelen. Het diplomatieke leiderschap van Frankrijk had een vorm nodig om tot uitdrukking te komen. De gedachten gingen uit naar periodieke bijeenkomsten van de zes regeringsleiders. Deze zouden ook volgens de Italiaanse premier Fanfani een 'leegte' in de Europese politiek kunnen vullen. Het plan stuitte tijdens een top in februari 1961 op Nederlands verzet, met als het argument dat GrootBrittannië niet voor de politieke samenwerking was uitgenodigd. ("Mijn 'neen' tegen De Gaulle", heet trots het betreffende hoofdstuk in Luns' memoires (Luns 1971: 139.)

Een jaar later lag er een onder het voorzitterschap van de Franse diplomaat Fouchet uitgewerkte versie van de Unieplannen. Ditmaal verzette behalve Nederland ook België zich. Enerzijds vonden Luns en Spaak de voorgestelde samenwerking op topniveau een onaanvaardbare aantasting van de supranationale verdragsstructuur. Anderzijds zeiden ze er wel mee te kunnen instemmen na Britse toetreding. Dit was merkwaardig, om niet te zeggen tegenstrijdig. Het was algemeen bekend dat Londen nog minder op had met supranationale beginselen dan Parijs. Dat het Europese communautaire ideaal voor de kleinere landen een hogere vorm van nationaal belang was, wekte op zichzelf geen verbazing. Echter, dat ze bereid waren dit Europese ideaal in te ruilen voor toelating van een partij die het, if anything, verder zou ondermijnen, makkte hun verpakking nogal doorzichtig. Het torpederen van de politieke unie leverde Luns de blijvende bitterheid van 
Adenauer op. (Op de top van februari 1961 zou de bondskanselier tegen de Nederlander hebben gezegd: "Wie können Sie, Herr Luns, so sprechen? Das sind doch ja alle Dummheiten die Sie da sagen.” (Adenauer in Bloes 1970: 132). Zelfs de wendbare Spaak verspeelde bijna zijn goede relatie met Parijs. Uiteindelijk overspeelde generaal De Gaulle zijn hand en keerde ook Duitsland zich tegen hem. Recent onderzoek maakt echter aannemelijk dat het Nederlandse verzet beslissend was (Vanke 2001). De plannen belandden in de kast.

In 1969 volgde na crisisrijke jaren tussen de Zes een moment van Europees elan. Op de top van Den Haag werd gevierd dat de douane-unie na twaalf jaar een feit was. Tevens werd een aantal slepende conflicten uit de jaren zestig opgelost. De Fransen (onder president Pompidou nu) hieven hun blokkade op Britse toetreding op en er werden afspraken gemaakt over de landbouwfinanciering. Tegelijk bekrachtigden de lidstaten de wens uit het stichtingspact tot nauwere politieke samenwerking, inclusief op het buitenlandspolitieke vlak. Grappig is dat de Nederlandse regering, die nota bene de gastheer was, in een brief aan de Tweede Kamer over de uitkomsten van de top stelde dat ze graag had gezien dat de eerste vier paragrafen van de slotverklaring, waarin de politieke doelen van de Europese eenwording werden herbevestigd, "in meer praktische termen zouden zijn uitgedrukt”...

In 1974 drukte president Giscard, met steun van bondskanselier Helmut Schmidt, de oprichting van de Europese Raad van regeringsleiders door. Ook dit was tegen de zin van Nederland en België alsmede de Commissie. Premier Den Uyl mocht van zijn Senaatsfractie zelfs niet naar de betreffende top in Parijs afreizen. (Hij ging toch.) De Europese Raad werd in Den Haag gezien als een gevaarlijk Frans speeltje en een bedreiging van de Commissie. Ambtenaren werden zenuwachtig als politici onder elkaar onvoorspelbare dingen gingen doen. Buitenlandse Zaken zag aankomen dat Algemene Zaken er met het prestige vandoor ging. Coalitiepartijen schoolmeesterden graag dat een Nederlandse minister-president staatsrechtelijk gezien geen echte baas is, zoals de Franse president of de Duitse bondskanselier, maar slechts een primus inter pares, die dus niet namens alle Nederlanders zou kunnen spreken.

De plannen voor regelmatige toppen leken op de Fouchet-plannen van De Gaulle, maar werden ditmaal 'communautair' ingekleurd en waren zo voor de Benelux verteerbaar. Zo kreeg de Commissievoorzitter een stoel aan de tafel van de regeringsleiders, zou de voorzitter van de Raad na afloop verslag doen aan het Europees Parlement en stemde Giscard in met rechtstreekse Europese parlementsverkiezingen (zie subpar. 5.3.1). Bovendien was Groot-Brittannië inmiddels tot de Gemeenschap toegetreden, waardoor Den Haag en Brussel minder de overheersing door een Frans-Duits blok vreesden. Als kers op de taart voor zijn land bedong de Belgische premier Tindemans dat van de drie toppen per jaar er ten 
minste een in Brussel of Luxemburg zou worden gehouden, "vanwege de cohesie van de Gemeenschapsinstellingen”. De Europese Raad kwam er.

In 1990-1991, in het grote debat over de vorm van Europa na de val van de Muur, ontpopte Nederland zich opnieuw als tegenstander van de oprichting van een Unie. Den Haag wilde vasthouden aan de bestaande Gemeenschap en ook de buitenlandse politiek daarin onderbrengen. Men wilde de rol van de regeringsleiders beperken en die van de Commissie aanzetten. Men vond, in een typische DGPZ/DGES-gespletenheid, de plannen voor buitenlandse politiek en defensie van het door het Luxemburgse voorzitterschap opgestelde conceptverdrag (juni 1991) én niet Atlantisch genoeg én niet communautair genoeg (Cloos e.a. 1993; Van den Bos 2008). Het tijdens het eigen voorzitterschap herschreven conceptverdrag leidde op 30 september 1990 tot de diplomatieke nederlaag van 'Zwarte Maandag'. Op basis van het Luxemburgse concept kwam er vervolgens een Unieverdrag dat in november 1991 in Maastricht door de twaalf regeringsleiders werd uitonderhandeld. De Unie kwam er.

In het institutionele debat van 2002-2004 over de instelling van een vaste voorzitter voor de Europese Raad vond men dezelfde posities als in 1974: Frankrijk was de gangmaker van het idee (met president Chirac, conventievoorzitter Giscard, gesteund door Londen en Madrid), Nederland en België voerden lange tijd het verzet van de kleine landen aan. De argumenten waren opnieuw: verzwakking van de positie van de Commissie en haar voorzitter, ondermijning van de communautaire methode, onzekerheid. De Nederlandse premier betoogde in februari 2003 dat Nederland 'geen twee kapiteins op één schip' wilde (Balkenende 2003). Daarbij was uiteraard de Commissievoorzitter de ene kapitein en de vaste Raadsvoorzitter de andere; de premier miskende dat de baas van de binnensfeer een heel andere positie zou hebben dan de nieuw ingestelde baas van de tussensfeer ... Nog steviger zette de Nederlandse staatssecretaris voor Europese Zaken het aan. Deze betoogde tegen de Franse plannen voor een Europese president dat ons land "geen Zonnekoning" wenste. Aldus jutte hij de Nederlands-Franse animositeit op tot 1672... (Nicolaï in Van Middelaar 2004) De vaste voorzitter van de Europese Raad kwam er.

\section{Fait accompli}

De verticalisering die de Europese Raad bracht kreeg uiteindelijk toch zijn beslag. Ook aan het Nederlandse verzet tegen institutionalisering van de Europese Raad van regeringsleiders, een constante van Luns in 1961 tot en met Balkenende in 2003, kwam een einde.

Wat gebeurde er in november 2006? Het reglement van orde van de ministerraad werd gewijzigd. Voortaan mag de minister-president elk punt agenderen dat hij wil. De reden: vanwege zijn rol in de Europese Raad kan hij niet altijd wachten tot 
de vakminister ermee komt en alle ministers ermee instemmen dat over een onderwerp wordt vergaderd. Nog interessanter: het voorstel kwam niet van Algemene of Binnenlandse Zaken, maar van Buitenlandse Zaken (dat aldus voorkwam dat het verder op achterstond zou worden gezet). Resultaat is dat de Nederlandse minister-president formeel uitstijgt boven de andere ministers en net als de meeste van zijn Europese collega's een regeringsleider is geworden.

In zulke details wordt prachtig zichtbaar hoe de druk van de Europese gezamenlijkheid doorwerkt tot in het hart van de staatsinrichting van de lidstaten.

Terwijl Nederland doorgaans achterhoedegevechten leverde, maakte België enkele malen tijdig de draai. Wellicht voelde het als kleinere staat de druk uit Parijs eerder en sterker. Maar ook maakten de Belgen een terechte afweging: is een formalisering van de tussensfeer niet te verkiezen boven het brute machtsspel van de buitensfeer? Als het erop aankwam gaf dat voor onze zuiderburen de doorslag. Aldus was het een francofone Belgische topdiplomaat die de haast theologische vete tussen gaullisten en supranationalisten over buitenlandse politiek beslechtte (in het Davignon-rapport uit 1970). Als gezegd gaf de Belgische premier Tindemans in 1974 zijn verzet tegen de Europese Raad op in ruil voor een gedeeltelijke zetel voor Brussel ('eenmaal per jaar'). Zijn opvolger Guy Verhofstadt vervolmaakte deze beweging door op de top van Nice van 2000 (dus opnieuw onder Frans voorzitterschap!) te bewerkstelligen dat alle Europese raden in Brussel worden gehouden. In november 2009 werd een Belg gekozen tot eerste voorzitter van de Europese Raad. De beide kingmakers van deze benoeming, de Franse president Sarkozy en de Duitse bondskanselier Merkel, verkozen de Belgische premier Van Rompuy boven de Nederlandse (niet-)kandidaat Balkenende voor de functie waartegen de Lage Landen zich samen hadden verzet en waarin de tussensfeer zich uitkristalliseert.

\subsection{HET SPEL AAN TAFEL}

In de Unie draait het om macht. En wat in Den Haag wel eens wordt onderschat: ook regels zijn een uitdrukking van macht, geen vervanging ervan; dit valt steeds bij de overtreding van regels te constateren. Derhalve is ook de sterk geïnstitutionaliseerde, regel gedreven binnensfeer van machtsverhoudingen doortrokken; dit geldt te meer de informele, politiekere tussensfeer. Men kan in Europese wetgeving, onderhandeling en naleving dus weinig voor gegeven nemen. Elke uitzonderingsbepaling op milieuterrein (fijnstof!), elke staatssteunmaatregel (ING!), elk eigenzinnig buitenlandspolitiek voorbehoud (Servië!) vergt inspanning en kan aan andere Brusselse vergadertafels repercussies hebben. Daarom zal een sterker bewustzijn van de in de tussensfeer vereiste politieke kwaliteiten ook positieve gevolgen hebben op de performance in de binnensfeer. 
Hoe kan in het licht van de hier geboden analyse het Nederlandse openbare bestuur in de aldus gegroeide Europese verhoudingen het beste de nationale belangen verdedigen? En hoe kan de Nederlandse bestuurlijke openbaarheid de eigen bevolking bij deze Europese besluiten betrekken? Daarover gaan tot slot de paragrafen 4.4 en 4.5. Met een drieledig antwoord op de eerste vraag: trek de conclusies uit het belang van de Europese Raad (4.4.1); erken de aard van de Unie als club van lidstaten (4.4.2); neem initiatief (4.4.3).

\subsubsection{TREK DE CONCLUSIES UIT HET BELANG VAN DE EUROPESE RAAD}

De onontkoombare en onomkeerbare machtspositie van de Europese Raad is ten langen leste door Nederland onderkend. De (niet-)kandidatuur van premier Balkenende voor het vaste voorzitterschap van dit eens verguisde lichaam, najaar 2009, markeerde wellicht een keerpunt. Het moment is gekomen de organisatorische en ambtelijke consequenties uit deze verschuiving te trekken.

Hoe beter in te spelen op het gegeven van de verticalere bestuursstructuur, waar aan de top dossiers worden verknoopt, deals worden gesloten en soms snel moet worden gehandeld?

Nederland heeft een zeer goede ambtelijke coördinatie, maar deze werkt bottomup: vanuit het individuele dossier naar boven. Dit volstaat niet in de huidige context. Een sterkere politieke regie top-down is nodig.

\section{Rol minister-president en Algemene Zaken}

De minister-president is als lid van de Europese Raad qualitate qua de belangrijkste Europese politicus die ons land telt. Deze conclusie vloeit onafwendbaar voort uit de conceptualisering van de Unie als een de 27 lidstaten omvattende politieke ruimte.

(Hoogstens zou men kunnen betogen dat de eurocommissaris zwaarder weegt, maar alleen in de situatie waarin een Nederlander een topfunctie in de Commissie bekleedt, à la Kroes met mededinging.) De minister-president draagt de verantwoordelijkheid voor het nationale EU-beleid. De historisch gegroeide situatie dat de minister van Buitenlandse Zaken de Europese politiek coördineert doet hieraan geen recht. De vervlechting in de tussensfeer betekent immers ook: Europa is binnenland.

De discussie over de verhouding tussen de ministeries van Algemene en Buitenlandse Zaken inzake de Europese politiek is oud. In recente jaren hebben meerdere adviesorganen zich hierover uitgelaten (ROB 2004; Raad van State 2005; Gemengde Commissie sturing EU-aangelegenheden 2005; WRR 2007). Van deze maakte de Raad van State de fundamenteelste keuze voor een sterkere politieke regie door de minister-president: 
"Het is de verantwoordelijkheid van de Minister-President ervoor te zorgen dat tijdig in de ministerraad doel, strategie en tactiek bij de Nederlandse inbreng in Brussel aan de orde komen. Daarvoor moet hij zich zelfstandig voorbereiden en laten informeren door onder meer - maar niet uitsluitend - ministers en ministeries, PV in Brussel en Brusselse instellingen. De Minister-President moet ook zelfstandig belangrijke Europese onderwerpen op de agenda van de ministerraad kunnen opvoeren, zonodig tegen de wens van de eerst verantwoordelijke minister in. De MinisterPresident moet ervoor zorgen dat het mandaat van de bewindsman/-vrouw van Europese Zaken ook in zijn verhouding tot de eerst verantwoordelijke bewindslieden duidelijk is." (Raad van State 2005: 18-19)

Als genoteerd (in subpar. 4.3.2) is de Europese agenderingsbevoegdheid voor de minister-president inmiddels een feit. Daarentegen zijn de positie van het ministerie van Algemene Zaken en de verhouding van de staatssecretaris van Europese Zaken tot de andere bewindspersonen nog niet opgehelderd.

In de ons omringende landen wordt de Europese politiek sterk vanuit de regeringsleider aangedreven. In Londen, Parijs en Berlijn zijn Downingstreet 1o, het Elysée (president) \& Matignon (premier, onder wiens verantwoordelijkheid de ambtelijke coördinatie plaatsvindt) respectievelijk het Bundeskanzleramt ruim bestaft met EU-adviseurs. Dit is niet louter te verklaren als uitvloeisel van een ter plaatse dirigistischer politieke cultuur; ook de Bondsrepubliek kent coalitieregeringen waarbij kanselier en minister van Buitenlandse Zaken van onderscheiden partijkleur zijn. Opvallend is eveneens dat de toetreders uit 2004, zoals Polen, de verantwoordelijkheid voor de Europese politiek als vanzelfsprekend onderbrachten bij hun minister-president. Deze landen werden niet geplaagd door communautaire ideologische sjablonen, maar trokken met een koel oog voor de Brusselse machtsverhoudingen de voor de hand liggende conclusie: Europa is Chefsache.

In de Nederlandse verhoudingen noodzaakt dit een ministerie van Algemene en Europese Zaken. Dit brengt de vervlechting van het nationale en het Europese alsmede de Europese verantwoordelijkheid van de minister-president beter tot uitdrukking. De staatssecretaris van Europese Zaken, die momenteel formeel onder de minister van Buitenlandse Zaken ressorteert, maar reeds in de (huidige) praktijk de politieke vertrouwensman van de minister-president in Europese aangelegenheden is en hem ook naar de Europese Raad vergezelt, zou dan rechtstreeks onder de minister-president dienen te vallen. Aldus zou deze bewindspersoon een sterkere positie jegens de vakministers met Europese dossiers (Economische Zaken, Landbouw, Justitie, Financiën...) innemen. Het ministerie van Buitenlandse Zaken blijft uiteraard de vakdepartementale verantwoordelijkheid dragen voor de Europese buitenlandse politiek, een terrein dat sterk in ontwikkeling is. 
Met deze wijziging zou Nederland bovendien tijdig inspelen op ontwikkelingen in de architectuur van de Unie. Dit punt is nog weinig onderkend. In het verdrag van Lissabon wordt de centrale Raad voor Algemene Zaken en Extern Beleid (RAZEB, zie ook subpar. 4.2.4), het maandelijkse overleg tussen de ministers van Buitenlandse Zaken, gesplitst. De interne beleidscoördinatie gaat naar de Raad voor Algemene Zaken (RAZ); de Europese buitenlandse politiek naar een Raad voor Extern Beleid (REB). De nieuwe RAz bereidt de Europese Raad voor en is verantwoordelijk voor coördinatie, financiële en institutionele aangelegenheden en alle horizontale dossiers. De meeste lidstaten zullen hierheen hun minister/ staatssecretaris voor Europese Zaken afvaardigen; het voorzitterschap zal denkelijk worden bekleed door de premier van het land dat het roulerende voorzitterschap van de gewone raden bekleedt. (Met de instelling van de vaste voorzitter van de Europese Raad ontvalt namelijk alléén aan de 27 premiers een potentieel grote Europese zichtbaarheid, terwijl al hun ministers dankzij de doorgaande carrousel in de gewone Raad onverminderd zes maanden glorie ten deel valt. ..) De nieuwe REB bespreekt de buitenlandse politiek, inclusief uitbreiding, handel, ontwikkelingshulp. Deze wordt voorgezeten door de Hoge Vertegenwoordiger nieuwe stijl. Een terugvertaling van deze splitsing naar de Nederlandse verhoudingen pleit eveneens voor enerzijds de tandem minister-president - staatssecretaris van Europese Zaken (RAZ), anderzijds de minister van Buitenlandse Zaken (REB).

Terecht schreef de WRR over deze verschuiving van het politieke primaat inzake Europa van Buitenlandse Zaken naar Algemene Zaken het volgende:

“Ongetwijfeld zijn aan deze denkrichting allerlei praktische bezwaren verbonden die serieuze aandacht verdienen, maar de achterliggende boodschap is uiterst belangrijk: EU-beleid is integraal onderdeel van het algemene regeringsbeleid en sluit om die reden aan bij de bijzondere verantwoordelijkheid van de minister-president. (...) Hiermee geeft het kabinet een duidelijk signaal af aan burgers, maatschappelijke organisaties en de nieuwsmedia dat de EU niet langer een onderdeel van de buitenlandse zaken van Nederland vormt en zijn legitimiteit mede ontleent aan Nederlandse politieke kanalen van vertegenwoordiging en verantwoording." (WRR 2007: 137-138)

\section{Ministeriële stuurgroep}

Een reeds in het verleden ingevoerd mechanisme van strakkere politieke regie is de zogenaamde ministeriële stuurgroep. Deze bestaat uit de minister-president, de vicepremier(s), de minister van Financiën, de minister van Buitenlandse Zaken, de staatssecretaris van Europese Zaken en de permanente vertegenwoordiger bij de Unie. De stuurgroep is opgericht ten tijde van het kabinet-Kok II met het oog op de onderhandeling van de Financiële Perspectieven van 1999, waarin voor zeven jaar het Europese budget werd vastgelegd. Ze functioneert ad hoc; dat wil zeggen, ze bestaat hangende en kan worden ingeroepen 'als het nodig is'. (Gerekend vanaf einde 2009 was de laatste maal dat de stuurgroep bijeenkwam wegens het boven- 
genoemde klimaatpakket van december 2008, de keer daarvoor wegens herziene Dienstenrichtlijn in 2006.)

Dit mechanisme stuit op weerstand bij de niet-vertegenwoordigde departementen en ook bij delen van Buitenlandse Zaken; niet iedereen praat er immers mee en het passeert bestaande structuren. Maar de snelheid en besluitvaardigheid die Europese onderhandelingen vereisen, laten geen keuze. Het heeft weinig zin doublures op politiek niveau van reeds bestaande coördinatiecommissies ('CoCo', 'CoCoHan') op te tuigen.

Sterker, de ministeriële stuurgroep, die nu slechts hangende is, zou permanent dienen te functioneren. Het criterium 'wanneer de situatie erom vraagt' is te vrijblijvend. Beter kan men het omkeren: Wanneer vraagt de situatie er niet om?

Een permanente ministeriële stuurgroep kan bovendien, wanneer daadwerkelijk zou worden besloten tot een ministerie van Algemene en Europese Zaken, de vrees voor concentratie van EU-besluitvorming ten burele van de minister-president dempen. Het waarborgt - afgezien van de formele verantwoording in de ministerraad - op structurele wijze de politieke inspraak van ten minste Buitenlandse Zaken en Financiën.

\section{Zorg om Commissie}

Het toenemende gewicht van de Europese Raad is een gegeven. Op de toppen is inmiddels de facto het politieke initiatief gelokaliseerd. Het 'exclusieve initiatiefrecht' uit het verdrag van Rome waaraan de Commissie zich blijft vastklampen is een juridische fictie geworden. (Uit eigen onderzoek van de Commissie bleek al in 2002 dat slechts in 10 procent van de gevallen wetgeving niet op vraag van Europese Raad, Europees Parlement of andere actoren was geïnitieerd.)

Daarentegen zijn de zorgen om de verzwakking van de Commissie waarmee deze evolutie uit de aard der zaak gepaard gaat op een ander punt juist te weinig hoorbaar. Den Haag dient er scherper op te letten dat de oorspronkelijke taken van de Europese Commissie als hoedster van het verdrag, als gezaghebbende marktmeester die de lidstaten terecht kan wijzen, overeind blijft. Een goed functionerende Europese markt is en blijft bij uitstek een existentieel Nederlands belang. Dit betekent binnen de vigerende verhoudingen dat men niet moet inzetten op een verdere politisering van de Commissie (zij zal nooit tot Europese regering kunnen uitgroeien), maar op het hameren op haar technocratische en rechtsprekende kwaliteiten. Concreter: Nederland heeft er geen enkel belang bij dat een voorzitter van de Commissie de spotlights van de internationale arena en het applaus in het Straatsburgse parlement opzoekt wanneer dit ten koste gaat van de aandacht van het college van commissarissen als geheel voor de mededingings- en andere regels voor de interne markt. 


\subsubsection{ERKEN EUROPA ALS CLUB VAN LIDSTATEN}

De tegenstelling tussen het nationale en het Europese resulteert in de neiging 'Brussel' buiten onszelf te lokaliseren, hetzij ten goede (in het oude supranationalisme), hetzij ten kwade (in het tegenwoordige humeur). Deze tegenstelling zou worden doorbroken door in woorden en daden te erkennen dat de Unie een club van lidstaten is die hun onderlinge verhoudingen voor een deel hebben ondergebracht in een institutionele structuur en voor een minstens zo belangrijk deel niet.

\section{Ambassades in de andere lidstaten}

De Europese politiek wordt derhalve niet louter op de as Den Haag - Brussel bedreven. De ambassades in de 26 andere lidstaten zijn er niet louter voor de klassieke bilaterale politiek; omgekeerd is de Permanente Vertegenwoordiging bij de Unie geen monopolist voor de Europese lijn. Denkend aan de Unie als een gezelschap van 27 betekent dat niet alle lijnen via Brussel lopen, maar dat je ook een netwerk van 26 ambassades van topkwaliteit nodig hebt. Inkrimping van het binnen-Europese postennetwerk, zoals bij regelmaat bepleit door de Tweede Kamer (opnieuw in november 2009 door de PvdA-fractie bij de begrotingsbehandeling Buitenlandse Zaken) is dan ook buitengewoon onverstandig.

In het Buza-jargon spreekt men van 'multi-bi': bilaterale ambassades benutten voor multilaterale taken (en vice versa). In de 26 hoofdsteden kan men een veel fijnmaziger informatiepositie opbouwen dan vanuit de PV alleen. In de hoofdsteden kan men de topambtenaren verantwoordelijk voor beleidsontwikkeling spreken, die doorgaans niet naar Brussel komen. Evenzo leert de begeleiding van ministeriële bezoeken, een voor de kleinere ambassades tijdrovende taak, toch zeer veel over de prioriteiten van partnerlanden.

Wil men de 26 ambassades voor dit doel benutten, dan moeten zij wel een meer shared-service-achtige rol krijgen. Hun instructies zouden (mede) kunnen worden opgesteld door vakdepartementen. De afgelopen veertig jaar was het daarentegen gebruik dat departementen raden mochten benoemen die zich aan de ambassadeur van Buitenlandse Zaken moesten onderschikken.

De noodzaak voor zulke voelhoorns is met de recente uitbreidingen van de Unie nog versterkt. Met 27 landen kan niet alles via Brussel en is het evenmin voldoende te weten wat Parijs, Berlijn en Londen willen. Momentum komt van vooruitkijkende allianties en bondjes tussen (groepjes van) lidstaten. Zoals de Britse oudambassadeur, Colin Budd, een Nederlands gehoor voorhield: "any country wanting to maximise its leadership chances still needs good bilateral embassies inside the EU." (Budd 2009) 


\section{Konvooi}

De plaats van Nederland in de Europese buitenlandse politiek is een apart chapiter, waar hier niet uitgebreid op zal worden ingegaan. In het verlengde van het voorgaande zij slechts kort opgemerkt dat het omdenken van de Unie in een konvooi van 27 schepen op de geopolitieke baren (zie subpar. 4.2.5) praktische repercussies kan en moet hebben.

Het doorbreekt ten eerste de in het Gemeenschapsdenken lang gekoesterde juridische fictie van de gelijkheid van lidstaten. Het betekent dat een bijzondere aandacht voor de groten volkomen gerechtvaardigd is. Wanneer Frankrijk, Duitsland en Groot-Brittannië op dezelfde (buitenlandpolitieke) koers zitten, varen allen die kant op. Meer nog, wanneer de big three een gezamenlijk initiatief nemen, zoals inzake de Iran-politiek, is er geen reden hier zenuwachtig van te worden omdat het buiten EU-kader zou zijn, zoals in het verleden de communautaire reflex was. De belangen en opvattingen in Parijs, Berlijn en Londen zijn doorgaans zo verschillend dat als ze het eens worden - opnieuw: in de buitenlandse politiek! - dit voor Nederland bijna zonder uitzondering ook goed is. (De tijd dat wij als (voormalige) koloniale macht zeer specifieke belangen hadden in bepaalde landen of werelddelen ligt inmiddels wel achter ons.)

De metafoor van het konvooi vraagt ook in Europees verband speciale aandacht voor de (andere) buurlanden. Het samenwerkingsverband van de Benelux heeft goede momenten gekend, maar verkeert momenteel in een dal. Gezien de uiteenlopende politieke culturen in met name Nederland en België moet men er geen wonderen van verwachten. Maar ook Frankrijk en Duitsland hebben veel minder met elkaar gemeen dan wel wordt voorgesteld; de kracht van hun relatie berust op het wederzijdse besef zonder de ander geen beslissende stappen in de Europese politiek te kunnen zetten. Voor de Benelux geldt derhalve het adagium: ook een verstandshuwelijk kan vruchtbaar zijn.

\subsubsection{NEEM INITIATIEF}

Het handelingsvermogen van een land in de Unie wordt het meest vergroot wanneer het erin slaagt de eigen belangen als Europese belangen ingang te doen vinden. Daartoe dien je niet volgend of remmend te zijn, maar te zorgen dat je initiatieven neemt, dat er naar je gekeken wordt.

In de geschiedenis van de Europese integratie zijn tal van voorbeelden van nieuw beleid dat tot stand kwam door enerzijds de roep om europeanisering vanuit de binnensfeer, anderzijds de druk vanuit een of meer lidstaten. Zonder de impuls vanuit de staten beweegt het niet, maar zonder een institutionele vervlechting ontstaat er geen stevigheid. De combinatie is beslissend. 
Een vroeg voorbeeld is het vrije verkeer voor werknemers, dat op uitsluitend Italiaans aandringen terechtkwam in het mijnbouwverdrag van 1951 (maar toen nog alleen voor geschoolde mijnarbeiders). Italië kende een grote werkloosheid en stimuleerde de emigratie; in plaats van steeds nieuwe bilaterale emigratieverdragen voor mijnarbeiders af te sluiten benutte de Italiaanse diplomatie het Europese stichtingsmoment van 1950-1951 om de factor arbeid een plaats in het verdrag te geven.

Ruw gezegd werden aldus in de jaren 1960 de Franse en Nederlandse boeren tot Europese boeren gemaakt, in de jaren 1970 de Deense milieupolitiek tot Europese milieupolitiek, in de jaren 1980 de Spaanse snelwegen tot Europese snelwegen, in de jaren 1989-1991 de Duitse munt tot Europese munt (maar onder druk van de partners) en in de jaren 2000 de Poolse en Maltese grenswachters allengs tot Europese grenswachters.

Het grote, reeds genoemde succes voor Nederland in dit opzicht was de gemeenschappelijke markt van 1958 ('plan Beyen'). Het voor Nederland als transportland bij uitstek economische belang bij een douane-unie werd overtuigend neergezet als een Europese zaak; het werd bovendien door Beyen vanaf zijn benoeming in september 1952 hardnekkig in het gesprek met de andere Vijf ingebracht (Beyen 1969). Bij een heropvoering van dit scenario in de jaren 1985-1992, toegespitst op het vrije verkeer van industriële goederen, kwam de impuls van Duitsland, Groot-Brittannië en de Commissie onder Delors, maar ook de Nederlandse Philips-directeur Wisse Dekker speelde als voorzitter van het Europese werkgeversplatform ERT een rol. De baten voor de Nederlandse economie waren enorm. In 2004 was het de Nederlandse eurocommissaris Bolkestein die het vrije verkeer van diensten agendeerde, maar dit plan - dat eveneens een belofte uit het stichtingspact serieus nam - sneuvelde op heftig publiek verzet in met name Frankrijk en België. Vertrouwend op de kracht van de eigen diensteneconomie hield de Nederlandse regering er in de Raad en de Europese Raad overigens lang (tot in 2006) aan vast.

'Europese' initiatieven komen derhalve niet alleen uit de instellingen van de Unie. Wanneer de Unie beleid ontwikkelt waar Den Haag "niet op zit te wachten", is dit niet de schuld van 'Brussel', maar hebben de (overige) lidstaten tegen de vernieuwing onvoldoende weerstand geboden. Immers, hoewel individuele beleidsmaatregelen nog wel eens bij meerderheid passeren, kan de ontginning van geheel nieuwe beleidsterreinen niet dan bij consensus van de 27 plaatsvinden. Omgekeerd betekent het dat Nederland zou moeten proberen de Europese agenda sterker te bepalen met onderwerpen waar het zelf sterk staat of specifieke problemen heeft. Te denken valt aan transportnetwerken, een gasrotonde, vrij dienstenverkeer-bis, of intensievere samenwerking inzake de grensbewaking. 
Tegenwoordig wekt men de indruk vooral afwachtend te zijn en bedreigingen te zien. De Haagse focus sinds de jaren negentig op de nettobetalerspositie heeft dit beeld ook bij de partners vastgezet. Vaak is het een kwestie van onderhandelingsstijl. Een verdediging van een generieke verlaging van het budget op bepaalde posten (bijvoorbeeld landbouw) in termen van een gezamenlijk Europees belang (bijvoorbeeld natuurbehoud of financiële prioritering van onderzoek) zou hetzelfde doel dichterbij brengen maar minder kwaad bloed zetten.

\subsection{DRIE STRATEGIEËN OM PUBLIEK TE WINNEN}

Waarom heeft de Europese politieke orde publiek nodig? Waarom zouden de mensen zich 'betrokken' moeten voelen? Die vraag moet zijn beantwoord om zeker te weten dat het in het slepende debat over de legitimiteit van de Unie niet gaat om 'solutions chasing a problem'.

Kort gezegd is het de breuk van 1989 die publieke instemming bij Europese besluiten noodzakelijk maakt. Zolang het in de oude Gemeenschap ging om low politics, om economische regelgeving en bureaucratisch geknutsel aan richtlijnen, kon dat in relatieve onzichtbaarheid geschieden. Het ging beperkte belangengroepen aan. Besluitvorming kon plaatsvinden op basis van de regels van het door alle lidstaten ondertekende verdrag. Sinds de lidstaten evenwel als Unie ook gezamenlijk streven op geopolitieke gebeurtenissen om hen heen te reageren, anders gezegd, sinds Europa 'politieker' werd, is een vorm van politieke verantwoording ten overstaan van de publieke opinie onontbeerlijk. Men kan immers niet in een verdrag vastleggen hoe te handelen wanneer er een crisis uitbreekt tussen Rusland en Oekraïne of wanneer de Libysche leider Khaddafi eenzijdig een akkoord over terugkeer van illegale migranten opzegt. Zulke legitimiteit moet enacted en embodied zijn. Het vergt oordeelskracht van politieke leiders in een onzekere situatie en publieke verantwoording achteraf.

Tegelijk is die legitimatie moeilijk vanwege de dubbelheid van de tussensfeer waar de belangrijkste besluiten plaatsvinden. Men kan niet, zoals de ideologen van de binnensfeer aanvankelijk hoopten, rekenen op een volledige shift ('spill-over') van de nationale naar een Europese loyaliteit. Evenmin is het geloofwaardig de Europese besluiten louter in termen van nationale belangen te verdedigen. In die zin blijft het schipperen. Maar het zou nuttig zijn bij dat schipperen de valkuilen uit het verleden te vermijden. Bovendien zijn er manieren om te bewerkstelligen dat Europese besluiten worden ervaren als onze besluiten. Dat is de kern van het verwerven van politieke legitimiteit: de overgang van hun besluiten (of jullie besluiten, zoals in de bij opening aangehaalde anekdote) naar onze besluiten.

In de kern kan men drie strategieën onderscheiden waarmee moderne staten de aandacht van het publiek winnen en vasthouden. Het gevoel van 'onze' rust er 
respectievelijk op een idee van 'ons volk', van 'in ons voordeel' of van 'onze zaak'. Met een historische knipoog kan men deze drie betitelen als de 'Duitse', 'Romeinse' en 'Griekse' publieksstrategie. Hieronder (subpar. 4.5.1 t/m 4.5.3) zal worden onderzocht welke mogelijkheden ze de Europese politiek bieden, meer in het bijzonder voor het Nederlandse openbare bestuur in de tussensfeer. Ze kunnen alle drie en gelijktijdig worden benut, mits men bedacht blijft op de klippen. In de hiernavolgende uiteenzetting is geen volledigheid nagestreefd, maar is beoogd dankzij voorbeelden de gevoeligheid voor ongewenste boemerangeffecten van de zoektocht naar publiek te vergroten.

\subsubsection{DUITSE STRATEGIE: IDENTITEIT, CULTUUR- EN SYMBOOLPOLITIEK}

De 'Duitse' publieksstrategie zet in op een culturele of historische identiteit van regeerders en geregeerden. Dezen spreken dezelfde taal of geloven in dezelfde waarden en heilige boeken of hebben dezelfde gewoonten of hun voorouders vochten in dezelfde oorlog. Bekende identiteitspolitieke elementen zijn een nationale geschiedschrijving, vlag en volkslied, nationale feestdagen, leerplicht en dienstplicht, codificatie van een eenheidstaal, monumenten voor helden.

\section{Cultuur en onderwijspolitiek}

In december 1973 stelden de regeringsleiders van de toen negen lidstaten een 'Verklaring over de Europese Identiteit' op. Inhoudelijk geen spannend document, maar van belang was het politieke feit van die verklaring zelf. De tekst werd door de Brusselse instellingen aangegrepen als rechtvaardiging voor voorstellen om deze gedeelde identiteit aan het licht te brengen, te herontdekken of te versterken. Als vanzelf kwam men in de Commissie en het Parlement uit bij de politieke technieken van het negentiende-eeuwse nationalisme: het oppoetsen van een Europees verleden als spiegel voor het wij in het heden, het in werking zetten van verhalen- en beeldenmachines.

In 1977 kwam de Commissie met een pakket cultuurpolitieke voorstellen. Het was gericht op het vrije verkeer van culturele goederen en diensten, maar bevatte ook enkele symbolisch beladen plannen. Zo was er het idee voor 'Europese zalen' in musea, waar werken "die deel uitmaken van het erfgoed van de Gemeenschap" moesten worden tentoongesteld. Andere plannen waren de oprichting van culturele instituten van de Gemeenschap en een serie van $365 \mathrm{tv}$-uitzendingen "van ten minste vijf minuten, gewijd aan een grote Europeaan uit verleden of heden”. De Raad van Ministers weigerde het rapport in behandeling te nemen. Groot-Brittannië en Denemarken voerden de oppositie aan, maar werden stilzwijgend gesteund door Frankrijk en Duitsland. Gezamenlijk cultureel erfgoed beschermen viel nog te overwegen, maar Europese musea en een heldengalerij, dat riekte naar onvervalste nation-building. Dat vonden de lidstaten niet de bedoeling. 
In de onderwijspolitiek ondervond men ook obstakels bij de bepaling van een Europese inhoud. Dieptepunt was de betrokkenheid van de Commissie bij de productie van een publieksboek Europese geschiedenis, Europa: geschiedenis van zijn bewoners (1990) van Jean Baptiste Duroselle. Het boek was een moreel succesverhaal over de triomf van de Europese eenheid tegen de boze krachten van de verdeeldheid - van Zeus' ontvoering van de prinses Europa, via de Romeinen en Karel de Grote, naar de rampen van het nationalisme en de nieuwe hoop na 1945. Komisch waren de verwikkelingen rond een bijbehorend lesboek. Historici uit twaalf landen schreven elk een concepthoofdstuk en ruzieden daarna over de woorden. In het hoofdstuk over Frankrijk moest de term 'invasies der Barbaren' worden vervangen door 'invasies der Germanen'. De Spaanse omschrijving van de Engelse zeeheld Sir Francis Drake als 'piraat' werd geschrapt. Het bleek moeilijk tot een neutrale, 'Europese' versie van historische gebeurtenissen te komen. De les van zulke identiteitspolitieke fiasco's was pijnlijk: de poging legitimiteit voor de gezamenlijke orde te verwerven door een gevoel van 'wij Europeanen' te scheppen, kon als een boemerang terugkaatsen. Het verwijt van propaganda lag op de loer.

De Duitse strategie van 'ons (ene) volk' verloopt vanwege de overweldigende concurrentie van de natiestaten moeizaam. De Gemeenschapsinstellingen zagen cultuurpolitieke initiatieven gekortwiekt en moesten wegens onenigheid over elke specifieke inhoud die aan 'Europa' zou kunnen worden gegeven uitwijken naar universele waarden (kosmopolitisme, mensenrechten), zelfverwijzing (de pères fondateurs) of lege symboliek (de Europese vlag). Dit laatste was succesvol.

\section{Vlag}

De Europese gemeenschappen ontbeerden lang een gezamenlijk symbool. De Europese vlag, het blauw met de twaalf sterren, behoorde sinds 1955 toe aan de Straatsburgse Raad van Europa. Pas in 1985 lukte het Commissie en Parlement toestemming te krijgen van de lidstaten voor het gebruik van diezelfde vlag. In juni 1986 werd hij voor het eerst in zijn nieuwe hoedanigheid gehesen.

Er was een typerend tussensfeercompromis aan voorafgegaan. Het idee van een Europese vlag werd in 1985 voorzichtig gepresenteerd; deze zou "natuurlijk in geen enkel geval het gebruik van nationale vlaggen in de weg" staan (Adonnino 1985). De invoering werd bepleit onder het motto: versterking van de zichtbaarheid van de Gemeenschap in het dagelijks leven van de burgers. Dit argument was nodig om aan het principebesluit van de regeringsleiders uit juni 1985 een juridische vertaling te kunnen geven. De Britse ambassadeur schrok namelijk toen hij na de zomer zag waar Thatcher mee had ingestemd. De voorstanders beseften dat er geen vlag zou komen als ze zich in nation-building-termen zouden uitdrukken. De Nederlandse voorzitter van de ambasssadeursvergadering, Rutten, vond de uitweg in het argument van de huisstijl, de corporate identity. De politieke conno- 
taties van 'vlag' werden ingetrokken en de Gemeenschap kreeg een 'logo'. Aangezien deze diplomatensubtiliteit aan gewone burgers ontgaat, hadden Delors c.s. alle reden tevreden te zijn met deze symboolpolitieke coup. Niemand heeft ooit een logo zien wapperen.

Juist de Nederlandse regering kreeg spijt. Vlag en volkslied werden in 2004 als 'symbolen van de Unie' opgenomen in het grondwetsverdrag (art. I-8). Na de gestrande ratificatie daarvan werden ze opnieuw onderwerp van discussie. Met name Den Haag, Londen en Praag vonden dat de vlag te veel aan staatsvorming deed denken. Daar werd het (nationale) publiek ongerust van, zo meende bijvoorbeeld minister Bot in november 2006. Op aandringen van deze drie lidstaten werden de symbolen buiten het in juni 2007 vastgestelde opvolgersverdrag gehouden. Het was een van de belangrijkste eisen van de Nederlandse regering. Daarentegen beschouwden zestien andere lidstaten dit als een pijnlijke amputatie. Zij namen de moeite in een aanhangsel te verklaren dat vlag en volkslied "voor hen de symbolen blijven van het gemeenschappelijk lidmaatschap van de burgers van de EU en van hun band met de Unie". 5

Men kan zich afvragen wat de Nederlandse regering en parlement beoogden met het ontzeggen van een juridische promotie aan vlag en volkslied. Wellicht was het een slimme strategische zet om het deels diffuse ongenoegen dat zich had geuit in het 'nee' van 2 juni 2005 een gezicht te geven; een gezicht dat als symbolisch ook verwijderbaar was. Er is een keerzijde. Of die vlag nu wel of niet in het verdrag staat, ze blijft alomtegenwoordig. Bijvoorbeeld op de eurobiljetten in de portemonnee van iedere Nederlander of op de kentekenplaten. Het publiek laat zich wat dat betreft niet foppen; de vlag blijft wapperen.

$\mathrm{Na}$ de dreun van het Europees referendum van 2005 ontbrak het in Den Haag evenwel aan oordeelskracht om uit een alles-of-niets-logica te blijven. Toch kan dat wel. Immers, waarom niet ingezet op een dubbele aanwezigheid van nationale en Europese vlag? Vergelijk de Franse president Sarkozy, wiens land de grondwet ook bij referendum afstemde: op Sarkozy's officiële, in alle openbare gebouwen (inclusief scholen!) aanwezige staatsportret van 2007 is hij als eerste president afgebeeld achter de Franse én de Europese vlag. De foto toont aan elke Franse burger de plaats van zijn land als natie en als lid van een groter gezelschap. Nu het verdrag van Lissabon is geratificeerd en de voor Den Haag pijnlijke grondwetsepisode is afgesloten kan er wellicht minder verkrampt over symbolen worden nagedacht.

Als corporate identity biedt de Unie veel houvast bij het slaan van een band met een publiek. Ze maakt iets zichtbaar. Tegelijk blijkt uit de ophef over haar statelijke implicaties opnieuw hoezeer een dergelijke gooi naar legitimiteit in zijn tegendeel kan omslaan. Maar juist als openbaar bestuur zou Den Haag moeten erkennen dat 
deze dubbelheid hoort bij het publieke bestaan. Zoals geldt voor elk politicus die een podium beklimt, geldt ook voor de Unie: wie zich toont aan het publiek, kan applaus óf hoon ten deel vallen.

\section{Grens}

In de tussensfeer van de gezamenlijke lidstaten werkt Europese identiteit anders dan in de Brusselse binnensfeer. Het draait er niet om de vraag 'Hoe worden we één?’, maar om de vraag 'Waarom zijn we samen?’. Niet: Hoe maken we van Belgen, Zweden en Bulgaren Europeanen, maar: Wat bindt hen?

Bij gelegenheid van elk nieuw verdrag debatteren de leden over hun gezamenlijke plaats in de ruimte en in de tijd. Dan gaat het om de waarden en woorden die een plaats in de preambule krijgen als motief voor hun samenzijn.

Essentieel is de spanning tussen de continentale belofte die Europa in zich draagt en de willekeur van het ledental. De zes oprichters van 1951 vertegenwoordigden maar een klein deel van het Europese statengezelschap en konden zich dus niet beroepen op culturele waarden of historische ervaringen van het continent als geheel. Toch was dat wel verleidelijk. De belofte van het nieuwe begin zou des te groter zijn als ze ook andere Europese landen omvatte. Daarom zetten de stichters hun verband open voor 'elke Europese staat' (Art. 98 EGKS). De uitnodiging werd in het pact van 1957 herhaald. Het was een gewichtige cultuurpolitieke stap. Hij droeg de belofte in zich: vandaag wij zessen, in de verre toekomst heel Europa. Dankzij deze teleologische wending kon de culturele en historische meerwaarde van het gehele continent alsnog worden gemobiliseerd, de eerbiedwaardige naam 'Europa' zonder gêne opgeëist.

Tegelijk bemoeilijkte deze uitnodiging aan niet-leden de ontwikkeling van een identiteit voor de kring hier en nu. Stel dat er, afgezien van het verre telos, geloofwaardige verhalen waren om het eigen publiek te wennen aan de Zes, zouden die ook nog gelden voor Zeven, Acht, Negen, Tien of meer? Mettertijd zouden de lidstaten merken dat de open deur een dynamiek in gang zette die het publiek meer van de gezamenlijkheid vervreemdde dan eraan bond. De open deur bracht willekeur, steeds nieuwe willekeur, welke moeilijk tot verhaal viel te maken. Dit bleek bij de eerste uitbreiding van 1973, die met de Britten, Denen en Ieren tot Negen, en meer nog bij die van 2004 met twee eilanden en acht Midden- en OostEuropese staten tot Vijfentwintig. Nadien voelde het (oude) publiek zich enigszins verloren: wat is dit voor Europa, houdt het nooit op, waar horen wij bij?

Deze publieke onzekerheid zal alleen kunnen worden gestuit door een grens te trekken. De vraag waar is ondergeschikt aan het principe. De uitbreiding van de Unie dient niet te worden beschouwd als doel op zichzelf, als nooit eindigend proces. Op enig moment is er behoefte aan een streep in het zand. Alleen zo kan 
identiteitspolitieke rust ontstaan; dit zijn wij; daar begint niet-wij. Pas vanaf dat moment kan men, heel voorzichtig, gaan werken aan 'Duitse' legitimering van de Unie.

\subsubsection{ROMEINSE STRATEGIE: KLANTEN}

De 'Romeinse' publieksstrategie beroept zich op een voordeel dat de bevolking ontleent aan het functioneren van de politiek. De regeerders bieden bescherming of veiligheid, ze scheppen mogelijkheden of ze geven geld. Het beoogde publiek bestaat uit klanten.

De twee fundamentele legitimaties van de nationale staat in deze categorie, veiligheid en welvaart, komen de Europese orde niet te hulp. De vrede op het continent sinds 1945 is niet twijfelloos aan de interne samenwerking te danken (al kan men de populariteit van de 'Europese gedachte' in de beginjaren er wel mee verbinden, zoals heden ten dage de populariteit van de NAvo in Oost-Europa). Een Europese welvaartsstaat is gezien de onderlinge welvaartsverschillen tussen lidstaten ondenkbaar. Evenmin als de gezamenlijkheid zich op de pax europeana kan beroepen, kan ze de rol van patronus, beschermheer van de hongerigen, op zich nemen.

Bescheidener vormen van 'Romeinse' voordelen zijn de toekenning van rechten of het leveren van 'resultaten'. De Nederlandse regering meent sinds het referendumechec van 2005 met die laatste toe te kunnen. Dit is een illusie.

\section{Rechten}

In het supranationale burgervertoog wordt van de toekenning van rechten en vrijheden aan individuen veel verwacht. Dankzij Europa mag men vrij reizen, handel drijven met het buurland, zijn moeder over de grens laten opereren, een vakantiehuis kopen in het zonnige zuiden, enzovoort. Echter, deze rechten zijn niet afdwingbaar op het niveau van de gezamenlijkheid. In de kern betreft het steeds non-discriminatie tussen inwoners van lidstaten, in de tussensfeer; de instellingen van de binnensfeer (met name Commissie en Hof) fungeren als toezichthouders. Het Europese recht is vanuit de optiek van de burgers bovenal: het recht in een andere lidstaat te mogen werken, studeren, ondernemen, verblijven, consumeren, ziek zijn.

Meteen valt op dat het al diegenen die 'thuis' blijven weinig zichtbare voordelen biedt. Gezien de geringe Europese arbeidsmobiliteit betreft dat de overgrote meerderheid van de mensen. Dit beperkt de 'Romeinse' legitimiteit die de rechten verschaffen. Ze scheppen mogelijkheden voor individuen buiten hun eigen lidstaat: de Poolse loodgieter in Frankrijk, de Franse drankverkoper in Duitsland, de Duitse student in Oostenrijk, de Nederlandse patiënt in Slovenië. Hoewel ze in 
beginsel voor iedereen gelden, worden deze rechten en vrijheden niet als voorrecht opgevat door het Europese publiek als geheel. Integendeel soms. Sommige thuisblijvers ondervonden er juist hinder van, in de vorm van concurrenten op de markt of de spreekwoordelijke caravan met Poolse bouwvakkers in de straat.

De 'Romeinse' strategie van voordelen raakt met zichzelf in de knoop. Achter de voordelen blijken allerlei nadelen schuil te gaan. De vergrote bewegingsruimte heeft als keerzijde de verdringing. En die keerzijde raakt wél de thuisblijvers - de Franse loodgieters in Frankrijk, de Oostenrijkse studenten in Oostenrijk, de Luxemburgse kiezers in Luxemburg. Die zijn eenvoudigweg met veel meer. Daarom wordt de ruil die de lidstaten ten behoeve van hun burgers aangaan, door een meerderheid van het publiek niet als voordelig ervaren. De wederzijdse opening van nationale rechten is voor de één (enkelen) een kans, voor de ander (velen) een bedreiging.

$\mathrm{Nu}$ was in het geval van de ene markt de verdringing precies het oogmerk: grotere concurrentie tussen bedrijven leidt tot grotere welvaart. Dit voordeel is heel concreet, bijvoorbeeld in de vorm van lagere prijzen, maar is niet te danken aan een (Europese) weldoener. Voor de 'onzichtbare hand' van Adam Smith kan het publiek niet applaudisseren. Of zoals Commissievoorzitter Delors ooit zei: op een interne markt word je niet verliefd. Men kan proberen dit te ondervangen, maar wat moeten mensen met de informatie dat de Europese markt per Europeaan jaarlijks 'ruim vijfhonderd euro per persoon' en 'drie miljoen banen' oplevert? ${ }^{6}$ Deze heel reële voordelen zijn ontastbaar.

In het geval van gelijke toegang tot ziekenhuizen, studiebeurzen of andere arrangementen van de welvaartsstaten, zoals sinds de invoering van het Europese burgerschap in 1993 op basis van jurisprudentie van het Hof stap voor stap bewerkstelligd, is het boemerangeffect van de verdringing nog sterker. Deze vorm van gelijke behandeling voor inwoners van alle lidstaten vraagt om een expliciete onderlinge solidariteit - tussen Finnen en Grieken of tussen Belgen en Bulgaren. Die blijkt niet bij voorbaat aanwezig. Men belandt hier in een vicieuze cirkel, aangezien die solidariteit, het Europese wij-gevoel, nu juist het doel was van de publieksqueeste. De Romeinse rechtenstrategie wil een wij opwekken, maar heeft het vanwege de aard van het stelsel zelf hard nodig. De bedoeling was: fijn, 'wij Europeanen' mogen in 27 landen werken. Het resulterende publieke geluid: Poolse bouwvakkers komen 'onze banen' afpakken, door de schuld van Brussel. Deze negatieve effecten, die het weefsel van de gezamenlijkheid raken, worden in en door de aanjagende binnensfeer volstrekt onderschat. Als publiekstrekker is de rechtenuitbreiding een strategie die de legitimiteit van Europa minder versterkt dan ondermijnt. 


\section{Resultaten}

Een bescheiden variant van de Romeinse publieksstrategie is erop te wijzen dat wat men doet, heus nuttig is. Tegenwoordig spreken politici in Londen, Den Haag, Parijs en Brussel veelal van het 'Europa van de resultaten' of het 'Europa van de projecten'. Kracht en zwakte zitten in de erdoor bewerkstelligde depolitisering.

Onder 'resultaat' kan van alles vallen. Een functionerende markt. Goede milieuregels. Studiebeurzen. Betere grensbewaking. Werkgelegenheid. Gratis pinnen in het buitenland. Een grensoverschrijdende busverbinding. Als het maar concreet en praktisch is. De kosten en belangenafwegingen blijven uit beeld. Het feit dat een subsidiepotje voor de een betaald wordt door de ander. Het feit dat de kans voor de een een concurrentiedreiging is voor de ander. Het feit dat de bescherming van de een extra regeldruk betekent voor de ander. Elk besluit rust op een belangenafweging, kent winnaars en verliezers, zoals ‘de mensen' uit ervaring heel goed weten. De Romeinse strategie schijnt soms haar eigen publiek te onderschatten.

Deze functionalistische legitimatie van de gezamenlijke orde schijnt in GrootBrittannië de enig denkbare. Sinds Thatcher tot Brown vragen Britse regeringsleiders hun partners om “a Europe which delivers”. Ze werden er aan tafel vaak om gekritiseerd, want ging het niet om meer, om een gezamenlijke lotsbestemming? Wanneer dit beperkte 'Romeinse' deuntje door meer lidstaten wordt aangeheven, is het een teken dat er iets aan de hand is.

De zomer van 2005 was zo'n moment. Het dubbele Frans-Nederlandse nee tegen het grondwetsverdrag kwam bij alle regeringen als een klap aan. De Unie scheen wankel. De 'Griekse' strategie van de democratische zegening via de stembus had gefaald; de kiezers zeiden nee. De 'Duitse strategie' van een gezamenlijke identiteit stuitte op verzet, zoals onder meer in Nederland bleek. In die precaire situatie kon men alleen nog terugvallen op de bescheiden claim van 'Romeinse' resultaten. Op 30 augustus 2005 stelde de Franse minister van Europese Zaken: "De prioriteit is Europa concreter te maken. Dat gaat via de ontwikkeling van ambitieuze en nuttige projecten." (Colonna 2005) Op 20 september 2005 zei de Nederlandse regering: "Nederland moet blijven werken aan tastbare resultaten op Europees niveau, ook al omdat die zullen bijdragen aan het vertrouwen van de burger." (Ministerie van BuZa 2005: 16) Een jaar later betoonden beide regeringen zich trots dat de andere lidstaten ook dit pad op waren gegaan - even veronachtzamend dat ze zelf beide andere routes hadden geblokkeerd.

Ook de Commissie paste zich snel aan de wind aan. Op 10 mei 2006 presenteerde voorzitter Barroso zijn antwoord op het constitutionele fiasco: 'A citizens' agenda: delivering results for Europe'. Een van de topmaatregelen volgde een jaar later. De telefoonmaatschappijen werden in 2007 gedwongen de roaming-tarieven voor Europees bellen fors te verlagen - ten gunste van alle consumenten met een 
mobiele telefoon. Dat men alles op alles zette om deze maatregel te kunnen doen ingaan pal voor de zomervakantie, gedurende welke miljoenen Europeanen veranderen in van verre stranden naar het thuisfront bellende toeristen, maakt duidelijk dat het in de volle zin van het woord public relations waren.

De Europese gezamenlijkheid kan de eervolle Romeinse rol van soeverein beschermheer niet spelen. Ze is geen geloofwaardig schild tegen oorlog en honger. Blijft over zich tot de bevolking te richten als aanbieder van voordelen. Dit leidt tot onvoorziene problemen. Waar iedereen een potentieel voordeel heeft, zoals in het geval van de rechten en vrijheden op de markt, blijkt niet iedereen dat te willen. Bij de 'resultaten' waarmee het publiek recentelijk tegemoet wordt getreden, meent men de bijbehorende praktische nadelen, afwentelingen of kosten uit zicht te kunnen houden. Dit is een illusie.

Eveneens pijnlijk is de veronachtzaming, niet van de vergeefs weggemoffelde praktische nadelen, maar van de eveneens altijd aanwezige symbolische nadelen. Deze worden door het publiek in veel sterkere emotionele termen beleefd. Tegen een diep gevoeld verlies van nationale identiteit (Duitse kosten) of democratische soevereiniteit (Griekse kosten) kunnen de praktische voordelen (Romeinse baten) die Europa brengt niet op. De Nederlandse regering probeerde het in een kort voor het Europese referendum van 2005 huis aan huis verspreide brochure met de tekst: "dankzij Europa (..) kunt u gratis pinnen in het buitenland". 7 Men hoefde niet lang te wachten op de droge repliek van de nee-campagne: "Hoera! Gratis pinnen. Daar geef ik vierhonderd-nog-wat jaar soevereiniteit voor op."8

De fundamentele zwakte van de Romeinse publieksqueeste is daarom deze. Ze maakt een inbreuk op een nationaal wij - want uiteindelijk moeten 'wij' uit de ene lidstaat betalen aan, plaatsmaken voor of delen met 'hen' uit de andere lidstaten zonder zelf een omvattend Europees wij te constitueren. Ze vertrouwt op het instrument van de kantoorwereld en de taal van het Europese project, maar schept zelf geen besef van een gedeelde politieke en historische werkelijkheid voor allen in de Europese kring. Deze zwakte ligt besloten in de benadering zelf van het publiek als klant of begunstigde. In tegenstelling tot 'lotgenoten' of 'medeburgers' scheppen 'medeklanten' geen wij-gevoel. Ze zorgen voor ergerniswekkend gedrang bij de kassa.

'Resultaten' zijn zeer ontoereikend om de diepe impact van de Unie op het nationale publieke leven te rechtvaardigen. Het is daarom tijd dat het Nederlandse openbare bestuur weer aansluiting vindt bij andere vormen om Europa van ons te maken. 


\subsubsection{GRIEKSE STRATEGIE: DE DEMOCRATISCHE ARENA}

De 'Griekse publieksstrategie' rust op de periodieke beoordeling door de bevolking van vertegenwoordigers die uit haar naam besluiten nemen, soms aangevuld met een rechtstreekse stemming van de bevolking over haar voorgelegde kwesties. Opdat het publiek de wetten en besluiten als 'onze zaak' ervaart, krijgt het een stem.

\section{Europees Parlement}

Sinds de oprichting is gestreefd naar de versterking van de democratische legitimiteit van de binnensfeer. Tegenover de Commissie kwam een parlementaire Vergadering bestaande uit nationale parlementariërs uit de lidstaten (zoals nu nog de NAVO-Assemblee functioneert). Met name de lidstaten België, Nederland en Italië streden lang voor rechtstreekse Europese verkiezingen. Dit idee was in het verdrag van Rome opgenomen, maar wegens Frans verzet sine die gebleven. Pas in 1974, onder Giscard d'Estaing, gaf Parijs toe. (Het was een concessie aan de Benelux in ruil voor oprichting van de Europese Raad van regeringsleiders.)

Sinds juni 1979 vinden elke vijf jaar rechtstreekse verkiezingen voor het Parlement plaats. De verwachtingen werden in één opzicht ingelost, in een ander opzicht niet. Het verkozen Parlement versterkte, bij ongewijzigde bevoegdheden, inderdaad zijn macht en gezag ten opzichte van de Raad. Meteen in december 1979 verwierpen de parlementariërs het door de Raad voorgestelde Gemeenschapsbudget voor 1980. Als om hun bestaan te bewijzen aarzelden ze niet de Gemeenschap in een politiek-financiële crisis te storten. Sindsdien heeft het Parlement er als underdog in elke verdragswijziging bevoegdheden bijeen gesprokkeld, met dank aan bevriende regeringen en de groeiende eigen (hinder)macht. Van tandeloos adviseur is het uitgegroeid tot medewetgever op vrijwel alle beleidsterreinen. In Brussel kan niemand eromheen.

Daarentegen werd een andere verwachting gelogenstraft. Het Parlement won niet de gunst van de kiezers. De kiezersopkomst vertoont een gestaag dalende lijn, van 63 procent in 1979 tot 45 procent in 2004 voor het gemiddelde over alle lidstaten. Weliswaar doet deze daling zich ook op nationaal niveau voor, maar de Europese daling is relatief groter en vertrok van een fors lager beginniveau. Uit onderzoek blijkt bovendien dat de Europese partijkeuze doorgaans niet op basis van Europese thema's wordt gemaakt, maar een afgeleide van nationale keuzes is. Politicologen spreken van 'tweede-orde-verkiezingen'.

De paradox is dus dat de kiesgerechtigden sinds dertig jaar steeds minder belangstelling voor het Parlement tonen, terwijl zijn formele macht in dezelfde periode sterk toenam. Vanuit de zoektocht naar Griekse legitimiteit is het een teleurstellend resultaat. Het Parlement speelt inmiddels een belangrijke rol in het machts- 
evenwicht tussen de instellingen, maar biedt niet het democratische fundament waarnaar de gezamenlijkheid op zoek was. Wel speler in de binnensfeer, geen vertolker van een Europese vox populi.

Ook de Nederlandse regering zette lang alle kaarten voor legitimiteit van de Uniebesluiten op het Europese Parlement, inclusief een 'politisering' van de Commissie. Ze bleef langer dan de feitelijke machtsverhoudingen rechtvaardigden vasthouden aan een volledige emancipatie van de binnensfeer, zonder te erkennen dat de Unie ook een ander fundament behoeft.

\section{Nationale parlementen}

De Unie is een club van parlementaire democratieën. Zonder het 27-stemmige nationale democratische stelsel stort Europa in. Aan dit besef ontbrak het lang. De ideologen van de binnensfeer wilden één nieuw electoraat scheppen en gingen voorbij aan het oude electoraat, de nationale kiezers. De ideologen van de staten meenden dat het nationale publiek alleen ten dienste stond van de afzonderlijke lidstaten - Duitse kiezers voor Duitsland, Zweedse kiezers voor Zweden, enzovoort. Beide scholen hebben ongelijk. De Europese politiek als geheel kan niet zonder de Duitse, de Zweedse en alle andere nationale kiezers. Het verzamelde nationale publiek kiest en controleert de leden aan de machtigste Europese tafel, het beslist over de gezamenlijke spelregels en over eigen en andermans lidmaatschap, het gaat beoordelen of voorgesteld Europees beleid nodig is.

\section{Verkiezing van de leden van de Europese Raad en Raad}

De funderende positie van de nationale democratieën wordt in het recentste pact door de regeringen erkend. In een prominent verdragsartikel schrijven ze het volgende:

"De werking van de Unie is gegrond op de representatieve democratie. De burgers worden op het niveau van de Unie rechtstreeks vertegenwoordigd in het Europees Parlement. De lidstaten worden in de Europese Raad vertegenwoordigd door hun staatshoofd of hun regeringsleider en in de Raad door hun regering, die zelf democratische verantwoording verschuldigd zijn aan hun nationale parlement of aan hun burgers." (Art. $10 \mathrm{EU})$

Nationale verkiezingen bepalen de samenstelling van de Europese Raad. Elk nationaal electoraat zendt één persoon naar de Europese toptafel. Toegegeven, het betreft een tweede-orde-functie, afgeleid van de eerste functie van nationale verkiezingen, het bemensen van nationale parlementen en regeringen. Toch neemt met de groeiende macht van de regeringsleiders in de Europese orde het belang van nationale verkiezingen toe. Wie wordt de nieuwe Duitse bondskanselier? Wie wordt de Britse eerste minister? Zulke nieuwsgierigheid komt voort uit meer dan diplomatieke roddelzucht. De breuken die nationale verkiezingen bren- 
gen zijn vitaal voor het Europese politieke leven. Zo bestond de 'reflectieperiode' na het Frans-Nederlandse nee van 2005 minder uit reflectie dan uit wachten op een nieuwe Franse president, met vers kiezersmandaat.

De dubbelrollen zijn beslissend. Een nationale regeringsleider bekleedt zoals betoogd het belangrijkste Europese ambt in eigen land. Als regeringsleider vertegenwoordigt hij zijn land in Europa, als lid van de Europese Raad vertegenwoordigt hij de Unie thuis. Eenzelfde vertegenwoordigingslijn loopt tussen nationale parlementen en de leden van de gewone Raad, de vakministers. Het geeft de parlementen een controlerende functie, een droit de regard, ten opzichte van de Raadsbesluiten. Ministers nemen, eventueel met opdrachten van het parlement, met nationale doelstellingen deel aan de besluitvorming in de Raad. Maar is een besluit genomen, dan vertegenwoordigt de minister thuis de Unie. Zo is het precies bedoeld: "De Raad bestaat uit een vertegenwoordiger van elke lidstaat op ministerieel niveau die gemachtigd is om de regering van de lidstaat die hij vertegenwoordigt, te binden", aldus het verdrag (Art. 16.2 EU).

In lidstaten zoals Denemarken, waar het parlement zeer kort op de regering zit, ziet men hoe dit de Unie versterkt. Het effect is namelijk dat de volksvertegenwoordiging de Brusselse onderhandelingen in wordt gezogen, dat behalve de Deense minister die aanzit ook de geest van de Folketing boven de onderhandelingstafel hangt. Intensieve controle werkt dus niet centrifugaal (zoals de Brusselse ideologen vrezen), maar juist centripetaal. Hier is voor de Tweede Kamer nog veel te winnen.

Via de regeringen worden de parlementen aan de Europese tafel getrokken, via de parlementen het nationale publiek. Dit blijkt het duidelijkst bij meerderheidsbesluiten. Ook als hij persoonlijk is overstemd, draagt een minister de verantwoordelijkheid voor een Europees besluit jegens het eigen nationale parlement - en uiteindelijk jegens de eigen bevolking.

Feit is dat veel ministers zich aan deze verantwoordelijkheid onttrekken. De verleiding is groot alleen de successen te claimen en bij eigen falen 'Brussel' de schuld te geven. Hoewel een nationaal parlement een niet-overtuigende minister ook naar huis zou kunnen sturen, blijkt het voor beide partijen aantrekkelijker te kiezen voor verontwaardiging en/of het in twijfel trekken van de handelingsbevoegdheid van de gezamenlijkheid: 'Dat mag Europa helemaal niet beslissen.' Zo kan ook de beoogde 'Griekse' legitimatie via het nationale parlement in haar tegendeel omslaan. In plaats van het gevoel van 'onze Europese besluiten' rijst het beeld van Brussel als buitenlandse bezettingsmacht. 


\section{Rechtstreekse betrokkenheid nationale parlementen}

Daarom poogt men sinds het begin van de jaren negentig de nationale parlementen dichter bij de Europese besluitvorming te betrekken. Rond de eeuwwisseling maakte in Londen en Parijs het idee van een 'Senaat' opgang, een permanente wetgevingskamer voor nationale parlementariërs op Europees niveau (Siedentop 2000).

Tegen deze gedachte hebben Commissie, Parlement en lidstaten als België en ook Nederland zich verzet. Ze meenden dat die tweede wetgevingskamer er in potentie is in de Raad. In het supranationale denken vertegenwoordigt het Europees Parlement namelijk de burgers en zou de Raad van Ministers uitgroeien tot Senaat (en daartoe zijn uitvoerende macht neerleggen ten gunste van de Commissie).

Deze redenering miskent dat het verzamelde nationale publiek niet per definitie dezelfde belangen, wensen en angsten heeft als datzelfde publiek in zijn hoedanigheid van Europees burger. Moet het stierenvechten worden verboden? Ja, dat is dierenmishandeling, zeggen het Europese parlement en veel nationale parlementen. Nee, dat is cultuur, zegt het Spaanse parlement. Europese regels voor echtscheiding? Ja, een vooruitgang in rechtsgelijkheid, hopen Europese burgers. Nee, een inbreuk op ons eigen burgerlijke recht, menen nationale burgers. Het Europese Parlement kan uit de aard der zaak niet al deze perspectieven verwoorden, evenmin als de nationale regeringen. Daarom vraagt het standpunt van de verzamelde nationale burgers om rechtstreekse vertegenwoordiging op Europees niveau.

In afgezwakte vorm haalde het plan voor een Senaat het verdrag van Lissabon, dat op 1 december 2009 in werking trad. Het brengt materieel gesproken geen nieuwe Europese instelling, maar wel een rechtstreekse, gezamenlijke betrokkenheid van nationale parlementen bij Europese wetgeving. Zij bepalen of wetgeving wel op Europees niveau mag plaatsvinden ('subsidiariteitstoets'). Wanneer de Commissie een wetsvoorstel doet, krijgen nationale parlementen als collectief zes weken de tijd voor een oordeel. Wanneer eenderde van de parlementen op grond van subsidiariteit bezwaar aantekent, is de Commissie verplicht het voorstel te heroverwegen; het is een 'gele kaart'. Ze kan het intrekken, amenderen of ongewijzigd opnieuw indienen. Deze laatste mogelijkheid wekte het ongenoegen van de voorstanders van een 'rode kaart'. In de praktijk maakt het weinig uit: de Commissie zal een democratisch front van negen of tien parlementen niet kunnen weerstaan.

Onder druk van de publieke opinie is de Nederlandse regering bijgedraaid. Oorspronkelijk was ze lauwtjes. Ze vreesde nog in september 2002 dat "de besluitvorming erdoor dreigt te worden vertraagd", oftewel dat betrokkenheid van nationale parlementen zand in de Europese beleidsmachine zou strooien, en dat het "de nationale en de Europese democratie met elkaar [zou] dreigen te verwarren", alsof die vertegenwoordigingslijnen niet al sinds 1951 onontwarbaar zijn (Ministerie 
van BuZa 2002). Na de referendumdreun van 2005 ontwikkelde Den Haag zich tot een pleitbezorger van de nationale parlementen. Tijdens de top van juni 2007 , waar de regeringsleiders een akkoord bereikten over de opvolger voor het grondwetsverdrag, ging een onverwacht heftige ruzie - om drie uur's nachts toen de echte deal gedaan was - tussen de Nederlandse en de Belgische premiers over precies dit punt. Balkenende wilde de nationale parlementaire controle versterken, de Belg Verhofstadt beschouwde dit als verraad aan het Parlement en het Europese project. Dit was geen Benelux-zijtoneel, maar een richtingenstrijd op het pad van de democratische legitimatie. Wezenlijk is beide sporen te blijven bewandelen.

Toch blijkt het oude denken taai. Nog in 2008 vroeg de Nederlandse regering aan de Tweede Kamer de eerder bedongen verplichte instemming bij de totstandkoming van gevoelige wetgeving op het terrein van justitie en binnenlandse veiligheid te schrappen. Het argument was dat het Europees Parlement voortaan veel meer bij zulke wetgeving is betrokken. Dit getuigt van onbegrip voor de aard van de Unie. Deze heeft en houdt een dubbel democratisch fundament. Het 'instemmingsrecht' op justitiebeleid is bovendien zeer wezenlijk. Toen de regeringen na de aanslagen van $9 / 11$ haast maakten met besluitvorming op dit gebied, waaronder het Europese arrestatiebevel, hebben nationale parlementen, waaronder het onze, kunnen tegenhouden dat de veiligheidsagenda van de executieve machten alle privacyoverwegingen van tafel veegde. Terecht noemde Eijsbouts de opvatting dat ofwel het Europese Parlement ofwel het nationale parlement controleert naïef:

“De regeringen hebben in de Unie zowel afzonderlijk als samen grote macht en moeten daarbij door zowel de nationale parlementen als door het Europese parlement worden gecontroleerd. Laat die parlementen met elkaar concurreren om de gunst van de kiezer in plaats van een aandeel te nemen in de verdere erosie van de Europese fundamenten.” (Eijsbouts 2008)

Politisering van onderwerpen die nu bureaucratische dossiers blijven vereist alerte media en een aandachtige publieke opinie; zolang je als Kamerlid met Europa niet in de krant komt zal de bekommernis gering blijven. Hoe dan ook is deze institutionele vernieuwing betekenisvol. In beginsel kunnen demonstraties en acties tegen of voor Europees beleid behalve in Brussel of Straatsburg nu ook plaatsvinden op het Malieveld of het Plein. De stem des volks kan in de Tweede Kamer doorklinken en vervolgens rechtstreeks bij de Commissie in Brussel worden neergelegd, zonder dempende tussenkomst van de regering. Het biedt de Unie een onontbeerlijke fundering.

\subsubsection{TRIBUNE \& TAFEL - CONCLUDERENDE OPMERKINGEN}

De ontwikkeling van de Unie tot een politieke orde die blijvend rust op de lidstaten en hun democratische instellingen weerspreekt de vigerende denkpatronen, in 
het bijzonder de sleetse tegenstelling 'supranationaal' versus 'intergouvernementeel'. Het lukt het Nederlandse openbare bestuur slechts moeilijk een positie te vinden tussen de clichés van de Europese superstaat en de soeverein samenwerkende staten in. De eigen miskenning van de verzelfstandiging van een dragende tussensfeer, uitgekristalliseerd in de Europese Raad, wreekt zich in publieke mispercepties. Een vergroting van het eigen handelingsvermogen in 'Brussel' vergt - op straffe van vergroot wantrouwen van de publieke opinie - een sterker besef bij de bevolking van de Europese krachtsverhoudingen, inclusief het besef dat 'méér Europa' niet 'minder Nederland' betekent.

Hiertoe dienen de Nederlandse staatsinstellingen hun Europese rol sterker uit te dragen: de Nederlandse minister-president is een Europees politicus, Nederlandse ministers dragen Europese verantwoordelijkheden, de Nederlandse Tweede Kamer is uit hoofde van haar controlerende droit de regard de facto een Europese instelling, enzovoort. Deze zichtbaarheid is bijvoorbeeld ook gebaat bij het frequenter laten wapperen van de Europese vlag naast de nationale driekleur in of op openbare gebouwen. De geopolitieke plaats van Nederland in de Unie, als lid van een 'konvooi' van 27, laat het niet toe die Unie louter als praktisch instrumentarium te zien, noch de gezamenlijke besluiten louter in termen van resultaat te verdedigen. Tegelijk moet men bedacht blijven op terugslageffecten die zich kunnen voordoen; van puur Brussel-georiënteerde informatie en communicatie moet men niet te veel verwachten ('propaganda').

Steeds moet worden gestreefd naar een onnadrukkelijke maar vasthoudende verbinding tussen het nationale en het Europese, uitgedragen in de arena van politieke woorden en handelingen voor de publieke tribune. Alleen in dit spel van openbaarheid en discretie kan de steun voor de Unie worden gevonden die het Nederlandse handelingsvermogen aan de Brusselse tafels vergroot. Alleen zo kunnen hun besluiten op termijn onze besluiten worden. 


\section{NOTEN}

$1 \quad$ Hoofdstuk ingediend 30 december 2009.

$2 \quad$ Klaus 1994, in: Carlos Reijnen, Op de drempel van Europa. De Tsjechen en Europa in de twintigste eeuw, Kampen 2005, 15 en 357; Gaitskell, 3 oktober 1962, in: Brian MacArthur (red.) The Penguin book of twentieth-century speeches, Londen 1999, 319-321, 321.

3 Belangrijke delen van dit hoofdstuk, met name de paragrafen 2 en 5, zijn gebaseerd op Van Middelaar (2009). Daar vindt men ook een uitgebreide vertoog-analyse van het politieke en wetenschappelijke spreken over Europa, blz. 16-30. Beeld ontleend aan de toespraak van dr. E.P. Wellenstein gehouden op 8 oktober jl. bij een symposium op Clingendael ter gelegenheid van zijn goste verjaardag. Slotakte van de Intergouvernementele Conferentie, 13 december 2007, 'Verklaring van het Koninkrijk België, de Republiek Bulgarije, de Bondsrepubliek Duitsland, de Helleense Republiek, het Koninkrijk Spanje, de Italiaanse Republiek, de Republiek Cyprus, de Republiek Litouwen, het Groothertogdom Luxemburg, de Republiek Hongarije, de Republiek Malta, de Republiek Oostenrijk, Roemenië, de Portugese Republiek, de Republiek Slovenië en de Slowaakse Republiek betreffende de symbolen van de Europese Unie' (Verklaring 52), in: Publicatieblad, 17.12.2007 C 306/o2. Barroso, in: de Volkskrant, 21 november 2007, 'Banken Europa moeten overstap vereenvoudigen'.

$7 \quad$ Nederlandse regering, huis-aan-huisbrochure Europees referendum, mei 2005.

8 'Willem de Zwijger', 23 mei 2005, 'Gratis pinnen!', op: dezwijger.blogspot.com (12 februari 2009). 



\title{
5 PLANOLOGIE EXTENDED. NAAR EEN NIEUWE TOEKOMST VAN RUIMTELIJK OPENBAAR BESTUUR
}

\author{
Luuk Boelens
}

\subsection{PLANOLOGIE EN OPENBAAR BESTUUR}

De toekomst van de planologie is van oudsher onlosmakelijk verbonden met de toekomst van het openbaar bestuur; of beter nog de overheid. Ondanks dat archaïsche vormen van een geplande overheidsbemoeienis met de inrichting van het land al dateren van oudsher ${ }^{1}$, kreeg de planologie voor het eerst breed, ongeacht de specifieke politieke en/of ideologische signatuur en in zijn meest moderne vormen, doorwerking als antwoord op de (economische) crises van de jaren twintig en dertig van de afgelopen eeuw. Zowel in communistische landen als de UssR, meer liberaal geïnspireerde federaties als de USA, fascistische, respectievelijk nationaal-socialistische landen als Italië en Duitsland, alsmede in meer pragmatische en minder uitgesproken staatssignaturen als de UK, Nederland en de Scandinavische landen, werd rond 1930 een meer rationele, planmatige en daarmee (ogenschijnlijk) meer rechtvaardige en effectieve ruimtelijke ordening van de samenleving bepleit. Dat zou de welvaartsgroei, alsmede het algemene welzijn ten goede komen. Na de eerste exercities op lokaal en regionaal niveau werd het op nationaal niveau in Nederland formeel geïnstitutionaliseerd tijdens de bezetting van 1940-1945. Het verkreeg echter vooral haar hoogtepunt gedurende de wederopbouw en de verzorgingsstaat van na die Tweede Wereldoorlog. Gegeven de enorme bouwopgaven, economische opleving, sociaal-ruimtelijke vraagstukken en hun focus op het zogenoemde 'algemene belang' zouden de overheid en haar planologen de meest aangewezen regisseurs zijn voor 'de best denkbare wederkerige afstemming van ruimte en samenleving, zulks terwille van die samenleving' (commissie-Van Veen 1973). Het was tevens gestoeld op prominente planningstheoretici als Dror (1968), Etzioni (1968) en Friedmann (1969) die ons indertijd wilden doen laten geloven dat overheidsplanning eigenlijk het ontbrekende element van de westerse vooruitgang was om te voorkomen dat zij stuurloos, chaotisch en ineffectief zou worden. En alhoewel de focus daarbij inmiddels wel is verlegd van blauwdrukplanning, naar meer flexibele, procedurele, interactieve en/of onderhandelingsgerichte varianten, van toelatings- naar ontwikkelingsplanologie, is de essentie van die gekoppelde inzet eigenlijk nog onveranderd. Ook de actuele geëngageerde en kritische (planning)theoretici positioneren de toekomst van de planologie doorgaans nog steeds 'preferably within a public sector led socio-spatial proces'; onder de bestaande en via het overheidsregime opgebouwde planningkaders van sturing en rechtszekerheid (Hajer, Sijmons en, Feddes 2006; Healey 2007; Albrechts 2008; Bertolini 2009; Zonneveld 2009). 
Maar het is de vraag of dat nog wel klopt en/of het per definitie wenselijk is. Ten eerste is sinds jaar en dag immers onmiskenbaar dat ruimtelijke planning niet uitsluitend en/of exclusief is voorbehouden aan de overheid. Tal van sociale actoren, ook buiten de overheid, zijn cruciaal en wellicht meer doorslaggevend voor de ruimtelijke ontwikkeling van een plek of regio (Kreukels 1985; Fainstein en Fainstein 1986; Stone 1989; Massey 1995; Mossberger en Stoker 2001). Eerder is er dan ook sprake van een stelsel, van een zich zelfs uitbreidend web van deelplanningen, verspreid over een veelvoud van partijen en actoren: in de (semi)publieke en private sfeer, de economie en de zorg, in het bedrijfsmanagement, tussen groepen mensen in de dagelijkse levenssfeer, in de al dan niet gouvernementele of non-gouvernementele netwerken van belangengroeperingen, in de culturele en creatieve hoeken, enzovoort. En - met uitzondering van wellicht een kortstondige periode gedurende de wederopbouw - is dit feitelijk ook altijd zo geweest. Wie heden ten dage iets zinnigs over de ruimtelijke planning zou willen zeggen doet er dan ook goed aan zich niet exclusief te beperken tot de overheid, maar vooral ook buiten die overheidswereld te kijken in andere sociale, economische, culturele en maatschappelijke domeinen, juist omdat daar een enorme en in de netwerksamenleving ook toenemende plandynamiek aanwezig is (Boelens, Spit en Wissink et al. 2006).

Ten tweede tast een dergelijke zorgvuldig opgebouwde overheidsinterne 'comfort zone' een verantwoorde en effectieve ruimtelijke planning ook aan. Hoe vernieuwend, geëngageerd en/of innovatief public-sector-led planners immers ook zouden mogen zijn, hoe ontwikkelingsgericht, discursief of de pluriforme samenleving een warm hart toedragend, de planningvoorstellen blijven uiteindelijk altijd binnen de padafhankelijkheden van precies diezelfde publieke sector. Het tendeert doorgaans naar algemene of generiek geformuleerde probleemdefinities van zichzelf, met een overwegend perspectief van de overheden, veelal resulterend in interne, tijdrovende coördinatieprocessen (zowel tussen de departementen als tussen de verschillende overheidslagen), interactie-overkill en 'Poolse landdagen', die uiteindelijk van alle franje ontdaan ook ultiem worden afgerekend op de periodieke algemene verkiezingen. Het resulteert doorgaans daarmee ook in minder innovatieve, 'middle-of-the-road' oplossingen, gebaseerd op concessie verlenende of subsidie gedreven basisprincipes; vaak nauwelijks duurzaam of met een in alle geledingen doorvoeld commitment; in principe eigenlijk nooit met risicodragende investeringen (Mommaas en Boelens 2005; Boelens 2009).

Echter, ook omgekeerd, dit systeem van afhankelijkheden en publieke regie, corrumpeert ook de andere maatschappelijke partijen; zowel die in de zogeheten 'business' als die in de 'civic society'. Want waarom zou een projectontwikkelaar mee-investeren in de hoofdinfrastructuur indien dit ten principale toch wel voor rekening komt van de overheid? Waarom zou een tuinder de wateroverlast in de winter op zijn perceel willen voorkomen, dan wel deze vasthouden voor de droge 
zomers, indien hij/zij daarop het inmiddels publieke waterschap toch wel kan aanspreken? Waarom zouden bewoners zich garant willen stellen voor het schoonhouden van hun straat, als zij daarvoor toch algemene belasting betalen aan de gemeentelijke vuilnisophaaldienst? Buiten enkele experimenten of voorbeeldprojecten komen structurele koerswendingen hier dan ook nauwelijks van de grond. Opmerkelijk zijn bijvoorbeeld de in de afgelopen tien jaar uitgevoerde experimenten naar (collectief) particulier en/of medeopdrachtgeverschap in de Nederlandse woningbouw. Vooralsnog constateert men ten laatste dat zelfs ten opzichte van onze Belgische of Duitse buren, de Nederlandse cultuur er eigenlijk niet (meer) naar is. Bewoners zouden in de loop van de tijd buitenspel zijn gezet (Noorman 2006: 36). In de afgelopen eeuw zouden zij langzaam maar zeker gewend zijn geraakt aan het feit dat, als men een nieuwe woning wenst, deze koopt uit de bestaande voorraad, toegewezen krijgt van de zijde van de overheid of corporatie, dan wel een kant-en-klaar ontwerp kiest van de tekeningen van een ontwikkelaar. De gehele grondmarkt en institutionele setting zouden nauwelijks meer ondersteunend zijn voor particulieren om zelf als opdrachtgever te fungeren. Niet alleen de overheid of de ontwikkelaars, maar ook de bewoners en corporaties zouden hier zelf schuld hebben; zij hebben het immers ook laten gebeuren.

Op dit punt van het betoog zou u wellicht de tegenwerping naar voren kunnen brengen dat het zo ook wel gemakkelijk en helder is: de overheid verantwoordelijk voor de publieke zaak en de (grote) algemene planningskaders en de buitengouvernementele maatschappelijke en/of ondernemende spelers verantwoordelijk voor de private en semipublieke zaak c.q. de eigen inrichting binnen die algemene publieke kaders. Anders dan bijvoorbeeld in de USA en/of België heeft het ons immers op het gebied van doelmatige rechtvaardigheid ook geen windeieren gelegd, respectievelijk de o zo ongewenste 'verrommeling' voorkomen. Daarenboven zouden de periodieke democratische verkiezingen en het (naar draagvlak gestructureerde) systeem van subsidie/concessieverlening versus boetes/belastingheffing (geven en nemen) de interactie tussen de publieke en private sferen naar behoren garanderen. Maar de vraag is nu juist of men een dergelijk systeem van scheiding en genuanceerde interactie tussen de publieke en private leefwereld in een steeds meer grenzeloze netwerksamenleving - zowel fysiek als naar sector nog wel kan ophouden. Het succes en falen van de grote, algemene kaders, de grote infra- en hoofdstructuren, onze veiligheid, ons welzijn en klimaat worden immers ook steeds meer door andere transnationale (f)actoren bepaald, die zich onttrekken aan de verantwoordelijkheid en zelfs aan het zicht van de (inter)nationale, laat staan de regionale en (boven)lokale overheid. Daarnaast hebben generieke beleidsmaatregelen in een steeds pluriformere samenleving ook tal van (onbedoelde en/of onverwachte) effecten, dan wel worden allerhande kansen, (mogelijke) vormen van zelforganisatie en autonome ontwikkelingen buiten de overheid gemist (Boonstra, Boelens 2010). Tegelijkertijd is de motivatie telkens 
ook weer wisselend geworden. Neem bijvoorbeeld het compacte stadsbeleid; dat heeft inmiddels niet één, maar tal van potentieel wisselende motivaties al naar gelang de regio en specifieke actor-netwerksetting (Boelens et al. 2010). Tenslotte is ook de planningcontext wezenlijk veranderd. De grote uitbreidingsopgaven, zoals die ten tijde van de wederopbouw en industrialisatie, bestaan niet meer. En daarmee is ook de oriëntatie van de ruimtelijke ordening feitelijk aan het veranderen: van de hardware naar de soft- en orgware van de opgave.

Selectiviteit is hier gewenst, precieze regionale focus en de actieve betrokkenheid van een veelheid aan allerhande stakeholders, zeker! In zoverre spoort ook dit betoog met het WRR-rapport Ruimtelijke ontwikkelingspolitiek van ruim tien jaar geleden (WRR 1998). Maar tegelijkertijd gaat het ook verder en radicaliseert het de indertijd feitelijk aan dat WRR-rapport ten grondslag liggende premissen. Gegeven de ervaringen met tien jaar public-sector-led maatschappelijke coalitievorming op de indertijd zogenoemde ruimtelijke ontwikkelingsgebieden (zie ook Van de Cammen en Bakker 2006), gegeven ook de 'lock-in effecten' die daarbij ondanks alle goede bedoelingen telkens weer naar boven komen, gegeven de voornoemde corrumperende effecten enzovoorts gaan er steeds meer geluiden op de traditionele oriëntatie radicaal om te draaien: outside-in in plaats van inside-out; voorbij Hét Plan (Salet en Majoor 2005; Mommaas en Boelens 2005; Boelens, Spit en Wissink 2006; Hillier 2007, enz.). In principe gaat dat zowel op voor de publieke, als de private sector, zowel voor de public, business als civic community. ${ }^{2}$ Maar als we ons in deze tekst beperken tot de overheid en het openbaar bestuur, gaat het hier om het faciliteren, in plaats van regisseren of (aan)sturen, van dynamische, autonome en/of potentiële allianties van heterogene actoren. Het openbaar bestuur en de planologie staan hier niet boven of buiten die ruimtedynamiek (als een deus ex machina, (scheids)rechter of regisseur), maar zijn zelf onderdeel geworden van die actor-netwerken.

\subsection{PLANOLOGIE IN EEN RELATIONELE RUIMTE}

Dat besef en die stelling sporen met de nieuwste inzichten die de afgelopen tien jaar binnen de sociale geografie en planologie tot wasdom zijn gekomen. Deze kunnen getypeerd worden als poststructuralistisch en relationeel (Thrift 1996; Murdoch 1997; Massey 1998; Graham \& Healey 1999; Doel 1999; Amin \& Thrift 2002; Whatmore 2002; Urry 2003; Massey 2005; Murdoch 2006). Zij zijn poststructuralistisch, omdat zij betekenis en actie, sociaal, economisch, maatschappelijk en daarmee ruimtelijk gedrag, niet proberen te verklaren uit de 'diepe' structuren van oorzakelijke verbanden (zoals bijvoorbeeld bij de neomarxisten, historisch-materialisten, kritisch-rationalisten of systeemtheoretici), maar veel meer vanuit de specifieke contexten en relativiteiten verbonden met een veel grotere pluraliteit aan betekenissen, gedrag en identiteiten 'aan de oppervlakte'. Systemen zijn hier niet gesloten, maar fundamenteel open, waarbij betekenis en 
actie worden bepaald door een (al dan niet complexe) context van extensieve relaties (Belsey 2002). Dat denken resoneert ook beter met de setting van de netwerksamenleving, met haar steeds verrassender wendingen, complexe relaties en (principieel) open, grenzeloze verbanden. In het verlengde daarvan wordt ook de ruimte, plek of plaats, niet langer gezien als een in zichzelf gegeven, alomvattend fenomeen of gewoon als een platform, een soort podium voor activiteiten, zoals bijvoorbeeld het wonen, werken, verkeer en de voorzieningen, c.q. alle mogelijke varianten en samenstellingen daartussenin. In de plaats daarvan wordt ruimte benaderd als een door en door relationeel gegeven; en dat op zijn minst in tweeërlei opzicht (Doel 2000; Massey 2005).

Ten eerste is in de actuele, grenzeloze netwerksamenleving de ruimte alhier immers altijd ook op de een of andere wijze gerelateerd aan de ruimte daar; in die zin dat de gebeurtenissen aldaar ook direct of indirect invloed hebben op de ruimtelijke ontwikkelingen en mogelijkheden hier. Zo hebben de problemen op de vastgoedmarkt in de USA in het afgelopen jaar een directe invloed gehad op de wereldwijde financieel-economische crises, het omvallen van banken - zoals die in Wognum - het record aantal faillissementen vooral ook in de bouwsector, leegstand in de kantorensector en op de bedrijfsterreinen, maar ook stagnerende mobiliteit, in combinatie met eveneens minder milieubelasting. Echter, eveneens in meer directe fysisch-geografische zin ontlenen Schiphol, de haven van Rotterdam en zelfs de Brainportregio Eindhoven hun betekenis niet alleen of exclusief aan zichzelf, maar vooral ook aan hun positie in grensoverschrijdende netwerken. Bijna de helft van het totaal aantal reizigers op Schiphol hoeft er immers eigenlijk niet te zijn, maar gebruikt de luchthaven alleen als hub tussen andere plaatsen van herkomst en bestemming.

Ten tweede is de ruimte ook relationeel, omdat het niet iets is wat onafhankelijk buiten ons staat, maar ook door en door, door ons gemaakt, veranderd en aangepast wordt; zeker ook in onze Lage Landen (Van der Woud 1987). Ruimte en plekken zijn derhalve geen enkel-, maar veelvouden, ontstaan uit en gemaakt door wisselende en verschillende (historische) sociale praktijken, politieke identificaties en economische vormen van toe-eigening. Daarmee kunnen er ook voortdurend worstelingen en gevechten ontstaan wiens lezing van de ruimte prioriteit zou moeten verdienen, of welke vormen van toe-eigening het meest dominant zijn. De geschiedenis leert dat de uitkomsten van die worstelingen - zeker de dominante - niet zozeer of enkel bepaald worden door bestaande regels en structuren, maar eerder aanleiding geven tot nieuwe sociaal- en economisch-ruimtelijke praktijken, en daarmee ook nieuwe regels en structuren. Verderop daarover meer. Hier is het voldoende op te merken dat de belangrijkste notie van de relationele geografen derhalve is dat 
"the performance of social practices and the performance of space go hand in hand. The performer (for example, the social agent) and the context of performance (for example space or place) are not distinct from one another, but they are both entangled in the heterogeneous processes of spatial becoming." (Murdoch 2006: 18)

Eigenlijk komt dat zeer dicht in de buurt van de hiervoor gegeven definitie van ruimtelijk ordening van de commissie-Van Veen over 'de best denkbare wederkerige aanpassing van ruimte en samenleving, zulks terwille van die samenleving'. Desondanks is de actuele planologenpraktijk en die van het openbaar bestuur terzake nog steeds een volstrekt andere. Nog steeds kleuren provinciaal planologen gebieden rood, groen, paars en grijs, proberen stad van het zogenoemde 'landelijke' ommeland te scheiden, zo alsof dat iets zou zeggen over de sociale praktijken die aldaar dominant of in ontwikkeling zijn (Structuurschets Zuidvleugel 2009). Nog steeds trekken - zij het nu wereldberoemde en alom vermaarde urbane architecten pijlen of plaatsen in opdracht van de lokale overheid kleurrijke bollen om de ontwikkeling van toekomstige ruimten te dicteren (Structuurvisie Almere 2.0 2009). Nog steeds zijn rijksplanologen op het gebied van duurzame gebiedsontwikkeling, MIRT of verstedelijkingskoersen overwegend met zichzelf in gesprek of met hun collega's binnen andere departementen of lagere overheden, teneinde op zijn best ontwikkelingskaders te bieden of concessies te geven aan buiten-gouvernementele actoren, die dan vaak ook nog eens elders duurzaam gecompenseerd moeten worden (zie o.a. de RAAM-brief in het kader van Randstad Urgent 2009; de MIRT-verkenning Antwerpen-Rotterdam 2009, enz.). Nog steeds is er geen radicale slag gemaakt naar een praktijk waarbij de ruimte niet buiten die planologen staat, of het openbaar bestuur niet gezien wordt als een neutrale instantie die over ruimtelijke sociale praktijken, worstelingen en dominante lezingen kan oordelen; naar een praktijk waarbij die overheidsinzetten zelf onderdeel zijn van ruimtelijk maatschappelijke en sociaaleconomische netwerken. Of, met andere worden, zoals door Foucault, Deleuze, Guattari en anderen al eerder opgemerkt, is er nog steeds geen radicale omslag gemaakt naar een praktijk waarbij het weinig zinvol is ons te affirmeren met of op zoek te gaan naar een algemeen referentiekader of transcendente orde, zoals hét 'algemeen welzijn' of 'algemeen belang' (Foucault 1968; Deleuze Guattari 1980). Nog steeds is de focus van planologen en het openbaar bestuur niet radicaal verlegd naar de netwerken, naar de manier waarop dingen en mensen met elkaar in relatie staan, hoe ze zich met elkaar verbinden, hoe ze zich vertakken en hoe planologen en openbare besturen in die actor-netwerken zinvol kunnen participeren. De cruciale en beslissende slag die nog steeds gemaakt moet worden is die naar het 'radicaal relationalisme'. Een absolute macht (een kracht of beweging die boven het krachtenspel van de wereld in wording verheven zou zijn) is in dat 'relationalisme' van die actuele netwerksamenleving immers niet langer denkbaar of duldbaar. Het komt eropaan telkens weer de specifieke verhouding van krachten te denken, die mogelijk kunnen 
evolueren tot iets wat meer is dan het specifieke eigenbelang (vgl. tevens Romein et al. 2009).

Willen planologen en/of overheden in die radicaal relationele wereld nog proactief kunnen acteren, dan wordt het begrip 'associatie' cruciaal, echter niet in de traditionele interactieve, discursieve of collaboratieve zin - zoals onder meer door Richard Sennett (1977); Jürgen Habermas (1984) en in het verlengde van hen door de planologen Judith Innes (1994) en Patsey Healley $(1998,2007)$ betoogd -, maar in een actor-netwerk of evolutionair-relationele zin. De eerste leiden immers al te gemakkelijk tot grote, algemene en vaak langdradige 'Poolse landdagen' over abstracte en algemene thema's , waarbij het proces eigenlijk belangrijker wordt dan de inhoud, gedragen door ontwerpexercities die feitelijk nergens over gaan (zoals bijvoorbeeld recent nog bij het VROM-traject Randstad 2040, 2008). Dergelijke inzetten zijn een kwart eeuw geleden al neergesabeld door Harald Weinrich (1987) als een 'Diktatur des Sitzfleisches': uiteindelijk krijgen zij gelijk die het langste blijven zitten en/of de meest volharding tonen c.q. de meest gevatte one-liner vertolken. Eerder gaat het hier om 'associaties' over zeer concrete en specifieke vraagstukken tussen primaire en leidende actoren; in evolutionaire zin gedefinieerd als diegenen die bereid zijn in hun omgeving te investeren, omdat ze er zelf beter van worden (De Langen et al. 2003; Yeung 2005; Boschma, Frenken 2006) . Daartoe hebben actor-netwerk-theoretici, als Callon (1986, 1995), Law (1986, 2004) en Latour $(1997,2005)$ het begrip translatie geïntroduceerd, doelend op het gegeven dat, wanneer men wetenschappelijke (of planologische) netwerken wenst uit te breiden door ruimte en tijd, ook actoren van andere (natuurlijke en sociale) pluimage geïnteresseerd moeten worden in die netwerken. Het betekent dat de doelen, taal en incentives van wetenschappers/planologen aangepast zullen moeten worden aan de incentives, doelen en taal van die andere (doorslaggevende) partijen. En dat is alleen voorstelbaar als men zich 'inleeft' in de leefwereld en associaties, kortom actor-netwerken van die andere (leidende) partijen.

Aanpassing aan een netwerk vereist een zekere mate van 'normalisatie', opdat goede en slagvaardige resultaten daadwerkelijk kunnen worden gefaciliteerd. Of omgekeerd geformuleerd: 'associational action' is het resultaat van netwerkmobilisatie en die netwerken zijn afhankelijk van bepalende actoren, opererend in daartoe geëigende institutionele settings (zowel in formele als informele zin). Het werken vanuit de onlosmakelijke driehoek atoren-netwerken-institutie is derhalve bepalend voor een succesvolle actor-relationele planningbenadering (Boelens 2009).

\subsection{OPENBAAR BESTUUR IN EEN RELATIONELE RUIMTE}

Voor de twee-eenheid openbaar en bestuur geldt hetzelfde als voor de tweeeenheid planologie en ruimte. Ook openbaarheid is niet iets wat onafhankelijk buiten ons staat, maar door en door, door ons, c.q. ook het private domein is 
gemaakt. Openbaarheid is derhalve tevens geen enkel-, maar een veelvoud, en het 'besturen' daarvan kan niet als buitenstaander, dan wel als een min of meer onafhankelijk scheidsrechter plaatsvinden, maar is nadrukkelijk en impliciet onderdeel van de diverse actor-netwerken en hun associaties die van die (specifieke) openbaarheid deel uitmaken. De actor-netwerken en daarmee openbaarheid van een hangjongere of dakloze, is bijvoorbeeld een volstrekt andere dan die van de forens of kosmopoliet, dan wel die van Turkse immigrante vrouwen en anderen (Graafland 1995; Sudjic 1992; Yücesoy 2006). Hetzelfde geldt voor die van de Waterschappen, de ANWB of de Transnational Corporation, enzovoorts. Meer dan dat, in het verlengde van het onderscheid tussen Arche, Cine en Tele-Citta (Boelens 1994, 2005) is ruimtelijke openbaarheid zelfs niet langer exclusief verbonden met manifeste actor-netwerken in de topografische ruimte van hier en nu en de lange duur in een soort 'glaciaal' tijdsperspectief (de longue durée van Fernand Braudel 1958). Dat is de nog steeds gebruikelijke benadering van ruimtelijke openbaarheid, en het gebruikelijke veld waarop overheden en planologen doorgaans ingrijpen. Maar tegelijkertijd is die openbaarheid ook steeds meer verbonden geraakt met actor-netwerken in een grenzeloze ruimte van fysieke mondiale netwerken in een 24-uurs tijdsperspectief, als met de meer fluïde ruimte van 'cyberspace' en 'instant time', waarbij op elk willekeurig tijdstip direct met (virtuele) personen of programma's aan de andere kant van de wereld gecommuniceerd kan worden (Castells 1996). Op elk willekeurig knooppunt van onze netwerksamenleving - neem bijvoorbeeld Utrecht CS - zien we deze verschillende vormen van openbaarheid dan ook strijden om dominantie. Maar belangrijker is wellicht dat hierdoor openbaarheid geen singulariteit meer is, waarbij formele en een gestandaardiseerde set van regels en normen heldere zones van openbaarheid ten opzichte van het private domein proberen af te bakenen. Eerder is openbaarheid hier een complexe multipliciteit (wellicht zelfs 'chaosmos') 3 geworden, waarbij heterogene actoren en entiteiten worstelen om coherentie binnen hun veelzijdige relaties en netwerken te organiseren. Hoewel een dergelijk begrip van openbaarheid een zeer breed terrein omvat en ook fundamenteel 'open' is, zal deze bijdrage - gelet op de beschikbare ruimte en tijd - zich beperken tot het ruimtelijk openbaar bestuur in de hiervoor beschreven actor-relationele setting. Cruciaal is ook hier dat het bestuur niet buiten of boven die openbaarheid staat, maar in zijn beleid, regels en acties zelf onderdeel is van die actor-netwerken.

Een dergelijk begrip van openbaar bestuur komt zeer dicht in de buurt van de urban regime theoretici (Stone 1989; Stoker, Orr 1994; Mollenkopf 1994; Mossberger, Stoker 2001; Hamilton 2004; Stone 2005). Die traditie start feitelijk bij Edward Banfield (1961) en Robert Dahl (1961) die bij de beantwoording van hun vraag 'Who Governs?', tegen de toen dominante (structuralistische) benaderingen in argumenteerden dat het stedelijk politieke systeem niet langer gedomineerd werd door een verticale oligarchie van een relatief kleine groep van politiekeconomische elites, maar door een meer pluralistisch, horizontaal systeem, 
waarbij een veel grotere variëteit aan allerhande belangengroeperingen in al dan niet wisselende coalities elkaar bestreden om politieke macht. Hier verschoof de aandacht van de structurele gronden voor politieke macht naar de wijze waarop besluitvormingsprocessen plaatsvonden, wie participeerden en wiens belangen uiteindelijk werden gediend. Die pluralistische benadering werd echter ook van meet af heftig bekritiseerd door structuralisten van diverse pluimage; omdat die zich daarbij onvoldoende rekenschap gaf van de wijze waarop de precieze relaties tussen staat en de onderliggende sociaaleconomische verhoudingen de politieke agenda bepaalden; omdat steden en derhalve stedelijke politiek c.q. haar beleidsprocessen niet beschouwd konden worden als afzonderlijke entiteiten, maar onderdeel zijn van grotere, thans zelfs mondiaal opererende (her)structureringsprocessen; en omdat in de beschouwing van beleidsprocessen de kansarmen buiten beschouwing bleven, die geen enkel middel hadden om in de stedelijke politiek te interveniëren (Bachrach en Baratz 1962; Peterson 1981; Harvey 1985). De urban regime analyses kunnen in dat debat gezien worden als een poging om tussen deze twee extreme polen van pluralistische heterogeniteit en structureel determinisme te navigeren. Agency en structure zijn dan ook twee begrippen die we herhaaldelijk bij de regime-theoretici kunnen terugvinden. Zij gaan uit van de overtuiging dat in toenemende mate heterogene en wisselende coalities tussen elites en diverse belangengroeperingen ontstaan rond steeds meer verschillende (maatschappelijke) vraagstukken, maar dat die coalities ook worden bepaald door structurele beperkingen en/of mogelijkheden die met de plaatselijke conjunctuur en/of haar positie in grotere netwerken te maken heeft. De precieze vorm of compositie van een stedelijk regime varieert in deze zin en volgens de regimetheoretici dan ook van stad tot stad, maar is in alle gevallen afhankelijk van of pas slagvaardig in zoverre het in staat is voldoende draagvlak bij de betrokken belangengroeperingen te creëren en tegelijkertijd adequate economische middelen daartoe in te zetten. ${ }^{4}$ In dit kader spreken Savitch, Kantor en Vicari (1997) van 'bargaining environments' die bepaald worden door de specifieke wisselwerking tussen de lokale belangengroeperingen, economische condities en leidende actoren aan de ene kant en intergouvernementele instituties en regime-dynamiek aan de andere kant; kortom opererend in de driehoek actoren-netwerken-instituties. Zij onderscheiden op deze wijze acht soorten regimes afhankelijk van structurele factoren (zoals onderhandelingscontext, participatiegraad, economische condities) en specifieke regime-karakteristieken (zoals coalitiepartners, leidende partijen en de mate van aanwezigheid van een publieke agenda): i.c. planner, distributor, grantsman, clientelist, radical, vendor, commercial en free-enterprise regimes.

Desondanks is de urban regime theorie in proactieve zin ook wel bekritiseerd dat het tendeert naar een selectieve distributie van (materiële) incentives en een achterkamertjespolitiek, waarbij publieke en private partijen, al dan niet in combinatie met wisselende maatschappelijke belangengroeperingen, verstrekkende afspraken maken zonder een brede democratische controle, of op zijn best met één 
achteraf (Sartori 1991; Imbroscio 1998; Davies 2002). Derhalve heb ik in The Urban Connection (2009) betoogd om de urban regime theorie ook nadrukkelijker in verband te brengen met het pleidooi voor een associative democracy van Cohen (1992), Rogers (1992), Hirst (1994, 2001), Bader (2001) en anderen. Dit pleidooi van een associative democracy vertrekt immers vanuit de overtuiging dat 'individuele vrijheid en algemeen welzijn' in de huidige tijd van pluralistische belangen en gefragmenteerde complexiteit het beste gediend zijn, als zoveel mogelijk zaken georganiseerd worden door vrijwillige, maar zelforganiserende open associaties in de public, business en civic society. In hun ogen zou associative democracy in staat zijn de steeds grotere kloof tussen staat en samenleving te overbruggen door het openbaar bestuur te 'pluraliseren' en de zich steeds autonomer ontwikkelende samenwerkingsverbanden (de regimes) in de (netwerk)samenleving meer publiek en transparant te maken. Tegelijkertijd zou het aansturen op een democratisch model van governance door zowel in de publieke als private sfeer een bottom-up perspectief te bieden voor een zelforganiserende efficiency, in de agency-structure context zoals door de urban regime theoretici geschetst (Cohen en Rogers 1992; Hirst 2001; Bader 2001).

Ten tweede is de urban regime theory ook wel bekritiseerd vanwege het feit dat het te veel ontleend zou zijn aan de specifieke setting en context in de USA en dat het bijvoorbeeld in de Europese setting niet zou werken (Strom 1996; Gissendanner 2004). De situatie in veel Europese landen, zoals bijvoorbeeld die in Duitsland, Nederland of Scandinavië, zou gebaseerd zijn op een geformaliseerde rechtstaat, waarbij een gespecialiseerde bureaucratie feitelijk de formatie van stedelijke coalities conditioneert. Anders dan in de USA zou de nationale overheid via nationale richtlijnen, subsidies en verboden een veel nadrukkelijker rol hebben in de inrichting van het land. Anders dan in de USA zouden sociaal geëngageerde partijen of belangengroeperingen hier niet zozeer het natuurlijk tegenwicht vormen voor een vaak kapitalistisch geïnspireerde 'groeipolitiek', maar deze juist ook zelf in een eigen agenda opnemen. Waar er in Europa een sterk bewustzijn aanwezig zou zijn voor de waarde van de stadsstructuur als geheel, zouden in de USA vooral de geëngageerde real-estate developpers de helden van een goede stadsuitleg zijn (Strom 1996). Niettemin laten juist Savitch, Kantor en Vicari (1997) zien dat hier niet zozeer sprake is van een tegenstelling, maar eerder van een andere samenstelling of een ander accent van het regime. Daarenboven geven zij ook in hun analyse van de werking van regimes in diverse Europese steden aan dat dit al naargelang de omstandigheden - zoals bijvoorbeeld bij economisch krimp of het falen van (volledige) rechtszekerheid - tevens kan veranderen. Sterker nog, juist in Europa, zou al naargelang de behoefte en mogelijkheden het perspectief van vrijwillige associaties gericht en stap voor stap uitgebreid kunnen worden en niet in de plaats van, maar naast het bestaande systeem van algemene rechtszekerheid en periodieke (representatieve) verkiezingen - de zogenoemde 'representatieve democratie' - kunnen worden geplaatst (zie tevens Hirst 2001). En ook in termen van 
Actor-Relational Planning (ARP) gaat het niet om het afschaffen van de verdiensten van de WRO en traditionele planologie op het gebied van algemene rechtszekerheid en transparantie, maar om het daarnaast nadrukkelijk op-en uitbouwen van nieuwe vormen van gemeenschappelijke (public-business-civic) associatie op specifieke thema's en vraagstukken van de actuele netwerksamenleving. Het kan daarbij bovendien evolutionair bouwen op vormen van maatschappelijk betrokken semipublieke of semiprivate associaties die voor de Tweede Wereldoorlog, ook in Nederland, zeer gebruikelijk waren: zoals bijvoorbeeld de waterschappen, de corporaties en concessie-districten (De Klerk 2008; Boelens 2009). Vernieuwing naar de actuele institutionele vereisten, context en actor-netwerkverhoudingen blijft evenwel permanent nodig.

\subsection{EEN DELTA-HAVENASSOCIATIE}

Neem bijvoorbeeld de havenconjunctuur. De innovatieve transitie van stapelplaats naar doorvoerhaven aan het eind van de negentiende eeuw werd niet zozeer gestimuleerd door de overheid of het zittende bedrijfsleven, maar door nieuwe, energieke en modern opgeleide ondernemers van buiten de gemeenschap (Plate 1934). De actor-netwerken van de zittende regenten, politici, bankiers en koopvaarders waren aanvankelijk zelfs tegen, omdat het hun gevestigde belangen en posities zou ondermijnen (Van der Laar 200o). Deze waren indertijd immers in belangrijke mate gestoeld op persoonlijke netwerken van familieleden, die zich niet alleen hadden gevestigd in de belangrijkste havensteden, maar ook in andere hoofd- en ambachtssteden (Lesger 1999). Met het toenemende productievolume als gevolg van de eerste industrialisaties en de daarmee gevraagde efficiëntere doorvoercapaciteit, waren deze traditionele actor-netwerken in hun patriarchale institutionele setting echter niet langer toereikend. Meer dan in de andere Hollandse havensteden kwam daartoe vooral in Rotterdam een relatief nieuwe en moderne groep ondernemers op, de cargadoors, die voor de beoogde transitie de drijvende kracht werden. Het waren ondernemers die zich bezighielden met het verplaatsen en opslaan van scheepsladingen en oorspronkelijk dicht in de buurt van de traditionele koopman stonden. Maar de industrialisatie had tot een scheiding van de functie van koopman en rederij geleid, waarbij de cargadoors precies in dat gat sprongen. Zij organiseerden het laden en lossen van de schepen voor de reder, alsook de opslag en het vervoer van de goederen voor de koopman. Tevens verzorgden zij de proviandering of bemiddelden ze bij scheepsreparaties. De effectiviteit en snelheid waarmee dit gebeurde gaf de haven van Rotterdam een cruciale voorsprong op zijn West-Europese concurrenten. Zij waren immers in staat buiten de oude patriarchale netwerken om slagvaardige relaties op te bouwen met tal van leidende en doorslaggevende maritieme en economische productieactoren, zowel in het voor- als in het achterland. Tegelijkertijd wist deze nieuwe opkomende elite van 'havenbaronnen' hun bedrijvigheid ook goed in te bedden in de stedelijke samenleving. Net als het traditionele patriarchaat van kooplieden onder- 
hielden zij constructieve verhoudingen met politiek en bestuur, die hun eindelijk ook min of meer ging faciliteren. Maar daarnaast speelden ze ook een prominente rol in het maatschappelijke en culturele leven van de stad. Ze realiseerden imposante projecten, zoals musea, een dierentuin, een voetbalstadion, ziekenhuizen, scholen, tuindorpen en openbare werken. Dit was natuurlijk deels ook ingegeven door banale economische en politieke motivaties: een gezonde en gelukkige arbeider zou beter produceren en minder neigen naar het revolutionaire gedachtegoed. Maar die instelling kwam volgens Len de Klerk ook voort uit weinig orthodoxe opvattingen over godsdienst en religie, en sloot aan bij het rationele geloof in vooruitgang en de verlichte 'zelfinteresse' om goede werken te verrichten (De Klerk 1998). Het markeert het liberale gedachtegoed van zelfverantwoordelijk burgerschap en de collectieve notie van een bottom-up 'concullega' openbaar bestuur - van elkaar beconcurreren waar het kan en samenwerken waar het moet die eigenlijk van oudsher al de delta-mentaliteit bepaalden (Boelens en Taverne 2009).

In dit licht bezien is de door Maynard Keynes ingegeven notie van de verzorgingsstaat, en de van overheidsgegeven verticaal georganiseerde vormen van rationele planning, die vanaf de Tweede Wereldoorlog en vooral vanaf de jaren zestig de havenontwikkeling structureerde, niet meer dan slechts een tijdelijke hick-up in een langere geschiedenis van maatschappelijk verantwoord ondernemerschap. Het Plan 2000+ (1969), Kustuitbreiding (1982), 1ste-, 2de- en 3de-lijnsknooppunten (1991) enzovoorts, lijken sinds de privatisering van het Gemeentelijk Havenbedrijf Rotterdam in 2004 immers al weer ver verleden tijd. Tegelijkertijd hebben de vooroorlogse havenbaronnen inmiddels het veld geruimd voor andere, meer transnationaal opererende buitenlandse spelers (Kreukels en Wever 1998). Niettemin blijkt de notie van noodzakelijke overheidsinterventie en waar nodig overheidssturing hardnekkig; wellicht vooral ook ingegeven door de huidige en afgelopen financiële en economische crises. Zo hebben de ministeries van VROM, EZ en v\&W elkaar thans weer gevonden in het beleidsstreven te komen tot een stringentere samenwerking tussen de diverse Nederlandse havens (VROM 2008; EZ 2009; V\&W 2009). Aanleiding wordt gevormd door de verwachte verdubbeling van de goederenstromen en een verviervoudiging van het te verwerken aantal containers in de komende dertig jaar. Gegeven de (maatschappelijke) kosten van de verbindingen in het achterland en het verwachte marktfalen op het gebied van duurzaamheid, een optimale benutting van ruimte en rijksinfrastructuur, en het voorkomen van buitensporige marktmacht, zou er voldoende legitimatie zijn om van overheidswege samenwerking van havens gericht te bevorderen, zo wordt gesteld. Dit zou dan kunnen resulteren in een hogere bezettingsgraad van terminals, specialisatie en efficiënt gebruik van de verbindingen in het achterland (кiм 2009). Van Rijn wijst er echter nu al op dat dit bij de betreffende havenbedrijven nog niet zo gemakkelijk te realiseren is; laat staan voor de aldaar gevestigde prominente en thans meer footloose georiënteerde maritieme ondernemers. De havens zouden bij 
navraag huiverig zijn voor een nationale holding, op onderdelen of concrete dossiers mogelijk nog wel tot coöperatie geneigd, maar dan daarbij eerder geïnteresseerd in strategische allianties met Belgische of Duitse havens dan met hun Nederlandse collega's (Van Rijn 2009). Bovendien wordt een groot deel van hun ontwikkeling al niet meer door de havenbeheerders zelf bepaald en is de (logistieke, ruimtelijk-economische en institutionele) context al een wezenlijk andere dan in het gezamenlijk ministerieel beleid en het kim-rapport wordt gesuggereerd.

Ten eerste is het maatschappelijk draagvlak voor (uitsluitend) doorvoer sterk tanend. Met logistieke activiteiten zelf wordt immers steeds minder verdiend. Het is een commodity geworden - een goed dat in al zijn hoedanigheden overal verkrijgbaar is - waarbij als gevolg van de toenemende internationalisering, de winstmarges steeds kleiner zijn geworden. De Nederlandse logistieke vrachtwagensector maakt dan ook sinds jaar en dag verlies en wordt in toenemende mate vervangen door operators uit Oost-Europa en andere lagelonenlanden, die met lagere kosten kunnen werken (NEA 2009). Door de in de afgelopen periode doorgevoerde automatisering is daarnaast het aantal (in)directe arbeidsplaatsen in en om de haven sterk afgenomen, onder een gelijktijdige toenemende verkeershinder en milieubelasting. Het resulteert in een situatie waarbij de lasten nog steeds sterk toenemen, maar de lusten structureel dalen. In die context is het dus nog maar de vraag of een verdubbeling of verviervoudiging van de doorvoer door de steeds pluriformer en mondiger Nederlandse samenleving nog wel geaccepteerd wordt.

Ten tweede - en zoals gezegd - laten ook de bepalende en leidende maritieme ondernemers zich thans weinig gelegen liggen aan welk nationaal of regionaal beleidsstreven dan ook. Die actoren bepalen thans eerder het beleid in de havens dan andersom. Hier dient niet alleen gewezen te worden op de enorme schaalvergroting en alliantievorming, die zich in de afgelopen tien jaar bij de maritieme carriers hebben voorgedaan. Zo beheersen de Deense Maersk-Sealand en de Franse CMA-CGM Group, samen met vier andere Aziatische global alliances (de New World, Grand, CYKHS en MCN Alliance) thans meer dan tweederde van de totale maritieme containermarkt met bijna 50 procent van alle containerschepen op de wereld (AXS 2009). Tegelijkertijd zijn hier grote Transnationale Terminal Operators opgekomen - zoals Hutchison Port Holdings, PSA International, Dubai Port World, Cosco Terminal Operations en APM Container Terminals - die (soms in opdracht van de voornoemde moederrederijen) zelf de gewenste havenfaciliteiten op verschillende plekken in de wereld bouwen en in beheer nemen. Daarbij hanteren ze eigen logistieke strategieën (zoals een point-to-point, hub \& spoke of multihub netwerk) gedicteerd door hun hoofdkantoren elders op de wereld; dit alles ongeacht of op zijn best alleen lettend op de restricties van het betreffende nationaal en regionaal beleid. 
Tenslotte is ook de havenpopulatie zelf steeds gevarieerder geworden. Een recent onderzoek van de Universiteit Utrecht in samenwerking met de Stratagem Groep laat zien dat bijvoorbeeld de Rotterdamse haven in de afgelopen 25 jaar een uitermate dynamische economie is geworden, waarbij ondanks de voor havens vaak benodigde langetermijninvesteringen nog niet eenvijfde van de bedrijven uit 1984 thans op dezelfde plek is terug te vinden (Atzema et al. 2009). Tegelijkertijd hanteren deze havenondernemers ook zelf steeds meer wisselende bedrijfsstrategieën, waarbij soms activiteiten van toegevoegde waarde verschuiven naar de bron, in het voorland (zoals bijvoorbeeld bij de petrochemie) en in een ander geval juist steeds meer naar de consument in het achterland (zoals bijvoorbeeld bij de fooden sappenlogistiek). Innovatieve cluster- en netwerkvorming in de traditionele haveneconomie vindt derhalve steeds minder in de haven zelf plaats. Omgekeerd komen in de haven echter ook steeds meer stedelijke diensten en activiteiten op, die zich (potentieel) 'vermengen' met traditionele havenactiviteiten. ${ }^{5}$

Tegen deze achtergrond, mede gelet op het hiervoor beschreven relationele perspectief van actoren-netwerken-instituties, concludeert het rapport dan ook dat de huidige institutionele setting en governance-structuur in de havenstad Rotterdam te weinig gedifferentieerd is en te veel uitgaat van het aansturen door de overheid of aan de overheid gerelateerde instellingen. ${ }^{6}$ Ook het beleidsstreven naar een nationale havenalliantie gaat daarvan wederom uit. Die inzet en die strategie doen volgens het rapport geen recht aan de recente evolutionaire ruimtelijkeconomische ontwikkeling van havens (Atzema et al. 2009: 89). Juist ook gegeven de eigen havendoelstellingen om enerzijds een blijvende vooraanstaande marktpositie in de mondiale scheepvaart te behouden en om anderzijds ook een veelzijdige, duurzame en kennisintensieve kwaliteitshaven te worden (Gemeente Rotterdam/Havenbedrijf Rotterdam 2004), is daarnaast een veel meer gedifferentieerde, open en relationele governance van die (semi)openbare besturen gewenst, die aansluit bij de (potentiële) actor-netwerken in de onderscheiden deelgebieden. In het verlengde van de bovenbeschreven dynamiek binnen de maritieme sector wordt hier zowel gewezen op de noodzaak van een samen met de betrokken havengebruikers te ontwikkelen 'upscaling' rond specifieke thema's voor bijvoorbeeld de Rijn-Maas-Schelde-delta of de Le Havre-Hamburg Range op het gebied van bijvoorbeeld duurzame bio-energie c.q. de logistieke modellen van de Transnational Terminal Operators. Tegelijkertijd wordt hier gewezen op de noodzaak van een geëngageerde 'downscaling' naar verschillende gebieden en thema's binnen de haven, rond innovatieve en bepalende actor-netwerken; ruimtelijkeconomisch onderscheiden naar co-siting (gericht op het fysiek samenbrengen van activiteiten door het gezamenlijk gebruik van aanwezige restruimten), cosourcing (gericht op het functioneel samenbrengen van activiteiten door het gezamenlijk gebruik van productiemiddelen) en co-flowing (gericht op het in netwerken samenbrengen van activiteiten door het gezamenlijk gebruik van informatie en kennis). Voor elk van die actor-netwerken is een specifiek eigen 'governance' 
gewenst die niet langer of op zijn minst niet alleen gericht is op het (geformaliseerd) genereren van inkomsten via havengelden, maritieme diensten en landlease c.q. het garanderen van voldoende rechtzekerheid daartoe, maar vooral op 'incentives' die bedoeld zijn om de gewenste veelzijdig kwaliteiten te realiseren, zoals bijvoorbeeld de uitonderhandeling van langlopende gebruikerscontacten, heffingen versus bijdragen in de beladingsgraad van heen- en retourstromen, reductie van de land-lease rate en afroming van winstmaximalisatie bij co-siting, contract-incentives bij open-source kennisdeling, risico-investeringen in veelbelovende duurzame innovaties, enzovoorts (Atzema et al. 2009: 85). Het relationele van het openbaar besturen zou hier dan niet alleen tot uitdrukking moeten komen in de wijze waarop het zelf een onlosmakelijk deel kan worden van die slagvaardige en vernieuwende actor-netwerken rond specifieke thema's en/of gebieden c.q. gebiedsregio's. De hiervoor genoemde associatieve democratische verankering en legitimiteit zouden daarvan onderdeel kunnen worden. Tegelijkertijd komt die relationaliteit dan ook daarin tot uitdrukking in hoeverre het in staat is de onderlinge interacties tussen de verschillende gebieden of thema's te leggen en waar nodig of gewenst in te brengen in de betreffende actor-netwerken, mogelijk leidend tot nog meer robuuste en krachtige translaties, enzovoorts.

\section{5 .5 RUIMTELIJK OPENBAAR BESTUUR ALS EEN RELATIONELE COMPLEXITEIT}

Deze actor-netwerk-relationaliteit, en vooral het gebrek aan een adequaat openbaar bestuurlijk antwoord daarop, is thans aan de orde voor tal van ruimtelijke vraagstukken; en dan niet alleen op het niveau van de mainports. Neem bijvoorbeeld de zo gewenste 'schaalsprong Almere'. Maar al te snel is dat vraagstuk gedecimeerd tot een overheidsintern handjeklap, waarbij een lokale toezegging om de bouw van 60.000 woningen mogelijk te maken staat tegenover een eventuele bijdrage van de zijde van de nationale overheid in een 2 tot 4 miljard euro begrote light-rail verbinding dwars door het IJ; zo alsof het een of het ander daadwerkelijk een 'schaalsprong' kan bevorderen, laat staan garanderen.7 Neem bijvoorbeeld het initiatief van Stedenbaan in de Zuidvleugel van de Randstad. Maar al te snel is dit op zich waardevolle initiatief gedecimeerd tot een onderhandeling tussen betrokken overheden en semi-overheidsinstellingen als NS en Prorail over een beoogde intensivering van programma's rond de stations; daarmee volstrekt voorbijgaand aan de zich autonoom ontwikkelende diversiteit aan mobiliteitsstijlen (Verburg et al. 2005) en de eigen dynamiek van beheerders, ontwikkelaars en bewoners op de betreffende gebieden (Urban Unlimited 2005, 2007). Neem bijvoorbeeld het Deltaprogramma IJsselmeergebied. Maar al te snel lijkt ook dit programma weer de speeltuin te worden van betrokken overheden en waterschappen, terwijl juist het duurzaam waterbeheer in deze delta van de Rijn, Maas en Schelde tot voor kort een van de meeste prominente en succesvolste voorbeelden van Common Pool Resource Management was (Raadschelders en Toonen 1993). In termen van de 
complexiteitstheorie (Prigogine en Stengers 1984; Byrne 1998; Portugali 2000; Teisman et al. 2009) is hier telkens weer sprake van een te oversimpele en traditionele reductie van een in feite complex vraagstuk tot een veronderstelde lineaire relatie tussen oorzaak en gevolg (6o.ooo wo + lightrail = 'schaalsprong'), terwijl de werkelijkheid veel ingewikkelder, dynamischer en ook van toevalligheden in elkaar zit. Het vooral intern gefocuste openbaar bestuur mist daarmee niet alleen innovatieve en veelbelovende associaties in de samenleving, maar vervreemdt zich ook daarvan. Het maakt zich in een steeds meer dynamische, netwerkgerichte en zelforganiserende samenleving feitelijk overbodig. Het functioneert op zijn best alleen nog als een financiële achtervang in tijden van crisis. En dat is jammer, want daarmee zal de samenleving naar verwachting ook minder transparant en democratisch worden, minder samenhangend en meer gefragmenteerd.

In de plaats daarvan zie ik 'een tweede (of wellicht beter: volgende) toekomst' voor me richting een relational, of wellicht ook wel complexity turn van het ruimtelijk openbaar bestuur. Een dergelijk ruimtelijk bestuur

- is fundamenteel open, outside-in, in plaats van de gebruikelijke premissen op de (relatief) gesloten, afzonderlijke systemen van publiek en privaat, de internationale, nationale, regionale en lokale agenda, en de verschillende departementen en sectoren daarbinnen;

- gaat uit van de premisse dat (bestuurlijke) macht niet het attribuut is van agents of agencies, maar van netwerken; dus van associaties, waarbij het niet als onpartijdige scheidsrechter opereert, maar zelf onderdeel is van die actor-netwerken;

- is gefocust, op specifieke concrete vraagstukken naar tijd en plaats, in plaats van op grote thema's van algemeen belang en welzijn, waarbij het zijn eigen corebusiness inbrengt op het gebied van draagvlak en rechtzekerheid, naast de middelen en belangendeling van de business en civic society;

- is daarmee ook door en door gefragmenteerd en gedifferentieerd, niet naar sfeer, schaal of sector, maar naar vraagstuk, thema of kans en de daarmee mogelijk verbonden ruimtelijke regimes, structuren en incentives;

- staat uiteindelijk ook aan de lat voor een zekere mate aan re-clustering, in de vorm van bijvoorbeeld Luhmanns notie van de autopoiesis (Luhmann 1990), waarbij de verschillende zelforganiserende actor-netwerken ook bijdragen aan de transformatie van de andere actor-netwerken in de samenleving tot mogelijk verassende vormen, maar wel een grotere mate aan robust complexity.

Een dergelijke nieuwe toekomst voor het ruimtelijke openbaar bestuur behoeft niet van de ene op de andere dag ingevoerd te worden. Het kan net als bij (en zo mogelijk complementair aan) de notie van associative democracy, stap voor stap naast en in aanvulling op de bestaande vormen van representatieve democratie en de bestaande vormen van wet- en regelgeving evolutionair, al naargelang de behoefte en mogelijkheden tot ontplooiing komen. Gegeven de ervaringen met de eerste initiatieven in die richting (Boelens 2009) lijkt daartoe niet zozeer het 
bestuur, maar vooral de achterliggende 'vierde macht', de ambtenarij en daarbinnen ontwikkelde padafhankelijke bureaucratie de belangrijkste bottleneck. Vooral in die richting lijkt me een nadere verdieping van deze eerste verkenning van de WRR nodig. Hoe kan vooral binnen de bureaucratie evolutionair gekomen worden voorbij de lock-in en tot een relationele vernieuwing van openbaar bestuur. Want hier gaat het niet om 'centraal wat moet, decentraal wat kan', een onderscheid tussen 'nationale projecten, ontwikkelings- en basisgebieden', noch om een lagen benadering, waarbij de 'droge voeten' laag en die van infrastructuur een taak van de (nationale) overheid zouden zijn en de occupatie en culturele lagen een taak voor andere actoren en domeinen. In een wereld van 'glocal complexity', fundamentele fragmentatie, dynamische actor-netwerken en vele centra, is immers niet op voorhand generiek te zeggen wat 'des centrums' en wat voor de periferie is; wat door ons en wat door hen ter hand genomen dient te worden. Ik heb me altijd al afgevraagd, waarom het VNO/NCW, indien zij bij monde van Bernard Wientjes de Rijksweg A4 Midden Delfland zo graag gerealiseerd ziet (interview VNO/NCW 2008), het draagvlak, de middelen en compenserende maatregelen daartoe niet zelf organiseert. De overheid (lees de ministeries van VROM en V\&W) kan bij succes de associatie dan altijd nog op de achterhand via wetgeving en jurisprudentie faciliteren. Omgekeerd geldt precies hetzelfde bij de bouw van bijvoorbeeld HST-stationsomgevingen of de Zuidas van Amsterdam, indien deze van cruciaal belang worden geacht voor de internationale concurrentiekracht van dit land. De keuzes daartoe - en wie of wat daartoe als attractor, leading of focal actor opereert - worden niet zozeer vooraf, maar eerder in de loop van het proces afhankelijk van tijd, plaats en vraagstuk - bepaald.

Sterker nog, in een degelijke nieuwe toekomst voor het ruimtelijk bestuur behoeven regering en parlement, wethouder en raad zich, in een al dan niet dualistisch stelsel, niet te beperken tot structuur- en wetgeving en/of toelatings- en verantwoordingsplanologie. Op termijn kunnen zij zich daarnaast potentieel ook als een van de partners profileren binnen en/of bij de voorbereiding van wisselende actor-netwerken op veelsoortige deelterreinen en ruimtelijk maatschappelijke vraagstukken. Doel daarvan is om uiteindelijk ook geen enkelvoudige, maar breed public-business-civic gedragen en daarmee robuuste ruimtelijke voorstellen te verkrijgen. Deze kunnen dan uiteindelijk en (bij goede voorbereiding waarschijnlijk) ook snel 'afgetikt' worden binnen de geformaliseerde structuren van representatieve democratie.

Hetzelfde is het geval bij de grensoverschrijdende en Europese ruimtelijke aangelegenheden. In plaats van wederom te vervallen in de op traditionele leest geschoeide, bureaucratische en de geld en tijd verslindende programma's als die van de European Spatial Developement Perspective (ESDP), INTERREG, Europees Fonds voor Regionale Ontwikkeling (EFRO), Trans Europese Netwerken (TEN) et cetera (vgl. hier bijvoorbeeld de onder redactie van Wil Zonneveld en Frank Evers 
uitgebrachte reeks NIROV-Europlan in de jaren 1990), lijkt het zinvoller op zoek te gaan naar concrete en doorslaggevende associaties met prominente leidende actoren in de business (TNC's) en civic society (INGO's) op dat schaalniveau. Het hiervoor genoemde voorbeeld van de gewenste 'upscaling'van havenbestuur tot verantwoorde en slagvaardige associaties in de Eurodelta of Hamburg-Le Havre Range is daarvan een voorbeeld.

Resteert dan nog de eis van maatschappelijke verantwoording en transparantie van al die ogenschijnlijk toevallig opkomende en willekeurig geleide regimes. Velen hebben hier reeds gewezen op de instant en overzicht verschaffende mogelijkheden die internet en GIS/GPS daartoe bieden (zie o.a. Byrne 1998: 148; Urry 2003: 112-113). Maar zoals Wies Sanders, in het verlengde van onder anderen Deleuze, Guattari en Hillier, al eens elders heeft beargumenteerd, lijkt me dat volstrekt onvoldoende (Deleuze, Guattari 1980; Hillier 2009; Sanders 2009). Internet, GIS/ GPS gaan immers vooral over 'tracing' (over zaken waarover men in retrospectieve zin kan worden geïnformeerd), niet over 'mapping' (mogelijke associatieve kansen en mogelijkheden), 'agencying' (specifiek geformeerde regimes, regels en institutionele settingen daartoe) en 'diagramming' (de wijze waarop de actor-netwerken en associaties transleren). Maar dat is eigenlijk de opmaat voor een volgende bijdrage. Want hier is nog een wereld te winnen en dergelijke dataverwerking en kaartenmakerij lijken me ook in de transitie naar een nieuwe toekomst van het ruimtelijk openbaar bestuur - en zijn blijvende en/of te verbeteren transparantie - feitelijk onontbeerlijk. 


\section{NOTEN}

Volgens Cliff Hague (2002: 2) is zelfs Hippodamus van Miletus 450 voor Christus de eerste stedelijke planner van Europa.

Onder de public community wordt hier vooralsnog die gemeenschap verstaan die verbonden is met het doen en laten, c.q. met de actor-netwerken van de overheid. Zij wordt uiteindelijk en in laatste instantie afgerekend op het vote-winning principe. De business community is dan de gemeenschap verbonden met ondernemersland; in laatste instantie gefocust op het moneymaking principe. De civic community is hier tenslotte de zich meer vrijelijk en vaak informeel georganiseerde netwerken van de burgers; vaak gefocust op interest-sharing. Alhoewel hiertussen natuurlijk tal van overlappingen voorkomen, fusies en tussenvormen, is het voor dit betoog wel structurerend gelet op de verschillende motivaties en drijfveren die achter die wisselende actor-netwerken schuilgaan.

3 Een begrip van Deleuze en Guattari (1980) om aan te geven dat de huidige openbaarheid zowel iets heeft van de chronologische wereld (de kosmos), als iets van de ongeordende, anachronistische wereld (de chaos).

Een regime wordt door Clarene Stone (1989) dan ook gedefinieerd als 'the informal arrangement by which public bodies and private interests function together in order to be able to make and carry out governing decisions'.

Zie o.a. Rotterdam Stadshavens

6 Ook het in 2004 geprivatiseerde Havenbedrijf Rotterdam is immers nog steeds voor 100 procent in eigendom van de overheid; $1 / 3$ van het rijk en $2 / 3$ van de gemeente Rotterdam.

Overeenkomstig de hier gegeven inzet lijkt die beoogde 'schaalsprong tot de vierde grootstad van Nederland' eerder afhankelijk van autonome en zichzelf organiserende associaties in de Almeerse bevolking en bedrijvigheid, zich positionerend in grotere grensoverschrijdende actor-netwerken, en waar nodig dan geflankeerd door openbaar beleid in het mogelijk maken of bevorderen van (ik noem maar een paar opties) een eventuele overloop van het origin-destination verkeer van Schiphol naar de luchthaven Lelystad/Almere, een eventuele doortrekking van de HSA naar opstelplaats Almere-Buiten, condities voor een optimale clusternetwerkvorming van bepaalde leidende bedrijfssectoren in Almere, bijdragen aan een gericht en Flevo-eigen festival- en eventbeleid, een ruimtelijk ontwikkelingskader voor de bevordering van unique selling points, enz. Elk van deze onderdelen vraagt - indien aan de orde - feitelijk om een eigen actor-netwerk-regime, waarbij het openbaar bestuur potentieel slechts een van de vele actoren is; niet meer en niet minder. De vraag hoeveel woningen er dan precies gebouwd moeten worden, dan wel of er daartoe een nieuwe peperdure light rail verbinding nodig is, lijkt eerder afhankelijk daarvan, dan omgekeerd. 

6 'T IS MAAR WAT JE DEMOCRATIE NOEMT...

W.L. Tiemeijer ${ }^{1}$

"Democratie in Nederland? Wat een lachertje! Zeker 80 procent van de bevolking is voor strengere straffen. Dan zal de wetgeving toch heeeel snel aangepast moeten worden. Waarom gebeurt dit dan niet? Snap er niets meer van."

www.telegraaf.nl Anna, Groningen 18.01.10

"Wie heeft het nou voor het zeggen in dit maffe land? Volgens democratisch gebruik zijn dat de burgers. De overheid heeft niets anders te doen dan de wensen van de burgers uit te voeren. Daarvoor wordt ze met belastinggeld betaald. Burgemeesters en ambtenaren die dit niet willen dienen per onmiddellijk te worden ontslagen wegens werkweigering. Zo gaat dat in deze harde wereld."

www.telegraaf.nl Bert, Enschede 18.01.10

"PvdA killing voor dit weggegeven land. Snel de democratie herstellen."

www.telegraaf.nl Travis, Absurdland 18.01.10

Wie een tijdje rondzwerft in de virtuele wereld, kan gemakkelijk de indruk krijgen dat het beroerd is gesteld met onze democratie. Een flink deel der Nederlanders meent dat de wijze waarop wij thans worden bestuurd niets met democratie uitstaande heeft. De 'zakkenvullers' in Den Haag luisteren totaal niet naar het volk en zorgen vooral goed voor zichzelf.

Men kan over zulke reacties natuurlijk wat lacherig de schouders ophalen.

Verstandig is dat echter niet. Als 'gewone burgers' het politieke systeem in Nederland niet langer als legitiem ervaren, kan dat ernstige gevolgen hebben. Bovendien zijn de 'reaguurders' bepaald niet de enige die twijfels hebben over onze democratie. Wat op internet wordt geschreven, is een soms weinig subtiel uitgedrukte variant van de kritiek die al lange tijd in politieke, wetenschappelijke en journalistieke kringen valt te vernemen over de staat van onze democratie. Nederland is een 'democratie in verval' (Mudde en Holsteyn 2002) en met grote regelmaat verschijnen er rapporten met plannen om het vertrouwen in de politiek te herwinnen. Onlangs nog sprak de Raad voor Openbaar Bestuur (ROB) haar 'grote ongerustheid' uit over de 'legitimiteitscrisis' die de raad waarneemt, en pleitte voor meer directe democratie teneinde het tij te keren (RОв 2010). Kortom, het ongenoegen op de discussiefora op internet is deels gezonken cultuurgoed. 
Maar is het allemaal echt zo erg? Naast wetenschappers die de noodklok luidden, zijn er altijd andere wetenschappers die het hoofd koel houden en de nuchtere cijfers erbij halen. En daaruit blijkt steevast dat het reuze meevalt. De steun voor de democratie als politiek systeem om het land te besturen is in Nederland welhaast universeel, de tevredenheid over de wijze waarop de democratie in Nederland functioneert behoort tot de hoogste van Europa, en het vertrouwen in de politieke instituties is vergeleken met het buitenland ook dik in orde.

Kunnen wij derhalve rustig gaan slapen? Dat valt nog te bezien. Wie de cijfers beter bekijkt, wordt er niet geruster op. In het eerste deel van dit hoofdstuk zal ik een overzicht geven van de voor Nederland beschikbare cijfers en uiteenzetten waarom deze eigenlijk maar weinig zeggen. In het tweede deel van dit hoofdstuk presenteer ik enkele eigen nieuwe onderzoeksresultaten die meer zicht geven op wat er dan wél aan de hand is. Het derde deel ten slotte is een meer essayistische beschouwing op basis van het voorgaande. Ik zal betogen dat we wel degelijk een probleem hebben, zij het een probleem waarover tegenwoordig angstvallig wordt gezwegen.

\subsection{WAT WE WETEN OVER DE STEUN VOOR DEMOCRATIE?}

In veel westerse landen is men rond de jaren zeventig begonnen met systematische en longitudinale meting van attitudes ten aanzien van democratie en politiek. Zo ook in Nederland. De belangrijkste Nederlandse bronnen zijn het Nationaal Kiezersonderzoek (NKO) van de gezamenlijke universiteiten en de Culturele Verkenningen van het SCP. Als het gaat om internationaal vergelijkend onderzoek, wordt veel gebruikgemaakt van de Eurobarometer, de European Values Study (EVs) en de World Values Survey (WVs). ${ }^{2}$ Op basis van deze enquêtes is er het nodige internationaal vergelijkend onderzoek gepubliceerd over de ontwikkeling van de steun voor democratie en het vertrouwen in politiek (zie bijv. Kaase en Newton 1995; Norris 1999; Dalton 2004).

\section{Objecten van steun}

Een constatering waarmee deze literatuur vaak begint is dat begrippen als 'de politiek' of 'de democratie' veelvormig en gelaagd zijn. Wie een goed beeld wil hebben van de relevante attitudes moet een conceptueel onderscheid aanbrengen binnen deze begrippen. Easton (1965) onderscheidde in dit verband drie politieke objecten van steun: the political community, the regime en political authorities. Deze driedeling is door anderen, zoals Dalton, verder uitgebreid. Zij maken binnen de categorie the regime nog onderscheid tussen principles, norms and procedures en institutions. In totaal onderscheiden zij dus vijf verschillende politieke objecten van steun.

1 De politieke gemeenschap. Hier gaat het om de mate waarin mensen zich identificeren met een bepaalde politieke gemeenschap en zich daarmee verbonden 
achten. Een dergelijk 'wij-gevoel' is vooral belangrijk in tijden van politieke spanning, teneinde te voorkomen dat de politieke gemeenschap uit elkaar valt.

2 Regime: principes. Hier gaat het om de mate waarin men democratie als algemeen principe prefereert boven andere manieren om de gemeenschap te besturen, zoals bijvoorbeeld een theocratie, een dictatuur of een militair regime.

3 Regime: normen en procedures. Dit betreft de steun voor de wijze waarop de democratie is ingericht. Democratieën kunnen namelijk verschillen in hun veronderstellingen over de rol van burgers, de daaraan verbonden politieke rechten, de institutionele vormgeving en regels voor omgang met conflicten, enzovoorts.

4 Regime: instituties. Op dit niveau gaat het om de houding van mensen ten aanzien van politieke instituties, zoals de regering, het parlement, politieke partijen, de rechterlijke macht, los van de vraag welke personen op dat moment de belangrijke posities bezetten in deze instituties. Het is van belang dat men deze instituties waarneemt als legitiem en hun besluiten accepteert.

5 De politieke autoriteiten. Dit zijn de concrete personen die momenteel de belangrijke posities bezetten in de politieke instituties, zoals de huidige minister-president, de huidige minister van Financiën, de huidige parlementsleden, enzovoorts.

Om het allemaal nog ingewikkelder te maken wordt door veel wetenschappers ook nog eens per objectniveau een onderscheid gemaakt tussen twee typen van steun, namelijk concrete en diffuse steun (Easton 1965) respectievelijk evaluatieve of affectieve steun (Dalton 2004). In totaal zijn er dus maar liefst tien indicatoren die men longitudinaal moet meten voor een werkelijk compleet beeld van de relevante attitudes ten aanzien van democratie en politiek.

\section{De gegevens voor Nederland}

Hoe scoort Nederland op de diverse indicatoren? En hoe verhoudt zich dat tot de scores van andere landen? Daarop ga ik hieronder in. Om het enigszins overzichtelijk te houden, laat ik het onderscheid in typen steun buiten beschouwing, en richt ik me alleen op de vijf niveaus van steun.

We beginnen met het hoogste niveau: de steun voor de politieke gemeenschap. Die wordt in het internationaal vergelijkend onderzoek doorgaans gemeten met twee standaardvragen, namelijk hoe trots men is burger te zijn van het betreffende land, en of men bereid zou zijn in een situatie van oorlog voor dat land te vechten. In de tabel staan de antwoorden voor Nederland. Vergeleken met andere landen zijn de percentages niet opmerkelijk hoog of laag. 
Tabel 6.1 Objectniveau 1: De politieke gemeenschap

\begin{tabular}{|c|c|c|c|c|c|}
\hline & 1981 & 1990 & 1999 & 2005 & 2008 \\
\hline $\begin{array}{l}\text { Hoe trots bent u er op dat u Nederlander bent? } \\
\text { (Percentage 'zeer trots' plus 'tamelijk trots') }\end{array}$ & 66 & 77 & 80 & 79 & 87 \\
\hline $\begin{array}{l}\text { Natuurlijk hopen we allemaal dat er geen oorlog } \\
\text { meer komt, maar als er een zou komen, zou u dan } \\
\text { bereid zijn voor uw land te vechten? (Percentage 'Ja') }\end{array}$ & 44 & 60 & - & 35 & - \\
\hline
\end{tabular}

Bron: 1981,1990, 1999, 2008: European Values Study; 2005: World Values Survey

Het volgende objectniveau betreft de regime principes. In het internationaal vergelijkende opinieonderzoek worden als indicator daarvoor meestal twee vragen gebruikt, elk met vier subvragen (zie tabel 6.2). De antwoorden op de laatste subvragen (grijs gearceerd) worden beschouwd als indicator voor de steun voor democratie als regime. Uit de tabel blijkt dat een riante meerderheid der Nederlan-

\section{Tabel 6.2 Objectniveau 2: Steun voor het systeem}

\begin{tabular}{|c|c|c|c|}
\hline $\begin{array}{l}\text { Ik ga een aantal politieke systemen beschrijven en vragen wat u van } \\
\text { elk vindt als een manier om dit land te besturen } \\
\text { (percentages 'zeer goed' plus 'behoorlijk goed') }\end{array}$ & 1999 & 2005 & 2008 \\
\hline $\begin{array}{l}\text { Een sterke leider hebben die zich niet druk hoeft te maken om } \\
\text { het parlement en verkiezingen }\end{array}$ & 27 & 38 & 37 \\
\hline $\begin{array}{l}\text { Experts en niet de regering nemen besluiten op basis van wat } \\
\text { hen het beste lijkt voor het land }\end{array}$ & 40 & 47 & 51 \\
\hline Het leger het land laten besturen & 1 & 7 & 3 \\
\hline Een democratisch politiek systeem hebben & 97 & 85 & 92 \\
\hline $\begin{array}{l}\text { Ik ga een aantal dingen voorlezen die mensen soms zeggen over } \\
\text { een democratisch politiek systeem. Zou u willen aangeven in hoeverre } \\
\text { u het er mee eens of oneens bent? (Percentage: (zeer) eens) }\end{array}$ & & & \\
\hline In een democratie functioneert het economische systeem slecht & 8 & - & 13 \\
\hline Democratieën zijn besluiteloos en er wordt teveel gekletst & 42 & - & 50 \\
\hline Democratieën zijn niet goed in het handhaven van de orde & 22 & - & 22 \\
\hline $\begin{array}{l}\text { Democratie kan misschien problemen hebben maar het is beter dan } \\
\text { enige andere vorm van regeren. }\end{array}$ & 97 & - & 93 \\
\hline
\end{tabular}

Bron: 1999, 2008: European Values Study; 2005: World Values Survey 
ders democratie een goede manier vindt om het land te besturen. Er is echter een substantiële groep die het ook geen slecht idee vindt als het land zou worden bestuurd door een sterke leider of experts die zich weinig gelegen hoeven te laten liggen aan de politiek. Internationaal gezien zijn de Nederlandse scores allesbehalve uitzonderlijk. Ze liggen eerder in de buurt van het gemiddelde.

Dan het volgende objectniveau: normen en procedures. De vraag die wordt gebruikt om de prestaties op dit niveau te meten, luidt als volgt:

"De wijze waarop de democratie in Nederland functioneert, bent $\mathrm{u}$ daarover al met al zeer tevreden, tamelijk tevreden, niet zo tevreden of helemaal niet tevreden?"

Voor deze vraag is in de Eurobarometer inmiddels een lange reeks van data opgebouwd (zie fig. 6.1). Anders dan bij de vorige vragen neemt Nederland hier wél een uitzonderlijke positie in. Ons land behoort tot de Europese top qua tevredenheid.

\section{Figuur 6.1 Objectniveau 3: normen en procedures}

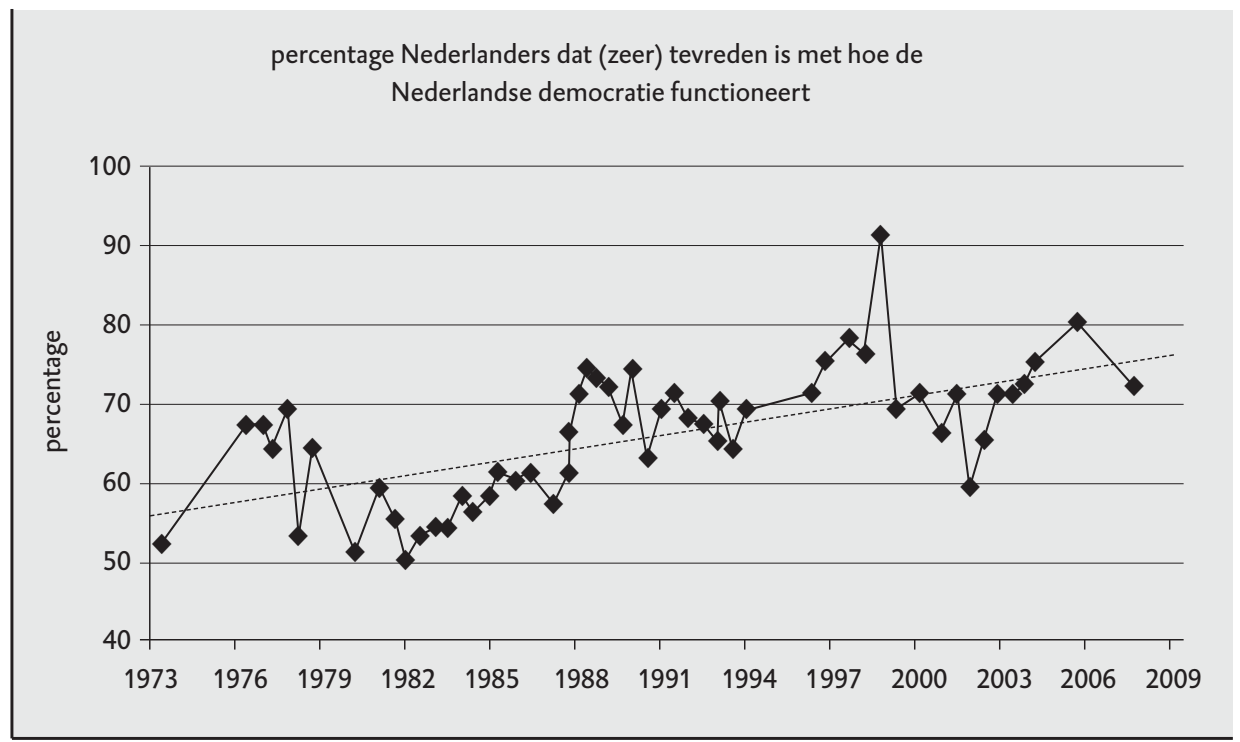

Bron: Eurobarometer

Daarna komt het op één na laagste objectniveau, te weten de steun voor de politieke instituties. Dit wordt doorgaans gemeten met de vraag naar de mate waarin men vertrouwen heeft in instituties zoals het parlement, de regering en politieke partijen. In de laatste meting van de Eurobarometer had 51, 49 respectievelijk 37 procent van de Nederlanders vertrouwen in deze politieke instituties. Deze 
scores lijken misschien niet zo hoog, maar liggen toch beduidend boven het Europees gemiddelde (zie ook tekstbox 6.1).

Tot slot het laagste objectniveau: het vertrouwen in de huidige politieke autoriteiten. Daarvoor geef ik hier geen cijfers. Als het gaat om de scores over concrete personen, bijvoorbeeld de 'rapportcijfers' voor premier Balkenende, Job Cohen of andere met name genoemde politici, kan men terecht bij de Maurice de Hondachtigen. Voor het vertrouwen in democratie en politiek zijn deze cijfers ook minder interessant. Het hoort nu juist tot de normale gang van zaken in een democratie dat de ene leider beter bevalt dan de andere, en dat men tegenvallende regeringen desgewenst bij verkiezingen naar huis kan sturen.

\section{Box 6.1}

\section{FF in een dipje?}

\section{FF in een dipje?}

Als het gaat om het vertrouwen in de Nederlandse politieke instituties gaven de laatste jaren veel dynamiek te zien. Nederland scoorde hier altijd hoog. Terwijl in andere landen het vertrouwen in politieke instituties de laatste decennia duidelijk afnam, was Nederland een van de weinige landen waar geen daling optrad. Sterker, er leek zelfs sprake van een stijging (zie Dalton 1999: 65, 2004: 38; Holmberg 1999). Aan het begin van het nieuwe millennium zakte het Nederlandse vertrouwen in de instituties echter plotseling flink. Sloot Nederland alsnog aan bij de internationale trend? Nee, toch niet. Vanaf 2005/2006 trad namelijk een licht herstel in, en "[i]n het najaar van 2008 nam het vertrouwen in politieke instituties aanzienlijk toe, tot aan of zelfs boven het niveau van 1999." (SCP 2009: 86). Of dit herstel duurzaam aanhoudt is nog even afwachten, maar vooralsnog lijkt het erop dat Nederland weer terug is in zijn internationale uitzonderingspositie.

Over het waarom van deze sterke maar tijdelijke dip bestaan verschillende meningen. Alle dynamiek rond de opkomst van Fortuyn zal hierin zeker een rol hebben gespeeld, maar de daling lijkt al eerder te hebben ingezet. Bovens en Wille (2008) menen dat de dip werd veroorzaakt door een combinatie van (waargenomen) slechte economische vooruitzichten en politiek gemotiveerde onvrede bij met name linksgeoriënteerde burgers over het rechtse karakter van de zittende regering en haar beleid. De oorzaak moet volgens Bovens en Wille dus niet worden gezocht bij intrinsieke kenmerken van die instituties als zodanig, maar in tijdelijke condities.

Daarentegen zijn er volgens Hendriks (2009) wél meer structurele ontwikkelingen in het spel, en moet de dip in vertrouwen worden begrepen als een tijdelijk interactie-effect van deze meer structurele ontwikkelingen. De Nederlandse consensusdemocratie heeft volgens Hendriks altijd een cultuur gehad van traagheid, gematigdheid, compromis en pragmatisme, en een afkeer van groots en meeslepend leiderschap. Op zichzelf is dat natuurlijk nog geen reden tot laag vertrouwen. In de eerste jaren van de eenentwintigste eeuw kwamen daar echter twee dingen bovenop, namelijk de (verdere) opkomst van de emotiecultuur, en een toenemend bewustzijn van risico en onveiligheid (aanslagen 9/11, moord Fortuyn, moord Van Gogh, vuurwerkramp, Volendambrand enz.). En dat 
zijn nou net zaken waarmee de onderkoelde Nederlandse consensusdemocratie slecht overweg kan. 'Risk plus emotion plus consensus propels suspicion' (blz. 486). Kortom, de vormgeving van de Nederlandse democratie is volgens Hendriks op zichzelf geen reden voor wantrouwen in de politieke instituties, maar kan dat wel worden in combinatie met specifieke omstandigheden waarop zij geen afdoende antwoord heeft.

\subsection{PROBLEMEN MET DEZE CIJFERS}

Afgaande op deze cijfers ziet de situatie er voor ons land niet slecht uit, integendeel. Weinig landen kunnen bogen op zoveel tevredenheid en vertrouwen als het gaat om de democratie. Of toch niet? Helaas vallen er bij deze cijfers enkele forse kanttekeningen te plaatsen. In deze paragraaf ga ik daar op in. Ik zal me daarbij richten op de drie middelste niveaus, die alle te maken hebben met 'het regime'. Dit zijn namelijk de niveaus waarop de discussie over 'democratische vernieuwing' zich toespitst.

\section{Wat is democratie?}

Om te beginnen is er een probleem met de vragen over 'democratie'. Het is allerminst gezegd dat respondenten bij het begrip 'democratie' aan hetzelfde denken als de wetenschappers die de enquêtes maken. Impliciet lijken die laatsten daar wel vanuit te gaan, want anders zouden zij vast niet het woord 'democratie' in de vraagstelling gebruiken, maar een omschrijving of operationalisering daarvan. In de andere enquêtevragen van objectniveau 2 gebeurt dat wel (zie tabel 2). Daarin wordt geen abstracte term gehanteerd (bijvoorbeeld 'een militair regime' of 'een verlichte dictatuur') maar wordt uitgelegd wat er wordt bedoeld. Zo niet bij de vragen voor democratie. Onbedoeld wordt daardoor aan de respondenten alle ruimte geboden om hun eigen - mogelijk onjuiste of utopische - concepties over de ideale wijze van landsbestuur in het woord te projecteren. Vervolgens antwoorden zij uiteraard dit ook te prefereren. Als iemand bijvoorbeeld denkt dat democratie betekent dat hij volledig vrij is om te doen en laten wat hij wil, zal hij ongetwijfeld een groot voorstander van democratie zijn, en antwoorden dit een goede manier te vinden om het land te besturen. Maar hebben we dan werkelijk een valide meting gedaan van de steun voor democratie?

Een kleine uitwijding over de betekenis van het begrip is hier op zijn plaats. Eigenlijk is de impliciete veronderstelling dat mensen wel weten wat democratie inhoudt rijkelijk optimistisch, want zelfs deskundigen hanteren vele verschillende beschrijvingen en definities. Er wordt dan ook wel gesproken van een 'essentially contested concept'. Dat laatste is echter wat overdreven. Democratie betekent letterlijk dat het volk regeert, en minimale en formele definities van democratie omvatten altijd uitspraken met betrekking tot de besluitvormingsprocedure. De kern van zulke definities is meestal dat in het politieke besluitvormingsproces (de 
meerderheid van) het volk in directe of indirecte zin, beslissend is. Dit is echter de minimale definitie. Moderne concepties van democratie zijn altijd uitgebreider, en bevatten bijna altijd noties met betrekking tot de vrijheid en gelijkheid van burgers. De wet kent alle burgers bepaalde rechten toe waaraan ook de staat zich heeft te houden. Anders gezegd: de democratie fungeert in de context van een rechtstaat.

Hedendaagse westerse samenlevingen zijn in feite een gelukkig huwelijk van de democratie en de rechtstaat. Hoewel beide moeilijk zonder elkaar kunnen, betreft het onderscheiden concepten, die aanvankelijk ook los van elkaar werden gebruikt. Van beide is de democratie-idee zonder meer de oudste. Het Athene van 400 jaar voor Christus was een democratie, maar zeker geen rechtstaat, want het ontbrak de Atheense burgers waarborgen ter bescherming van de individuele vrijheid. ${ }^{3}$ Pas in de achttiende eeuw ontwikkelden denkers als Locke en Montesquieu het gedachtegoed dat resulteerde in de idee van de rechtstaat. Die is in essentie dus een toevoeging aan de democratie, zij het één die daarmee zozeer verweven geraakt is dat men landen zonder rechtstatelijke vrijheden, niet zou willen aanmerken als een volbloed democratie. Dat het om twee afzonderlijke ideeën gaat blijkt echter in de terminologie die in politicologische literatuur wordt gehanteerd. Wetenschappers spreken van de democratische rechtstaat (of in het Engels: liberal democracy). ${ }^{4}$

Terug naar de democratie-items in enquêtes. Voor de interpretatie van de antwoorden is het noodzakelijk te weten wat respondenten onder democratie verstaan. Vreemd genoeg wordt die vraag vrijwel nooit gesteld -, noch in het binnenland, noch in het buitenland. Een van de zeldzame uitzonderingen zijn de Nederlandse Nationale Kiezersonderzoeken van 1973 en 1994. Daarin werd aan de respondenten open gevraagd waaraan zij denken als ze het woord democratie horen. "The most remarkable finding is that most answers do not refer, directly or indirectly, to the literal meaning of democracy - government by the people or popular sovereignty," concludeert Thomassen (1995:384). De respondenten bleken het begrip vooral te associëren met vrijheden, terwijl bijvoorbeeld participatie, representatie en gemeenschapszin veel minder vaak worden genoemd. Deze primaire associatie van democratie met vrijheid is allesbehalve een uniek Nederlands verschijnsel. Zij wordt ook in andere landen aangetroffen (zie Baviskar en Malone 2007; Carrión 2008). "People across the globe associate democracy primarily with liberty, followed at a far distance by more procedural aspects of democracy like 'government by the people', 'electoral choice' and this other basic value, 'equality' (before the law)” (Thomassen 2007: 421, cursivering toegevoegd).

Concluderend, veel mensen denken bij het woord democratie in eerste instantie aan zaken die men strikt genomen eerder zou beschouwen als definiërende kenmerken van de rechtstaat dan aan zaken die betrekking hebben op democratie als procedure om tot besluiten te komen. Het is dus de vraag of je mag concluderen 
dat, zoals Thomassen samenvat, een overweldigende meerderheid van de burgers vindt dat 'democracy is an ideal form of government'. (2007: 421, cursivering toegevoegd). Zeggen de mooie cijfers wel iets over de attitudes ten aanzien van procedures en praktijken om politieke knopen door te hakken? Als mensen bij democratie vooral denken aan vrijheid, maakt de riante steun voor democratie opeens niet zoveel indruk meer. Wie wil er nou geen vrijheid? Tegelijkertijd wordt een stuk begrijpelijker dat twee formeel niet-democratische oplossingen voor besturen van het land, bijna de helft van de Nederlanders een (behoorlijk) goed idee lijkt.

\section{Representatief of direct?}

Een hiermee verwant probleem is dat onduidelijk is welk type democratie respondenten bij dit soort vragen eigenlijk voor ogen hebben. Denken zij daarbij aan een representatieve democratie als de huidige Nederlandse? Of hebben ze wellicht een (meer) directe democratie voor ogen? Beschouwen zij beide hoofdvormen als gelijkwaardige vormen van democratie? Of reserveren zij net als Rousseau dat edele predicaat alleen voor een directe democratie, en beschouwen zij de representatieve democratie als niet werkelijk 'democratisch'?

Dat laatste valt niet uit te sluiten. Veel Nederlanders zeggen in onderzoek naar meer inspraak te verlangen. Zo vindt al sinds 1970 ongeveer tweederde tot driekwart van de mensen dat de inspraak van burgers op het bestuur van gemeente en provincie veel of een beetje groter moet worden (SCP 1998: 743; SCP 2009: 250). Ook vindt bijna driekwart van de Nederlanders dat 'de burgemeester moet worden gekozen door de inwoners van de gemeente' en is meer dan tachtig procent het eens met de stelling dat 'over sommige, voor ons land belangrijke beslissingen door de kiezers zelf moet worden gestemd, het zogenaamde referendum'. In het Continu Onderzoek Burgerperspectieven is ongeveer tweederde het eens met de stelling dat het goed zou zijn 'als burgers meer konden meebeslissen over belangrijke politieke kwesties', terwijl slechts 14 procent het daarmee oneens is. (Van der Meer et al. 2009: 7).

Het is dus niet duidelijk wat eigenlijk de ideale democratie is waartegen men de huidige praktijk afzet. Is dat een representatieve of een (meer) directe democratie? Voor de interpretatie van de vraag naar tevredenheid met de huidige democratische praktijk maakt dat nogal verschil. Als iemand voor zijn oordeel uitgaat van de ideale representatieve democratie, duidt ontevredenheid waarschijnlijk niet op fundamentele systeemkritiek, maar op ongenoegen over onjuiste toepassing van procedures en normen die hij op zich onderschrijft. Als iemand voor zijn oordeel echter ervan uitgaat dat alleen een directe democratie mag gelden als de ware democratie, kan onvrede een uiting zijn van een veel fundamenteler ongenoegen met de huidige praktijk. In dat geval zal betere toepassing van de huidige procedures weinig soelaas bieden. 


\section{'Satisfaction with democracy'}

Hiermee zijn we in feite aangeland op het derde objectniveau, te weten het oordeel over de democratische procedures en normen. Hoe oordelen de mensen over de wijze waarop de abstracte democratische idee in hun land is geconcretiseerd? Het gaat daarbij niet alleen om representatief versus direct, maar ook om andere vormgevingskwesties. Het ene land kent bijvoorbeeld een systeem van strikt proportionele vertegenwoordiging en coalities, het andere land een tweepartijensysteem, winner takes all. Welnu, zag het Nederlandse plaatje er hier niet prachtig uit? De tevredenheid met de wijze waarop de democratie functioneert neemt immers gestaag toe. Er mag dan flink gemopperd worden op onze democratie, maar eigenlijk zijn we heel content.

Helaas... wetenschappers dóen wel alsof de vraag 'hoe tevreden men is met de wijze waarop de democratie functioneert' de steun meet voor de democratische normen en procedures, maar dat is niet terecht. Wie tijdreeksen bekijkt van de resultaten zal zien dat het antwoord op deze vraag correleert met de economische prestaties van een land (Van de Walle 2004; Tiemeijer 2006). Dat zou eigenlijk niet mogen gebeuren als deze vraag het oordeel meet over de wijze waarop het abstracte ideaal van democratie concreet is uitgewerkt in normen en procedures. Ondanks verwoede pogingen van D'66 tot verandering kennen we nog vrijwel hetzelfde constitutionele systeem als begin jaren zeventig. Desondanks laat de grafiek op pagina 209 heftige fluctuaties zien. Door diverse wetenschappers is deze enquêtevraag dan ook geproblematiseerd. Volgens Linde en Ekman meet zij niet zozeer de steun voor de principes van het regime, maar veeleer "the level of support for how the democratic regime works in practice" (2003: 405). Canache, Mondak en Seligson vinden zelfs dat we vanwege de problemen met validiteit maar beter de hele vraag overboord kunnen zetten. Dat gaat Anderson weer te ver. Volgens hem meet de vraag "regime performance and is somewhere in-between specific support and institutional confidence" (2002: 11). Volgens Dalton menen de meeste wetenschappers "that it measures the performance of the system, not the system as an ideal or set of formal rules" (2004: 12). De cijfers weerspiegelen dus de mate waarin het politieke systeem resultaten weet te leveren die burgers belangrijk achten. ${ }^{5}$ En, zo voegt hij er aan toe: "It would be extremely valuable to expand future data collections to focus on public norms regarding how the democratic process should function."

Kortom, het feit dat in Nederland de 'tevredenheid met hoe de democratie functioneert' in de afgelopen decennia geleidelijk aan is gestegen (net als bijvoorbeeld het consumentenvertrouwen) zal vast wel iets betekenen. De grote vraag is alleen wat. De resultaten zeggen vermoedelijk meer over de outcome van het democratisch proces dan over de wijze waarop de Nederlandse democratie institutioneel is ingericht. 


\section{Concluderend}

Als het gaat om wat mensen nu echt vinden van de wijze waarop in Nederland politieke besluiten tot stand komen, weten we eigenlijk maar weinig. Uit de bestaande kwantitatieve longitudinale onderzoeken valt niet goed op te maken in hoeverre mensen de specifieke vormgeving van de Nederlandse democratie steunen. Sterker nog, we weten eigenlijk nauwelijks wat mensen onder 'democratie' verstaan. Al met al is democratie een term die verwantschap vertoont met wat Edelman heeft aangeduid als een 'condensation symbol' (Edelman 1964: 6). Dat is een relatief onbepaalde term die een hele reeks betekenissen, ideeën en gevoelens samenvat in één krachtig symbool of begrip. Juist omdat iedereen zijn eigen betekenissen kan projecteren in deze symbolen, kan hun werking zo krachtig en hun aantrekkingskracht zo groot zijn.

\subsection{EEN GEDEELD VOLK?}

Wie wil oordelen over de prestaties van een machine moet allereerst weten waartoe hij dient. Zolang je niet weet wat de functie van de machine is, kun je wel beschrijven hoe die eruitziet en welke onderdelen eraan zitten, maar daarmee begrijp je het ding nog niet. Dat geldt ook voor democratie. Je kunt wel proberen het begrip 'democratie' te beschrijven door haar constituerende kenmerken te identificeren, maar daarmee dring je niet door tot de kern. De democratie wordt pas werkelijk begrijpelijk, en men kan haar prestaties pas werkelijk beoordelen, als je weet welk probleem zij beoogt op te lossen.

En dat is het probleem van de gedeeldheid. Zoals Machiavelli reeds schreef, zodra mensen op een beperkte ruimte samenleven, ontstaan er onvermijdelijk conflicten. Democratie is een set van procedures en instituties die tot doel hebben om conflicten zonder bloedvergieten te pacificeren, en wel door alle individuele willen te aggregeren tot een bindend besluit dat het beste die wil van allen representeert. In de kern is de democratische rechtstaat dus een conflictoplosmachine. En zoals elke krantenlezer kan constateren, wanneer de machine toeren maakt, gaat dat soms gepaard met veel lawaai en spektakel. Politiek in actie is langdurig praten, overleg, overtuiging, retoriek, handjeklap, koehandel, trekken en duwen, gekonkel achter de schermen, bespelen van de publiciteit - alles wat politici nodig achten om gegeven een bepaalde belangentegenstelling het maximale voor hun achterban binnen te halen. Het is vaak geen verheffend schouwspel, maar dat ligt nu eenmaal in de aard van het werk: het uitvechten van conflicten.

Maar wat nu als men helemaal niet ziet dat er belangenconflicten zijn? Wat nu als men meent dat volstrekt helder is wat 'de burger' en 'het volk' willen? Hoe ziet dan het politieke schouwspel eruit? Redelijk onbegrijpelijk en deprimerend. Er is veel rumoer, eindeloze ruzie en gekift, en als men dan eindelijk eens iets besluit, is het vaak iets anders dan de mensen willen. Dus kennelijk vinden politici het 
belangrijker hun eigen belangen veilig te stellen... Hoe vreemd deze gedachtegang ook moge klinken voor political sophisticates, volgens Hibbing en Theiss-Morse (2002) redeneren veel burgers op deze manier. Veel mensen interesseren zich volgens Hibbing en Theiss-Morse voor hooguit een paar politieke onderwerpen, en denken dat hun medeburgers ook enkel belang hechten aan die paar onderwerpen. Zij gaan er dus impliciet of expliciet vanuit dat er brede consensus bestaat over de vraag wat de belangrijkste politieke problemen zijn. (Voor een deel is die er natuurlijk ook. Nagenoeg iedereen wil betaalbare medische zorg, een groeiende economie, goede pensioenen, minder misdaad, meer onderwijs, gelijke kansen, enzovoort. De politieke discussie gaat natuurlijk vooral over de vraag hoe dat te realiseren.) Bovendien gaan deze burgers ervan uit dat er een beste manier bestaat om die problemen op te lossen, die men kan vinden als men maar goed en onpartijdig over het probleem nadenkt. Welnu, als er slechts een handjevol problemen is dat er werkelijk toe doet, waarom besteden de politici dan zoveel aandacht aan andere zaken? Waarom verspillen zij zoveel tijd aan ruzie en gedoe, in plaats van gewoon de problemen aan te pakken? Blijkbaar draait het in de politiek niet om wat het volk wil, maar om andere zaken, namelijk het najagen van eigenbelang en te vriend houden van 'special interests'. Hibbing en Theiss-Morse vatten samen:

\footnotetext{
“Ordinary people [...] believe that Americans generally agree on overall societal goals. While they realize that different opinions exist on the best way to achieve those goals, they are convinced there is a reasonable way of proceeding that can be divined by hard-working, unbiased, intelligent people. In so believing, the American people are viewing the governing process as the marriage of Rousseau's general societal will and the progressives' confidence in scientific implementation processes. [...] People do not see a need for political debates and brokered decisions. They simply do not believe debates and compromises are necessary, since we all want the same general things, since the best way to achieve those things will be readily apparent to those who study the problems in an unbiased way, and since the little details of policy are not that important anyway. To put it simply, the people yearn for the "end of politics." (2002: 157)
}

Dit is een prikkelende - en ook enigszins controversiële - analyse. Zou die ook voor Nederland gelden? Hoewel er in ons land (nog) geen onderzoek is gedaan naar deze materie van de omvang van dat van Hibbing en Theiss-Morse, zijn er wel wat snippertjes onderzoek die dezelfde kant op wijzen. Zo nam Van Wessel (2009) individuele diepte-interviews af bij twintig burgers met laag politiek zelfvertrouwen en tenminste enige politieke interesse. Ook bij hen klinkt het beeld door van een ongedifferentieerde gemeenschap. "De eigen kennis, ervaring en visie lijkt voor respondenten vaak te gelden als exemplarisch voor het gezonde verstand van burgers in meer algemene zin, dat op allerlei terrein, onproblematisch, tot uitgangspunt verheven kan en moet worden" (blz. 96). Wat in een bepaalde context een 'goede beslissing' zou zijn, ligt volgens haar respondenten steeds voor de hand, "vaak zonder dat er sprake is van identificatie van een poli- 
tieke opponent of opponerende visie" (samenvatting). Politici daarentegen handelen volgens haar respondenten vaak 'op eigen titel', dat wil zeggen, vanuit veronderstelde persoonlijke overtuiging of voor eigen belang. Van Wessel vond dan ook weinig begrip bij deze burgers voor het moeizame proces van onderhandelen en compromisvorming dat bij democratie hoort.

Deze gegevens lijken goed te passen bij die visie op politiek van de respondenten van Hibbing en Theiss-Morse. Het betreft echter een selecte steekproef van maar twintig respondenten. Het zou de moeite waard zijn meer onderzoek te doen. Immers, als inderdaad waar is dat een flink deel der Nederlanders geen belangentegenstelling waarneemt op de voor hen belangrijke punten, werpt dat een ander licht op onvrede over de politiek. Het lijkt dan verstandig om, vóórdat men bijvoorbeeld inzet op politieke hervormingen, eens te kijken of die onvrede ook blijft voortbestaan nadat men een wat reëler beeld heeft gekregen van de politieke realiteit. Zijn burgers nog steeds ontevreden nadat zij beter doordrongen zijn van de fundamentele tegenstellingen die de politiek moet zien te pacificeren? Kan onvrede misschien ten dele worden weggenomen door een beter 'management van verwachtingen'?

\subsection{EMPIRISCHE GEGEVENS}

Daarmee kom ik op het tweede deel van dit hoofdstuk. Hierin wil ik enkele empirische resultaten presenteren die betrekking hebben op de thematiek van de vorige paragrafen. Zij komen uit een opinieonderzoek onder een representatieve steekproef van 781 Nederlanders uit de database van TNS-Nipo. Het veldwerk hiervoor werd door bureau Veldkamp verricht van 5 januari tot en met 12 januari $2010 .{ }^{6}$

\subsubsection{WAT IS DEMOCRATIE?}

Zoals eerder in dit hoofdstuk werd geschreven, is niet gezegd dat respondenten onder 'democratie' hetzelfde verstaan als wetenschappers. Daarom heb ik aan alle respondenten van de enquête de open vraag gesteld: "Wat betekent voor $u$ het woord 'democratie'? Waaraan denkt u bij dit woord"? Deze vraag is bijna identiek aan een vraag die in de Nationale Kiezersonderzoeken van 1973 en 1994 is gesteld. De antwoorden zijn derhalve gecodeerd naar de categorieën die ook in die kiezersonderzoeken werden gehanteerd.7 In de onderstaande tabel staan de resultaten voor de drie metingen.

Duidelijk is dat ook anno 2010 democratie vooral wordt geassocieerd met het woord vrijheid. Wel is er sprake van een flinke toename in het aantal mensen dat bij democratie allereerst denkt aan zaken die vallen onder de categorie 'vertegenwoordiging, verkiezingen, democratische procedures en instituties', en een afname van het aantal mensen dat geen antwoord kan of wil geven. Hier lijkt sprake van een trend. ${ }^{8}$ 
Tabel 6.3

Eerste associaties bij democratie

\begin{tabular}{|c|c|c|c|}
\hline$N=781$, antwoorden in percentages & 1973 & 1994 & 2010 \\
\hline Vrijheid van meningsuiting, persvrijheid & 17 & 16 & 21 \\
\hline Andere verwijzingen naar vrijheid & 18 & 17 & 18 \\
\hline Gelijkheid, solidariteit en gemeenschapszin & 14 & 13 & 11 \\
\hline Participatie (inspraak, medezeggenschap, meebeslissen) & 9 & 17 & 17 \\
\hline $\begin{array}{l}\text { Vertegenwoordiging, verkiezingen, democratische } \\
\text { procedures en instituties }\end{array}$ & 7 & 12 & 20 \\
\hline Uiteenlopende negatieve en sceptische associaties & 7 & 2 & 2 \\
\hline Diverse andere associaties & 13 & 13 & 6 \\
\hline Geen associaties ('weet niet', 'dat zegt me niets') & 15 & 10 & 5 \\
\hline Totaal & 100 & 100 & 100 \\
\hline
\end{tabular}

Bron 1973 en 1994: NKO 1973, NKO 1994

In de volgende tabel zijn de antwoordcategorieën verder ingedikt. Nader bepaald: de eerste twee categorieën zijn samengenomen onder het kopje 'vrijheid', en de vierde en vijfde zijn samengenomen onder het kopje 'besluitvorming'. Verder zijn de laatste drie categorieën samengevoegd, en is een uitsplitsing gemaakt naar drie opleidingsniveaus. ${ }^{9}$ Op de komende pagina's zal ik regelmatig de uitsplitsing naar onderwijsniveau geven, want dit is een belangrijke voorspeller van allerhande politieke gedragingen (Bovens en Wille 2009).

Tabel 6.4 Eerste associatie bij democratie: ingedikt

\begin{tabular}{|c|c|c|c|c|}
\hline \multirow[b]{2}{*}{$N=781$, antwoorden in percentages } & \multirow[t]{2}{*}{ Totaal } & \multicolumn{3}{|c|}{ Opleidingsniveau } \\
\hline & & laag & midden & hoog \\
\hline Vrijheid & 39 & 44 & 43 & 28 \\
\hline Gelijkheid, solidariteit en gemeenschapszin & 11 & 11 & 10 & 11 \\
\hline Besluitvorming(sprocedures) & 37 & 22 & 37 & 52 \\
\hline Overigen en weet niet & 13 & 22 & 10 & 9 \\
\hline
\end{tabular}

De verschillen zijn opvallend. Hoger opgeleiden denken bij het woord 'democratie' beduidend vaker aan zaken die te maken hebben met de wijze waarop besluiten tot stand komen. Lager en middelbaar opgeleiden daarentegen denken in meerderheid aan 'vrijheid'. Als men de moderne democratische rechtstaat beschouwt als een huwelijk van twee partners, namelijk de rechtstaat en de demo- 
cratie, is de conclusie dat lager en middelbaar opgeleiden het begrip 'democratie' vooral associëren met de eerste van beide partners, en hoger opgeleiden vaker met de tweede partner.

Na deze eerste open vraag ging de enquête dieper in op de betekenis van het begrip 'democratie'. Daartoe kregen de respondenten tien mogelijke kenmerken van een democratie voorgelegd. Van elk van deze kenmerken werd hen gevraagd of deze 'zeer kenmerkend', 'enigszins kenmerkend' of 'niet kenmerkend' zijn voor een democratie. In de grafiek staan de resultaten. Opnieuw blijkt de hoge score van de vrijheid van meningsuiting.

\section{Figuur 6.2 Kenmerken van democratie}

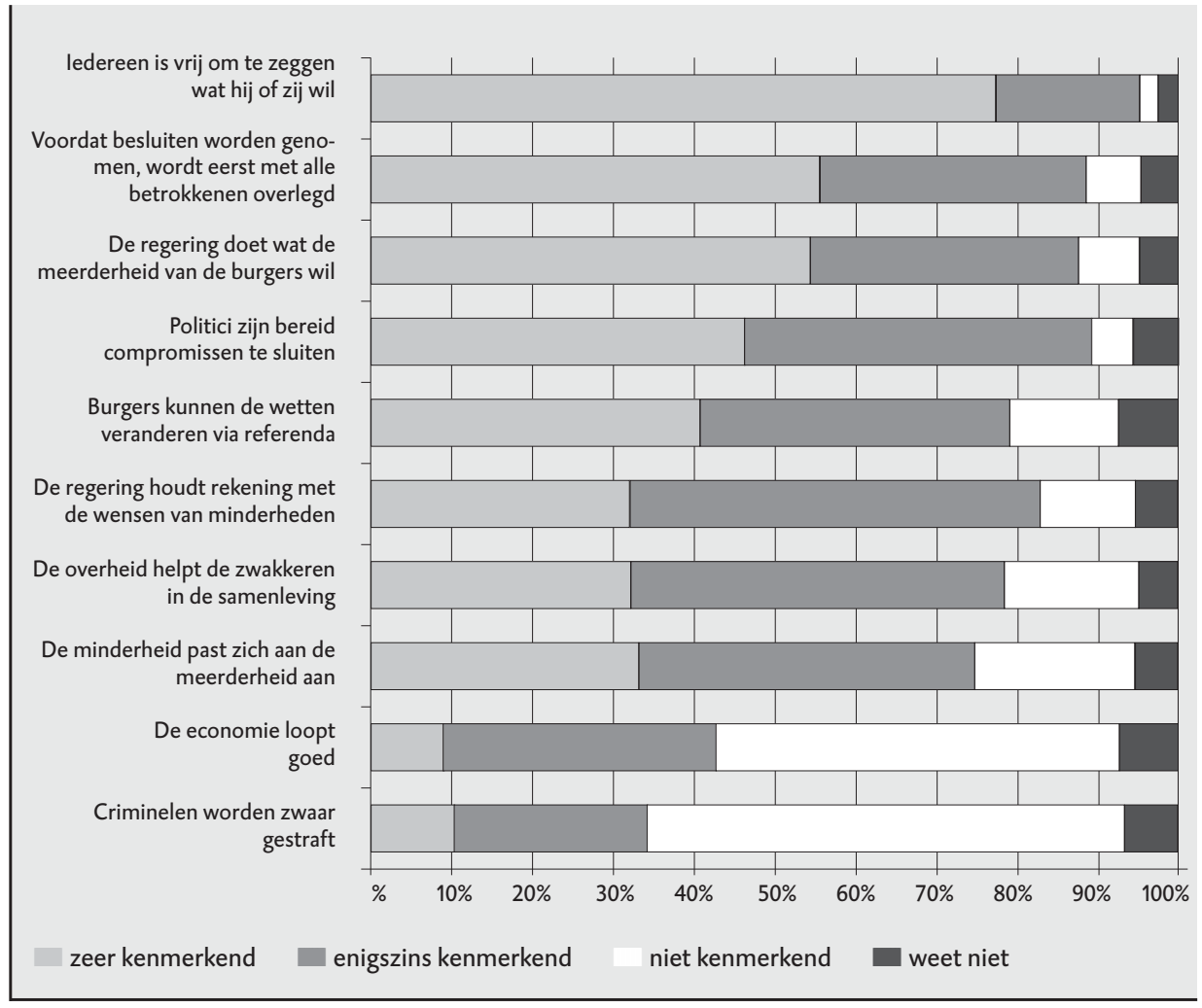

\subsubsection{MEER DIRECTE DEMOCRATIE}

Eerder schreef ik dat in de gebruikelijke vragen over de tevredenheid met democratie geen onderscheid wordt gemaakt tussen representatieve democratie en meer directe vormen van democratie. In deze enquête is wel doorgevraagd op dit onderwerp. Allereerst heb ik de vraag 'recht op de man af' gesteld, en wel als volgt: 
"In Nederland hebben we een systeem waarin de burgers politieke vertegenwoordigers kiezen. Die politieke vertegenwoordigers nemen dan de beslissingen en besturen het land. Sommige mensen pleiten echter voor een systeem waarin de burgers zoveel mogelijk alles zélf beslissen, bijvoorbeeld door middel van referenda en volksvergaderingen. De taak van de politici is dan om uit te voeren wat de burgers hebben besloten."

De helft van de respondenten werd nu gevraagd welk systeem hun voorkeur heeft, de andere helft welk systeem ze het meest democratisch vinden. In tabel 6.5 staan

Tabel 6.5

Oordeel over systeem

\begin{tabular}{l|r|r|r|r} 
Welk systeem heeft voorkeur? & Totaal & \multicolumn{3}{|c}{ Opleidingsniveau } \\
\cline { 3 - 5 } $\mathrm{N}=401$, antwoorden in percentages & & laag & midden & hoog \\
\hline Burgers kiezen politieke vertegenwoordigers die de & & & & \\
beslissingen nemen & 61 & 43 & 55 & 81 \\
Burgers beslissen zoveel mogelijk zelf & 28 & 36 & 36 & 13 \\
Maakt me niet uit & 7 & 11 & 6 & 5 \\
Weet niet/geen mening & 4 & 10 & 3 & 1 \\
\hline Totaal & 100 & 100 & 100 & 100 \\
\hline
\end{tabular}

\begin{tabular}{l|r|r|r|r} 
Welk systeem meest democratisch? & \multirow{2}{*}{ Totaal } & \multicolumn{3}{|c}{ Opleidingsniveau } \\
\cline { 3 - 5 } $\mathrm{N}=380$, antwoorden in percentages & & laag & midden & hoog \\
\hline Burgers kiezen politieke vertegenwoordigers die de & & & & \\
beslissingen nemen & 50 & 43 & 45 & 62 \\
Burgers beslissen zoveel mogelijk zelf & 36 & 35 & 41 & 29 \\
Maakt niet uit & 7 & 8 & 9 & 4 \\
Weet niet/geen mening & 7 & 14 & 5 & 5 \\
\hline Totaal & 100 & 100 & 100 & 100 \\
\hline
\end{tabular}

Opvallend is het verschil in scores tussen hoger opgeleiden, en lager en middelbaar opgeleiden. De eersten zijn significant positiever over het representatieve systeem dan de andere twee groepen. Die kiezen vaker voor een systeem waarin de burgers zoveel mogelijk zelf beslissen, en vinden dit ook vaker het meest democratische systeem. Verderop in de enquête is de respondenten zes stellingen voorgelegd over het (gewenste) directe karakter van de Nederlandse democratie. In de tabel staan de antwoorden. 
Tabel 6.6

Stellingen over (meer) directe democratie

\begin{tabular}{l|r|r|r|r}
$\mathbf{N}=781$, antwoorden in percentages & $\begin{array}{r}\text { (helemaal) } \\
\text { mee } \\
\text { eens }\end{array}$ & $\begin{array}{r}\text { noch eens, } \\
\text { noch } \\
\text { oneens }\end{array}$ & $\begin{array}{r}\text { (helemaal) } \\
\text { mee } \\
\text { oneens }\end{array}$ & $\begin{array}{r}\text { weet } \\
\text { niet }\end{array}$ \\
\hline $\begin{array}{l}\text { Ik vind dat de politiek over het algemeen te veel } \\
\text { naar de burgers luistert }\end{array}$ & 3 & 24 & 70 & 3 \\
$\begin{array}{l}\text { Burgers moeten meer rechtstreekse invloed krijgen } \\
\text { op de politiek }\end{array}$ & 48 & 31 & 19 & 2 \\
$\begin{array}{l}\text { In Nederland moeten we meer referenda } \\
\text { hebben }\end{array}$ & 49 & 24 & 22 & 5 \\
$\begin{array}{l}\text { Het is goed dat de politiek wordt overgelaten aan } \\
\text { gekozen politici, en niet iedereen zich er mee bemoeit }\end{array}$ & 52 & 30 & 16 & 2 \\
$\begin{array}{l}\text { Burgers zijn vaak onvoldoende deskundig om goed } \\
\text { te kunnen oordelen over politieke onderwerpen }\end{array}$ & 45 & 31 & 22 & 2 \\
$\begin{array}{l}\text { Ik vind dat de politiek over het algemeen te weinig } \\
\text { naar de burgers luistert }\end{array}$ & 59 & 27 & 12 & 2 \\
\hline
\end{tabular}

Bij vier van de zes stellingen scoort het meer 'direct democratische antwoord' het hoogste. Nadere analyse leert dat de scores op de stellingen met elkaar correleren en tezamen één schaal vormen (Cronbachs alfa $=0,77$, na omkering van de scores voor de tweede, derde en zesde stelling). De gemiddelde score op deze stellingen kan dus worden beschouwd als een indicator voor de variabele 'wens tot meer directe democratie'. Daarbij staat 1 voor de laagst denkbare waarde (oneens met alle stellingen ten faveure van meer directe democratie) en 3 voor de hoogste denkbare waarde (eens met alle stellingen ten faveure van meer directe democratie). De gemiddelde score bedraagt nu voor de lager opgeleiden 2,36, voor de middelbaar opgeleiden 2,27, en voor de hoger opgeleiden 1,98.

Kortom, hoe lager het opleidingsniveau, hoe groter de wens tot meer direct democratische elementen..$^{10}$ Opvallend is dat de breuklijn in deze attitudes vooral lijkt te lopen tussen de lagere en middelbaar opgeleide groepen enerzijds en de hoger opgeleide groep anderzijds. Bovens en Wille vinden diezelfde scheidslijn in hun analyse van NKO-data over de mate waarin mensen deelnemen aan politieke activiteiten, zoals meedoen aan een demonstratie of deelnemen in een door de overheid georganiseerd publiek debat (2009: 21). Het blijken vooral de hoger opgeleiden die hierin participeren, niet de lager of middelbaar opgeleiden. In het licht van de bovenstaande resultaten is dat enigszins onverwacht, omdat hierin juist de lager en middelbaar opgeleide groepen zich relatief vaak uitspreken vóór meer directe democratie. Op deze schijnbaar tegenstrijdige uitkomsten kom ik later terug. 


\subsubsection{GEDEELDHEID}

Een centraal punt in het voorgaande was de vraag in hoeverre mensen eigenlijk waarnemen dat er verschillende standpunten en belangen bestaan waartussen de politiek een compromis moet zien te vinden. Deze vraag is op twee wijzen verder uitgediept.

\section{Grootste probleem}

Allereerst is aan de helft van de respondenten de open vraag gesteld wat zij momenteel beschouwen als het grootste probleem waarvoor ons land staat ${ }^{11}$; vervolgens is hen gevraagd te schatten hoe groot het aandeel van de Nederlanders is die dit óók als het grootste probleem zien. Daarbij konden ze kiezen uit vijf categorieën: (bijna) iedereen, een meerderheid van de Nederlanders, ongeveer de helft van de Nederlanders, een minderheid van de Nederlanders, (bijna) niemand. De open antwoorden op de eerste vraag zijn vervolgens gecodeerd naar de categorieën die worden gehanteerd in de сов (Dekker et al. 2009). Hieronder staan de resultaten. Daarbij is per categorie ook aangegeven hoeveel mensen naar schatting van de respondenten het betreffende antwoord eveneens beschouwden als grootste probleem in ons land. ${ }^{12}$

\section{Tabel 6.7 Grootste probleem in Nederland}

\begin{tabular}{|c|c|c|c|c|c|}
\hline \multirow[t]{2}{*}{$\begin{array}{l}\mathrm{N}=394, \text { antwoorden in } \\
\text { percentages }\end{array}$} & \multirow[t]{2}{*}{ Genoemd } & \multicolumn{4}{|c|}{$\begin{array}{l}\text { Hoeveel Nederlanders beschouwen dit óók } \\
\text { als het grootste probleem in Nederland? }\end{array}$} \\
\hline & & $\begin{array}{l}\text { bijna ieder- } \\
\text { een / meer- } \\
\text { derheid }\end{array}$ & $\begin{array}{r}\text { ongeveer } \\
\text { de helft }\end{array}$ & $\begin{array}{r}\text { minder- } \\
\text { heid / bijna } \\
\text { niemand }\end{array}$ & weet niet \\
\hline Inkomen en economie & 28 & 69 & 26 & 3 & 2 \\
\hline Immigratie en integratie & 15 & 78 & 17 & 3 & 2 \\
\hline Criminaliteit en veiligheid & 12 & 62 & 34 & 2 & 2 \\
\hline Samenleven, normen en waarden & 10 & 33 & 31 & 33 & 3 \\
\hline Politiek en bestuur & 6 & 59 & 18 & 14 & 9 \\
\hline Werkgelegenheid & 5 & 35 & 50 & 10 & 5 \\
\hline Zorg en vergrijzing & 5 & 37 & 42 & 21 & 0 \\
\hline Totaal kleine onderwerpen* & 14 & 41 & 36 & 21 & 2 \\
\hline Weet niet & 5 & - & - & - & - \\
\hline Totaal & 100 & 57 & 29 & 11 & 3 \\
\hline
\end{tabular}


De inschattingen zijn opmerkelijk. In alle gevallen denken de respondenten dat minstens de helft, en in veel gevallen zelfs een meerderheid, óók vindt dat de betreffende kwestie het grootste probleem is van ons land. Nadere analyse leert dat lager opgeleiden nog wat sterker het aantal gelijkgezinden overschatten dan de middelbaar opgeleiden, terwijl de hoger opgeleiden het minst overschatten. Alle opleidingsklassen zitten echter flink te hoog.

Deze grote discrepantie roept de vraag op of het wel betrouwbare resultaten zijn. Is het misschien een artefact van de vraagstelling? Een mogelijke tegenwerping is dat mensen mogelijk de vraag hebben geïnterpreteerd als 'denkt u dat anderen dit ook een groot probleem vinden', en niet als het grootste probleem. Bij sommige respondenten zal dit vast het geval zijn. Toch zijn er twee redenen waarom dit toch zeker niet de enige verklaring zal zijn. Ten eerste gaf de vraagstelling weinig reden tot misverstand. Die luidde letterlijk: " $U$ schreef zojuist op dat volgens $u$ [antwoord] het grootste probleem in ons land is. Hoeveel mensen in Nederland denkt $u$ dat het hiermee eens zijn, en dit óók beschouwen als het grootste probleem in ons land? Ten tweede doet hetzelfde verschijnsel zich elders in de enquête voor. Daar werd de helft van de respondenten gevraagd hoeveel vertrouwen ze hebben in de Nederlandse regering, en de andere helft hoeveel vertrouwen ze hebben in de Nederlandse politici. Ze konden antwoorden op een vierpuntsschaal (heel weinig vertouwen, weinig vertrouwen, veel vertrouwen, heel veel vertrouwen). Daarna werd hen gevraagd een schatting te geven van het percentage Nederlanders dat ook (heel) weinig/veel vertrouwen in de regering respectievelijk politici heeft. Ook hier bleek een systematische overschatting van het aantal gelijkgezinden. Zo antwoordde 12 procent van de respondenten dat ze heel weinig vertrouwen in de regering hebben, maar schatten zij gemiddeld dat 67 procent van de Nederlanders ook 'heel weinig vertrouwen' in de Nederlandse regering heeft. En bijvoorbeeld 46 procent antwoordde dat zij weinig vertrouwen in de Nederlandse politici heeft, terwijl zij gemiddeld schatten dat 58 procent ook 'weinig vertrouwen' in de Nederlandse politici heeft. Ook hier geldt weer dat de hoger opgeleiden er het minst naast zitten, en de lager opgeleiden het meest. ${ }^{13}$

\section{Oog voor en acceptatie van gedeeldheid}

Verderop in de enquête kregen mensen vijf stellingen voorgelegd die alle betrekking hebben op het feit dat er in de samenleving sprake is van tegengestelde wensen en belangen, en er vaak compromissen gesloten moeten worden. Zie de onderstaande tabel. De eerste twee stellingen draaien om de noodzaak van compromissen, de volgende twee stellingen om oog voor de wensen van minderheden. De laatste stelling is wat indirecter. Wie het met deze stelling eens is, meent kennelijk dat het volk als zodanig duidelijk spreekt en geen onderling conflicterende boodschappen aan de politiek afgeeft. Wie daarentegen meent dat het volk ten principale verdeeld is, zal minder snel instemmen met deze stelling. 
Tabel 6.8 Stellingen oog voor en acceptatie van gedeeldheid

\begin{tabular}{|c|c|c|c|c|}
\hline$N=781$, antwoorden in percentages & $\begin{array}{r}\text { (helemaal) } \\
\text { mee } \\
\text { eens }\end{array}$ & $\begin{array}{r}\text { noch eens, } \\
\text { noch } \\
\text { oneens }\end{array}$ & $\begin{array}{r}\text { (helemaal) } \\
\text { mee } \\
\text { oneens }\end{array}$ & $\begin{array}{r}\text { weet } \\
\text { niet }\end{array}$ \\
\hline \multicolumn{5}{|l|}{ In de politiek is compromissen sluiten vaak } \\
\hline $\begin{array}{l}\text { onvermijdelijk } \\
\text { In de politiek moet men vasthouden aan zijn idealen }\end{array}$ & 77 & 15 & 5 & 3 \\
\hline en geen compromissen sluiten & 15 & 33 & 48 & 4 \\
\hline Het hoort bij democratie dat de regering soms dingen & & & & \\
\hline $\begin{array}{l}\text { besluit die slechts een minderheid van de burgers wil } \\
\text { In een democratie moet de regering alleen doen wat }\end{array}$ & 34 & 31 & 30 & 5 \\
\hline de meerderheid van de burgers wil & 36 & 37 & 23 & 4 \\
\hline Veel problemen kunnen makkelijk worden opgelost & & & & \\
\hline als de politiek maar beter naar de burgers zou luisteren & 55 & 25 & 17 & 3 \\
\hline
\end{tabular}

Op het eerste gezicht vindt de meerderheid dat compromissen er nu eenmaal bij horen, terwijl het beeld voor de positie van minderheden minder eenduidig is. Opvallend is hoeveel mensen denken dat veel problemen makkelijk kunnen worden opgelost als de politiek maar beter naar de burgers luistert.

Nadere analyse leert dat de scores op de stellingen met elkaar correleren en tezamen één schaal vormen (Cronbachs alfa = 0,62 na omkering van de scores voor de eerste en derde stelling). Wat deze schaal precies uitdrukt is lastig te omschrijven. Laten we het houden op een indicator die 'oog voor en acceptatie van gedeeldheid' meet. Een gemiddelde score van 1 staat voor de laagst haalbare waarde (oneens met alle stellingen die getuigen van oog voor en acceptatie van gedeeldheid) en 3 voor de hoogst haalbare waarde (eens met alle stellingen die getuigen van oog voor en acceptatie van gedeeldheid). De gemiddelde score bedraagt nu voor de lager opgeleiden 1,93, voor de middelbaar opgeleiden 2,07, en voor de hoger opgeleiden 2,34. Kortom, hoe hoger opgeleid, hoe meer oog voor en acceptatie van gedeeldheid. ${ }^{14}$

\subsubsection{OORDEEL OVER 'DE NEDERLANDSE DEMOCRATIE'}

Tot slot enkele evaluatieve oordelen over de Nederlandse democratie. Zoals eerder uiteengezet, luidt de standaardvraag in de Eurobarometer 'hoe tevreden men is met de wijze waarop de democratie in Nederland functioneert.' Dat is een problematische vraag, omdat niet erg duidelijk is wat die precies meet, en omdat het woord 'democratie' erin terugkeert. Ik heb daarom in de enquête twee vragen gesteld die hetzelfde zijn opgebouwd, maar een ander object hebben, namelijk de volgende: 
1 Hoe tevreden bent $\mathrm{u}$ over de mate waarin in Nederland ieders vrijheid en rechten worden beschermd?

2 En hoe tevreden bent u over de manier waarop in de Nederlandse politiek besluiten tot stand komen?

Met deze twee vragen zijn als het ware de rechtstatelijke en de democratische component van ons bestuurlijke systeem uit elkaar getrokken. Wie vindt dat het met de vrijheden in ons land prima is gesteld, maar problemen heeft met de wijze waarop de besluiten tot stand komen, kan dat melden, en vice versa. In de tabel staan de antwoorden.

Tabel 6.9

Oordelen over functioneren Nederlandse democratie

\begin{tabular}{|c|c|c|c|c|}
\hline \multirow{2}{*}{$\begin{array}{l}\mathrm{N}=781 \text {, antwoorden in percentages } \\
\text { tamelijk of zeer tevreden }\end{array}$} & \multirow[t]{2}{*}{ Totaal } & \multicolumn{3}{|c|}{ Opleidingsniveau } \\
\hline & & laag & midden & hoog \\
\hline Tevreden over vrijheid en rechten & 69 & 57 & 69 & 79 \\
\hline Tevreden over wijze waarop besluiten tot stand komen & 49 & 39 & 45 & 62 \\
\hline
\end{tabular}

De score op de eerste vraag levert cijfers op die vergelijkbaar zijn met de Eurobarometer-resultaten voor de vraag naar de 'tevredenheid met het functioneren van de democratie'. Al sinds eind jaren tachtig fluctueren die rond de zeventig procent (zie figuur 6.1). De tevredenheid over de wijze waarop besluiten tot stand komen blijkt echter beduidend lager te liggen. ${ }^{15}$ Ook hier is er weer verschil in resultaat naar opleidingsniveau.

\section{Is Nederland een democratie?}

Aan de respondenten is ook gevraagd hoe belangrijk ze het vinden om in een democratie te leven. Het verbaast niet dat de overgrote meerderheid dat heel belangrijk vindt. Meteen daarna werd echter een vervolgvraag gesteld, namelijk deze: "En in hoeverre is Nederland volgens u een democratie?” De respondenten konden hun antwoord invullen op een zevenpuntsschaal, waarbij 1 stond voor 'helemaal geen democratie' en 7 voor 'absoluut een democratie'. Het gemiddelde antwoord was 5,62. Wederom was er verschil naar opleidingsniveau, maar het verschil was niet groot: gemiddeld 5,33 voor laag opgeleiden, 5,58 voor middelbaar opgeleiden en 5,90 voor hoger opgeleiden.

Een interessante vraag is natuurlijk waarom sommige mensen vinden dat Nederland nog geen volbloed democratie is. Daarom is aan iedereen die een 5 of lager scoorde (264 respondenten, eenderde van de totale steekproef) open gevraagd waarom Nederland volgens hen niet (volledig) een democratie is. In het kader staat een bloemlezing uit de antwoorden. 


\section{Box 6.2 Waarom Nederland geen volledige democratie is}

\section{Waarom Nederland geen volledige democratie is}

- Als we stemmen voor een bepaalde regering, komt er toch een andere. Vriendjespolitiek.

- Niet altijd wordt je mening geaccepteerd als die verschilt van de meerderheid.

- Nog veel beslissingen worden uitsluitend door politieke partijen genomen. Bijvoorbeeld de invoering van de euro. Indien het volk had mogen beslissen was de euro niet ingevoerd.

- Omdat ik deze zogenaamde democratie niet terugvind in de manier waarop Nederland geregeerd word. Nederlanders willen veel dingen, maar een heel groot deel hiervan wordt nooit gerealiseerd omdat de prioriteit van politici vaak ergens anders ligt. Toch raar, als zij het volk vertegenwoordigen!

- Men luistert in Den Haag helemaal niet naar de bevolking. Laatste keer was bij het ophogen van de pensioengerechtigde leeftijd naar 67. Er is heel veel commentaar op (geweest) via o.a. de vakbonden, maar er wordt niet naar geluisterd. Iemand in een zwaar beroep 'moet dan maar worden omgeschoold' om op 45-jarige leeftijd een andere baan te krijgen. Dat gaat dus niet werken.

- De bevolking wordt te weinig betrokken bij belangrijke beslissingen. De macht ligt bij de regering.

- Omdat er vanuit de regering niet echt meer naar de bevolking geluisterd wordt.

- Ik denk dat er veel binnenskamers politiek bedreven wordt en dat men je veel voorspiegelt en zich daar later niet aan houdt.

- Wij worden geregeerd door een christelijke minderheid die haar denkbeelden opdringt.

- Er zijn te grote verschillen.

- Omdat deze regering ondanks duidelijke tegenspraak van haar volksvertegenwoordiging toch doet wat ze wil.

- Er worden ook nogal eens wat beslissingen genomen waar de meeste mensen volgens mij niet achterstaan. kilometerheffing enzovoorts!

- Omdat men bang is voor de buitenlanders in Nederland en dus doet wat zij willen. Men luistert dus niet naar de Nederlanders.

- Omdat geld (mee)regeert en de PVV geen democratische partij is, maar wel groot dreigt te worden.

- Omdat er te veel wetjes zijn.

- Kijk hoe groot onze camping aan het worden is.

Alle antwoorden zijn vervolgens gecodeerd. In de onderstaande tabel staat het resultaat. (Omdat respondenten meer dan één reden konden geven, ligt het totaal percentage boven 100\%.) 
$\mathrm{N}=264$, antwoorden in percentages genoemd

Met betrekking tot vrijheid

Je mag/kunt hier niets zeggen, verwijzingen naar vrijheid van meningsuiting

Andere verwijzingen naar vrijheid

\section{Met betrekking tot besluitvorming}

De regering doet niet wat (de meerderheid van) het volk wil/gaat haar eigen gang/ denkt alleen aan eigen belangen

De regering luistert niet/weet niet wat er leeft.

Geen inspraak/medezeggenschap voor burgers, geen referendum

Gebrek aan daadkracht/leiderschap, slapheid/compromiscultuur

Je krijgt niet de premier/coalitie/regering waarop je hebt gestemd

Beloften worden niet nagekomen

Andere belangen dan de wil van het volk zijn bepalend (geld, Europa etc)

Gebrek aan openheid, achterkamertjespolitiek

6

\section{Met betrekking tot 'stand van het land'/resultaten}

Verwijzingen naar misstanden/onrechtvaardigheden in samenleving

Oneens met bepaald beleid of plan

Te veel regels/betutteling

Overigen en weet niet

Het beeld is duidelijk. Hoewel er een grote variëteit in antwoorden is, hebben veruit de meeste genoemde redenen te maken met de wijze waarop de besluiten in Nederland worden genomen, en dan vooral met een verondersteld gebrek aan correspondentie tussen wat de regering besluit en wat 'het volk' of de meerderheid der burgers wil. ${ }^{16}$

\section{Analyse}

Tot slot ga ik in op de vraag wat voorspellers zijn van de positieve of negatieve evaluaties die in deze paragraaf centraal staan. Daarom zijn enkele regressieanalyses gedaan met als afhankelijke variabelen de tevredenheid over rechten en vrijheden, de tevredenheid over de wijze waarop besluiten tot stand komen, en de mate waarin Nederland een democratie is. 
De analyse is in drie stappen gedaan, en omvat in totaal vijf onafhankelijke variabelen.

1 In model 1 zijn twee variabelen betrokken. De eerste is het opleidingsniveau. Uit de literatuur blijkt immers dat opleidingsniveau een cruciale variabele is bij allerlei politieke attitudes. In het voorgaande bleken ook steeds duidelijke verschillen in resultaat tussen de opleidingsniveaus. De tweede variabele is 'stem voor coalitie/oppositie'. Dit is een dichotome variabele die aangeeft of iemand bij de parlementsverkiezingen van 2006 heeft gestemd op een partij die vervolgens lid werd van de regering, of dat hij heeft gestemd op een partij die vervolgens in de oppositie ging (of de kiesdrempel niet haalde). Deze variabele is in het model opgenomen, omdat uit onderzoek bekend is dat wie op een regeringspartij heeft gestemd, meestal iets positiever oordeelt over democratie en politiek dan de overige kiezers (Anderson en Guillory 1997; Norris 1999b; Dalton 2004). Het is immers 'zijn' partij die nu aan de macht is.

2 In model 2 is hieraan een derde variabele toegevoegd, namelijk 'overschatting van het aantal medestanders'. Deze variabele is het gemiddelde per respondent van zijn antwoord op twee vragen, namelijk de mate waarin hij overschat hoeveel mensen net als hijzelf onderwerp $\mathrm{x}$ beschouwen als het grootste probleem in ons land, en de mate waarin hij overschat hoeveel mensen net als hijzelf (heel) weinig of (heel) veel vertrouwen hebben in de regering respectievelijk de Nederlandse politici. De verwachting is dat hoe groter de overschatting, hoe negatiever men zal scoren op de afhankelijke variabelen.

3 In model 3 zijn nog een vierde en vijfde variabele toegevoegd, namelijk de eerder beschreven indicator voor de mate waarin men meer direct democratische elementen wenst, en de eerder beschreven indicator voor oog voor en acceptatie van gedeeldheid. De verwachting is dat een hogere score op de indicator 'meer direct democratische elementen' gepaard gaat met een negatiever score op de afhankelijke variabelen, terwijl een hogere score op de indicator voor 'oog voor en acceptatie van gedeeldheid' gepaard gaat met een positiever score op de afhankelijke variabalen.

Voor methodologische details verwijzen zij naar bijlage 1 van hoofdstuk 6 . In tabel 6.11 staan de analyses.

De verklarende kracht van de drie modellen wordt weergeven door de adjusted $R^{2}$. Het eerste model blijkt slechts geringe verklarende kracht te hebben. Op basis van alleen opleiding en stemgedrag bij de laatste verkiezingen kan slechts 5 respectievelijk 6 en 11 procent van de totale variantie worden verklaard. In het tweede model is de mate van overschatting toegevoegd, en daardoor verdubbelt de verklaarde variantie bij de eerste twee vragen, terwijl deze ook bij de derde vraag beduidend stijgt. In het derde model maakt de verklaarde variantie echter de grootste sprong omhoog. Dit model kan bij de eerste twee vragen bijna eenderde van de totale variantie verklaren, en bij de laatste vraag een kwart. 
Tabel 6.11 Voorspellers van evaluatieve oordelen ten aanzien van democratie

\begin{tabular}{|c|c|c|c|}
\hline Bèta's & Model 1 & Model 2 & Model 3 \\
\hline Opleidingsniveau & $0,17^{* *}$ & 0,09 & $-0,04$ \\
\hline Stem coalitie/oppositie & 0,16 & $0,13^{*}$ & 0,06 \\
\hline Overschatting gelijkgezinden & & $-0,28^{* * *}$ & $-0,20 * *$ \\
\hline Indicator 'meer directe democratie' & & & $-0,35^{* * *}$ \\
\hline Indicator 'oog en acceptatie gedeeldheid' & & & $0,14^{*}$ \\
\hline Adjusted $\mathrm{R}^{2}$ & 0,05 & 0,12 & 0,28 \\
\hline
\end{tabular}

${ }^{*} \mathrm{p}<.05, \quad{ }^{* *} \mathrm{p}<.01, \quad{ }^{* * *} \mathrm{p}<.001$

Hoe tevreden bent u over de mate waarop in de Nederlandse politiek besluiten tot stand komen? $(\mathrm{N}=\mathbf{2 5 0})$

\begin{tabular}{|c|c|c|c|}
\hline Bèta's & Model 1 & Model 2 & Model 3 \\
\hline Opleidingsniveau & $0,20 * *$ & 0,13 & $-0,02$ \\
\hline Stem coalitie/oppositie & 0,16 & $0,14^{*}$ & 0,06 \\
\hline Overschatting gelijkgezinden & & $-0,24^{* * *}$ & $-0,14^{*}$ \\
\hline Indicator 'meer directe democratie' & & & $-0,28^{* * *}$ \\
\hline Indicator 'oog en acceptatie gedeeldheid' & & & $0,27^{* * *}$ \\
\hline Adjusted $\mathrm{R}^{2}$ & 0,06 & 0,11 & 0,30 \\
\hline
\end{tabular}

${ }^{*} \mathrm{p}<.05, \quad{ }^{* *} \mathrm{p}<.01, \quad{ }^{* * *} \mathrm{p}<.001$

In hoeverre is Nederland volgens u een democratie? $(\mathrm{N}=\mathbf{2 4 8})$

\begin{tabular}{|c|c|c|c|}
\hline Bèta's & Model 1 & Model 2 & Model 3 \\
\hline Opleidingsniveau & $0,24^{* * *}$ & $0,18^{* *}$ & $-0,07$ \\
\hline Stem coalitie/oppositie & $0,24^{* * *}$ & $0,22^{* * *}$ & $0,17^{* *}$ \\
\hline Overschatting gelijkgezinden & & $-0,24^{* * *}$ & $-0,17^{* *}$ \\
\hline Indicator 'meer directe democratie' & & & $-0,22^{* *}$ \\
\hline Indicator 'oog en acceptatie gedeeldheid' & & & $0,15^{*}$ \\
\hline Adjusted $\mathbf{R}^{2}$ & 0,11 & 0,16 & 0,25 \\
\hline
\end{tabular}

${ }^{*} \mathrm{p}<.05, \quad{ }^{* *} \mathrm{p}<.01, \quad{ }^{* * *} \mathrm{p}<.001$

Met name de indicator voor 'meer directe democratie' blijkt een krachtige voorspeller te zijn. In alle gevallen hebben de gevonden verbanden de verwachte richting. 
Twee dingen zijn opvallend. Ten eerste de geringe betekenis van het opleidingsniveau. Zoals gezegd is opleiding een belangrijke factor bij veel attitudes, maar in deze modellen blijkt opleiding maar weinig variantie te verklaren. Bovendien verdwijnt het effect van opleidingsniveau vrijwel geheel als men ook rekening houdt met de attitudes ten aanzien van direct democratische elementen en gedeeldheid. Kennelijk zijn dit mediërende variabelen waarnaast geen zelfstandig effect van opleidingsniveau bestaat. Ten tweede is het effect van de mate van overschatting opvallend. Dat is misschien wel de belangrijkste uitkomst van deze analyses. Weliswaar is het effect van de indicator voor meer directe democratie nog groter, maar dat is welbeschouwd niet zo vreemd. De stellingen waarop die indicator is gebaseerd, liggen inhoudelijk namelijk dicht aan tegen de afhankelijke variabelen. Daarentegen ligt veel minder voor de hand dat louter het feit dat iemand het aantal gelijkgezinden overschat, ook effect heeft op die evaluaties. Gezien de hoogte van de bètacoëfficiënten gaat het om een substantieel effect dat bovendien robuust is. In alle gevallen is het significant, en het effect blijft grotendeels overeind na toevoeging van de krachtige indicatoren voor 'meer directe democratie' en de - iets minder krachtige - indicator voor gedeeldheid.

\subsection{BESCHOUWING: ONVREDE ALS KENNISPROBLEEM}

Ik zet nu een punt achter het empirische deel en ga meer beschouwend verder. Eigenlijk weten we maar weinig over hoe het is gesteld met de steun voor de Nederlandse democratie. Degenen die beweren dat het de laatste decennia hard de verkeerde kant opgaat, hebben wat uit te leggen, want voor zover er cijfers beschikbaar zijn, laten die toch echt een ander beeld zien. Er is geen sprake van een dalende trend, eerder het omgekeerde. Bovendien doet Nederland het vergeleken met andere landen beslist goed.

Toch moeten we ons niet al te zeer laten geruststellen door deze cijfers. Over een aantal relevante attitudes worden in de grote enquêtes geen vragen gesteld, en van de vragen die wél worden gesteld, is niet altijd duidelijk wat ze precies meten.

Kennelijk gaat er iets goed in Nederland, maar wat het dan precies is dat goed gaat is minder duidelijk. Wat bedoelen mensen wanneer zij antwoorden dat democratie een goede manier is om een land te besturen? Als zij democratie vooral associëren met vrijheid, is die uitkomst niet zo indrukwekkend, want wie is er nu tegen vrijheid? Fijn dat het aantal mensen dat tevreden is 'met de wijze waarop de democratie functioneert' zo hoog ligt. Maar als dat vooral betekent dat ze tevreden zijn over met name de economische toestand van het land, mogen we daaruit niet zomaar concluderen dat ze ook blij zijn met de concrete vormgeving van het democratische systeem. In de enquête die voor dit hoofdstuk werd uitgevoerd, werden enkele vragen gesteld die poogden meer rechtstreeks de betreffende attitudes te meten. Heel geruststellend waren de resultaten niet. Wat betekent het als minder dan de helft van de mensen antwoordt dat zij tevreden zijn over de wijze 
waarop in de Nederlandse politiek besluiten tot stand komen? Dat een meerderheid vindt dat de politiek te weinig naar de burgers luistert, en dat eenderde meent dat we eigenlijk geen volledige democratie hebben?

\section{Karakter of kennis?}

Een van de wijzen waarop men het ongenoegen over de Nederlandse politiek en democratie kan duiden, is door te veronderstellen dat kennelijk niet iedereen even democratisch gezind is. Sommige mensen hebben blijkbaar een antidemocratisch karakter. Hun gebrek aan democratische gezindheid is een onderdeel van hun - wellicht autoritaire - persoonlijkheid (Altemeyer 1996). We kunnen maar beter niet te veel van zulke types in ons land hebben, want anders kan de democratie in gevaar komen. Dit is echter niet de invalshoek van dit hoofdstuk. Hierin zou ik scepsis en onvrede ten aanzien van de politiek, haar instituties en prestaties veeleer willen zien als een kennisprobleem. Ze hoeven helemaal niet te duiden op een 'fout' karakter, maar zouden best eens kunnen voortkomen uit een beperkte en mogelijk onjuiste waarneming van de realiteit.

Twee 'kennisgebreken' vallen op. Allereerst kan onvrede over de huidige democratische praktijk voortkomen uit een weinig reëel beeld van wat democratie behelst en vermag. $\mathrm{Nu}$ is het natuurlijk ook geen messcherp afgebakend begrip, maar als we mensen vragen waaraan zij als eerste denken bij het woord democratie, komen er regelmatig antwoorden die een nogal beperkte opvatting van het concept suggereren. Veel mensen associëren democratie in eerste instantie met vrijheid. Dat is natuurlijk de 'leuke' kant van democratie. Vrijheid is het onderdeel van het democratische pakket dat iedereen wil hebben. Maar hoe zit het met de minder 'leuke' kanten van democratie, zoals de noodzaak rekening te houden met andersdenkenden, en de soms onaangename gevechten die men moet leveren om te komen tot een aanvaardbaar compromis (dat maar bleek zal afsteken bij het ideaal)? In hoeverre realiseert iedereen zich dat naast de 'lusten' van de vrijheid onvermijdelijk ook de 'lasten' van het samenleven in pluriformiteit staan? Hiermee verweven is een tweede 'kennisgebrek'. Het is opmerkelijk dat nogal wat mensen een vertekend beeld hebben van de mate waarin het volk 'gedeeld' is. Als men respondenten vraagt wat zij als grootste probleem in dit land beschouwen, en vervolgens vraagt te schatten hoeveel landgenoten het met hen eens zijn, antwoorden zij veelvuldig dat een meerderheid, of toch minstens de helft van de mensen er hetzelfde over denkt. Het aantal medestanders wordt systematisch overschat, en niet zo'n beetje ook. Dat fenomeen treedt eveneens op als men respondenten vraagt hoeveel Nederlanders zij denken dat - net als zijzelf - (heel) veel of weinig vertrouwen hebben in de regering respectievelijk Nederlandse politici. De respondenten denken dat de meeste landgenoten hetzelfde oordeel hebben.

Deze 'bijziendheid' is een vorm van het psychologisch verschijnsel dat in de wetenschappelijke literatuur bekendstaat als 'social projection' of het 'false 
consensus effect'. Dit houdt in dat mensen geneigd zijn te denken dat de meerderheid hetzelfde oordeelt over een bepaalde kwestie als zij zelf - ook als in werkelijkheid slechts een minderheid het met hen eens is. Om precies te zijn: "Members of the majority slightly underestimate the size of their own group, whereas members of the minority strongly overestimate the size of theirs." (Krueger en Clement 1997: 299) Dit effect is in vele studies gevonden. Daarbij varieerden de onderzochte oordelen van de voorkeur voor een bepaalde presidentskandidaat tot de bereidheid met een sandwichbord reclame te maken.

Hoe groot is de overschatting? Krueger en Clement calculeerden dat op basis van twee meta-analyses (Mullen et al. 1988 en Gross \& Miller 1997). In de ene meta-analyse bleken mensen die een minderheidsstandpunt innemen, gemiddeld te denken dat 55 procent van de mensen het met hen eens zijn, terwijl dat in de andere meta-analyse 60 procent was. Deze percentages stemmen goed overeen met de gemiddelde overschattingen die in mijn enquête werden gevonden. Over de verklaring van dit effect zijn er veel meningen:

"The most common cognitive accounts emphasize selective exposure and/or cognitive availability and accessibility people normally associate with (and therefore have available in memory) others who are similar to themselves," concluderen Biernat en Eidelman in een recent overzicht (2009: 316).

Daarnaast spelen vermoedelijk allerlei motivationele factoren een rol, zoals de behoefte aan zelfbevestiging en bescherming van zelfvertrouwen.

Het is raadzaam hier even stil te houden, zodat de betekenis van deze bevindingen goed kan doordringen. Het belang ervan kan moeilijk worden overschat. Als alle burgers gemiddeld genomen denken dat - zolang duidelijk tegenbericht uitblijft hun standpunt tevens de mening van de meerderheid is, wordt politiek een ontnuchterend schouwspel. Het kan de feitelijke minderheid hard met de neus op onvermoede en onaangename feiten drukken. Het is dan ook niet vreemd dat, naarmate men sterker gebukt gaat onder de optische illusie van valse consensus, men ook negatiever oordeelt bij de evaluatieve enquêtevragen over de Nederlandse democratie. Naarmate iemand sterker meent dat iedereen hetzelfde wil, wordt immers onbegrijpelijker waarom de politiek dat niet gewoon uitvoert? Waarom steeds dat voortdurende geruzie en eindeloze gepraat? En waarom neemt men dan ten langen leste ook nog eens het verkeerde besluit, namelijk iets anders dan het volk wil? Op zo'n moment gaan mensen zelf verklaringen verzinnen. Hibbing en Theiss-Morse stellen dat veel Amerikanen dan concluderen dat er kennelijk 'special interests' in het spel zijn die de politici in hun greep hebben, en waardoor zij uiteindelijk anders beslissen dan het volk wil. Een aantal Nederlanders denkt er ook zo over. In ons land lijkt echter vooral een andere verklaring favoriet: de politiek 'weet niet wat er leeft', en daarom doet ze steeds de verkeerde 
dingen. De meeste respondenten vinden dat de politiek te weinig naar de mensen luistert (zie ook Tiemeijer 2009; Van der Meer et al. 2009), en maarliefst 55 procent is het (zeer) eens is met de discutabele stelling dat "veel problemen makkelijk kunnen worden opgelost als de politiek maar beter naar de burgers zou luisteren”. Kortom, dat er sprake is van een kennisprobleem zullen de meeste burgers van harte onderschrijven. Alleen leggen ze dat bij de politici neer!

Dit alles werpt een ander licht op de wens tot meer directe democratie die uit de vorige bladzijden sprak. Op zich is het geen nieuws dat veel burgers een voorkeur hebben voor meer direct democratische elementen. Dat weten we al uit het nationaal kiezersonderzoek en de onderzoeken van het SCP. De vraag is alleen wat dit precies betekent. Hebben mensen werkelijk de authentieke wil tot grotere politieke activiteit? Zullen zij werkelijk hun wensen omzetten in daden zodra de politiek hen daartoe de ruimte biedt? Dat mag betwijfeld worden. Ten eerste, áls er dan eens een referendum wordt gehouden in Nederland, blijkt het vaak een hele opgave om een zodanige opkomst te realiseren dat het referendum überhaupt geldig is. Ten tweede, uit de analyse op de vorige pagina's bleek dat de voorkeur voor meer direct democratische elementen het hoogst is bij de groepen waar je die juist het minste zou verwachten, namelijk bij lager en middelbaar opgeleiden. De praktijk leert namelijk dat inspraak en politieke participatie aangelegenheden zijn waar vooral hoger opgeleiden zich graag mee inlaten, terwijl de lager opgeleiden het meestal laten afweten - vaak ondanks verwoede pogingen van goedwillende beleidsmakers om ook hen erbij te betrekken (Hartman 2000; IMO et al. 2003; Wille 2001; Bovens en Wille 2009). Waarom spreken deze lager opgeleiden zich dan tóch uit voor meer directe democratie? Een ander merkwaardig fenomeen is dat juist degenen die zeggen dat ze meer inspraak willen, relatief vaak de stelling onderschrijven dat het "goed zou zijn als het bestuur van het land werd overgelaten aan enkele krachtige leiders”. (Dekker en Steenvoorden 2008). Dat lijkt toch tegenstrijdig.

Dus wat betekent dan die gerapporteerde sterke voorkeur van de lager opgeleiden voor meer directe democratie? Opnieuw leveren Hibbing en Theiss-Morse een plausibel antwoord. Volgens hen moet deze voorkeur niet zozeer begrepen worden als een wens om zelf daadwerkelijk politiek actief te worden, maar veeleer als een uiting van het verlangen een stevig halt toe te roepen aan zelfzuchtige politici die alleen maar zouden denken aan hun eigenbelang en de 'special interests' waarvan ze afhankelijk zijn. Voor de Nederlandse situatie kan daar nog een tweede element aan worden toegevoegd: meer directe democratie lost het veronderstelde kennisprobleem van politici op, doordat hierdoor de informatiekloof tussen burger en politicus kleiner wordt of zelfs geheel gedicht. Illustratief zijn in dit verband de reacties op de vraag waarom bepaalde respondenten Nederland geen volledige democratie vinden. Overheersend was het antwoord dat de regering 'niet luistert' en niet doet wat 'het volk' wil. Geen van de 264 respondenten die de 
vraag kregen voorgelegd, sprak echter van een gefrustreerde wens om zelf politiek actief te worden.

\section{Crippled epistemology}

Terug naar het kennisprobleem van de burgers: weet iedereen wel even goed wat democratie inhoudt? Ziet iedereen even scherp dat er belangentegenstellingen zijn die bewerking behoeven, en die het onsmakelijke schouwspel dat politiek soms kan zijn noodzakelijk maken? Het antwoord is nee. Een deel der Nederlanders ziet dat niet. Dat valt nauwelijks te ontkennen. De relevante vraag is veeleer hoe groot de betreffende groep is. Zijn het slechts enkelingen of is het een substantieel deel van de bevolking? Het ligt er natuurlijk aan hoe hoog je de kennislat legt, maar mijn educated guess zou zijn dat tien à vijftien procent van de Nederlandse burgers denkbeelden heeft over wat democratie en politiek zijn - en zouden moeten zijn die zo ver verwijderd zijn van de realiteit dat teleurstelling en onvrede welhaast onvermijdelijk zijn. Een deel van de burgers heeft een sterk consumentistisch beeld van politiek. Die wordt geacht per ommegaande te leveren wat 'het volk' wenst. En als dat niet meteen wordt geleverd, wordt dit niet geïnterpreteerd als teken dat er kennelijk andere belangen of praktische beperkingen in het spel zijn, maar als 'bewijs' dat men blijkbaar 'niet weet wat er leeft' en/of er alleen maar zit voor de eigen portemonnee. Een deel van de bevolking heeft last van wat Sunstein recentelijk aanduidde als een 'crippled epistemology' (2009:41). ${ }^{17}$

Maar niet te lang getreurd. De keerzijde van dit slechte nieuws is namelijk dat het ook nieuwe perspectieven biedt voor het vergroten van het vertrouwen in de politiek en de legitimiteit van het openbaar bestuur. Als het gaat om het probleem van gebrekkige legitimiteit, zijn er in beginsel drie reacties mogelijk. De eerste is: de schouders erover ophalen. Een zekere mate van onvrede hoort er nu eenmaal bij. Men zou bijvoorbeeld kunnen stellen dat die altijd al heeft bestaan, en hooguit de laatste jaren meer zichtbaar is geworden. Redenen daarvoor zijn bijvoorbeeld de opkomst van internet en de post-Fortuyn behoefte om toch vooral 'de straat' een stem te geven. Kortom, laten we het hoofd koel houden, de Nederlandse democratie kan best tegen een stootje, in andere landen is het allemaal nog veel erger, en die zijn ook nog steeds niet uit elkaar gevallen. Deze relativerende reactie is de laatste jaren weinig populair.

Aanmerkelijk vaker valt de tweede reactie te vernemen: de overheid moet anders. Sinds begin jaren negentig verschijnen met grote regelmaat rapporten en adviezen die beogen het openbaar bestuur zo te veranderen dat de onvrede over de politiek zal afnemen en het vertrouwen toeneemt. We hebben zelfs enige jaren een minister voor bestuurlijke vernieuwing gehad. Tot nu toe heeft het allemaal echter weinig opgeleverd, en de stroom publicaties gaat dan ook gewoon door. Begin 2010 bijvoorbeeld sprak de Raad voor het Openbaar Bestuur van een legitimiteitscrisis en pleitte zij meer directe democratie (RОВ 2010). 
$\mathrm{Nu}$ kunnen er uiteraard best goede redenen zijn om de democratische regels, procedures en instituties aan te passen aan de eisen van de tijd. Maar laat men vooral niet de illusie hebben dat hierdoor de onvrede onder bepaalde groepen burgers over politiek en openbaar bestuur opeens zou verdwijnen. Waar die voortkomt uit irreële opvattingen over wat democratie behelst en vermag, zal het nauwelijks verschil maken. Sterker nog, het risico bestaat zelfs dat we van de wal in de sloot geraken. Wie kijkt naar andere landen, ziet een grote variëteit in uitwerkingen van de abstracte idee van democratie in concrete regels en procedures, bijvoorbeeld in winner-takes-all systemen (Engeland) of landen met veel meer direct democratische elementen (de Verenigde Staten). De onvrede is daar over het algemeen echter niet minder, integendeel. Het Nederlandse model van strikte proportionaliteit lijkt juist relatief goed te scoren (Anderson en Guillory 1997; zie echter ook Norris 1999b).

De derde reactie is: de burgers moeten veranderen - althans, een deel van de burgers. Hen moet bijvoorbeeld meer begrip worden bijgebracht van de empirische werkelijkheid waarmee de politiek wordt geconfronteerd en de logica van de democratische praktijk die daaruit voortvloeit. Deze educatieve insteek kent een respectabele traditie. John Stuart Mill was al een groot voorstander van wat men democratische Bildung zou kunnen noemen. Tegenwoordig is zij echter minder populair. Wie durft tegenwoordig nog openlijk te beweren dat de oorzaak van de kloof en de politieke onvrede mogelijk ten dele ligt bij de slechte geïnfomeerdheid van bepaalde burgers? In april 2007 verscheen de meest recente editie van de parlementaire studie (een uitgebreide enquête onder alle Tweede Kamerleden). Daaruit bleek dat een aantal Kamerleden de schuld voor de kloof mede bij de burgers legt. "Kiezers hebben, zo vinden politici, te weinig politieke kennis, en kunnen daarom niet echt volgen wat er in Den Haag gebeurt," lichtte onderzoeker Thomassen toe. ${ }^{18}$ Dit standpunt kon in de serieuze media bepaald niet op veel begrip rekenen, en op internet uitten veel mensen hun verontwaardiging over deze 'arrogantie'.

Kortom, als het gaat om de vraag hoe de kloof te verkleinen is er in het actuele debat in feite sprake van eenrichtingsverkeer. Onvrede duidt erop dat het 'de politiek' is die iets verkeerd doet, niet de burger. Het is dus ook de politiek die de kloof moet verkleinen door stappen te zetten in de richting van de burgers, niet omgekeerd. Er is bijna niemand die beweert dat sommige burgers misschien ook wat meer hun best mogen doen, en wellicht een stapje richting openbaar bestuur zouden kunnen zetten. De politieke en bestuurlijke elite lijkt zich te hebben neergelegd bij de consumentistische visie dat het allemaal de schuld is van de politiek, en geeft daarmee in feite voeding aan die visie. Dat is weinig behulpzaam, want de burger is natuurlijk niet alleen maar een klant. Burgerschap is óók een ambt. Deze laatste formulering komt uit een publicatie van de WRR uit 1992 die werd opgesteld onder leiding van Herman van Gunsteren. "Met deze wat ongebruikelijke 
aanduiding wordt bedoeld [...] dat aan de toelating tot en de uitoefening van burgerschap eisen van competentie worden gesteld" (1992: 19). En welke zijn dan die competenties? De WRR verzet zich tegen de idee dat uitspraken daarover onmogelijk zouden zijn, en elke beoordeling van competentie vermeden zou moeten worden, omdat het de vrijheid van burgers zou schenden. Het gaat volgens de raad om oordeelkundigheid. "Zonder oordeelkundigheid is competent optreden van burgers niet goed voorstelbaar” (1992: 41). Gelukkig kan men dit tot op zekere hoogte leren, namelijk door aan burgerlijke handelingspraktijken deel te nemen. Al doende maakt men zich de competenties eigen. Hiermee voegt Van Gunsteren zich dus in de traditie van De Tocqueville die politieke associaties zag als gratis scholen voor democratie

Mijn betoog sluit hierop aan, zij het dat het me niet zozeer gaat om 'vaardigheden' maar allereerst om 'kennis'. Elk gezond oordeel begint met een voldoende adequate waarneming van de praktijk waartoe men wordt geacht zich te verhouden. Helaas is daar soms enige inspanning voor nodig. Maar mag men van burgers die daadwerkelijk serieus genomen willen worden, niet verwachten dat zij zich enigermate informeren over de wereld waarvan zij onderdeel uitmaken? Is dat geen onderdeel van goed burgerschap?

\section{Tot slot}

Mijn conclusie luidt dat het (veronderstelde) gebrek aan legitimiteit van het Nederlandse openbaar bestuur ten dele wordt veroorzaakt door onbegrip over de werking van democratie. Het moet dus mogelijk zijn om door middel van betere verspreiding van kennis die legitimiteit te verhogen. Hoe dat concreet aangepakt moet worden is een andere vraag. Het lijkt op voorhand niet iets waarmee de overheid zich intensief moet bezighouden. Dat is meer iets voor partijen op enige afstand, zoals onderwijs of media. Zeker de eerste heeft traditioneel al een onomstreden - rol op dat gebied. Het zou ook niet moeten gaan om rechtstreekse 'propaganda' voor het huidige democratische systeem. Het is al heel wat als onderwijs en media proberen om mensen meer oog bij te brengen voor de principiële pluriformiteit in standpunten, en de consequenties hiervan voor de democratische praktijk. In alle gevallen dienen zij te waken voor simplistische voorstellingen van zaken.

Enfin, het punt van de uitwerking gaat het bestek van dit hoofdstuk te buiten. Het gaat om het principiële punt. Als het gaat om de legitimiteit van de democratie en onvrede over het huidig functioneren ervan, zijn er meer mogelijkheden dan de schouders ophalen of het systeem op de schop nemen. Er is nog een derde weg: durven erkennen dat dit probleem ten dele het gevolg is van een 'crippled epistemology' en die te lijf gaan. We zijn nooit uitgeleerd. 


\section{NOTEN}

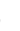

De volgende mensen wil ik graag danken voor hun zeer waardevolle hulp en commentaar bij dit hoofdstuk: Maud Adriaansen, Paul Dekker, Loek Halman, Beatrijs Haverkamp, Josje den Ridder, Peggy Schyns.

Veel data uit deze onderzoeken zijn verkrijgbaar via www.europeanvaluesstudy.eu en www.worldvaluessurvey.org.

Ook telde niet iedereen als burger. Vrouwen, armen en 'allochtonen' hadden geen burgerrechten.

Deze en de vorige alinea zijn gebaseerd op Thomassen 1991, De Jong 1991 en Diamond 2003. Wanneer men een voorbeeld zou willen noemen van een rechtstaat zonder democratie, komt Singapore een heel eind in de richting.

Opvallend is de naam die aan het derde niveau wordt gegeven. Heette dat niveau in Dalton (1999) nog 'performance', in Dalton (2004) heet het 'norms and procedures'. Dat niveau meet Dalton vervolgens wel weer met een performanceindicator, namelijk 'satisfaction with democracy'.

Een technische verantwoording is op aanvraag bij de auteur verkrijgbaar. De ongeschoonde steekproef bedroeg 791 Nederlanders. Hiervan hadden echter tien respondenten de enquête in zeer korte tijd ingevuld, en bijna overal 'weet niet' ingevuld. Deze zijn uit het onderzoeksbestand verwijderd.

Een aantal respondenten noemde meerdere associaties. Bij hen is alleen de eerste associatie gecodeerd, en zijn de tweede en volgende associatie genegeerd.

Deze percentages dienen met enige voorzichtigheid benaderd te worden. Ten eerste omdat, anders dan in 1973 en 1994, in de 2010-peiling gebruik werd gemaakt van bevraging via een internetpanel, ten tweede omdat zoveel jaren na de vorige peilingen niet meer valt te achterhalen of de codering voor 2010 geheel identiek is aan die van 1973 en 1994 .

Hierbij is de driedeling in opleidingsniveaus van het CBS aangehouden, gebaseerd op SOI 2006

Hierbij zijn de respondenten die op één of meer van de stellingen met 'weet niet' antwoordden, buiten de analyse gelaten. Het betrof 51 respondenten, ofwel 6,5 procent van de steekproef.

1 De vraag is ook gesteld in een gesloten variant, waarbij respondenten konden kiezen uit de categorieën die ook in de Eurobarometer worden gehanteerd. De antwoorden hiervan bleken echter minder bruikbaar. In de Eurobarometer mag men de twee grootste problemen aangeven, terwijl men in mijn enquête maar één categorie mocht kiezen. In de Eurobarometer-vraag ontbreken voorts twee 'populaire' antwoordcategorieën, te weten 'de buitenlanders/allochtonen' en 'normen en waarden'. Resultaat was dat bijna de helft van de respondenten koos voor het algemene antwoord 'de economische situatie'. Deze resultaten blijven derhalve verder buiten beschouwing.

2 Deze resultaten wijken enigszins af van de сов-data uit ongeveer dezelfde 
periode, waarin 'normen en waarden' beduidend hoger scoren (zie Dekker et al. 2009) Het is niet helemaal duidelijk wat hiervan de oorzaak is. Voor de strekking van het betoog op deze pagina's, te weten het fenomeen van 'overschatting', is dit echter niet van belang.

13 Overigens blijkt er nauwelijks verschil in de antwoordpercentages bij beide vragen. Dit past in het beeld dat uit ander onderzoek bekend is, namelijk dat mensen nauwelijks onderscheid maken tussen de verschillende politieke spelers. Het is allemaal 'Den Haag' (zie ook Tiemeijer 2008, 2009).

14 Hierbij zijn de respondenten die op één of meer van de stellingen met 'weet niet'antwoordden, buiten de analyse gelaten. Het betrof 57 respondenten, ofwel 7,3 procent van de steekproef.

15 Het is mogelijk dat, doordat de vragen in deze volgorde meteen na elkaar werden gesteld, er een substractie-effect heeft plaatsgevonden, maar dat is in dit geval juist beoogd. Het gaat me expliciet om het antwoord op de tweede vraag minus eventuele waardering voor de rechtstatelijke vrijheden.

16 Het bleek dat veel mensen democratie allereerst associëren met vrijheid. Hier blijkt echter dat degenen die Nederland niet volledig democratisch vinden, als reden daarvoor meestal niet wijzen naar een gebrek aan vrijheid, maar naar gebreken in de besluitvorming. Nadere analyse leert dat bij de vraag naar de betekenis van democratie, deze groep respondenten het begrip inderdaad significant minder vaak met vrijheid associeert dan de overige respondenten (34 versus 44 procent, chi-kwadraat $<0,05$ ). Sunstein heeft de term weer overgenomen van Hardin, die het begrip overigens in iets beperktere betekenis gebruikt. Reformatorisch Dagblad, 3 april 2007, blz. 3. 


\section{BIJLAGE BIJ HOOFDSTUK 6: DETAILS STATISTISCHE ANALYSE}

\section{Schaalconstructies}

De schalen voor 'meer directe democratie' en 'oog voor en acceptatie van gedeeldheid' zijn als volgt geconstrueerd. De onderliggende stellingen werden met een vijfpuntsschaal voorgelegd. Per stelling is vervolgens de waarde 1 toegekend aan de antwoorden 'helemaal mee eens' en 'mee eens', de waarde 2 aan het antwoord 'noch eens, noch oneens', en de waarde 3 aan de antwoorden 'helemaal mee oneens' en 'mee oneens'. De schaal geeft nu de gemiddelde score op de set van stellingen.

\section{Operationalisering variabelen}

In de regressieanalyse zijn de volgende variabelen gebruikt.

- Afhankelijke variabelen

- Eerste twee onderdelen van tabel 11: ordinaal, vier niveaus: (1) heel weinig (2) weinig (3) veel (4) heel veel.

- Derde onderdeel van tabel 11: ordinaal, zevenpunts ( $1=$ helemaal geen democratie, 7 absoluut een democratie).

- Onafhankelijke variabelen

- Opleidingsniveau: ordinaal, zevenpunts, (1) is laagste niveau, ( 7$)$ is hoogste niveau.

- Stem op coalitie of regering: dichotoom: (I) $=\mathrm{CDA}, \mathrm{PvdA}, \mathrm{CU},(\mathrm{O})=$ overige partijen.

- Indicatoren voor 'meer directe democratie' en 'oog voor en acceptatie van gedeeldheid': continu, minimale waarde 1 en maximale waarde 3. Hoe hoger de waarde, hoe meer men geporteerd is van direct democratische elementen, en hoe meer oog/acceptatie men heeft voor 'gedeeldheid'.

- Overschatting: continu, lopend van -10o tot 100.

Dan een toelichting bij de wijze waarop de waarde voor overschatting is berekend. Dit is een getal dat per respondent is gebaseerd op twee antwoorden uit de enquête.

- De vraag hoeveel procent van de mensen volgens de respondent net als hijzelf (heel) weinig/veel vertrouwen heeft in de Nederlandse regering/Nederlandse politici. Van dit geschatte percentage is afgetrokken het feitelijke percentage respondenten dat in de enquête net als de respondent (heel) weinig/veel vertrouwen heeft in de Nederlandse regering/politici. Wat resteert is het percentage overschatting.

- De vraag hoe groot deel van de Nederlanders net als de respondent onderwerp x beschouwt als het grootste probleem waarvoor ons land momenteel staat. Van het antwoord dat respondenten hier gaven, is het werkelijke percentage dat in 
de enquête dit onderwerp als grootste probleem noemde afgetrokken. Wat resteert is het percentage overschatting.

Nota bene: het antwoord op de schattingsvraag was hier niet in percentages, maar in vijf categorieën, namelijk: (bijna) iedereen, een meerderheid der Nederlanders, ongeveer de helft, een minderheid der Nederlanders, (bijna) niemand. Daarom zijn in de berekening deze categorieën omgezet in percentages, en wel als volgt: (bijna) iedereen is 95 procent, een meerderheid der Nederlanders is 72,5 procent, ongeveer de helft is 50 procent, een minderheid is 27,5 procent, en (bijna) niemand is 5 procent.

Van beide overschattingspercentage is vervolgens het gemiddelde bepaald, en dat is gebruikt als invoer voor de regressieanalyse.

De $\mathrm{N}$ in deze regressieanalyses is beduidend lager dan de totale steekproefomvang van de enquête. Dit komt doordat de laatste vraag slechts aan de helft van de respondenten is gesteld. Van hen zijn bovendien alleen die mensen meegenomen die op geen van de stellingen met 'weet niet' antwoordden en die in 2006 hebben gestemd.

\section{Logistische analyse}

De analyse in de hoofdtekst is een lineaire regressieanalyse. Men kan hier het bezwaar tegen inbrengen dat een logistische analyse hier beter zou zijn, in ieder geval bij de eerste twee vragen. Dit zijn immers vierpuntsvariabelen (heel tevreden, tevreden, ontevreden, heel ontevreden) die normaliter worden gereduceerd tot twee variabelen (tevreden, ontevreden). Bovendien kozen veruit de meeste respondenten niet voor de twee extreme categorieën maar voor de twee gematigde categorieën. Kortom, deze afhankelijke variabelen neigen naar een dichotome variabele. Dat vereist een andere regressietechniek, namelijk logistische regressie. Daarom heb ik ook via die methode een analyse gedaan. Het resultaat is vergelijkbaar met dat van de lineaire regressieanalyse: naarmate meer factoren worden toegevoegd, verdwijnt opleidingsniveau als zelfstandige voorspeller. De indicator 'directe democratie' blijkt de grootste voorspeller, maar 'overschatting gelijkgezinden' is tevens een substantiële voorspeller, die ook in het derde model een zelfstandig, betekenisvol en significant effect blijft behouden. 


\title{
7 NIEUWE SCHEIDSLIJNEN EN DE TURBULENTE RELATIE TUSSEN POLITIEK, MEDIA EN BURGERS
}

\author{
Maud Adriaansen $\mathbb{6}$ Philip van Praag
}

\subsection{INLEIDING}

De positie van zowel politiek als media is in de afgelopen decennia sterk veranderd. De politiek heeft te maken met een transformatieproces van de vertegenwoordigende democratie. Politieke partijen, zoals die aan het eind van de negentiende eeuw in Europa zijn ontstaan rond diepgaande sociale, godsdienstige en regionale tegenstellingen, hebben vormgegeven aan de moderne parlementaire democratie en hebben het politieke leven tot het laatste kwart van de twintigste eeuw gedomineerd. Partijen wisten grote groepen burgers aan zich te binden, burgers voor wie het vanzelfsprekend was dat partijen bij de verkiezingen een mandaat kregen om ze gedurende vier jaar te vertegenwoordigen. Partijen stonden in veel landen lange tijd garant voor stabiele politieke verhoudingen. Het gezag van openbaar bestuur en politieke autoriteiten werd in deze periode breed geaccepteerd.

De afgelopen dertig jaar is in West-Europa het maatschappelijke en politieke belang van deze tegenstellingen, vaak aangeduid als maatschappelijke scheidslijnen of cleavages, gestaag afgenomen. De 'bevroren' partijpolitieke verhoudingen zijn geleidelijk 'ontdooid' en in veel landen zijn nieuwe partijen ontstaan. Partijen hebben als gevolg hiervan te maken met functieverlies, terugloop van het ledental en vermindering van maatschappelijk aanzien. Bij elke verkiezing zijn tegenwoordig omvangrijke electorale verschuivingen zichtbaar. Een van de gevolgen van deze ontwikkeling is dat het vierjarige mandaat, waar volksvertegenwoordigers zich op beroepen, voor veel kiezers geen vanzelfsprekende zaak meer is. Bij talloze onderwerpen voelen veel kiezers zich niet adequaat vertegenwoordigd door de partij waar ze in het stemhokje hun mandaat aan hebben gegeven. Politieke partijen en gekozen vertegenwoordigers worstelen met de vraag hoe ze beter invulling kunnen geven aan hun representatiefunctie. Partijen blijven een belangrijke rol spelen maar veranderen langzaam van karakter. De partijorganisaties krijgen een professioneler karakter en worden sterker gedomineerd door politieke leiders. Onder invloed van deze ontwikkelingen transformeren veel Europese parlementaire stelsels op een moeizame wijze tot een nieuw type vertegenwoordigende democratie, vaak aangeduid als toeschouwersdemocratie.

Niet alleen het politieke systeem is onderhevig aan belangrijke veranderingen, ook het mediasysteem doorloopt een transformatieproces. De massamedia - in eerste instantie de kranten en later ook radio en televisie - hebben sinds het begin van de 
twintigste eeuw een belangrijke rol vervuld in de politieke socialisatie en emancipatie van grote groepen burgers. Ze deden dat echter niet of nauwelijks in onderlinge concurrentie, omdat veel media direct of indirect waren verbonden aan maatschappelijke bewegingen en gericht waren op specifieke doelgroepen. De mediamarkt had dan ook gedurende zeer lange tijd het karakter van een gesloten en weinig concurrerende aanbodmarkt. In de jaren negentig is zij open gebroken en in betrekkelijk korte tijd getransformeerd tot een sterk concurrerende vragersmarkt.

Terwijl het transformatieproces van media en politiek gaande was en is, kwam een belangrijk nieuw, door gevestigde politieke partijen en media lang niet onderkend, maatschappelijk vraagstuk op: het immigratie- en integratievraagstuk. Volgens een aantal wetenschappers gaat het niet om een tijdelijk conflict, maar om een nieuwe blijvende ideologische tegenstelling; een culturele tegenstelling tussen voorstanders van een soepel immigratiebeleid, tolerantie tegenover niet-westerse culturen, globalisering en Europese integratie aan de ene kant en tegenstanders van verdere Europese integratie, globalisering en culturele diversiteit aan de andere kant. Dit kan betekenen dat de electorale markt zich van een door één dimensie gedomineerde ruimte, de traditionele economische links-rechtstegenstelling, ontwikkelt tot een tweedimensionaal vlak met een economische én een culturele dimensie.

Zowel politiek als media moeten reageren op deze nieuwe culturele tegenstelling. In de aanloop naar de verkiezingen van 2002 werd de nieuwe tegenstelling voor het eerst duidelijk zichtbaar. Fortuyn en zijn LPF verweten de politiek dat zij een cultureel liberale positie innam en onvoldoende oog had voor de mening van veel Nederlanders. De media werd eveneens verweten te weinig aandacht te hebben voor de problemen rond immigratie en integratie en vooral een multicultureel verhaal te vertellen. Daarmee werd ook in de media de mening van een deel van de Nederlanders niet gerepresenteerd. Aan de kant van de politiek vormt de nieuwe culturele tegenstelling een grote uitdaging voor gevestigde partijen, die verweten worden dat zij veel burgers slecht representeren, maar biedt zij tevens electorale mogelijkheden voor nieuwe politieke partijen. De media geeft het de kans te bewijzen dat ze in deze tijd van medialogica openstaan voor alle nieuwe ontwikkelingen. In dit hoofdstuk stellen we de vraag of de verschillende media meer aandacht besteden aan onderwerpen van de culturele dimensie dan voorheen, of de berichtgeving op een specifieke manier geduid kan worden en of de cultureel conservatieve oriëntatie blijvend zal zijn.

Dit hoofdstuk is als volgt opgebouwd. In paragraaf 7.2 worden eerst de meer algemene ontwikkelingen op de mediamarkt beschreven die de context vormen, we gaan daarbij in op de door commercialisering en technische ontwikkelingen veroorzaakte fragmentatie van de mediamarkt en de gevolgen van het dominant 
worden van de medialogica voor de politieke berichtgeving. In paragraaf 7.3 wordt aandacht besteed aan de opkomst van nieuwe maatschappelijke scheidslijnen, de betekenis daarvan voor politieke partijen, de wijze waarop de media met deze nieuwe ontwikkelingen omgaan en de vraag of de media aansluiting hebben gevonden bij burgers die ontvankelijk zijn voor deze nieuwe maatschappelijke tegenstelling. Paragraaf 7.4 is gewijd aan een beschouwing over de gevolgen van de eerder beschreven ontwikkelingen voor de intermediaire rol van de media in de Nederlandse democratie. We sluiten af met een concluderende paragraaf (7.5), waarin we kijken wat de gevolgen zijn voor het openbaar bestuur. In dit hoofdstuk vatten we het openbaar bestuur op als het geheel van organisaties en activiteiten die zich richten op het tot stand brengen en uitvoeren van beslissingen. Het gaat ons met name om de politiek verantwoordelijke top van het openbaar bestuur, die slechts kan functioneren op basis van vertrouwen dat zij geniet van de gekozen volksvertegenwoordigers.

\subsection{VERANDERINGEN IN DE MEDIAMARKT}

Tot begin jaren tachtig hadden de Nederlandse media weinig reden zich zorgen te maken over de afname van hun product; lezers en kijkers hadden weinig keuze en accepteerden zonder al te veel morren wat de media hen presenteerden. Hoewel het nog niet duidelijk tot uiting kwam, hadden veel burgers in de jaren tachtig hun trouw aan media (en partijen) al grotendeels opgezegd. Twee ontwikkelingen schiepen de voorwaarden voor een fundamentele verandering van de mediamarkt. Allereerst was er vanaf eind jaren tachtig een sterke groei van het aantal televisiezenders, vooral van Nederlandstalige commerciële en regionale zenders. Dit werd gevolgd door de snelle opkomst van internet en andere technologische ontwikkelingen vanaf midden jaren negentig. In een korte tijd veranderde de mediamarkt daardoor van een aanbodmarkt in een vragersmarkt (Van Cuilenburg, Neiens en Scholten 1999: 7). Anno 2010 kent Nederland met tien landelijke televisiezenders, zeven commerciële en drie publieke zenders, drie gratis dagbladen en in ruim 70 procent van de huishoudens een snelle internetaansluiting een zeer sterk concurrerende mediamarkt.

Op de door de media gedomineerde aanbodmarkt was weinig concurrentie en werd slechts mondjesmaat rekening gehouden met voorkeuren van lezers en kijkers. Media berichtten weliswaar voor een specifieke achterban, maar richtten zich vooral op wat zij dachten wat goed was voor hun publiek, niet op wat het publiek wilde (Brants en Van Praag 2005). De vragersmarkt die begin jaren negentig ontstaat wordt daarentegen gekenmerkt door een felle strijd om marktaandelen en reclame-inkomsten waardoor aanbieders gedwongen worden in vergaande mate rekening te houden met de wensen en behoeften van de afnemers. In de ogen van Van Cuilenburg et al. gaat het om een markt waarop het publiek al snel afhaakt als het zich moet inspannen, bijvoorbeeld als informatie te moeilijk, te abstract of 
te weinig aansprekend is. Het is voor media op een vragersmarkt veel moeilijker om grote groepen te interesseren voor politiek relevante informatie, maar ook reclame en amusement kunnen de aandacht vaak niet vasthouden. Het publiek is in de ogen van deze communicatiewetenschappers tegenwoordig veeleisend, ongedurig en snel afgeleid en heeft talloze mogelijkheden om te ontsnappen aan een communicatieboodschap.

De opkomst van internet en andere technologische ontwikkelingen hebben er daarnaast voor gezorgd dat er met informatie anders wordt omgegaan dan voorheen. Ten eerste is door deze ontwikkelingen de nieuwscyclus versneld. Elke nieuwe ontwikkeling waar ook ter wereld is direct te volgen, niet alleen via nieuwszenders en internet, maar ook via mobiele netwerken. Dit zet redacties van traditionele nieuwsmedia onder druk om niet slechts de al bekende feiten te brengen, maar steeds een eigen invalshoek te kiezen, iets toe te voegen aan ontwikkelingen die al 'oud' zijn, want al enkele uren bekend. Ten tweede wordt de concurrentie op de markt voor politiek nieuws versterkt door de snelle groei van het aantal burgers dat ervan uitgaat dat voor politieke informatie niet betaald hoeft te worden. Gratis kranten zijn elke werkdag verkrijgbaar en daarnaast kan iedereen op elk moment van de dag gratis informatie verwerven via internet, via websites van de traditionele media, via nieuws websites als Nu.nl en door de mogelijkheid gericht te zoeken via zoeksystemen als Google (commissie-Brinkman 2009: 30). De concurrentie tussen traditionele media als televisienieuws en betaalde kranten enerzijds en de nieuwe media anderzijds is hierdoor nog verscherpt.

Op deze sterk gefragmenteerde mediamarkt is het totale aanbod van nieuws over politieke en maatschappelijke ontwikkelingen - in de traditionele media en de digitale media - de laatste twintig jaar toegenomen. Tegelijkertijd ondervindt nieuws veel meer dan voorheen concurrentie van andere soorten media-inhoud. In het totale dagelijkse aanbod van de diverse media, neemt het aandeel van nieuws een veel bescheidener plaats in dan enkele decennia geleden. Dit is het best zichtbaar bij het televisieaanbod. De drie zenders van de publieke omroep zenden nog steeds elke avond een redelijke hoeveelheid nieuws, actualiteitenrubrieken, talkshows en andere relevante informatieve programma's uit (procentueel ruim $20 \%$ van de zendtijd tussen 18:00 en 24:00 uur, iets meer dan dertig jaar geleden). De kijker kan echter slechts bij twee (RTL4 en SBS6) van de zeven landelijke commerciële zenders informatie ontvangen die van belang is voor het invullen van zijn rol als burger in een democratische samenleving. Bij de helft van alle zenders komt de kijker dus niet of nauwelijks politieke informatie tegen. Het aanbod van de zeven landelijke commerciële zenders bestaat de laatste jaren nog voor slechts 6 procent uit nieuws en andere maatschappelijk relevante informatieve programma's (De Beus, Brants en Van Praag 2009). 
Deze groeiende fragmentering van de mediamarkt heeft gevolgen voor het openbaar bestuur en de politieke partijen. Enerzijds betekent het dat er meer mogelijkheden zijn om burgers te bereiken, maar anderzijds dat het steeds moeilijker wordt om de burgers te bereiken die nauwelijks of geen kranten lezen en het nieuws ook niet via de televisie volgen. Het is zeker niet uitgesloten dat deze groep in de naaste toekomst geleidelijk zal groeien. Voor het openbaar bestuur vormt het een belangrijke uitdaging deze groep op de hoogte te houden van belangrijke beleidsontwikkelingen en van hun rechten en plichten als burger.

\subsubsection{DE OPKOMST VAN DE MEDIALOGICA}

De fragmentatie van de mediamarkt en de sterk toegenomen concurrentie hebben ingrijpende gevolgen voor het functioneren van de media. In het streven hun kijkers en lezers vast te houden stellen journalisten zich thans veel assertiever op ten opzichte van de politiek. Op een sterk concurrerende vragersmarkt worden de eisen van de media steeds dwingender en dit heeft invloed op de wijze waarop de journalistiek met politieke informatie omgaat en bericht over partijen, parlement, politici en openbaar bestuur. Deze ontwikkeling wordt veelal omschreven als het dominant worden van de medialogica. ${ }^{1}$ Ideaaltypisch kenmerkt een volledig ontwikkelde medialogica zich door een zestal aspecten die betrekking hebben op het functioneren van de media en de afwegingen die de media maken. Deze aspecten, die zijn samengevat in figuur 7.1, behandelen we hier kort en we laten zien in welke mate de aspecten in Nederland aanwezig zijn.

Volgens het ideaaltype van de medialogica laten media zich veel sterker dan in het verleden leiden door hun eigen belang als medium, veelal gedefinieerd in termen van marktaandeel, kijkcijfers, oplagecijfers en reclame-inkomsten. Hoewel de mediamarkt van oudsher een gereguleerde markt is, zijn de parallellen met een 'gewone' markt de laatste decennia sterker geworden. Voor commerciële omroepen zijn de inkomsten uit reclame doorslaggevend voor hun voortbestaan, terwijl het voor kranten gaat om een combinatie van inkomsten uit abonnementen, losse verkoop en advertenties. Voor publieke omroepen gaat het slechts gedeeltelijk om reclame-inkomsten, belangrijke maatstaven voor succes zijn het behalen van marktaandelen onder verschillende doelgroepen en voor de verschillende omroeporganisaties het aantal leden. Dit betekent dat marktoverwegingen een steeds grotere rol gaan spelen in de (politieke) berichtgeving, terwijl het algemeen belang en de discussie daarover veelal op de tweede plaats komt. Media achten het, als het heel scherp geformuleerd wordt, niet langer hun belangrijkste taak om in een tijd van medialogica een bijdrage te leveren aan een goed functionerend democratisch stelsel.

Journalisten vinden het in de tweede plaats minder vanzelfsprekend dan vroeger dat ze berichten over zaken die voor de burger van belang kunnen zijn, dat wil 
Figuur 7.1 Vragersmarkt en media logica

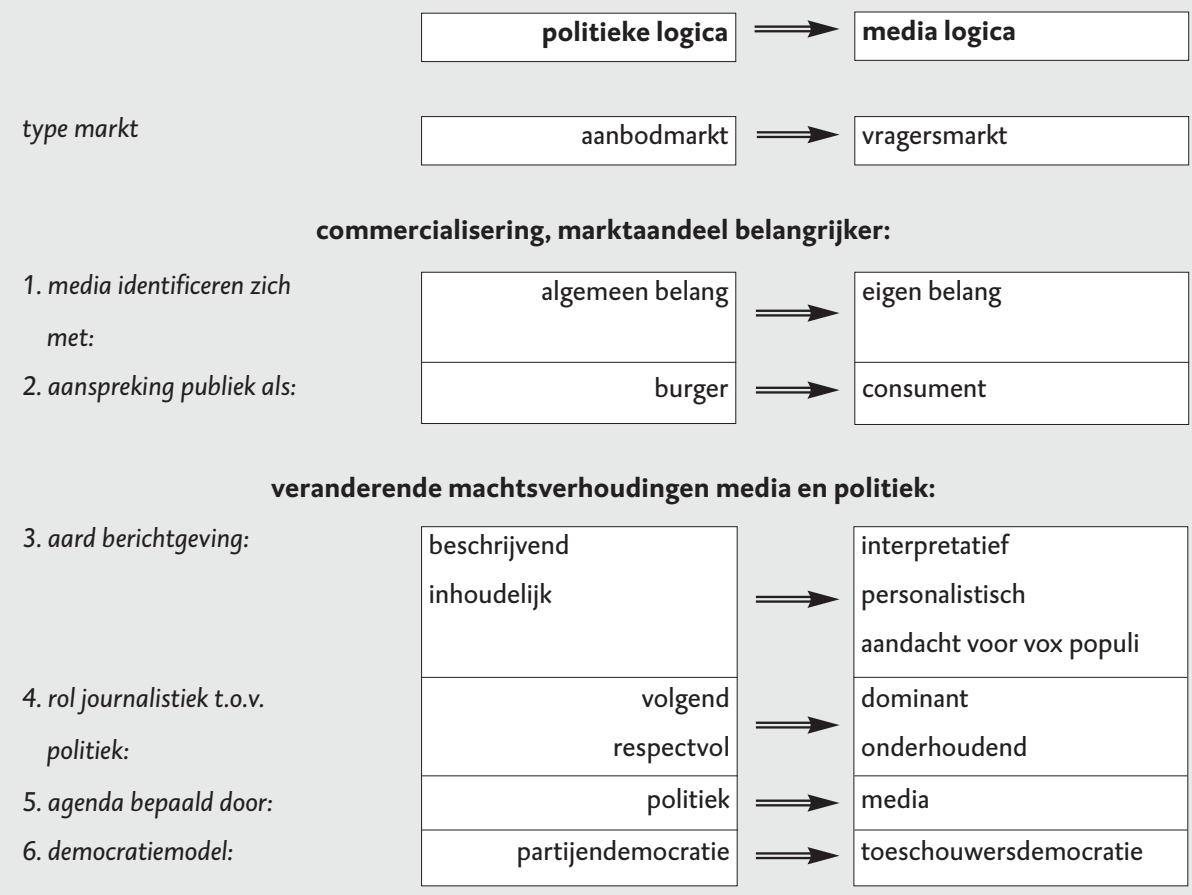

zeggen zaken waarvan hij op de hoogte zou dienen te zijn om mee te denken over de ontwikkeling van de samenleving en zijn rol als staatsburger en kiezer goed te kunnen vervullen. Hallin spreekt in dit verband van een ontwikkeling van "citizen centric model of news" naar een "market oriented one" (Hallin 200o). In een sterk gefragmenteerde, concurrerende en vluchtige mediamarkt is elk medium in de eerste plaats geïnteresseerd in de burger als consument. Redacties laten zich leiden door wat zij denken dat hun doelgroep kan boeien, journalisten identificeren zich sterk met de wensen en behoeften van hun publiek of wat zij denken dat de wensen van het publiek zijn.

Bij alle media is zichtbaar dat ze in hun redactiebeleid veel meer rekening zijn gaan houden met hun publiek, maar dat betekent niet dat ze alle op dezelfde wijze reageren. Commerciële omroepen en kranten die een breed en weinig in politiek geïnteresseerd publiek bedienen, geven minder prioriteit aan het als saai beschouwde politieke nieuws of nemen dat helemaal niet op in hun programmering. Voor zover ze nog wel aandacht besteden aan nieuws, wordt het veelal luchtig gebracht. Kwaliteitskranten, televisienieuws en actualiteitenrubrieken berichten nog wel veel over politieke ontwikkelingen en gebeurtenissen, maar zijn 
systematisch op zoek naar een invalshoek die hun publiek kan boeien. Dat gebeurt onder andere door een sterkere focus op politieke conflicten (ook als het bijzaken betreft) en een sterke nadruk op onthullingen, drama, emotie en (vermeende) misstanden en schandalen. Inhoudelijke behandeling en uitdieping van relevante politieke onderwerpen krijgt minder prioriteit (Van Praag en Brants 200o).

De gevolgen van deze veranderingen in het redactiebeleid worden zichtbaar bij het derde kenmerk, de aard van de berichtgeving. Ten tijde van de aanbodmarkt was berichtgeving feitelijk en inhoudelijk en had een sterk beschrijvend karakter. Er was een taakverdeling tussen politiek en journalistiek, waarbij de media verslag doen van de werkzaamheden van politici en beleidsmakers, wel een keuze maken uit het dagelijks nieuwsaanbod, maar verder geen actieve rol spelen in de nieuwsgaring (Semetko et al. 1991). In de huidige door medialogica gedomineerde berichtgeving dient de journalist het politieke nieuws op een aantrekkelijke en onderhoudende manier te brengen. Hij vergaart actief nieuws, jaagt op primeurs, kiest een interpretatiekader met bijbehorend frame voor zijn berichtgeving en overlegt en onderhandelt met enige regelmaat met politici en voorlichters over berichtgeving. Begin jaren negentig werd in de vs al geconstateerd dat de journalistiek steeds minder feitelijk en beschrijvend is en steeds meer interpretatief (Patterson 1993). In Engeland stelde McNair (200o) een sterke stijging vast van analyses en commentaar ten koste van verslagen en berichtgeving, met tegelijkertijd een zeer sterke groei van het aantal columnisten.

Een aspect van de interpretatieve journalistiek is de stijgende belangstelling van journalisten voor de wijze waarop het politieke spel gespeeld wordt, welke strategie door de politiek wordt gehanteerd om doelstellingen te bereiken en wie daar succesvol is en wie niet. Het volgen en analyseren van het politieke proces krijgt daardoor vaak meer aandacht dan de beleidsuitkomst van datzelfde proces. De professionals die dat politieke proces begeleiden zijn in toenemende mate onderwerp van nieuws en documentaires. De uit de sportwereld bekende kleedkamerjournalistiek heeft in de politieke verslaggeving zijn intrede gedaan; het wordt daar veelal aangeduid met de term horse race of wedstrijdverslaggeving. Hierdoor besteden media veel aandacht aan opiniepeilingen en onderwerpen die gepresenteerd worden met behulp van een strategisch frame, zoals verslaggeving van politieke conflicten en campagnes (Strömbäck en Lee Kaid 2008), zowel in Nederland als daarbuiten. In de campagne 1998 bleek al dat meer dan de helft van de openingszinnen van het NOS-Journaal een strategisch verklarend frame had (Van Praag en Brants 2000: 249). Het aandeel beleidsinhoudelijk nieuws in de campagneverslaggeving op televisie en in kranten daalt. Bij de landelijke kranten was in 2003 een kwart van de berichtgeving inhoudelijk, in 1998 was dat nog eenderde. Op televisie is vooral bij RTL de aandacht voor inhoudelijke onderwerpen sterk gedaald: bij het RTL-Nieuws was in 2003 ruim een kwart van het campagnenieuws inhoudelijk, bij het Nos-Journaal was dit 45 procent. Toch blijkt dat ondanks de 
toenemende aandacht voor strategisch nieuws, wedstrijdverslaggeving en peilingen, nog steeds een substantieel deel van de berichtgeving inhoudelijk is (Brants en Van Praag 2005; De Vreese 2008; Kleinnijenhuis en Scholten 2007).

Politieke berichtgeving wordt onder druk van de medialogica sterker gepersonaliseerd dan in het verleden. Individuele politici staan steeds vaker centraal, terwijl politieke instituties, waaronder partijen, op de tweede plaats staan. Ook over het persoonlijke leven van politici wordt er meer bericht. Politici, maar ook belangrijke journalisten, gedragen zich steeds frequenter als mediastars (Brants 1998; Hallin en Mancini 2004: 278). De media zijn overigens niet de enige oorzaak van deze personalisering. Door de verzwakte binding tussen partijen en burgers zijn individuele politici voor burgers belangrijker geworden en spelen partijen hier op in met hun mediabeleid (zie verder subpar. 7.2.2). Politici die populair zijn of het goed doen in de media, door hun korte en krachtige uitspraken of hun persoonlijkheid, kunnen op veel aandacht rekenen, ongeacht de omvang van hun partij. Zo kreeg D'66-fractievoorzitter Pechtold met drie zetels in de Tweede Kamer veel meer aandacht dan de fractieleiders van twee andere, aanzienlijk grotere oppositiepartijen, toenmalig sP-leider Kant en VvD-leider Rutte. In het tijdperk van de media-logica hebben media wel een bias, maar die is doorgaans niet politiek, zoals veel media vaak verweten wordt, ze hebben vooral een voorkeur voor spraakmakende politici.

Behalve door personalisering kenmerkt veel politieke berichtgeving zich ook door het centraal stellen van het gezichtspunt van de 'man in de straat', de zogenaamde 'vox populi'. Bij veel gebeurtenissen krijgt de ervaring of de mening van de burger veel aandacht, vaak ten koste van de mening van vertegenwoordigers van politieke partijen of overheden. In Nederland zijn de media dit onderdeel van de medialogica na het succes van Fortuyn veel meer aandacht gaan geven. Een hoofdstuk in een beleidsnotitie van de hoofdredacteur van het Journaal droeg in 2002 de titel 'Van de staat naar de straat' (NOS-Journaal 2002).

Een belangrijk vierde kenmerk van medialogica is de veranderde opstelling van de journalistiek ten opzichte van de politiek. De journalist is steeds meer verantwoordelijk voor het onderhoudende karakter van de berichtgeving. Dat leidt ertoe dat hij in de praktijk zeer dominant aanwezig is, zeker in televisieprogramma's, terwijl de politicus een bijrol heeft. In nieuws- en actualiteitenrubrieken komen vooral journalisten aan het woord en moeten politici tevreden zijn met enkele, veelal korte quotes. In het algemeen geldt dat alleen zeer populaire, of gezien hun functie toonaangevende, politici in de gelegenheid zijn om eisen te stellen aan de programmamakers. Ook in talkshows en discussieprogramma's is de presentator - vaak gaat het tegenwoordig om een duo - belangrijker dan de gast of gasten. Tijdens verkiezingscampagnes komt de dominante rol van journalistieke moderatoren scherp tot uiting bij verkiezingsdebatten (Van der Geer 200o). 
Een vijfde kenmerk betreft de bereidheid van de media om de politieke agenda door de politiek zelf te laten bepalen. Van oudsher was deze taakverdeling voor de media vanzelfsprekend, dit hoorde bij de respectvolle (sacerdotal) benadering van de politiek, maar onder invloed van de medialogica is dat inmiddels niet langer het geval (Semetko et al. 1991). Media willen zelf een actieve en belangrijke politieke rol vervullen. Niet zozeer omdat ze politieke doelstellingen nastreven, maar omdat ze willen scoren met onthullingen en scoops die door andere media worden overgenomen en die vervolgens de politieke agenda bereiken. Afgaande op het aantal door mediaberichtgeving geïnspireerde Kamervragen en spoeddebatten slagen de media hier kennelijk goed in. Onderzoek laat echter zien dat deze ambitie van de redacties om een actieve politieke rol te vervullen in Nederland maar ten dele wordt gerealiseerd. De invloed van politici op mediaberichtgeving is nog steeds aanzienlijk groter dan de invloed die de media op hun beurt op politici uitoefenen (Kleinnijenhuis 2003).

Een laatste belangrijk kenmerk van de door medialogica beheerste politieke berichtgeving is dat deze onderdeel is van een fundamentele transformatie van het stelsel van vertegenwoordigende democratie in West Europa. De maatschappelijke ontwikkelingen die de mediamarkt ingrijpend hebben veranderd hebben ook de relatie tussen burgers en politiek veranderd. De traditionele massapartij, ontstaan rond de negentiende-eeuwse maatschappelijke scheidslijnen, heeft het politieke leven gedurende een belangrijk deel van de twintigste eeuw gedomineerd. Manin (1997) spreekt in dit verband van een partijendemocratie, waarin de politieke partijen het publieke debat beheersten, de agenda bepaalden en over veel gezag beschikten. Deze partijendemocratie bestaat niet meer en de oude democratische stelsels bevinden zich in een overgangfase naar een audience democracy of een 'toeschouwersdemocratie', waarin partijen zich ontwikkelen tot een instrument in de handen van een politieke leider (zie ook De Beus 2001). Personalisering is een wezenlijk kenmerk van deze nieuwe vorm van democratie: het vertrouwen in en de uitstraling van politici zijn belangrijke electorale troeven. Toekomstgerichte verkiezingsprogramma's lijken veel minder belangrijk te worden.

Zoals blijkt uit de hierboven geschetste ontwikkelingen is in Nederland zeker sprake van een dominant worden van de medialogica, maar het gaat wel om een gematigde variant, behorend bij een Noordwest-Europees mediamodel, zoals geschetst door Hallin en Mancini (2004). Een belangrijk onderdeel van dit model is de sterke positie van een onafhankelijke publieke omroep. Iyengar en McGrady (2007) laten in een kort vergelijkend overzicht zien dat in landen met een sterke publieke omroep de aandacht voor politiek nieuws nog steeds op een kwantitatief beduidend hoger niveau ligt dan in meer commerciële mediastelsels met (bijna) uitsluitend private zenders, zoals de vs. Het hierboven geschetste overzicht geeft aan dat ook voor Nederland geldt dat de aandacht voor politiek nieuws weliswaar 
van karakter veranderd is en de aandacht voor het politieke spel en het bijbehorende strategische nieuws is toegenomen, maar dat de kranten, het NOS-Journaal, het RTL-Nieuws en de actualiteitenrubrieken het publiek nog steeds van veel relevante politieke informatie voorzien. Bovendien kan strategisch en conflictueus nieuws zeker in een meerpartijensysteem veel nuttige informatie voor burgers bevatten. Ondanks de relatief sterke positie van de publieke omroep in Nederland wordt het ook voor burgers in Nederland steeds gemakkelijker het dagelijks nieuwsaanbod op de televisie en in de krant te ontwijken.

\subsubsection{GROEIEND WANTROUWEN TUSSEN MEDIA EN POLITIEK}

De verandering van de berichtgeving over de politiek leidt tot veel commentaar en kritiek van politici op de journalistiek. Uit een in 2006 gehouden onderzoek onder parlementariërs en parlementair journalisten blijkt dat journalisten deze kritiek op sommige punten nauwelijks onderschrijven. Zo is van de journalisten 25 procent van mening dat de beroepsgroep te veel interpreteert tegenover 56 procent van de ondervraagde parlementariërs. Op andere punten zijn journalisten echter behoorlijk cynisch over het eigen functioneren; de stelling dat de parlementaire journalistiek gekenmerkt wordt door incidentenjournalistiek krijgt de steun van tweederde van de beroepsgroep. Ook zijn journalisten verontrust over de ontwikkeling dat er steeds meer aandacht uitgaat naar het politieke spel: bijna de helft van de journalisten is van mening dat te weinig aandacht besteed wordt aan de inhoud van de politiek en te veel aan het politiek bedrijf (Brants, De Vreese, Möller en Van Praag 2010).

Toch reageert de politiek wel degelijk op de veranderde houding van de media. Zowel politieke partijen als het openbaar bestuur zijn in de loop van de tijd gedwongen zich aan te passen aan de sterk veranderende mediaomgeving. Bij de partijen komt dat tot uiting in een langzame professionalisering van hun verkiezingscampagnes, bij het openbaar bestuur in een gestage groei van de afdelingen voorlichting. Dit heeft zowel grote invloed op de campagnevoering als op het voorlichtings- en mediabeleid van de overheid. Politieke partijen hebben daarbij te maken met aanzienlijk minder beperkingen dan het openbaar bestuur.

De eerste aanpassingen in het mediabeleid van de overheid dateren van eind jaren zestig, ze worden gesymboliseerd door de introductie van de wekelijkse persconferentie van de minister-president in 1970. In datzelfde jaar stelt de commissieBiesheuvel dat openbaarheid een centraal uitgangspunt voor beleid moet zijn; dit was een reactie op de groeiende behoefte aan politieke informatie van de zich uit het keurslijf van de verzuiling losmakende media. De keuze voor actieve persvoorlichting was een breuk met de voorafgaande periode van passieve voorlichting aan de media (Van Praag 2001; Wagenaar 1997). Een volgende stap wordt in 1984 gezet in het rapport Heroverwegen Voorlichting Rijksoverheid, waarin public relations en 
voorlichting voor het eerst worden beschouwd als functies van overheidsvoorlichting. Bij public relations gaat het onder andere om het systematisch beïnvloeden van de beeldvorming over de organisatie en het adviseren van bewindslieden over hun publieke optredens namens de organisatie. Dit geeft voorlichters de mogelijkheid een veel actievere rol te spelen in hun contacten met journalisten. Bij voorlichting als beleidsinstrument gaat het erom vastgesteld beleid aanvaard te krijgen door de burgers. Hierbij kan gebruik worden gemaakt van publiekscampagnes die een gedragsbeïnvloedend karakter hebben. Midden jaren tachtig was dit instrument nog omstreden onder voorlichters (Wagenaar 1997).

Een lastig probleem voor het openbaar bestuur is hoe om te gaan met de communicatie van niet vastgesteld beleid. Traditioneel startte de voorlichting pas na de vaststelling van beleid en dat is vanuit het perspectief van een neutraal ambtelijk apparaat begrijpelijk. Het organiseren van publieke steun voor omstreden plannen was in eerste instantie de taak van politieke partijen. Zolang partijen sterk geworteld waren in de maatschappij, een duidelijk herkenbare ideologie uitdroegen en over gezag in de samenleving beschikten vormde dit geen probleem. Door de organisatorische zwakte en het bleke profiel van partijen enerzijds en de toegenomen mondigheid van de burgers anderzijds zijn partijen vaak niet meer in staat om in de beleidsvoorbereidende fase een breed draagvlak te creëren voor omstreden beleid. Tegenstanders van beleidsvoornemens spelen vaak in op de behoefte van de media aan nieuws en conflicten, verwerven daarmee ruime aandacht in de publiciteit en winnen zo in een vroeg stadium de slag om de publieke opinie. Dit werd vanaf begin jaren negentig urgenter door de dominant wordende medialogica; de laatste jaren zien we tevens dat media vaker zelf partij kiezen bij omstreden beleidsvoornemens. Het openbaar bestuur kan hierdoor op grote achterstand komen. De commissie-Wallage (2001) onderkent dit en stelt dat voorlichting over nog niet door het parlement goedgekeurde beleidsvoorstellen mogelijk moet zijn. Dit wel onder de voorwaarden dat voorlichting zakelijk en feitelijk dient te zijn, de overheid herkenbaar moet zijn als afzender, de inhoud van het beleid centraal dient te staan en de communicatie in redelijke verhouding moet staan tot die van anderen. Deze voorwaarden zijn vooral gericht op gecontroleerde publiciteit, maar de slag om de publieke opinie vindt grotendeels plaats via vrije publiciteit. De commissie-Wallage ziet wel dat hiervoor nieuwsmanagement nodig is, maar komt niet verder dan de aanbeveling dat de overheid 24 uur per dag moet inspelen op de informatiebehoefte van de media, dat communicatie een volwaardig en integraal onderdeel van het beleidsproces moet zijn en dat de departementale directies voorlichting de regie, samenhang en kwaliteit van de communicatie dienen te waarborgen. Het valt te betwijfelen of dit in de praktijk voldoende is voor een effectief beleid.

Idealiter betekent nieuwsmanagement dat zorgvuldig wordt nagedacht over timing van het in de publiciteit treden, met welke boodschap, met welke frames en 
gericht op welke doelgroep. Dat kan betekenen dat men een persbericht uitgeeft, of een persconferentie of een pseudo-evenement organiseert (met de mogelijkheid van mooie beelden). Daarnaast zal men in de praktijk intensief contact moeten onderhouden met redacties en individuele journalisten, soms een primeur moeten geven aan een medium en 'off the record' achtergrondinformatie verstrekken die spoort met de medialogica. Persoonlijke contacten zijn van belang om eventuele verkeerde beeldvorming bij te sturen, onderwerpen en gebeurtenissen te herdefiniëren of van een ander frame te voorzien. Meer in het algemeen is belangrijk de betrokken overheidsorganisatie of politieke actor zo gunstig mogelijk in de publiciteit te krijgen. Het gaat dan om activiteiten die tegenwoordig worden gezien als het werkterrein van een spindoctor, activiteiten waar veel voorlichters niets mee te maken willen hebben, omdat ze het associëren met manipulatie, het vertellen van halve waarheden, soms regelrecht liegen en/of het bedrijven van partijpolitiek. Niet iedereen denkt hier echter hetzelfde over (Aalbers 2000: 62-79) en er is een grijs gebied tussen feitelijke informatieverstrekking en liegen. Als het gaat om de interpretatie van de feiten kunnen voorlichters een belangrijke rol spelen, ongeacht of men dit 'spindoctoring' noemt of niet. Het hangt van de individuele rolopvatting van een voorlichter af hoe hij invulling geeft aan persoonlijk contact met journalisten (Smits 2001). Nieuwsmanagement, waaronder een actief persbeleid dat inspeelt op de opkomst en de behoeften van de interpreterende journalistiek, maakt spindoctor-activiteiten onvermijdelijk, maar dat kan niet betekenen dat alles geoorloofd is.

Politieke partijen zijn, ondanks hun organisatorische en financiële zwakte, minder beperkt in de wijze waarop ze omgaan met de praktijk van de medialogica dan het openbaar bestuur. Zo had het CDA in 2006 een team dat onder eigen naam op verschillende blogs actief was om standpunten van het CDA aan de discussie toe te voegen (Van Praag 2007). Deze anonieme inmenging in het debat ligt voor overheidsorganen gevoeliger dan voor partijen. Kenmerkend is ook een incident uit de PvdA-campagne van 1994, waarin woordvoerder Dig Istha van Wim Kok het NosJournaal had beloofd dat de lijsttrekker in een toespraak enkele belangrijke nieuwe beleidsvoorstellen zou doen. Het journaal dacht een primeur te hebben en opende ermee. Enkele dagen later onthulde de Volkskrant dat het om oud nieuws ging dat al in het verkiezingsprogramma van de partij stond. Istha was tevreden, maar de redactie van het journaal heeft daarna nauwelijks meer aandacht besteed aan campagneactiviteiten (Brants en Van Praag 1995). Destijds was deze praktijk van nieuwsmanagement als reactie op de veranderende mediamarkt nieuw, maar het laat zien wat de onbedoelde effecten ervan kunnen zijn. Het stimuleert het wantrouwen van media; de angst bij journalisten om voor (partij)politieke doelstellingen gebruikt te worden is sterk gegroeid. In het eerder geciteerde onderzoek bevestigt ruim 80 procent van de journalisten dat politici hen gebruiken door het lekken van informatie en bijna 70 procent van de Kamerleden erkent dat. Het wekt geen verbazing dat enerzijds journalisten sterk geïnteresseerd zijn in de strategi- 
sche motieven van politici en dat anderzijds politici zich vaak onheus behandeld voelen door de media en vinden dat journalisten zelf macht willen uitoefenen. Als er ergens sprake is van een cynisme-spiraal, dan is dat tussen parlementaire journalistiek en de politiek (Brants et al. 2010); van beide kanten is er sprake van een groeiend wantrouwen in elkaars intenties. Het wantrouwen aan de kant van de journalistiek in de gevestigde politieke partijen draagt ertoe bij dat de media juist grote belangstelling hebben voor nieuwe maatschappelijke problemen waar politiek en openbaar bestuur geen pasklare antwoorden voor hebben.

\subsection{NIEUWE POLITIEKE SCHEIDSLIJNEN EN DE POSITIE VAN DE MEDIA}

In de afgelopen jaren is in Nederland onder burgers veel onrust ontstaan over immigratie en integratie. Deze onrust werd zichtbaar door de grote electorale verschuivingen ten tijde van de verkiezingen van 2002, maar achteraf gezien was in kiezersonderzoek al vanaf 1994 een veranderende attitude ten opzichte van immigratie en integratie waarneembaar (Adriaansen, Van der Brug en Van Spanje 2005). In veel Europese landen is sprake van vergelijkbare onrust en van de opkomst van nieuwe partijen die deze thema's politiseren. Voordat we hierop ingaan laten we eerst de veranderde opstelling van burgers ten opzichte van politiek zien, waarna we het belang van deze nieuwe beleidsonderwerpen behandelen om ten slotte in te gaan op de wijze waarop de media hiermee omgaan.

\subsubsection{VERANDERENDE BURGERS: ZWEVENDE KIEZERS EN ZAPPENDE KIJKERS}

Het Nederlandse partijsysteem en de aanbodmarkt voor media kwamen voort uit twee ooit zeer dominante maatschappelijke scheidslijnen: een sociaaleconomische en een religieuze. Na de jaren zestig zijn de maatschappelijke scheidslijnen verzwakt, maar de invloed van de oude scheidslijnen is niet volledig verdwenen (Bovens, Pellikaan en Trappenburg 1998: 42-43). In het dagelijks leven van burgers zijn de scheidslijnen veel minder tastbaar dan vroeger; het verenigingsleven is ontzuild en bij de schoolkeuze speelt kwaliteit vaak een grotere rol dan het levensbeschouwelijke karakter van de school. In de politiek zijn een sociaaleconomische en een religieuze dimensie nog wel zichtbaar, al is vooral de laatste niet meer zo dwingend. Ook in het medialandschap zijn de oude scheidslijnen nog maar beperkt aanwezig; veel aan partijen verwante media zijn verdwenen of hebben afstand genomen van de partij waarmee zij verbonden waren. Wel hebben veel media nog een herkenbaar ideologische signatuur of worden geassocieerd met politieke stromingen. Voor zowel de politieke partijen als de media geldt dat zij zich dienen staande te houden op een vragersmarkt. In deze context wordt wel gesproken over zwevende kiezers en zappende kijkers (Simons 1998). 
De verzwakking van de maatschappelijke scheidslijnen in Nederland heeft geleid tot een zeer open partijsysteem, waarin politieke partijen onder druk staan hun aanbod aan te passen aan de vraag van de kiezer. Het stemgedrag van burgers is in de afgelopen decennia veel minder stabiel geworden. Enerzijds twijfelen kiezers meer en langer tussen partijen, anderzijds wisselen kiezers ook vaker dan vroeger daadwerkelijk van partij. De electorale volatiliteit is in Nederland in vergelijking met veel andere landen vrij hoog (Adriaansen en Van Praag 2006; Mair 20o8; Van der Kolk, Aarts en Rosema 2007). Dit betekent overigens niet dat kiezers stuurloos zijn en van links naar rechts zwalken; veelal wordt getwijfeld en gewisseld tussen verwante partijen (Adriaansen et al. 2005). De trouw aan partijen is echter afgenomen, dat is niet alleen zichtbaar in het stemgedrag, ook het aantal mensen dat lid was van een partij was vroeger veel hoger dan nu (Voerman en Van Schuur 2009).

Niet alleen in hun stemgedrag houden burgers minder vast aan gewoontes, voor hun mediagedrag geldt hetzelfde. Eerder WRR-onderzoek toont dat burgers tegenwoordig ongeveer even veel uren per week aan mediagebruik besteden als in 1970. Sinds de jaren 1970 is de tijd besteed aan televisie echter toegenomen en meer recent neemt daarnaast het computer- en internetgebruik een groeiend deel van de tijd in beslag. Daar staat tegenover dat aan radio en gedrukte media steeds minder tijd wordt besteed. Broeders en Verhoeven laten met cijfers van het begin van deze eeuw zien dat Nederlanders steeds meer voor commerciële media kiezen en daarmee samenhangend dat entertainment terrein wint ten opzichte van serieuze informatie (Broeders en Verhoeven 2005: 101-104). Burgers verdelen hun tijd anders over de verschillende mediasoorten en -inhoud dan vroeger. Bovendien gaan ze heel anders met media om: waar kijkers vroeger een hele avond naar een bepaalde omroep keken, wisselen zij nu regelmatig van zender. De uitbreiding van het aantal televisiezenders heeft van kijkers zappers gemaakt: kijkers wisselen tussen programma's of kijken zelfs meerdere programma's tegelijkertijd - en surfen wellicht ondertussen over internet.

Hoewel de electorale verschuivingen in veel andere Europese landen gradueler zijn dan in Nederland, passen de Nederlandse ontwikkelingen in een algemeen beeld van toegenomen instabiliteit van kiezersgedrag (Pellikaan, De Lange en Van der Meer 2007; Pellikaan, Van der Meer en De Lange 2003). Deze veranderingen in kiesgedrag - evenals veranderingen in de mediakeuze - worden in belangrijke mate veroorzaakt door het afgenomen belang van de oude maatschappelijke scheidslijnen. Sociale en religieuze identiteiten zijn verzwakt en zelfs kiezers die zichzelf rekenen tot een van deze identiteiten zijn minder geneigd hun stemgedrag daaraan te conformeren. Dit proces van toegenomen instabiliteit, afgenomen partij-identificatie en de opkomst van nieuwe partijen wordt aangeduid als partisan dealignment (Dalton, Flanagan en Beck 1984). Sinds de jaren tachtig wordt onder politicologen een debat gevoerd over de mogelijke opkomst van 
nieuwe scheidslijnen, gevolgd door een realignment van het partijstelsel, maar de conclusie was tot nu toe dat nieuwe politieke tegenstellingen niet vergelijkbaar waren met de oude en dat ze slechts geringe invloed hebben op stemgedrag (Correljé en Van Kersbergen 1998). Recent is het debat over een mogelijke realignment of herschikking van het Europees partijstelsel door Kriesi et al. $(2006,2008)$ nieuw leven ingeblazen.

\subsubsection{EEN NIEUWE POLITIEKE SCHEIDSLIJN}

Kriesi et al. $(2006,2008)$ beargumenteren dat er een nieuwe maatschappelijke scheidslijn is ontstaan als gevolg van de internationalisering. Veel burgers voelen weerzin en angst tegen de gevolgen van dit ingrijpende veranderingsproces, ze voelen zich in hun maatschappelijke positie bedreigd; deze auteurs omschrijven deze groep burgers als verliezers. Degenen die baat hebben bij dit proces worden omschreven als winnaars. Kriesi et al. verklaren recente electorale ontwikkelingen vanuit de onrust die hieruit voortvloeit. Met behulp van een inhoudsanalyse van mediaberichtgeving hebben Kriesi et al. partijposities onderzocht in zes Europese landen, waaronder Nederland. Zij stellen op basis daarvan dat de oorspronkelijke sociaaleconomische en religieuze scheidslijnen getransformeerd zijn naar een economische en een culturele dimensie, die beide lopen van openheid en integratie naar geslotenheid en demarcatie. Een economische dimensie bestond al, de culturele dimensie is in de afgelopen decennia in deze vorm ontstaan, aldus Kriesi et al.

De economische en culturele dimensie behelzen verschillende onderwerpen. De economische dimensie betreft onder meer de rol van de overheid in de economie en de gewenste omvang van de welvaartsstaat. Het gaat dan om keuzes als lage of hoge uitkeringen, handelsbeperkingen wel of niet opheffen, open of gesloten grenzen, minimaal of maximaal aanbod van collectieve goederen. Kriesi et al. (2008) positioneren de protectionistische nationale markt diametraal tegenover de neoliberale vrije markt met open grenzen. Op de culturele dimensie staat multiculturele of kosmopolitische visie tegenover een cultuurprotectionistische visie. De culturele dimensie behelst verschillende onderwerpen, waaronder immigratie en integratie van allochtonen, maar ook Europese integratie. Het gaat dan concreet om het wel of niet beperken van immigratie, assimilatie of multiculturalisme, wel of geen uitbreiding van de Europese Unie, (EU). In de visie van Kriesi kunnen de verliezers van de globalisering, waaronder veel laagopgeleiden maar ook kleine ondernemers, geplaatst worden aan de demarcatiekant op beide dimensies, terwijl de winnaars aan de integratiekant staan als voorstanders van een open economie en culturele tolerantie.

Politicologen zijn ervan overtuigd dat de electorale ruimte zich thans heeft ontwikkeld tot een tweedimensionale ruimte. Sommige auteurs stellen dat Neder- 
land driedimensionaal is, met twee dominante dimensies en een religieuze dimensie als zwakke derde dimensie. Aarts en Thomassen (2008: 231) stellen in dit verband het volgende:

"The Dutch case can be regarded as emblematic in the light of a new dimension of political conflict, which is now catching scholarly attention... The emergence of a cultural conflict dimension is not restructed to the national borders, but visibile in many European countries."

Dat er momenteel twee dominante dimensies zijn, daar zijn wetenschappers het wel over eens en ook over de grote lijnen van die dimensies, alleen over hoe ze precies ingevuld worden bestaat discussie. Wij kiezen ervoor de terminologie van Kriesi te gebruiken, omdat we vooral ingaan op de nieuwe culturele conflictdimensie.

Het idee van twee ideologische dimensies wordt in hoofdlijnen door veel wetenschappers gedeeld, maar over hoe de dimensies er precies uitzien zijn de meningen verdeeld. Kriesi et al. (2008) stellen dat beide dimensies lopen van integratie en openheid aan de ene kant naar demarcatie en geslotenheid aan de andere kant. Op de economische dimensie betekent dit dat de protectionistische nationale markt aan de demarcatiekant tegenover de neoliberale vrije markt met open grenzen aan de integratiekant staat. Terwijl traditioneel op de economische dimensie staatsinterventie en een sterke verzorgingsstaat staan tegenover de vrije markt, stellen Kriesi et al. dus dat het steeds meer gaat om een onderscheid tussen geslotenheid en openheid. De culturele dimensie wordt door Kriesi et al. eveneens breed geformuleerd, zowel immigratie en integratie als Europese integratie passen binnen deze dimensie. Om spraakverwarring te voorkomen hebben we het in dit hoofdstuk waar het gaat over de economische dimensie over links (voor staatsinterventie en de verzorgingsstaat) en rechts (voor de vrije markt). Bij de culturele dimensie hebben we het over integratief (tegen beperking immigratie en voor culturele eigenheid immigranten) en demarcatief (voor beperking immigratie en voor culturele integratie immigranten).

Bij de opkomst van deze nieuwe tegenstellingen zijn enkele kanttekeningen te plaatsen. Van der Brug (2007) vraagt zich af of de politieke tegenstellingen rond immigratie en integratie daadwerkelijk voortkomen uit structurele belangentegenstellingen tussen groepen, die de maatschappij net zo ingrijpend verdelen als de oude scheidslijnen, of dat er sprake is van minder diepe en blijvende politieke tegenstellingen. Burgers kunnen immers op het ene terrein verliezer zijn en op het andere terrein winnaar. Dat is objectief gezien waar, toch is het goed mogelijk dat deze mensen zich op alle terreinen verliezer voelen en juist deze perceptie is zeer belangrijk. Het is daarom mogelijk dat de huidige culturele en economische dimensies inderdaad zullen leiden tot nieuwe maatschappelijke scheidslijnen. Een 
onderzoek van het SCP wijst voorzichtig in die richting: 15 procent van de Nederlanders vindt dat mensen zoals zij vooral nadelen ondervinden van het verdwijnen van de grenzen en het meer open worden van de economie, terwijl 45 procent het er niet mee eens is (Steenvoorden, Van der Meer en Dekker 2009: 6). Op basis van deze cijfers lijkt dus 15 procent van de Nederlanders zichzelf te zien als verliezer van de globalisering. Uit ander onderzoek blijkt dat tweederde van de Duitsers zich zorgen maakt over 'maatschappelijke ontwikkelingen' en dat 15 procent zich echt als verliezer van die ontwikkelingen ziet (Neugebauer 2007: 84-86). Steun voor de stelling van Kriesi et al. dat het gaat om maatschappelijke scheidslijnen die geworteld zijn in structurele maatschappelijke veranderingen, kan ook gevonden worden in de door Bovens en Wille (2009) omschreven groeiende belangentegenstelling tussen hoog- en laagopgeleiden.

Een tweede kanttekening betreft de positionering van partijen. Van der Brug en Van Spanje (2009) laten zien dat ideeën van kiezers inderdaad op een economische en een culturele dimensie in te delen zijn. De verschillende auteurs zijn het er ook over eens dat partijen zich op enig moment aan de voorkeuren van kiezers zullen moeten aanpassen, maar zij zijn vooralsnog verdeeld over de vraag in hoeverre partijen dat nu al hebben gedaan. Kriesi et al. (2008) stellen op basis van hun inhoudsanalyse dat een deel van de partijen nu al gebruikmaakt van de nieuwe scheidslijnen, dat de partijen die het beste inspelen op de belangen en angsten van de verliezers van internationalisering de drijvende kracht achter de transformatie van de West-Europese partijsystemen zijn en dat andere partijen zich in reactie hierop herpositioneren. Van der Brug en Van Spanje (2009) vinden echter op basis van een in 2005/2006 uitgevoerde expertsurvey in 14 Europese landen dat partijen zich vooralsnog voornamelijk op de economische dimensie positioneren. Zij stellen dat er in veel landen sprake is van een gat in de electorale markt, omdat veel kiezers linkse opvattingen huldigen op de economische dimensie en demarcatieve op de culturele, maar zich bij geen enkele partij op deze manier gerepresenteerd vinden. Al met al is het waarschijnlijk dat er momenteel sprake is van een transitiefase, waarin gevestigde partijen zich in een proces van aanpassing aan gewijzigde kiezersvoorkeuren bevinden. Ook Kriesi et al. (2008) geven aan dat dit proces binnen gevestigde partijen traag verloopt, omdat deze veranderingen interne spanningen en weerstand oproepen. In Nederland zijn er verschillende aanwijzingen dat sommige partijen zich aanpassen. Veel partijen hebben de laatste jaren zich scherper geprofileerd op de culturele dimensie. Zo neemt de linkse SP steeds vaker een demarcatief standpunt in wanneer het gaat om immigratie en Europese integratie en heeft het hardere PvdA-standpunt over integratie tot felle debatten binnen deze partij geleid. Een nieuwe partij als de demarcatieve PVV schuift daarentegen naar links op de economische dimensie, volgens sommigen is dat in reactie op gemeten kiezersvoorkeuren (NRC Handelsblad 2009a, 2009b). 
In Nederland en wellicht ook in andere landen lijken de verschillende politieke partijen zich dus langzaam op beide dimensies te herpositioneren. Kriesi et al. (2008) stellen bovendien dat de culturele dimensie steeds meer invloed heeft op het stemgedrag, maar of de culturele dimensie net zoveel invloed zal hebben als de economische is op dit moment nog niet vast te stellen. Wel is sinds 2002 in Nederland een toegenomen polarisatie zichtbaar, zowel tussen partijen als tussen groepen burgers. Partijen die zich duidelijk profileren op de culturele dimensie doen het electoraal goed. Een deel van de burgers heeft behoefte aan partijen met een duidelijk en herkenbaar standpunt tegen immigratie en verdergaande Europese integratie. Dit is waarschijnlijk geen kortstondige bevlieging, maar een blijvend verschijnsel, in Nederland en veel andere Europese landen. Veel moeilijker is het om te voorzien welke politieke partijen in Nederland in staat zijn met succes en voor langere tijd op deze nieuwe dimensie electorale steun te mobiliseren. Dit kunnen gevestigde of nieuwe partijen zijn, maar het is ook goed denkbaar dat geen enkele partij erin slaagt voor langere tijd deze groep kiezers aan zich te binden. Een scenario waarin een nieuwe partij met succes deze kiezers gedurende één of twee verkiezingen weet te representeren, waarna weer een andere partij opkomt die deze kiezers aanspreekt, behoort eveneens tot de mogelijkheden. Indien deze nieuwe culturele tegenstelling wel blijvend is, maar niet tot stabiele partijvorming leidt, dan zal de hoge electorale volatiliteit voorlopig blijven bestaan. Dit is niet alleen van belang voor het nationale niveau; het is goed mogelijk dat het openbaar bestuur hier ook op lokaal en provinciaal niveau mee te maken krijgt. Zelfs als het niet blijvend is, dan zullen culturele onderwerpen de komende tien jaar onderwerp van heftig politiek debat blijven.

\subsubsection{DE INVLOED VAN NIEUWE SCHEIDSLIJNEN OP DE POSITIE VAN DE MEDIA}

Uit het voorgaande blijkt dat het denken van burgers niet alleen te duiden is met behulp van een economische dimensie, maar ook een culturele dimensie. Bovendien is het waarschijnlijk dat politieke partijen zich aan deze dimensies zullen aanpassen of dit misschien al doen. In deze paragraaf gaan we na hoe de media reageren op deze nieuwe culturele scheidslijn. Als de culturele scheidslijn inderdaad invloed heeft op het handelen van media, dan mag verwacht worden dat de aandacht voor onderwerpen van de culturele dimensie gegroeid is. Daarbij zijn verschillende vragen van belang. Ten eerste de vraag of media meer aandacht besteden aan onderwerpen van de culturele dimensie dan vroeger en of er specifieke media zijn die meer dan anderen aandacht besteden aan deze onderwerpen. Ten tweede de vraag of sommige media specifiek positie kiezen op de culturele dimensie; wordt berichtgeving over culturele onderwerpen op een bepaalde manier geduid? Juist in een vragersmarkt, zoals uitgebreid besproken in subparagraaf 7.2.1, voelen media zich genoodzaakt om in te springen op de vraag van het publiek en meer specifiek de eigen doelgroep. Deze twee vragen worden hier achtereenvolgens besproken. 


\section{Aandacht voor de culturele dimensie in de media}

Boomgaarden (2007: 111-112) heeft onderzocht hoeveel berichten er over etnische minderheden in de verschillende kranten zijn verschenen tussen 1991 en 2005, over televisie zijn geen vergelijkbare cijfers beschikbaar. In figuur 7.2 is zichtbaar dat de berichtgeving over etnische minderheden in alle landelijke kranten is toegenomen, nadat in 2001 een trendbreuk is opgetreden. Vliegenthart (2007: 39-40) laat in een vergelijkbare analyse van Nederlandse krantenberichtgeving ook zien dat de aandacht gestaag is gegroeid, met een duidelijke piek in 2002. Vliegenthart (2007) kijkt daarbij naar het onderwerp immigratie en integratie in de periode van 1995 tot en met 2004, terwijl Boomgaarden (2007) kijkt naar nieuws over immigratie en etnische vooroordelen in de periode van 1991 tot en met 2005. Op basis van de bevindingen van deze auteurs is de conclusie gerechtvaardigd dat de aandacht voor immigratie en integratie van allochtonen is gegroeid. Naar berichtgeving over immigratie in de verschillende Nederlandse media is veel onderzoek gedaan. Helaas is de berichtgeving over de EU niet zo uitgebreid onderzocht.

\section{Figuur 7.2 Media-berichtgeving over etnische minderheden, per krant}

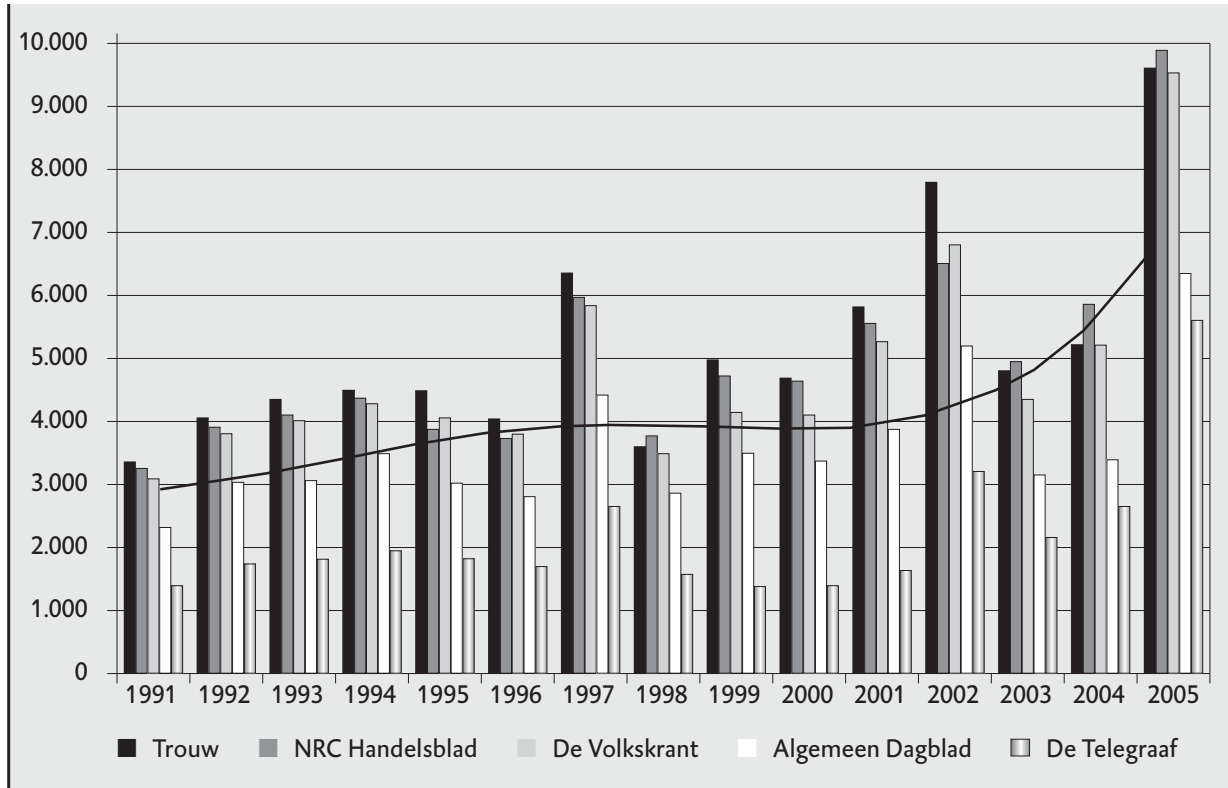

Bron: Boomgaarden (2007: 111-112)

In het algemeen besteden media dus meer aandacht aan de culturele dimensie, waarbij er echter grote verschillen zijn tussen de kranten. De hoeveelheid berichten per jaar in Trouw (5.168), NRC Handelsblad (5.00o) en de Volkskrant (4.783) ligt beduidend hoger dan in het Algemeen Dagblad (3.578) en De Telegraaf (2.154). 
Daarbij moet worden opgemerkt dat er in de eerste drie kranten altijd al veel meer berichten verschijnen over politieke en maatschappelijke ontwikkelingen. Opvallend is dat de verhouding in aandacht tussen de kranten tamelijk stabiel is, die was in 2005 niet anders dan in 1991.

De berichtgeving over culturele onderwerpen fluctueert overigens sterk. Vliegenthart (2007) laat zien dat de berichtgeving sterk gerelateerd is aan specifieke gebeurtenissen, zo was de piek in de periode 2001/2002 een reactie op de aanslagen in New York en de opkomst van Pim Fortuyn tijdens verkiezingen in Nederland. De piek in 2005 was een reactie op de moord op Theo van Gogh in november 2004. In figuur 7.2 is daarnaast nog een piek zichtbaar in 1997 voorafgaand aan de nieuwe vreemdelingenwet.

\section{Duiding van de culturele dimensie in de media}

Media zijn in één belangrijk opzicht anders dan partijen: waar partijen een standpunt moeten innemen als zij een onderwerp ter sprake brengen, hoeven media dit niet te doen. Media kunnen een specifiek standpunt innemen, maar kunnen een onderwerp ook simpelweg aandacht geven als zij denken dat hun doelgroep daar behoefte aan heeft. Het is daarom de vraag of media positie kiezen op de culturele

Tabel 7.1 Duiding media-berichtgeving etnische minderheden, per medium

\begin{tabular}{|c|c|c|c|c|}
\hline & $\begin{array}{l}\text { aantal berichten } \\
\text { etnische } \\
\text { minderheden }\end{array}$ & $\begin{array}{l}\text { demarcatieve } \\
\text { duiding } \\
\text { 'bedreiging' }\end{array}$ & $\begin{array}{l}\text { integratieve } \\
\text { duiding } \\
\text { 'waardevol' }\end{array}$ & $\begin{array}{l}\text { verhouding } \\
\text { demarcatief/ } \\
\text { integratief* }\end{array}$ \\
\hline \multicolumn{5}{|l|}{ Televisie } \\
\hline * NOS-Journaal & 19 & 0,06 & 0,06 & 1,1 \\
\hline * RTL-Nieuws & 28 & 0,19 & 0,01 & 29,3 \\
\hline \multicolumn{5}{|l|}{ Kranten } \\
\hline * Algemeen Dagblad & 77 & 0,12 & 0,02 & 6,7 \\
\hline * NRC Handelsblad & 98 & 0,27 & 0,20 & 1,3 \\
\hline * De Telegraaf & 61 & 0,13 & 0,02 & 6,4 \\
\hline * Trouw & 91 & 0,32 & 0,07 & 4,7 \\
\hline * de Volkskrant & 84 & 0,23 & 0,08 & 2,8 \\
\hline Totaal & 458 & 1,32 & 0,46 & 2,9 \\
\hline \multicolumn{5}{|c|}{$\begin{array}{l}\text { * De 'verhouding demarcatief/integratief is berekend door de waarde voor de demarcatieve duiding 'bedreiging' te delen } \\
\text { door de waarde voor de integratieve duiding 'waardevol'. Waardes hoger dan } 1 \text { betekenen meer demarcatieve dan inte- } \\
\text { gratieve duiding, waardes lager dan } 1 \text { betekenen meer integratieve dan demarcatieve duiding. }\end{array}$} \\
\hline
\end{tabular}

Bron: gebaseerd op Boomgaarden (2007: 163)

Gemeten gedurende vier weken in november en december 2004. 
dimensie. Een antwoord op deze vraag is te vinden in de manier waarop media berichtgeving over immigratie en integratie framen, oftewel in welk kader media informatie plaatsen en hoe ze het duiden. Boomgaarden (2007: 111-112) heeft in kaart gebracht in hoeveel gevallen etnische minderheden als bedreiging ('threat frame’) of als waardevol ('benefit frame’) worden geduid. We gaan er hierbij vanuit dat de duiding als bedreiging een cultureel demarcatieve duiding is en de duiding als waardevol een cultureel integratieve duiding is. Voor de waarden van de frames in tabel 1 geldt dat de waarde hoger is naarmate er meer berichten op deze manier geduid worden. We moeten hierbij opmerken dat de aantallen waarnemingen voor het televisienieuws beperkt is.

Hoewel alle onderzochte media nieuws over etnische minderheden zowel op een cultureel demarcatieve manier (bedreiging) als op een cultureel integratieve manier duiden (waardevol), bestaan er grote verschillen tussen media wat betreft de verhouding tussen cultureel demarcatieve en integratieve duiding. Door NOS-Journaal en NRC Handelsblad worden etnische minderheden even vaak als waardevol en als bedreigend geportretteerd. Andere media duiden etnische minderheden veel vaker als bedreiging dan als waardevol. Bij RTL-Nieuws is het verschil het grootst: dit medium heeft 29 keer zoveel cultureel demarcatieve als cultureel integratieve berichtgeving. Ook De Telegraaf en Algemeen Dagblad schrijven veel vaker in termen van bedreiging. Hoewel deze drie media dus in absolute termen minder over etnische minderheden berichten, duiden ze de berichten veelal op een cultureel demarcatieve manier en lijken dus inderdaad een veelal impliciet standpunt in te nemen.

Boomgaarden heeft een periode van vier weken in november en december 2004 onderzocht; hierbij moet worden opgemerkt dat dit de periode kort na de moord op Theo van Gogh betreft. Weliswaar werd er toen relatief veel bericht over moslims en terreurdreiging, en was er dus relatief veel berichtgeving en werd er ook vaker een demarcatieve duiding aan gegeven, maar het gaat hier juist om de verhouding tussen twee soorten frames die sterk verschilt tussen media. Die verhouding geeft aan dat sommige media anders dan andere media omgaan met onderwerpen die kenmerkend zijn voor de nieuwe culturele tegenstellingen. Daarnaast heeft ook Vliegenthart (2007: 42-44) onderzoek gedaan naar duiding van immigratie en integratie in de media tussen 1995 en 2004 . Hij bekijkt twee cultureel demarcatieve duidingen: 'Islam als bedreiging' en 'beperking van immigratie'. Helaas is op basis van zijn studie geen verhouding te berekenen van demarcatieve en integratieve duidingen. Uit deze data blijkt dat de duiding 'Islam als bedreiging' pieken vertoonde na 11 september 2001 en na 2 november 2004. Daarnaast bleek echter ook dat demarcatieve duidingen in de periode vanaf 2001 veel vaker voorkwamen dan in de periode daarvoor: in de periode 2001-2004 kwamen beide demarcatieve duidingen ruim drie keer zo vaak voor als in de periode 1995-2000. Deze data zijn dus in lijn met die van Boomgaarden. 
Samenvattend kan worden gesteld dat de aandacht voor immgratie en integratie in de media is gegroeid en dat sommige media een demarcatieve duiding geven aan immigratie en integratie. RTL-Nieuws, De Telegraaf en Algemeen Dagblad duiden immigratie het meest als bedreiging, terwijl NOS-Journaal, NRC Handelsblad en de Volkskrant dit het minste doen en daardoor meer een middenpositie tussen demarcatie en integratie kiezen.

De toegenomen aandacht van de media voor onderwerpen van de culturele dimensie betekent dat partijen en actoren die een uitgesproken standpunt innemen over deze onderwerpen veel ruimte krijgen in alle media. Voor nieuwe partijen met een demarcatieve stellingname kan dit gunstig zijn, zeker als uit opinieonderzoek blijkt dat deze partijen veel steun genieten. Een zeker opportunisme is de media daarbij niet vreemd. Bij afkalvende steun verliezen partijen en politici hun nieuwswaarde voor de media. Voor het openbaar bestuur op nationaal en lokaal niveau betekent het een en ander dat alle onderwerpen die met de culturele dimensie te maken hebben veel aandacht krijgen, zeker als het geïnterpreteerd kan worden als falend beleid of als er aanwijzingen zijn dat er onenigheid bestaat op bestuurlijk niveau. Wel is te verwachten dat de media in veel gevallen niet allemaal voor dezelfde duiding zullen kiezen.

\subsubsection{DE CULTURELE DIMENSIE EN HET MEDIAGEBRUIK VAN BURGERS}

Sommige media lijken dus een positie te kiezen op de culturele dimensie. Het is de vraag of deze media daarmee de burgers bereiken die ze met deze berichtgeving zouden kunnen aantrekken en wellicht ook willen aantrekken. Om deze vraag te kunnen beantwoorden is gekeken naar de achtergrondkenmerken en het mediagebruik van burgers met verschillende posities op de culturele dimensie. Om de

Tabel 7.2

Vragen culturele dimensie, percentages

\begin{tabular}{|c|c|c|c|c|c|c|}
\hline \multicolumn{7}{|c|}{ Vraag over aanwezige immigranten: allochtonen moeten... } \\
\hline \multicolumn{5}{|c|}{... eigen cultuur behouden } & \multicolumn{2}{|c|}{... zich geheel aanpassen } \\
\hline 1 & 2 & 3 & 4 & 5 & 6 & 7 \\
\hline $3 \%$ & $4 \%$ & $8 \%$ & $16 \%$ & $20 \%$ & $21 \%$ & $28 \%$ \\
\hline \multicolumn{7}{|c|}{ Vraag over nieuwe immigratie: asielzoekers moeten... } \\
\hline \multicolumn{5}{|c|}{... meer toegelaten worden } & \multicolumn{2}{|c|}{... meer teruggestuurd worden } \\
\hline 1 & 2 & 3 & 4 & 5 & 6 & 7 \\
\hline $4 \%$ & $6 \%$ & $10 \%$ & $28 \%$ & $20 \%$ & $15 \%$ & $18 \%$ \\
\hline
\end{tabular}

Bron: NKO 2006, $\mathrm{n}=2728$ 
respondenten in te delen op de culturele dimensie zijn twee vragen uit het Nederlands Kiezersonderzoek (NKO) van 2006 gebruikt, die zijn opgenomen in tabel 7.2.

Om de mening van respondenten op de culturele dimensie te meten is hier naar analogie van Pellikaan et al. (2003) zowel een vraag over beperking van nieuwe immigratie als een vraag over integratie van aanwezige immigranten gebruikt. De vraag over nieuwe immigratie was of er meer asielzoekers moeten worden toegelaten of meer teruggestuurd, waarbij respondenten een antwoord tussen 1 en 7 konden geven. De vraag over aanwezige immigranten was of allochtonen hier moeten kunnen leven met behoud van de eigen cultuur of dat zij zich geheel moeten aanpassen. Op basis van de antwoorden op deze twee vragen zijn de respondenten ingedeeld in drie groepen: integratief (gemiddeld 2 en lager), midden (gemiddeld hoger dan 2 en lager dan 5) en demarcatief (gemiddeld 6 en hoger). Op basis van deze indeling is 4 procent van de respondenten cultureel integratief te noemen, 66 procent behoort tot het culturele midden en 31 procent kan als cultureel demarcatief omschreven worden.

Tabel 7.3 toont het opleidingsniveau van burgers die cultureel demarcatief zijn, afgezet tegenover dat van degenen die cultureel integratief zijn of een middenpositie innemen. Hier moet worden opgemerkt dat de groep burgers die cultureel

\begin{tabular}{|c|c|c|c|c|}
\hline & $\begin{array}{c}\text { cultureel } \\
\text { integratief } \\
n=97\end{array}$ & $\begin{array}{c}\text { cultureel } \\
\text { midden } \\
n=1795\end{array}$ & $\begin{array}{c}\text { cultureel } \\
\text { demarcatief } \\
n=836\end{array}$ & $\begin{array}{c}\text { alle } \\
\text { respondenten } \\
n=\mathbf{2 7 2 8}\end{array}$ \\
\hline \multicolumn{5}{|c|}{ Opleiding hoogst voltooid } \\
\hline - Laag & 12 & 18 & 39 & 24 \\
\hline - Midden & 51 & 52 & 50 & 52 \\
\hline- Hoog & 37 & 30 & 11 & 25 \\
\hline \multicolumn{5}{|c|}{ Politieke interesse } \\
\hline- Niet & 11 & 17 & 30 & 21 \\
\hline - Redelijk & 56 & 71 & 61 & 67 \\
\hline - Zeer & 33 & 13 & 9 & 12 \\
\hline \multicolumn{5}{|c|}{ Politiek cynisme* } \\
\hline - Niet cynisch & 55 & 49 & 35 & 45 \\
\hline -Cynisch & 45 & 51 & 65 & 55 \\
\hline
\end{tabular}


integratief is erg klein is. Burgers die cultureel demarcatief zijn, zijn gemiddeld veel lager opgeleid dan de twee andere groepen; 39 procent is lager opgeleid. Dit is in lijn met Kriesi et al., die stellen dat een cultureel integratieve opvatting vaker voorkomt naarmate het opleidingsniveau stijgt. Zij stellen dat educatie een 'cultureel liberaliserend' effect heeft, omdat opleiding mensen cultureel tolerant maakt en omdat mensen door hogere taalvaardigheden meer contact krijgen met andere culturen. Ook Bovens en Wille (2009) leggen in hun studie over de diplomademocratie een vergelijkbaar verband tussen opleiding en cultureel liberalisme. Verder zijn degenen die cultureel demarcatief zijn vaker niet politiek geïnteresseerd (30\%) dan de twee andere groepen en veel politiek cynischer (65\%).

Het mediagebruik van burgers die cultureel demarcatief zijn wijkt af van dat van andere burgers. Zoals in tabel 7.4 zichtbaar is, kijken deze burgers veel televisienieuws (92\%), zowel het NOS-Journaal (64\%) als RTL-Nieuws (40\%) zijn goed bekeken. Opvallend is dat de cultureel demarcatieve burgers veel meer naar het RTL-Nieuws kijken dan de andere twee groepen. Verder leest een ruime meerderheid van de cultureel demarcatieve burgers kranten (71\%), maar daarbij gaat het voornamelijk om regionale kranten (40\%) en De Telegraaf (24\%). De mate waarin deze groep het Algemeen Dagblad (10\%), Sp!ts (8\%) en Metro (8\%) leest wijkt niet af van de andere groepen. De andere betaalde landelijke kranten NRC Handelsblad (4\%), de Volkskrant (2\%), Trouw (1\%) en Het Parool (0\%) worden niet of nauwelijks gelezen, in tegenstelling tot de andere groepen. Internet wordt door deze groep niet veel gebruikt voor politieke informatie (5\%), terwijl dit in de andere groepen iets meer is. Hoewel burgers die cultureel demarcatief zijn minder landelijke kranten lezen en internet gebruiken dan gemiddeld, kijken ze wel veel televisienieuws, zelfs iets meer dan gemiddeld. Een ruime meerderheid van deze groep neemt dagelijks nieuws tot zich via televisie, kranten of internet (92\%) en dit is vergelijkbaar met de andere twee groepen burgers. Deze groep gebruikt dus niet minder media voor nieuws dan gemiddeld, maar wel andere media.

\subsubsection{DE AANSLUITING TUSSEN MEDIA EN BURGERS}

In de aanloop naar de verkiezingen van 2002 werd zichtbaar dat er onder een deel van de Nederlandse burgers onrust bestond over het thema immigratie en integratie. Naast de economische scheidslijn werd de culturele scheidslijn relevant voor de attitudes en het stemgedrag van burgers. De media spelen hier sinds 2001 op in door meer aandacht te besteden aan immigratie en integratie. Bij alle kranten, van de Volkskrant tot De Telegraaf, is een groei van het aantal berichten over deze onderwerpen te zien. Het hoeft geen verbazing te wekken dat de media veel meer zijn gaan berichten over deze nieuwe culturele scheidslijn. Op een door medialogica gedomineerde vragersmarkt kunnen media slechts overleven door ruime aandacht te geven aan onderwerpen die in brede kring leven. Bovendien gaat het nieuws rond immigratie- en integratievraagstukken altijd gepaard met heftige 
Tabel 7.4

Mediagebruik burgers, percentages

\begin{tabular}{|l|c|c|c|c|} 
& $\begin{array}{c}\text { cultureel } \\
\text { integratief } \\
\mathbf{n = 9 7}\end{array}$ & $\begin{array}{c}\text { cultureel } \\
\text { midden } \\
\mathbf{n = 1 7 9 5}\end{array}$ & $\begin{array}{c}\text { cultureel } \\
\text { demarcatief } \\
\mathbf{n = 8 3 6}\end{array}$ & $\begin{array}{c}\text { alle } \\
\text { respondenten } \\
\mathbf{n}=\mathbf{2 7 2 8}\end{array}$ \\
Gebruik alle media & 95 & 92 & 92 & 92 \\
Gebruik televisie nieuws dagelijks & 72 & 68 & 75 & 70 \\
NOs-Journaal & 68 & 60 & 64 & 61 \\
RTL4 Nieuws & 25 & 32 & 40 & 34 \\
Gebruik kranten dagelijks & 72 & 74 & 71 & 73 \\
De Telegraaf & 8 & 16 & 24 & 18 \\
De Volkskrant & 22 & 10 & 2 & 8 \\
Trouw & 5 & 3 & 1 & 2 \\
NRC Handelsblad, NRC.next & 11 & 8 & 4 & 7 \\
Algemeen Dagblad & 7 & 12 & 10 & 11 \\
Het Parool & 6 & 2 & 0 & 2 \\
Metro & 13 & 9 & 8 & 9 \\
Spits & 14 & 10 & 8 & 10 \\
Een regionale krant & 32 & 38 & 40 & 39 \\
Overige kranten & 3 & 3 & 2 & 3 \\
Gebruik internet nieuws dagelijks & 13 & 9 & 5 & 8 \\
\hline
\end{tabular}

Bron: NKO 2006

conflicten en emoties, bij uitstek ingrediënten voor onderhoudende berichtgeving en uitzendingen die grote delen van het publiek aanspreken.

Media hoeven zich daarbij veelal niet te verantwoorden voor wisselende accenten, kunnen met een beroep op pluriformiteit tegengestelde visies aan het woord laten komen en kunnen dit vaak doen zonder zelf expliciet kleur te bekennen. Voor gevestigde politieke partijen is dat veel moeilijker, die moeten niet alleen aandacht besteden aan de onderwerpen, ze moeten ook duidelijk een standpunt innemen, consistent zijn in hun opstelling en laten zien hoe problemen kunnen worden opgelost. Toch lijken sommige media wel positie gekozen te hebben. Terwijl de media vroeger verweten werd dat ze vooral op een cultureel integratieve manier berichtten, zijn er nu media die voor een demarcatieve duiding kiezen door immigratie primair als een bedreiging te duiden. Op basis van de globale analyses in deze paragraaf kan vastgesteld worden dat de externe pluriformiteit, de verschillen tussen de media, op de culturele dimensie thans duidelijk aanwezig is.

De vraag is hierbij of de veelal impliciete stellingname altijd een bewuste keuze is van deze media. Vaak komt een impliciet standpunt voort uit het denken vanuit een bepaalde mindset. Standpunten worden dan niet openlijk gepropageerd, maar 
klinken wel door in de berichtgeving. Duidelijk is dat de media op de culturele dimensie hun doelgroep weten te vinden. De groep burgers die cultureel demarcatief is blijkt tamelijk vaak naar het RTL-Nieuws te kijken, een programma dat relatief veel berichten brengt met een cultureel demarcatief frame. Van de door deze groep veelgelezen regionale kranten weten we helaas niet hoe ze precies berichten over deze onderwerpen. Daarnaast worden De Telegraaf en in mindere mate het Algemeen Dagblad veel gelezen, kranten die beide relatief veel cultureel demarcatieve standpunten naar voren brengen. Wellicht willen deze media de standpunten van cultureel demarcatieve burgers representeren, wellicht is het een welbegrepen commercieel belang, maar een feit is dat er media zijn waar deze burgers zich op de culturele dimensie thuis voelen.

\subsection{GEVOLGEN VOOR DE INTERMEDIAIRE ROL VAN DE MEDIA}

De hierboven beschreven toegenomen concurrentie en fragmentering op de mediamarkt en de manier waarop media op een nieuwe scheidslijn reageren, hebben gevolgen voor de functie van de media in de democratie. De media worden geacht drie essentiële functies te vervullen in een democratisch stelsel (Wildenmann en Kaltefleiter 1965). Het gaat daarbij in de eerste plaats om de top-down-functie van de media, oftewel de informatiefunctie. De burgers dienen op pluriforme wijze op de hoogte te worden gehouden van relevante politieke ontwikkelingen, spanningen en problemen in de maatschappij, om in staat te zijn om hun democratische rol als burgers te kunnen vervullen. Media hebben de taak het publiek voor te lichten en daarmee participatie te stimuleren; ze kunnen 'mobilizing agents' zijn. Ten tweede hebben de media een bottom-up-functie, de media zijn een 'civic forum', daarom ook wel de platformfunctie genoemd. De veelzijdigheid aan geluiden uit de samenleving, variërend van wensen en eisen van actie- en belangengroepen tot alle enigszins relevante politieke opvattingen en gevoelens, dienen in de media aan bod te komen, zodat zowel burgers als politici daar kennis van kunnen nemen. Daarbij gaat het er niet om dat in een specifiek medium alle opvattingen en invalshoeken behandeld worden, een dergelijke interne pluriformiteit is voor een afzonderlijk medium onhaalbaar, maar dat het gezamenlijke aanbod van de media daar recht aan doet. De media dienen dus gezamenlijk een zo volledig mogelijke externe pluriformiteit te garanderen. Ten derde vervullen de media een controlefunctie als kritische waakhond, niet alleen ter voorkoming van machtsmisbruik, maar ook om politieke leiders en het openbaar bestuur ter verantwoording te roepen en hun beleidsvoornemens en de uitvoering van het beleid aan een kritische inspectie te onderwerpen. Deze functies schetsen een ideaalbeeld waar het mediastelsel als geheel aan zou moeten voldoen.

Deze drie functies van de media, vooral de eerste en de derde functie, betreffen zowel de wetgevende, de uitvoerende als de controlerende macht. Het geeft de media een belangrijke rol in een democratisch stelsel en in het Verenigd Konink- 
rijk spreekt Burke in de achttiende eeuw al over de media als de vierde macht. Terwijl de bevoegdheden en de onderlinge verhoudingen tussen de eerste drie machten in elk democratisch stelsel geheel of gedeeltelijk zijn vastgelegd (en vaak gespreid zijn over meerdere instituties), is dit ten aanzien van de media niet het geval. Het is de eigen verantwoordelijkheid van de media hoe en in welke mate ze invulling geven aan deze drie functies. In het kader van de veranderingen op de mediamarkt gaan we hier vooral na wat deze ontwikkelingen betekenen voor de invulling van deze drie functies. Daarbij past een belangrijke kanttekening. De wijze waarop de functies in het verleden zijn vervuld mag niet geïdealiseerd worden, zowel wanneer het gaat om de periode voor 1990 als om de tijd van de verzuiling, toen de interne pluriformiteit van veel media veel te wensen overliet en de informatiefunctie en de platformfunctie karig werden ingevuld.

De in dit hoofdstuk beschreven ontwikkelingen hebben als gevolg dat vooral de top-down-informatiefunctie van de media onder druk is komen te staan en de controlefunctie een andere inhoud krijgt. In de eerste plaats vindt door de opmars van de medialogica binnen het politiek nieuws een verschuiving plaats van inhoudelijk, beleidsgeoriënteerd nieuws naar strategisch nieuws, sfeernieuws en peilingen. Dit blijkt uit de analyses van de campagneverslaggeving door kranten en het televisienieuws, maar het komt ook buiten verkiezingstijd tot uiting in de grote aandacht voor conflicten en beleidsproblemen. Vaak krijgt deze aandacht het karakter van een korte maar krachtige hype, die iedereen na enige tijd weer vergeten is. Het groeiend wantrouwen tussen media en politiek versterkt deze ontwikkeling. Dit veranderde accent binnen de politieke berichtgeving heeft gevolgen voor de controlefunctie van de media, die steeds vaker de persoonlijke performance van een politicus of minister betreft en vaak pas in de tweede plaats zijn of haar beleid. De personalisering van de controlefunctie is voor redacties vaak gemakkelijk in te vullen en leidt bovendien tot onderhoudende berichtgeving. Wanneer de politiek verantwoordelijken in het openbaar bestuur zelf continu het onderwerp van controle zijn en meningsverschillen tussen bewindslieden onderling uitvergroot worden kan dit verlammend gaan werken.

Ten tweede heeft de zeer grote concurrentie op de gefragmenteerde mediamarkt gevolgen voor de handhaving van de professionele journalistieke normen. Tot deze professionele normen behoren nauwkeurigheid, het dubbel checken van feiten, meerdere bronnen raadplegen en het toepassen van hoor en wederhoor. Deze normen staan onder druk door de grote prioriteit die redacties geven aan het hebben van een primeur en de angst om als één van de laatste met bepaald nieuws te komen. Dit kan niet alleen de nauwkeurigheid en betrouwbaarheid van de informatiefunctie onder druk zetten, het kan eveneens gevolgen hebben voor de kwaliteit van de invulling van de controlefunctie. Elk vermeend schandaal of beleidsfalen wordt in eerste instantie door veel media met grote ophef gebracht en steeds minder nemen media de tijd de zaak in een afgewogen perspectief te plaatsen. 
Voor het openbaar bestuur betekent dit dat, als het politieke informatie op een evenwichtige manier in de media wil krijgen, dit hoge eisen aan zijn communicatiebeleid stelt. Er wordt steeds meer gevraagd om een proactieve houding van de overheid. Exemplarisch is wat dit betreft de recente discussie over het vaccin tegen respectievelijk baarmoederhalskanker en de Mexicaanse griep, waarbij op internet allerlei angstverhalen de ronde deden die door veel andere media werden overgenomen. In analyses achteraf is de overheid verweten zich met de nieuwe informatiesituatie nog geen raad te weten en te laat op deze geruchten te reageren (NRC.NEXT 2009a 2009b).

De informatiefunctie van de media staat ook onder druk, doordat het voor burgers steeds gemakkelijker wordt om politiek nieuws te ontwijken. Door de toename van het aantal televisiezenders met weinig of geen politiek nieuws en meer recent de themakanalen, wordt het steeds gemakkelijker om nergens meer politiek nieuws 'per ongeluk' tegen te komen. De verdere ontwikkeling van digitale televisie, waardoor de kijker zijn eigen programma-aanbod kan samenstellen, zal dit effect nog versterken. Verwacht mag worden dat hierdoor een substantiële groep burgers steeds moeilijker te bereiken zal zijn. Voor het openbaar bestuur vormt het een belangrijke uitdaging deze groep op de hoogte te houden van beleidsvoornemens en -maatregelen. Eigen websites en eigen media kunnen een instrument zijn, zij zijn zeker noodzakelijk, maar het belang ervan moet niet worden overschat. Burgers die het nieuws niet meer volgen via de traditionele media gaan ook niet zelf actief op zoek naar maatschappelijk en politiek nieuws op websites van politieke partijen of overheidsorganisaties. Het zijn vooral de hoogopgeleide burgers die het nieuws toch al intensief volgen, die dankbaar gebruikmaken van het aanbod op weblogs en nieuwssites. Voor het democratisch stelsel kan door deze ontwikkeling een probleem ontstaan. Burgers worden geacht mede vorm te geven aan de samenleving en een zekere verantwoordelijkheid te dragen. Daarvoor is het wenselijk dat zij enigszins op de hoogte zijn van politieke ontwikkelingen en kwesties.

De platformfunctie, waarbij de media een platform zijn voor geluiden vanuit de samenleving, staat niet onder druk. Door fragmentatie van de mediamarkt is er veel meer informatie beschikbaar dan in het verleden. De groei van het informatieaanbod is niet alleen tot stand gekomen via de talloze nieuwsportals op internet en websites van overheden en belangengroepen, maar ook door de opkomst van de succesvolle gratis kranten. Hierdoor kunnen geluiden uit de samenleving gemakkelijker hun weg vinden naar de publiciteit. Bovendien krijgt de platformfunctie meer prioriteit bij veel media dan in het verleden. Zeker na het succes van Fortuyn en zijn partij de LPF, zijn veel media zich ervan bewust geworden dat ze in de jaren negentig van de vorige eeuw ontwikkelingen in de samenleving niet voldoende onderkend hebben. In paragraaf 7.3 is gebleken dat media snel gereageerd hebben op het ontstaan van een nieuwe culturele dimensie. Sinds 2002 zijn 
media er veel meer op gespitst om geluiden uit de samenleving een platform te bieden. Bij nagenoeg elk onderwerp van enig maatschappelijk belang komt de burger aan het woord, ofwel via een paar straatinterviews ofwel door een snel uitgevoerde opiniepeiling. Het openbaar bestuur wordt hierdoor soms geconfronteerd met een snelle en onverwachte publieke meningsvorming en wordt in het debat in de media door journalisten vaak in het defensief gedrongen. Problematisch daarbij is dat veelal niet duidelijk is hoe representatief een paar leuke of scherpe quotes zijn of hoe deugdelijk de uitgevoerde enquête is. Vastgesteld kan echter worden dat de media de platformfunctie goed en wellicht zelfs beter vervullen dan vroeger, mede doordat de media commerciëler geworden zijn en herkenbaar willen zijn voor hun doelgroep.

De intermediaire rol van de media verandert, maar het belang ervan neemt zeker niet af. Wel gaat dit ten koste van de maatschappelijke positie van politieke partijen. Gezien het mandaat dat partijen van de kiezers bij verkiezingen krijgen mag verwacht worden dat zij verwoorden wat er in de samenleving leeft en desgewenst vertalen in concrete eisen, de zogenoemde articulatiefunctie van politieke partijen. Sinds de jaren zeventig is waarneembaar dat deze articulatiefunctie steeds vaker wordt vervuld door de media; burgers wenden zich eerder tot de media dan tot politieke partijen met klachten en problemen. Het dominant worden van de medialogica, de opkomst van nieuwe maatschappelijke problemen en de grote prioriteit die de media tegenwoordig geven aan de platformfunctie hebben deze tendens versterkt.

\subsection{CONCLUSIE}

In dit hoofdstuk zijn we ingegaan op twee ontwikkelingen die van invloed zijn op het functioneren van het openbaar bestuur: het transformatieproces van de vertegenwoordigende democratie en het transformatieproces van het mediasysteem. In deze slotparagraaf zullen we kijken hoe beide processen elkaar beïnvloeden en versterken. Zowel de electorale markt als de mediamarkt heeft zich ontwikkeld van een stabiele aanbodmarkt naar een sterk concurrerende en dynamische vragersmarkt. Zowel voor de gevestigde politiek als voor de oude media heeft dit grote onzekerheid gecreëerd, het heeft het zelfvertrouwen van veel politici en journalisten aangetast. Op beide markten zien we de soms razendsnelle opkomst van nieuwe spelers, soms ook weer gevolgd door een snelle aftocht. Voor veel van de nieuwe spelers staat nog allerminst vast dat ze blijvend een rol zullen spelen.

Zowel de politieke partijen als de media zijn daarbij sinds het begin van deze eeuw geconfronteerd met het manifest worden van belangrijke nieuwe maatschappelijke problemen. In Nederland, en veel andere Europese landen, zien veel politicologen naast de traditionele economische links-rechtstegenstelling een nieuwe 
culturele dimensie ontstaan, waarbij een multiculturele integratieve visie staat tegenover een cultuurprotectionistische demarcatieve visie. Voor zowel de media als de politiek vormt het een groot probleem hoe hier op gereageerd moet worden. Deze nieuwe tegenstelling heeft de onzekerheid van journalisten en politici van gevestigde politieke partijen in eerste instantie nog verder vergroot.

De veranderingen op de electorale markt bleken voor het eerst bij de verkiezingen voor de Tweede Kamer in 1994. Sindsdien is de volatiliteit op de electorale markt nog toegenomen; vooral de verkiezingen van 2002 en 2006 kenmerkten zich door grote politieke verschuivingen. De oude politieke partijen hebben veel moeite zich aan te passen aan deze tweedimensionale structuur en vooral om zich herkenbaar op te stellen op deze nieuwe dimensie. Tegelijkertijd dient vastgesteld te worden dat de electorale markt in Nederland, dankzij het kiesstelsel, een zeer open karakter heeft en veel kansen biedt aan nieuwe stromingen en bewegingen in de samenleving. Sinds 1994 heeft een groot aantal nieuwe politieke partijen op lokaal en nationaal niveau succes gehad: de Socialistische Partij, ouderenpartijen, lokale partijen waaronder veel leefbaarheidspartijen, de LPF, en sinds 2006 de Partij voor de Dieren en de Partij voor de Vrijheid. Hoewel het electorale systeem in Nederland dus zeer open is en er vanaf 2001 verschillende nieuwe cultureel demarcatieve partijen zijn ontstaan, hebben deze partijen tot nu toe slechts een beperkte bijdrage kunnen leveren aan het openbaar bestuur. Op nationaal niveau heeft alleen de LPF in 2002 enkele maanden, met weinig succes, deelgenomen aan het eerste kabinet-Balkenende. Op lokaal niveau hebben vooral lokale partijen, sommige met een sterk demarcatief profiel, en de SP vaker geparticipeerd in het openbaar bestuur. Deze deelname aan het bestuur laat een wisselend beeld zien van enerzijds succesvolle coalities en anderzijds gemeenten die kampen met grote bestuurlijke problemen, vaak veroorzaakt door interne problemen en gebrek aan bestuurservaring bij lokale partijen. Geconstateerd kan worden dat nieuwe politieke partijen ondanks hun electorale successen tot nu in beperkte mate succesvol hebben deelgenomen aan het openbaar bestuur.

De mediamarkt is in de jaren negentig eveneens opengebroken. Het dominant worden van de medialogica heeft ertoe geleid dat de aandacht voor beleidsinhoudelijke zaken is gedaald, hoewel zeker niet gemarginaliseerd, en dat de aandacht voor politiek-strategische onderwerpen, conflicten, drama en grote en kleine schandalen is gestegen. Politici maken zich soms kwaad over de wijze waarop de media berichten over de politiek. Dat is zeker niet altijd ten onrechte, maar vereist een paar kanttekeningen. Ten eerste worden het dalend vertrouwen in de politiek en het groeiend cynisme niet door de media veroorzaakt. Hoewel er in de vs onderzoeken zijn die een verband aantonen tussen negatieve en strategische mediaberichtgeving enerzijds en negatieve politieke attitudes anderzijds, is dit verband door onderzoekers in Nederland en andere Europese landen ter discussie gesteld. Bovendien lokken partijen en het openbaar bestuur door hun gedrag en 
hun strategie van newsmanagement deze berichtgeving in belangrijke mate zelf uit. Hoe en in welke mate het openbaar bestuur haar newsmanagement moet professionaliseren vormt echter een dilemma. Enerzijds lokt het onmiskenbaar wantrouwen uit aan de kant van de journalistiek, anderzijds kan het openbaar bestuur het zich niet permitteren om niet te reageren als oude en nieuwe media, soms met dubieuze of onjuiste argumenten, het publiek proberen te mobiliseren tegen bepaalde beleidsvoornemens.

De media werden in 2002, evenals de politieke partijen, overvallen door de snelle opkomst van Pim Fortuyn en zijn partij. Zij hebben zich echter veel sneller aangepast aan de nieuwe situatie dan de politieke partijen. Alle media zijn meer aandacht gaan besteden aan kenmerkende onderwerpen van de nieuwe culturele dimensie - integratie en immigratie - en bovendien kiezen enkele media een meer cultureel demarcatieve positie en andere juist een integratieve positie. Media kunnen natuurlijk veel gemakkelijker en vrijblijvend berichten over een omstreden en gepolitiseerd thema dan politieke partijen, die altijd geacht worden een standpunt in te nemen en een oplossing aan te dragen. Vooral de gevestigde en vaak bestuursverantwoordelijkheid dragende partijen hebben daar grote moeite mee. Het is voor de media daarentegen om meerdere redenen juist aantrekkelijk om veel aandacht te besteden aan alle problemen rond integratie en immigratie, het zijn onderwerpen die goed passen bij de vereisten van de medialogica - emotioneel geladen, een breed publiek aansprekend en daarmee altijd goed voor pittige uitspraken - en waar zowel tussen de partijen als binnen de partijen veel conflicten over zijn. Met een zekere gretigheid worden deze problemen door de media belicht en uitvergroot. Deze onderwerpen stellen de oude spelers op de mediamarkt, ongeacht of ze zelf stelling nemen, in staat te laten zien dat zij in tegenstelling tot de gevestigde politieke partijen, het contact met brede lagen van de bevolking niet verloren hebben. De nieuwe spelers, vooral de verschillende blogs op internet, willen juist laten zien dat zij op deze punten beter functioneren dan de traditionele media. De aandacht voor deze onderwerpen kent wel een zekere golfbeweging, maar zolang het een sterk gepolariseerd onderwerp blijft waar een deel van de politieke partijen mee worstelt, valt het niet te verwachten dat de media hun belangstelling ervoor zullen verliezen. De opkomst van de nieuwe culturele tegenstelling is dan ook een zege voor de oude én de nieuwe media. 


\section{NOOT}

Het begrip media logic werd in 1979 voor het eerst gebruikt door Altheide \& Snow. In hun benadering staan vooral de technische vereisten en het format van de media centraal: 'how material is organized, the style in which it is presented, the focus or emphasis on particular characteristics of behavior, and the grammar of media communication. (...) Media logic becomes a way of seeing and interpreting social affairs' (Altheide en Snow, 1979: 10-11). Mazzoleni (1987) gebruikte het voor het eerst voor een onderzoek naar de rol van media bij verkiezingscampagnes. In Nederland introduceren Brants en Van Praag het begrip in een boek over de campagne van 1994 (Brants en Van Praag 1995). De Raad voor Maatschappelijke Ontwikkeling brengt in 2003 een rapport uit onder de titel Medialogica, waarin het begrip breder wordt omschreven dan in de meeste wetenschappelijke literatuur. 


\title{
8 DE PRODUCENTENBENADERING
}

\author{
Menno van der Veen, Susanne Sleenhoff \& Tanja Klop
}

\section{$8.1 \quad$ INLEIDING}

\subsubsection{PRODUCENTEN VERSUS CONSUMENTEN}

Recentelijk besloot een aantal plaatselijke gemeenten tot het invoeren van een taalcoachproject. ${ }^{1}$ Vrijwilligers die de landstaal goed spreken, zouden migranten helpen om de taal eveneens machtig te worden. Het ging om een project waarbij sociale interactie net zo belangrijk werd gevonden als kennisoverdracht. $\mathrm{Al}$ doende - bestellen bij de slager, vragen stellen tijdens een ouderavond op schoolleert men was het credo. De reacties op dit project kunnen in twee soorten worden onderscheiden: die van de consumptieve en van de productieve soort. Dat onderscheid staat centraal in dit hoofdstuk. Aan de hand van het voorbeeld van het taalcoachproject introduceren we de begrippen hier alvast kort.

De groep mensen die wij 'consumenten' noemen, zagen niets in het project. Ze vreesden langere rijen bij de supermarkt als daar opeens taalcoaches zouden verschijnen die migranten dwongen hun bestelling nog eens over te doen als er taalfouten werden gemaakt. Veel consumenten vonden dat ze voor dit soort projecten geen belasting betaalden en verzetten zich luidruchtig tegen al die 'softe' sociale projecten.

Hoe anders werd het taalcoachproject benaderd door wat wij de 'producenten' noemen. Velen omarmden het initiatief als een gelegenheid om een bijdrage te leveren aan hun omgeving en bovendien gaf het project de kans aan migranten om ook een producent te worden. De slogan 'het begint met taal' benadrukt dat migranten door taal te leren beter in staat zullen zijn om hun omgeving (mede) vorm te geven.

Met dit voorbeeld willen wij het onderscheid aanzetten tussen een overheid die consumentenbenadering en een overheid die een producentenbenadering kiest om haar inwoners te benaderen. Een producentenbenadering stelt de mogelijkheid die mensen hebben om hun leven en omgeving vorm te geven voorop, een consumentenbenadering stelt eerder de rechten van individuele inwoners ten opzichte van de overheid voorop. Als mensen worden aangesproken als consument, dan zullen ze zich ook zo gedragen.

Bij de producentenbenadering horen vragen naar de legitimiteit van het openbaar bestuur, de legitimiteit van het overheidsingrijpen, de vraag naar het onderscheid 
tussen de privésfeer en de publieke sfeer, en de vraag naar de individuele verantwoordelijkheid van inwoners van de rechtstaat. We gaan in dit hoofdstuk niet op al die vragen in. Voor sommige van de vragen geldt dat de producentenbenadering als work in progress nog geen afdoende antwoord op de specifieke problematiek biedt. Waar dat het geval is zullen we in de tekst een oplossingsrichting aangeven. Voor andere vragen geldt dat ze buiten het bestek van dit hoofdstuk vallen. We richten ons in dit hoofdstuk namelijk in de eerste plaats op de specifieke situatie waarin de overheid niet overgaat tot het afdwingen van bepaald door haar gewenst gedrag, maar een bewustzijnsgedrag of mentaliteitsverandering teweeg poogt te brengen bij mensen zonder dat ze daarbij gebruikmaakt van het geweldsmonopolie. We willen in dit hoofdstuk laten zien dat de overheid mensen beter als producenten (als scheppers) van hun omgeving kan benaderen dan als consumenten. Campagnes en evenementen bieden vervolgens een goede illustratie van het verschil tussen een consumenten- en producentenbenadering.

\subsubsection{OРBOUW}

Allereerst bespreken we de bezwaren tegen een overheid die inwoners als 'consumenten' benadert tegen de achtergrond van de consumentensamenleving.

We benoemen daarbij drie bezwaren tegen een overheid die haar inwoners als consumenten benadert; infantilisering (subpar. 8.2.1), de nadruk die een consumentenbenadering legt op sociale contracten (subpar. 8.2.2) en het wantrouwen tussen overheid en inwoners waarop een consumentenbenadering is gestoeld (subpar. 8.2.3). Het overkoepelende argument is dat uit het feit dat overheden in beginsel geen commerciële aanbieders zijn volgt dat een consumentenbenadering tot onoverkomelijke problemen leidt (subpar. 8.2.4). Om misverstanden te verkopen, benadrukken we hier dat we actieve consumenten (hier begrepen als inwoners die met hun portemonnee bepaalde maatschappelijke doelen proberen te verwezenlijken) als producenten beschouwen.

In de volgende paragraaf beschrijven we de contouren van een producentensamenleving en zetten we uiteen wat het betekent wanneer de overheid inwoners als producenten aanspreekt (subpar. 8.3.1). Producenten zijn in die voorstelling van zaken allereerst individuen die zichzelf als scheppers van hun leven en omgeving beschouwen. Daaruit volgt een verantwoordelijkheid voor hun omgeving. De taak van de overheid is om individuen in staat te stellen om hun omgeving te (co-)creëren. Het overheidsbeleid moet zich daarmee richten op onderwerpen die de overheid beter dan de individuele producenten voor haar rekening kan nemen. Daarop (in subpar. 8.3.2) bespreken we hoe de producentenbenadering zich verhoudt tot het 'ambt burger' zoals dat in 1992 door Herman van Gunsteren voor de WRR werd beschreven. Er zijn raakvlakken tussen de verantwoordelijkheden die Van Gunsteren aan het ambt burger verbindt en de verantwoordelijkheden van 
een producentensamenleving. Het belangrijkste verschil tussen beide is dat de producentenbenadering zich daarvoor niet op ‘burgers' maar op 'individuen’ richt.

Ten slotte (subpar. 8.3.3) bespreken we het begrip omgeving en beschrijven we hoe de overheid de omgeving van de individuen binnen kan dringen. We gaan kort in op de legitimatie van het binnendringen van de omgeving. Daartoe gaan we in op een aantal indelingen die vaak gehanteerd worden om mensen bij overheidsbeleid te betrekken en benoemen we hoe die zich verhouden tot de producentenbenadering. Die benadering breiden we vervolgens uit met een reflectie op wat het uitgangspunt moet zijn als overheden inwoners vragen om te participeren.

In de laatste paragraaf (8.4) bespreken we daarbij wat het denken in termen van een evenement voor participatie betekent (subpar. 8.4.1 en 8.4.2), reflecteren we op de zin en onzin van evenementen (par. 8.4.3), en gaan we kort in op rituelen als specifieke vorm om mensen bij een bepaald onderwerp te betrekken.

Om een beeld te krijgen van evenementen en de mate waarin een overheid succesvol van evenementen gebruik zou kunnen maken hebben we een aantal gesprekken gevoerd. In het bijzonder gaat het om Jaap Spreeuwenberg en Pieter di Stefano van Coolpolitics dat naam heeft gemaakt met het verbinden van inhoudelijke op jongeren toegesneden programma's aan evenementen zoals het popfestival Lowlands, Mieke van Heeswijk en Mat Poelmans van het overheidsprogramma Burgerlink dat zich onder andere richt op burgerparticipatie op internet, en Maurits Rade van stichting Happy Chaos dat inhoudelijke evenementen voor twintigers organiseert. De reden om enige aandacht te besteden aan de interviews die we hen hebben afgenomen is dat zij dagelijks op verschillende manieren geconfronteerd worden met de vraag hoe mensen kunnen worden aangesproken om deel te nemen aan discussies over maatschappelijke vraagstukken. De hoofdvraag die wij hen hebben gesteld, luidt: op welke manier kan een boodschap de omgeving van mensen binnendringen zodat ze bereid zijn om aan de oproep gehoor te geven.

\subsection{CONSUMENTEN}

Een consumentenbenadering door overheden kent twee dimensies. Ten eerste klantvriendelijkheid: overheidsinstanties proberen de behoeften van inwoners de cliënten - centraal te stellen in de manier waarop zij hun organisatie inrichten. Ten tweede accepteren overheidsinstanties dat de verhouding aanbieder-consument die de private sector kenmerkt ook de relatie met hun inwoners kenmerkt en zien inwoners als consumenten die bepaalde diensten verwachten en daarvoor een bepaalde prijs betalen. Een consumentenbenadering plaatst inwoners dan in een individuele contractuele verhouding tot de overheid. Een inwoner betaalt belasting en mag daarvoor diensten verwachten. 
Wij verzetten ons in dit hoofdstuk tegen de tweede variant van de consumentenbenadering. Als de overheid haar front desks en back offices wil inrichten op een manier die aansluit bij de behoeften van degenen die er gebruik van maken, dan kunnen we dat alleen maar toejuichen. Het gaat erom dat in die tweede dimensie de consumentenbenadering verder reikt dan het verbeteren van de 'servicekwaliteit'. Een consumentenbenadering sluit aan bij de principes van de consumentensamenleving en creëert (of versterkt) eerder het wantrouwen dat het wil bestrijden dan dat het er een medicijn tegen zou vormen. We bespreken in deze paragraaf allereerst in grote lijnen enkele kenmerken van de consumentensamenleving (subpar. 8.2.1) en de kritiek dat zij inwoners zou infantiliseren. Daarop bespreken we de praktijk van sociale contracten (subpar. 8.2.2) en gebruiken we een aan de speltheorie ontleend argument om te betogen dat een consumentenbenadering het wantrouwen juist versterkt (subpar. 8.2.3). In de laatste subparagraaf (8.2.4) bespreken we kort hoe ons beeld van de consumentensamenleving zich verhoudt tot de belangrijke trend waarbij consumenten steeds meer nadruk leggen op het zelf creëren.

\subsubsection{CONSUMENTENSAMENLEVING}

Een consumentensamenleving is een samenleving waarin het kopen van materiële goederen tot een doel op zichzelf is verheven. De consumentensamenleving heeft zich na de Tweede Wereldoorlog ontwikkeld en is de afgelopen twee decennia tot wasdom gekomen. Sloterdijk (2007) spreekt in die context bijvoorbeeld van het 'reëel bestaande' consumentisme. In een consumentensamenleving staat consumeren in het teken van een behoefte aan prikkels (Piët 2003). Er wordt ook wel van een wegwerpmaatschappij gesproken. Wat niet lekker is of niet meer in de smaak valt wordt weggegooid of afgedankt. Een consumentensamenleving legt een sterke nadruk op directe behoeftebevrediging. Vanwege die nadruk houden velen haar verantwoordelijk voor de verspilling die westerse samenlevingen kenmerkt, die leidt tot overproductie en daarmee tot een bovenmatige $\mathrm{CO}^{2}$-uitstoot en tot grote sociale ongelijkheid op mondiaal niveau (Fahlquist 2009). Er wordt ook wel betoogd dat een consumentensamenleving niet draait om consumenten maar om de belangen van enkele grote bedrijven die schijnbehoeften creëren waardoor mensen steeds meer gaan kopen.

De Amerikaanse politicoloog Benjamin Barber schreef in 2007 het boek De Infantiele Consument. Barber beschrijft de consumentensamenleving als een samenleving die gedomineerd wordt door multinationals die een eeuwige jeugd proberen te creëren waarin steeds nieuwe schijnbehoeften worden gecreëerd. De consumentensamenleving die Barber schetst is erop gericht mensen zo min mogelijk zelf te laten nadenken en infantiliseert doelbewust. De negenjarige moet zich als een volwassene gedragen en de volwassen vrouw of man moet eruitzien als (en de behoeftes hebben van) een tiener (zie ook Spangenberg \& Lampert 2009). 
Barber spreekt van een infantiel ethos dat volgens hem voor een op consumptie gerichte samenleving niet minder betekent dan wat Webers protestantse ethiek betekende voor de ondernemerscultuur van de op productie gerichte handelskapitalistische samenleving. Bovendien leidt het consumentisme ertoe dat het kapitalisme niet meer wordt gecorrigeerd door democratische machten maar die machten steeds meer weet te beteugelen.

Deze vorm van kapitalisme staat lijnrecht tegenover een kapitalisme dat zich niet op consumptie maar op productie richt. Dat op productie gerichte kapitalisme is gelieerd aan deugden die bijdragen aan democratie, verantwoordelijkheidsgevoel en burgerzin.

Echter, vandaag de dag is kapitalisme volgens Barber gelieerd aan ondeugden die democratie, verantwoordelijkheidsgevoel en burgerzin juist ondermijnen. Barber stelt dat het infantiele ethos verder reikt dan de populaire cultuur. In het onderwijs worden mensen niet als zelfstandige studenten maar als merkgerichte consumenten benaderd, in de politiek komt hij een op privatisering, narcisme en eigenbelang gerichte ideologie tegen die zich kenmerkt door een discours van simplistische tegenstellingen.

Ondanks de bezwaren die tegen de consumentensamenleving worden geuit, is de consument - misschien naast die van 'het gezin' - een van de weinige collectiviteiten die politiek nog aanvaardbaar is (Van der Veen 2007). De consument weet zich ook door steeds meer wetten beschermd.

De afgelopen vijftien jaar hebben de rechten van bijvoorbeeld werknemers moeten wijken voor 'flexibilisering', de rechten van individuen hebben moeten wijken voor veiligheidsmaatregelen (legitimatieplicht), terwijl de rechten van consumenten - niet in de laatste plaats door EU-wetgeving ${ }^{2}$ - steeds meer zijn toegenomen.

De aantrekkelijkheid van de consument als collectiviteit schuilt in een paradox; consumentgericht denken doet recht aan het toegenomen individualisme, terwijl het zich tegelijkertijd richt op de massa. Consumeren is een individualistische bezigheid maar tegelijkertijd is iedereen consument.

Andere collectiviteiten veronderstellen tegenstellingen: tegenover werkgevers staan werknemers, tegenover armen staan rijken. Als de overheid inwoners als consumenten benadert, dan kiest ze voor een apolitieke collectiviteit waarin ieder individu zich herkent. In positief gekleurde beschrijvingen, wordt de consument voorgesteld als een mondige burger die niet alleen eisen stelt met betrekking tot prijs, service, garantie en veiligheid. 
Er wordt op gewezen dat die consumenten meer successen boeken dan wetgevende instanties in hun acties voor het implementeren van sociale en ecologische duurzaamheidsnormen (e.g. Sassatelli 2006; Goleman 2009). In het verleden zijn bijvoorbeeld acties gevoerd voor dolfijnvriendelijke tonijn, en in 2009 werd in Nederland succesvol actie gevoerd voor 'slaafvrije' chocolade (de groene Sint). Daar staat tegenover dat er een bijna onoverbrugbare tegenstelling bestaat tussen het ideaal van de verantwoordelijke consument die met zijn portemonnee publieke doelen verwezenlijkt en het infantilisme dat er juist toe leidt dat consumenten alleen maar bezig zijn met behoeftebevrediging. Ondanks de grote mediaaandacht voor duurzame producten nemen die in het assortiment in supermarkten bijvoorbeeld nog steeds een zeer bescheiden positie in (Voormolen 2009).

De tegenstelling kan overigens worden samengevat met de tegenstelling tussen een 'actieve' en een 'passieve' modus. Anders gezegd: in zoverre de consumentensamenleving wordt omarmd, wordt zij geschetst als een samenleving van actieve, mondige, sociaal betrokken mensen. In zoverre zij wordt bekritiseerd, zijn diezelfde mensen opeens passieve speelballen van de commercie die zonder bijgedachten de wereld de vernieling in kopen.

Mondige consumenten (en actieve burgers) zijn pendanten van de producenten/ scheppers (we gebruiken die termen door elkaar) die wij in dit hoofdstuk centraal stellen, maar we kiezen in dit hoofdstuk voor het gezichtspunt dat een 'mondige consument' in zoverre hij voor iets anders actie voert dan betere producten voor lagere prijzen, geen consument is maar een idealist. We stellen de rol van consument gelijk met die van het individu dat zijn (economisch) nut wil maximaliseren in de hoedanigheid van een koper.

Barbers opvatting dat consumentisme een infantiele kant heeft is verdedigbaar. Als de overheid ervoor kiest om mensen te behandelen alsof ze hen een spelcomputer wil verkopen, behandelt ze hen als kinderen zonder dat ze hen werkelijk iets te bieden heeft dat op directe behoeftebevrediging lijkt. En kinderen - ook als ze volwassen zijn - hebben dat meteen door en reageren geïrriteerd op wat zij dan als leugens of propaganda ervaren. Daarmee is de slogan die mensen uitnodigde hun stem uit te brengen voor de Europese verkiezingen van 2004 - 'Europa, best belangrijk!!' - niet alleen infantiel, maar ook nutteloos. De slogan hanteert wel de taal van het consumentisme, maar biedt niet de directe behoeftebevrediging. Het punt is dat, ook als de overheid een consumentensamenleving niet zou moeten bestrijden maar omarmen, zij nog haar inwoners niet zou moeten benaderen volgens de wetten van de consumentensamenleving, omdat zij hen geen directe behoeftebevrediging te bieden heeft. 


\subsubsection{SOCIALE CONTRACTEN}

Een consumentenbenadering vindt haar wortels in de idee van een sociaal contract waarin burgers een individuele relatie onderhouden met de overheid. Dat contract komt uiteindelijk neer op een aantal individuele rechten en plichten van het individu. In ruil voor hun belastingafdrachten levert de overheid publieke goederen. Instemming met het contract wordt in beginsel afgeleid uit het feit dat een inwoner niet emigreert (Den Hartogh 2002). De idee van een sociaal contract als legitimatie van de verhouding tussen overheid en inwoners heeft de afgelopen jaren aan betekenis gewonnen en ze 'landt' ook steeds vaker in echte contracten.

Vincent Jones (2006) wijst in dit kader op de praktijk van 'government by contract' die er onder andere in uitmondt dat er 'laatste kans'-contracten worden getekend met spijbelaars of jongeren die een overtreding of misdrijf hebben begaan. In die overeenkomsten beloven de jongeren zich aan een aantal strenge gedragsregels te houden op straffe van de tenuitvoerlegging van een gevangenisstraf. De morele status van dergelijke sociale contracten is twijfelachtig, omdat er maar in zeer beperkte mate sprake is van instemming en ze vormen soms zelfs een manier om individuen in specifieke situaties meer verplichtingen op te kunnen leggen dan anders was mogelijk geweest, terwijl degene die ze oplegt vaak aan niet meer gebonden is dan hij al was zonder de overeenkomst. Hiertegenover staan andere voorbeelden waarin de overeenkomsten wel degelijk een tweezijdig karakter hebben, maar die zijn schaars, omdat het gelijkheidsbeginsel veel van die overeenkomsten in de weg staat. Een consumentenbenadering die de relatie tussen overheid en inwoners voorstelt als een contract berust daarmee op een fictie van een tweezijdigheid in de relatie tussen individuele burgers en overheidsinstanties die meestal niet bestaat en waarvan het maar de vraag is of zij wenselijk is. Immers, of het contract bevat eenzijdig opgelegde bepalingen - zoals bij een standaard erfpachtovereenkomst - en er is dan geen sprake van een wilsovereenstemming tussen twee partijen over de inhoud, dan wel de overeenkomst bevat specifiek onderhandelde voorwaarden, maar die komen al snel in strijd met het gelijkheidsbeginsel en zijn minder transparant waardoor de inhoud van de overeenkomst niet goed te controleren valt.

\subsubsection{WANTROUWEN}

Hugh Collins (1999) gebruikt de speltheorie om inzichtelijk te maken dat coöperatief gedrag van partijen in een transactie voortkomt uit een natuurlijke neiging om niet samen te werken. Collins benoemt drie dimensies van een transactie: een relationele, een economische en een juridische dimensie. De juridische dimensie ziet toe op risicoallocatie. We laten haar hier verder buiten beschouwing.

In de economische dimensie van een overeenkomst staat nutsmaximalisatie voorop. Het volgt uit de logica van het prisoner's dilemma dat verkopers van 
nature geneigd zijn om hun klanten op te lichten. Echter, omdat ook klanten dit dilemma begrijpen zijn ze op hun hoede, en precies daarom worden ze niet bedrogen. Omdat de verkoper weet dat zijn klant weet dat hij hem wil oplichten als hij daar een economisch voordeel van verwacht en omdat de klant weet dat de verkoper weet dat hij zich daarvan bewust is, werken verkoper en klant juist samen. De basis van die samenwerking is echter een neiging om niet samen te werken maar voor nutsmaximalisatie te kiezen. Als de klant de winkel voor de laatste keer bezoekt en de pakkans verwaarloosbaar is, zal hij zijn producten niet afrekenen als de winkelier geen voorzorgsmaatregelen neemt.

De speltheoretische benadering wordt vaak bekritiseerd, omdat ze rationaliteit veronderstelt en gevoelens buiten spel zet. Collins onderscheidt, zoals gezegd, ook een relationele dimensie (Collins 1999; Van der Veen 2009) waarin vertrouwen centraal staat en die in hechte gemeenschappen soms belangrijker is dan de economische dimensie van de transactie.

Maar in zijn algemeenheid kunnen we toch wel stellen dat consumenten (grote) aanbieders als Microsoft of Philips wantrouwen en daarom allerhande garanties verwachten van die aanbieders. Tegelijkertijd voelen grote warenhuizen en winkelcentra zich genoodzaakt om zich in hun winkels met beveiligingsmedewerkers en camera's tegen diefstal te beschermen. Dat wantrouwen verdwijnt pas als de relationele dimensie de transactie gaat beheersen; als de verkoper en de koper elkaar goed kennen en/of beiden lid zijn van dezelfde gemeenschap. Die gemeenschappen en relaties zijn de afgelopen decennia veelal verdwenen. Daarmee gaat ook de economische dimensie van een transactie de relatie tussen verkoper en koper (meer) beheersen.

We kunnen de economische dimensie niet zomaar wegdenken als we iets willen zeggen over overheden die hun inwoners op een klantgerichte manier benaderen. Bij die benadering hoort een economische dimensie waarbij de cliënt zich afvraagt of hij voldoende waar krijgt voor zijn belastinggeld of zijn inspanningen. Naarmate het vertrouwen - de relatie - tussen de overheid in inwoners afneemt, zal dat wantrouwen de relatie meer gaan beheersen. Op die manier draagt een consumentenbenadering alleen maar bij aan het wantrouwen dat tussen overheid en inwoners bestaat als de relationele dimensie zich niet op voorhand al kenmerkte door een voldoende mate van vertrouwen. Een voorbeeld hiervan is de inentingscampagne tegen de Mexicaanse Griep in 2009 waarbij wantrouwen op sommige momenten overheerste.

Overigens stellen we niet dat een gezond wantrouwen niet centraal zou mogen staan in een democratische rechtstaat. Het systeem van de trias politica en de checks and balances is erop gericht om machtsmisbruik door zowel individuen als instituties te voorkomen. De wetgevende, rechtsprekende en uitvoerende macht 
horen elkaar in zekere mate te wantrouwen en er valt ook te betogen dat het systeem van dualisme dat sinds 2002 de verhouding tussen wethouders en de gemeenteraad beheerst doelbewust een flinke dosis wantrouwen aan het systeem van de gemeentepolitiek heeft toegevoegd.

Wij hebben het echter niet over het systeem waarop wetgeving tot stand komt en wordt uitgevoerd, maar over de situaties waarin de overheid inwoners direct aanspreekt om een bewustzijns-, mentaliteits- of gedragsverandering te bewerkstelligen.

Zelfs als we het wel over het systeem van wetgeving hebben, stellen we dat mensen als producenten benaderd moeten worden. Het wantrouwen van de producent die zich afvraagt of nieuwe wetgeving hem wel in staat stelt om vorm te geven aan zijn eigen omgeving, is constructiever dan het wantrouwen van de consument die er op voorhand al van uitgaat dat dit niet het geval is en daarom garanties eist.

\subsubsection{CONSUMENTISME 2.0}

We hebben in deze paragraaf betoogd dat de overheid haar inwoners niet als consumenten moet benaderen. De belangrijkste argumenten daarvoor zijn dat de overheid geen directe behoeftebevrediging kan bieden, het met de consumentenbenadering verbonden sociaal contractdenken berust op een fictie van tweezijdigheid en dat een consumentenbenadering het wantrouwen creëert of versterkt dat het juist wil bestrijden.

De consumentensamenleving zelf hebben we hierboven voorgesteld als een aanbiedermarkt die mensen tot passieve kopers degradeert. We doen de realiteit daarmee enigszins tekort: er bestaat op dit moment een grote create it yourself trend die zich niet beperkt tot internet. 'Samplekunst' is bijvoorbeeld een (door grote muziekmaatschappijen verfoeide) trend; populaire bands stellen tegenwoordig hun muziek ter beschikking om te remixen. De Iphone, Apples succestelefoon, kon een van de meest succesvolle apparaten ter wereld worden omdat gebruikers honderden applicaties voor het apparaat maakten. Het interieur en de carrosserie van de Fiat 500 kan door klanten zelf worden samengesteld waardoor tientallen verschillende combinaties mogelijk zijn.

Met andere woorden: zowel de avant garde als multinationals spelen in op een behoefte van mensen om vorm te geven, om te produceren. Er bestaat een tegenbeweging waarin het zelf scheppen en doen meer centraal komt te staan en die de consumentensamenleving misschien zou kunnen ombuigen in wat wij hieronder een producentensamenleving noemen. 


\subsection{PRODUCENTEN}

Een producentenbenadering betreft geen retorische omkering van het woord consument. Met de term producent (of schepper) willen we benadrukken dat individuen (co-) producent zijn van hun leven en omgeving en dat die eigenschap vooraf gaat aan de concrete rollen - consument, burger, kiezer - die zij vervolgens innemen. We geven in deze paragraaf allereerst een schets van de (ideale) producentensamenleving, we bespreken hoe de producentenbenadering zich verhoudt tot neorepublikeins burgerschap en gaan tenslotte in op het essentiële begrip omgeving.

\subsubsection{SCHETS VAN PRODUCENTENSAMENLEVING}

In dit deel van het hoofdstuk gaan we in op de contouren van de producentenbenadering. Die benadering biedt een alternatief voor de benadering van de consument en heeft een andere visie op burgerschap. In de tabel onderaan deze paragraaf benoemen we een aantal vragen waar de producentenbenadering een antwoord op formuleert dat evenwel nog niet compleet is.

Een producentenbenadering stelt de gave en het verlangen van mensen om hun eigen leven en omgeving mede vorm te geven centraal. We hebben het in dit hoofdstuk in het bijzonder over de manier waarop de overheid mensen aan zou moeten spreken, maar uit de producentenbenadering volgt ook een sterke verantwoordelijkheid van individuen. In beginsel is iedereen verantwoordelijk voor de creaties waaraan hij bijdraagt.

Het punt is dat leven 'scheppen' betekent; zelfs als een individu nooit iets produceert wat de moeite waard is, dan nog is zijn leven zelf een belangwekkende creatie. Dat is althans hoe dat leven moet worden benaderd als we er beleid voor maken. De vraag is vervolgens: hoe kunnen degenen die zich niet in voldoende mate de schepper van hun eigen leven voelen in staat gesteld worden om een leven tot stand te brengen dat ze als hun eigen creatie ervaren? Dat levert een plicht op voor ons, als omstanders, maar ook voor het individu.

Een producent is verantwoordelijk voor zijn eigen leven, voor zijn directe omgeving en uiteindelijk ook, als groep, voor het land en de wereld. Of een individu al dan niet deelneemt aan de civil society is voor ons niet de vraag. De vraag is: wat brengt dat individu op dit moment tot stand en wat zou hij of zij met de juiste hulp tot stand kunnen brengen. Dat betekent ook dat het niet willen meedoen aan de samenleving (in zoverre dat mogelijk is) een keuze is die de niet-deelnemer mag maken, die niet moreel verwerpelijk is, zolang hij die keuze maar weloverwogen maakt en de gevolgen daarvan (minder inkomsten, minder sociale contacten) maar accepteert. 
Een producentensamenleving behandelt mensen als volwassenen. De scheppers zullen rekenschap af moeten leggen over de vraag: vind je datgene wat je tot stand hebt gebracht voldoende? Is dit een creatie waar je achter staat?

De vraag ‘Sta je achter deze creatie?’ is allereerst een vraag naar de verantwoordelijkheid die het individu zichzelf oplegt. Het ingooien van een ruit levert bijvoorbeeld de creatie van een winderig raam op, maar de meeste mensen zullen toch wel vinden dat we in beginsel elkaars ruiten niet ingooien.

Toch kent een consequent doorgedachte producentensamenleving wel de 'kantiaanse optie', dat betekent dat, wanneer mensen een beroep doen op hun eigen autonomie, ze gestraft kunnen worden op basis van vergelding. Zo mag de dief die geen spijt heeft van zijn daad en ook geen beroep doet op verzachtende omstandigheden zijn bezit worden afgenomen. De 'pluk-ze-wetgeving' die het een rechter mogelijk maakt om naast het opleggen van een boete of gevangenisstraf over te gaan tot voordeelontneming is in overeenstemming met dit uitgangspunt.

De moordenaar die stelt dat hij vindt dat er mag worden gemoord en volledig bij zijn verstand is, krijgt in de producentensamenleving de doodstraf. Het gaat dan bijvoorbeeld om degenen die de gevolgen van hun daden overzien en aanvaarden en niet het recht van anderen erkennen om daar een moreel oordeel over uit te spreken (Van der Veen 2006).

Los van de 'kantiaanse optie' voor de non-conformist hoort een producent rekening te houden met de belangen van anderen, dat volgt uit het feit dat hij die anderen nodig heeft om te kunnen creëren.

Anders gezegd: de producentensamenleving heeft sterke communitaristische kenmerken, maar die komen voort uit een individualistisch gezichtspunt (autonomie, gave om te scheppen), daarom accepteert ze ook dat niet iedereen op dezelfde manier aan de samenleving wil meedoen.

Een producentensamenleving is een samenleving waarin het individu samen met anderen zijn omgeving creëert. Hij moet in staat worden gesteld om te kunnen scheppen. Die visie op de overheid verschilt van die van een consumentensamenleving. In die laatste visie gaat het steeds om een kosten-batenanalyse; het individu wordt geacht uiteindelijk te profiteren van het overheidsbeleid. In een consumentensamenleving leidt dat er (soms) toe dat individuen vervolgens hun rechten op gaan eisen bij de overheid; ze willen 'meer waar voor hun geld' (Van den Brink 2002; zie ook subpar. 8.1.2). Het denken in termen van een sociaal contract leidt ertoe dat inwoners de overheid niet beschouwen als een entiteit die door hen zelf gecreëerd is, maar als een instituut op afstand waarvoor ze betalen en waarvan ze horen te profiteren. Het contract wordt, anders gezegd, gedacht als een contract 
met de overheid en niet als een contract tussen individuen waaruit de overheid voortkomt. Zo er in de producentensamenleving al ruimte is voor een sociaal contract, dan betreft het die laatste variant. Daardoor wordt de kwaliteit van het overheidsbeleid ook een verantwoordelijkheid van de producenten en staat niet de individuele verhouding tot de overheid maar tot de andere individuen centraal (zie ook tabel 8.1). De overheid als zodanig faalt ook niet ten opzichte van de inwoners. De inwoners falen met haar.

Uit dat individualistische uitgangspunt volgt overigens geen 'minimale overheid'. In een (ideale) producentensamenleving kan draagvlak bestaan voor een sterke overheid die ook producten kan leveren die liberale politieke stromingen liever aan marktpartijen voorbehouden (cf. Den Hartogh 2002).

De inwoners van de (ideale) producentensamenleving aanvaarden kortom geen sterk onderscheid tussen henzelf en de overheid. Ze zien de overheid als een uitvoerende instantie van hun gemeenschappelijke preferenties. Dat betekent dat zij medeverantwoordelijk zijn voor de resultaten van het overheidsbeleid en in het geval van een falend beleid zelf verantwoordelijkheid moeten nemen. Als het onderscheid tussen overheid en inwoners wegvalt, wordt de vraag niet zozeer 'Moet de overheid deze dienst wel leveren', maar 'Welke organisatievorm stelt ons het best in staat om ons leven en onze omgeving te scheppen'.

De producentensamenleving benoemt het creëren als belangrijkste waarde en voegt daar maatschappelijke verantwoordelijkheid en solidariteit aan toe naast keuzevrijheid en individualisme. Dat doet ze allereerst met het zogenoemde consistentiebeginsel waarin producenten verantwoordelijk zijn voor hun gedrag als ze op de hoogte zijn van de gevolgen en bovendien een alternatieve keuze konden maken. Zo aanvaardt Fahlquist (2008) bijvoorbeeld een verantwoordelijkheid van consumenten die producten kopen die tot stand zijn gekomen door uitbuiting of waarvan de totstandkoming met veel ecologische schade gepaard gaat wanneer die consumenten daarvan op de hoogte behoorden te zijn en een reëel alternatief hadden. De verantwoordelijkheid voor een gevolg neemt af naarmate de producent zich verder van het eindresultaat verwijderd weet. Denk aan een steen die in het water valt, naarmate de kringen zich verder van de plek bevinden waar de steen viel, zal de verantwoordelijkheid voor de deining ook afnemen.

In sommige gevallen zal een producentensamenleving weinig verschillen van een consumentensamenleving, namelijk wanneer keuzevrijheid de belangrijkste waarde is. Beleid dat al goed past bij de waarden van de producentensamenleving is bijvoorbeeld het principe 'de vervuiler betaalt', dat leidde tot de verwijderingsbijdrage voor elektrische apparatuur. Ook de voorgenomen invoering van het rekeningrijden past in principe goed bij dat uitgangspunt in zoverre het plan ertoe strekt om automobilisten medeverantwoordelijk te maken voor het fileprobleem. 
Een goed voorbeeld van een wet waarin we elementen van de producentenbenadering zien is de Wet Maatschappelijke Ondersteuning uit 2007 (WMO). ${ }^{3}$ De WMO is een kaderwet die poogt ruimte te bieden aan de wens van mensen om voor elkaar te zorgen (mantelzorg) en om bovendien zelf zorg in te kopen met een persoonsgebonden budget. Het wettelijke recht om tussen geld of een concreet product te mogen kiezen is in dat licht een mooie stap. De WMO moet uiteindelijk worden afgerekend op de vraag of meer mensen zich dankzij de wet de schepper van hun eigen leven voelen en of meer mensen verantwoordelijkheid nemen als producent van hun omgeving. Als blijkt dat de ruimte die de wet biedt wordt gevuld met lokale regelgeving ook nog eens met de regels van de commerciële aanbieder die de aanbestedingsprocedure heeft gewonnen zullen de 'zorgcliënten' zich machtelozer voelen dan voorheen; heen en weer geslingerd tussen tientallen voorwaarden die ook nog eens per aanbieder verschillen.

Echter, omdat de waarden die aan een producentensamenleving ten grondslag liggen anders zijn dan die van de oprukkende consumentensamenleving, zal zij soms tot een radicale omwenteling leiden. Het ligt bijvoorbeeld voor de hand dat

Tabel 8.1

\section{Consumenten en producentenbenadering tegen elkaar uitgezet}

\begin{tabular}{l|l}
$\begin{array}{l}\text { Consumentenbenadering } \\
\begin{array}{l}\text { De consument geeft zijn leven vorm door uit een } \\
\text { bepaald aanbod datgene te kiezen wat hem bevalt. }\end{array}\end{array}$ & $\begin{array}{l}\text { Producentenbenadering } \\
\text { omgeving te scheppen. }\end{array}$ \\
\hline $\begin{array}{l}\text { In beginsel is een consument een van de rollen die } \\
\text { een mens kan aannemen. }\end{array}$ & $\begin{array}{l}\text { Het mensbeeld van de producent gaat aan de } \\
\text { rollen die een mens kan innemen vooraf. }\end{array}$ \\
$\begin{array}{l}\text { Baseert verantwoordelijkheid van mensen op de } \\
\text { voorwaarden van het sociale contract. }\end{array}$ & $\begin{array}{l}\text { Baseert verantwoordelijkheid van mensen op } \\
\text { het uitgangspunt dat produceren nooit vrijblijvend } \\
\text { kan zijn. }\end{array}$ \\
$\begin{array}{l}\text { Individuen ontlenen hun rechten ten opzichte van } \\
\text { de staat aan de voorwaarden van het sociale } \\
\text { contract. }\end{array}$ & $\begin{array}{l}\text { Individuen ontlenen hun rechten aan het uitgangs- } \\
\text { punt dat de staat er is om haar inwoners in staat te } \\
\text { stellen vorm te geven aan hun leven en omgeving. }\end{array}$
\end{tabular}

Tabel 8.2

Consumentenbenadering + producentenbenadering

\section{Consumentenbenadering + producentenbenadering}

Beide benaderingen stellen het individualisme centraal en veronderstellen dat groepen voortkomen uit gemeenschappelijke belangen van individuen. 
een 'scheppersperspectief' zal breken met het consumentenperspectief dat in kunst- en cultuurbeleid de overhand dreigt te krijgen en bezoekersaantallen niet tot doel op zich zal verheffen.

We benadrukken aan het slot van deze subparagraaf nog het volgende: de producentenbenadering beschouwt individuen als volwassen mensen die hun eigen leven en omgeving creëren. Maar de producentenbenadering gaat er niet vanuit dat iedereen daar in dezelfde mate toe in staat is. De producentensamenleving staat los van de grote druk die mensen ervaren in een prestatiesamenleving en waartegen niet iedereen bestand is (Trappenburg 2006; Dehue 2008). De vraag: 'Is het voldoende wat je tot stand hebt gebracht?' krijgt door individuele en gemeenschapsnormen invulling, maar uit het stellen van de vraag volgt geen 'prestatiesamenleving'. Maatjesprojecten die uitgaan van een een-op-eenrelatie tussen een mentor en een jongere, migrant of ex-gedetineerde (Hurenkamp et al. 2008) en projecten die sociale uitsluiting pogen te bestrijden vormen ook goede voorbeelden van producentenbenaderingen.

\subsubsection{HET AMBT BURGER}

Het mensbeeld van een individu dat een veelheid aan rollen en identiteiten aan kan nemen, waarvan de persoonlijkheid tot stand komt in subjectieve en collectieve processen en dat zichzelf vormgeeft door te besluiten waar het wel en niet aan deelneemt ligt ten grondslag aan een producentenbenadering. De producentenbenadering voegt aan dat mensbeeld de collectieve en individuele verantwoordelijkheid voor die processen toe. Het individu is verantwoordelijk voor het resultaat van het proces, de samenleving draagt de verantwoordelijkheid om ervoor te zorgen dat individuen tot het scheppen in staat worden gesteld (cf. Nussbaum \& Sen 1993). We spraken hierboven over de burgerrol en de consumentenrol die mensen aan kunnen nemen. Dat betekent dat hun persoonlijkheid niet samenvalt met een van die rollen. Tegelijkertijd worden mensen steeds beter in het aannemen van volledige rollen zodat we in sommige gevallen beter van identiteiten kunnen spreken. Op internet doen velen niet anders dan tal van aliassen aannemen waarvan sommigen zich ontwikkelen tot wat je 'volle persoonlijkheden' kunt noemen.

We willen in die context nog stilstaan bij de notie neorepublikeins burgerschap van Van Gunsteren (WRR 1992). Die notie staat model voor tal van literatuur waarin gevraagd wordt om een nieuwe of andere invulling van burgerschap of zelfs wereldburgerschap (Barber 2007; Singer 2004). De producentenbenadering doet een beroep op waarden die vaak met burgerschap worden geassocieerd zoals solidariteit en verantwoordelijkheid. De onderbouwing wordt echter niet in de eerste plaats gezocht in het gemeenschapsdenken of in de voorstelling van het sociaal contract, maar in het mensbeeld van de producent. Kortom, de kiem van die burgerschapswaarden vinden we in het 'mens-zijn' en niet in een specifieke rol 
van het individu. We menen daarmee een probleem op te lossen dat we in de benadering van Van Gunsteren tegenkomen zonder dat we zijn normatieve stelling dat aan burgerschap eisen mogen worden gesteld principieel afwijzen.

Met zijn conceptie van burgerschap benoemde Van Gunsteren een aantal uitgangspunten die in 2010 niet achterhaald zijn, waarvan zijn opvatting dat aan de toelating tot het burgerschap eisen kunnen worden gesteld de meest opvallende was. Dat uitgangspunt is zichtbaar geworden met de invoering van verplichte inburgeringscursussen voor migranten en met bijvoorbeeld het vaststellen van de canon van de Nederlandse geschiedenis als uitgangspunt voor het middelbaar geschiedenisonderwijs.

De nadruk die Van Gunsteren legt op de autonomie van het individu enerzijds en op het belang van de publieke ruimte anderzijds doet recht aan zowel het individualisme als de noodzaak om samen te werken in een publieke ruimte die meer is dan alleen de rationele uitkomst van individuele preferenties. Kortom, ze is verenigbaar met een producentenbenadering. Burgerschap is volgens Van Gunsteren een ambt: geen volle identiteit maar een hoedanigheid waarin mensen zich (zouden moeten) verhouden tot de republiek:

"Burgerschap is een ambt in de republiek. Met deze wat ongebruikelijke aanduiding wordt bedoeld (a) dat de burger niet identiek is met de hele of gewone mens, (b) dat aan de toelating tot en de uitoefening van burgerschap eisen van competentie worden gesteld en (c) dat burgerschap een ambt naast andere ambten in de republiek is dat de uitoefening daarvan onder omstandigheden modificeert." (WRR 1992: 19)

Er doet zich met Van Gunsterens conceptie van burgerschap een probleem voor dat de producentenbenadering kan oplossen en dat we willen illustreren met een voorbeeld. Stel, de overheid wil dat de inwoners van het land zich bewust zijn van het belang van duurzame landbouw. Een informatiecampagne en de dag van de duurzame landbouw moeten mensen van dat belang overtuigen met als doel dat significant meer mensen in de supermarkt voor duurzame producten kiezen. Ervan uitgaande dat het evenement zich richt op degenen die niet van nature al deze keuze maken, richt de actie zich op een invulling van 'goed (wereld-) burgerschap'.

In burgerschapstermen is het doel dat de burger de consument corrigeert als hij in de supermarkt het goedkope, niet duurzame product kiest. We weten inmiddels dat dat niet vaak gebeurt (Te Velde et al. 2002). Vanuit het perspectief dat Van Gunsteren ons voorhoudt zou er nu reden kunnen zijn om over te gaan tot wetgeving. Immers, als mensen in hun hoedanigheid van burger het eigen consumentengedrag niet corrigeren, dan moet de overheid dat gedrag afdwingen. De eisen die we aan goed burgerschap mogen stellen vormen daar afdoende legitimatie 
voor. Maar de eisen vertellen ons niet in welke hoedanigheid we mensen het best kunnen aanspreken als er geen draagvlak bestaat voor wetgeving, maar wel voor het teweegbrengen van de feitelijke verandering.

Een producentenbenadering lost dit op door mensen niet aan te spreken 'alsof ze burgers zijn', maar door ervan uit te gaan dat ze verantwoordelijk zijn voor de omgeving die ze creëren. Deze kan dat 'vriendelijk' doen door te benadrukken dat duurzame landbouw een plaats verdient in de omgeving van de producenten. En als die benadering niet werkt kan het een hardere toon kiezen. Uit het consistentiebeginsel volgt dat, als mensen in hun reflexieve identiteit vinden dat ze als consument 'eigenlijk' ook andere afwegingen zouden moeten maken dan alleen die van de prijs en de behoeftebevrediging, die keuze op basis van het consistentiebeginsel kan worden afgedwongen.

We hebben daar het construct burgerschap niet voor nodig. Een punt dat evenwel verdere uitwerking behoeft is de vraag of burgerschap niet ook een beperking oplegt aan wat de overheid van haar inwoners mag vragen. Als burgerschap als ambt wegvalt, kan dat een vrijbrief bieden voor steeds verdergaand ingrijpen van de overheid in de private sfeer. De rem die daarop zou moeten worden gezet is dat ingrijpen in ieder geval een grens vindt in het beginsel dat overheidsingrijpen zich tot doel moet stellen mensen beter in staat te stellen vorm te geven aan hun omgeving en moet worden beperkt door het gegeven dat de ovrheid naar haar aard niet geschikt is om sommige thema's aan te pakken. Dit geldt in ieder geval voor thema's die een sterke ideologische keuze met zich mee brengen (zoals politiek activisme) of die te maken hebben met het gevoelsleven of seksuele geaardheid.

\subsubsection{OMGEVING}

Individuen houden zich niet uitsluitend bezig met het creëren van zichzelf, maar ook met het creëren van hun omgeving. Die omgeving is niet alleen meer materieel van aard, maar ook virtueel en staat in schril contrast tot de samenleving die we hier opzettelijk vaag definiëren als de ruimte buiten de omgeving. Uitgangspunt is dat mensen zich coproducenten van hun omgeving weten en dat in die omgeving ruimte is voor een 'wij-boodschap', terwijl daarbuiten eerder sprake is van een wij-zijtegenstelling. Zo slaagde Barack Obama er tijdens de verkiezingscampagne voor de Amerikaanse presidentsverkiezingen in 2008 in om een graag geziene bewoner van de omgeving van veel kiezers te worden en kon daarom gekozen worden met een boodschap van 'hoop' en 'met elkaar' (yes, we can!) in plaats van een harde wij-zijcampagne te voeren zoals zijn voorganger George W. Bush had gedaan. Wij-zij is een tegenstelling die we eerder met de samenleving dan met onze omgeving associëren, voor 'met elkaar' geldt het omgekeerde. De Duitse filosoof Peter Sloterdijk (2009) hanteert een omgevingsbegrip dat schatplichtig is aan Martin Heidegger (2001), maar waar Heidegger omgeving 
verbond met (geboorte)grond wijst Sloterdijk erop dat we inmiddels weten dat omgeving het resultaat is van formeel design, technische middelen, juridische bijstand en politieke organisatie. Hij verbindt aan omgeving ook de therapeutische dimensie van de kunst van het vormgeven aan de ruimte. Zo heeft 'omgeving' dus de notie van thuis en van maakbaarheid. Het is niet duidelijk waar die omgeving begint en waar ze ophoudt, maar we kunnen wel zeggen wat ze representeert: omgeving staat voor een materiële of virtuele ruimte die ons vormt en die we mede vormen. Het gaat dan wat ons betreft ook om waarden, normen, waarheden en voorkeuren. Als de overheid een beroep doet op gemeenschapszin, dan stellen we ons automatisch de vraag: 'Draagt de manier waarop ik me inspan voor het gemeenschappelijk belang bij aan mijn omgeving?’

Om mensen tot 'meedoen' te bewegen zal een overheid dus die omgeving binnen moeten zien te dringen en moeten laten zien dat het individu door hem binnen te laten beter in staat zal zijn om zijn eigen omgeving te creëren. Duurzaamheid, orgaandonatie, vrijwilligerswerk staan allemaal in het teken van 'mijn omgeving'. Dat betekent dat er niet zozeer sprake is van afnemend altruïsme of een toenemend egoïsme, maar dat het onderscheid binnen-buiten (en daarmee omgevingsamenleving) toeneemt. Het is dan ook niet verwonderlijk dat Hurenkamp et al. vaststellen dat altruïsme nog volop bloeit (2008) en dat de meeste vrijwilligersprojecten zich op mensen richten en niet op 'het systeem' of 'het bestuur'. De onderzoekers noemen een rapport van het Sociaal Cultureel Planbureau (SCP) dat stelt dat leefstijl een steeds belangrijker motivatie tot burgerschap vormt. "De toekomstige vrijwilliger zal projectgericht zijn en ingesteld op wisselende rollen" (Hurenkamp et al. 2008: 30). Kleinschalige projecten lijken bovendien het meest aan te slaan bij de behoeften van vrijwilligers.

Die uitkomsten passen bij het beeld van individuen die hun omgeving (co)produceren. In die omgeving zijn ze best bereid om anderen (soms op duizenden kilometers afstand) te helpen en zich in te spannen voor de goede zaak, maar daarbuiten zijn ze dat een stuk minder. Als de overheid wordt gewantrouwd, dan is dat omdat ze gezien wordt als een hinderlijke indringer in de omgeving. De overheid zou een facilitator moeten zijn, maar dringt via 'samenlevingsproblematiek' hinderlijk de omgeving binnen. De overheid staat al snel voor 'bureaucratie', 'bestuurlijke onmacht', 'zakkenvullers', 'falende integratie', enzovoorts.

\section{Binnendringen van de omgeving}

Een producentenbenadering resulteert in de vraag: hoe kunnen we de omgeving van individuen binnendringen? Daarmee bevinden we ons op een hellend vlak: er bestaan veel bezwaren tegen een alom aanwezige overheid en het beeld van een overheid die precies weet hoe zij de omgeving van haar inwoners moet binnendringen, roept een associatie op met totalitarisme. Evenwel, eigen aan de producentenbenadering is dat het binnendringen altijd ziet op het aandragen van moge- 
lijkheden om de eigen omgeving te produceren. Dat uitgangspunt betekent dat er nooit op een totalitaire wijze kan of mag worden binnengedrongen. De producentenbenadering staat ook garant voor een 'tweezijdigheid', terwijl een consumentenbenadering eerder leidt tot propaganda, omdat ze er vooral op vertrouwt dat mensen zich vanzelf op een bepaalde manier gaan gedragen wanneer zij maar vaak genoeg met dezelfde boodschap worden geconfronteerd.

In de tweede plaats gaat het hier om boodschappen waarvoor politiek draagvlak bestaat. Anders gezegd, zolang de rechtstaat en de democratie naar behoren functioneren, horen die ook zelf een rem te zetten op de wijze en het karakter van het binnendringen.

Overheden kunnen niet bij iedereen aanbellen - en dat is ook niet wenselijk-, dus zal er een manier moeten worden gevonden om op een andere manier de omgeving binnen te dringen. Als we individuen bereid willen vinden om deel te nemen aan het vormgeven van de samenleving op een manier die verdergaat dan alleen het najagen van het individuele kortetermijnbelang, kunnen we niet volstaan met argumenteren. Mensen beschermen bewust dan wel onbewust hun bestaande attitudes door informatie te negeren, te weerleggen of zich af te schermen van boodschappen die de eigen attitudes bedreigen (Smith \& Mackie 200o). Het aanbieden van informatie is daarmee op zichzelf niet voldoende. In de producentenbenadering moet vooropstaan dat mensen door informatie in hun omgeving toe te laten in staat zijn om betere keuzes te maken voor hun omgeving.

Als we mensen bewust willen maken een mentaliteitsverandering teweeg te willen brengen, of willen dat ze daadwerkelijk hun gedrag veranderen, is een attitudeverandering nodig. En om attituden daadwerkelijk te veranderen, moeten strategieën om attituden te veranderen of te ontwikkelen worden toegepast.

Tanja Klop heeft in haar promotieonderzoek attituden van middelbare scholieren ten aanzien van moderne biotechnologie bestudeerd en beschreven hoe met communicatieve en educatieve middelen deze attituden kunnen worden ontwikkeld (Klop 2008). Attitudes verwijzen naar consistente evaluatieve oordelen die een consequentie kunnen hebben voor daadwerkelijk gedrag. We bespreken het proefschrift hier om kritiek te leveren op algemene groepsindelingen zoals die vaak door overheden worden gebruikt. Het minutieuze onderzoek van Klop maakt daar duidelijk de beperkingen van inzichtelijk. Attitudes helpen de sociale omgeving te begrijpen, te controleren en belangrijke verbintenissen met anderen te uiten. Ze omvatten opinies en meningen, affecten en informatie over acties ten opzichte van het attitudeobject. Wanneer een attitude gevormd is, wordt deze (sterk) gekoppeld aan de representatie van het object. Het is dus zinvoller om attitudes te onderzoeken dan opinies die vluchtig zijn en minder consistent. 
Klop stelde zich de vraag of er verschillende groepen konden worden geïdentificeerd op basis waarvan kon worden voorspeld welke groepen voor welke manier van aanspreken (of onderwijzen in dit geval) gevoelig zouden zijn? Om te achterhalen en meetbaar te maken wat de scholieren wisten en vonden van moderne biotechnologie werd gebruikgemaakt van de driedelige theorie van attitudes (Eagly \& Chaiken 1993; Katz \& Stotland 1959). Volgens deze theorie bestaat een attitude uit een cognitieve, een affectieve en een gedragscomponent. Op basis van die theorie konden vier groepen worden onderscheiden: 'voorstanders', 'bezorgde sceptici', 'afwijzenden' en 'twijfelaars'. De laatste, vrij grote, groep scholieren kenmerkte zich door een onbestemde attitude. De leerlingen wisten niet zeker of ze nu voor of tegen moderne biotechnologie moesten zijn. Het algemene begrip van de onderwerpen liet te wensen over. Er bestonden dus subgroepen van scholieren die op een eigen manier moderne biotechnologie benaderden. Die groepen zouden idealiter ook op verschillende manieren benaderd moeten worden. Dit uitgangspunt werd toegepast in een experimentele onderwijsmodule. Tegen de verwachting in bleek dat die gedifferentieerde vorm van onderwijs ertoe leidde dat een tamelijk grote groep scholieren uit de groepen 'voorstanders' en 'bezorgde sceptici' opschoof naar de groep van 'twijfelaars'. De onderwijsmodule leidde tot een toename van meer positieve en meer ambivalente (twijfelende) attitudes.

Er kunnen verschillende conclusies aan deze uitkomsten worden verbonden, maar waar het hier om gaat is dat de indeling en omschrijving van de groep 'twijfelaars' achteraf viel te bediscussiëren. De groep bleek bijzonder heterogeen. De 'twijfel' liep uiteen van ambivalentie ('in het ene geval ben ik het er niet mee eens, bij het andere wel') wat duidt op een weloverwogen attitude, tot echte twijfel waarbij de leerling echt niet wist waar het over ging, laat staan wat hij/zij met moderne biotechnologie aan moest.

Door de statistische aanpak van het onderzoek is het onderscheid tussen deze verschillende typen twijfel niet gemaakt. De onderwijsmodule had daardoor misschien niet de beoogde uitwerking. Zelfs een minutieus uitgevoerd onderzoek naar attitudes dat op maat gesneden leek voor het beoogde doel, levert daarmee een groepsindeling op die op zijn best een indicatief karakter heeft voor attitudes van scholieren, maar die nauwelijks voorspellende waarde heeft voor het resultaat van een onderwijsvorm die op basis van die groepsindeling is aangepast.

\section{Groepsindelingen}

Het proefschrift van Klop brengt bezwaren aan het licht tegen groepsindelingen in typen burgers zoals we die kennen uit de (beleids) sociologie. Concreet betekent dit dat er gekeken wordt naar kenmerken van personen, gedragingen, of andere verschijnselen die mogelijk in relatie kunnen staan met een bepaald profiel. Een bekende indeling is die in afhankelijke, afzijdige, afwachtende en actieve burgers (WRR 2002; Verhoeven 2009). Die indeling beschrijft de manier waarop mensen 
zich tot de overheid verhouden en de wijze waarop zij bereid zijn om te participeren, terwijl ze ook wordt gehanteerd om de wijze waarop mensen actief deelnemen aan de civil society te benoemen (e.g. Hurenkamp et al. 2008). Afzijdige burgers zijn bijvoorbeeld nauwelijks politiek actief en ook nauwelijks bereid om zich in te spannen voor hun buurt, terwijl actieve burgers de politiek actief volgen en vaak ook bereid zijn om zich in te spannen voor een project in de buurt (Verhoeven 2009: 38). De voorspellende of verklarende waarden van deze groepsprofielen laten vaak te wensen over of schieten het doel van het instrument voorbij.

Een groepsindeling betreft altijd een fictieve indeling. Verhoeven benadrukt weliswaar dat de typen burgers die hij in zijn proefschrift onderscheidt niet in het wild rondlopen, maar de zeggingskracht van die groepsindelingen wordt toch vaak ruim genomen. Een dergelijke indeling past niet bij een producentenbenadering. Ze plakt een te algemeen profiel op mensen en wordt ondanks alle disclaimers toch al snel als een menstype gehanteerd. De grootste misvatting van het model wordt dan dat het miskent (althans niet centraal stelt) dat ook afzijdige of afhankelijke burgers (co)producenten van hun leven en omgeving zijn. Ook het 'niet meedoen' aan een buurtinitiatief kan grote invloed hebben op de buurt of de sfeer in de straat. Die invloed kan alleen op waarde worden geschat wanneer we een individu als 'producent' aanspreken ('Vind je dat je niet mee hoeft te doen?' 'Wat is nodig om jou in staat te stellen mee te doen, als je dat toch zou willen?’ enz.)

Toch kunnen we meestal niet zonder enige vorm van indeling. Hoewel de ene wandelaar de andere niet is, hebben ze toch beide belang bij goede wandelpaden en goed aangegeven wandelroutes. Het gaat er om een fictieve indeling te kiezen die het best aansluit bij het doel van het aanspreken. Die functie moet geschikt zijn voor het doel waartoe zij is bestemd, met dien verstande dat de overheid daarbij aan strenge ethische uitgangspunten is gebonden die wat ons betreft verenigbaar horen te zijn met een producentenbenadering. Een neutrale indeling als 'wandelaar' (u maakt gebruik van het bos in uw hoedanigheid van wandelaar) is met die indeling verenigbaar, maar een indeling die mensen 'afzijdig' of 'afhankelijk' noemt is dat niet. Het gaat er bij indelingen die mensen uitnodigt om mee te doen namelijk steeds om dat mensen een handelingsperspectief krijgen aangereikt dat hen wijst op hun opties en op verantwoordelijkheden die ze kunnen nemen. Een wandelaar die buiten de paden loopt verpest op sommige plekken de omgeving waar hij graag wandelt. Op die manier moet hij worden aangesproken. De opmerking 'wij kennen hier veel wandelaars' verschilt dan ook sterk van de opmerking die een van de auteurs vernam: 'wij hebben hier nu eenmaal veel afzijdigen'.

\section{Vier i's}

Om een boodschap succes te laten hebben zal de overheid de omgeving van producenten binnen moeten weten te dringen om daar een verandering teweeg te brengen. Als een boodschap als 'leef duurzamer' of 'wordt donor' niet de omge- 
ving binnendringt, blijft ze steken in de samenleving en zullen mensen zich eerder tegen die boodschap afzetten of haar eenvoudigweg negeren. Het binnendringen in de omgeving van producenten leidt tot een vorm van aanspreken die verband zoekt met sociale psychologie, die mensen aanspreekt in rollen en identiteiten die zij daadwerkelijk ervaren en die hen helpt om hun omgeving vorm te geven. Sociaal psycholoog Van Vugt (2009) onderscheidt vier elementen die de keuze van individuen in sociale dilemma's bepalen: identiteit, informatie, instituties \& incentives (4 i's). Het gaat dan om de groepsidentiteit, het beschikken over goede informatie, vertrouwen in de instituties (Fiske 2004) die informeren of uitvoeren en bepaalde prikkels (bijv. een slooppremie) om de juiste keuze te maken.

Uitgangspunt van de vier i's vormt the tragedy of the commons: het gegeven dat er vaak op een zelfzuchtige, op de korte termijn gerichte, manier gebruik wordt gemaakt van publieke goederen, diensten of ruimte (Hardin 1968). Door die keuzes wordt uiteindelijk de samenleving benadeeld. Een gunstige beslissing inzake een sociaal dilemma betekent dan dat iemand een beslissing neemt die het welzijn van de samenleving en niet alleen zijn eigen welzijn ten goede komt. Een verpleegster die in haar werk veel te maken heeft met kleine kinderen neemt een gunstige beslissing wanneer ze besluit om zich te laten inenten tegen $\mathrm{HiN}_{1}$ (Mexicaanse griep), hoewel ze de bijwerkingen van de inenting vreest.

De vier i's passen bij de producentenbenadering, omdat ze de omgeving van individuen centraal stellen en vanuit daar de vraag stellen hoe we individuen kunnen bewegen hun verantwoordelijkheid te nemen. Een aardig voorbeeld van een geslaagde campagne die verenigbaar is met de vier i's van Van Vugt vormt de Bobcampagne. Wel of geen alcohol drinken is een sociaal dilemma waarmee veel automobilisten zich geconfronteerd weten. Van oudsher bestaat er een sterke sociale druk om alcohol te drinken. Een van de meest succesvolle campagnes van de afgelopen jaren tegen het gebruik van alcohol in het verkeer, de uit België overgenomen Bob-campagne, is een succesvol voorbeeld van een sociale marketingcampagne die de omgeving weet binnen te dringen en bij weet te dragen aan een mentaliteitsverandering (Lagasse 2004). In de campagne wordt benadrukt dat iemand in een groep geen alcohol moet drinken ('de Bob is'), omdat hij op die manier beter in staat is om zijn eigen leven en omgeving blijvend te creëren. De invalshoek van de campagne is dat iemand niet alleen vanavond maar ook volgende week met zijn vrienden uit wil gaan en daarom nu van de alcohol moet afzien. Er wordt ook geen moreel oordeel over alcoholgebruik of dronkenschap in uitgesproken. De campagne laat vooral zien dat een groep beter af is als iemand 'niet drinkt'. De campagne vertrouwt met andere woorden op de groep die zelf het sociale dilemma (wel of niet drinken) moet oplossen. Ze relativeert het belang van de zendende instituties (er wordt niet gezegd 'de overheid adviseert u om niet te drinken'), maar weet juist daardoor de incentive 'veilig thuiskomen' te benadrukken zonder in te gaan op de strafrechtelijke sancties die op alcoholgebruik voor bestuurders van voertuigen staan. 


\subsubsection{KORTE SAMENVATTING}

De producentenbenadering is verenigbaar met een vorm van aanspreken en betrekken waarin individuen worden uitgenodigd om vorm te geven aan hun eigen omgeving en daarvoor verantwoordelijkheid te nemen. Groepsindelingen lopen al snel het risico te algemeen te worden, maar waar het sociaal complexe onderwerpen betreft is een benadering op basis van attituden kansrijk in zoverre die benadering zich maar beperkt tot het bepaalde onderwerp en geen 'menstype' wordt. We hebben betoogd dat in zoverre in het binnendringen van de omgeving het produceren door individuen centraal staat er geen onoverkomelijke bezwaren hoeven te bestaan tegen een overheid die binnendringt.

\subsection{EVENEMENTEN EN PARTICIPATIE}

In de slotparagraaf van dit hoofdstuk willen we ingaan op het nut van evenementen en een 'evenementenbenadering' van participatie en campagnes introduceren die past bij een producentenbenadering. We introduceren allereerst de tweeledige betekenis van de term 'evenement', daarna reflecteren we vanuit die benadering op twee modellen van burgerparticipatie, daarop bespreken we evenementen in de zin van manifestaties en reflecteren we op de gesprekken die we hebben gevoerd om een beter zicht te krijgen op nut en noodzaak van evenementen. We eindigen met een beschrijving van rituelen die een vorm zijn van evenementen die een beroep doen op emoties en een sterke nadruk leggen op collectieve ervaringen.

\subsubsection{EVENEMENTEN}

Evenementen zijn om twee redenen van belang. In de eerste plaats gaat het om de notie van het evenement die we hier verbinden met de omgeving van de producenten. In zoverre een evenement in de omgeving van een individu plaatsheeft slaat de term niet op wat er georganiseerd wordt, maar op de verandering die een evenement teweegbrengt.

Badiou (2005, 2007) stelt dat het 'menselijke van de mens' niet in zijn behoeften (eten, voortplanting) schuilt - dat noemt hij juist het dierlijke - maar in de mogelijkheid om deel te nemen aan waarheidsprocessen. Die processen reserveert hij voor de domeinen wetenschap, liefde, kunst en politiek. In die gebieden doen zich evenementen voor, gebeurtenissen die het weten schokken en die de domeinen blijvend veranderen. Mensen kunnen de consequenties van die evenementen onderzoeken. Ze nemen dan deel aan waarheidsprocessen die Badiou gelijkstelt met 'het goede'. Door deel te nemen aan een evenement of aan het doordenken van de consequenties ervan kan een individu zich (als mens) verwezenlijken. Hij kan onderdeel uitmaken van een proces dat hem overstijgt en dat hem overleeft. Die nadruk op zelfverwezenlijking is grotendeels afwezig in overheidscommuni- 
catie, maar zou er juist centraal in kunnen staan. De bereidheid van individuen om een bijdrage te leveren neemt vanzelfsprekend toe wanneer zij deelnemen als een vorm van zelfverwezenlijking zien. Het belang dat wij in dit hoofdstuk aan evenementen hechten vindt zijn wortels bij Badiou, zij het dat wij elke gebeurtenis in de omgeving van individuen die een duidelijk voor en na kent een evenement noemen. Een huwelijksvoltrekking of de diagnose van een ernstige ziekte zijn dan ook voorbeelden van evenementen, maar bijvoorbeeld ook de vertoning van een documentaire ten gevolge waarvan iemand besluit vegetariër te worden.

In de tweede plaats is een evenement ook een manifestatie. Het beat the heat-festival (2009) was bijvoorbeeld een evenement dat tot doel had om mensen te betrekken bij de onderhandelingen over een klimaatakkoord tijdens de top in Kopenhagen. De kritiek op dat festival was dat het niet aansloot bij de belevingswereld van het publiek en daardoor resulteerde in een zinloos 'zenden' van een boodschap (Beunders 2009). Dat is geldverspilling. We zouden kunnen spreken van 'dubbele evenementen': om zin te hebben moeten evenementen die de overheid organiseert, ondersteunt of initieert in de samenleving ook in de omgeving van de deelnemers het karakter van een evenement hebben.

\section{De belevingseconomie}

In haar boek De Emotiemarkt (2003) benoemt Piët de overgang van verschillende fases in een economie waarin belevingen centraal staan; de belevingseconomie. Volgens Piët bevinden we ons in het penthouse van de piramide van Maslow waardoor de westerse samenleving eindelijk aan haar emoties is toegekomen. Die nadruk op emoties en op zelfverwerkelijking heeft de belevingseconomie en een belevingscultuur op gang gebracht. Het gaat om een overgang waarbij emotionele behoeftes niet langer als bijproduct worden gezien maar als kernactiviteit van de emotiemarkt. In de eerste fase van de belevingseconomie denken we dat geluk te vinden door prikkels. Evenementen vormen dan een manier waarop emoties worden gemaakt. Een volgend evenement geeft mensen nog meer prikkels waardoor er gewenning en verveling optreedt. Denk aan de readymade ervaringen in pretparken als Disneyworld, popconcerten van megasterren, of de celluloid emoties waarmee Hollywoodfilms miljoenen mensen bereiken. Die evenementen zijn betekenisloos in de zin dat ze een vorm van behoeftebevrediging vormen, maar meestal geen relevant effect kennen anders dan de behoefte aan een nog sterkere prikkel. Dat principe van 'steeds heftiger' en directere behoeftebevrediging zagen we ook bij het infantiele consumentisme van Barber en toont verwantschap met de spektakelmaatschappij van Debord (1976).

Het gaat Piët om de volgende fase van de belevingseconomie waarin emotionele behoeftes een kernactiviteit van de emotiemarkt vormen. Daardoor krijgen evenementen ook een andere betekenis en invulling. Evenementen roepen nu geen 'voorgekookte' emoties meer op, maar stellen emoties centraal. Door een evene- 
ment wordt uiting gegeven aan die emotie in plaats van dat deze erdoor wordt opgeroepen; niet meer de beleving maar de ervaring staat centraal. Evenementen worden dan een vorm van zingeving of zelfverwezenlijking. Door de nadruk te leggen op de belevingseconomie benadrukt Piët net als Keulartz de expressieve en emotionele kanten en mogelijkheden van participatie (Keulartz 2009). Dat past bij een producentenbenadering; het gaat erom mensen in een actieve modus aan te spreken en hen werkelijk mee te laten doen.

\section{Rituelen}

Een voorbeeld waarin die expressieve en emotionele kanten meer centraal staan leveren rituelen. De voorstelling van een ritueel als middel om het sociaal wenselijke aantrekkelijk te maken vinden we onder andere in de communitaristische natuurfilosofie (Jordan 2003; Keulartz 2009). Rituelen worden beschouwd als een sociaal drama met een uitgesproken performatief karakter en zijn verwant aan de uitvoerende kunsten. Ze zijn hier vooral interessant, omdat ze een positieve en productieve of scheppende verwerking van morele en emotionele gevoelens mogelijk maken (Keulartz 2009). Het uitvoeren van een ritueel biedt daarmee een ervaring en maakt het mogelijk om ook de emotionele aspecten in participatie een plek te geven. Een ritueel kan op verschillende manieren en voor verschillende doeleinden ingezet worden. Voorbeelden van rituelen zijn bijvoorbeeld de nationale Boomfeestdag waarbij basisschoolleerlingen bomen planten, de verkiezing van prins Carnaval, of de jaarlijkse dodenherdenking op 4 mei.

Het ritueel past bij een producentenbenadering. Het geeft individuen een nieuwe mogelijkheid om vorm te geven aan hun leven en omgeving, terwijl een ritueel tegelijkertijd bijdraagt aan het vormen van een groepsidentiteit die, mits de juiste rituelen worden gebruikt, de bereidheid om voor de groep of het collectieve doel te kiezen in sociale dilemma's doet toenemen.

Een initiatieritueel zou de overheid kunnen inzetten voor de inenting tegen baarmoederhalskanker door meisjes van dertien. Door zich te laten inenten horen ze bij een speciale groep van vrouwen op weg naar volwassenheid. Het is een erkenning van dertienjarige meisjes. In dit ritueel staan emoties van verwachting en nieuwsgierigheid centraal. De prik is de beproeving die deze jonge vrouwen moeten doorstaan om beschermd te zijn in de toekomst en erbij te horen. Het ritueel zou op het bezwaar kunnen stuiten van ouders dat op die manier de seksualiteit van jonge meisjes te veel benadrukt wordt (HPV is een seksueel overdraagbare aandoening), maar dat is niet noodzakelijk het geval. Het ritueel zou in het teken kunnen staan van volwassenheid en kan de angsten en zorgen die daarbij horen (ook van ouders) juist een plaats geven.

Stoppen met roken zou zich lenen tot een offerritueel waarbij mensen hun asbak inleveren. 
Een voorbeeld van een wat schokkender ritueel zou bijvoorbeeld een dag kunnen zijn waarop deelnemers aan een inburgeringcursus de confrontatie aan moeten met de oordelen en vooroordelen van autochtonen om in dat strijdritueel een basis voor gemeenschappelijkheid te vinden. Niet alles leent zich voor nieuwe rituelen, maar de benadering is kansrijk: in deze voorbeelden gaat het om onderwerpen die een essentiële rol spelen in het leven van veel mensen; volwassen worden, gezondheid, de leefomgeving. Uiteindelijk gaat het er ook om dat beleidsmakers een fingerspitzengefühl voor rituelen zouden moeten ontwikkelen wat zou helpen om vorm te geven aan evenementen van inspraakavonden tot collectieve vaccinatiedagen of, anders gezegd, om van die vaak enigszins halfslachtige bijeenkomsten een ritueel te maken. Daarmee wordt de impact groter en ook hier geldt dat de grens van de impact die het openbaar bestuur zou moeten nastreven discussie behoeft. Als uitgangspunt hanteren wij het beginsel dat, naarmate een ritueel er meer toe dient om mensen een producent van hun omgeving te maken, de mate van impact (van binnendringen in de omgeving) ook mag toenemen.

\subsubsection{PARTICIPATIE}

Het rechtstreeks betrekken van burgers bij vormgeving, uitvoering en evaluatie van overheidsbeleid heeft de afgelopen jaren veel aan populariteit gewonnen en komt voort uit het idee dat het rechtstreeks betrekken van mensen bij het vormen van beleid of in andere processen, veel voordelen oplevert (Irwin 2001; Jasanoff 2003; OECD 2009). Het gaat om een behoefte van inwoners om vorm te geven aan hun omgeving, en een behoefte van de overheid om op een directe manier kennis te nemen van de behoeftes van de bevolking.

Er bestaan verschillende modellen die laten zien hoe en waarom burgers kunnen worden betrokken bij beleid (Glass 1979; Nelkin en Pollak 1979; Rowe \& Frewer 2005). Een cognitieve benadering beschouwt burgers als een bron van nuttige inzichten en kennis die kan worden aangeboord (Wynne 2001). Een instrumentele benadering wijst erop dat deelname van het publiek aan politieke besluitvormingsprocessen het vertrouwen vergroot van mensen in de instituten die verantwoordelijk zijn voor de uitvoering van het gezamenlijk overeengekomen beleid (Bentley 2005). Een normatieve benadering wijst er tenslotte op dat burgers ook worden ingezet om de democratische kwaliteit van de besluitvoering te verhogen omdat ze een bron zijn van heersende normen en waarden.

In de praktijk mogen burgers vooral meepraten en meedenken in debatten, burgerjury's, consensusconferenties, focusgroepen en meer van dit soort mechanismen. Meestal mogen burgers niet echt meedoen in het bestuur (Keulartz 2009). Ze krijgen dan wel de beleving van het openbaar bestuur voorgeschoteld maar niet de ervaring. Een voorbeeld daarvan vonden we in een reportage (Schreuder 2009) over de reacties van bewoners van Amsterdam die op het August Allebéplein in 
het stadsdeel Slotervaart wonen. De bewoners zouden graag actiever betrokken worden bij de nieuwe inrichting van het plein.

Het liefst willen de omwonenden hun alternatief in 'coproductie' met het stadsdeel uitwerken. Martijn Rutte (bewoner): "Het stadsdeel heeft altijd de mond vol van samenwerken met bewoners.” Maar in de praktijk verloopt de samenwerking moeizaam, vertelt stadssocioloog en wetenschapper Thaddeus Müller die de actievoerders adviseert. Müller: "Er heeft officieel inspraak plaatsgevonden. Maar echt meedenken wordt niet gewenst. Je zou als gemeente likkebaarden over zoveel betrokkenheid, maar in plaats daarvan gaan alle deuren op slot zodra bewoners daadwerkelijk meedenken over hun omgeving." Adri Boomgaard (bewoner): "Als wij een gesprek willen voeren met de stadsdeelwethouder, zegt zij dat onze toon haar niet bevalt en dat ze ons agressief vindt."

Het cynisme over participatie-initiatieven dat soms ontstaat, laat zich vanuit een producentenbenadering verklaren; mensen denken de kans te krijgen om vorm te geven aan hun omgeving, maar worden alleen maar gehoord en hebben vervolgens vaak geen inzicht in wat er met hun ideeën is gebeurd. Een producentenbenadering wijst erop dat meedenken eigenlijk ook een vorm van meebesturen (coproduceren, zie onder) hoort te zijn, in de zin dat het geen zin heeft om mee te denken wanneer beleidsmakers niet aannemelijk kunnen maken dat meedenken van invloed is op het uiteindelijke besluit. De Algemene Wet Bestuursrecht benoemt dat belang ook, maar over de invloed van procedures die niet voortkomen uit een wettelijk recht tasten we vaak in het duister.

\section{Figuur 8.1 Participatie driehoek van May (2007)}

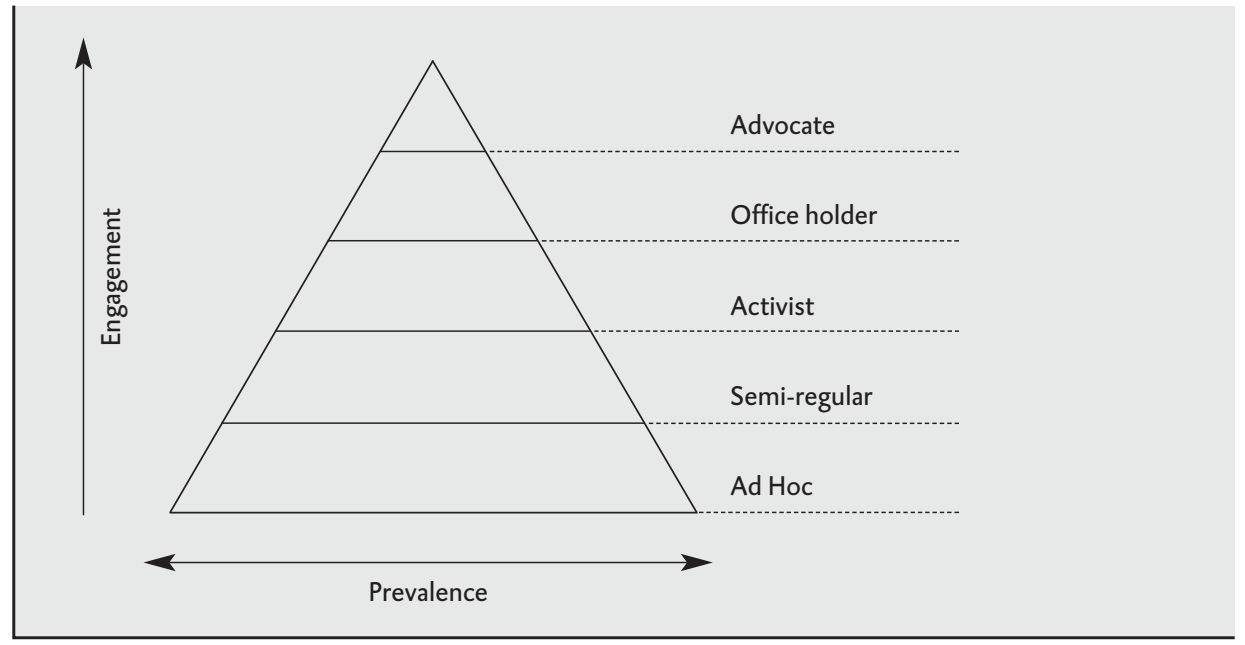


De manier waarop mensen daadwerkelijk kunnen deelnemen aan beleidsprocessen laat zich op verschillende manieren indelen. De participatieladder van Arnstein (1969) is een veelgebruikte indeling. Hierin worden de verschillende rollen die een burger kan aannemen in een participatieproces afgezet tegen de mate van invloed die een burger heeft in die rol. De oorspronkelijke ladder kent acht verschillende treden, maar wordt vanuit praktisch oogpunt meestal teruggebracht tot vijf treden. De treden zijn: informeren, raadplegen, adviseren, coproduceren en beslissen (IAP 2007; Van Helden et al. 2009). De indeling wordt bekritiseerd, omdat ze zich vooral richt op de uitvoerende en vertegenwoordigers van het beleid en niet op de deelnemers (May 2007). De treden en de rollen krijgen burgers door de overheid min of meer toegewezen. Dat is niet goed verenigbaar met een producentenbenadering, omdat ze de vraag stelt: 'Welke input verwacht de overheid van burgers?' en niet 'Op welke manier stelt de overheid mensen in staat om coproducent te zijn van hun omgeving?’. Er bestaat echter geen onoverbrugbare tegenstelling tussen de piramide en de producentenbenadering. De vraag naar het coproduceren hoort aan de toepassing van de ladder vooraf te gaan. Als het bijvoorbeeld gaat om voorzieningen in een nieuwe woonwijk kan het 'meebeslissen' de meest voor de hand liggende methode zijn, terwijl valt te betogen dat voor de beantwoording van de vraag 'wel of geen genetisch gemodificeerde groentes toestaan?' de mening van experts en politici de overhand moet hebben en verder kan worden volstaan met het informeren en raadplegen van de bevolking.

In tegenstelling to Arnsteins ladder stelt de driehoek van betrokkenheid van May (2007) het perspectief van de burger centraal. In deze driehoek wordt de gangbaarheid van participatie afgezet tegen de mate van betrokkenheid en wordt er gekeken in hoeverre de deelnemer in staat en bereid is tot een specifieke vorm van betrokkenheid (zie figuur 8.1). Ook hier worden vijf verschillende niveaus onderscheiden: ad hoc, semi-regulier (semi-regular), activist, betrokkenheid uit hoofde van een bepaalde positie (office holder) en voorvechter (advocate). De driehoek laat zien dat, naarmate de betrokkenheid toeneemt, het aantal burgers dat daaraan deelneemt afneemt. De plaats die een burger kan innemen in deze driehoek wordt gedeeltelijk bepaald door de burger zelf: de vraag is in hoeverre die bereid is om zich meer te verdiepen in de verschillende onderwerpen die zijn aandacht vragen, bijeenkomsten te organiseren, te lobbyen, enzovoorts.

Het interessante aan die driehoek is dat we deze ook vanuit een normatief individualistisch gezichtspunt kunnen gebruiken. Doe ik genoeg? Zou ik me niet duurzamer voor onderwerpen moeten inzetten? Die benadering past bij een producentenbenadering. We mogen ervan uitgaan dat de bereidheid om 'activist' of 'advocate' te worden toeneemt, naarmate we een onderwerp meer tot onze omgeving rekenen. Met andere woorden, de driehoek maakt ook de 'carrière' die individuen kunnen maken op een onderwerp inzichtelijk. 
Tenslotte kan de driehoek gebruikt worden om de vraag te stellen: 'Waarom kent dit onderwerp slechts ad-hocbetrokkenheid?' ‘En is dat een probleem?' Het Amsterdamse huurbeleid kenmerkt zich bijvoorbeeld door ad-hocbetrokkenheid van bewoners die pas activistisch worden als reactie op beleid dat vaak al vaststaat. Door de gemeente gefinancierde huurteams proberen 'bewonerscommissies' op te richten die zich blijvend met het beleid van woningbouwverenigingen en stadsdelen bemoeien. Een volgende vraag is dan: zitten de juiste mensen in die commissies? Anders gezegd, worden mensen die graag in die commissies zouden plaatsnemen of wiens stem op dit moment in de commissies ontbreekt daartoe feitelijk (en niet alleen op papier) in staat gesteld. De piramide van May vormt een nuttig instrument om die vragen te stellen.

\subsubsection{REFLECTIE OP EVENEMENTEN}

De jaarkalender van 2009 toont dat er geen sprake is van een tekort aan evenementen. Ieder jaar wordt opnieuw ingeluid als het jaar van... 2009 jaar is onder andere het Darwinjaar. Oktober 2009 was de maand van de energiebesparing, maar het was ook borstkankermaand en kennismaand. Er was een week van de rechtspraak, een week van de democratie, enzovoorts, en dan hebben we de 'dagen van' nog niet eens genoemd.

Een evenement dat de omgeving van mensen niet weet binnen te dringen is daarmee op voorhand zinloos, omdat het ongemerkt voorbij zal gaan. Een voorbeeld daarvan is de afsluiting van 'Amsterdam Wereldboekenstad' (2007-2008) dat een grootse viering van literatuur aan het IJ had moeten worden met muziek, gedichten en vuurwerk, maar dat nauwelijks 250 man wist te trekken op een plek die ruimte aan duizenden mensen biedt.

Er moet een effect optreden, anders wordt er in feite belastinggeld weggegooid. Als de gemeente Amsterdam mensen uitnodigt om melding te maken van discriminatie, dan hoort dat tot meer meldingen te leiden en in het teken te staan van een maatschappelijke mentaliteitsverandering. De specifieke campagne 'melden helpt' van de gemeente faalt, omdat ze wel de nadruk legt op het 'slachtofferschap' van de gediscrimineerde maar geen handelingsperspectief schetst. De gediscrimineerde wordt niet duidelijk gemaakt wat hij met het melden opschiet en degenen die het billboard passeren krijgen geen perspectief van een Amsterdam zonder discriminatie voorgeschoteld. Het falen van de campagnes blijkt uit de informatie die de gemeente verschafte: de bereidheid om discriminatie te melden neemt door campagnes toe, maar tegelijkertijd is het gevoel gediscrimineerd te worden alleen maar toegenomen (Gemeente Amsterdam, 9 juli 2008). Een evenement zou zich bijvoorbeeld meer op dat gevoel kunnen richten en emoties van gediscrimineerden (en degenen die discrimineren) centraal kunnen stellen. Een producentenbenadering zou daarbij niet veronderstellen te weten hoe discrimineren de gediscri- 
mineerden beperkt in het vormgeven van hun leven en omgeving, maar die vraag ook centraal stellen, zodat het op maat gesneden 'bestrijdingsmethodes' kon ontwikkelen.

In september 2009 werden drie interviews gehouden met experts die we onze visie op evenementen en de producentenbenadering voorlegden. Het ging vooral om de notie van een 'dubbel evenement' waarbij de nadruk die Piët legt op de rol van emoties in die evenementen ook een rol speelde.

Het eerste interview vond plaats met Mat Poelmans en Mieke van Heesewijk, respectievelijk directeur en adviseur e-participatie van Burgerlink. Burgerlink is een initiatief van de staatssecretaris van Binnenlandse Zaken en Koninkrijksrelaties. In een driejarig stimuleringsprogramma proberen zij onder andere door het ontwikkelen van e-participatie-instrumenten burgers te betrekken bij het verbeteren van publieke dienstverlening, openbaar bestuur en sociale cohesie. Het tweede interview betrof een gesprek met Maurits Rade. Hij is duovoorzitter van HappyChaos: een stichting die in 2000 opgericht is door Amsterdamse studenten en redacteuren van weekblad Vrij Nederland. HappyChaos organiseert evenementen om het maatschappelijk debat te voeren met meer dan woorden alleen. De stichting richt zich op jongeren. Tenslotte werden Jaap Spreeuwenburg, directeur van Coolpolitics en Pieter di Stefano van Coolpolitics geïnterviewd. Coolpolitics is een ngo die culturele projecten over politiek en burgerschap ontwikkelt en ondersteunt met als doel om de politieke en maatschappelijke betrokkenheid onder jongeren te vergroten.

De geïnterviewden betwijfelden of evenementen een geschikte manier vormden voor de overheid om burgers aan te spreken. De manier waarop de overheid dat op dit moment doet was dat in hun beleving in ieder geval niet. Ze brachten naar voren dat de uitkomst van een evenement vaak voor aanvang al vaststaat. Meedoen aan een dergelijk evenement is dan een schijnvorm van democratie. Daarnaast werd gesteld dat overheidsevenementen op voorhand zouden worden gewantrouwd, omdat de overheid ze organiseert. Rade reageerde enthousiast op het voorstel om ervaring meer centraal te stellen in evenementen. Op die manier worden mensen volgens hem uitgedaagd om zelf met het probleem of de issue aan de slag te gaan. Dat past bij de doelstelling van HappyChaos. Spreeuwenberg en Di Stefano van Coolpolitics waren minder enthousiast. Op het moment dat de overheid probeert om mensen aan te spreken door hun leefwereld binnen te dringen, stelden zij dat zij per definitie als niet te vertrouwen partij werd beschouwd. Sterker nog, het binnendringen van de overheid in de eigen leefwereld werd als onwenselijk gezien. Spreeuwenberg stelde dat hij de aanwezigheid van de overheid 'op zijn Hyves' als een (nog) grotere inbreuk op zijn privacy ervoer dan wanneer zij achter de voordeur opdook. 
Het leek hen onmogelijk dat de overheid in een live-evenement de emoties van de burgers centraal zou stellen. De overheid was daar in hun ogen een te grote en anonieme organisatie voor die daar de vrijheidsgraden en bewegingsvrijheid niet voor heeft. Spreeuwenberg en Di Stefano zagen een evenement zoals Coolpolitics die organiseert wel als zinvol, mits de uitkomst voor het beleid nog niet vast zou staan, maar door het evenement bepaald zou kunnen worden. Zij zouden in het evenement de keuzes ter discussie stellen en het daarbij laten. Hun evenement zou geen handelingsperspectief bieden.

Poelmans en Van Heeswijk van Burgerlink noemden de website petities.nl waarmee mensen zelf een onderwerp met voldoende steun op de politieke agenda kunnen plaatsen. Het indienen van de petitie is een (virtueel) evenement dat ruimte biedt voor emoties.

Het is opmerkelijk dat degenen die stellen dat de overheid niet succesvol is in het organiseren van 'dubbele evenementen' daar zelf wel in slagen of benaderingen voor ontwikkelen, in sommige gevallen zelfs in opdracht van een overheid. Het is met andere woorden niet onmogelijk om evenementen te laten slagen, maar voor de overheid is de opgave erg ingewikkeld en de conclusie dat zij terughoudend zal moeten zijn ligt voor de hand. We eindigen hier met een hoopgevend (maar erg specifiek) voorbeeld: de eigen-krachtconferenties die plaatsvinden in het kader van de uitvoering van de WMO. In die conferenties maken mensen met familie, vrienden en kennissen zelf afspraken over een hulptraject en blijven hulpverleners fysiek op afstand. De eerste resultaten van die conferenties zijn hoopgevend in de zin dat afspraken worden nagekomen. Die eigen-krachtconferenties passen bij een producentenbenadering; ze tonen verwantschap met een ritueel (de conferentie en de onderhandelingen), en stellen het scheppen van eigen leven en omgeving voorop. Ze hebben daarmee ook het karakter van een dubbel evenement; ze markeren een verandering in de omgeving van individuen, terwijl de conferenties zelf een evenement vormen.

\subsubsection{TOT SLOT}

We hebben in dit hoofdstuk de contouren geschetst van de producentenbenadering. Die benadering kent drie uitgangspunten.

1 Ieder mens is (maar niet iedereen in dezelfde mate) een coproducent van zijn leven en omgeving.

2 Als de overheid mensen op een zinvolle manier aan wil spreken, dan zal ze hun omgeving moeten binnendringen.

3 Het binnendringen in de omgeving van individuen vindt zijn legitimatie en zijn beperking in het feit dat het individuen in staat hoort te stellen om vorm te geven aan hun omgeving. 
Toch bleek dat door de nadruk die wij op het binnendringen leggen, er soms tot ver achter de voordeur zal worden ingegrepen. Het voorbeeld waarbij van het aanbieden van een HPV-injectie een nieuw ritueel werd gemaakt maakte dat inzichtelijk. Door sterk vast te houden aan de opdracht dat hier sprake is van neutraal ingrijpen in de zin dat de overheid nieuwe mogelijkheden aan haar inwoners biedt en hen geen opties afneemt (de prik houdt geen enkel oordeel over seksuele voorkeur of wijze van samenleven in) kan dit toch gerechtvaardigd zijn, omdat het hogere doel van het voorkomen van baarmoederhalskanker hier vooropstaat. Een producentenbenadering stelt aan overheidsoptreden de eis dat het inwoners in staat moet stellen om hun omgeving beter vorm te geven dan zonder het optreden. Verdere uitwerking is hier echter nog nodig om te voorkomen dat dit deontologische principe in een retorische truck ontaardt om zeer sterke ingrepen aanvaardbaar te maken.

We hebben laten zien hoe die benadering zich verhoudt tot de consumentensamenleving, tot de participatiemodellen en tot het thema burgerschap. Een producentensamenleving komt met veel verantwoordelijkheid voor individuen, en vraagt van de overheid dat zij mensen als volwassenen behandelt en manieren zoekt om hun omgeving binnen te dringen. In dat binnendringen hoort voorop te staan dat een producentenbenadering mensen laat zien hoe ze hun leven en omgeving beter kunnen coproduceren. Het onderscheid publieke en private sfeer is in de producentenbenadering niet scherp, omdat de producentenbenadering vooropstelt dat leven gelijkstaat met het (mede)vormgeven van de eigen omgeving.

Evenementen vormen een manier van zelfverwerkelijking als ze zich niet beperken tot readymade prikkels, maar de mogelijkheid bieden om emoties te ervaren. Op die manier wordt een evenement ook een creatie van de aanwezigen en dat past bij een producentenbenadering. De kiem van de producentensamenleving is er al, maar voor haar verwezenlijking is nog een weg te gaan. 


\section{NOTEN}

$1 \quad$ Het voorbeeld is ontleend aan het Taalcoaches-project, zie de website http://hetbegintmettaal.nl (8 maart 2010).

2 Zie bijv. de website http://ec.europa.eu/consumers/rights/cons_acquis_en.htm (8 maart 2010).

$$
\text { Zie bijv. http://www.minvws.nl/dossiers/wmo/default.asp (8 maart 2010). }
$$




\title{
9 ONVOORSPELBARE VERANTWOORDING. MEERVOUDIGE VERANTWOORDING EN DE NIEUWSMEDIA
}

\author{
Thomas Schillemans
}

\section{$9.1 \quad$ INLEIDING}

Het Centraal Administratie Kantoor (CAK) is een relatief kleine en bij het grote publiek onbekende publieke organisatie. Het is desondanks een belangrijke schakel in het zorgstelsel dat in 2009 alleen al 21 miljard euro uitkeerde aan AWBZ-instellingen. Tussen 2007 en 2009 besteedde het kritische televisieprogramma Kassa vijf uitzendingen aan de 'telefonische onbereikbaarheid, wirwar aan brieven en onterechte beschikkingen' die volgens de redactie schering en inslag zouden zijn bij het CAK. De aanleiding voor het behandelen van het CAK in deze uitzending betrof de aankondiging dat bewoners van AWBZ-instellingen per 1 januari 2008 een hogere eigen bijdrage moeten betalen.

Gedurende de CAK-campagne betoonde Kassa zich een effectief en doortastend knooppunt van publieke verantwoording. Om te beginnen was de redactie van het programma op zich een actief verantwoordingsforum dat, 'bewapend' door de openbaarheid van bestuur en de vrijheid van meningsuiting, de ruimte nam om het CAK publiekelijk de maat te nemen. Tegelijk spoorde de redactie formele verantwoordingsfora aan om het CAK onder de loep te nemen. Kamerlid Agnes Kant stelde daardoor kritische vragen aan de regering, de Nationale Ombudsman liet optekenen dat "het hoog tijd werd dat er een einde kwam aan de chaos", en burgers konden hun klachten over het CAK melden bij Kassa, maar ook bij het Algemeen Dagblad. Dit leidde weer tot nieuwe berichtgeving in andere media met uiteindelijk ingrijpende - en voor het publiek vermoedelijk positieve - gevolgen. Het Algemeen Dagblad vatte de uitkomst daarvan en de eigen bijdrage eraan als volgt samen:

\footnotetext{
"Het Administratiekantoor Bijzondere Zorgkosten (CAK-Bz) gaat met voorrang alle klachten behandelen, die lezers de afgelopen week naar het AD hebben gestuurd. (...) Een paar klachten: 'Zij zijn telefonisch niet te bereiken', 'Oudere mensen krijgen slapeloze nachten van het CAK', 'Het is een puinhoop' en 'Mijn ervaring? Balen!' Het CAK heeft beloofd alle klagende lezers met voorrang te helpen. Zij zijn daarvan al op de hoogte gebracht." (Algemeen Dagblad, I februari 2008)
}

In de afgelopen decennia heeft het publieke domein ingrijpende veranderingen doorgemaakt die vaak worden samengevat onder de noemer 'horizontalisering'. Door uiteenlopende macroprocessen als verzelfstandiging, europeanisering, 
informatisering, privatisering, vermarkting en mediatisering is de traditionele rol van de overheid onder druk komen te staan. De hiërarchische beslissingsmacht van de centrale overheid verminderde en is gedeeltelijk verplaatst naar andere actoren, waardoor de staat volgens bezorgde commentatoren is uitgehold (Rhodes 1994) en de politiek is verplaatst (Bovens 2005a). De verplaatsing van bestuur heeft ingrijpende gevolgen voor het bestaande systeem van democratische verantwoording, waarin de relatie tussen minister en Kamer het centrale knooppunt is. De verplaatsing van zeggingsmacht ondermijnt dit systeem, want hoe kunnen ministers zich zinnig verantwoorden wanneer belangrijke besluiten elders zijn genomen?

De horizontalisering van de staat verloopt deels door exogene processen (met name informatisering en mediatisering) en is deels een endogeen product van beleidsbeslissingen uit de afgelopen decennia (zoals privatisering, europeanisering en verzelfstandiging). Aanvankelijk was er bij de herziening van de publieke sector sinds de oliecrises beperkte aandacht voor de borging van publieke belangen en de aanpassing van stelsels van publieke verantwoording (zie WRR 2000). In het laatste decennium wordt op dit punt echter een grote inhaalslag gemaakt (Schillemans \& Oude Vrielink 2007). Publieke verantwoording is sindsdien 'in', en de verantwoordingsverplichtingen waarmee publieke actoren te maken hebben zijn langs vele lijnen geïntensiveerd (Bovens en Schillemans 2009; Van Duijvenboden et al. 2009; Algemene Rekenkamer 2008). Naast een toename van formele vormen van verantwoording is er ook sprake van meer informele verantwoording aan kritische burgers, belangengroepen en vooral nieuwsmedia. Dit stelsel roept moeilijke vragen op ten aanzien van proportionaliteit (Is er niet te veel toezicht en verantwoording?, zie Noordegraaf \& Sterrenburg 2009), samenhang (Algemene Rekenkamer 2008) en goed bestuur (Hoe verhoudt het ge-horizontaliseerde stelsel van publieke verantwoording zicht tot de kwaliteit van de publieke taakuitvoering?). Het gecombineerde effect van horizontaal bestuur, horizontale verantwoording en informele verantwoording aan media is onvoorspelbaarheid; hetgeen moeilijk te verenigen is met klassieke opvattingen over verantwoording. In traditionele opvattingen over democratische verantwoording is voorspelbaarheid een belangrijke waarde. Verantwoording werkt goed als duidelijk is wie waarvoor verantwoordelijk is en door wie, wanneer en hoe ter verantwoording wordt geroepen. In een horizontaler stelsel van publieke verantwoording is al snel sprake van onvoorspelbaarheid, waarin niet helemaal duidelijk is wie verantwoordelijk is voor taken, of er verantwoording over wordt verlangd en door wie en wanneer dat dan eventueel gebeurt. Met name de potentiële kritische berichtgeving door nieuwsmedia zet een zekere druk op verantwoordingsregimes en maakt ze onvoorspelbaar. Dit kan nadelige gevolgen hebben voor de kwaliteit van de publieke sector, doordat het organisaties schuw, bang voor verandering of bureaucratisch - zo niet allemaal tegelijk - kan maken. In deze beschouwing verkennen we de mogelijkheden om met deze onvoorspelbaarheid om te 
gaan, vanuit de aanname dat horizontalisering ten dele een gegeven is. We verbinden daartoe twee vaak separaat behandelde trends: de kritische rol van de media in het openbaar bestuur en de verbreding van publieke verantwoording. Het is de gecombineerde impact van beiden die verantwoordingsprocessen onvoorspelbaar maakt; het gaat er dus om oplossingen te vinden die beiden adresseren.

Deze beschouwing heeft de volgende opbouw. Eerst bespreken we het concept publieke verantwoording en de traditionele focus daarbinnen op hiërarchie en voorspelbaarheid. Daarna analyseren we de horizontalisering van het bestuur en publieke verantwoording en de onvoorspelbaarheid die daarmee samenhangen. Vervolgens kijken we meer specifiek naar verantwoording aan de media en hoe dit ingrijpt in de horizontalisering van bestuur. Daarbij besteden we speciale aandacht aan zelfstandige bestuursorganen (Zво's), omdat zij een centrale rol vervullen in het debat over horizontalisering. In het laatste deel verkennen we een aantal innovatieve manieren waarmee zво's en de centrale overheid productief kunnen omgaan met onzekere publieke verantwoording in een kritische mediaomgeving.

\subsection{VOORSPELBARE PUBLIEKE VERANTWOORDING}

\subsubsection{PUBLIEKE VERANTWOORDING}

Publieke verantwoording is een begrip met een smalle kern waaraan een breed aantal verwachtingen en vooronderstellingen kan worden gekoppeld. In normatieve zin is 'verantwoording' een moeilijk hanteerbaar begrip: het verwijst naar allerlei normen en waarden die in het bestuur van belang kunnen worden geacht. Op procesniveau is het begrip daarentegen verrassend helder. Veel auteurs komen tot betrekkelijk vergelijkbare definities wanneer zij de kern van publieke verantwoording beschrijven. Doorgaans wordt verantwoording dan gedefinieerd als een communicatierelatie tussen een handelende persoon of instantie (een 'actor') en een beoordelende persoon of instantie (een 'forum'), waarbij de actor zich verplicht voelt of verplicht is om het forum inzicht te geven in zijn handelen (in de ruimste zin van het woord) en dit indien nodig toe te lichten en te rechtvaardigen. ${ }^{1}$ Het gaat daarbij over bepaalde handelingen waaraan bepaalde verwachtingen zijn gekoppeld en waarvoor bepaalde randvoorwaarden gelden. De actor geeft inzicht in zijn gedrag, geeft er een verklaring voor en verdedigt zich zonodig tegen aantijgingen. Het forum bevraagt de actor, neemt kritisch kennis van diens handelingsverslag, stelt mogelijk aanvullende vragen en verwoordt eventueel kritiek. Het forum beoordeelt zo het handelen van de actor, hetgeen formele of informele consequenties kan hebben voor de actor. Bij een positief oordeel horen positieve consequenties zoals beloningen. Vaak echter gaat het bij verantwoording om negatieve consequenties, om sancties. De significante ander tot wie de actor zich richt kan een persoon, groep of organisatie zijn. Ook kan het 
forum van metafysische aard zijn, zoals God, de natuur of het eigen geweten. Verantwoording is doorgaans retrospectief en gericht op gedane zaken. Prospectieve verantwoording over voorgenomen plannen is echter ook mogelijk. De kern is steeds dat het gedrag van de actor centraal staat en dat het forum daarover oordeelt tegen een achtergrond van potentiële (vermoede of waarschijnlijke) consequenties.

Een verantwoordingsproces beslaat doorgaans drie fasen (Elzinga 1989: 70-72; Mulgan 2003: 30). In de informatiefase doet de actor verslag van zijn handelen in het licht van de verwachtingen die daarvoor gelden. In de debatfase wordt dit handelingsverslag beproefd in een proces van hoor en wederhoor tussen actor en forum. Het forum kan hier aanvullende informatie opvragen, nadere vragen stellen en voorlopige oordelen formuleren. De actor zal zijn gedrag zonodig nader toelichten, verklaren, rechtvaardigen en verdedigen. De verantwoording sluit af met een oordeel van het forum. Het forum meet het geconstateerde gedrag aan normen die liefst expliciet maar in de praktijk regelmatig impliciet zijn.

In deze oordeelsfase besluit het forum of het formele sancties toepast, zoals beloning, bevordering, boetes, ontslag of het aanscherpen van regelgeving. Daarnaast zijn ook informele sancties mogelijk. Er kan allereerst sprake zijn van informele consequenties via netwerken, als het forum gesprekspartner is van een hiërarchisch bovengeschikte partij (bijv. de minister), door hem wordt benoemd en/of wordt gerekruteerd uit politiek-bestuurlijk relevante kringen. Er kan vervolgens ook sprake zijn van informele sancties via openbaarheid, wanneer de oordelen van het forum richting het algemene publiek worden gepubliceerd. Vooral de mogelijkheid om reputatieschade te veroorzaken door openbaarheid van oordelen is voorshands een belangrijke informele sanctie. Ook kan verantwoording aan een forum zonder sanctionerende bevoegdheden, zoals de Algemene Rekenkamer, worden opgevolgd door sancties van een ander forum dat wel over sanctionerende bevoegdheden beschikt, namelijk in dit geval de Tweede Kamer. De Algemene Rekenkamer doet 'alleen maar' onderzoek. Het rapporteert echter aan de Tweede Kamer en die kan er consequenties aan koppelen. 'In de schaduw van de hiërarchie' van het parlement wordt onderzoek van de Rekenkamer in het openbaar bestuur daarom als een krachtige vorm van controle beleefd (Meijer 2002: 162163). Hetzelfde geldt voor de nieuwsmedia: zij doen 'slechts' verslag van wat publieke organisaties en politici doen, maar kunnen op die manier wel, zoals reeds geillustreerd in het voorbeeld van het CAK, uitgroeien tot geduchte verantwoordingsfora.

Stelsels van publieke verantwoording kunnen naar drie dimensies worden onderscheiden. Op het hoogste niveau van abstractie is sprake van verantwoordingsregimes. Dit is het geheel aan bestaande verantwoordingsverplichtingen en mechanismen in een bepaalde sector (zie ook Bakker en Yesilkagit 2005). Eén niveau lager 
kunnen we verantwoordingsmechanismen onderscheiden. Dit zijn specifieke relaties tussen een actor en een forum, zoals die tussen een uitvoeringsorganisatie en een departement, inspectie of raad van toezicht. En tot slot is er het doel van verantwoording: wat wordt binnen een verantwoordingsregime verwacht van de actor. In traditionele opvattingen over publieke verantwoording worden verantwoordingsregimes gekarakteriseerd door ordening en hiërarchie, ondersteunen de mechanismen deze ordening door breed en generiek informatie te verlangen en is het doel vaak naleving van de regels en aanwijzingen.

\subsubsection{HIËRARCHIE EN VOORSPELBAARHEID}

Traditioneel werkt publieke verantwoording in het openbaar bestuur langs hiërarchische lijnen: de publieke dienst werkt onder verantwoordelijkheid van ministers, die zich aan het parlement verantwoorden en in laatste instantie aan de kiezende burgers. Het is een stelsel waarin eenduidigheid en daarmee voorspelbaarheid een impliciete kernwaarde is, hetgeen het beste begrijpelijk te maken is door het openbaar bestuur te zien als een keten van principaal-agentrelaties (zie Moe 1984: 765-766; Przeworski et al. 1999; Strøm 2000: 267-268).

In de democratische keten van principaal-agentrelaties wordt beschikkingsmacht steeds van principaal naar agent gedelegeerd. In deze keten van delegaties is iedere schakel beurtelings principaal en agent, behalve de eerste principaal (het electoraat) en de laatste agent (de uitvoerende ambtenaar). Het electoraat delegeert via verkiezingen aan gekozen vertegenwoordigers die weer het leeuwendeel van hun taken doordelegeren aan de regering. De regering is zelf agent van de Kamer, maar is ook principaal van het ambtelijk apparaat. Ook binnen het ambtelijke apparaat is de taakuitvoering steeds benedenwaarts in de hiërarchische lijn gedelegeerd, van hogere naar lagere ambtenaren en van centrale beleidsafdelingen naar decentrale uitvoerende diensten. Iedere principaal in deze delegatieketen probeert het gedrag van 'zijn' agenten te monitoren door ze periodiek ter verantwoording te roepen en zonodig en waar mogelijk te corrigeren. De gehele keten kan als democratische delegatieketen worden aangeduid.

De democratische delegatieketen fungeert in theorie het beste indien de relaties tussen de actoren en de verwachtingen waaraan hun handelen moet voldoen stabiel en voorspelbaar zijn. Als duidelijk is wat de verschillende verantwoordingsfora (of principalen) verwachten van hun actoren (of agenten), en als duidelijk is waar alle actoren voor verantwoordelijk zijn, dan is de kans het grootst dat actoren ook handelen naar de preferenties van hun principalen. In een voorspelbaar en geordend stelsel van verantwoording is er het minste sprake van agency loss: onduidelijkheid en meerduidigheid die actoren de ruimte biedt af te wijken van de preferenties van hun principalen en hun eigen belang na te streven (Strøm 200o). Zodra er meerdere actoren zijn en actoren gedeeltelijk onafhankelijk zijn (en zich dus niet geheel hoeven te verantwoorden), verliest het stelsel aan eendui- 
digheid. Hetzelfde gebeurt door de introductie van meerdere, deels onafhankelijke en deels overlappende verantwoordingsfora. En precies dit is de kern van wat er de afgelopen decennia in het openbaar bestuur is gebeurd: er zijn veel verschillende actoren en veel verschillende verantwoordingsfora gekomen, waardoor een meervoudig stelsel van publieke verantwoording is ontstaan (zie hierna). De gangbare beleidsrespons is tot nu toe geweest om te proberen de meerduidigheid van verantwoordingsstelsels te ordenen en te reguleren. Indien er meerdere verantwoordingsarrangementen zijn, dan dienen zij steeds een onderscheiden focus te hebben en onderling in balans te zijn, zo wordt vaak aangeduid in de literatuur (vgl. Behn 2001: 125; Van Montfort 2004: 82; WRR 2004: 243; Werkgroep Publieke Verantwoording 2008).

\subsection{HORIZONTAAL EN ONVOORSPELBAAR BESTUUR}

De horizontalisering van bestuur ${ }^{2}$ ondermijnt de eenduidigheid van de democratische delegatieketen en het stelsel van publieke verantwoording. In de internationale literatuur over publieke verantwoording wordt dit probleem - verantwoording over verplaatste taakuitvoering - als het meest urgent gezien. Een door auteur dezes en Ossege uitgevoerde analyse van artikelen in vijftien belangrijke internationale wetenschappelijke tijdschriften liet zien dat zo'n tweederde van de artikelen over verantwoording in de afgelopen tien jaar problemen van complex bestuur behandelde. ${ }^{3}$ We bespreken hierna de horizontalisering van de uitvoering (= actor) en de horizontalisering van publieke verantwoording (= forum) en hun consequenties in termen van het onvoorspelbaarder maken van publieke verantwoording.

\subsubsection{HORIZONTALISERING BELEIDSUITVOERING}

De horizontalisering van het openbaar bestuur is een belangrijke trend van de afgelopen decennia, die regelmatig in emotionele termen wordt besproken (Schillemans 2007a: 18-21). Horizontalisering contrasteert met de verticaliteit van het traditionele openbaar bestuur. De verticaliteit wijst erop dat relaties tussen personen en organisatieonderdelen zijn gebaseerd op hiërarchische verhoudingen en geformaliseerde regels. Horizontalisering verwijst naar een bonte verzameling nieuwe relaties en werkwijzen die zijn gebaseerd op meer vrijwillige overeenkomsten tussen meer nevengeschikte partijen. De kern van horizontalisering is goed weer te geven in de beroemde woorden van Abram de Swaan (1979): het is een overgang van een bevels- naar een onderhandelingshuishouding. Uiteenlopende verschijnselen als interactief bestuur, sturing via convenanten en contracten, publiek-private samenwerking en verzelfstandiging zijn voorbeelden van horizontaliserend bestuur (Michels en Meijer 2003; Bovens 2003). Veel uitvoerende taken zijn vanaf de jaren negentig verzelfstandigd, geprivatiseerd of gedecentraliseerd. Er zijn nu honderden zelfstandige bestuursorganen en bijna 
tweeduizend rechtspersonen met een wettelijke taak die jaarlijks ongeveer 117,5 miljard euro uitgeven (Algemene Rekenkamer 2009). Bij de delegatie van uitvoeringstaken behield de overheid vaak een residuale verantwoordelijkheid voor de taken die door anderen werden uitgevoerd en waar ministers op werden aangesproken (RMO 2008). Daarnaast is ook het toezicht geprofessionaliseerd en deels verzelfstandigd (Van der Knaap et al. 2002 ; Yesilkagit 2009). Taken worden bovendien vaak in publiek-private, Europese, of andere internationale netwerken voorbereid en ontwikkeld. Ook de relatie met burgers is veranderd. Publieke organisaties bieden veel meer informatie over zichzelf aan, openen meer kanalen voor participatie en verantwoorden zich ook direct aan hun afnemers.

Er zijn allerlei redenen, zowel goede als slechte, waarom overheden de uitvoering van publieke taken regelmatig beleggen bij een bont palet aan niet geheel hiërarchisch onderschikte verbanden en organisaties. Zeer vaak treden overheden daarbij buiten de heldere kaders van het Huis van Thorbecke; die worden kennelijk als knellend ervaren. De relevantie voor de publieke verantwoording over de uitvoering van publieke taken is dat deze horizontalisering van de uitvoering de gewenste duidelijkheid van het stelsel ondergraaft. Horizontalisering van de uitvoering betekent dat de verantwoordingsactor diversifieert: het wordt daardoor minder duidelijk wie er ter verantwoording kan worden geroepen over de uitvoering van bepaalde taken. Indien feitelijke beslissingsmacht (deels) bij private, supranationale of onafhankelijke publieke actoren berust, kan de minister nog wel ter verantwoording worden geroepen, maar heeft hij de facto of de jure maar beperkte controle over de beklaagde uitvoering. Dat wil overigens niet zeggen dat ministers niet in staat zijn desgewenst de meeste publieke organisaties als ZBO's, agentschappen of publieke ondernemingen te sturen. Individuele organisaties zijn ondanks hun formele zelfstandigheid op zich wel stuurbaar; al was het maar omdat de minister het ultimum remedium van de wet tot zijn beschikking heeft. Wel is het zo dat het gehorizontaliseerde systeem vanwege omvang en complexiteit als zodanig beperkt stuurbaar is.

\subsubsection{HORIZONTALISERING PUBLIEKE VERANTWOORDING}

Parallel aan de horizontalisering van de taakuitvoering zijn ook de stelsels van publieke verantwoording gehorizontaliseerd. De meeste organisaties met publieke taken hebben te maken met verschillende verantwoordingsfora. $\mathrm{Zij}$ verantwoorden zich in de eerste plaats direct of indirect in de verticale lijn aan ministerie, en via die lijn aan ministers, de Tweede Kamer en uiteindelijk aan de burger. Zij verantwoorden zich daarnaast in meer diagonale lijn aan gedeeltelijk zelfstandige inspecties en/of toezichthouders, maar ook aan de Algemene Rekenkamer en de Nationale ombudsman. Veel uitvoerende organisaties kennen vervolgens een raad van toezicht of commissarissen. Ten slotte verantwoorden zij zich in meer horizontale richting aan de afnemers van publieke diensten, in visitatieprocessen of 
andere professionele kwaliteitsinstrumenten en uiteindelijk door toegenomen transparantie aan wie het maar weten wil (zie Bovens \& Schillemans 2009). In recente overheidsdocumenten over verantwoording staat deze meervoudigheid van publieke verantwoording steeds centraal als een feit maar ook als een uitdaging (zie bijv. Ministerie van BZK 2005; Ministerie van BZK 2008; Algemene Rekenkamer 2008; Werkgroep Publieke Verantwoording 2008).

Het aantal formele verantwoordingsfora is in de praktijk vaak wat lager dan het aantal de facto informele verantwoordingsfora. Dit blijkt bijvoorbeeld uit een kleine enquête die werd uitgevoerd bij een achttal sectoren van publieke dienstverlening (Schillemans et al. 2008). Het ging hier om dienstverleners in verschillende zorgdomeinen, hbo en mbo, welzijn en wonen. Figuur 9.1 geeft een overzicht van de verantwoordingsrelaties van deze publieke dienstverleners. In het onderzoek was hen gevraagd aan te geven welke formele organen (zoals cliëntenraden en raden van toezicht) er bij hun organisaties bestonden. Ook was hen gevraagd aan te geven met welke externe partijen zij intensieve contacten onderhielden. Zonder uitzondering kwam daaruit naar voren dat deze organisaties zich tot zeer veel anderen te verhouden hebben. Die relaties staan weliswaar niet primair in het teken van een formele verantwoording, desondanks worden publieke organisaties in al die relaties wel degelijk aangesproken op hun keuzen en worden zij er soms ter verantwoording geroepen. Figuur 9.1 geeft de externe (verantwoordings)relaties van een gemiddelde publieke dienstverlener weer, zoals die naar voren komt in aangehaald onderzoek. Allereerst hebben zij meestal te maken met de volgende hiërarchisch bovengeschikte verantwoordingsfora: de rijksoverheid, een specifieke inspectie of toezichthouder, gemeente en provincie. Ze zijn afgebeeld boven de organisatie in figuur 9.1. Daarnaast beschikken publieke dienstverleners meestal over een aantal semi-interne organen: een cliëntenraad of ander orgaan dat afnemers vertegenwoordigt, een orgaan dat namens deskundigen soms advies geeft, een orgaan zoals een ombudsman of klachtencommissie die zich op klachten, beroep en bezwaar richt, en ook een raad van toezicht of commissarissen. Naast deze formele kanalen zijn er nog andere partijen waarmee zij intensieve, informele relaties onderhouden: ketenpartners, collegainstellingen, andere publieke instellingen, belangenorganisaties en lokale en soms landelijke media. In totaal leidt dit tot een verantwoordingsregime, waarin publieke dienstverleners veelal te maken hebben met dertien belangrijke (groepen van) externe verantwoordingsfora.

De consequentie van de toename van verantwoordingsfora is opnieuw dat het de werking van de voorspelbare democratische delegatieketen ondergraaft. Na de diversificatie van de actor diversifieert nu ook het verantwoordingsforum. Dit kan ertoe leiden dat organisaties worden overladen met verantwoordingsvragen, met tegenstrijdige eisen van verschillende verantwoordingsfora of juist met het uitblijven van verantwoordingsvragen, omdat de verschillende fora slechts een 


\section{Figuur 9.1 Brede publieke verantwoording}

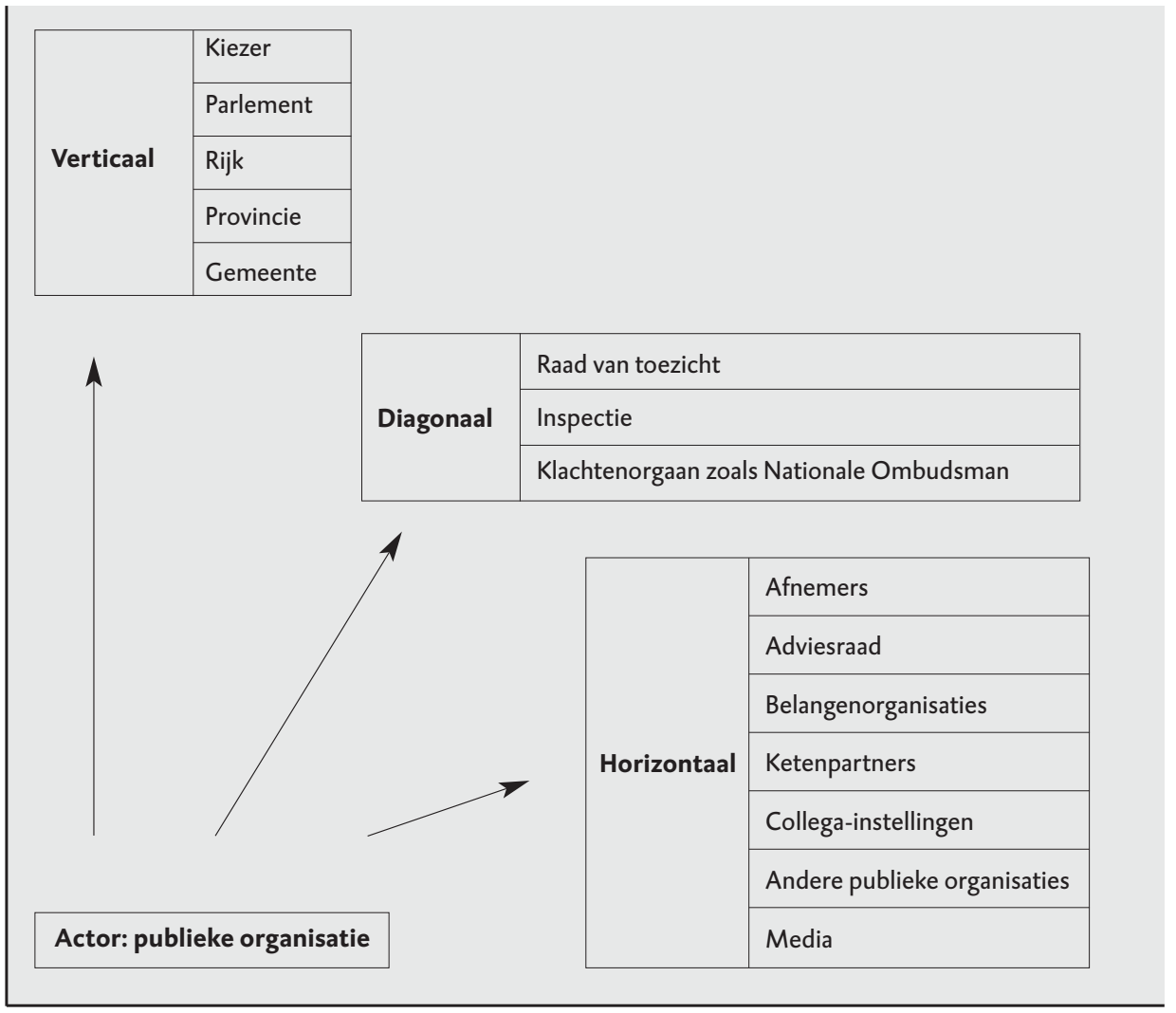

deelverantwoordelijkheid zien of verwachten dat een ander ingrijpt. Dit maakt het verantwoordingsproces onvoorspelbaar. Een Nederlands zelfstandig bestuursorgaan voerde bijvoorbeeld al enkele jaren een bepaald beleid, dat was geaccordeerd door de Tweede Kamer. Een ongelukkige gebeurtenis leidde tot een incident waarover werd bericht in de pers, waarna de minister, een inspectie, de Tweede Kamer, de raad van toezicht én een commissie van experts om opheldering en verantwoording vroegen. De aanleiding hiervoor was een kritisch artikel in De Telegraaf: pas nadat de krant van wakker Nederland erover berichtte werden ook de verschillende formele verantwoordingsfora wakker. Dit leidde tot een serie vragen, rapporten en maatregelen, die tot op zekere hoogte een herziening van het bestaande beleid inhielden. De onvoorspelbaarheid van het stelsel met meerdere verantwoordingsfora werd zo versterkt door de onvoorspelbaarheid van mediaberichtgeving. De 'agenda' van formele verantwoordingsfora zoals burgers (McCombs 2004), het parlement (Brants \& Van Praag 2005), raden van toezicht en cliëntenraden (Schillemans 2007a) wordt ten dele door mediaberichtgeving bepaald; zodoende versterkt mediaberichtgeving de onvoorspelbaarheid van 
verantwoordingsprocessen. In de volgende paragraaf gaan we hier dieper op in en concentreren ons op een bijzonder maar veelvoorkomend 'geval': zelfstandige bestuursorganen in het nieuws.

\subsection{VERANTWOORDING AAN DE MEDIA}

In de naoorlogse periode hebben de media zich ontwikkeld van betrekkelijk volgzame schoothonden van de macht naar onafhankelijke, veelvormige maar vaak wel kritische commentatoren (Van Vree et al. 2003; Brants \& Van Praag 2005). Deze ontwikkeling heeft beslist positieve zijden. In het geval van het CAK was er bijvoorbeeld een mêlee aan klachten die dankzij het redactioneel activisme van Kassa ongetwijfeld sneller en met meer urgentie ter hand is genomen. Tegelijkertijd vervult de actievere rol van hedendaagse media velen ook met de nodige zorg. Het zou ertoe leiden dat we ons bevinden in een tijdperk van medialogica (RMO 2003) dat het publieke debat in haar greep zou houden, waardoor we zouden afstreven op een mediacratie of een dramademocratie (Elchardus 2002).

Media fungeren zowel in directe als in indirecte zin als verantwoordingsfora voor publieke organisaties. In directe zin kunnen media zelfstandig als verantwoordingsforum worden beschouwd. Immers, journalisten stellen geregeld kritische vragen aan gezagsdragers, zij wegen de antwoorden kritisch en publiceren daarover geregeld kritische stukken. Vanuit het perspectief van publieke organisaties is dit al snel een vorm van sanctioneren: zij vrezen reputatieschade door negatieve berichten.

Media danken deze rol aan drie bronnen. In de eerste plaats biedt de grondwettelijke vrijheid van meningsuiting journalisten de gelegenheid kritische vragen te stellen aan gezagsdragers en er kritische artikelen of uitzendingen over te maken. Vervolgens zorgt de veranderde opvatting over openbaarheid in het publieke domein ervoor dat zij ook daadwerkelijk informatie ontvangen. Bestuurlijke informatie voorbij de openbaarheid van vergadering is in toenemende mate een recht geworden van journalisten, in plaats van een gunst. De introductie van het gesprek met de minister-president in 1970 direct uit de ministerraad is in dat opzicht een historisch moment: het primeurrecht van de Kamer verschoof min of meer naar de pers. Niet langer deed de ministerraad als eerste verslag aan het parlement over zijn overleg, nu deed men dat als eerste aan de pers - en langs die weg uiteraard direct aan de Nederlandse burger en de volksvertegenwoordigers. In de derde plaats biedt de Wet openbaarheid van bestuur sinds 1980 journalisten (en andere burger-verantwoordingsfora) ook daadwerkelijke toegang tot de meeste overheidsinformatie.

De media spelen voorts een belangrijke indirecte rol bij publieke verantwoording, doordat zij een informerende en vooral attenderende rol vervullen voor de belang- 
rijkste democratische verantwoordingsfora. Om te beginnen zijn ze veruit de belangrijkste bron van informatie over de overheid voor burgers. Het formele stelsel van publieke verantwoording wordt 'afgesloten' met het kiesrecht en het vermogen van de burgers als ultieme principalen in het bestuur om gezagsdragers naar huis te sturen. Om dit op betekenisvolle wijze te doen is het noodzakelijk dat burgers ook kennis hebben van wat hun vertegenwoordigers in het bestuur daadwerkelijk doen. Onderzoek heeft steeds weer laten zien dat voor de grote meerderheid van burgers de media zonder concurrentie het belangrijkste informatiekanaal zijn (McCombs 2004; zie ook Blanken 2009). In dat opzicht vervullen de media dus een zeer belangrijke intermediaire (sic!) rol in het formele stelsel van publieke verantwoording. Bovendien spelen ze ook een preventieve, gedragssturende rol (zie Arnold 2004): als gezagsdragers weten dat de kans groot is dat er zal worden bericht over hoe zij zich gedragen, dan heeft dit invloed op wat zij doen. Alleen de anticipatie op berichtgeving stuurt dus al gedrag in die zin dat gedrag dat er slecht af zou komen in de pers wordt ontmoedigd (dat is overigens niet alleen maar positief).

Verder maken ook parlementariërs in belangrijke mate gebruik van informatie van de media om toezicht te houden op het bestuur. Dit blijkt alleen al uit het aantal Kamervragen dat direct op mediaberichtgeving is gebaseerd. Kennelijk is het zo dat Kamerleden mediaberichtgeving een gezaghebbende bron van informatie over de samenleving achten die zij actief gebruiken in hun toezicht op het bestuur. Vanuit de bestuurskunde wordt deze 'scannende' rol van toezicht houden wel omschreven als een vorm van fire alarm: toezichthouders als Kamerleden maar ook inspecties en departementale toezichthouders scannen (onder meer) mediaberichtgeving op rooksignalen die erop duiden dat er ergens iets systematisch fout zit (McCubbins \& Schwartz 1984). En net als brandweerlieden treden ze pas op nadat ze zijn gewaarschuwd door het alarm. Vanuit de communicatiewetenschap is hetzelfde proces beschreven met de burglar alarm metafoor voor het nieuws (Arnold 2004).

Belangrijk te beseffen is dat het initiatief voor berichtgeving niet alleen bij journalisten ligt. Vaak worden media getipt en oneerbiedig gezegd 'gebruikt' door politici, ministeries, andere publieke organisaties, belangengroepen of burgers, die om uiteenlopende redenen proberen berichtgeving te entameren en te beïnvloeden.

Het kritische punt ten aanzien van de media in het perspectief van publieke verantwoording is dat de pers (terecht, vanuit de eigen logica) slechts all the news that's fit to print publiceert. Journalisten berichten niet over alles wat er in het openbaar bestuur gebeurt, maar berichten alleen over wat daar nieuwswaardig aan is. Het articuleren van wat nieuwswaardig is gebeurt niet primair door de gezagsdragers, zoals nog wel grotendeels het geval was in de verzuilde naoorlogse periode, maar is in laatste instantie een 'gave' waarover de journalistiek beschikt. Journalisten bepalen wat nieuwswaardig is, en bevoordelen daarbij het schandaal 
boven het succes en de anomalie boven de normaliteit. De meeste organisaties en gebeurtenissen in het openbaar bestuur kunnen daardoor onderwerp van mediaberichtgeving worden, al gebeurt dat meestal niet. En als er dan berichtgeving volgt over een publieke organisatie heeft dat al snel het karakter van een roep om verantwoording, omdat publieke organisaties vaak negatief in het nieuws komen.

Neem de zelfstandige bestuurorganen, organen die belast zijn met openbaar gezag en niet geheel ondergeschikt zijn aan de minister, die zo'n emblematische rol vervullen in de Nederlandse discussie over horizontaal bestuur (Van Thiel 2000; Bovens 2003; Michels \& Meijer 2003). Een belangrijk deel van wat de overheid 'doet', doet het via honderden zelfstandige bestuursorganen waar meer mensen werken dan bij de centrale overheid (Van Thiel 200o: 39). De meeste zBO’s doen weinig dingen die de media nieuwswaardig vinden. Desalniettemin is er een constante stroom van berichten over Zво's en weten hun bestuurders dat hun handelen door journalisten onder de loep kan worden genomen. Hierna volgt een indicatie van de berichtgeving over zво's - maar ook andere uitvoerende organisaties - die vooral duidelijk maakt dat zij weliswaar niet in het centrum van de media-aandacht staan, maar dat er wel degelijk een constante stroom berichten over deze organisaties is die vaak ook een negatieve toon heeft en dus belangrijk is in het perspectief van publieke verantwoording. ${ }^{4}$

Figuur 9.2 laat zien hoe vaak Zво's het centrale onderwerp zijn in de berichtgeving. ${ }^{5}$ De figuur laat zien dat de Volkskrant, NRC Handelsblad en Het Financieele Dagblad ieder jaar zo'n 300 tot 700 berichten publiceren over ZBO's. Dit komt neer op gemiddeld zo'n vijf berichten per dag waarin zBO's centraal staan.

\section{Figuur 9.2 Omvang berichtgeving over ZBO's in 3 kranten 1999-2008}

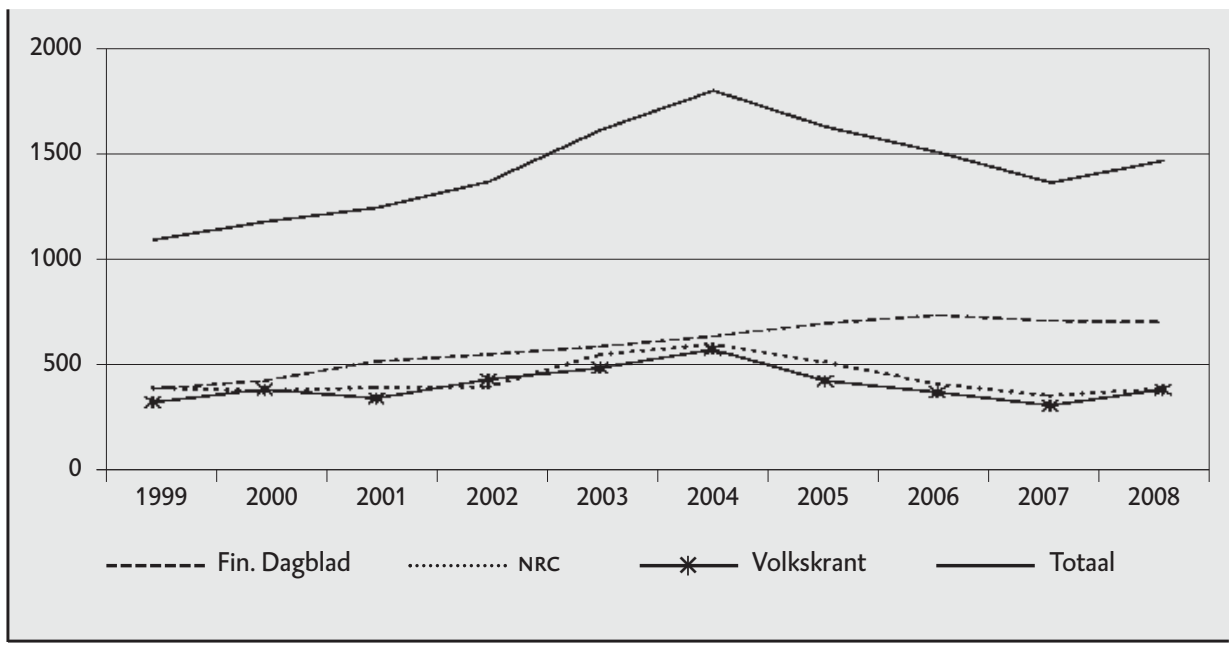


Sommige Zво's, zoals de Nederlandsche Bank of het UwV, worden vrijwel dagelijks in de krant of in andere media genoemd. Veel andere zво's komen slechts bij uitzondering aan bod. Desalniettemin, wanneer we kijken naar alle berichtgeving over organisaties, dan blijkt dat ook 'onbekende’ zво's zoals de Energiekamer (198 berichten in 2008) en het NCDO ( 161 berichten in 2008) met regelmaat aan bod komen. ${ }^{6}$

De Haagse politiek krijgt ondanks de verplaatsing van publieke taken nog steeds de meeste media-aandacht. Desondanks behandelt bij indicatie eenderde deel van de berichten in kwaliteitskranten uitvoerende organisaties zoals zво's, maar ook maatschappelijke ondernemingen als onderwijs- en zorginstellingen en publieke monopolisten zoals Schiphol.7 De berichtgeving was - volgens het adagium dat goed nieuws geen nieuws is - veel vaker negatief dan positief. Uitvoerende organisaties werden in 45 procent van de gevallen in neutrale termen beschreven, in 40 procent van de gevallen was het negatief en in 14 procent van de gevallen positief. In de meeste gevallen gingen de negatieve verhalen over falend management, nalatige personen of slecht bestuur. Doorgaans zijn het berichten naar aanleiding van incidenten, waar journalisten doorgaans structurele oorzaken voor suggereren. Volgens een grove inschatting is zo'n tweederde van de negatieve berichten van deze aard. Een klein derde deel van de negatieve berichten verschijnt naar aanleiding van meer structurele problemen, zoals falend beleid of overmatige bureaucratie.

Wanneer we wat preciezer kijken naar de verdeling van positieve en negatieve aandacht, dan wordt duidelijk dat er vooral verschillen zijn tussen organisaties ten aanzien van hun taken en berichtgeving. Grofweg kunnen organisaties worden ingedeeld als publieke dienstverleners (scholen, ziekenhuizen, gevangenissen, uitkeringsinstanties), regulerende organisaties (inspecties, toezichthouders, Nederlandsche Bank) en informatieorganisaties (CBS, NWO, Onderzoeksraad voor veiligheid). Analyse van de berichtgeving liet zien dat publieke dienstverleners vooral uitgesproken in het nieuws komen: zij ontvangen de meeste kritiek, maar daarentegen ook bijna alle lof. De toezichthouders en vooral de informatieorganisaties figureren sterk in neutrale zin in berichten, als bronnen van autoriteit of feiten in berichten waarin andere actoren het goed of juist slecht gedaan hebben.

Een analyse van alle uitzendingen uit één seizoen van de kritische consumentenprogramma's Radar, Kassa en Zembla bevestigt dit beeld. Voor zover publieke organisaties het hoofdonderwerp zijn van hun uitzendingen is het doorgaans negatief en komen zij als onverschillige, onwillige of incapabele organisaties voor het voetlicht. Er zit een zeker verhaal van 'opkomen voor de zwakkeren', of - anders geformuleerd - 'de burger versus de instantie' in de meeste items. Bijvoorbeeld de weerloze zieke in het vieze ziekenhuis; de gewone burger die wordt vermalen door de trage molens van de gemeente. De aankondiging van de 


\begin{tabular}{|c|c|c|c|}
\hline \multicolumn{4}{|c|}{ Aantallen positieve, neutrale en negatieve berichten totaal } \\
\hline & $\begin{array}{c}\text { Totaal aantal } \\
\text { positieve berichten }\end{array}$ & $\begin{array}{c}\text { Totaal aantal } \\
\text { neutrale berichten }\end{array}$ & $\begin{array}{c}\text { Totaal aantal } \\
\text { negatieve berichten }\end{array}$ \\
\hline & $14 \%$ & $45 \%$ & $40 \%$ \\
\hline \multicolumn{4}{|c|}{ Verdeling positieve en negatieve berichten over verschillende typen organisaties } \\
\hline & Informatie-organisaties & Dienstverleners & Regulerende organisaties \\
\hline $\begin{array}{l}\text { Procentueel aandeel in } \\
\text { negatieve berichten }\end{array}$ & $0 \%$ & $88 \%$ & $12 \%$ \\
\hline $\begin{array}{l}\text { Procentueel aandeel in } \\
\text { positieve berichten }\end{array}$ & $7 \%$ & $86 \%$ & $7 \%$ \\
\hline $\begin{array}{l}\text { Procentueel aandeel in } \\
\text { berichten totaal }\end{array}$ & $9 \%$ & $75 \%$ & $16 \%$ \\
\hline
\end{tabular}

uitzendingen zijn wat dat betreft illustratief. In 2008 waren er bijvoorbeeld de volgende deelonderwerpen: 'zwakbegaafd en opgesloten', 'gek door gemeente', 'consumenten tegen slimme meters', 'gebrekkig toezicht op misbruik', en 'verzwegen medische missers'.

Publieke organisaties komen al met al redelijk veel - en redelijk vaak negatief - in het nieuws. In de totale nieuwsstroom zijn de traditionele Haagse machten dominant. Vanuit organisaties bezien zijn media daarentegen zeer belangrijk: zelfs betrekkelijk kleine en onbekende organisaties zijn met enige regelmaat onderwerp van berichtgeving. Dit gegeven past bij bevindingen van betrokkenen: in een kleine serie focusgroepen is betrokkenen gevraagd of zij ervaren dat er veel mediaaandacht is en media voor hen belangrijk zijn, en zonder uitzondering gaf men daarbij aan dat dit in sterke mate het geval is. De grens tussen verantwoording aan de media en het overdragen van informatie aan de media is daarbij in de praktijk moeilijk te trekken. Gegeven het feit dat journalisten negatief nieuws nieuwswaardiger vinden dan positief nieuws - en gegeven het feit dat negatief nieuws een smet op een reputatie werpt en door formele verantwoordingsfora kan worden waargenomen - is omgang met de media al gauw enigszins riskant. Er bestaat een dunne lijn tussen vragen van journalisten en vragen om verantwoording. Anders gezegd, door de dubbele rol van media bij verantwoordingsprocessen als zelfstandig verantwoordingsforum en als informatiebron voor de formele verantwoordingsfora, is alle berichtgeving in de media relevant uit het oogpunt van publieke verantwoording. 


\subsection{VERANTWOORDING EN ONVOORSPELBAARHEID}

Publieke verantwoording is in theorie gebaat bij voorspelbaarheid en overzichtelijkheid, zo is hier aan het begin gesteld. Het regime werkt in theorie het beste wanneer duidelijk is wie er verantwoordelijk is voor welke taak en met welke middelen, wat de normen en doelen zijn die bij de taak in het geding zijn, wie het verantwoordingsforum is en hoe het zal opereren. De horizontalisering van het bestuur compliceert dit beeld: er zijn vaak vele actoren betrokken bij de uitvoering, er zijn verschillende verantwoordingsfora die (kunnen) toezien en er is selectieve mediaberichtgeving, die de formele verantwoordingsfora kan activeren. Deze ontwikkelingen maken verantwoordingsprocessen wezenlijk onvoorspelbaar. Het kan zijn dat geen van de verschillende verantwoordingsfora optreedt wanneer dat nodig is. Het is de paradox van meervoudige verantwoording: juist het feit dat verschillende verantwoordingsfora actief zijn kan tot gevolg hebben dat geen van hen zich geroepen voelt op te treden. Het kan omgekeerd in andere situaties ook zo zijn dat meerdere verantwoordingsfora optreden en feitelijk met elkaar gaan concurreren. Opvallend is bijvoorbeeld dat bij een aantal recente problemen bij grote uitvoeringsorganisaties, de taken van alle betrokkenen (ministerie, organisatie, inspectie, raad van toezicht, orgaan dat afnemers vertegenwoordigt) in de nasleep werden heroverwogen en dat ze allen bemoeienis hadden met de zaak in kwestie (Schillemans 2007a). Gedurende de 'crisis' richtten zij zich allemaal op dezelfde zaak, zij het vaak vanuit verschillende perspectieven. Dit leidt in theorie tot wat Koppell (2005) noemde multiple accountabilities disorder: meervoudige verwachtingen en impulsen uit publieke verantwoording waar tegenstrijdige verwachtingen uit voortkomen. Het kan organisaties lamleggen of inefficiënt maken, omdat zij het alle verantwoordingsfora tegelijk naar de zin trachten te maken, daardoor inconsequent en ineffectief worden en er uiteindelijk toch niet in slagen al hun meesters te behagen.

Onzekerheid over potentiële verantwoording kan nadelig werken in het bestuur. Het risico bestaat dat bestuurders en organisaties zich vooraf gaan indekken tegen alle potentiële verantwoordingsvragen. Dit heeft als potentieel gevaar goal-displacement. Het voldoen aan een norm wordt dan een doel op zich, en de organisatie richt zich niet langer op het bereiken van het achterliggende doel waar die norm een indicator voor was. Politieagenten gaat het dan om aantallen processenverbaal - en niet om veiligheid - en wetenschappers tellen alleen nog aantallen publicaties - en niet de kenniswinst door hun onderzoek (zie ook Meijer et al. 2009). Het kan er vervolgens ook toe leiden dat verantwoordingsprocessen formaliseren. Ze gaan dan niet meer over feitelijke praktijken in het openbaar bestuur maar over formele systemen. Alleen de prestaties op papier worden dan beoordeeld en niet meer de daadwerkelijk geleverde kwaliteit. Dit is bijvoorbeeld opgetekend bij veel visitaties: zij richten zich, bijvoorbeeld in de zorg, op de kwaliteit van de kwaliteitsbewaking en nauwelijks meer op de kwaliteit van de zorg zelf 
(Schillemans 2009). Bovendien kan al te dreigende en onzekere verantwoording lerend en innovatief gedrag ontmoedigen. Een te rigoureus verantwoordingsregime verandert publieke instellingen in defensieve, formalistische, door regels en formulieren geobsedeerde bureaucratieën. Uit angst voor de publieke afrekening nadien vermijden bestuurders moeilijke of onzekere keuzes. Dat heeft overigens wel een zeker gunstig preventief effect: zonder twijfel behoedt het hen (en ons) voor sommige boude maar onverstandige keuzen. Maar het nadeel daarvan is dat lastige vraagstukken op de lange baan kunnen worden geschoven en dus ook onopgelost blijven. Uit zorg over de kwaliteit en de prestaties moeten publieke organisaties verantwoording afleggen -, maar waar deze te scherp is, leidt dit tot defensief gedrag waardoor, paradoxaal genoeg, de kans juist kleiner wordt dat die kwaliteit en prestaties ook daadwerkelijk worden geleverd.

Tegelijk biedt onzekere verantwoording ook enkele voordelen waar het bestuur gebruik van kan maken. Juist het brede stelsel van toezichthouders genereert meer inzicht in de uitvoering en biedt extra kansen om problemen op te sporen. Het geeft als zodanig dus ook houvast. Het CAK-voorbeeld waarmee deze beschouwing begon geeft daar een mooi voorbeeld van: juist de gecombineerde inzet van Ombudsman, oppositieleden, televisie- en krantenredacties leidde ertoe dat de problemen die burgers kennelijk bij het CAK ondervonden sneller ter hand werden genomen. Bovendien heeft onzekerheid ook een reflectie bevorderend potentieel, dat onder de juiste omstandigheden kan worden gebruikt om de kwaliteit van de publieke taakuitvoering te versterken. We werken deze positieve punten in de volgende paragrafen verder uit.

In het vervolg van deze bijdrage verleggen we de analyse van trends in bestuur en verantwoording naar de vraag hoe de overheid kan omgaan met de onzekere verantwoording die eruit voortkomt. Daarbij hanteren we als uitgangspunt dat de omvang van de onzekerheid te beïnvloeden is door de overheid, want waar horizontalisering voortkomt uit beleidsbeslissingen kunnen die vaak ook weer ongedaan worden gemaakt. Tegelijk zal het verschijnsel als zodanig voorlopig in ieder geval nog wel blijven bestaan, want een deel van de drijvende krachten valt buiten het beïnvloedingsbereik van de nationale overheid. Dat geldt zeker voor de rol van de nieuwsmedia die - gelukkig - niet wordt bepaald in Den Haag.

Hoe zou een respons eruit kunnen zien? Uitgangspunt is dat onvoorspelbaarheid een gegeven is, waarin publieke organisaties en het nationale bestuur prudent moeten opereren. Regulering ervan is niet onmogelijk maar uitbannen wel. Een prudente benadering vergt een combinatie van accepteren, benutten én bestrijden. Acceptatie betreft het uitgangspunt: verantwoordingsregimes inrichten op basis van de erkenning van onvoorspelbaarheid. Benutten draait erom gebruik te maken van de onvoorspelbaarheid waar mogelijk - er zitten ook voordelen aan onvoorspelbaarheid die hierna voor het voetlicht worden gebracht. De media kunnen 
daarin overigens zeer goed gebruikt worden, zowel door de bestuurders van uitvoeringsorganisaties om hun organisatie te etaleren als door landelijke toezichthouders en ministeries om informatie over de uitvoering te krijgen en er een zekere druk op te kunnen uitoefenen. Tot slot gaat het ook om het bestrijden van onvoorspelbaarheid - niet in het algemeen maar heel gericht daar waar het een erg nadelige invloed heeft. We bespreken de respons hierna in hoofdlijnen langs de drie niveaus die hier aan het begin zijn onderscheiden: de regimes van verantwoording, de inzet van specifieke verantwoordingsmechanismen en het doel van verantwoording. Dit leidt niet tot een concreet programma voor aanpassingen en veranderingen. Het is in de eerste plaats een pleidooi voor een wisseling van perspectief: een onzekere omgeving vergt een andere benadering van publieke verantwoording en kritische media. De nu volgende beschouwing wil daar handreikingen voor geven.

\subsubsection{VERANTWOORDINGSREGIME: VAN HIËRARCHIE NAAR REDUNDANTIE}

De eerste stap in onze respons richt zich op de ordening van verantwoordingsregimes. De traditionele hiërarchische inrichting van het openbaar bestuur veronderstelt een hiërarchie in de verhoudingen tussen actoren en eenduidigheid ten aanzien van verwachtingen en normen die op gespannen voet staat met de feitelijke horizontalisering van het openbaar bestuur. Dit is niet vreemd, het is een noodzakelijke basis voor democratisch bestuur die niet kan wijken onder de druk van maatschappelijke en bestuurlijke horizontalisering. Desalniettemin is het zinnig om als aanvulling hierop inspiratie te zoeken bij auteurs die de laatste decennia over de voordelen van redundantie hebben geschreven voor de inrichting van complexe stelsels of systemen. Zij beschrijven hoe redundantie - hier: overlap tussen verantwoordingsmechanismen - kan helpen om complexe systemen te beheersen en te sturen. De inzichten zijn zeer bruikbaar als uitgangspunt voor de inrichting van complexe verantwoordingsregimes.

In het denken over redundantie in de publieke sector is het baanbrekende artikel uit 1969 van Landau van groot belang. Hier gaf hij een hoogst verrassend bevestigend antwoord op de vraag of een betrouwbaar systeem kan worden opgebouwd uit onbetrouwbare onderdelen. Zijn stelling was dat dit niet alleen mogelijk was, maar zelfs op tal van plaatsen in het openbaar bestuur feitelijk al het geval was. Het argument voor redundantie luidt eenvoudig gesteld dat complexe systemen aan betrouwbaarheid winnen als zij bestaan uit parallelle, overlappende of concurrerende schakels. Want de ene schakel kan dan, mits hij onafhankelijk opereert, de fouten van de anderen corrigeren. Redundantie geldt daarom als een substituut voor perfecte onderdelen.

Pleitbezorgers van redundantie baseren hun argumentaties doorgaans op in het oog springende voorbeelden waar grote risico's in het geding zijn. Zij laten zien 
dat redundantie de sleutel is tot goede beveiliging van nucleaire installaties (Carroll 2004), de snelle wederopbouw van hoofdkantoren van multinationals na de aanslagen van 11 september (Stein 2002) en het Manhatten-project (Bendor 1985). Ook in de Amerikaanse grondwet zijn redundante elementen geïncorporeerd om het risico van machtsmisbruik door de gekozen machten tegen te gaan. Daartoe zijn machten gescheiden, bestaan er verschillende stemrondes, procedures voor codecisie bij belangrijk besluiten en andere checks and balances (Bendor 1985: 38). In feite gaat het ook hier steeds om redundante systemen. Het belang van redundantie neemt toe in omstandigheden van complexiteit en onzekerheid (Landau 1969: 352; Bendor 1985: 54); de trefwoorden in de beschouwingen tot zover. Redundantie is een manier om flexibeler met beide te kunnen omgaan.

Redundantie heeft in beginsel een aantal voordelen. Het biedt de mogelijkheid om de meervoudigheid aan doelen en waarden bij overheidsbeleid te incorporeren in plaats van a priori te pogen meervoudigheid op te heffen. Soms is redundantie goedkoper dan afstemming en coördinatie, omdat er veel lagere (re)organisatie- en afstemmingslasten zijn (Wildavsky 1973). Redundantie kan voorts het informatieprobleem van toezichthouders mitigeren, omdat het informationele rijkdom creëert. Verantwoordingsfora zoals departementale toezichthouders en raden van toezicht kampen als principalen per definitie met informatieasymmetrie (zie Strøm 200o). Zij moeten hun oordelen baseren op informatie die door de organisatie zelf wordt geproduceerd en dus ook kan worden bewerkt. Om manipulatie te voorkomen kennen de meeste verantwoordingsarrangementen daarom beschermingsmaatregelen die de tijdigheid, betrouwbaarheid en volledigheid van informatie garanderen. Een zekere competitie tussen verantwoordingsfora past hierbij, omdat het informatie 'perst' uit overheidsorganisaties (Bendor 1985: 257). Overlappende verantwoordingsarrangementen kunnen elkaar voorts compenseren of versterken. Neem nogmaals het voorbeeld van het CAK waar deze beschouwing mee begon: slechts door het samengaan en ook concurreren van media en formele verantwoordingsfora als Kamerleden en de Ombudsman werden de kennelijke problemen sneller ter hand genomen. Dit laatste argument is het belangrijkste: als de organisatie de verantwoordingsprocessen complexer en onvoorspelbaarder worden is het een stap in de goede richting om meer redundantie in te bouwen door parallelle verantwoordingsarrangementen. Het is een geval van catching thieves with thieves: in een horizontaler en onvoorspelbaarder stelsel van publieke taakuitvoering is er dan een horizontaler en redundanter stelsel van publieke verantwoording.

Tegenover de voordelen van redundantie staan uiteraard ook potentiële nadelen. Twee in het bijzonder verdienen hier vermelding. In de eerste plaats is redundantie natuurlijk niet gratis: aan parallelle verantwoordingsarrangementen zijn uiteraard kosten verbonden. Het hebben van overlappende toezichthoudende organisatieonderdelen, bijvoorbeeld in wat vaak de controletoren is genoemd 
(commissie-Van Lunteren 2004), is een forse kostenpost. Op dit punt zijn de media en de Wet openbaarheid van bestuur een nuttige vorm van redundantie. Het is in zekere zin een vorm van gratis, redundante verantwoording, al zijn er natuurlijk wel kosten verbonden aan de omgang met de media door personen en organisaties in het openbaar bestuur.

Het tweede nadeel van redundante verantwoording is dat het een variëteit aan inhoudelijke signalen oplevert en dat de eindverantwoordelijkheid zoek kan raken. Zoals hier reeds een aantal keren is aangegeven: waar er meerdere verantwoordingsfora zijn is het risico reëel dat ze allemaal op de ander wachten wanneer zich misstanden voordoen of dat ze zich terugtrekken op hun eigen deelverantwoordelijkheid. Ook op dit punt kunnen de media een nuttige rol vervullen doordat journalisten zich met grote (en voor betrokkenen soms erg vervelende) vasthoudendheid blijven richten op elementaire vragen over succes of falen van beleid. De meeste technische en als zodanig zeer belangrijke elementen van beleid zijn niet nieuwswaardig, journalisten zoeken vooral naar de situaties waar het helemaal fout of juist wonderbaarlijk goed ging. Op die manier vormt juist de journalistiek een belangrijke check op het falen van formele verantwoordingsfora. En met succes: bij grote affaires in de afgelopen periode zoals corruptie in Limburg, de hbo-fraude of ook de problemen bij het CAK was de redundante verantwoording aan de media elementair in het opsporen en agenderen van de problemen.

Dit pleidooi voor redundantie is in eerste instantie vooral gericht op de bril waarmee we het stelsel van publieke verantwoording bezien. Overlap tussen verantwoordingsfora biedt extra zekerheid, vergroot de kans dat zulke fora ingrijpen en vergroot de hoeveelheid informatie die er over uitvoerende organisaties beschikbaar is. Zoals met veel zaken in het leven is de praktische uitwerking hiervan een kwestie van maatvoering: soms zal de overheid de overmatige overlap tussen verantwoording vragende partijen moeten bestrijden om de verantwoordingslast te verminderen of de centrale controle te versterken. In andere gevallen is de ordenende taak van de overheid eerder gelegen in het compenseren van gebrekkige redundantie door het inrichten van een extra verantwoordingsforum of het verbreden van de toezichtbasis van een inspectie. In alle gevallen biedt redundantie, in aanvulling op de blijvende centrale rol van de democratische delegatieketen, het eerste deel van het antwoord op de vraag hoe de overheid kan omgaan met onvoorspelbare verantwoording.

\subsubsection{VERANTWOORDINGMECHANISMEN: VAN RECHTMATIGHEID NAAR PRESTATIES}

Het tweede deel van de benadering richt zich op de keuze van verantwoordingsmechanismen. Veel traditionele publieke verantwoordingsarrangementen zijn generiek van karakter (zie Schillemans \& Bovens 2009). Ze vragen van de actor 
een brede verantwoording over een reeks van onderwerpen. Deze publieke verantwoording is sterk gestandaardiseerd en in zekere zin aanbodgericht. Verantwoordingsdocumenten, zoals jaarverslagen, kennen standaardindelingen, vaste protocollen en formulieren waarin is voorgeschreven hoe, zo uniform mogelijk, grote hoeveelheden gegevens moeten worden aangeleverd. Traditionele verantwoording is ook sterk geroutiniseerd en komt met de vaste regelmaat van kwartalen, seizoenen of jaren op ons af. Ze is niet alleen in regels en protocollen vastgelegd, ze is ook sterk gericht op regelconform gedrag. Vooral voor de rechtmatigheid en comptabiliteit, de financiële verantwoording, is veel aandacht.

Het nadeel van deze focus in een context van onvoorspelbare verantwoording is tweeledig. In de eerste plaats kan de gevreesde, potentiële verantwoording organisaties nodeloos defensief maken en het minutieus naleven van de regels tot doel op zich maken. Publieke organisaties doen dan aan goal-displacement en verliezen de uiteindelijke uitkomsten van hun werk uit het oog. In het verlengde daarvan kan het organisaties risico-avers en onnodig bureaucratisch maken.

In de huidige context zou het goed zijn naar verantwoordingsmechanismen te kijken die zich sterker richten op de doelstellingen van beleid en organisaties en minder aanzetten tot defensief gedrag. Er zijn op dat punt de laatste jaren interessante innovaties op gang gekomen. Van Rijn en Van Twist (2009) hebben een aantal innovaties besproken op het gebied van verantwoorden, waarin het verantwoordingsproces steeds wordt teruggebracht tot een beperkt aantal scherp gedefinieerde en bediscussieerde prioriteiten. Deze innovaties komen onder vergelijkbare namen: CompStat, CityStat, StateStat, MaasStat - we vatten deze samen als X-Stat.

Een terugkerend element bij de verschillende varianten van X-Stat is de Stat van statistiek. Via geavanceerde registratie- en weergavesystemen wordt statistische informatie sterk verdicht en gelaagd weergegeven. Informatie over bijvoorbeeld ontwikkelingen van onveiligheid of leefklimaat wordt idealiter samengevat in enkele powerpoints en enkele A4's met de belangrijkste ontwikkelingen of beleidsresultaten. Dit vergt veel voorbereiding en bewerking van informatie, dus op dat punt is het geen versobering, maar het leidt wel tot een sobere en puntige presentatie van informatie. X-Stat werkt natuurlijk alleen maar wanneer actor en forum erin slagen de informatie-uitwisseling en hun onderlinge dialoog toe te spitsen op een zeer beperkt aantal, maar absoluut cruciale indicatoren of doelstellingen. Dit kan alleen in die gevallen waar zij het eens zijn over de gewenste uitkomsten. Een focus op maatschappelijke eindeffecten vergroot hier de kans op: rondom criminaliteitscijfers (zo laag mogelijk), schoolprestaties (diploma's), enkele kernindicatoren van zorg (bereik en sterftecijfers) bestaat grote consensus over wat de doelen zijn. Pas als die er is - of kan worden gerealiseerd in het proces - is het goed om deze informatie vervolgens in hoorzittingen te bespreken, met 
leidinggevenden én collega's. Daarbij gaat het erom te analyseren wat de betekenis is van de gepresenteerde informatie voor de kwaliteit van beleidsuitvoering. Zodoende ontstaat als het goed is een fijnmazig inzicht in de maatschappelijke ontwikkelingen en de effectiviteit en kwaliteit van het ingezette beleid.

In de statistische benadering die hier wordt beschreven blijft natuurlijk het risico op goal-displacement bestaan. Dit is hanteerbaar onder een aantal condities. In de eerste plaats is het van belang alleen dan kwantitatieve indicatoren te gebruiken en te benoemen wanneer die een goede maat vormen voor de gewenste uitkomsten van het beleid. Dat klinkt wellicht triviaal maar is het niet: in veel delen van de publieke sector wordt te vuur en te zwaard gemeten wat gemeten kan worden, zonder dat dit noodzakelijkerwijs informatie oplevert die leert of het beleid van een organisatie effectief is. In de tweede plaats dient de meer gefocuste verantwoordingsinformatie ook te worden gecomplementeerd door een kwalitatief hoogwaardig 'debat' tussen actor en forum. Het aardige van de oorspronkelijke comp stat meetings bij de politie in New York waren de checks and balances in de opzet: een districtshoofd presenteert de eigen cijfers, die worden vergeleken met die van andere korpsen, besproken met zijn conculega's onder aanwezigheid van de korpsbaas. De combinatie van hiërarchie en peer review voorkomt dan dat de mooi gepresenteerde informatie het eind- in plaats van het beginpunt is van het verantwoordingsproces. Een derde waarborg is het om een derde partij, de Rekenkamer bijvoorbeeld of een periodiek visitatiecollege, voor de 'productie' van informatie te laten zorgen om zo de manipulatie te beperken.

Van Rijn en Van Twist bespreken ook een andere uit de Angelsaksische wereld overgewaaide innovatie op het gebied van verantwoording: delivery units. De Prime Minister's Delivery Unit werd door Blair na zijn herverkiezing in 2001 opgericht. Deze kleine eenheid, direct onder de premier, zorgde ervoor dat 'deliverables' werden onderscheiden, dat er cijfers over de voortgang van het gevoerde beleid beschikbaar kwamen, en dat de regering zich kon verantwoorden over de realisatie van beleid. De Britse ontwikkelingen zijn door het kabinet-Balkenende met interesse gevolgd - het voormalige hoofd van de Britse Delivery Unit, Michael Barber, heeft er zelfs een presentatie gehouden. Deze filosofie van delivery is een belangrijke innovatie en inspiratiebron geweest voor het kabinet bij zijn verantwoordingsdag in 2008, zij het dat de zeggingskracht nog heel duidelijk kan worden versterkt. Belangrijk is de focus op een beperkt aantal maatschappelijke effecten, en het 'leveren' van gespecificeerde producten of resultaten, die het risico op formalisering en goal-displacement vermindert.

In het huidige bestuur worden deze vormen van verantwoording spaarzaam gebruikt. Het zou zeer de moeite waard zijn er op zijn minst op experimentele basis mee te werken, zeker in een gemediatiseerde omgeving. Het biedt voordelen in termen van focus op resultaten en beperkt de verantwoordingslast die organisa- 
ties ervaren. Bovendien leiden deze vormen van verantwoording tot eenduidiger conclusies, hetgeen in een kritische mediaomgeving positieve waarde heeft. Ook de 'feiten \& cijfers' doen het goed in het nieuws. En de hoorzittingsvorm die bij CompStat en delivery kan worden gebruikt kan zeer nieuwswaardig zijn, zoals bij parlementaire enquêtes en onderzoeken steeds duidelijk wordt. Voor publieke organisaties bieden deze vormen kansen om ten overstaan van betrokkenen en het algemene publiek te laten zien wat men doet. Voor het openbaar bestuur als zodanig biedt dit mogelijkheden om de kwaliteit van publieke verantwoording te vergroten en en passant 'gebruik' te maken van de media als goedkope, redundante verantwoordingsfora.

\subsubsection{DOEL VAN VERANTWOORDING: VAN NALEVEN NAAR VERBETEREN}

Het derde deel van de respons betreft het doel dat in verantwoordingsprocessen wordt nagestreefd. Het doel van veel verantwoordingsarrangementen is traditioneel om naleving van regels en geboden te bevorderen. In veel domeinen en ten aanzien van veel regels is dat ook van groot belang. Tegelijkertijd vergt de complexiteit van veel opgaven en de onvoorspelbaarheid van verantwoordingsprocessen vaak een benadering die meer is gericht op vooruitgang en verbetering (Van Gunsteren 1999). Dit vergt verantwoordingsprocessen die verantwoordende partijen aansporen om dieper te denken over hun keuzen en te leren van het verleden.

Verrassend genoeg biedt de onvoorspelbaarheid van horizontaler bestuur op zich ook aangrijpingspunten voor het versterken van reflectief gedrag. Onvoorspelbaarheid kan schuw maken, bureaucratisch gedrag opwekken of zelfs regelrechte leugens. Dat is allemaal waar. Desalniettemin is onzekerheid ook een zeer belangrijke creatieve kracht. Zo is het bijvoorbeeld vaak productief als er enige onzekerheid bestaat in verantwoordingsprocessen, omdat dit cognitieve stimulansen geeft aan actoren. Het gaat dan bijvoorbeeld om enige onzekerheid over de opzet en vorm van het proces of over het optreden en de normen van het forum. Dit heeft als voordeel dat de kans op ritualisering - verantwoordingsprocessen die plichtmatig maar betekenisloos verlopen - vermindert. Enige onzekerheid leidt tot mentale scherpte bij betrokkenen, al is het uiteraard een kwestie van maatvoering, want te grote onzekerheid heeft een verlammend effect of lokt juist strategisch gedrag uit.

De Amerikaanse sociaal psychologen Lerner en Tetlock (1999) hebben op een rij gezet wat er in de sociale psychologie bekend is over de effecten van verantwoording. In dat onderzoek gaat het steeds om experimenten waarin proefpersonen een opdacht krijgen waarover zij zich vervolgens aan iemand moeten verantwoorden. Een van hun conclusies is dat verantwoording vooral effectief is in anticipatie. Als mensen weten dát zij zich later over hun keuzen moeten verantwoorden, heeft dit vooruitzicht reeds invloed op hun keuzen. 
Een belangrijke les uit dit onderzoek is dat onzekerheid positieve effecten heeft. Actoren zullen hun keuzen namelijk beter doordenken en in breder perspectief afwegen wanneer zij weten dat zij a) later ter verantwoording zullen worden geroepen door b) een gezaghebbend forum waarvan c) niet exact bekend is welke normen het zal hanteren. Dit leidt volgens Lerner en Tetlock tot pre-emptive selfcriticism. Actoren bekritiseren dan de verschillende opties die zij hebben - in anticipatie op een verwachte verantwoording - en verwerken daarbij veel meer informatie dan zij bij reguliere keuzeprocessen doen. Het leidt letterlijk tot betere afwegingen (wat overigens niet hetzelfde is als betere uitkomsten). Deze les is in de publieke sector vooral relevant in al die situaties waarin de actor over discretionaire ruimte beschikt en de taak complex is.

Onzekerheid vergt wel altijd maatvoering; bij omvangrijke onzekerheid zullen actoren schaduwarchieven opbouwen om zich in te dekken tegen geanticipeerde verantwoordingsvragen (zie Noordegraaf \& Sterrenburg 2009). Het gaat er dus om enige onzekerheid te brengen die van situatie tot situatie verschilt.

Concreet kan dit betekenen dat de mate van openheid in verantwoordingsarrangementen wordt vergroot, zodat actoren weten dat hun gedrag kan worden waargenomen. Ook hier kunnen de media dus behulpzaam zijn om de werking van publieke verantwoording te verbeteren. Het kan ook betekenen dat de debatfase van verantwoording vaker de vorm aanneemt van een hoorzitting, waarin ambtelijke betrokken personen of experts een rol vervullen. Het kan ook helpen te experimenteren met vormen en bewust te variëren met vormen: actoren leren na verloop van tijd omgaan met bepaalde vormen van verantwoording en de productieve spanning die er mee gepaard gaat kan dan verdwijnen.

\subsection{SLOT}

Hoe kan de overheid omgaan met de onvoorspelbaarheid van verantwoordingsprocessen door de horizontalisering en mediatisering van het bestuur?

In dit essay is betoogd dat de organisatie van publieke verantwoordelijkheden, de inrichting van verantwoordingsstelsels en de druk van de nieuwsmedia een onvoorspelbaarheid met zich meebrengt die moeilijk past in de klassieke handelingsrepertoires van de overheid. De respons van de overheid zou uit drie elementen kunnen bestaan. Op het niveau van verantwoordingsregimes biedt redundantie de mogelijkheid om flexibeler om te gaan met een onzekere omgeving en extra zekerheden in te bouwen. Op het niveau van verantwoordingsmechanismen verdient het aanbeveling te experimenteren met nieuwe vormen die specifieker zijn en meer resultaatgericht. En op het niveau van de doelen van verantwoording is het in veel situaties aan te bevelen de focus te verleggen van naleving naar reflectie, leren en prestatieverbetering. De gemeenschappelijke noemer onder deze drie 
stappen is steeds dat ze, op basis van acceptatie van onzekerheid en complexiteit, zoeken naar manieren om de aandacht binnen verantwoordingsprocessen te leggen op de kwaliteit van bestuur en een proces van permanente en gestage verbetering. Het is daarbij zaak de fundamentele onvoorspelbaarheid van bestuurlijke processen als een (manipuleerbaar) gegeven te accepteren. De nadelen die ermee verbonden zijn kunnen gericht worden bestreden; omgekeerd zijn er ook zeker voordelen aan verbonden die kunnen worden benut om het leervermogen van het openbaar bestuur en van uitvoerende organisaties te verbeteren. De meer horizontale vormen van verantwoording zijn het meest geëigend voor deze taak, de klassieke hiërarchische vormen van verantwoording passen eerder bij de focus op rechtmatigheid en naleving van normen. In de onderstaande tabel (9.2)worden de hoofdlijnen van het betoog kort herhaald.

Tabel 9.2

Hoofdlijnen betoog kort herhaald

\begin{tabular}{|l|l|l} 
& $\begin{array}{l}\text { Traditionele verant- } \\
\text { woording }\end{array}$ & $\begin{array}{l}\text { Onzekere verantwoording bij hori- } \\
\text { zontaal bestuur en kritische media }\end{array}$ \\
\hline Verantwoordingsregime & $\begin{array}{l}\text { Hiërarchisch geordend en } \\
\text { voorspelbaar }\end{array}$ & $\begin{array}{l}\text { Meervoudig, onvoorspelbaar, redun- } \\
\text { dant, hiërarchische eindverantwoorde- } \\
\text { lijkheid, media als nuttige aanvulling }\end{array}$ \\
\hline $\begin{array}{l}\text { Verantwoordingsmecha- } \\
\text { nismen }\end{array}$ & $\begin{array}{l}\text { Breed, generiek, cyclisch, } \\
\text { geroutiniseerd }\end{array}$ & $\begin{array}{l}\text { Specifiek, fijnmazig, veranderlijk, hoog- } \\
\text { waardige informatie }\end{array}$ \\
\hline Doelen verantwoording & $\begin{array}{l}\text { Financiën en rechtmatig- } \\
\text { heid }\end{array}$ & Effectiviteit, kwaliteit en leervermogen \\
\hline
\end{tabular}

De media vervullen een dubbele rol in deze analyse. Enerzijds is hun kritische rol en vooral ook de manier waarop formele verantwoordingsfora gebruikmaken van de media - een belangrijke drijvende kracht achter de onvoorspelbaarheid van het bestuur. Du moment dat de agenda van Kamerleden, inspecties en leden van raden van toezicht niet meer wordt beïnvloed door mediaberichtgeving (of de kans daarop) verliezen media ook die aandrijvende werking. Tot die tijd vormen ze als institutie een externe macht waarmee het bestuur en publieke uitvoeringsorganisaties te maken hebben. Anderzijds bieden de media ook mogelijkheden aan het nationale bestuur om de bestuurders van uitvoerende organisaties. Het nationale bestuur kan gebruik maken van de mogelijkheden en kwaliteiten van de media als extra vorm van controle op de uitvoering of als nuttig vehikel om bestuurders bij de les te houden. Uitvoerende organisaties kunnen de druk van berichtgeving aanwenden om zich te verbeteren en zich ondertussen ook ten overstaan van belangrijke stakeholders te verbeteren. 
In deze beschouwing is het uitgangspunt steeds geweest dat horizontalisering a) een gegeven is dat echter b) tot op zekere hoogte manipuleerbaar is. Er is daarbij een belangrijk onderscheid te maken tussen situaties van horizontalisering, waar de overheid lijdend of genietend voorwerp is, en horizontaliseren, waar de overheid de architect is van de ontwikkeling. In concreto verlopen beide ontwikkelingen parallel. Dat bijvoorbeeld de relatie tot de media is veranderd, heeft enerzijds te maken met een professionele ontwikkeling die zich gelukkig grotendeels buiten het bereik van de overheid afspeelt, maar wordt anderzijds evenzeer beïnvloed door keuzen van de overheid ten aanzien van bijvoorbeeld de openbaarheid van bestuur. Dit onderscheid wordt in de academische en beleidsmatige literatuur over het bestuur vaak niet gemaakt, maar is wel zeer relevant. Voor zover de horizontalisering van bestuur voortkomt uit beleidsbeslissingen is namelijk nog een laatste stap in de beleidsrespons mogelijk: de overheid kan beslissingen ook weer ongedaan maken, zoals bijvoorbeeld ten aanzien van de verzelfstandiging van uitvoeringstaken schoorvoetend gebeurt. De legitieme behoefte aan eenduidigheid en controle dient daarbij steeds te worden gebalanceerd met de specifieke kwaliteitseisen die er bij de specifieke taak in het geding zijn. Tegelijk is het in een onvoorspelbaar en redundant verantwoordingsregime belangrijk steeds voor ogen te blijven houden dat de klassieke hiërarchische lijn van democratische verantwoording in laatste instantie cruciaal is. Deze lijn kan de onvoorspelbaarheid van het regime niet beteugelen, maar is wel de belangrijkste drager van democratische legitimatie en is - wanneer zich grote problemen voordoen in en door het openbaar bestuur ook de uiteindelijk meest geëigende route naar oplossingen voor urgente problemen. Voor de alledaagse problemen in een complex bestuur onder mediadruk daarentegen is het goed om deze klassieke lijn aan te vullen met redundante, meer gefocuste en reflectie stimulerende vormen van verantwoording. 


\section{NOTEN}

Graag dank ik Sandra Jacobs en Christoph Ossege voor hun onderzoeksondersteuning ten behoeve van dit essay.

Dit essay combineert nieuwe inzichten en gegevens met elementen uit eerdere publicaties, met name Schillemans \& Bovens 2009 en Schillemans $2007 \mathrm{~b}$.

Zie voor deze definitie van publieke verantwoording Bovens 2005b. Zie ook Day en Klein 1987: 5; Romzek en Dubnick, 1998: 6; Mulgan 2003: 9; Pollitt 2003: 89; WRR 2004: 188.

Hier wordt overigens niet beweerd dat horizontale verhoudingen een novum zijn in het openbaar bestuur. Het gegeven is van alle tijden (zie de bijdrage van Den Hoed en Schouten in deze bundel). Wel is de omvang ervan in de laatste decennia met name door europeanisering en verzelfstandiging toegenomen.

In de analyse is gekeken naar alle artikelen met 'accountability' in de titel of de summary van 1998-2008, in de volgende journals: American Public Administration Review, Public Administration Review, Local Government Studies, European Law Journal, Public Administration, Journal of Public Administration Research $\&$ Theory, Administration \& Society, West European Politics, Governance, European Union Politics, Policy \& Politics, Journal of Common Market Studies, Regulation $\&$ Governance, European Journal of Political Research, Journal of European Public policy, Journal of Social Policy, Journal of European Integration, Leadership. De analyse hierna is gebaseerd op drie nieuwsanalyses: een gefocuste analyse van berichtgeving over zво's over een periode van tien jaar, een analyse van alle berichtgeving over een aantal zво's gedurende één jaar en een intensieve analyse van berichtgeving over alle uitvoerende organisaties gedurende één maand. Zie de volgende noten voor het onderzoek.

Het onderzoek naar mediaberichtgeving over zво's over tien jaar is gedaan door een analyse op een geselecteerd aantal zoektermen via lexisnexis van de archieven van de drie kranten: de Volkskrant, NRC Handelsblad en Het Financieele Dagblad. De archieven zijn redelijk betrouwbaar - voldoende voor de doelstelling van dit essay om een indicatie van de media-aandacht voor zво's te vinden.

Er is alleen gekeken naar die artikelen waarin zво's worden genoemd in de titel of de lead van een artikel. In de verdere body van veel artikelen zullen nog meer Zво's worden genoemd, die echter niet centraal zullen hebben gestaan in die artikelen (bijvoorbeeld verwijzingen naar CBS-cijfers). De selectie is op deze manier gemaakt om een indicatie te krijgen van het volume aan artikelen waarin zBO's of een specifiek ZвO het centrale onderwerp of lijdend voorwerp van een artikel was. Er is om twee redenen gekozen voor alleen deze kranten. Allereerst zijn we uitgegaan van de aanname die door veel communicatiewetenschappers wordt gehanteerd dat een analyse van één of slechts enkele kwaliteitsmedia voldoende is om een goed beeld te krijgen van de berichten in alle media überhaupt. Er is namelijk een grote mate van overlap in thema's tussen verschillende media en de kwali- 
teitsmedia zijn agendabepalend (zie McCombs 2004: 27; Arnold 2004: 201). In de tweede plaats is Het Financieele Dagblad toegevoegd aan de kwaliteitskranten NRC Handelsblad en de Volkskrant, omdat een eerdere analyse in het Verenigd Koninkrijk liet zien dat juist een financieel dagblad relatief veel aandacht zou kunnen besteden aan ZBO’s (Deacon \& Monk 2001).

Er is gezocht met een combinatie van zoektermen: enerzijds algemene zoektermen (zBO, zelfstandig bestuursorgaan, zelfstandige bestuursorganisatie, verzelfstandigde organisatie, verzelfstandiging, quango, agentschap(pen), baten-lastendienst(en)), anderzijds met de namen van grote zBO's. Net als bij het gebruik van lexisnexis geldt ook hier: het uiteindelijke aantal gevonden artikelen is niet absoluut betrouwbaar, maar wel voldoende robuust om als indicatie voor het totale aantal te kunnen dienen.

In aanvulling op de berichtgevingsanalyse over tien jaar is ook het aantal berichten geanalyseerd over een lijst van 28 zво's gedurende één jaar. Dit om een indruk te krijgen van de omvang van de pack journalism waarmee organisaties te maken hebben: het gegeven dat op enig moment er zeer veel mediaberichten zijn over hetzelfde onderwerp. Hiertoe is via lexisnexis naar alle berichten gekeken over de organisatie, waarbij de persberichten die lexisnexis ook meetelt buiten beschouwing zijn gelaten. De analyse richtte zich op de periode september 2008-augustus 2009 .

In deze - derde - telling is gekeken naar zelfstandige bestuursorganen, batenlastendiensten, staatsmonopolisten zoals Schiphol en maatschappelijke ondernemingen die met publiek geld publieke taken uitvoeren. Gekozen is bij dit laatste voor organisaties die zijn aangesloten bij het Platform Maatschappelijke Ondernemingen (PMO). Dit zijn ondernemingen in verschillende sectoren van de zorg, welzijn, wonen en hoger onderwijs excl. universiteiten. In alle artikelen is gecodeerd in welke mate ze nu negatief, neutraal of positief waren over de genoemde publieke organisaties.

De rationale van de selectie was om zoveel mogelijk alle de facto uitvoerders van publieke taken met enige autonomie in de analyse te betrekken. 50 procent van de berichten ging over de maatschappelijke ondernemingen die zijn aangesloten bij PMO, 26 procent van de berichten behandelde ZBO's (vooral DNB en zorgautoriteit), 13 procent van de berichten staatsmonopolisten (vooral ov-bedrijven en Schiphol) en 11 procent van de berichten baten-lastendiensten (vooral inspecties). Er is geanalyseerd in hoeveel van de artikelen dergelijke organisaties expliciet een rol spelen. Dit is gedaan door alle berichten in de rubrieken binnenland, economie of opinie (incl. voorpagina) van twee kranten (NRC Handelsblad en de Volkskrant) gedurende één maand te coderen. In precies 400 van de 1390 gecodeerde artikelen werden bovenstaande organisaties genoemd.

De analyse is uitgevoerd in de Volkskrant en NRC Handelsblad in februari 2009. Deze maand is 'blind' gekozen: dat wil zeggen daar is in januari 2009, zonder kennis van de aanstaande gebeurtenissen voor gekozen. Of dit representatief is voor de berichtgeving in alle maanden is niet te zeggen. De maand bleek enkele 
gebeurtenissen in petto te hebben die de focus op de nationale politiek legden. Met name de erkenning dat er toch echt ook in Nederland recessie was na negatieve cijfers van het СРВ leidde tot veel berichten over de coalitiepartijen en het regeringsbeleid. Daarnaast waren enkele gebeurtenissen die juist de blik op uitvoerende organisaties met een zekere autonomie zetten: het neerstorten van een vliegtuig bij Schiphol, enkele affaires bij maatschappelijke ondernemingen rondom slecht beleid (Spectrum Twente en een omstreden neuroloog), dreigend faillissement bij zorginstellingen als Philadelphia en een directeur van een woningcorporatie met een wel heel dure auto en omstreden transacties (Rochdale). 
10 VAN ONDERGRAVING NAAR ONDERVRAGING. OVER DE VORMGEVING VAN GEZAG IN EEN GEMEDIATISEERDE WERELD

\author{
Wytske Versteeg \& $\mathbb{8}$ Maarten Hajer
}

\title{
10.1 INLEIDING
}

Deze bijdrage gaat over het gezicht van de politiek: we benaderen het openbaar bestuur in termen van gezag dat vormgeving behoeft. Het openbaar bestuur wordt hierbij breed gedefinieerd als het geheel van organisaties dat zich bezighoudt met de besturing van de maatschappij, inclusief alle gezagsdragers die de overheid (en semioverheid) letterlijk een gezicht geven. Centraal staat de vraag hoe de mogelijkheden tot gezaghebbend optreden van het openbaar bestuur worden beïnvloed door mediatisering.

Ter beantwoording van die vraag introduceren we allereerst onze benadering waarin gezaghebbende politiek onlosmakelijk verbonden is met dramaturgie en een begrip van politiek als performance. Die begrippen moeten niet worden gezien als 'postmoderne nieuwlichterij': dramaturgie en performance zijn, nuchter beschouwd, al sinds eeuwen een onontkoombaar en essentieel element van iedere vorm van gezaghebbend bestuur. Vervolgens richten we onze blik op recente veranderingen in het mediapolitieke landschap, en zetten we uiteen hoe die veranderingen de voorwaarden voor het vormgeven van gezag hebben gewijzigd en bemoeilijkt - reden waarom juist nu hernieuwde aandacht voor politiek als performance van belang is. We stellen dat de tegenwoordige interactie tussen bestuur en media risico's met zich meebrengt voor de legitimiteit, de stabiliteit alsook de intelligentie van de besluitvorming. We verzetten ons tegelijkertijd tegen de suggestie dat een gemediatiseerde politiek noodzakelijkerwijze gepaard zou gaan met een antagonistische publieke sfeer en een zogeheten dumbing down. We illustreren deze stelling door middel van een casestudy. We beëindigen onze bijdrage met een overdenking van de gevolgen van deze ontwikkeling voor de publieke sfeer, om zo een handelingsperspectief voor de toekomst te schetsen.

\subsection{DE POLITIEK IS EEN DRAMA: DE DRAMATURGIE VAN HET POLITIEKE SPEL}

Politiek is theater. Dat erkende men al ten tijde van de Griekse stadstaat, de oervorm van ons democratisch denken. Destijds werd het theatrale aspect van de politiek tegelijkertijd gewaardeerd en gewantrouwd. Gewaardeerd als in de kunst der retorica, en gewantrouwd als iets wat door zijn onechtheid, zijn gespeeldheid de morele waarden van de polis zou kunnen aantasten en daarmee een bedreiging 
vormde voor goed burgerschap. Een filosoof als Aristoteles liet er geen misverstand over bestaan dat een politiek spreker moet kunnen inspelen op ethos, pathos en logos om geloofwaardigheid te kunnen verwerven. Dat wil zeggen dat de spreker zichzelf zal moeten presenteren als een gezaghebbende, betrouwbare bron, dat hij zal moeten inspelen op de emoties van zijn gehoor en dat hij rationele argumenten voor zijn standpunt zal moeten geven.

Die brede, inclusieve klassieke definitie heeft echter plaatsgemaakt voor een meer op de filosofie van Descartes te herleiden opvatting van het openbaar bestuur. Hierin wordt een scherpe scheidslijn getrokken tussen enerzijds het legalistische, formele gezag en anderzijds het charismatische of dramaturgische gezag, tussen de ambtelijke en politieke deugden. Volgens het weberiaanse ideaalbeeld horen emoties bij de hitte van de politieke strijd, maar dient de ambtenarij neutraal, rationeel en onbewogen te blijven, en zich te baseren op de logos van feiten en wetenschappelijke kennis.

Maar de tegenstelling tussen een theatrale en een inhoudelijke politiek is een valse, zoals blijkt wanneer we de geschiedenis van onze gevestigde politieke instituties onder de loep nemen, in het bijzonder die van het parlement. Theatrale enscenering en het tot zijn recht komen van inhoudelijk debat blijken namelijk innig met elkaar verbonden te zijn. Dit is prachtig beschreven door Jean-Philippe Heurtin (2005) in zijn studie van de parlementen van de Franse Revolutie. De jonge revolutionairen bleken, na bestudering, in de periode van de Franse Revolutie niet minder dan 17 ontwerpen te hebben ontwikkeld voor hun nieuwe centrale institutie. Die zoektocht naar een revolutionair optimum werd geleid door de vraag hoe ruimtelijke vorm en inhoudelijke kwaliteit elkaar beïnvloedden; men zocht naar een symbolische ruimte, waarin iedereen zichzelf gemakkelijk hoorbaar zou kunnen maken, waar ook de rede deel uitmaakt van het debat, en waar het publiek letterlijk getuige zou kunnen zijn van de afweging door verkozenen. Staging - het ruimtelijk vormgeven aan een interactie met behulp van oude en nieuw uit te vinden symbolen - ging hier hand in hand met een bredere moreelethische zoektocht naar de vorm van een goede politieke gemeenschap. Er stond veel op het spel: Lodewijk XVI had tenslotte zelf ook al een 'parlement' geherintroduceerd. De revolutionairen moesten zich hier wezenlijk van onderscheiden. Op een moment dat het parlement nog niets van zijn tegenwoordige, vanzelfsprekende legitimiteit verworven had, moest men zoeken naar een manier om het abstracte, nog ongearticuleerde publiek symbolisch vorm te geven. De grote les in Heurtins studie is dat het parlementaire proces met zijn nu quasi-natuurlijke maar evengoed dramatisch uitgelichte besluitvormingsmomenten zich slechts gaandeweg tot de essentie van de republiek ontwikkelde. In die institutionele vormgeving schuilt dus een tweede betekenis van democratische 'representatie': de volksvertegenwoordiging representeert het volk niet 'slechts' volgens electorale lijnen, maar ook in symbolische zin door de abstracte demos - de bevolking als politieke 
eenheid - in ruimte en tijd gecomprimeerd zichtbaar en tastbaar te maken, door een spanningsboog te bieden aan het democratisch proces, met uitgelichte besluitvormingsmomenten daarbinnen.

Dit is een voorbeeld van performativiteit, waarbij de vormgeving van de interactie tussen politieke actoren en publieken daadwerkelijk de maatschappelijke werkelijkheid beïnvloedt. Heurtins studie toont aan dat inhoud en vormgeving niet als tegengestelden moeten worden gezien: ze gaan hand in hand. Omgekeerd is ook de huidige, schijnbaar rationele logos van het openbaar bestuur niet van theater ontdaan. De relatie tussen wetenschap, bureaucratie en politiek komt met zijn eigen rituelen en artefacten (zie bijvoorbeeld Goodsell 1988; Yanow 1995). Ook een technocratische, schijnbaar antitheatrale benadering ontkomt hier niet aan. De al te nadrukkelijke suggestie dat het hier slechts om de inhoud en de cijfers gaat moet immers dramaturgisch worden vormgegeven, als een specifieke vorm van gezaghebbend spreken (Ezrahi 1990).

\subsection{OUDERWETS GEZAG: DE KLASSIEK-MODERNISTISCHE ORDE}

Recentelijk is juist dit gezaghebbend spreken als probleem van het openbaar bestuur in de aandacht komen te staan. Alvorens over te gaan tot een analyse en duiding van de aanjagers van die worsteling, definiëren we de hier gehanteerde betekenis van gezag. Daarbij gaan we ook in op de relatie tussen enerzijds gezag en anderzijds dramaturgie of performance.

De Dikke Van Dale (1992) biedt ons drie betekenissen van gezag. Allereerst is er de machtsbevoegdheid, 'een in de rechtsorde verankerde en omlijnde bevoegdheid om uiteindelijk zo nodig door macht te handhaven beslissingen te nemen'. Vervolgens is er de betekenis 'regering, de overheid of de lichamen en personen die haar vertegenwoordigen', en een derde omschrijving luidt onder andere 'macht op grond van geestelijk overwicht; (...) het gewicht dat men aan zijn oordeel, zijn uitspraken hecht (...); het geloven zonder eigen onderzoek, alleen omdat hij het gezegd heeft'.

De eerste twee betekenissen beschrijven gezag als iets wat hoofdzakelijk juridisch gedefinieerd is, vastgelegd in de wettelijke orde: men bekleedt een gezagspositie. De derde betekenis heeft een connotatie van irrationaliteit; het eigen denken wordt opzijgeschoven om in plaats daarvan kritiekloos te geloven in dat van een ander.

Dit ideaaltype beschrijven we als de klassiek-modernistische opvatting van gezag. Gezag berust bij een bestuur op territoriale leest, met een machtscentrum op het niveau van de natiestaat, met een kenmerkende eenheid van gedeelde institutionele regels, rituelen en conventies, al dan niet aangevuld door gezag ontleend aan de charismatische performances van individuele personen; en een demos (de 


\begin{tabular}{l|l}
$\begin{array}{l}\text { Klassiek-modernistisch, } \\
\text { formeel gezag }\end{array}$ & $\begin{array}{l}\text { Gezag op basis van juridische bevoegdheid en verondersteld geestelijk } \\
\text { overwicht }\end{array}$ \\
\hline $\begin{array}{l}\text { Klassiek-modernistisch, } \\
\text { formeel Bestuur }\end{array}$ & $\begin{array}{l}\text { Vastgelegde institutionele regels, conventies en bevoegdheden zorgen } \\
\text { voor een 'vanzelfsprekend' gezag; de bestuurlijke definitie van } \\
\text { maatschappelijke problemen wordt door de wetenschap gelegitimeerd }\end{array}$ \\
\hline $\begin{array}{l}\text { Klassiek-modernistische, } \\
\text { formele opvatting van de } \\
\text { demos }\end{array}$ & $\begin{array}{l}\text { De demos wordt juridisch/geografisch gedefinieerd door de grenzen van } \\
\text { de natiestaat }\end{array}$ \\
\hline
\end{tabular}

burgers die een politieke eenheid vormen) die samenvalt met de juridische definitie van de inwoners van de natiestaat.

Hoewel de klassiek-modernistische gezagsopvatting geenszins is verdwenen, komt ze voort uit de politieke conflicten van de negentiende en twintigste eeuw en is ze beduidend minder effectief voor de 'nieuwe', dikwijls zeer complexe werkgebieden van het openbaar bestuur. Om te begrijpen waarom dat het geval is, gaan we hier kort in op de grondslagen van het succes van de klassiek-modernistische orde.

Allereerst is de klassiek-modernistische orde sinds de vrede van Westfalen territoriaal georganiseerd. De grenzen van een politieke gemeenschap zijn geografisch bepaald, en die geografische basis stelde een leider in staat om gezaghebbend te spreken voor zijn volk. Bovendien pasten de verschillende instituties - supranationaal, internationaal, nationaal, provinciaal, lokaal - als een Russische matrouchka in elkaar. Dit zorgde voor een heldere verdeling in jurisdicties en bijbehorende gezagssferen. Verkiezingen en universeel kiesrecht gaven de politiek leiders een mandaat, terwijl politiek en bureaucratie volgens weberiaanse opvattingen hiërarchisch waren georganiseerd. Politieke partijen vervulden een cruciale rol als kweekvijvers voor politiek talent en als bemiddelaars tussen volk en volksvertegenwoordiging. Met name binnen het verzuilde stelsel hadden zij bovendien door hun eliteoverleg een conflictdempende werking. De wetenschap bood een inhoudelijke legitimatie van het beleid, terwijl in de loop der tijd ook burgerparticipatie deel ging uitmaken van het beleidsvormingsproces. Het ging hier echter om een gecontroleerde toevoeging aan het beleidsproces, niet om een fundamentele herstructurering ervan. Ten slotte werkten ook de - in aantal en aanbod nog overzichtelijke - media mee aan het gezag van het openbaar bestuur, doordat zij zichzelf dikwijls eerder beschouwden als verslaggevers dan als critici. Zo droegen de diverse instituties van de klassiek-modernistische orde met name in de tweede helft van de twintigste eeuw bij aan het nationale project van de welvaartsstaat. 
De natiestaat bood de stabiliteit en administratieve voorwaarden waaronder de economie kon opbloeien, terwijl de daardoor ontstane welvaart weer kon terugvloeien in de vormen van gelden voor onderwijs, zorg en welzijn. Politieke instituties, economische ontwikkeling en culturele loyaliteit concentreerden zich op het begrensde, relatief controleerbare territorium van de natiestaat. Dit is echter niet langer het geval.

De hierboven verkort omschreven 'klassiek-moderne' orde staat toenemend onder druk (voor een uitgebreidere beschouwing, zie Hajer 2000, 2003, 2009). Enerzijds is de economie sterk geglobaliseerd, zoals maar al te duidelijk blijkt uit de huidige financiële crisis. Terwijl de gevolgen daarvan voelbaar worden op het vlak van de natiestaat, bezit de staat niet de politieke macht om de ontwikkelingen te kunnen controleren - in zekere zin een vermindering van de soevereiniteit. De 'territoriale synchroniteit' is verbroken, nu veel problemen (milieu, migratie, terrorisme) grensoverschrijdend zijn en niet meer binnen één jurisdictie kunnen worden opgelost. Terwijl de Europese Unie (EU)een rol speelt in het aanpakken van dergelijke grensoverschrijdende problemen, blijft het dikwijls moeizaam om in dat verband als eenheid op te treden, laat staan dat burgers zich kunnen identificeren met deze supranationale organisaties. Maar ook de identificatie met de natiestaat is in toenemende mate gecompliceerd, denk bijvoorbeeld aan de discussie over de dubbele nationaliteit en al dan niet conflicterende identiteiten. Tegelijkertijd zien we nieuwe vormen van nationalisme, die vooral lijken terug te verlangen naar een staat die geborgen is door zijn geslotenheid, een uniform Nederland waarin 'geluk nog heel gewoon was'. Voor het openbaar bestuur is het onmogelijk om aan dat verlangen tegemoet te komen, wat weer kan leiden tot nieuwe gevoelens van wantrouwen. Dat risico is des te groter naarmate de trouwe aanhang, en daarmee uiteindelijk de legitimiteit van politieke partijen verder afbrokkelt.

Samenvattend kan worden gesteld dat de klassiek-modernistische orde momenteel op drie punten een tekort vertoont:

I Op het gebied van implementatie: zoals Pressman en Wildavsky (1973) al vaststelden, bestaat er een groot verschil tussen de werkelijkheid van beleidsvorming en beleidsuitvoering. Het gevolg is dat veel vastgesteld beleid niet wordt uitgevoerd, of dat nu komt door politieke weerstand uit het veld, doordat het beleid onpraktisch is of door een combinatie van beide factoren.

2 Op het gebied van leren: het tekstboekideaal van de beleidscyclus veronderstelt dat het openbaar bestuur double loop leert door middel van evaluatie en feedback. In de praktijk blijkt de beleidswerkelijkheid echter dusdanig weerbarstig en veranderlijk dat voortdurende interactie met actoren uit het veld noodzakelijk is om effectief beleidsleren mogelijk te maken.

3 Op het gebied van legitimiteit: de democratische legitimiteit van de klassiekmodernistische orde berust op het systeem van gekozen volksvertegenwoordigers. Volgens het weberiaanse principe beslist de politiek namens het publiek, 
waarna de technische uitvoering kan worden overgelaten aan de bureaucratie. Tegenwoordig zien we echter dikwijls dat een publiek zich pas vormt nadat er tot beleid besloten is, dat wil zeggen in het stadium van beleidsuitvoering, wanneer de abstracte politiek tastbaar wordt in concrete maatregelen. Bovendien is de macht van democratische vertegenwoordigers gebonden aan de territoriale schaal, terwijl de rol van niet-gekozen ambtenaren groeit wanneer een probleem jurisdicties overschrijdt. Dit kan leiden tot weliswaar effectieve, maar daarom niet altijd legitieme oplossingen, terwijl het democratisch besluitvormingsmoment in het ergste geval wordt gereduceerd tot een leeg ritueel.

\subsection{DE STEM(MEN) VAN HET GEZAG: EEN ALTERNATIEVE CONCEPTUALISERING}

Het klassiek-modernistische genre is allerminst verdwenen, maar de daarin gelegde nadruk op een eenzijdige, in jurisdicties vastgelegde gezagspositie biedt geen volledige omschrijving van het hedendaagse openbaar bestuur. De interacties rond grensoverschrijdende politieke problemen hebben een nieuwe vorm van bestuur opgeleverd. Dit wordt in de bestuurskundige literatuur omschreven als 'netwerk governance': dikwijls grensoverschrijdende netwerken van overheidsen niet-overheidsactoren. Netwerk governance wordt gekenmerkt door interdependentie: actoren zijn zich ervan bewust dat een probleem niet door één actor of één jurisdictie kan worden opgelost, maar plaatsvindt in een institutionele leegte (Hajer 2003), waarin men niet kan terugvallen op duidelijke, algemeen geaccepteerde regels en normen om de politieke besluitvorming in banen te leiden. Niet slechts het besluit op zich, maar ook de bepaling van het probleem (wat wordt meegenomen en wat niet), en de wijze waarop men tot een beslissing zou moeten komen worden onderdeel van de onderhandeling.

Het moge duidelijk zijn dat de klassiek-modernistische opvatting van gezag, met zijn nadruk op formele gezagsposities en passieve acceptatie, ontoereikend is om de nieuwe praktijken van network governance te schragen. Er bestaat echter een alternatieve denkrichting over gezag, die beter aansluit op de tegenwoordige praktijken. Hierbij wordt gezag niet opgevat als een te bekleden positie, maar als een al dan niet aanwezige kwaliteit van communicatie. Zo baseert Friedman (1990) zich op de etymologische herkomst van het woord autoriteit (Latijn: auctor) om het relationele karakter ervan aan te geven:

\footnotetext{
“Het Latijnse 'auctor' (...) duidt op beide betekenissen van het Engelse 'author' [auteur]: (1) een schrijver, en (2) een actor in de zin van de persoon verantwoordelijk voor een actie of het inzetten van een reeks acties. (...) Zo beschouwd wordt een persoon met autoriteit begrepen als iemand tot wie een beslissing of opinie herleid kan worden, als tot de bron van die beslissing of opinie, of anders als iemand die een in het verleden begonnen handelingswijze voort draagt, voortzet of
} 
'vergroot' naar het heden. Maar het is even belangrijk om niet de notie te negeren van een 'auctor' in de eerste betekenis van een schrijver, getuige, of iemand die ergens verslag van doet." (Friedman, 1990: 74-76)

Een gezaghebbende institutie is volgens Friedman een bron die een specifiek verhaal vertelt over maatschappelijke gebeurtenissen, er zo betekenis of zin aan geeft en daarmee een bepaalde handelingswijze inzet of voortzet. Maar zo'n verhaal is geenszins vanzelfsprekend. Want, stelt Friedrich (1958).

"[Gezaghebbende vormen van communicatie] bezitten het potentieel om op redelijke wijze te worden uitgewerkt - ze zijn het 'waard om te worden geaccepteerd'. Zo bezien is gezag een kwaliteit van communicatie, eerder dan van personen, en als we spreken over het gezag van een persoon, is dat een korte uitdrukking om aan te geven dat hij beschikt over de capaciteit om een gezaghebbende communicatie te starten. De capaciteit van mensen om te spreken in betekenisvolle termen, om de zaken te zeggen die zo kunnen worden uitgewerkt, varieert enorm. Deze capaciteit, denk ik, wordt geïmpliceerd wanneer we over sommige van hen spreken als 'autoriteiten'." (Friedrich 1958: 35-37; cursivering in origineel)

Volgens deze auteurs wordt gezag dus niet kritiekloos geaccepteerd, maar kan het ook worden betwijfeld en ter discussie worden gesteld. Sterker nog, Mark Warren (1996) beargumenteert dat een persoon of instituut nu juist autoriteit verwerft wanneer en doordat de mogelijkheid bestaat om die autoriteit te betwijfelen. We vertrouwen het openbaar bestuur wanneer we weten dat er sprake is van kritisch toezicht, in het bijzonder op het gebied van complexe en technische zaken. Dit is een cruciale stap. Een gezaghebbend instituut wordt dan niet, zoals de Van Dale stelt, op grond van zijn jurisdictie geloofd zonder onderzoek, maar voorlopig en conditioneel geloofd in het besef dat er onderzoek zal volgen wanneer het eerder gestelde vertrouwen beschaamd blijkt. Gezag vloeit niet automatisch voort uit de positie van een actor, maar uit zijn wijze van communiceren - wat ook inhoudt dat het gezag van gevestigde instituten plotseling kan worden uitgedaagd door communicatief vaardige actoren zonder duidelijke achterban. Een dergelijke vorm van gezag sluit aan op de werkelijkheid van de burger op stand-by, die schijnbaar politiek passief is, maar onmiddellijk en effectief in actie komt wanneer zijn of haar belangen worden geschaad (Hajer 2003; Verhoeven 2009). Dit gezagsgenre, dat voorkomt naast en in combinatie met het klassiek-moderne, definiëren we hier als discursief gezag: een gezag op basis van een te ondervragen framing van problemen en oplossingen, en de bijbehorende claims op de werkelijkheid. Een gezaghebbend actor is in staat om zijn probleemdefinitie en oplossingssuggestie in het debat overeind te houden en te laten domineren. 
Tabel 10.2 Gezag op basis van communicatie: een discursieve respectievelijk dramaturgische opvatting van gezag

\begin{tabular}{|l|l|l|l}
$\begin{array}{l}\text { Discursief } \\
\text { gezag }\end{array}$ & $\begin{array}{l}\text { Op basis van een te ondervragen } \\
\text { betekenisgeving }\end{array}$ & $\begin{array}{l}\text { Dramatur- } \\
\text { gisch gezag }\end{array}$ & Gezag op basis van vormgeving \\
\hline $\begin{array}{l}\text { Biscursief } \\
\text { Bestuur }\end{array}$ & $\begin{array}{l}\text { Het bestuur moet zijn definities } \\
\text { (van maatschappelijke proble- } \\
\text { men, beleidskwesties) op } \\
\text { verschillende podia 'waar-maken', } \\
\text { in een proces van voorlopige en } \\
\text { steeds betwistbare betekenis- } \\
\text { geving }\end{array}$ & $\begin{array}{l}\text { Dramatur- } \\
\text { gisch } \\
\text { bestuur }\end{array}$ & $\begin{array}{l}\text { Het bestuur moet politieke onder- } \\
\text { werpen persoonlijk en 'ervaarbaar' } \\
\text { maken; gepersonifieerd gezag } \\
\text { op basis van in situ performances } \\
\text { (zowel ad hoc als in gevestigde } \\
\text { rituelen) }\end{array}$ \\
\hline $\begin{array}{l}\text { Discursieve } \\
\text { opvatting } \\
\text { van de } \\
\text { demos }\end{array}$ & $\begin{array}{l}\text { Publieken bestaande uit schijn- } \\
\text { baar passieve burgers, die echter } \\
\text { onmiddellijk een actief publiek } \\
\text { kunnen vormen wanneer hun } \\
\text { verhaal niet gehoord wordt of } \\
\text { hun belangen geschaad lijken te } \\
\text { worden }\end{array}$ & $\begin{array}{l}\text { gramatur- } \\
\text { gische } \\
\text { opvatting } \\
\text { van de } \\
\text { demos }\end{array}$ & $\begin{array}{l}\text { Publieken die zich vormen en } \\
\text { verbonden voelen op basis van } \\
\text { gedeelde en gezamenlijk ervaren } \\
\text { emoties }\end{array}$ \\
\hline
\end{tabular}

Gezaghebbende communicatie is echter niet slechts een kwestie van woorden en definities, maar vooral ook van de wijze waarop die betekenisgeving wordt vormgegeven. Daarom onderscheiden we naast de discursieve benadering ook een dramaturgische opvatting van gezag. Waar de discursieve gezagsopvatting leunt op een talige, rationele ondervraging van uiteenlopende perspectieven op de werkelijkheid, is het dramaturgische gezagsgenre primair emotioneel. Hier gaat het niet om kritisch ondervragen, maar juist om het creëren van een identiteit, bijvoorbeeld door middel van gevestigde symbolen en rituelen, of juist door ad-hocinterventies zoals een geïmproviseerde toespraak op het moment van een crisis, maar ook door de keuze voor of aankleding van een ruimte of podium. Kort gezegd behelst dramaturgisch gezag het vermogen om een politiek proces tot een gezamenlijke ervaring te maken - een ervaring die, al naargelang de vormgeving van dat proces, meer of minder emotioneel kan zijn. Het is belangrijk om op te merken dat rationaliteit en emotionaliteit hier niet in hiërarchische zin worden gebruikt: zowel de discursieve ondervraging als de dramaturgische beleving van gezag zijn van belang in het politieke proces, niet in de laatste plaats omdat emoties van cruciaal belang zijn voor ons beoordelingsvermogen.

Dat betekent ook dat de scheidslijn tussen gezag en vertrouwen in bovenstaande definities niet gemakkelijk te trekken valt. We kunnen Friedrichs omschrijving van gezaghebbende communicatie als 'waard om te worden geaccepteerd' bijna 
vervangen door 'waard om te worden vertrouwd'. Die gezaghebbende kwaliteit van communicatie kan volgens onze ideaaltypering worden bewerkstelligd door positie, kritische ondervraging of juist de ervaring van verbondenheid, maar komt veel vaker tot stand in een proces dat de drie gezagsgenres met elkaar verweeft.

Zowel voor de discursieve als voor de dramaturgische gezagsopvatting geldt dan ook dat zij niet 'in plaats van' het klassiek-modernistische gezagsgenre komen, maar daar in het verleden al deel van uitmaakten en aan toe hebben bijgedragen de bovengenoemde beschrijving van Heurtin biedt op dat punt afdoende illustratie. Idealiter houden de diverse gezagsgenres elkaar in evenwicht en versterken ze elkaar, door formele rechten en waarborgen te combineren met enerzijds een kritisch debat en anderzijds emotionele identificatie. Tegenwoordig zien we echter dikwijls dat het openbaar bestuur weliswaar in formeel opzicht gezaghebbend is, maar niet wordt geschraagd door gezag ontleend aan het discursieve of dramaturgische genre. Dit zorgt voor een extra kwetsbaarheid in situaties waar de politieke eenheid van de demos niet per se samenvalt met zijn traditionele definitie van de inwoners van de natiestaat. Op dat moment is immers ook de band tussen burgers en openbaar bestuur verre van vanzelfsprekend, en vervullen de media een - letterlijk - mediërende rol. Mediabeelden en -verhalen zijn een cruciale vorm van bemiddeling tussen burger en openbaar bestuur; enerzijds belichten zij overheidshandelen dat voor de burger anders onzichtbaar zou blijven, anderzijds scheppen ze voor de bestuurder een beeld van de (gewone, boze, enz.) burger. De centrale vraag voor de toekomst van het openbaar bestuur is daarbij, in termen van Chantal Mouffe (2005: 20), of de media de relatie tussen burger en openbaar bestuur beïnvloeden op agonistische of juist op antagonistische wijze:

“(...) terwijl er bij antagonisme sprake is van een wij-zijrelatie, waarin de twee partijen vijanden zijn die op geen enkele gedeelde grond met elkaar overeenkomen, is agonisme een wij-zijrelatie waarbij de strijdende partijen, hoewel zij erkennen dat er geen rationele oplossing voor hun conflict bestaat, desalniettemin de legitimiteit van hun opponenten erkennen. Ze zijn 'tegenstanders', geen vijanden." (Chantal Mouffe 2005: 20)

Met andere woorden: in hoeverre leveren de veranderende media een constructieve bijdrage aan een democratisch klimaat door een variëteit aan legitieme visies te tonen, en in hoeverre doen zij daaraan juist afbreuk, doordat via schandaalberichtgeving de gedeelde grond afbrokkelt en vijandbeelden worden versterkt?

\subsection{HET MEERVOUD VAN MEDIA? REPRESENTATIE IN VEELVOUD}

De termen 'media', 'burgers' en 'openbaar bestuur' zijn in zekere zin misleidend. Ze suggereren immers enkelvoudige, duidelijk van elkaar te onderscheiden elementen. Enerzijds gaat achter deze paraplutermen een veelvoud van actoren 
schuil: er is de complexiteit van het gelaagde openbaar bestuur inclusief governance netwerken; er zijn meerdere publieken; en de verschillende media-actoren concurreren met elkaar om de koppen of het grootste aantal kijkers of bezoekers. Anderzijds zijn die actoren veel meer met elkaar verweven en moeilijker van elkaar te onderscheiden dan de afzonderlijke termen suggereren. Met name sinds de komst van internet 2.o, het (video)mobieltje, en de ontwikkeling van nieuwe digitale netwerken dragen burgers actief bij aan 'het nieuws', en de boven geschetste 'burger op stand-by' kan zich plotseling actief in de politiek mengen. Op hun beurt spelen de media een rol in de diverse stadia van de traditionele beleidscyclus. Terwijl ze dikwijls actief worden ingezet door politieke actoren (denk bijvoorbeeld aan de proefballon, of het gebruik van talkshow-optredens voor het lanceren van ideeën of voor het legitimeren van beslissingen, een praktijk waarop veelal pas later Kamervragen volgen), blijft ook het meer idealistische beeld bestaan van de media als waakhonden van het openbaar bestuur omwille van het algemeen belang, of juist als egoïstische cynici, slechts uit eigenbelang gericht op het destructieve drama dat nu eenmaal meer kijkers trekt. Over het antwoord op de normatieve vraag of een toenemende mediatisering noodzakelijkerwijs ten koste gaat van de rationaliteit van het publieke debat, bestaat geen consensus, zoals we in het onderstaande nog zullen zien. Maar voordat we die vraag ook maar kunnen behandelen, plaatsen we eerst die ontwikkelingen in perspectief die algemeen worden geschaard onder de brede noemer van 'mediatisering' (vgl. bijv. ook RMO 2003; ROB 2003).

Allereerst wordt in dit verband dikwijls de dumbing down genoemd - het verschijnsel dat de media minder aandacht zouden hebben voor de inhoud en zich in plaats daarvan in toenemende mate zouden richten op vorm, entertainment en schandaal.

Niet de boodschap, maar de persoonlijkheid van de politicus zou centraal staan, met het bijbehorende risico op schandaalberichtgeving en -politiek. In de woorden van Manuel Castells (2007).

"Burgers (...) vertrouwen op de mediarapportages van de positie van kandidaten; en uiteindelijk is hun besluit wat te stemmen afhankelijk van hun vertrouwen in een gegeven kandidaat. Daarom wordt karakter, zoals geportretteerd in de media, essentieel; omdat waarden - dat wat het meest betekent voor de meerderheid van de mensen - worden belichaamd in de persoon van kandidaten. Politici zijn de gezichten van de politiek. Als geloofwaardigheid, vertrouwen en persoonlijkheid kritieke punten worden in het beslechten van politieke uitkomsten, dan worden vernietiging van geloofwaardigheid en karaktermoord machtige politieke wapens.” (blz. 242-243)

Amerika vormt op dit punt het meest bekende voorbeeld, of beter, schrikbeeld. Mede door het grote verschil in politieke cultuur kan de Nederlandse situatie hier- 
mee echter niet zomaar worden vergeleken (vgl. bijv. Van Praag 2001; Brants en Van Praag 2005).

Daarnaast gaan er stemmen op die stellen dat de toenemende aandacht voor de persoonlijke stijl van politici niet noodzakelijkerwijs ten koste hoeft te gaan van de inhoud. Het simpele feit dat de politiek een gezicht heeft, kan immers juist leiden tot meer betrokkenheid bij de inhoud - en het zijn uiteindelijk personen die we al dan niet vertrouwen (zie Van Zoonen 2005; Corner en Pels 2003; vgl. Hajer, Laws et al. 2009). Bovendien blijkt keer op keer dat kijkers, luisteraars, publieken actief interpreteren wat hun wordt voorgeschoteld en of deze specifieke bron inderdaad gezagwekkend is en hun vertrouwen verdient (zie bijv. Gamson, Croteau et al. 1992: 288 en verder). Terwijl dit voor het ene beleidsonderwerp gemakkelijker is dan voor het andere, nuanceert deze observatie in elk geval de these van een algemene dumbing down. ${ }^{1}$

Een tweede gesignaleerde ontwikkeling is dat er sprake zou zijn van toenemend cynisme en een groeiende dominantie van de medialogica, die nu eenmaal drijft op conflict; waar alles goed gaat, valt niets te melden. Bovendien wordt 'wat nieuws is' in belangrijke mate bepaald door wat Herbert Gans (1979) aanduidde als story suitability: kan iets worden verteld langs narratieve lijnen van conflict en drama? Het risico hiervan zou zijn dat het publiek een al te negatief beeld krijgt van het openbaar bestuur, doordat positieve feiten niet worden gemeld en cynisme wordt aangemoedigd. Omgekeerd zou deze medialogica niet alleen het denken van burgers, maar ook dat van 'het' openbaar bestuur beïnvloeden. Het maken van beleid en het maken van nieuws raakt in toenemende mate met elkaar verbonden, zodat wat op het eerste gezicht slechts externe communicatie is, op het tweede gezicht een vorm van beleidsmaken kan blijken (Cook 2006: 167). Ook hier geldt echter dat de veronderstelde ontwikkeling in de richting van personalisering, sensatiezucht en nihilisme allerminst eenduidig is (zie bijvoorbeeld Vettehen, Nuijten et al. 2005; Van Aelst 2006).

Een derde ontwikkeling is de diversificatie en fragmentarisering van de diverse mediapublieken en hun relatie tot het politieke bestuur. Elders (Hajer 2009) beschreven we dit verschijnsel als de politics of multiplicity, een begrip dat we hier vertalen als een politiek van veelvoudigheid. In een politiek van veelvoudigheid is er ten eerste geen sprake van een eenduidig politiek centrum; de politiek krijgt vorm op verschillende podia. Die podia zijn uiteraard niet allemaal even belangrijk, maar het is moeilijk om op voorhand te voorspellen welk podium cruciaal zal blijken. Ten tweede is er sprake van een veelvoud aan publieken, waarvan het handelen eveneens vaak moeilijk voorspelbaar is. Mede door het gemak waarmee beeld en geluid tegenwoordig kunnen worden opgenomen en verspreid, is het voor politieke actoren haast onmogelijk geworden om 'voor een thuispubliek' te spelen. Wat binnen één schijnbaar besloten context gezegd wordt, kan plotseling 
openbaar zijn en terechtkomen bij een heel ander publiek, dat wat er gezegd is op zijn eigen manier zal lezen en interpreteren - denk bijvoorbeeld aan de in een collegezaal gedane uitspraken van Kay van der Linde, die tot zijn eigen verrassing openbaar werden. Ten derde is er een veelvoud aan concurrerende media, waarbij internet een belangrijke rol speelt in het stimuleren van kwalitatief sterk uiteenlopende burgerjournalistiek - hoewel de actualiteitenforums nog altijd sterk leunen op juist de traditionele media.

Juist omdat 'het publiek' zo ongrijpbaar is, wordt het voor de verschillende actoren - of deze nu commerciële of politieke doeleinden hebben - des te belangrijker om overtuigend gestalte te geven aan de stem van het volk. We horen in de media een roep om sterk leiderschap, terwijl omgekeerd de politiek op zoek lijkt naar wat 'het volk' nu wil. Het meest bekende verschijnsel op dit gebied zijn de grotendeels op mediaberichten gebaseerde Kamervragen - een verschijnsel waarin overigens met name de meer populistische partijen uitblinken. ${ }^{2}$ Het risico lijkt dat van een hyperventilerende, zwabberende politiek, een vrees die blijkens het rapport Vertrouwen en zelfuertrouwen gedeeld wordt door de Kamerleden zelf (Verbeet 2009). Waar burgers een rol in de media opeisen, claimen de diverse media een recht op het weergeven van de stem van het volk. Deels gebeurt dat via mediagenieke opiniepeilers als Maurice de Hond of plotseling opgekomen enkelingen die claimen voor een groep te spreken en vervolgens overal worden geïnterviewd, deels ook via talkshows of websites als Geen Stijl - nieuwe politieke ruimtes die op hun beurt de parlementaire politiek beïnvloeden.

Samenvattend: de geschetste ontwikkelingen brengen risico's met zich mee op het gebied van intelligentie, stabiliteit en legitimiteit van de besluitvorming. De complexiteit van politieke vraagstukken verdwijnt uit beeld wanneer beleid moet worden verkocht in mediagenieke oneliners. Al dan niet zelfbenoemde experts zijn graag bereid de media te woord te staan, en winnen juist aan spreektijd op grond van hun afwijkende mening, een verschijnsel dat opnieuw kan leiden tot de delegitimatie van beleid. De media zijn voor hun nieuwswaarde immers afhankelijk van een crisis- of conflictframe, wat kan leiden tot snelle escalaties.

Tegelijkertijd kunnen hier - juist door de boven geschetste veelvoud en verstrengeling van de diverse actoren binnen openbaar bestuur, media en demos - weinig algemene uitspraken over worden gedaan. Zonder de risico's te willen uitvlakken lijkt het belangrijk om ons bewust te zijn van het specifieke standpunt van waaruit we deze ontwikkelingen bezien. Te vaak worden mediabeschouwingen gekleurd door een dikwijls onuitgesproken nostalgisch verlangen naar de periode waarin de media zich nog volgzaam toonden. Op die manier ontstaat er een vals verhaal van verval, dat het verleden te rooskleurig voorstelt en het heden portretteert als een situatie die door machteloosheid wordt gekenmerkt. Vanuit het besef dat dramaturgie en performance altijd al deel uit hebben gemaakt van politiek en openbaar 
bestuur, stellen wij een andere denkrichting voor. De veranderingen in het mediapolitieke landschap hebben niet plotseling een show gemaakt van een voorheen authentieke politiek, maar ze hebben wel de voorwaarden veranderd waaronder het gezag van het openbaar bestuur dramaturgisch vorm krijgt. Gezag was nooit vanzelfsprekend, maar veel meer dan eerder wordt de betekenis of definitie die de overheid aan een bepaald beleidsonderwerp geeft, plotseling en succesvol betwist door actoren met een gezag dat uitsluitend aan de media ontleend is. Voor bestuurders betekent dit dat zij rekening moeten houden met de mogelijkheid van onverwacht snelle escalatie van 'hun' beleidsonderwerp via een mediahype. In het onderstaande illustreren we deze stelling aan de hand van de casus van de HPVvaccinatiecampagne, die we in perspectief plaatsen door een vergelijking met het op punten verwante geval van de Britse Food Standards Agency.

\subsection{CASUS HPV-VACCINATIECAMPAGNE: TUSSEN KERN- BOODSCHAP EN KAPPERSPRAATJE}

De volgens het RIVM 'mislukte' vaccinatiecampagne tegen het humaan papilloma virus (HPV), in het voorjaar van 2009, springt in het oog als een recent voorbeeld van schijnbaar door de media gefnuikte overheidssturing. De keuze voor een enkele casus ter illustratie van een complexe thematiek behelst altijd een element van willekeurigheid. De HPV-vaccinatie is in dit verband echter interessant, omdat het onderwerp zowel moreel als wetenschappelijk complex is en daarom moeilijk communiceerbaar; omdat het de complexe relatie tussen gezag en vertrouwen toont; en ten slotte omdat het bij uitstek een voorbeeld is van de politiek van veelvoudigheid en van de manier waarop 'het publiek' door verschillende partijen gestalte wordt gegeven. Opmerkelijk is bovendien dat het hierbij niet ging om een crisissituatie maar om 'gewoon beleid', zodat de felle publieke reactie niet door het RIVM was voorzien. Wij concentreren ons hier op de wijze waarop de relatie tussen de diverse actoren vorm krijgt via de traditionele en de nieuwe media, waarbij de vraag centraal staat in hoeverre het proces van meningsvorming via de media als agonistisch of juist als antagonistisch kan worden gekenschetst, met de bijbehorende gevolgen voor de legitimiteit en stabiliteit van de besluitvorming. We stellen ons bovendien de vraag of er in deze casus sprake is van de gevreesde dumbing down als gevolg van de medialogica.

Op 1 april 2008 verschijnt het rapport Vaccinatie tegen baarmoederhalskanker, waarin de Gezondheidsraad adviseert om de HPV-vaccinatie op te nemen in het Rijksvaccinatieprogramma. Op 8 juli 2008 bevestigt minister Klink in een brief aan de Tweede Kamer dat hij dit advies overneemt, onder voorbehoud van kosteneffectiviteit. In oktober 2008 zendt het televisieprogramma Zembla een aflevering uit onder de naam 'Het omstreden kankervaccin'. In de uitzending komt een voormalig consultant van de farmaceutische industrie aan het woord, die uitlegt hoe zij in opdracht van de fabrikant getracht heeft om via diverse media onopvallend 
aandacht te vragen voor baarmoederhalskanker, 'de mensen bang te maken'. Er worden vraagtekens gezet bij mogelijke belangenverstrengeling (waarvan geen sprake bleek) tussen leden van de Gezondheidsraad en de twee belangrijkste fabrikanten van het vaccin, Glaxo Smith-Kline en concurrent Sanofi Pasteur MSD, en bij gynaecologen die voorlichting en werving in elkaar laten overlopen. Ook worden experts gehoord die stellen dat het geld voor het vaccin elders effectiever kan worden ingezet, en dat er nog geen duidelijkheid is over de langetermijneffecten bij twaalfjarigen. De SP verzoekt hierop om een nieuw onderzoek, terwijl minister Klink alle aantijgingen van belangenverstrengeling van de hand wijst.

In november 2008 meldt de minister dat HPV-vaccinatie vanaf 2009 wordt opgenomen in het RVP. Het gaat hierbij om het vaccin Cervarix, geproduceerd door Glaxo Smith-Kline. In februari 2009 stelt het RIVM Voorlichtingscentrum een toolkit beschikbaar aan (communicatie)professionals bij de GGD. De handleiding daarvan vermeldt het volgende:

De kernboodschap is:

Vanaf 2009 worden meisjes in Nederland gratis ingeënt tegen baarmoederhalskanker. Zij krijgen hiervoor een persoonlijke uitnodiging. De inenting is voor alle meisjes die zijn geboren in 1997 of daarna. Ook meisjes die zijn geboren in 1993, 1994, 1995 en 1996 krijgen een uitnodiging. ${ }^{3}$

Onder de noemer Tips en suggesties wordt hieraan het volgende toegevoegd:

De communicatie over de HPV-vaccinatie geeft het beste resultaat als u verbindende elementen opneemt in de verschillende uitingen. Op die manier zorgen ze er niet alleen voor dat u verschillende doelgroepen bereikt, er ontstaat ook herkenning en samenhang: $1+1=3$.

De verbindende elementen in deze campagne zijn:

- De slogan: Prik en bescherm; voorkom baarmoederhalskanker!

- Het beeld dat bij de slogan hoort;

- De Kernboodschap: zie boven. ${ }^{4}$

Het hier gehanteerde model veronderstelt impliciet dat er sprake is van eenrichtingsverkeer tussen een actieve zender en een passieve ontvanger. Het RIVM was echter niet de enige die over de HPV-vaccinatie trachtte te communiceren. Al in 2006 verschenen er reclames met ex-DollyDot Angela Groothuizen in de hoofdrol, onder de noemer beschermjedochter.nl. Deze website, inclusief press kit, had het aanzien van een neutrale voorlichtingssite; er werd zelfs niet expliciet gesproken over een vaccin. Slechts door het aanklikken van de disclaimer was te zien dat Sanovi Pasteur MSD de bron van deze informatie vormde. Omgekeerd begonnen er, zeker na de bewuste Zembla-uitzending, steeds meer berichten te circuleren over de vermeende gevaren van inenting. Zo zouden er in Amerika meisjes 
verlamd zijn geraakt of gestorven vlak na de inenting met Gardasil. Canadees onderzoek constateerde al eerder dat YouTube-video's overwegend een negatief beeld schetsten van vaccinatieprogramma's, en dat de negatieve video's ook beter werden bekeken dan de positieve (Keelan, Pavri-Garcia et al. 2007). Onder andere de issuegroepen Vereniging Kritisch Prikken (www.nvkp.nl) en www.verontrustemoeders.nl maakten veel gebruik van media en internet om informatie te verspreiden die vaak niet gestoeld was op medische feiten. YouTube-video's gebruikten bovendien een dramaturgisch format waartegen weinig traditionele campagnes opgewassen zouden zijn; zo circuleerde er een filmpje waarin een fragment uit de film over het einde van Hitler en zijn trawanten, Der Untergang, zo was ondertiteld dat het leek alsof het de HPV-besluitvormingsprocedure bij het RIVM betrof.

Zelfs zonder deze vertroebeling zou het echter ingewikkeld zijn geweest om adequaat te communiceren over de HPV-vaccinatie. Het onderwerp ligt ten eerste moreel ingewikkeld. Meisjes vanaf twaalf jaar konden zelfstandig beslissen of zij tot inenting wilden overgaan, desnoods zonder toestemming van de ouders. De HPV-vaccinatie is echter alleen effectief wanneer het meisje nog niet besmet is geraakt, of in andere woorden, wanneer zij nog niet seksueel actief is. Daarnaast bestond er geen wetenschappelijke consensus over de wenselijkheid van hpv vaccinaties, een wenselijkheid die immers slechts kan worden bepaald door de weging van de diverse factoren zodat opname in het vaccinatieprogramma per definitie een politieke keuze is. Ten slotte zijn tieners als doelgroep notoir lastig te bereiken.

Desalniettemin rekende het RIVM erop dat 75 procent van de doelgroep (bestaande uit twaalfjarigen en voor de inhaalcampagne uit dertien- tot zestienjarigen) zich zou komen laten inenten. Toen in maart 2009 de campagnes startten, daalde de opkomst echter al snel van 60 procent in de eerste week naar 47 procent in de tweede week. De RIVM-website vermeldt dat vanaf het begin van de campagne tot 18 april 2009, 49 procent van de opgeroepen meisjes de prik heeft gehaald. In een interview met NRC Handelsblad wijt directeur prof.dr. Coutinho de teleurstellende opkomstcijfers onder andere aan de vroegtijdige en zeer felle lobby van de industrie. Daarnaast stelt hij het volgende.

"Dat [de mogelijke schade aan de algemene vaccinatiebereidheid] neem ik die wetenschappers kwalijk die zich nu uitspreken tegen het vaccin. Het is misschien ongebruikelijk dat ik mij tegen hen richt, want het is legitiem voor onderzoekers om hun twijfels te hebben als het gaat om dit type vraagstukken. Daar moet je wetenschappelijk over discussiëren. Bijvoorbeeld in de relevante tijdschriften. Maar als je dat hebt verloren, omdat je geen sterke argumenten had, is het niet in orde om die twijfels opnieuw te ventileren."

En: 
"We wilden die complicatie [van de seksuele connotaties] vermijden. Daarom hebben we bewust gekozen voor een campagne die helemaal was gericht op de medische kant: een prik tegen kanker. Achteraf gezien hadden we beter die seksuele overdraagbaarheid van het virus wel prominenter mee kunnen nemen. Deze enorme toestand heeft daar voor een deel mee te maken. Maar de media hebben ook een gekke rol gespeeld. De tegenstelling is enorm uitvergroot. En dan is er internet. Daar hebben we ons op verkeken. Daar zitten mensen te praten alsof ze bij de kapper zitten. Maar als iemand op internet schrijft dat haar dochter is doodgegaan door het vaccin, wordt dat als een echt feit aangenomen. Dat is net zo serieus als een rapport van de Gezondheidsraad waar een jaar over is nagedacht." 5

Coutinho betitelt de ontstane reactie als 'krankzinnig' en 'irrationeel'. Hij analyseert de gevolgen van mediatisering vanuit de formele, klassiek-modernistische orde, en benadrukt in zijn uitspraken een gezagsopvatting op basis van positie; discussie moet worden beperkt tot de relevante tijdschriften. Wanneer de media zich daar niet aan houden, levert dat in zijn analyse risico's op voor zowel de legitimiteit als de intelligentie van de besluitvorming. Het drama regeert, de ratio moet wijken - of toch niet?

Het vaccinatiedebat kreeg een staartje ten tijde van de Mexicaanse griep, november 2009, waarbij met name de websites www.verontrustemoeders.nl en www.prikmijmaarlek.nl veel aandacht kregen in de traditionele media. Die aandacht is echter overwegend kritisch, zoals blijkt uit onderstaand overzicht van de landelijke krantenberichten in de (willekeurig gekozen) week 9-11-2009/ 14-11-2009 (zoekstring: 'kritisch prikken'). In reactie op de complottheoretici opende de overheid de site www.grieppandemie.nl, en plaatste banners op fora.

Het moge duidelijk zijn dat de mediacommotie rondom vaccinatie niet 'slechts' om de medische discussies draaide. De onderliggende kwestie is die van het gezag van de overheid, in dit geval gerepresenteerd door het RIVM en het ministerie van Volksgezondheid (Vws), en van de wetenschappelijke kennis waarop deze zich baseert: nee tegen prik, nee tegen het gezag. ${ }^{6}$ Bekijken we dat 'nee' tegen de HPVvaccinatie echter nader, dan is het zeer de vraag of het hierbij slechts ging om een door de media aangewakkerde irrationaliteit. In eerder onderzoek merkte Brian Wynne op dat: sceptische reacties van het publiek niet reageren op (verondersteld onjuist ingeschatte) risico's op zichzelf, of op de mediarepresentaties daarvan, maar eerder publieke oordelen zijn over dominante wetenschappelijke en politieke instituties en hun gedrag, inclusief hun representatie van het publiek (Wynne 2001: 1). In dit verband is de referentie naar Softenon/Des veelzeggend: terwijl de overheid verzekert dat er ditmaal geen enkel risico bestaat, onthoudt het publiek dat die verzekering al eerder is gegeven en destijds niet waargemaakt. Dat het publieke wantrouwen deels gebaseerd is op wetenschappelijk onjuiste informatie, maakt de reactie op zichzelf nog niet irrationeel. Het is daarom extra ernstig, en contra- 
Tabel 10.3 Krantenberichten over de Mexicaanse griep

\begin{tabular}{|c|c|c|c|}
\hline Datum & Krant & Kop & Strekking artikel \\
\hline $\begin{array}{l}9-11- \\
2009\end{array}$ & de Volkskrant & $\begin{array}{l}\text { Kans op ernstige bijwerking } \\
\text { miniem: onderzoekers weerspreken } \\
\text { verhalen over hersenschade } \\
\text { en onvruchtbaarheid door vaccin }\end{array}$ & $\begin{array}{l}\text { Er is nooit wetenschappelijk bewijs } \\
\text { geleverd voor vaccinatieschade }\end{array}$ \\
\hline $\begin{array}{l}10-11- \\
2009\end{array}$ & De Telegraaf & Griepprik & $\begin{array}{l}\text { Minister Klink noemt de griepprik } \\
\text { veilig; paniekverhalen over vaccina- } \\
\text { tie afkomstig van volstrekte leken }\end{array}$ \\
\hline $\begin{array}{l}11-11- \\
2009\end{array}$ & Spits & $\begin{array}{l}\text { Mama twijfelt over prik; overheid } \\
\text { strijdt tegen valse info, zwangeren } \\
\text { bezorgd }\end{array}$ & $\begin{array}{l}\text { Zwangeren vrezen vaccinatieschade; } \\
\text { de overheid probeert internetfabels } \\
\text { te bestrijden }\end{array}$ \\
\hline $\begin{array}{l}11-11- \\
2009\end{array}$ & Trouw & $\begin{array}{l}\text { Wetenschap, overheid, industrie, } \\
\text { twijfel }\end{array}$ & $\begin{array}{l}\text { Het vertrouwen in overheid, weten- } \\
\text { schap en professional is afgenomen; } \\
\text { toch zou de overheid vaccinatie- } \\
\text { boodschappen moeten laten } \\
\text { verkondigen door de huisarts }\end{array}$ \\
\hline $\begin{array}{l}11-11- \\
2009\end{array}$ & $\begin{array}{l}\text { NRC Handelsblad/ } \\
\text { NRC Next }\end{array}$ & $\begin{array}{l}\text { Prikangst uit complotvrees van } \\
\text { 'verontruste moeders': wantrouwen } \\
\text { zat vroeger in het dorpscafé/Het } \\
\text { vaccin is: (a) wapen (b) chip (c) kwik; } \\
\text { verhalen circuleren op het web }\end{array}$ & $\begin{array}{l}\text { Het specifieke karakter van internet } \\
\text { maakt het gemakkelijk om ongecen- } \\
\text { sureerd 'informatie' te verspreiden, } \\
\text { die vooral mensen buiten het } \\
\text { systeem aanspreekt }\end{array}$ \\
\hline $\begin{array}{l}11-11- \\
2009\end{array}$ & $\begin{array}{l}\text { Algemeen } \\
\text { Dagblad }\end{array}$ & $\begin{array}{l}\text { Goede gezondheidszorg kent } \\
\text { ernstige bijwerkingen }\end{array}$ & $\begin{array}{l}\text { Als er nog grote epidemieën voor- } \\
\text { kwamen, zou er geen voedings- } \\
\text { bodem voor complottheorieën zijn }\end{array}$ \\
\hline $\begin{array}{l}13-11- \\
2009\end{array}$ & Trouw & $\begin{array}{l}\text { Pokkenprik in } 1800 \text { eveneens } \\
\text { omstreden; déjà vu }\end{array}$ & $\begin{array}{l}\text { Weerstand tegen inenting kent } \\
\text { lange geschiedenis }\end{array}$ \\
\hline $\begin{array}{l}14-11- \\
2009\end{array}$ & De Telegraaf & $\begin{array}{l}\text { Argwaan regeert; hoe komt het dat } \\
\text { wij bij oproep griepvaccinatie } \\
\text { massaal twijfelen aan bestuurders } \\
\text { en medische stand? "Overheid } \\
\text { heeft geen idee wat er leeft bij de } \\
\text { mensen" "Gebrek aan transparantie } \\
\text { maakt wantrouwig" }\end{array}$ & $\begin{array}{l}47 \% \text { van } 4600 \text { ondervraagde } \\
\text { respondenten achtte verzet tegen } \\
\text { vaccinatie gegrond; de overheid } \\
\text { bepaalt niet meer waarover mensen } \\
\text { praten }\end{array}$ \\
\hline
\end{tabular}

productief, dat deze reactie door het RIVM in de media werd afgedaan als gebaseerd op 'indianenverhalen' en kappersgesprekken.?

De reactie van het RIVM was gestoeld op een klassiek-modernistische opvatting van gezag; de wetenschap levert gegevens en via de Gezondheidsraad een weging aan, de politiek beslist, RIVM en GGD's voeren uit, het passieve publiek volgt. Er ontstonden echter problemen op het vlak van implementatie, deels door de repre- 
sentatie in de media, maar ook doordat het RIVM zich blijkbaar onvoldoende bewust was van het specifieke publiek van deze campagne en de wijze waarop dat werd beïnvloed door de politiek van veelvoudigheid. Zowel bij de HPV-campagne als voor de Mexicaanse griep onderschreven professionals (huisartsen, virologen) niet zonder meer het overheidsbeleid; een aantal van hen tekende in de media protest aan. Issuegroepen als 'Verontruste moeders' en de 'informatieve' site www.prikmijmaarlek.nl kregen uitgebreid het woord en stelden publiekelijk geen enkele vaccinatie-informatie van de overheid te vertrouwen - inclusief die van de huisartsen en wetenschappers. De eenling met de afwijkende mening kreeg op radio, tv en in de krant relatief veel spreektijd, in overeenkomst met een narratieve medialogica die tegenover een protagonist ('de overheid') graag een antagonist zet (de complottheoretici). Kijkt men naar de door Google gerapporteerde trends, dan lijkt het erop dat de oude media de spookverhalen in de nieuwe media belangrijker maken dan zij op internet zijn (gemeten in termen van ingevulde zoektermen en unieke websitebezoekers). Hoewel het hier slechts gaat om trends waaraan weinig gedetailleerde conclusies verbonden kunnen worden, lijkt de rol van de anti-vaccinatiesites als informatiebron relatief beperkt. Dat wijst ons op het fenomeen van gezag dat exclusief ontleend is aan de media (media derived authority, Herbst 2003). De issuegroepen vertegenwoordigen niet noodzakelijkerwijs een grote achterban en spreken niet op basis van expertise, maar komen plotseling in de belangstelling te staan doordat de media de groepen uitnodigen en de leden interviewen. Vervolgens ontstaat er een zichzelf versterkend proces en plotseling vormen de 'Verontruste moeders' het gezicht van de wantrouwige burger.

Hieruit zou men kunnen concluderen dat - paradoxaal genoeg - vooral de oude media in deze casus een risico vormden voor de stabiliteit, legitimiteit en intelligentie van het vaccinatiebeleid. Zij gaven immers de antagonisten meer aandacht dan deze wellicht op het web gekregen zouden hebben, wakkerden daarmee de twijfel aan de betrouwbaarheid van de overheid aan en bemoeilijkten zo de implementatie van het vaccinatiebeleid.

Desalniettemin kan deze mediahype niet zomaar worden afgedaan als een voorbeeld van dumbing down. Diezelfde traditionele media - inclusief De Telegraaf en gratis kranten- plaatsen immers nadrukkelijk vraagtekens bij de complotwebsites waarop zij zelf de aandacht vestigen. Hoewel de antagonistische boodschap van issuegroepen als 'Verontruste moeders' via de traditionele media dus relatief veel ruimte krijgt, wordt deze ook weer in perspectief geplaatst, en niet slechts in het hoofdredactioneel commentaar. De publieke sfeer die op deze wijze via de media gestalte krijgt lijkt dan ook - anders dan op de sites van genoemde issuegroepen eerder agonistisch dan antagonistisch te zijn. Dat neemt niet weg dat de kranten, al dan niet bij monde van experts, soms scherpe kritiek leveren op de wijze waarop de overheid communiceert, en dan met name op de 'monopolisering' van het debat. Terwijl het gezag van het openbaar bestuur in deze casus dus duidelijk 


\section{Figuur 10.1}

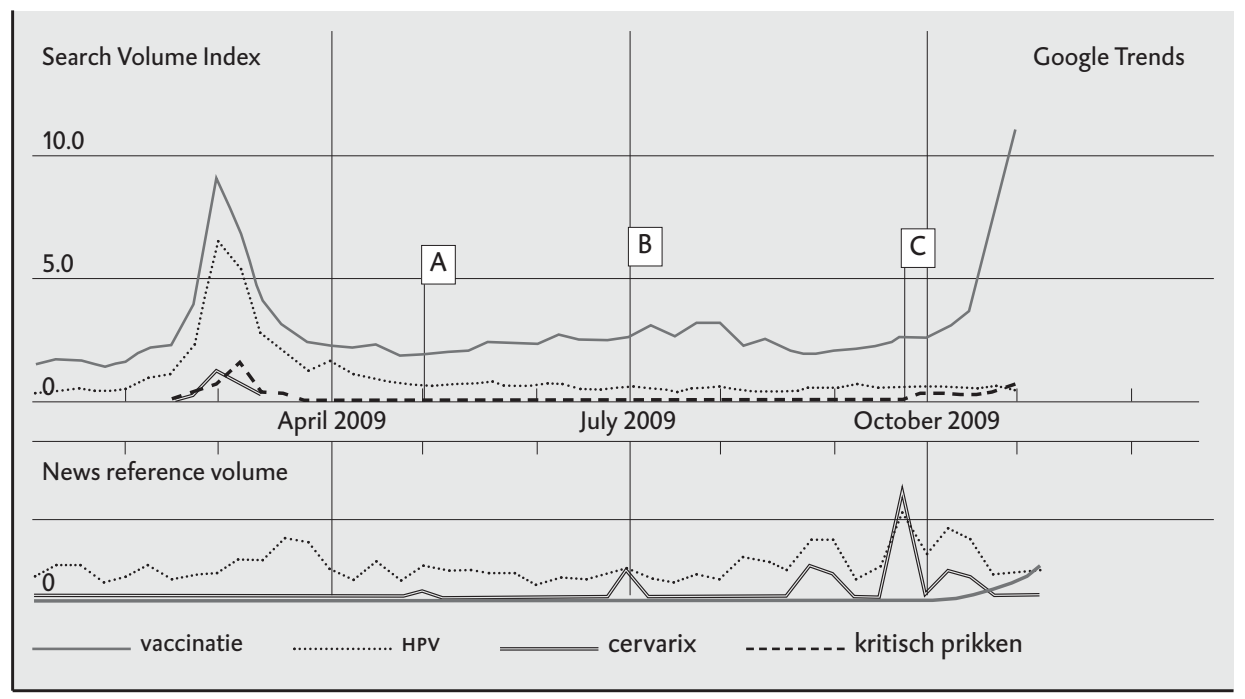

Bron: Google Trends, 15-11-2009

Google index gebaseerd op gemiddeld Nederlandse invoer van zoekterm 'HPV' in 2009.

Weergegeven zoektermen: HPV (1), vaccinatie $(3,0)$, cervarix $(0,1)$, kritisch prikken $(0,1)$.

De zoekterm 'verontruste moeders' kende te weinig dataverkeer om te worden opgenomen.

\section{Figuur 10.2}

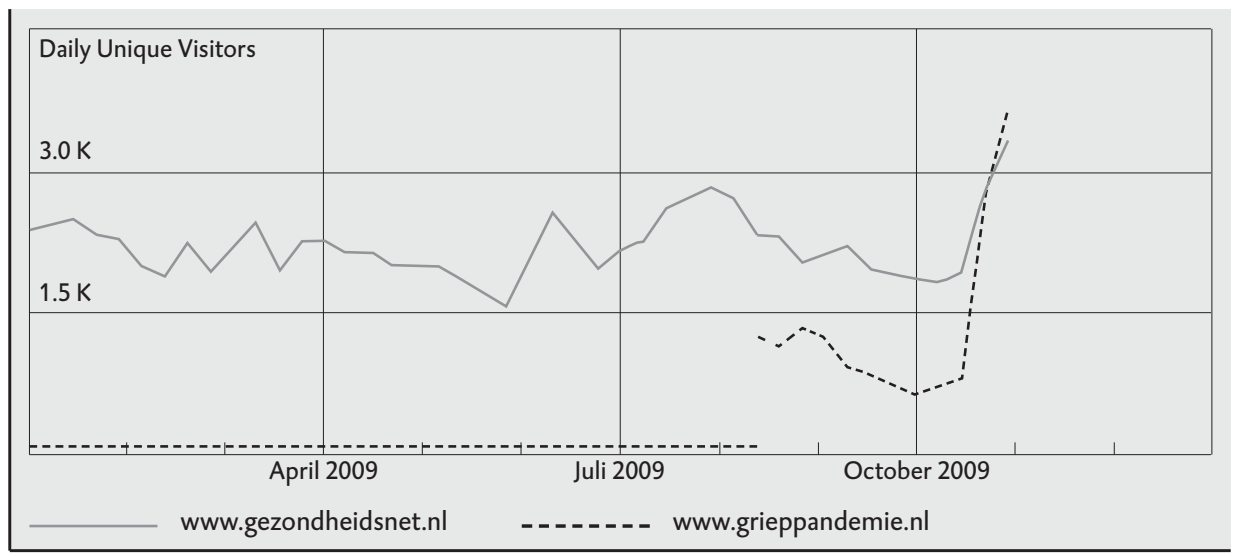

Bron: Google Trends, 15-11-2009

De populariteit van de sites www.grieppandemie.nl, www.gezondheidsnet.nl, www.prikenbescherm.nl, www.nvkp.nl, www.verontrustemoeders.nl; de laatste drie sites kenden te weinig dataverkeer om te worden opgenomen. De overheidssite www.grieppandemie.nl is relatief populair in verhouding tot de concurrerende sites van issuegroepen en steekt ook de algemene gezondheidssites naar de kroon. 
wordt betwist door actoren die hun gezag slechts ontlenen aan de media, is van een algemene dumbing down of een antagonistische publieke sfeer uiteindelijk geen sprake. Wel is de assumptie van het openbaar bestuur als een gesloten, hooghartige elite die het debat zou monopoliseren een terugkerend verschijnsel in het recente Nederlands debat. Problematisch daaraan is niet zozeer het idee van een besturende elite als wel het terugkerend beeld van een bestuur dat niet langer wordt gedragen door een bredere onderlaag, en al evenmin als vanzelfsprekend wordt gelegitimeerd door wetenschappelijke kennis. Enerzijds vloeit dit beeld direct voort uit de huidige problemen van de klassiek-modernistische orde, anderzijds kan het gemakkelijk door de media worden versterkt en via een sneeuwbaleffect leiden tot des te meer afzijdigheid, cynisme of vijandigheid. Hier willen we de vraag stellen of een discursieve opvatting van gezag behulpzaam zou kunnen zijn. Wanneer het openbaar bestuur zichzelf immers niet meer beschouwt als vanzelfsprekend gezaghebbend, zal het ook het publiek op andere wijze benaderen, en dat heeft weer gevolgen op dramaturgisch gebied.

Een voorbeeld van een dergelijke benadering vinden we in de Engelse Food Standards Agency (FSA, zie Hajer, Laws, Versteeg 2009 voor een uitgebreide beschrijving); een organisatie die is opgericht na de vertrouwensbreuk van de BSE-crisis. Om het vertrouwen van het publiek terug te winnen legde de FSA zich onder meer toe op de performance of uncertainty: publieke duidelijkheid op zoveel mogelijk verschillende podia, niet slechts over datgene wat bekend is, maar ook over die feiten waar men nog niet zeker van kan zijn. Door schade en schande leerde men niet slechts te zeggen wat men bedoelde, maar daarbij ook direct expliciet te maken wat er niet bedoeld werd. De FSA onderhield een uitgebreid contact met de diverse publieken, en besteedde daarbij ook aandacht aan voedselveiligheidsonderwerpen die weliswaar geen wetenschappelijke, maar wel publieke prioriteit hadden. Bovendien werden er burgers opgenomen in de wetenschappelijke comités, zodat de vragen van 'het' publiek al vóór de fase van beleidsontwikkeling tastbaar vorm zouden krijgen. Het ging daarbij niet alleen om de institutionalisering van een 'postnormaal' of constructivistisch wetenschapsbeleid; de 'consumentenexpert' bleek behulpzaam bij het anticiperen op de wijze waarop het onderwerp uiteindelijk in de media terecht zou komen. Tegelijkertijd koos men in die mediaoptredens voor een duidelijke rolverdeling, onder andere door voortdurend actief te scripten wie er voor een bepaald beleidsthema letterlijk gezichtsbepalend zou zijn. Bij voorkeur koos men voor iemand die ook wat betreft uiterlijke kenmerken bij het onderwerp betrokken zou kunnen zijn; zo verstrekte een vrouwelijke voorlichter informatie over borstvoeding, en onderhield de FSA nauw contact met leiders van de verschillende etnische groepen. Ook werd besloten om alle bijeenkomsten van het bestuur in de openbaarheid te laten plaatsvinden, en via de website beschikbaar te stellen. Geleidelijk ontstond een transparantieparadox: door de toegenomen openbaarheid nam de belangstelling van de media juist af. 
De transparantieparadox is niet het enige dilemma waar de FSA mee worstelde. Zo kan het toegeven van in de media uitvergrote onzekerheden aanvankelijk juist leiden tot een toename van het cynisme, bestaat er een spanningsveld tussen de noodzakelijke interactie met stakeholders (netwerk governance) en de noodzaak om in de media een hard imago als consumentenwaakhond te propageren, en blijft er sprake van een voortdurend balanceren tussen voorlichting en interactie. Toch zien we hier de contouren van een andersoortige gezagsrelatie, één waarin de verschillende publieken serieus worden genomen zodat wetenschappelijke dissensus minder snel zal leiden tot de delegitimatie van beleid via de media. In het onderstaande zullen we verder verkennen hoe een dergelijke gezagsrelatie vorm zou kunnen krijgen.

\subsection{DE VOORLICHTING VOORBIJ: GEZAGHEBBEND SPREKEN IN EEN GEMEDIATISEERDE PUBLIEKE SFEER}

Volgens recent onderzoek van het SCP (Dekker en Steenvoorden 2008) vindt meer dan de helft van de Nederlanders dat de regering méér zou moeten luisteren naar de mening van burgers en van wetenschappelijke experts, terwijl er juist minder aandacht zou moeten worden besteed aan berichten uit de media. Het onderzoek verscheen in september 2008 en lijkt haaks te staan op de HPV-vaccinatieaffaire, die kort daarna zou volgen: blijkbaar verlangden deze burgers, precies zoals het RIVM, naar meer rationaliteit in het beleidsproces. Aan dit verlangen ligt een veronderstelde dichotomie tussen informatie en communicatie ten grondslag, een onderscheid tussen feitelijke gegevens en de vertekening die deze in het communicatieproces ondergaan of, in termen van de gezagsgenres die we eerder onderscheiden, weg van de emotionele dramaturgie, terug naar het rationele debat of het formele leiderschap.

Het is twijfelachtig of een dergelijke wens kan worden vervuld. We zien immers dat het primair juridisch gedefinieerde klassiek-modernistische gezagsgenre niet vanzelfsprekend wordt ondersteund door het discursieve en dramaturgische gezagsgenre. Hoewel de sterke daling in het politiek vertrouwen van het begin van deze eeuw eerder tijdelijk dan structureel lijkt, kan het hedendaagse openbaar bestuur zich toch niet zonder meer baseren op het morele en geestelijk overwicht dat besloten ligt in het klassiek-modernistische woord 'overheid'. Meer dan eerder zullen de door de overheid 'geleverde' definities en betekenissen via de media worden aangevochten. Terwijl de wetenschap eerst fungeerde als schijnbare unanieme legitimatie van het overheidshandelen, brengen de media nu dikwijls juist de wetenschappelijke dissensus voor het voetlicht. Juist wanneer het openbaar bestuur weigert zich te laten ondervragen en tegenwerpingen afdoet als irrationeel, komt zijn gezag ter discussie te staan. Het formele gezag van het openbaar bestuur wordt dan zowel op agonistische wijze ondervraagd als op antagonistische wijze ondergraven. De casus biedt daarvan een treffend voorbeeld. 
Ook de dramaturgie van de klassiek-modernistische orde lijkt minder onaantastbaar dan dat eerder in de naoorlogse periode het geval was. Enerzijds zijn er zorgen over de kwaliteit en eigentijdsheid van gevestigde rituelen als Prinsjesdag en het parlementair debat. Onder druk van met name de populistische politici nemen ook de gevestigde partijen publiekelijk afstand van 'het Haagse gedoe', in de hoop zichzelf te kunnen presenteren als buitenstaanders, eerder burgers dan politici. Anderzijds is er de opkomst van opvallende nieuwe politieke ruimtes als de talkshow en internet, met eigen vormen en normen en een eigen dramaturgie. De talkshow lijkt een nieuw politiek ritueel te zijn geworden, waarin zowel 'het publiek' als 'de politiek' letterlijk een gezicht gegeven wordt - denk aan de gewoonte om de vox populi te laten horen, maar ook aan de tendens om in te zoomen op het persoonlijk leven van politici. Of het openbaar bestuur in deze nieuwe politieke ruimtes al dan niet gezichtsverlies lijdt, is sterk afhankelijk van het meer of minder mediagenieke optreden van individuele bestuurders en politici. Tegelijkertijd onttrekt een groeiend aantal politieke ruimtes in de vorm van governance netwerken zich juist aan het oog van de burger, niet in de laatste plaats doordat zij ook voor de media bijzonder onaantrekkelijk zijn om te portretteren totdat zo'n normaliter onzichtbaar netwerk bij een (al dan niet gefingeerd) schandaal betrokken raakt. We vatten deze situatie samen in tabel 10.3.

De vraag is hoe het openbaar bestuur in deze situatie, waarin noch de formeeljuridische noch de discursieve noch de dramaturgische benadering afdoende is, gezag kan (her)winnen en handhaven. Cruciaal lijkt het daarbij om te erkennen dat klassiek-modernistisch, discursief en dramaturgisch gezag in dit geval sterk met elkaar verweven zijn: het moreel gezag van het openbaar bestuur berust voor burgers op de mogelijkheid om de gekozen beleidslijnen te kunnen ondervragen en als emotioneel juist te kunnen ervaren. Dat betekent dat er geen quick fix kan worden gevonden op het gebied van voorlichting. Eerdere adviesrapporten (Wallage 2001; Wolffensperger 2005) wezen er reeds op dat communicatie niet langer als voorlichting aan het eind van het beleidsproces kan worden gezien, maar dat de 'buitenwereld' zo vroeg mogelijk in de beleidsontwikkeling moet worden binnengehaald. Het is echter de vraag of zelfs die constatering ver genoeg gaat. Zo spreekt een auteur als Michael Crozier (Crozier 2007) over een situatie van recursive governance, waarmee hij de aandacht wil vestigen op het grote belang van de tegenwoordig voortdurend tussen instituties, burgers en media heen- en weergaande informatiestromen. Het is dan ook twijfelachtig of het openbaar bestuur in staat zal zijn om meer afstand te bewaren tot de media, zoals het ROB suggereerde in haar rapport Politiek en media: pleidooi voor een latrelatie (RОв 2003). Zelfs wanneer politiek en openbaar bestuur meer afstand tot de media zouden bewaren, weerhoudt dit andere actoren er niet van om te proberen via de media het beleid in alle fasen van het beleidsproces te beïnvloeden, zoals we ook in de casus zagen. Overheidscommunicatie en overheidshandelen zijn onlosmakelijk verweven: het gaat niet om het controleren van informatie in een stabiele omgeving, maar om 
Tabel 10.4 Governance genre en gezagsgenre

\begin{tabular}{|c|c|c|c|}
\hline $\begin{array}{l}\text { Governance } \\
\text { genre }\end{array}$ & Gezagsgenre(s) & $\begin{array}{l}\text { Krachtig in gemediati- } \\
\text { seerde samenleving? }\end{array}$ & $\begin{array}{l}\text { Zwakte in gemediati- } \\
\text { seerde samenleving? }\end{array}$ \\
\hline $\begin{array}{l}\text { Klassiek- } \\
\text { modernistisch }\end{array}$ & $\begin{array}{l}\text { Formeel gezag geworteld } \\
\text { in een min of meer } \\
\text { vaststaand repertoire van } \\
\text { performances en settings }\end{array}$ & $\begin{array}{l}\text { In het verleden sterk } \\
\text { ontwikkelde dramaturgie, } \\
\text { inclusief symbolen en } \\
\text { rituelen; formele } \\
\text { legitimiteit }\end{array}$ & $\begin{array}{l}\text { In een gemediatiseerde } \\
\text { samenleving weinig } \\
\text { discursief gezag-relatief } \\
\text { weinig mogelijkheden tot } \\
\text { ondervraging; drama- } \\
\text { turgisch gezag in nieuwe } \\
\text { politieke ruimtes als de } \\
\text { talkshow sterk afhankelijk } \\
\text { van individuen }\end{array}$ \\
\hline $\begin{array}{l}\text { Netwerk } \\
\text { governance }\end{array}$ & $\begin{array}{l}\text { Gezag op basis van } \\
\text { effectiviteit, geworteld in } \\
\text { interacties die een ad hoc } \\
\text { relatie tussen stakeholders } \\
\text { tot stand brengen }\end{array}$ & $\begin{array}{l}\text { Juist door onzichtbaarheid } \\
\text { groot vermogen tot } \\
\text { oplossen van grensover- } \\
\text { schrijdende problemen }\end{array}$ & $\begin{array}{l}\text { In een gemediatiseerde } \\
\text { samenleving weinig drama- } \\
\text { turgisch gezag - weinig } \\
\text { mogelijkheden tot ervaring, } \\
\text { geringe zichtbaarheid voor } \\
\text { niet-directe stakeholders en } \\
\text { daarmee voedingsbodem } \\
\text { voor complottheorieën }\end{array}$ \\
\hline
\end{tabular}

het managen van communicatie in een vloeiende omgeving (Crozier 2007: 7). $\mathrm{Nu}$ roept het 'managen' van communicatie gedachten op aan overheidsspin, zoals die met name bekend werd in Groot-Brittannië onder New Labour. Een dergelijke, puur dramaturgische benadering is echter een onderschatting van burgers en media: voor iedere vorm van spindoctoring ontstaan er nieuwe vormen van ontmaskering, en de kans is groot dat dit uiteindelijk leidt tot een cyclus waarin wederzijds wantrouwen steeds meer centraal komt te staan. Kern van de huidige situatie is immers juist dat wie bestuurt, voortdurend in het oog gehouden wordt door de diverse massamedia - wat overigens niet betekent dat zij ook het juiste beeld schetsen. Ook de zoektocht naar nieuwe politieke rituelen, bijvoorbeeld op het gebied van burgerschap, kan slechts succesvol zijn als inhoud samengaat met vorm: een holle versterking van de dramaturgie is gedoemd om te mislukken, ook als dat gepaard gaat met grootschalige burgerschapsevenementen (vgl. de bijdrage van Van der Veen et al. in deze verkenning).

Een alternatieve benadering richt zich juist op het versterken van het discursieve gezag, door zoals Wolffensperger c.s. (2005) ook suggereerden, de 'buitenwereld' binnen te halen, en burgers in een vroeg stadium bij de beleidsontwikkeling te betrekken. Op die manier wordt de discursieve ondervraging al in het beleidsproces geïncorporeerd, in de hoop dat zo de uiteindelijke beleidsresultaten minder 
kwetsbaar zullen zijn. Hierbij zien we echter dikwijls een gebrekkige dramaturgie. De spanningsboog van het proces is vaak al weinig tastbaar voor de direct betrokkenen, laat staan voor de burgers die in abstracto worden gerepresenteerd - wat ontbreekt is de emotionele identificatie die de politieke talkshow wel biedt (in positieve of negatieve zin).

Pierre Bourdieu (Bourdieu 2001: 250) beschreef de invloed van de televisie als een game of mirrors, reflecting one another. Dat is een pakkend beeld, omdat het in woorden vangt hoe de media niet slechts een bepaalde werkelijkheid weerspiegelen, maar ook hun eigen weerspiegeling daarvan en zo tot in het oneindige verder, zonder dat nog duidelijk is wat een weerkaatsing van een weerkaatsing is en waar het werkelijke beeld begon - we zagen dat ook in de casus. Zo bezien wordt de publieke sfeer een complex systeem, waarin een klein incident tot grote en lang niet altijd voorspelbare gevolgen kan leiden. Vanuit diezelfde complexiteitstheorie zou het advies aan het openbaar bestuur luiden om 'reserveruimte' in te bouwen, een overtolligheid die de geschetste problemen rond leren, legitimiteit en implementatie wellicht gedeeltelijk zou kunnen oplossen of voorkomen, zij het niet zonder investering. Wanneer beleid niet los te zien valt van communicatie, de overheid niet automatisch gezaghebbend is en 'de' burger ongrijpbaar, vraagt dat immers om een andere benadering van beeldvorming - dat wil zeggen, om een voortdurend onderzoek naar de wijze waarop beelden gevormd worden. Hoe vormen burgers hun beeld van het openbaar bestuur in het algemeen, en beleidsonderwerpen in het bijzonder; en omgekeerd, hoe vormt de beleidsmaker zijn beeld van de burgers waarop het beleid gericht moet zijn?

Terwijl de exacte vorm van een crisis uiteraard nooit kan worden voorspeld, valt soms wel te voorzien wat meer of minder controversiële onderwerpen zijn. Relevante vragen zijn dan bijvoorbeeld of er aan het onderwerp al eerder mediaaandacht is besteed, en in hoeverre het thema 'leeft' op internet - de controverse rond vaccinaties werd bijvoorbeeld deels gevoed door Amerikaanse berichten en filmpjes. Beseft men dat monopolisering van kennis door een gesloten elite een terugkerende klacht is in het maatschappelijk debat, dan kunnen twijfels over de onafhankelijkheid van een adviesorgaan vooraf deels worden voorkomen door een zo groot mogelijke transparantie over het eigen functioneren. Daartoe dient men ook kennis te hebben van de kennis die 'de' burger bezit: in hoeverre zijn de verschillende publieken op de hoogte van het bestaan, de functie en het functioneren van het adviesorgaan? Hoe wordt er door uiteenlopende groepen gedacht over de diverse beleidsonderwerpen, wat vinden zij belangrijk en welke vragen leven er? Hoe nemen die publieken nieuws tot zich, nemen zij nog nieuws tot zich? Welke blogs worden gelezen, welke tijdschriften, welke betaalde of gratis kranten, welke programma's bekeken? Welke andere actoren, bedrijven of belangengroepen proberen hun boodschap voor het voetlicht te brengen en op welke wijze gebeurt dat? Een degelijke kennis over de specifieke middelen en mogelijk- 
heden om de diverse publieken te bereiken, kan niet alle, maar wel veel onaangename verrassingen voorkomen. Op het vlak van dramaturgie zagen we bovendien dat de FSA diverse gezichten inzette voor de verschillende nieuwsonderwerpen.

Dit is meer dan slechts een kwestie van herkenbaarheid; het helpt de kijker om een politiek onderwerp op persoonlijke wijze te ervaren. Hoe men een dergelijke verpersoonlijking van de politiek en de bijbehorende vervaging tussen privé en publiek normatief waardeert, hangt misschien vooral af van het gehanteerde democratisch ideaal. In termen van Marres (2003: 44):

"Vanuit een definitie van politiek als een kwestie van vertrouwen valt de ondermijning van het onderscheid tussen publiek en privé samen met de ondermijning van de politiek: de aanwezigheid van fragmenten uit het privéleven in het publieke domein ondergraaft het vertrouwen in het publieke imago van de politiek, en daarmee uiteindelijk de politiek zelf. Maar vanuit een definitie van politiek als een kwestie van meningsverschil en confrontatie, schept de ondermijning van de scheiding tussen publiek en privé juist kansen voor politiek: dankzij de traceerbaarheid die media mogelijk maken, is het domein van kwesties waarover politieke controverses kunnen ontstaan aanzienlijk verbreed."

Dat vereist wel dat emoties op hun waarde worden geschat, als onderdeel van de oordeelsvorming binnen de publieke sfeer. Dat wil niet zeggen dat onder het publiek levende gevoelens klakkeloos moeten worden overgenomen, noch dat het openbaar bestuur hier machteloos tegenover zou staan. Evenmin kunnen zij echter zomaar worden afgedaan als 'irrationeel'. Beter zou het openbaar bestuur eraan doen zich af te vragen wat de agonistische of zelfs de antagonistische burger drijft, en of er onder een schijnbaar irrationele handelwijze een rationele argumentatie schuilgaat (vgl. Verhoeven 2009). Terwijl het veelvoud aan mediaboodschappen niet zonder risico's is, kan dat uit democratisch oogpunt immers ook worden gewaardeerd als een veelstemmigheid die ruimte biedt voor de uitdaging van vanzelfsprekendheden (wat uiteraard niet wil zeggen dat iedereen gelijke mogelijkheden heeft om die uitdaging te poneren). Dat burgers de boodschap van het openbaar bestuur niet zonder meer aannemen, is wellicht niet alleen maar negatief in een publieke sfeer waar marketing zich steeds meer vermomt als neutrale voorlichting. De vraag of de media een bijdrage leveren aan het democratisch klimaat of daaraan juist afbreuk doen, kan daarom niet in zijn algemeenheid worden beantwoord. Waar ligt de grens tussen een cynische ondergraving en een kritische ondervraging van het openbaar bestuur?

Dat neemt niet weg dat het voor de overheid cruciaal is om burgers te kunnen bereiken, zo niet met gedeelde betekenisgeving dan toch met informatie waarop zij hun oordeel kunnen baseren. Naar aanleiding van de stroom verwarrende en foutieve internetberichten over de zogenoemde Mexicaanse griep werd daarom wel gesteld dat de overheid zich pro-actief op sociale netwerksites als Twitter 
moet begeven. Daar zou zij in dialoog moeten gaan met burgers, maar dan wel in het besef 'dat zij het niet altijd het eerste of het beste weet en dat ze anderen nodig heeft. Dat is immers de crux: je kunt deze webtoepassingen niet los zien van de gedachte die eraan ten grondslag ligt - dat gebruikers in alle openheid samenwerken'. Elders werd ietwat cynisch geopperd dat de overheid een voorbeeld kan nemen aan de methoden van de tabaksindustrie, die creatieve voorlopers uit de jongerencultuur rekruteert met sigaretten, in de hoop dat leeftijdgenoten hun voorbeeld navolgen. ${ }^{9}$ De eerdergenoemde FSA werkte feitelijk al via een dergelijke methode, door te zoeken naar sleutelfiguren met een uitgebreid netwerk in vooral moeilijk te bereiken groepen. Een dergelijk netwerk vergemakkelijkt het relationeel spreken, met name ook voor die publieken die elke vorm van overheidsinformatie als verdacht beschouwen. Het juiste genre, het juiste podium, de juiste spreektaal kunnen de communicatie tot op zekere hoogte vergemakkelijken ongeacht of het daarbij gaat om iets wat het openbaar bestuur zelf wil vertellen, of om het afzwakken of tegenspreken van een in de media circulerende boodschap. Dat is des te belangrijker nu de media een beleidsonderwerp binnen zeer korte tijd tot crisis kunnen uitvergroten. Voor het doen functioneren van een dergelijk netwerk is het echter wel cruciaal om de oude metafoor van de vaste boodschap die door een zender aan een passieve ontvanger doorgegeven wordt, te vervangen door het huidige beeld van informatie die voortdurend in beweging is, tussen zenders en ontvangers heen en weer gaat en daarbij voortdurend geïnterpreteerd en vervormd wordt. Kleinschalige interactie binnen een (al dan niet virtueel) netwerk kan dan helpen om een beleidsonderwerp zo te framen dat de betekenis ervan leesbaar wordt voor het bedoelde publiek. De bovengenoemde adviezen geven echter ook al aan hoe moeilijk het is om in die interactie een positie te bepalen; de overheid neemt als informatieverschaffer uiteraard een bijzondere positie in, maar de dramaturgie van de nieuwe media maakt juist iedereen gelijk.

Het openbaar bestuur doet er dan ook goed aan na te gaan hoe het voor haar essentiële spoor van wetenschappelijke beleidsvoorbereiding als gezagsbasis kan worden herwonnen. 'Fact-regardingness' is een cruciale waarde, net zo goed als toekomstonderzoek in de vorm van scenario's en assessments de overheid kan helpen bij het nemen van strategische beslissingen. Deze belangrijke poten onder het klassiek-modernistische bestuur zijn echter niet zonder aanpassing te kopiëren naar de huidige gemediatiseerde samenleving. In een tijd waarin politieke bestuurders veelvuldig worden geconfronteerd met tendentieuze berichtgeving of suggestieve opzetjes die het gezag van het openbaar bestuur ondermijnen, is het van belang dat wordt gekeken hoe juist in dergelijke situaties een koppeling kan worden gelegd naar de in principe krachtige ondersteuning door wetenschappelijk onderzoek. Die cruciale rol wordt bemoeilijkt nu ook de gezagsbasis van het wetenschappelijk onderzoek geërodeerd is ('dat zijn uw feiten!'), terwijl de experts nog wel worden aangehaald om elkaar in de media tegen te spreken. Het voornoemde onderzoek naar de Britse FSA toont echter aan dat er ook hier een 
genre kan worden gedefinieerd dat wel in staat is om wetenschappelijk onderzoek te mobiliseren voor het verwerven van politiek gezag. Daartoe dienen enerzijds bestaande onzekerheden te worden erkend, terwijl anderzijds helder kan worden aangegeven op welke gebieden wel breed gedeelde wetenschappelijke consensus bestaat (zie bijvoorbeeld een website als www.klimaatportaal.nl). Dit biedt de ruimte om in de media belichte fabels te ontkrachten en tegemoet te komen aan de vraag naar rationaliteit - althans voor die publieken die de moeite nemen dergelijke informatiesites te zoeken en bezoeken.

Voor het openbaar bestuur als gezaghebbende actor betekent dat een terugkeer naar de betekenis van auctor of auctoritas als bron van een verhaal - een van de vele mogelijke bronnen van de vele verhalen binnen de gemediatiseerde samenleving. In het theater of de literatuur zijn we bereid ons ongeloof op te schorten wanneer het verhaal 'klopt' (discursief gezag), wanneer we de verteller vertrouwen op grond van zijn positie (formeel gezag) of wanneer deze blijkt te beschikken over een buitengewone emotionele overtuigingskracht (dramaturgisch gezag). Het openbaar bestuur beschikt niet langer over de vanzelfsprekende formele autoriteit die in staat was om burgers een verhaal op te leggen. In plaats daarvan zal zij moeten streven naar contextuele geloofwaardigheid; iedere politieke uitspraak of handeling moet passen binnen het script en de logica van het gegeven podium, door het doelpubliek gericht aan te spreken zonder daarbij een ander publiek geweld aan te doen. Politiek gezag vereist daarom de kundigheid om een situatie te kunnen lezen en te beantwoorden met een politieke stijl die vorm en inhoud, principe en presentatie met elkaar verweeft (Pels 2003: 57). Voor deze kundigheid is noch formeel noch discursief noch dramaturgisch gezag op zichzelf voldoende; slechts de combinatie van dramaturgische presentatie, de mogelijkheid tot discursieve uitdaging en het besef van duurzame betrouwbaarheid is in staat om de diverse publieken aan te spreken en in een beleidsdiscours met elkaar te verbinden.

Politiek is theater. Maar dat maakt het nog niet onecht. 


\section{NOTEN}

1 Een interessant voorbeeld hiervan is het vertrouwen dat Amerikaanse kijkers hechtten aan The Daily Show, een satirisch programma dat de praktijken van politiek en media ter discussie stelt, juist door deze te parodiëren.

Zie het vervolgonderzoek hiernaar op de weblog Sargasso:

http://sargasso.nl/archief/2007/05/15/tweede-kamerleden-zijn-mediajunksvervolg/

3 http://preventieziektezorg.rivmvoorlichtingscentrum.nl/toolkithpvvaccinatie/ 4 http://preventieziektezorg.rivmvoorlichtingscentrum.nl/toolkithpvvaccinatie/

$5 \quad$ F. Vermeulen, 'De stelling van Roel Coutinho: hype over HPV-vaccin riskant voor bestrijding infectieziekten. NRC Handelsblad, 21-03-2009

6 W. van der Bles en N. Lucas, 'Nee tegen prik, nee tegen gezag', Trouw, 27-03-2009

7 'Indianenverhalen', interview Roel Coutinho, Pauw\&Witteman 10-03-2009 en vervolgens overgenomen door diverse kranten; vergelijk bovengeciteerde uitspraak uit F. Vermeulen, 'De stelling van Roel Coutinho: hype over HPV-vaccin riskant voor bestrijding infectieziekten, NRC Handelsblad, 21-03-2009.

8 S. Cels en J. van den Steenhoven, 'Klink kan voordeel hebben bij internet; overheid mag burgerforums niet onweersproken laten; samenwerking kan ook', NRC Handelsblad, 11-11-2009.

9 W. Kohler, 'Een besluit voor de hele bevolking; spookverhalen zitten Klink dwars', NRC Handelsblad, 10-11-2009 


\section{OVER DE AUTEURS}

\section{Maud Adriaansen}

Maud Adriaansen studeerde in 2005 af in de economie aan de Vrije Universiteit en de politicologie aan de Universiteit van Amsterdam. Momenteel rondt zij haar proefschrift af aan de Amsterdam School of Communications Research (ASCOR) van de Universiteit van Amsterdam. Dit proefschrift gaat over de invloed van mediagebruik op politiek cynisme en stemgedrag. Zij schreef haar proefschrift naast haar werk als marktonderzoeker bij Veldkamp en als wetenschappelijk medewerker bij de Wetenschappelijke Raad voor het Regeringsbeleid (WRR). Zij publiceert onder meer over attitudes en gedrag van burgers, politieke communicatie en politieke marketing.

\section{Luuk Boelens}

Luuk Boelens is bijzonder hoogleraar planologie aan de Universiteit Utrecht, een leerstoel ingesteld door VROM met betrekking tot mobiliteit en ruimtelijke ordening. Hij is afgestudeerd aan de TU Delft stedenbouwkunde en haalde zijn doctoraal in de socio-genesis van stedenbouw, planologie en filosofie met de thesis 'Stedenbouw en planologie - een onvoltooid project, naar een communicatief handelen in stedenbouw en ontwerp'. Hij werkte verscheidene jaren voor de provincie Zuid-Holland als projectleider van grote onderzoeksprojecten, was secretaris van de commissie regionale plannen van de PPC, en van 1991 tot 1997 plaatsvervangend hoofd van het Randstadprojectteam en projectleider van grote beleidsgevoelige projecten in de Randstad. Tot augustus 2002 was hij projectleider en strategisch adviseur bij de vakgroep planvorming van Holland Railconsult. Sinds 1999 is hij zelfstandig adviseur en sinds 2000 mededirecteur van Urban Unlimited, bureau voor netwerkplanning.

\section{Huub Dijstelbloem}

Huub Dijstelbloem is onderzoeker en projectleider bij de WRR. Daarnaast is hij verbonden aan de leerstoelgroep wetenschapsfilosofie van de Universiteit van Amsterdam. Hij studeerde filosofie en wetenschapsdynamica aan de UvA en aan de École des Mines in Parijs en promoveerde op een proefschrift over de democratische dimensie van problemen op het snijvlak van wetenschap en politiek (aids, BSE, milieuproblemen). Van 2006 tot 2009 was hij programmacoördinator bij het Rathenau Instituut. Van 1999 tot 2006 was hij eerder aan de WRR verbonden. Daarvoor was hij partner en senioronderzoeker van sci-Quest. Hij heeft enkele tientallen publicaties op zijn naam staan, vooral op het gebied van politieke theorie en maatschappelijke en technologische vraagstukken. Recentelijk verschenen van hem onder andere de boeken De migratiemachine (Van Gennep 2009, red. met A. Meijer) en Politiekvernieuwen. Op zoeknaar publiek in de technologische samenleving (Van Gennep 2008). Hij is lid van de redactie van het tijdschrift Krisis. 


\section{Maarten Hajer}

Maarten Hajer is directeur van het Planbureau voor de Leefomgeving (PBL) en hoogleraar politicologie aan de Universiteit van Amsterdam. Hij studeerde politicologie en planologie aan de UVA en promoveerde in 'politics' aan de Universiteit van Oxford. Hij werkte aan de universiteiten van Leiden en München en daarna als senior onderzoeker bij de WRR (1996-1998). Zijn belangrijkste boeken zijn The Politics of Environmental Discourse (Oxford University Press 1995), Deliberative Policy Analysis - Governance in the Network Society (Cambridge University Press, redactie samen met Henk Wagenaar, 2003) en zijn recente Authorative Governance - Policy Making in an Age of Medialization (OxfordUniversity Press 2009).

\section{Paul den Hoed}

Paul den Hoed is sinds 1973 verbonden aan de WRR als onderzoeker en projectcoördinator. Hij is als bestuurssocioloog afgestudeerd bij J.A.A. van Doorn in Rotterdam en is in 1995 bij H.R. van Gunsteren aan de juridische faculteit in Leiden gepromoveerd op een historisch-institutionele analyse van bestuur en beleid (Bestuur en beleid van binnenuit). De thema's waarover hij binnen en buiten de WRR heeft gepubliceerd, liggen op het terrein van de verhouding staat en maatschappij, planning, bestuursgeschiedenis, eigentijds burgerschap, grootstedelijke infrastructuur, rechtstaat, media en onderwijsbeleid. Hij maakte als redacteur van het tijdschrift Beleid en Maatschappij vele themanummers en verzorgde jubileumboeken over 50 jaar ministerie van Algemene Zaken (AZ) (1987) en over 35 jaar WRR en 100 jaar adviesraden (2007).

\section{Jan Willem Holtslag}

Jan Willem Holtslag is sinds 2008 als adviserend lid verbonden aan de WRR. Hij studeerde in 1974 af in de politieke en sociale wetenschappen aan de Universiteit van Amsterdam. Zijn werkzaamheden speelden zich af op de ministeries van Algemene Zaken (AZ) en Binnenlandse Zaken en Koninkrijksrelaties (BZK). Daar was hij achtereenvolgens raadadviseur buitenlandse betrekkingen, asiel en migratie, en sociaaleconomische politiek. Ook was hij secretaris bij verschillende kabinetsformaties $(1986,1989,1994)$. Bij BZK was hij achtereenvolgens directeurgeneraal Openbaar Bestuur en secretaris-generaal.

\section{Tanja Klop}

Tanja Klop is postdoctoraal onderzoeker bij de sectie Biotechnologie en Samenleving op de afdeling Biotechnologie van de Technische Universiteit Delft en is daarnaast verbonden aan het Kluyver Centre for Genomics of Industrial Fermentation. Zij heeft zich na haar studie biologie toegelegd op de wetenschapseducatie en -communicatie. Van 2003 tot 2008 heeft ze promotieonderzoek gedaan aan het Rotterdams Instituut voor Sociaal-wetenschappelijk Beleidsonderzoek van de Erasmus Universiteit. Van 2007 tot 2008 was zij als onderzoeker verbonden aan het Freudenthal instituut voor didactiek van wiskunde en 
natuurwetenschappen van de Universiteit Utrecht. Hier heeft zij voornamelijk onderzoek gedaan naar onderwijsvernieuwingen (context-concept benadering) binnen het biologieonderwijs. Momenteel doet zij als postdoc onder andere onderzoek naar communicatiestrategieën in 'user-producer interaction in functional genomics innovations' (NWO) en is nauw betrokken bij de vernieuwingen van de 'Reizende DNA-labs' van Genomics Centres of Excellence (CSG).

\section{Luuk van Middelaar}

Luuk van Middelaar is politiek filosoof en historicus. Hij was van augustus 2008 tot december 2009 columnist voor NRC Handelsblad en was in het verleden werkzaam als adviseur voor respectievelijk eurocommissaris Frits Bolkestein in Brussel en VVD-fractieleider Jozias van Aartsen in Den Haag. Sinds januari 2010 maakt hij als speechschrijver deel uit van het kabinet van de Belg Herman Van Rompuy, de eerste vaste voorzitter van de Europese Raad van regeringsleiders. Van Middelaar studeerde filosofie en geschiedenis aan de Rijksuniversiteit Groningen en de E.H.E.S.S. in Parijs. Hij studeerde in 1999 af op de doctoraalscriptie Politicide (Van Gennep, 1999). Hij promoveerde in 2009 op een proefschrift over de Europese politieke eenwording, De passage naar Europa. Geschiedenis van een begin (Historische Uitgeverij, derde druk 2010). Vertalingen van dit boek in het Frans, Pools en Hongaars zijn in voorbereiding.

\section{Philip van Praag}

Philip van Praag is als universitair hoofddocent verbonden aan de afdeling Politicologie van de Universiteit van Amsterdam en als onderzoeker aan the Amsterdam School of Communication Research (ASCOR). Hij publiceert regelmatig in vaktijdschriften en in Nederlandse media over politieke partijen, verkiezingscampagnes, referenda en de Nederlandse politiek. Hij schreef sinds 1995 samen met Kees Brants een aantal boeken over Nederlandse verkiezingen en de veranderende relatie tussen media en politiek. Het laatste boek, Politiek en media in verwarring, de verkiezingscampagnes in het lange jaar 2002, verscheen in 2005 . Een nieuw boek is in voorbereiding.

\section{Sebastiaan Princen}

Sebastiaan Princen is universitair hoofddocent aan het departement Bestuurs- en Organisatiewetenschap van de Universiteit Utrecht. Zijn onderzoek richt zich op vraagstukken van Europees en internationaal bestuur en beleid. De afgelopen jaren heeft hij onder andere gepubliceerd over politieke agendavorming in de Europese Unie, de invloed van de EU op de Nederlandse rijksoverheid en de rol van belangengroepen in de Europese beleidsvorming. Recente publicaties omvatten onder meer Agenda-setting in the European Union (verschenen bij Palgrave, 2009) en The New Eurocrats. National Civil Servants in EU Policy-Making (met Karin Geuijen, Paul 't Hart en Kutsal Yesilkagit; verschenen bij Amsterdam University Press 2008). 


\section{Thomas Schillemans}

Thomas Schillemans werkt sinds 2008 als docent en onderzoeker aan het departement Bestuurs- en Organisatiewetenschap van de Universiteit Utrecht. Hij werkte eerder onder meer bij de Raad voor Maatschappelijke Ontwikkeling. In 2007 promoveerde hij cum laude op het proefschrift Verantwoording in de schaduw van de macht. Horizontale verantwoording bij zelfstandige uitvoeringsorganisaties. In zijn onderzoek staat de relatie van beleidsuitvoering met de maatschappelijke omgeving centraal. Hij richt zich op thema's als: horizontale en publieke verantwoording, maatschappelijke ondernemingen, zelfstandige bestuursorganen en agentschappen, de rol van de media in de beleidsuitvoering. In het najaar van 2009 is hij als academic visitor verbonden aan het Center for Social Impact, van de University of New South Wales, in Sydney.

\section{Steven Schouten}

Steven Schouten is wetenschappelijk medewerker bij de WRR. Hij studeerde nieuwe en theoretische geschiedenis aan de Universiteit van Amsterdam en de Universiteit van Valladolid (Spanje). In 2007 promoveerde hij op een proefschrift over het leven en sociaal-politieke gedachtengoed van de Duits-joodse schrijver en politiek activist Ernst Toller (1893-1939) aan het Europees Universitair Instituut in Florence (Italië). Tot en met het einde van 2008 doceerde Schouten moderne en contemporaine geschiedenis aan Gonzaga University in Florence (Italië). Voorheen was hij consultant public affairs, lobby en strategische communicatie bij Praaning Meines Consultancy (thans: Meines en Partners) in Den Haag. In diezelfde periode was hij tevens coördinator van het Duits-Nederlands Journalistenstipendium, een uitwisselingsprogramma van Duitse en Nederlandse journalisten.

\section{Susanne Sleenhoff}

Susanne Sleenhoff is promovenda bij de sectie Biotechnologie en Samenleving op de afdeling Biotechnologie van de Technische Universiteit Delft. Ze studeerde biologie met de specialisatie wetenschapscommunicatie aan de Radboud Universiteit te Nijmegen. Haar promotieonderzoek gaat over de rol die emoties spelen in communicatie over industriële biotechnologie en hoe en in welke mate deze in staat zijn mensen te betrekken bij de ontwikkeling van deze technologie. Dit is een onderzoek bij het Centre for Society and Genomics dat wordt uitgevoerd binnen het Kluyver Centre for Genomics of Industrial Fermentations welke beide Centre's of Excellence zijn van het Nationaal Genomics Initiatief (NGI). Van 2006 tot 2008 was zij EU-projectleider van twee projecten bij dezelfde sectie. Een project keek naar het koopgedrag van consumenten ten aanzien van genetisch gemodificeerd voedsel (CONSUMERCHOICE) en het andere project combineerde onderzoek naar ethiek met wetenschapscommunicatie in nanobiotechnologie (NanoBio-RAISE). 


\section{Will Tiemeijer}

Will Tiemeijer is afgestudeerd als neerlandicus en werkte van 1989 tot 2005 bij het ministerie van Onderwijs, Cultuur en Wetenschappen (ocw) in diverse functies, met name op het gebied van communicatie. In 2006 promoveerde hij op het proefschrift Het geheim van de burger; over staat en opinieonderzoek, dat werd bekroond met de Van Poelje Jaarprijs van de Vereniging van Bestuurskunde. Will Tiemeijer schreef diverse publicaties over opinieonderzoek, waaronder een boek voor het grote publiek genaamd Wat 93,7 procent van de Nederlanders moet weten over opiniepeilingen. Sinds 2007 werkt hij bij de WRR als wetenschappelijk medewerker.

\section{Menno van der Veen}

Menno van der Veen is wetenschapper, schrijver, moderator en bedenker van politieke en culturele programma's. Hij studeerde rechten en wijsbegeerte aan de Universiteit van Amsterdam en promoveerde aan de Technische Universiteit Delft op een onderzoek naar ontwikkelingsovereenkomsten in grootstedelijke vernieuwingsprojecten. Hij werkte kort als postdoc aan de UvA (Amidst) en werkt nu als postdoc bij de TU Delft waarbij hij zich richt op ethische en juridische aspecten van bio-energie en de verhouding tussen rijke landen en ontwikkelingslanden. Dit is een onderzoek bij het Centre for Society and Genomics dat wordt uitgevoerd binnen het Kluyver Centre for Genomics of Industrial Fermentations welke beide Centre's of Excellence zijn van het Nationaal Genomics Initiatief (NGI). Hij is mede-eigenaar van Taqt dat zich specialiseert in trainingsprogramma's voor medezeggenschap en democratische vaardigheden. Hij schrijft regelmatig artikelen voor Nederlandse kranten en was columnist van NRC Handelsblad en NRC.NEXT. Voor cultureel centrum de Balie in Amsterdam ontwikkelde hij series over politieke cultuur en de serie 7080 over het morele perspectief van de generatie geboren tussen 1970 en 1990. Die serie resulteerde in het boek Moralitijd (Van Gennep 2008) waarvoor hij samen met journaliste Sarah Meuleman de redactie voerde. Zijn boek Welkom in Youtopia verschijnt dit jaar.

\section{Wytske Versteeg}

Wytske Versteeg is als politicoloog verbonden aan de Universiteit van Amsterdam, en studeerde daarnaast sociale geografie aan dezelfde universiteit en drama aan de Hogeschool Gent. In 2008 verscheen van haar hand Dit is geen dakloze, dat genomineerd werd voor de Jan Hanlo Essayprijs. Momenteel schrijft ze voor Lemniscaat aan een tweede boek onder de werktitel Onvoorstelbaar. Verder werkte ze mee aan de totstandkoming van diverse publicaties, onder andere Authoritative Governance, Policy Making in the Age of Mediatization en Meervoudige democratie, ervaringen met vernieuwend bestuur. 


\section{Kutsal Yesilkagit}

Kutsal Yesilkagit is universitair hoofddocent en verbonden aan het departement Bestuurs- en Organisatiewetenschap van de Universiteit Utrecht. Hij is in 2001 in Leiden gepromoveerd op de rol van de Turkse militairen in het islamitisch onderwijsbeleid. Sinds hij in Utrecht werkzaam is verricht hij onderzoek naar de relatie tussen politiek en bestuur, de europeanisering van nationale bestuurstelsels en onafhankelijke (markt)autoriteiten. Samen met Ido de Haan en Mark Bovens is hij betrokken bij het door Nwo gefinancierde onderzoek naar Alternatieven voor de parlementaire democratie. Daarnaast verricht hij op basis van een door het Montesquieu Instituut verleende onderzoekssubsidie onderzoek naar het functioneren van Europese netwerken van onafhankelijke marktautoriteiten en hun invloed op politiek en bestuur in de lidstaten van de Europese Unie. Zijn werk is verschenen in internationale tijdschriften zoals Public Administration, West European Politics en Journal of Administrative Research $\&$ Theory. Yesilkagit is lid van de redactie van het tijdschrift Beleid $\mathbb{*}$ Maatschappij. 


\section{LITERATUUR}

Aalbers, S. (200o) Achter de schermen - een onderzoek naar de aanwezigheid van spin doctors in de Nederlandse politiek, doctoraalscriptie politicologie. Amsterdam: Universiteit van Amsterdam.

Aarts, K. en J. Thomassen (2008) 'Dutch voters and the changing party space 1989-2006', Acta Politica 43, 2-3: 203-234.

Abbott, K.W. en D. Snidal (2009) 'The governance triangle: regulatory standards institutions and the shadow of the state', blz. 44-88 in W. Mattli en N. Woods (red.) The politics of global regulation, Princeton: Princeton University Press.

Adoninno Committee (1985) 'Report submitted to the Milan European Council (Milan, 28-29 June 1985)', Bulletin EEC 1985-7, Supplement, 18-30.

Adriaansen, M., W. van der Brug en J. van Spanje (2005) ‘De kiezer op drift?’ in K. Brants en P. van Praag (red.) Politiek en media in verwarring: de verkiezingscampagnes in het lange jaar 2002, Amsterdam: Het Spinhuis.

Adriaansen, M., en P. van Praag, (2006) 'Hoe systematisch zijn partijen op zoek naar hun kiezers? Politieke doelgroepmarketing bij de verkiezingen van 2002', Jaarboek Documentatiecentrum Nederlandse Politieke Partijen 2005.

Aelst, P. van (2006) Toeschouwer, speler of scheidsrechter? Een empirische studie over de rol van de media in de verkiezingscampagne van 2003, Antwerpen: Universiteit Antwerpen.

Aerts, R., H. de Liagre Böhl, P. de Rooy en H. te Velde (1999a) Land van kleine gebaren: een politieke geschiedenis van Nederland, 1780-1990, Nijmegen, Amsterdam: SUN.

Aerts, R. (1999b) 'Een staat in verbouwing: van republiek naar constitutioneel koninkrijk, 1780-1848' in R. Aerts, H. de Liagre Böhl, P. de Rooy en H. te Velde (1999) op. cit.

Aerts, R. (2009a) Het aanzien van de politiek: geschiedenis van een functionele fictie, Amsterdam: Bert Bakker.

Aerts, R. (2009b) 'Nationale beginselen? Een transnationale geschiedenis van politiek en grondwet in de negentiende eeuw', Bijdrage en mededelingen betreffende de geschiedenis der Nederlanden, 124, 4: 580-599.

Albrechts, L. (2008) 'Spatial planning as transformative practice', Ruimte en planning 2008-3: 10-18.

Algemene Rekenkamer (2008) Kaders voor toezicht en verantwoording, Den Haag: Algemene Rekenkamer.

Algemene Rekenkamer (2009) Verantwoording en toezicht bij rechtspersonen met een wettelijke taak, deel 5. Terugblik 2009, Den Haag: Algemene Rekenkamer.

Altemeyer, B. (1996) The authoritarian specter, Cambridge: Harvard University Press. Amin, A. en N. Thrift (2002) Cities: Reimagining the urban, Cambridge: Polity Press.

Anderson, C.J. en C.A. Guillory (1997) 'Political institutions and satisfaction with democracy: A cross-national analysis of consensus and majoritarian systems', The American political science review, 91, 1: 66-81. 
Anderson, C.J. (2002) Good questions, dubious Inferences, and bad solutions: some further thoughts on satisfaction with democracy, Research paper 116, Binghamton: Center for Democratic Performance, State University of New York.

Andeweg, R.B. (2003) ‘Beyond representativeness? Trends in political representation', European Review 11, 2: 117-161.

Andeweg, R.B. en G.A. Irwin (2009) Governance and politics of the Netherlands, New York: Palgrave Macmillan.

Ankersmit, F. (2008) 'De plaag van de transactiestaat' in F. Ankersmit en L. Klinkers (red.) De tien plagen van de staat. De bedrijfsmatige overheid gewogen, Amsterdam: Van Gennep.

Arendt, H. (1958) The human condition (Charles R. Walgreen Foundation lectures) Chicago: University of Chicago Press.

Arnold, R.D. (2004) Congress, the press and political accountability, New Jersey: Princeton University Press.

Arnstein, S.R. (1969) 'A ladder of citizen participation', Journal of the American Planning Association 35, 4: 216-224.

Atzema, O., L. Boelens en B. Veldman (2009): Voorbij de lock-in: Een economisch institutionele herpositionering van de Rotterdamse haven, Den Haag: Stratagem Group.

Baalen, C. van (red.) (2005) Koningin Beatrix aan het woord, 25 jaar troonredes, officiële redevoeringen en kersttoespraken, Den Haag: Sdu Uitgevers.

Bache, I. en M. Flinders (red.) (2004) Multi-level governance, Oxford en New York: Oxford University Press.

Bachrach, P. en B. Morton (1962) 'Two faces on power', American Political Science Review 56: $947-952$.

Backes, C.W. (2006) Internationale Vergelijking Implementatie EU-Richtlijnen Luchtkwaliteit, Utrecht: Centrum voor Omgevingsrecht en Beleid/NILOs, Universiteit Utrecht.

Bader, V. (2001) 'Introduction', blz. 1-14. in Paul Hirst en Veit Bader (red.) Associative Democracy: The real third way. Londen: Cass.

Badiou, A. (2005) De ethiek: essay over het besef van het Kwaad, Utrecht: IJzer.

Badiou, A. (2007) Being and event, Londen: Continuum.

Bakker, W. en K. Yesilkagit (red.) (2005) Publieke verantwoording. Regimes van inzicht en rekenschap bij de uitvoering van publieke taken, Amsterdam: Boom.

Balkenende, J.P. (2003) 'Europa niet gebaat bij twee stuurlui', de Volkskrant, 4 februari.

Banfield, E. (1961) Political influence, Glencoe: Free Press.

Barber, B.R. (2007) De infantiele consument, Amsterdam: Ambo.

Barroso, J.M. (2006) A citizens' agenda: delivering results for Europe, Europese Commissie, SPEECH/o6/286 (10 mei).

Baviskar, S., M. Fran en T. Malone (2004) 'What democracy means to citizens - And why it matters', Revista europea de estudios latinoamericanos y del Caribe, 76: 3-24.

Behn, R.D. (2001) Rethinking democratic accountability, Washington, DC: Brookings Institution Press. 
Bekke, H., K. Breed en P. de Jong (red.) (2009) Naar een collegiaal en samenhangend overheidsbestuur: de lokale bestuurspraktijk als wenkend perspectief voor het rijk? Den Haag: Sdu Uitgevers.

Bell, M. (2002) 'Beyond European labour law? Reflections on the EU racial equality directive', European Law Journal, 8, 3: 384-399.

Belsey, C. (2002) Poststructuralism: A very short introduction, Oxford: Oxford University Press.

Bendor, J. (1985) Parallel systems. Redundancy in government, Berkeley: University of California Press.

Bentley, T. (2005) Everyday democracy: why we get the politicians we deserve, Londen: Demos.

Berg, J.Th.J. van den en H.A.A. Molleman (1974) Crisis in de Nederlandse politiek, Alphen aan den Rijn: Samsom.

Berg, J.Th.J. van den (1983) De toegang tot het Binnenhof: de maatschappelijke herkomst van de Tweede Kamerleden tussen 1849 en 1970, Weesp: Van Holkema \& Warendorf.

Berridge, G.R. (2002) Diplomacy: theory and practice. Basingstoke: Palgrave.

Bertolini, L.F.M. (2009) The planning of mobility, inaugurele rede, Amsterdam: University of Amsterdam.

Besselink, L.F.M. (2005) 'De Invloed van Europeanisering op de Constitutionele Verhoudingen in Nederland', Beleid en Maatschappij, 32, 1: 45-55.

Besselink, L.F.M. (2007) Een samengestelde Europese constitutie - A composite European constitution, Groningen: Europa Lwa Publishing.

Beunders, H. (2009) 'Milieubewustzijn kun je niet afdwingen; Overheid en wetenschap gaan over het milieu, maar jegens beide heerst argwaan' NRC Handelsblad, 14 december.

Beus, J. de (2001) Een primaat van politiek, Amsterdam: Vossiuspers.

Beus, J. de, K. Brants en P. van Praag (2009) Media en hun rol in de Nederlandse democratie, Bijdrage aan de Democratic audit in Nederland. Conferentie te Berg en Dal, 27 mei 2009.

Beyen, J.W. (1968) Het spel en de knikkers. Een kroniek van vijftig jaren, Rotterdam: Donker.

Biernat, M. en S. Eidelman (2007) 'Standards' in Arie W. Kruglanksi \& E. Tory Higgins (red.) Social Psychology: Handbook of Basic Principles, 2 ed. New York: The Guildford Press.

Bijsterveld, S. van (2002) The empty throne. Democracy and the rule of law in transition, Utrecht: Lemma.

Blanken, H. (2009) Mediamores, over digitale cultuur, bloggende burgers en journalistieke ethiek, Amsterdam: Atlas.

Bloes, R. (1970) Le 'Plan Fouchet' et le problème de l’Europe politique, Bruges: Collège d'Europe.

Blok, L. (1987) Stemmen en kiezen. Het kiesstelsel in Nederland in de periode 1814-1850, Groningen: Wolters-Noordhoff/Forsten. 
Blom-Hansen, J. en J. Christensen (2004) Den europæiske forbindelse, Aarhus: Magtudredningen.

Boelens, L. (1994) 'De patroonloosheid van de Randstad. Het probleem van gespleten werelden', blz. 121-140 in E. Agricola, et al. (red.) Archipolis - over de grenzen van architectuur, Delft: Eburon.

Boelens, L. (2005) Van planologie naar fluviologie? Inaugurele rede, Utrecht: Universiteit Utrecht.

Boelens, L., Spit, T. en B. Wissink (red.) (2006) Planning zonder overheid, een toekomst voor planning, Rotterdam: o1o-Publishers.

Boelens, L. (2009a) The urban connection; An actor-relational approach to urban planning, Rotterdam: o1o-Publishers.

Boelens, L. en E. Taverne (2009b) 'Waarom steden als delta's floreren', blz. 229-258 in L. Lucassen en W. Willems, Waarom mensen in de stad willen wonen 1200-2010, Amsterdam: Bert Bakker.

Boelens, L. et al. (red.) (2010) Compacte Stad extended; Ontwerp en politiek/Design and Politics nr. 4, Rotterdam: o1o-Publishers.

Bohman, J. (2004) 'Realizing deliberative democracy as a mode of inquiry: pragmatism, social facts and normative theory', Journal of Speculative Philosophy 18, 1: $23-43$.

Boomgaarden, H.G. (2007) Framing the others. News and ethnic prejudice, Amsterdam: University of Amsterdam.

Boonstra, B. en L. Boelens (2010) 'Self-organisation in urban development; towards a new pespective on spatial planning', DISp (forthcoming).

Börzel, T.A. en T. Risse (200o) 'When Europe hits home: Europeanization and domestic change', European integration online papers (EIoP) 4, 15 .

Börzel, T.A. en T. Risse (2003) 'Conceptualizing the domestic impact of Europe', blz. 57-80 in K. Featherstone en C. Radaelli (red.) The politics of Europeanization, Oxford: Oxford University Press.

Bos, B. van den (2008) Mirakel en debacle. De Nederlandse besluitvorming over de Politieke Unie in het Verdrag van Maastricht, Leiden: Universiteit Leiden.

Boschma, R. en K. Frenken (2006) 'Why is economic geography not an evolutionary science', Journal of Economic Geography 6, 3: 273-302.

Bottenburg, M. van (1995) 'Aan den Arbeid!', in de wandelgangen van de Stichting van de Arbeid 1945-1995, Amsterdam: Bert Bakker.

Bouckaert, G., B.G. Peters en K. Verhoest (2010) The coordination of public sector organizations: shifting patterns of public management, New York: Palgrave Macmillan.

Bourdieu, P. (2001) 'Television', European Review 9, 3: 245-256.

Bovens, M., W. Derksen, W. Witteveen, F. Becker en P. Kalma (1995) De verplaatsing van de politiek: een agenda voor democratische vernieuwing, Amsterdam: Wiarda Beckman Stichting.

Bovens, M., H. Pellikaan en M. Trappenburg (1998) Nieuwe tegenstellingen in de Nederlandse politiek, Amsterdam: Boom. 
Bovens, M. (2002) 'De permanente verplaatsing van de politiek', Socialisme en Democratie 59, 12: 14-20.

Bovens, M. (2003) De digitale republiek. Democratie en rechtsstaat in de informatiemaatschappij, Amsterdam: Amsterdam University Press.

Bovens, M. en K. Yesilkagit (2005) De invloed van Europese richtlijnen op de Nederlandse wetgever, Nederlands Juristenblad, 80, 10: 520-529.

Bovens, M. (2005a) 'De verspreiding van de democratie', Beleid en Maatschappij 32, 3: 119-127.

Bovens, M. (2005b) 'Publieke verantwoording: Een analysekader', blz. 25-55 in W. Bakker en K. Yesilkagit (red.) Publieke verantwoording. Regimes van inzicht en rekenschap bij de uitvoering van publieke taken, Amsterdam: Boom.

Bovens, M., P. 't Hart en M. van Twist (2007) Openbaar bestuur: Beleid, organisatie en politiek, Alphen aan den Rijn: Kluwer.

Bovens, M. en A. Wille (2008) 'Deciphering the Dutch drop: ten explanations for decreasing political trust in The Netherlands', International review of administrative sciences, 74, 2: 283-306.

Bovens, M. en T. Schillemans (red.) (20o9a) Handboek publieke verantwoording, Den Haag: Lemma.

Bovens, M. en A. Wille (20ogb) Diploma democracy: on the tensions between meritocracy and democracy, Utrecht: Universiteit Utrecht.

Brants, K. en P. van Praag (1995) Verkoop van de politiek: de verkiezingscampagne van 1994, Amsterdam: Het Spinhuis.

Brants, K. (1998) 'Who is afraid of infotainment', European Journal of Communication, 13, 3: 315-335.

Brants, K. en P. van Praag (red.) (2005) Politiek en Media in Verwarring: de verkiezingscampagnes in het lange jaar 2002, Amsterdam: Het Spinhuis.

Brants, K., C. de Vreese, J. Möller en P. van Praag (2010) 'The real spiral of cynicism? Symbiosis and mistrust between politicians and journalists', The International Journal of Press Politics, 15, 1: 25-40.

Braudel, F. (1958) 'Histoire et sciences sociales; La longue duree', Societies, Economies, Ci/vi/izations, 26: 725-753.

Breeman, G. en A. Timmermans (2009) 'Maatschappelijke pressie en bestuurlijke responsiviteit' in H. Bekke, K. Breed en P. de Jong (red.) Naar een collegiaal en samenhangend overheidsbestuur: de lokale bestuurspraktijk als wenkend perspectiefvoor het rijk? Den Haag: Sdu Uitgevers.

Brink, G. van den (2002) Mondiger of moeilijker? Een studie naar de politieke habitus van hedendaagse burgers, WRR Voorstudies en achtergronden V 115, Den Haag: Sdu.

Broeders, D. en I. Verhoeven (2005) 'Kiezen uit overvloed. Sociaal-culturele ontwikkelingen in vraag en aanbod in het medialandschap', in W.B.H.J. van de Donk, D.W.J. Broeders en F.J.P.M. Hoefnagel (red.) Trends in het medialandschap: vier verkenningen, Amsterdam: Het Spinhuis.

Brug, W. van der (2007) Een crisis van de partijendemocratie? Inaugurele rede, Amsterdam: Universiteit van Amsterdam. 
Brug, W. van der en J. van Spanje (2009) 'Immigration, Europe and the 'new' cultural dimension', European Journal of Political Research, 48, 3: 309-334.

Budd, C. (2009) Wat bepaalt het succes van de Nederlandse diplomatie, Willem van Oranjelezing 2009.

Bulmer, S. en W. Wessels (1987) The European council. Decision-making in European politics, Basingstoke: Macmillan.

Byrne, D. (1998) Complexity theory and the social sciences; an introduction, Londen: Routledge.

Callon, M. (1986) 'Some elements of a sociology of translation: domestication of the scallops and the fishermen of St Brieuc Bay', blz. 196-229 in J. Law (red.) Power, action and belief, a new sociology of knowledge? Londen: Routledge \& Kegan Paul.

Callon, M. (1995) 'Agency and the hybrid collectif', The South Atlantic quarterly 94/2, 481-507.

Cammen, H. van der (2006) Gebiedsontwikkeling: kansen en condities voor maatschappelijke meerwaarde, Den Haag: NIROv.

Canache, D., J.J. Mondak en M.A. Seligson (2001) 'Meaning and Measurement in CrossNational Research on Satisfaction with Democracy' The public opinion quarterly 65, 4: 506-528.

Carpenter, D.P. (2001) The forging of bureaucratic autonomy. Reputations, networks, and policy pnnovation in executive agencies, 1862-1928, Princeton: Princeton University Press.

Carrión, J.F. (2008) 'Illiberal democracy and normative democracy: How is democracy defined in the Americas?', in M.A. Seligson (red.) Challenges to democracy in Latin America and the Caribbean: Evidence from the Americas barometer 2006-2007, gedownload van http://sitemason.vanderbilt.edu/lapop/AmericasBarometer 2006

Carroll, J.S. (2004) 'Redundancy as a design-principle and an operating principle', Risk Analysis 24, 4: 955-957.

Castells, M. (1996) The rise of the network society (The information age: Economy, society and culture, vol. 1) Cambridge/Oxford: Blackwell.

Castells, M. (2007) 'Communication, power and counter-power in the network society', International Journal of Communication 1: 238-266.

Chavannes, M. (2009) Niemand regeert. De privatisering van de Nederlandse politiek, Rotterdam: NRC Boeken.

Christensen, T. en P. Lægreid (red.) (2006) Autonomy and regulation. Coping with agencies in the modern state, Cheltenham: Edward Elgar.

Cloos, J., G. Reinesch, D. Vignes en J. Weyland (1994) Le Traité de Maastricht: Genèse, analyse, commentaires, Brussel: E. Bruylant.

Coen, D. en M. Thatcher (2008) 'Network governance and multi-level delegation: European networks of regulatory agencies', Journal of Public Policy, 28, 1: 49-71.

Cohen, J. en C.F. Sabel (1997) 'Directly-deliberative polyarchy', European Law Journal, 
Cohen, J. en J. Rogers (1992) 'Secondary associations and democratic governance', Politics and Society 20, 4: 391-472.

Collins, H. (1999) Regulating contracts, Oxford: Oxford University Press.

Colonna, C. (2005) Redevoering op de 13de ambassadeursconferentie te Parijs, 30 augustus. Commissie-Brinkman (2009) De Volgende Editie. Adviesrapport van de Tijdelijke Commissie Innovatie en Toekomst Pers, Den Haag: Sdu Uitgevers.

Commissie Hoofdstructuur Rijksdienst (1980) Elk kent de laan die derwaart gaat, Den Haag: Staatsuitgeverij, 3de en tevens hoofdrapport.

Commissie Toekomst Overheidscommunicatie (2001) In dienst van de democratie, Den Haag: Sdu Uitgevers.

Commissie-Van Lunteren (2004) Verantwoordelijkheid en verantwoording. IBO Regeldruk en Controletoren, Den Haag: ministerie van Financiën.

Commissie-Van Veen (1971) Bestuursorganisatie bij de kabinetsformatie 1971: rapport van de Commissie Interdepartementale Taakverdeling en Coördinatie, Den Haag: SDU.

Cook, T. (2006) 'The news media as a political institution: looking backward and looking forward', Political Communication 23, 2: 159-171.

Coolsaet, R. (1998) The transformation of diplomacy at the threshold of the new millennium, available at

http://pswservi.ugent.be/rc/Nederlands/Artikels/IP/IPWatzwaarder.htm.

Corner, J. en D. Pels (2003) Media and the restyling of politics, Londen: Sage.

Correljé, A. en K. van Kersbergen (1998) 'De West-Europese partijstelsels: van oude scheidslijnen... de dingen die niet voorbijgaan', blz.34-57 in M. Bovens, H. Pellikaan en M. Trappenburg (red.) Nieuwe tegenstellingen in de Nederlandse politiek, Amsterdam: Boom.

Couve de Murville, M. (1971) Une politique étrangère, 1958-1969, Parijs: Editions Plon.

Crince Le Roy, R. (1971) De vierde macht: de ambtelijke bureaucratie als machtsfactor in de staat, Baarn: Het Wereldvenster.

Crozier, M. (2007) 'Recursive Governance: Contemporary political communication and public policy', Political Communication 24, 1: 1-18.

Cuilenburg, J. J. van, P. Neiens en O. Scholten (red.) (1999) Media in overvloed, Amsterdam: Amsterdam University Press.

Daalder, H. (1974) Politisering en lijdelijkheid in de Nederlandse politiek, Assen: Van Gorcum.

Dahl, R. (1961) Who Governs? Democracy and power in an American city, New Haven: Yale University Press.

Dalton, R.J., S.C. Flanagan en P.A. Beck (red.) (1984) Electoral change in advanced industrial democracies: realignment or dealignment?, Princeton: Princeton University Press.

Dalton, R.J. (1999) Political support in Advanced Industrial Democracies, Irvine, CA: University of California, Irvine, School of Social Sciences.

Dalton, R.J. (2004) Democratic challenges, democratic choices: The erosion of political support in advanced industrial democracies, Oxford: Oxford University Press.

Dam, M. van (2009) Niemands land: biografie van een ideaal, Amsterdam: De Bezige Bij. 
Davies, J. (2002) 'Urban regime theory: a normative empirical critique', Journal of Urban Affairs 24, 1-17.

Debord, G. (1967) La Société du spectacle, Buchet-Chastel: Paris. Nederlandse vertaling: (1976) De spektakelmaatschappij. Vert. J. Kloosterman en R. van de Kraats, Baarn: Het Wereldvenster.

DeHousse, R. (1997) 'Regulation by networks in the European Community: The role of European agencies', Journal of European Public Policy, 4, 2: 246-261.

Dehue, T. (2008) De depressie-epidemie: over de plicht het lot in eigen hand te nemen, Amsterdam: Augustus.

Dekker, P. en E. Steenvoorden (2008) Continu onderzoek burgerperspectieven: kwartaalbericht 2008-2, Den Haag: Sociaal en Cultureel Planbureau.

Dekker, P., T. van der Meer en I. van Goede (2009) СОв Kwartaalbericht 2009 nr. 4, Den Haag: Sociaal en Cultureel Planbureau.

Deleuze, G., F. Guattari (1980) Mille plateaux. Capitalisme et schizophrénie. Paris: Editions de Minuit.

Deth, J.W. van en J.C.P.M. Vis (1995) Regeren in Nederland: het politieke en bestuurlijke bestel in vergelijkend perspectief, Assen: Van Gorcum.

Dewey, J. (1927) The public and its Problems, New York: H. Holt and Company.

Dijstelbloem, H. (2008) Politiek vernieuwen. Op zoek naar publiek in de technologische samenleving, Amsterdam: Van Gennep.

Doel, M. (1999) Poststructuralist geographies: The diabolical art of spatial science, Edinburgh: Edinburgh University Press.

Doel, M. (200o) 'Un-glunking geography; spatial science after dr. Seus and Gilles Deleuze', blz. 117-135 in Crang, Mike and Nigel Thrift (red.) Thinking Space, Londen: Routledge.

Dolowitz, D.P. en D. Marsh (200o) 'Learning from abroad: The role of policy transfer in contemporary policy-making', Governance, 13, 1: 5-24.

Doorn, J.A.A. van en C.J.M. Schuyt (1978) De stagnerende verzorgingsstaat, Meppel: Boom. Dostal, J.M. (2004) 'Campaigning on expertise: How the OECD framed EU welfare and labour market policies - And why success could trigger failure’, Journal of European Public Policy, 11, 3: 440-46o.

Douma, W., K. Pieters, K. Feenstra et al. (2007) Pilot-Monitor EU invloed. Een onderzoek naar de realiseerbaarheid van een permanente monitor voor het meten van de invloed van Europese regelgeving op in Nederland geldende wet- en regelgeving, Onderzoek in opdracht van de ministeries van Buitenlandse Zaken en Justitie.

Dror, Y. (1968) Public policymaking reexamined, Scranton: Chandler Publishing Co.

Dunk, H.W. von der (1988) 'Nederland ten tijde van de Eerste Wereldoorlog', blz. 348-359

in J.C. Boogman et al. (red.) Geschiedenis van het moderne Nederland: politieke, economische en socilae ontwikkelingen, Houten: De Haan.

Eagly, A.H. en S. Chaiken (1993) The psychology of attitudes, New York: Harcourt College Publishers.

Easton, D. (1965) A systems analysis of political life, Chicago: University of Chicago Press. Eberlein, B. en A.L. Newman (2008) 'Escaping the international governance dilemma? 
Incorporated transgovernmental networks in the European Union', Governance, 21, 1: 25-52.

Edelman, M. (1964) The symbolic uses of politics, Urbana: University of Illinois Press (1985). Egeberg, M. en J. Trondal (1999) 'Differentiated integration in Europe: The case of the EEA country Norway', Journal of Common Market Studies, 37, 1: 133-142.

Egeberg, M., G.F. Schaefer en J. Trondal (2003) 'The many faces of EU Committee governance', West European Politics, 26, 3: 19-40.

Eijsbouts, W.T. (200o) 'De Raad van Opperhoofden. Over het regeringsstelsel van de Unie', blz. 59-87 in A.K. Koekkoek (red.) Bijdragen aan een Europese Grondwet, Staatsrechtconferentie 200o, Deventer: Tjeenk Willink.

EIPA-ECR (2009) The institutional impact of EU legislation on local and regional governments. A case study of the 1999/31/EC Landfill Waste and 2004/18/EC Public Procurement Directives, Barcelona: EIPA-ECR.

Elchardus, M. (2002) De dramademocratie, Tielt: Lannoo.

Elzinga, D.J. (1989) 'Politieke verantwoordelijkheid. Over verval en vooruitgang in de politieke democratie’, blz. 63-79 in M. Bovens, C. Schuyt en W. Witteveen, Verantwoordelijkheid: retoriek en realiteit. Verantwoording in publiek recht, politiek en maatschappij, Zwolle: W.E.J. Tjeenk Willink.

Etzioni, A. (1968) The active society; a theory of societal and political processes, New York: Free Press.

Ezrahi, Y. (1990) The descent of Icarus: science and the transformation of contemporary democracy, Cambridge MA: Harvard University Press.

Fahlquist, J.N. (2009) 'Moral responsibility for environmental problems - Individual or institutional', Journal of Agricultural and Environmental Ethics 22: 109-124.

Fainstein, S.S. en N.I. Fainstein (1983) 'Regime strategies communal resistance, and economic forces', blz. 245-282 in S. Fainstein et al. (red.) Restructuring the city: The political economy of urban redevelopment, New York: Longman.

Fennema, M. en J. Rhijnsburger (2007) Dr. Hans Max Hirschfeld: man van het grote geld, Amsterdam: Bert Bakker.

Finer, S.E. (1999) History of government from the earliest times (3 volumes), Oxford: Oxford University Press

Fiske, S.T. (2004) Social beings: A core motives approach to social psychology, Hoboken: Wiley.

Fortuyn, P. (2002a) De verweesde samenleving: een religieus-sociologisch traktaat, Uithoorn: Karakter.

Fortuyn, W.S.P. (1997) Tegen de islamisering van onze cultuur: Nederlandse identiteit als fundament, Utrecht: Bruna.

Fortuyn, W.S.P. (2002b) De puinhopen van acht jaar Paars: de wachtlijsten in de gezondheidszorg. ... een genadeloze analyse van de collectieve sector en aanbevelingen voor een krachtig herstelprogramma, Uithoorn: Karakter.

Foucault, M. (1968) L'archeologie du savoir, Parijs: Editions de Minuit.

Friedman, R. (1990) On the concept of authority in political philosophy, New York: University Press. 
Friedmann, J. (1969) 'Notes on societal action', Journal of the American Institute of Planners $35,5: 311-318$.

Friedrich, C. J. (1958) Authority, Cambridge MA, Harvard University Press.

Frissen, P.H.A. (1999) De lege staat, Amsterdam: Nieuwezijds.

Furedi, F. (2009) 'Met afwijzen van gezag komt vrijheid in het gedrang', NRC Handelsblad, Opinie en Debat, 14 november 2009.

Gamson, W.A. et al. (1992) 'Media images and the social construction of reality', Annual

Review of Sociology 18: 373-393.

Gans, H. (1979) 'Deciding what's news: Story suitability', Society 16, 3: 65-77.

Geer, P. van der (2000) 'Het slotdebat als strijd om de spotlight' in P. van Praag en K. Brants

(red.) Tussen beeld en inhoud. Politiek en media in de verkiezingen van 1998,

Amsterdam: Het Spinhuis.

Gemeente Almere (2009) Structuurvisie Almere 2.o, Almere: Gemeente Almere.

Gemeente Amsterdam start campagne om discriminatie te melden (laatst geraadpleegd

9-7-2008) http://amsterdam.nl/gemeente/college/freek_ossel/redactionele/ amsterdam_start

Gemeente Rotterdam/Havenbedrijf Rotterdam (2004) Havenplan 2020; Ruimte voor kwaliteit, Rotterdam: Gemeente Rotterdam.

Geuijen, K. et al. (2008) The new eurocrats. National civil servants in EU policy-making, Amsterdam: Amsterdam University Press.

Geuss, R. (2001) Public goods, private goods, Princeton: Princeton University Press.

Gissendanner, S. (2004) 'Mayors, governance coalitions and strategic capacity; Drawing

lessons from Germany for theories of urban governance', Urban Affairs Review 40: 44-77.

Glass, J.J. (1979) 'Citizen participation in planning: The relationship between objectives and techniques', Journal of the American Planning Association 452, 2: 180-189.

Goede, P. de (1999) Omroepbeleid met en tegen de tijd: interacties en instituties in het

Nederlandse omroepbestel, 1919-1999, Amsterdam: Cramwinckel.

Goleman, D. (2009) Groene intelligentie: het belang van ecologie voor een eerlijke markt, Amsterdam: Contact.

Goodsell, C.T. (1988) The social meaning of civic space: studying political authority through architecture, Lawrence: University Press of Kansas.

Graafland, A. (1995) De Architectuur van het Onbehagen: dakloos in New York en Amsterdam, Nijmegen: SUN.

Graham, S. en P. Healey (1999) 'Relational concepts of space and place: issues for planning theory and practice', European Planning Studies, 7, 5: 623-646.

Gross, S.R. en N. Miller (1997) 'The golden section and bias in perceptions of social consensus', Personality and social psychology review, 1: 241-271.

Guiraudon, V. (2000) 'European integration and migration policy: Vertical policy-making as venue shopping', Journal of Common Market Studies 38, 2: 251-271.

Gunsteren, H.R. van (1976) The quest for control: a critique of the rational-central-rule approach in public affairs, Londen: John Wiley.

Gunsteren, H.R. van (1994) Culturen van besturen, Amsterdam: Boom. 
Gunsteren, H. van en E. van Ruyven, (red.) (1995) Bestuur in de ongekende samenleving, Den Haag: Sdu Uitgevers.

Gunsteren, H.R. van (1998) A theory of citizenship. Organizing plurality in contemporary democracies, Colorado: Westview Press.

Gunsteren, H.R.van (1999) 'Zwartepieten of selectief sturen? Over de logica van politieke verantwoording', Bestuurskunde 8, 4: 136-144.

Haan, I. de (1993) Zelfbestuur en staatsbeheer: het politieke debat over burgerschap en rechtsstaat in de twintigste eeuw, Amsterdam: Amsterdam University Press.

Haan, I. de en H. te Velde (1996) 'Vormen van politiek: veranderingen van de openbaarheid in Nederland, 1848-1900', Bijdragen en Mededelingen betreffende de Geschiedenis der Nederlanden 111, 2: 167-200.

Habermas, J. (1984) Theorie des kommunikativen Handelns: Zwei Bände. Frankfurt am Main: Suhrkamp.

Habermas, J. (1985) Die Neue Unübersichtlichkeit, Frankfurt am Main: Suhrkamp.

Habermas, J. (1989) The structural transformation of the Public Sphere, Cambridge, Mass.: MIT Press.

Habermas, J. (1996) Between facts and norms, Cambridge, Mass.: Polity Press.

Hajer, M. (2000) Politiek als vormgeving, Amsterdam: Vossiuspers.

Hajer, M. (2003a) 'Policy without polity? Policy analysis and the institutional void', Policy Sciences 36, 2: 175-195.

Hajer, M. (2003b) 'A frame in the fields' in M.A. Hajer \& H. Wagenaar (2003) Deliberative policy analysis: Understanding governance in the network society theories of institutional design, Cambridge: Cambridge University Press.

Hajer, M., D. Sijmons en F. Feddes (red.) (2006) Een plan dat werkt: ontwerp en politiek in de regionale planvorming, Rotterdam: NAi.

Hajer, M. (2009c) Authoritative governance: Policy-making in the age of mediatization, Oxford: Oxford University Press.

Hajer, M. en J. Uitermark (2009a) 'Performing authority after the assassination of Theo van Gogh', blz.76-96 in M. Hajer (2009) op. cit.

Hajer, M. et al. (2009b) 'Authority through Deliberative Governance: the British Food Standards Agency in action', blz. 125-169 in M. Hajer (2009) op. cit.

Hallin, D.C. (200o) 'Commercialism and professionalism in the American news media', blz. 218-237 in J. Curran en M. Gurevitch (red.) Mass Media and Society, Londen: Arnold.

Hallin, D.C. en P. Mancini (2004) Comparing media systems: Three models of media and politics, Cambridge: Cambridge University Press.

Hamilton, D.K. (2004) 'Developing regional regimes: A comparison of two metropolitan areas', Journal of Urban Affairs 26, 4: 455-477.

Hamilton, K. en R. Langhorne (1995) The practice of diplomacy: Its evolution, theory and administration, Londen: Routledge.

Hardin, G. (1968) 'The tragedy of the commons', Science 162, 3859: 1243-1248.

Hartman, I. (2000) 'Wie doen er mee aan het publieke debat?', Tijdschrift voor de sociale sector, september, 28-33. 
Hartogh, G. den (2002) Mutual expectations: A conventionalist theory of law, Dordrecht: Kluwer Academic Publishers.

Harvey, D. (1985) The urbanization of capital: studies in the history and theory of capitalist urbanization, Baltimore: John Hopkins University Press.

Have, W. ten (1999) De Nederlandse Unie. Aanpassing, vernieuwing en confrontatie in bezettingstijd 1940-1941, Amsterdam: Prometheus.

Haverland, M. (2005) 'Europeanisering van beleid in soorten en maten: milieu en transport vergeleken', Beleid en Maatschappij, 32, 1: 24-33.

Healey, P. (2007) Urban complexity and spatial strategies: Towards a relational planning for our times, Londen/New York: Routledge.

Healey, P. (1997) Collaborative planning: Shaping places in fragmented societies, Basingstoke/New York: Palgrave Macmillan.

Heidegger, M. (2001) De landweg, Budel: Damon.

Helden, W.J. van, J. Dekker, P.C. van Dorst en E.J.E. Govers-Vreeburg (2009) 'We gooien het de inspraak in', Een onderzoek naar de uitgangspunten voor behoorlijke burgerparticipatie, Den Haag: De Nationale Ombudsman.

Hendriks, A. (2009) 'Contextualizing the Dutch drop in political trust: connecting underlying factors', International Review of Administrative Sciences, 75, 3: 473-492.

Hendriks, F. (2009) 'Democratic reform between the extreme makeover and the reinvention of tradition: the case of the Netherlands', Democratization, 16, 2: 243-268.

Herbst, S. (2003) 'Political authority in a mediated age', Theory and Society 32, 4: 481-503.

Héritier, A., C. Knill en S. Mingers (1996) Ringing the changes in Europe. Regulatory competition and the transformation of the State. Britain, France, Germany, Berlijn: De Gruyter.

Heurtin, J.P. (2005) 'The circle of discussion and the semicircle of criticism', blz.754-769 in B. Latour en P. Weibel Making things public; Atmospheres of democracy. Karlsruhe: ZKM/MIT Press.

Hibbing, J.R. en E. Theiss-Morse (2002) Stealth democracy: Americans' beliefs about how government should work, Cambridge: Cambridge University Press.

Hillier, J. (2007) Stretching beyond the horizon: A multiplanar theory of spatial planning and governance, Aldershot: Ashgate.

Hillier, J. (2009) 'Poststructural complexity: strategic navigation in an ocean of theory and practice', in M. Cerreta, G. Concilio en V. Monno (red.) Knowledges and values in strategic spatial planning, Amsterdam: Kluwer.

Hirst, P. (1994) Associative democracy: New forms of economic and social governance, Cambridge: Polity Press.

Hirst, P. (2001) 'Democracy and Governance' in J. Pierre (red.) (2000) Debating governance: authority, steering and democracy. Oxford/New York: Oxford University Press.

Hoed, P. den, W.G.M. Salet en H. van der Sluijs (1983) Planning als onderneming (WRR Voorstudies en achtergronden V 34, Den Haag: Staatsuitgeverij.

Hoed, P. den (2007) 'Een keur van raadgevers: honderd jaar vaste adviescolleges', blz. 78-8o; blz. 128-138 in P. den Hoed en A.G. Keizer (red.) Op steenworp afstand. 
Op de brug tussen wetenschap en politiek, WRR 35jaar, Amsterdam: Amsterdam University Press.

Hoekstra, H. (2005) Het hart van de natie: morele verontwaardiging en politieke verandering in Nederland 1870-1919, Amsterdam: Wereldbibliotheek.

Hoekstra, R.J. (2009) Jaarrede Nederlandse Juristen Vereniging, 12 juni.

Hoeven, J. van der (1958) De plaats van de grondwet in het constitutionele recht, Zwolle: Tjeenk Willink.

Holmberg, S. (1999) 'Down and down we go: Politcal trust in Sweden' in P. Norris (red.) Critical citizens: global support for democratic government, Oxford : Oxford University Press.

Holsteyn, J.J.M. van en C.E. Mudde (red.) (2002) Democratie in verval, Amsterdam: Boom. Hooghe, L. en G. Marks (2001) Multi-Level Governance and European Integration, Lanham: Rowman \& Littlefield.

Hooghe, L. en G. Marks (2003) 'Unraveling the central state, but how? Types of multi-level governance', American Political Science Review 97, 2: 233-243.

Hooykaas, G.J. en F.J.P. Santegoets (red.) (1996) De briefwisseling van Thorbecke, deel V: 1845-1853, Den Haag: Instituut voor Nederlandse Geschiedenis.

Houkes, A. (2009) Christelijke vaderlanders: Godsdienst, burgerschap en de Nederlandse natie (1850-1900), Amsterdam: Wereldbibliotheek.

Houwink ten Cate, J. (1995) 'De mannen van de daad' en Duitsland, 1919-1939: het Hollandse zakenleven en de vooroorlogse buitenlandse politiek, Den Haag: Sdu.

Hurenkamp, M., E. Tonkens en J.W. Duyvendak (2008) Wat burgers bezielt: een onderzoek naar burgerinitiatieven, Amsterdam: UvA en NICIS Kenniscentrum Grote Steden. IAP2 (2007) Spectrum of Public Participation, http://www.iap2.org/associations/4748/ files/spectrum.pdf (last visited 29-10-2009)

IJsselmuiden, P.G. van (1988) Binnenlandse Zaken en het ontstaan van de moderne overheidsbureaucratie in Nederland, 1813-1940, Kampen: Kok.

Imbroscio, D. (1998) 'Reformulating urban regime theory', Journal of Urban Affairs 20 : 233-248.

Innes, J. (1995) 'Planning Theory's Emerging Paradigm: Communicative action and interactive practice', Journal of Planning Education \& Research 14: 140-143.

Instituut voor Maatschappelijke Ontwikkeling en Expertisebureau voor Innovatieve Beleidsvorming, Forum voor democratische Ontwikkeling (2003) Samenleving en politiek; naar nieuwe verbindingen, gedownload van: http://www.publiekpolitiek.nl/Bestanden/the-XPIN-files/Samenleving-en-politiek-tien-jaar-motieWillems.

Irwin, A. (2001) 'Constructing the scientific citizen: science and democracy in the biosciences', Public Understanding of Science 10, 1: 1-18.

Iyengar, S. en J. McGrady (2007) Media politics: a citizen's guide, New York: W.W. Norton. Janse, M. (2007) De afschaffers: publieke opinie, organisatie en politiek in Nederland 18401880, Amsterdam: Wereldbibliotheek.

Jasanoff, S. (2003) 'Technologies of humility: Citizen participation in governing science', Minerva 41, 3: 223-244. 
Jitta, A.C. (1932) Functionele decentralisatie: de grondgedachte van den corporatieven staat binnen het kader der parlementaire democratie, Groningen: Wolters.

Jonge, J.A. de (1988) 'Het economisch leven in Nederland 1895-1914', blz. 245-276 in J.C. Boogman et al. (red.) Geschiedenis van het moderne Nederland: politieke, economische en sociale ontwikkelingen, Houten: De Haan.

Jordan III, W.R. (2003) The sunflower forest. Ecological restauration and the new communication with nature, Berkeley: University of California Press.

Kaase, M .en K. Newton (1995) Beliefs in government, Oxford: Oxford University Press. Kappelhof, T. (2007) 'Omdat het historisch gegroeid is. De Londense Commissie-Van Rhijn en de ontwikkeling van de sociale verzekeringen in Nederland (1937-1952)', in http://www.inghist.nl/Onderzoek/tijding/bijdragen/Omdat_het_historisch _gegroeid_is/kappelhof_gegroeid.pdf (webpublicatie)

Katz, D. en E. Stotland (1959) 'A preliminary statement to a theory of attitude structure and change', blz. 423-475 in S. Koch (red.) Psychology: A study of a science, New York: McGraw-Hill.

Keck, M.E. en K. Sikkink (1998) Activists beyond borders. Advocacy networks in international politics, Ithaca : Cornell University Press.

Keelan, J., V. Pavri-Garcia et al. (2007) 'YouTube as a source of information on immunization: A content analysis', JAMA 298, 21: 2482-2484.

Keman, J.E., J.J. Woldendorp en D. Braun (1985) Het neo-korporatisme als nieuwe politieke strategie, krisisbeheersing met beleid en (door) overleg?, Amsterdam: CT Press.

Kennan, G.F. (1997) ‘Diplomacy without diplomats?’ Foreign Affairs 76, 5: 198-207.

Kennedy, J.C. (1995) Nieuw Babylon in aanbouw, Nederland in de jaren zestig, Meppel: Boom.

Kennisinstituut voor het Mobiliteitsbeleid (KiM) (2008) Samenwerking tussen zeehavens, Den Haag: KiM.

Keohane, R.O. (2002) Power and governance in a partially globalized world, Londen: Routledge.

Keulartz, F.W.J. (2009) 'Participatie, Gemeenschap en Rituelen; De performatieve wending' in H. Dijstelbloem, J. Keulartz en M. van der Veen Van wie is het bos eigenlijk? Essays over participatie en natuurbeheer, Driebergen: Staatsbosbeheer.

Keulen, M. van (2006) Going Europe or Going Dutch. How the Dutch government shapes European Union policy, Amsterdam: Amsterdam University Press.

Kleinnijenhuis, J. (2003) 'Het publiek volgt media die de politiek volgen', in RMO (red.) Medialogica. Over het krachtenveld tussen burgers, media en politiek, Den Haag: RMO.

Kleinnijenhuis, J. et al. (2007) Nederland vijfstromenland: de rol van de media en stemwijzers bij de verkiezingen van 2006, Amsterdam: Bert Bakker.

Klerk, L. de (1998) Particuliere plannen: denkbeelden en initiatieven van de stedelijke elite inzake de volkswoningbouw en de stedenbouw in Rotterdam 1860-1950. Rotterdam: NAi Uitgevers.

Klerk, L. de (2008) De modernisering van de stad 1850-1914: De opkomst van de planmatige stadsontwikkeling in Nederland. Rotterdam: NAi-Uitgevers. 
Klinken, G. van (2003) Actieve burgers: Nederlanders en hun politieke partijen 1870-1918, Amsterdam: Wereldbibliotheek.

Klinkers, L. (2006) 'Parlement en regering, rijp voor een nieuwe levenscyclus?', blz. 15-16.

Bijlage bij: Nationale conventie, Hart voor de publieke zaak, aanbevelingen van de Nationale conventie voor de 21ste eeuw, Den Haag: Nationale conventie.

Klop, T. (2008) Attitudes of secondary school students towards modern biotechnology,

Rotterdam: Erasmus Universiteit Rotterdam.

Knaap, P. van der, C. Termeer en M. van Twist (2002) 'Omwille van effectief toezicht.

Reflecties op risico's van een hype, Bestuurskunde 11, 3: 94-98.

Knepper, S. en J. Kortenray (2008) De vertrouwenscrisis: Over het krakend fundament van de samenleving, Amsterdam: Meulenhoff.

Knill, C. en D. Lehmkuhl (2002) 'The National impact of EU regulatory policy: Three Europeanization mechanisms', European Journal of Political Research 41, 2: 255280.

Knippenberg, H. en B. de Pater (1988) De eenwording van Nederland, schaalvergroting en integratie sinds 1800 , Nijmegen: SUN.

Kolk, H. van der, K. Aarts en M. Rosema (2007) ‘Twijfelen en kiezen’, blz. 211-234 in K. Aarts, H. Van der Kolk en M. Rosema (red.) Een verdeeld electoraat. De Tweede Kamerverkiezingen van 2006, Utrecht: Spectrum.

Koopmans, T. (1970 ) 'De rol van de wetgever', blz. 221-235 in Honderd jaar rechtsleven, Jubileumbundel Nederlandse juristenvereniging, Zwolle/Deventer.

Koppell, J.G. (2005) 'Pathologies of Accountability. ICANN and the Challenge of Multiple Accountabilities Disorder', Public Administration Review 65, 1: 94-109.

Kossmann, E.H. (1986) De Lage Landen 1780-1980: Twee Eeuwen Nederland en België. Deel I, 1780-1914, Amsterdam: Agon.

Krabbe, H. (1883) De Burgerlijke staatsdienst in Nederland, Leiden: S.C. van Doesburgh.

Kreukels, T. (1985) 'Planning als spiegel van de westerse samenleving', Beleid en Maatschappij 12 .

Kreukels, T. en E. Wever (red.) (1998) North sea ports in transition: Changing Tides. Assen: Van Gorcum.

Kriesi, H., E. Grande, R. Lachat, M. Dolezal, S. Bornschier en T. Frey, T. (2006) ‘Globalization and the transformation of the national political space: Six European countries compared', European Journal of Political Research 45: 921-956.

Kriesi, H. en T. Frey (2008) 'The Netherlands: a challenge that was slow in coming', blz. 154-182 in H. Kriesi et al. (red.) West European Politics in the Age of Globalization, Cambridge: Cambridge University Press.

Krueger, J. en R.W. Clement (1997) 'Consensus estimates by majorities and minorities: The case for social projection', Personality and Social Psychology Review 1: 299319.

Kuik, F. van (2009) 'Adviezen over de vernieuwing van de rijksdienst', in H. Bekke, K. Breed en P. De Jong (2009) op. cit.

Laar, P. van der (200o) Stad van formaat; geschiedenis van Rotterdam in de negentiende en twintigste eeuw, Zwolle: Waanders. 
Lagasse, L. (2004) Sociale marketing. Instrument voor duurzame gedragsveranderingen bij grote groepen, Antwerpen: De Boeck.

Landau, M. (1969) 'Redundancy, rationality and the problem of duplication and overlap', Public Administration Review 29, 4: 346-358.

Langen, P. de en M.H. Nijdam (2003) Leader firms in de Nederlandse martitieme cluster: Theorie en praktijk, Delft: Delft University Press.

Latour, B. (1997) On actor network theory, Paper to the actor network and after conference, Keele, Staffordshire: Keele University.

Latour, B. (2005) Reassembling the social: An introduction to actor-network-theory;

Oxford: Oxford University Press.

Law, J. (1986) 'On power and its tactics', Sociological Review 34: 1-34.

Law, J. (2004) After Method: Mess in social science research, New York: Routledge.

Leerssen, J. (2006) De bronnen van het vaderland. Taal, literatuur en de afbakening van Nederland 1806-189o, Nijmegen:Vantilt.

Lerner, J.S. en P.E. Tetlock (1999) 'Accounting for the Effects of Accountability', Psychological Bulletin 125, 2: 255-275.

Lesger, C. (1999) 'De mythe van de Hollandse wereldstapelmarkt in de zeventiende eeuw', blz. 6-25 in NEHA-jaarboek 1999 (62).

Liagre Böhl, H. de (1999) 'Consensus en polarisatie: spanningen in de verzorgingsstaat' in R. Aerts, H. de Liagre Böhl, P. de Rooy en H. te Velde (1999) op. cit.

Lijphart, A. (1986) Verzuiling, pacificatie en kentering in de Nederlandse politiek, Amsterdam: De Bussy.

Lijphart, A. (1999) Patterns of democracy, government forms and performance in thirtysix countries, New Haven: Yale University Press.

Linde, J. en J. Ekman (2003) 'Satisfaction with democracy: A note on a frequently used indicator in comparative politics', European journal of political research, 42, 3: 391-408.

Loots, J. (2004) Voor het volk, van het volk: van districtenstelsel naar evenredige vertegenwoordiging, Amsterdam: Wereldbibliotheek.

Luhmann, N. (1990) Essays on self-reference, New York: Columbia University Press.

Luns, J.M.A.H. (1971) Luns: “Ik herinner mij. . .” : vrijmoedige herinneringen van J.M.A.H.

Luns zoals verteld aan Michel van der Plas, Leiden: Sijthoff.

Mair, P. (2008) 'Electoral volatility and the Dutch party system', Acta Politica, 43: 235-253.

Majone, G. (1996) Regulating Europe, Londen: Routledge.

Manin, B. (1997) The principles of representative Government, Cambridge: Cambridge University Press.

Marres, N. (2003) 'Beter productief wantrouwen dan misplaatst vertrouwen: over de politieke verdiensten van media-affaires', Krisis 1: 36-52.

Marres, N.S. (2005) No issue, no public: democratic deficits after the displacement of politics, Amsterdam: Universiteit van Amsterdam.

Massey, D. (1995) Spatial division of labour: Social structures and the geography of production, 2nd edition. Basingstoke: Mcmillan.

Massey, D. (1998) Power-geometries and the politics of space-time, Hettner-Lecture 
Department of Geography, Heidelberg: University of Heidelberg.

Massey, D. (2005) For Space, Londen: Sage Publications.

Mastenbroek, E. (2003) 'Surviving the deadline: The transposition of EU directives in the Netherlands', European Union Politics 4, 4: 371-395.

Mastenbroek, E. en S. Princen (te verschijnen) 'Time for EU Matters. The Europeanization of Dutch Central Government', Public Administration.

May, J. (2007) 'The triangle of engagement: An unusual way of looking at the usual suspects', Public Money \& Management 27, 1: 69-75.

McCombs, M. (2004) Setting the agenda. The mass media and public opinion, Cambridge: Polity Press.

McCubbins, M.D., Schwartz, T. (1984) 'Congressional oversight overlooked. Police patrol versus fire alarm', American Journal of Political Science 28, 1: 165-179.

McNair, B. (200o) Journalism and democracy: An evaluation of the political public sphere, Londen: Routledge.

Meer, T. van der, Dekker, P. en Steenvoorden, E. (2009) сов Kwartaalbericht 2009 nr. 3 Den Haag: Sociaal en Cultureel Planbureau.

Meijer, A. (2002) De doorzichtige overheid. Parlementaire en juridische controle in het informatietijdperk, Delft: Eburon.

Meijer, A., S. Grimmelikhuijsen en G.J. Brandsma (2009) 'Transparantie’, blz. 205-227 in M. Bovens en T. Schillemans (red.) (2009) op. cit.

Melissen, J. (red.) (2005) The new public diplomacy: Soft power in international relations, Houndmills: Palgrave.

Merriënboer, J. van (2006) Mansholt. Een biografie, Amsterdam: Boom.

Mertens, F.J.H. (2005) 'Bewijzen van goede dienstverlening, commentaar op een WRRrapport', Nederlands Tijdschrift voor Onderwijsrecht 17, 2: 63-78.

Michels, A. en A. Meijer (2003) 'Horizontalisering van bestuur: een vraag om nieuwe vormen van publieke verantwoording', Bestuurswetenschappen 57, 4: 329347.

Middelaar, L. van (2004) 'Verblind door de Zonnekoning. Nederland en de democratische representatie in Europa', blz. 115-146 in B.F. Steur e.a. (red.) Democratische vergezichten. Essays over de representatieve democratie in Nederland, Den Haag: ROB.

Ministerie van Binnenlandse Zaken en Koninkrijksrelaties (2005) Minder last, meer effect. Zes principes van goed toezicht, Den Haag: ministerie van Binnenlandse Zaken en Koninkrijksrelaties.

Ministerie van Binnenlandse Zaken en Koninkrijksrelaties (2008) Publiek Verantwoorden. Handreikingen voor openheid in goed bestuur, Den Haag: ministerie van Binnenlandse Zaken en Koninkrijksrelaties.

Ministerie van Binnenlandse Zaken en Koninkrijksrelaties (2009) Verantwoordelijk burgerschap: een kwestie van geven en nemen, Den Haag: ministerie van Binnenlandse Zaken en Koninkrijksrelaties.

Ministerie van Buitenlandse Zaken (2003) 'Europa in de steigers. De Nederlandse inbreng in de volgende fase van de Conventie over de toekomst van Europa', TK 20022003, 28604 en 28473, nr. 3, Den Haag: Sdu Uitgevers. 
Ministerie van Buitenlandse Zaken (2005) Staat van de Europese Unie 2005-2006, TK 20052006, 89444 nr. 1, Den Haag: Sdu Uitgevers.

Ministerie van Economische Zaken (2009) Economische visie op de lange termijn ontwikkeling van de Mainport Rotterdam; Op weg naar een Mainport Netwerk Nederland. Den Haag: ministerie van Economische Zaken.

Ministerie van Verkeer en Waterstaat (2009) Reactie op onderzoek KiM naar samenwerking van zeehavens, TK 2009-2010, 29862 nr. 19, Den Haag: Sdu Uitgevers.

Ministerie van Volkshuisvesting, Ruimtelijke Ordening en Milieubeheer (2008) Structuurvisie Randstad 2040, Den Haag: ministerie van Volkshuisvesting, Ruimtelijke Ordening en Milieubeheer.

Moe, T. (1984) 'The new economics of organization', American Journal of Political Science 28: 739-777.

Moeyes, P. (2001) Buiten Schot: Nederland tijdens de Eerste Wereldoorlog, 1914-1918, Amsterdam: De Arbeiderspers.

Mollenkopf, J. (1992) A phoenix in the ashes; the rise and fall of the Koch coalition in New York City politics, New Jersey: Princeton University Press.

Mommaas, H. en L. Boelens (2005) 'De nieuwe markten benadering in het Heuvelland' in N. Aarts, R. During en P. van der Jagt (red.) Land te koop, Wageningen: WUR.

Montfort, C.J. van (2004) Ruimte voor goed bestuur. Tussen prestatie, proces en principe, WRR-webpublicatie nr. 2, www.wrr.nl

Mossberger, K. en G. Stoker (2001) 'The evolution of urban regime theory: The challenge of conceptualization', Urban Affairs Review 36: 810-835.

Mouffe, C. (2005) On the political. Thinking in action, Londen: Routledge.

Mulgan, R. (2003) Holding power to account. Accountability in modern democracies, Basingstoke: Palgrave.

Mullen, B., J.L. Atkins, D.S. Champion, C. Edwards, D. Hardy, J.E. Story en M. Vanderklok, (1985) 'The false consensus effect: A meta-analysis of 115 hypothesis tests', Journal of Experimental Social Psychology, 21, 262.

Müller, W.C., M. Bovens, J. Christensen, M. Jenny en K. Yesilkagit (te verschijnen) 'Legal Europeanization: Comparative perspectives', Public Administration.

Murdoch, J. (1997) 'Towards a geography of heterogeneous associations', Progress in Human Geography 21: 321-337.

Murdoch, J. (2006) Post-structuralist geography: a guide to relational space, Londen: Sage.

Napel, H. ten (2002) 'Het nieuwe constitutionalisme' in J. van Holsteyn en C. Mudde (red.) Democratie in verval, Amsterdam: Boom.

Nationale conventie (2006) Hart voor de publieke zaak: aanbevelingen van de Nationale Conventie voor de 21ste eeuw.

NEA (2009) Rentabiliteit van het wegvervoer op weg naar een nieuw dieptepunt, persbericht zomer 2009, Rijswijk: NEA.

Nelkin, D. en M. Pollak (1979) 'Public participation in technological decisions: reality or grand illusion?’, Technology Review 81: 55-64.

Nelson, R.R. (1977) The moon and the ghetto, an essay on public policy analysis, New York: Norton. 
Neugebauer, G. (2007) Politische Milieus in Deutschland. Die Studie der Friedrich-EbertStiftung, Ulm: Ebner \& Spiegel.

Newman, A.L. (2008) 'Building transnational civil liberties: Transgovernmental entrepreneurs and the European data privacy directive', International Organization 62: 103-130.

Noël, E. (1976) Les rouages de l'Europe. Comment fonctionnent les institutions de la Communauté européenne, Parijs: F. Nathan.

Noordegraaf, M. en J. Sterrenburg (2009) 'Publieke professionals en verantwoordingsdruk', blz. 231- 254 in M. Bovens en T. Schillemans (red.) op. cit.

Noorman, A.W. (2006) Particulier opdrachtgeverschap; tussen droom en daad staan instituties in de weg, Rotterdam: SEV.

Norris, P. (red.) (1999a) Critical citizens : global support for democratic government, Oxford: Oxford University Press.

Norris, P. (1999b) 'Institutional explanations for political support' in P. Norris (red.) Critical citizens: global support for democratic government, Oxford: Oxford University Press.

NOs-Journaal (2002) Ten aanval, Notitie van hoofdredacteur Hans Laroes, Hilversum: Nos. NRC Handelsblad (2009b, 13 juni) 'Standpunten van de PVV zweven van VVD naar SP'. NRC Handelsblad (2009a, 13 juni) 'PVV schuift op naar links over economie'. NRC-NEXT (2009b, 11 november) 'Nu nog de spookverhalen ontkrachten; Hoe Klink tot zijn besluit kwam'.

NRC-NEXT (2009a, 12 november) 'Het vaccin is: (a) wapen (b) chip (c) kwik; Verhalen circuleren op het web'.

Nussbaum, M. en A. Sen (red.) (1993) The quality of life, Oxford: Clarendon Press. OECD (2009) Focus on citizens: Public engagement for better policy and services, Parijs: OECD.

Oud, P.J. (1990) Staatkundige vormgeving in Nederland: Deel I 1840-1940, Assen: Van Gorcum.

Page, E. (1998) 'The impact of European legislation on British public policy-making: A research note', Public Administration, 76, 4: 803-809.

Patterson, T.E. (1993) Out of order, New York: Knopf.

Pellikaan, H., T. van der Meer en S. L. de Lange (2003) 'The road from a depoliticized to a centrifugal democracy', Acta Politica 38, 1: 23-50

Pellikaan, H., S.L. de Lange en T. van der Meer (2007) 'Fortuyn's legacy: Party system change in the Netherlands', Comparative European Politics, 5: 282-302.

Pels, D. (2003) 'Aesthetic representation and political style: re-balancing identity and difference in media democracy', blz. 41-66 in J. Corner en D. Pels Media and the Restyling of Politics: consumerism, celebrity and cynicism, Londen: Sage.

Pesch, U. (2008) ‘The publicness of public administration', Administration \& Society 40, 2: 170-193.

Peterson, P.E. (1981) City limits, Chicago: University of Chicago Press.

Piët, S. (2003) De emotiemarkt. De toekomst van de beleveniseconomie, Amsterdam: Pearson Education Benelux. 
Plate, A. (1934) Mémoires 9o, eigen uitgave. Assen: Politieke Unie in het Verdrag van Maastricht.

Poelje, G.A van (1959) Osmose. Een aantekening over het elkander doordringen van de beginselen van openbaar bestuur en particulier beheer, Alpen aan den Rijn: Samsom.

Poelje, G.A. van (1967) Het nieuwe burgerschap. Commissie, Raden en wat dies meer zij, Alphen aan den Rijn: Samsom.

Poelje, S.O. van (1974) 'Coördinatie van het milieubeleid', blz. 63-71 in Overheid en milieu, de groei en de beperkingen, Baarn: Het Wereldvenster.

Poelje, S.O van (1977) 'De veertien wetsfamilies', blz. 53-56 in Vereniging van Nederlandse Gemeenten (VNG), De veertien wetsfamilies, verslag van de 18 februari gehouden studiedag t.g.v. het afscheid van prof. dr. S.O. van Poelje van het IBW, Den Haag: VNG.

Polak, J.M. (1986) 'Parlementariers zijn geen rechters' in Nederlandsch Juristenblad: weekblad behorende bij de Nederlandsche jurisprudentie, 61, 40: 1282.

Portugali, J. (200o) Self-organization and the city, Heidelberg: Springer-Verlag Berlijn. Praag, P. van en K. Brants (200o) 'Politieke Communicatie in een consensusdemocratie' in P. van Praag en K. Brants (red.) Tussen beeld en inhoud. Politiek en media in de verkiezingen van 1998, Amsterdam: Het Spinhuis.

Praag, P. van (2001) 'Media en openbaar bestuur: de uitdaging van de interpreterende journalistiek' Bestuurskunde 10, 7: 310-319.

Praag, P. van (2007) 'De verkiezingscampagne: professioneler en feller' in K. Aarts, H. van der Kolk en M. Rosema (red.) Een verdeeld electoraat. De Tweede Kamerverkiezingen van 2006, Utrecht: Het Spectrum.

Pressman, J.L. en A. Wildavsky (1973) Implementation; how great expectations in Washington are dashed in Oakland, Berkeley: University of California Press.

Prigogine, I. en I. Stengers (1984) Order out of chaos: man's new dialoques with nature, Londen: Heinemann.

Princen, S. en K. Yesilkagit (2005) 'Tussen Brussel en de Polder. De Europeanisering van politiek en bestuur in Nederland', Beleid en Maatschappij, 35, 1: 1-12.

Princen, S. (2009) Agenda-setting in the European Union, Basingstoke: Palgrave.

Przeworski, A., S. Stokes en B. Manin (1999) Democracy, accountability, and representation, Cambridge: Cambridge University Press.

Putten, J. van (1977) ‘Adviseren maar namens wie?’, blz. 133-135 in Wetenschappelijke Raad voor het Regeringsbeleid (WRR), Adviseren aan de overheid, WRR serie Voorstudies en achtergronden, Den Haag: Staatsuitgeverij.

Raad van State (2005) 'De invloed van de Europese Unie voor de Nederlandse staatsinstellingen’ TK 2005-2006 29993 nr. 27, Den Haag: Sdu Uitgevers.

Raadschelders, J.C.N. en Th. A.J. Toonen (1993) 'Theorie, casus en perspectief voor onderzoek', blz. 179-192 in J.C.N. Raadschelders en Th.A.J. Toonen (red.) Waterschappen in Nederland: Een bestuurskundige verkenning van de institutionele ontwikkeling, Hilversum: Verloren.

Rhinard, M. (2002) Ideas, interests, and policy change in the European Union: The 
mobilization of frames by actors in the agricultural and biotechnology policy sectors, proefschrift, Cambridge: University of Cambridge.

Rhodes, R. (1994) 'The hollowing out of the state: The changing nature of the public service in Britain', Political Quarterly, 65, 2: 138-151.

Ridder, K. de en H. Winter (2006) 'Interbestuurlijk vertrouwen: de onzichtbare bestuurlijke cohesie' in A. Kosten en P. de Goede (red.) Bouwen aan vertrouwen in het openbaar bestuur. Diagnoses en remedies, Den Haag: Elsevier.

Rigter, D.P. et al. (1995) Tussen sociale wil en werkelijkheid: een geschiedenis van het beleid van het ministerie van Sociale Zaken. Den Haag: vUGA Uitgeverij.

Rijn, R. van en M. van Twist (2009) 'Verantwoorde vernieuwing? Innovatie van publieke verantwoording', blz. 255-274 in M. Bovens en T. Schillemans (red.) op. cit.

Rijn, T. van (2009) 'Havensteden huiverig voor nationale holding', PM 21 december 2009. RMO (2003) Medialogica. Over het krachtenveld tussen burgers, media en politiek, Den Haag: Sdu Uitgevers.

RMO (2008) De ontkokering voorbij. Slim organiseren voor meer regelruimte, Amsterdam: SWP.

RОВ (2003) Politiek en media: pleidooi voor een LAT-relatie, Den Haag: Raad voor Openbaar Bestuur.

Romein, E., M. Schuilenberg en S. van Tuinen (red.) (20o9) Deleuze Compendium, Amsterdam: Boom.

Romein, J. en A. Romein (1947), 'Abraham Kuyper: de klokkenist der kleine luyden, 1837-1920', deel IV, blz. 145-177 in Ibidem, Erflaters van onze beschaving: Nederlandse gestalten uit zes eeuwen, Amsterdam: Querido's Uitgeversmaatschappij.

Romein, J. (1976) Op het breukvlak van twee eeuwen, 2de druk: Amsterdam: Querido, hoofdstuk XVIII en XIX.

Rooy, P. de (1999a) 'Een zoekende tijd: de ongemakkelijke democratie, 1913-1949', in R. Aerts, H. de Liagre Böhl, P. de Rooy en H. te Velde (1999) op. cit.

Rooy, P. de (1999b) 'Zonderlingen, Oproermakers en Toekomstmenschen', blz. 39-61 in: F. Boterman en P. de Rooy, Op de grens van twee culturen. Nederland en Duitsland in het Fin de Siècle, Amsterdam: Balans.

Rooy, P. de (2005) Republiek van rivaliteiten, Nederland sinds 1813, Amsterdam: Metz en Schilt.

Rooyen, E. van (2009) De Europeanisering van belangengroepen en politieke partijen in Nederland: 1990-200o, Amsterdam: Pallas Publications/Amsterdam University Press.

Rosanvallon, P. (1998) Le peuple introuvable: Histoire de la représentation démocratique en France, Parijs: Gallimard.

Rosanvallon, P. (2006) Democracy past and future, New York: Columbia University Press.

Rosanvallon, P. (2008) Counter-democracy: Politics in an age of distrust, Cambridge: Cambridge University Press.

Rosenthal, U. en A. Ringeling (red.) (1976) Regeren door nota’s (1976), Themanummer Beleid en Maatschappij ingeleid door voorzitter Tweede Kamer A. Vondeling, jaargang III, nr. $3 / 4$. 
Rosenthal, U. et al. (1996) Openbaar bestuur: Beleid, organisatie en politiek, Alphen aan den Rijn: Samsom/H.D. Tjeenk Willink.

Rowe, G. en L.J. Frewer (2005) 'A typology of public engagement mechanisms', Science, Technology, \& Human Values 30, 2: 215-290.

Sabel, C.F. en J. Zeitlin (2008) 'Learning from difference: The new architecture of Experimentalist governance in the European Union', European Law Journal 14, 3: 271-327.

Salet, W. en S. Majoor (red.) (2005) Amsterdam Zuidas: European space. Rotterdam: o1oPublishers.

Sanders, W. (2009) 'Unmappables; Connecting people to possible worlds', blz. 166-181 in L. Boelens (2009) The urban connection; An actor-relational approach to urban planning, Rotterdam: o1o-Publishers.

Sartori, G. (1984) Social science concept: Systematic analyses, Beverly Hills: Sage Publications.

Sas, N.C.F. van en H. te Velde (red.) (1998) De eeuw van de Grondwet: Grondwet en politiek in Nederland, 1798-1917, Deventer: Kluwer.

Sassatelli, R. (2006) 'Virtue, responsibility and consumer choice: Framing critical consumerism' in J. Brewer en F. Trentmann (red.) Consuming cultures, global perspectives: Historical trajectories transnational changes, Oxford: Berg.

Savitch, H., P. Kantor en S. Vicari (1997) 'The political economy of urban regimes', blz. 175-188 in E. Strom en J. Mollenkopf (red.) (2007) The urban politics reader, New York: Routledge.

Scheele, D. (2006) Doelmatigheid in de rechtshuishouding. Een rechtseconomische analyse, Den Haag: Boom juridische uitgevers.

Scheffer, P.J. (2002) 'Het multiculturele drama', NRC Handelsblad, 29 januari.

Schendelen, R. van (2010) More Machiavelli in Brussels: The art of lobbying the EU, Amsterdam: Amsterdam University Press.

Schillemans, T. en M. Oude Vrielink (2007) Horizontale verantwoording als complement en substituut. Trendstudie naar de ontwikkeling van het denken over horizontale verantwoording op rijksniveau en de meerwaarde ervan voor het verticale toezicht, Den Haag: ministerie van Binnenlandse Zaken en Koninkrijksrelaties.

Schillemans, T. (2007a) Verantwoording in de schaduw van de macht. Horizontale verantwoording bij zelfstandige uitvoeringsorganisaties, Den Haag: Lemma.

Schillemans, T. (2007b) 'Horizontale verantwoording bij zelfstandige uitvoeringsorganisaties: redundant en complementair', Beleid en Maatschappij 34, 4:199-209.

Schillemans, T., T. Brandsen, E. van Hout en M. Oude Vrielink (2008) Horizontale verantwoording bij maatschappelijke ondernemingen, Delft: PMO.

Schillemans, T. en M. Bovens (2009a) 'Publieke verantwoording 2.o: sober maar scherp', blz. 275-293 in M. Bovens en T. Schillemans (red.) op. cit.

Schillemans, T. (2009b) 'Visitaties als vorm van verantwoording', blz. 161-180 in M. Bovens en T. Schillemans (red.) op. cit.

Schmidt, V. (2002) 'Does discourse matter in the politics of welfare state adjustment?' Comparative Political Studies 35, 2: 168-193. 
Schout, A. (2009) 'Integraalbestuur bij de Europese Commisie' in H. Bekke, K. Breed en P. de Jong (red.) op. cit.

Schreuder, A. (2009) 'Bruisend hart dreigt dicht te slippen met supermarkt', NRC Handelsblad, 4 december 2009.

Schuyt, C.J.M. en E. Taverne (2000) 1950: welvaart in zwart-wit, Den Haag: Sdu.

Schuyt, K. en R. van der Veen (red.) (1986) De verdeelde samenleving: een inleiding in de ontwikkeling van de Nederlandse verzorgingsstaat, Leiden/Antwerpen: Stenfert Kroese.

Scott, J.C. (1998) Seeing like a state: How certain schemes to improve the human condition have failed, New Haven and Londen: Yale University Press.

SCP (1998) Sociaal en Cultureel Rapport 1998: 25 jaar sociale verandering, Den Haag: Sociaal en Cultureel Planbureau.

SCP (2009) De sociale staat van Nederland, Den Haag: Sociaal en Cultureel Planbureau.

Semetko, H.A. et al. (1991) The formation of campaign agendas: a comparative analysis of party and media roles in recent American and British elections, Hillsdale: Lawrence Erlbaum Associates.

Sennett, R. (1977) The fall of the public man, New York: Knopf.

Siedentop, L. (2001) Democracy in Europe, New York : Columbia University Press.

Simons, J. (1998) Zwevende kiezers, zappende kijkers, Amsterdam: Amsterdam University Press.

Singer, P. (2004) One world: the ethics of globalization, New Haven: Yale University Press.

Slaughter, A.M. (2000) 'Governing the global economy through government networks', blz. 177-205 in M. Byers (red.) The role of law in international politics: Essays in international relations and international law, Oxford: Oxford University Press.

Slaughter, A.M. (2004) A new world order, Princeton: Princeton University Press.

Sloterdijk, P. (2007) Woede en tijd: een politiek-psychologisch essay, Amsterdam: Boom. Sloterdijk, P. (2009) Sferen band 2, II, Schuim: plurale sferologie, Amsterdam: Boom. Smith, E.R. en D.M. Mackie (200o) Social psychology, Philadelphia: Psychology Press. Smit-Kroes, N. (1991) 'Lubbers als premier' in A. Joustra en E. van Venetië (uitg.) Ruud Lubbers: manager in de politiek, Baarn: Anthos.

Smits, J.H. (2001) 'Spin doctors aan het Binnenhof? Over rolopvattingen van directeuren Voorlichting bij de rijksoverheid', Bestuurskunde, 10, 7: 320-329.

Smulders, B. (2009) 'An ever mighty European Council - some recent institutional developments', Editorial Comments, Common Market Law Review 46, 5: 13831393.

Snels, B. en N. Thijssen (red.) (2008) De grote kloof, verhitte politiek in tijden van verwarring, Amsterdam: Boom.

Spangenberg, F. en M. Lampert (2009) De grenzeloze generatie, Amsterdam: Nieuw Amsterdam.

Steenvoorden, E., T. van der Meer en P. Dekker (2009) Continu onderzoek burgerperspectieven, kwartaalbericht 3. Den Haag: Sociaal en Cultureel Planbureau.

Stein, J.G. (2002) 'Bad translation or double standard? Productivity and accountability 
across the private, public and voluntary sectors', The Review of Economic Performance and Social Progress, 2: 259-275.

Steunenberg, B. et al. (2005) De omzetting van Europese richtlijnen: Instrumenten, technieken en processen in zes lidstaten vergeleken, Den Haag: WODC.

Stoker, G. en M. Orr (1994) 'Urban regimes and leadership in Detroit', Urban Affairs Quarterly 1: 48-73.

Stone, C. (1989) Regime politics: Governing Atlanta 1946-1988, Lawrence: The University Press of Kansas.

Stone, C. (2005) Rethinking the policy-politics connection, Policy Studies 26: 241-26o.

Strom, E. (1996) 'In search of the growth coalition: American urban theories and the redevelopment of Berlin', blz. 141-150 in E. Strom en J. Mollenkopf (red.) (2007) The Urban Politics Reader, New York: Routledge.

Strøm, K. (2000) 'Delegation and accountability in parliamentary democracies', European Journal of Political Research 37: 261-289.

Strömbäck, J. en L. Kaid (red.) (2008) The handbook of election news coverage around the world, New York: Routledge.

Struycken A.A.H. (1914) De Grondwet, haar karakter en waarde, Gouda: Quint.

Stuurman, S. (1983) Verzuiling, kapitalisme en patriarchaat: aspecten van de ontwikkeling van de moderne staat in Nederland, Nijmegen: SUN.

Sudjic, D. (1992) The 100 mile city, Orlando: Harcourt.

Sunstein, C.R. (2009) Going to extremes : how like minds unite and divide, New York: Oxford University Press.

Swaan, A. de (1979) 'Uitgaansbeperking en uitgaansangst. Over de verschuiving van bevelshuishouding naar onderhandelingshuishouding', De Gids 142, 8: 483-509.

Teisman, G., A. van Buuren en L. Gerrits (red.) (2009) Managing complex governance systems: Dynamics, self-organization and coevolution in public investments, Londen: Routledge.

Thiel, S. van (200o) Quangocratization: Trends, causes, consequences, Utrecht: ICS.

Thiel, S. en K. Yesilkagit (2006) Respondentenrapport Cobra Enquête. Erasmus Universiteit Rotterdam en Universiteit Utrecht.

Thiel, S. van (2008) 'The empty nest syndrome: Dutch ministries after the separation of policy and administration', Paper presented at IRSPM conference, 25-27 March 2008, Brisbane Australia.

Thoenes, P. (1962) De elite in de verzorgingsstaat: sociologische proeve van een terugkeer naar Domineesland, Leiden: Stenfert Kroese.

Thomassen, J.J.A. (1995) 'Support for democratic values' in H.D. Klingemann en D. Fuchs, Citizens and the state, Oxford: Oxford University Press.

Thomassen, J.J.A. (2007) 'Democratic values' in R.J. Dalton en H. Klingemann, The Oxford handbook of political behavior, Oxford: Oxford University Press.

Thrift, N. (1996) 'New urban eras and old technological fears; Reconfiguring the goodwill of electronic age', Urban Studies 33, 8: 1463-1494.

Tiemeijer W.L. (2006) Het geheim van de burger: over staat en opinieonderzoek, Amsterdam: Aksant. 
Tiemeijer, W.L. (2008) Wat 93,7 procent van de Nederlanders moet weten over opiniepeilingen, Amsterdam: Aksant.

Tiemeijer, W.L. (2009) Vertrouwen in de regering, presentatie op het NPSO-symposium 'Het gebruik van vragenlijsten in survey-onderzoek', 27 mei 2009, Amsterdam.

Tjeenk Willink, H.D (1980) Regeren in een dubbelrol, Den Haag: Staatsuitgeverij (achtergrondstudie nr 1 bij het derde rapport van de Commissie Hoofdstructuur Rijksdienst).

Torenvliet, R. et al. ( 2005) 'Van Poldermodel naar Lobbymodel?', Themanummer Beleid en Maatschappij 32, 4: 167-172.

Trappenburg, M. (2006) De ethiek van de publieke sector, dr. J.M. den Uyl-lezing, 18 dec. 2006.

Turpijn, J. (2008) Mannen van gezag: de uitvinding van de Tweede Kamer, 1848-1888, Amsterdam: Wereldbibliotheek.

Uitterhoeve, W. et al. (red.) (1990) De staat van Nederland: Nederland en zijn bewoners. De opmerkelijke feiten en hun samenhang, Nijmegen: SUN.

Ulbig, S.G. (2008) 'Voice is not enough', Public Opinion Quarterly 72, 3: 523-539.

Urban Unlimited (2005) Almanak Stedenbaan, Rotterdam/Den Haag: Provincie ZuidHolland.

Urban Unlimited (2007) Wonen rond knooppunten, Rotterdam: Stadsregio Rotterdam. Urry, J. (2003) Global complexity, Cambridge: Polity.

Vanke, J.W. (2001) 'An impossible union. Dutch objections to the Fouchet Plan, 1959-62', Cold War History 2, 1: 95-112.

Veen, M. van der (2006) 'Liever oog om oog', NRC Handelsblad, 24 januari.

Veen, M. van der (2007) 'Stop de passieve consumentensamenleving. Op naar de scheppende producentenmaatschappij', NRC Handelsblad, 27 januari.

Veen, M. van der (2009) Contracting for better places: a relational analysis of development agreements in urban development projects, Amsterdam: IOs Press.

Velde, H. te, N. Aarts en C. van Woerkom (2002) 'Dealing with ambivilence: farmers' and consumers' perceptions of animal welfare in lifestock breeding', Journal of Agricultural and Environmental Ethics 15: 203-219.

Velde, H. te (1999) 'Van grondwet tot grondwet: oefenen met parlement, partij en schaalvergroting, 1848-1917' in R. Aerts, H. de Liagre Böhl, P. de Rooy en H. te Velde (1999) op. cit.

Velde, H. te (2010) Van Regentenmentaliteit tot populisme, Amsterdam: Bert Bakker.

Verbeet, G. (2009) Parlementaire zelfreflectie 2007-2009; Vertrouwen en zelfuertrouwen, Den Haag: Tweede Kamer der Staten-Generaal.

Verburg, T. et al. (2005) Leef- en mobiliteitsstijlen Stedenbaan: Een onderzoek in opdracht van Urban Unlimited. Utrecht: Universiteit Utrecht.

Verhoeven, I. (2009) Burgers tegen beleid. Een analyse van dynamiek in politieke betrokkenheid, Amsterdam: Aksant.

Vettehen, P., K. Nuijten et al. (2005) 'News in an age of competition: The case of sensationalism in Dutch television news, 1995-2001' Journal of Broadcasting $\&$ Electronic Media 49, 3: 282-295. 
Vincent-Jones, P. (2006) The new public contracting: regulation, responsibility, relationality, Oxford: Oxford University Press.

Vliegenthart, R. (2007) Framing immigration and integration. Facts, parliament, media and anti-immigrant party support in the Netherlands, proefschrift, Amsterdam: Vrije Universiteit.

Voerman, G. en W.H. van Schuur, (2009) De Nederlandse politieke partijen en hun leden (1945-2009), bijdrage aan de Democratic audit in Nederland. Conferentie te Berg en Dal, 27 mei 2009.

Voormolen, S. (2009) 'Knipoog naar geitewollensokkendrager; duurzaam moet concurrentie het nakijken geven. "Duurzame" consument moet omzet en winst van Albert Heijn vergroten', NRC Handelsblad, 18 december.

Vos, H. (2008) De impact van de Europese Unie: beleidsterreinen, strijdpunten en uitdagingen, Leuven: Acco.

Vossen, K. (2003) Vrij vissen in het Vondelpark. Kleine politieke partijen in Nederland 19181940, Amsterdam: Wereldbibliotheek.

Vree, F. van, C. Vos, H. Wijfjes en J. Bardoel (2003) 'Het ontstaan van een politiek-publicitair complex 1960-2002', blz. 67-98 in RMO, Medialogica. Over het krachtenveld tussen burgers, media en politiek, Den Haag, Sdu Uitgevers.

Vreese, C.H. de (2008) ‘The Netherlands: Media logic and floating voters?’, blz. 145-159 in J. Strömbäck en L. Lee Kaid (red.) The handbook of election news coverage around the world, New York: Routledge.

Vries, J. de en K. Yesilkagit (1999) 'Core executives and party policies: Privatization in the Netherlands', West European Politics, 22, 1: 115-137.

Vugt, M. van (2009) 'Averting the tragedy of the commons; Using social psychological science to protect the environment', Current Directions in Psychological Science 18, 3: 169-173.

Wagenaar, M. (1997) De Rijksvoorlichtingsdienst: geheimhouden, toedekken en openbaren, Den Haag: Sdu Uitgevers.

Wallage, J. (2001) In dienst van de democratie: het rapport van de Commissie Toekomst Overheidscommunicatie, Den Haag: Sdu Uitgevers.

Walle, S. van de (2004) Perceptions of administrative performance: the key to trust in government, Leuven: Katholieke Universiteit Leuven.

Warren, M. (1996) 'Deliberative democracy and authority', The American Political Science Review 9o, 1: 46-6o.

Weber, M. (1919) Politik als Beruf, voordracht in het revolutiejaar 1918-1919, voor het eerst in druk verschenen in 1919, later meermalen herdrukt o.a. in: M. Weber (1988) Gesammelte Politische Schriften, Tübingen: J.C.B. Mohr.

Weinrich, H. (1987) 'System, Diskurs und die Diktatur des Sitzfleisches', Merkur 8.

Weintraub, J. (2007) 'The theory and politics of the public/private distinction', in J. Weintraub en K. Kumar (1997) Public and Private in Thought and Practice. Perspectives on a grand dichotomy, Chicago: University of Chicago Press.

Werkgroep Publieke Verantwoording (2008) Vertrouwen in verantwoording, Den Haag: ministerie van Binnenlandse Zaken en Koninkrijksrelaties. 
Werkgroep Sint (1994) Inschakeling van intern en extern personeel, begrotingsvoorbereiding 1995, deelrapport nr. 5, maart 1994. Eindrapport van de heroverwegingswerkgroep 'Inschakeling van intern en extern personeel (voorzitter: M. Sint). Den Haag: s.n.

Werts, J. (2008) The European Council, Londen: John Harper.

Wessel, M.G.J. van (2009) Ontevreden over het functioneren van de democratie; maar hoe moet het dan wel? Den Haag: ministerie van Binnenlandse Zaken en Koninkrijksrelaties.

Wessels, W. (1997) 'An ever closer fusion? A dynamic macropolitical view on integration processes', Journal of Common Market Studies 35, 2: 267-299.

Whatmore, S. (2002) Hybrid geographies: natures, cultures, spaces, Londen: Sage.

Whytock, C.A. (2005) 'Rational design theory of transgovernmentalism: The case of EU-US merger review cooperation', Boston University International Law Journal 23, 1: 2-53.

Wijfjes, H. (2004) Journalistiek in Nederland 1850-20oo. Beroep, cultuur en organisatie, Amsterdam: Boom.

Wijk, H.D. van, W. Konijnenbelt en R.M. van Male (1999) Hoofdstukken van bestuursrecht, Groningen: Wolters-Noordhoff.

Wildavsky, A. (1973) 'If planning is everything, maybe it's nothing', Policy Sciences 4: 27-53.

Wildenmann, R. en W. Kaltefleiter (1965) Funktionen der Massenmedien, Frankfurt am Main: Athenäum Verlag.

Wille, A. (2001) 'Politieke participatie en representativiteit in het interactieve beleidsproces' in J. Edelenbos en R. Monnikhof, Lokale interactieve beleids-vorming: een vergelijkend onderzoek naar de consequenties van interactieve beleidsvorming voor het functioneren van de lokale democratie, Utrecht: Lemma.

Witteveen, W.J. (200o) 'Het politieke primaat als regie van de wetgever' in W.J. Witteveen, H.R.B.M. Kummeling en F.A.M. Stroink Het primaat van de politiek: Staatsrechtconferentie 1999, Deventer: Tjeenk Willink.

Wittenveen, W.J., B. van Klink, met bijdragen van W. de Been en P. Blok (2002) De sociale rechtsstaat voorbij. Twee ontwerpen voor het huis van de rechtsstaat, Den Haag: Sdu

Wolffensperger, G. (2005) Rijksbrede Takenanalyse; 50 aanbevelingen voor communicatie met en door een Andere Overheid, Den Haag: Gemengde Commissie Communicatie.

Wolffram, D.J. (2003) Vrij van wat neerdrukt en beklemt: staat, gemeenschap en sociale politiek (1870-1918), Amsterdam: Wereldbibliotheek.

Woltjer, J.J. (1994) Recent verleden: Nederland in de twintigste eeuw, Amsterdam: Uitgeverij Muntinga.

Woud, A. van der (1987) Het Lege Land, De ruimtelijke orde van Nederland 1798-1848. Amsterdam: Uitgeverij Contact.

Woud, A. van der (2006) Een nieuwe wereld: het ontstaan van het moderne Nederland, Amsterdam: Bert Bakker.

WRR (1975) De organisatie van het openbaar bestuur. Enkele aspecten, knelpunten en voorstellen, Den Haag: Sdu Uitgevers. 
WRR (1980) Plaats en toekomst van de Nederlandse industrie, Den Haag: Staatsuitgeverij. WRR o.l.v. H. van Gunsteren (1992) Eigentijds burgerschap, Den Haag: Sdu Uitgevers. WRR (1998) Ruimtelijke Ontwikkelingspolitiek. Den Haag: Sdu Uitgevers. WRR (2000) Het borgen van publiek belang, Den Haag: Sdu Uitgevers. WRR (2002) De toekomst van de nationale rechtsstaat, Den Haag: Sdu Uitgevers. WRR (2004a) De staat van de democratie. Democratie voorbij de staat, Amsterdam:

Amsterdam University Press.

WRR (2004b) Bewijzen van goede dienstverlening, Amsterdam: Amsterdam University Press.

WRR (2006) Lerende overheid. Een pleidooi voor probleemgerichte politiek, Amsterdam: Amsterdam University Press.

WRR (2007a) Europa in Nederland, Nederland in Europa, Amsterdam: Amsterdam

University Press.

WRR (2007b) Identificatie met Nederland, Amsterdam: Amsterdam University Press.

Wynne, B. (2001) 'Creating public alienation: Expert cultures of risk and ethics on GMOs', Science as Culture 10, 4: 445-481.

Yanow, D. (1995) 'Built space as story: the policy stories that buildings tell', Policy Studies Journal 23.

Yesilkagit, K. (2004) 'Bureaucratic autonomy, organizational culture and habituation: Politicians and independent administrative bodies in the Netherlands', Administration \& Society 36, 5: 528-552.

Yesilkagit, K. (2009) 'Inspecties' blz. 117-142 in M. Bovens en T. Schillemans (red.) op. cit. Yeung, H. (2005) 'Rethinking relational economic geography', Transactions of the Institute of British Geographers, New Series 30, 1: 37-51.

Yücesoy, E. (2006) Everyday urban public space; Turkish immigrant women's perspective, Utrecht: Utrecht University Press.

Zonneveld, W. (2009) Fragmentatie en structuur; uitdaging voor ruimtelijk onderzoek en beleid, inaugurele rede uitgesproken op 21 augustus 2009, Delft: Technische Universiteit Delft.

Zoonen, L. van (2005) Entertaining the citizen: When politics and popular culture converge, Critical media studies. Lanham, MD: Rowman \& Littlefield.

Zouridis, S. (2009) De dynamiek van bestuur en recht: Over de rechtsstaat als bestuurswetenschappelijkfenomeen, Den Haag: Lemma. 


\section{RAPPORTEN AAN DE REGERING}

\section{Eerste raadsperiode (1972-1977)}

1 Europese Unie

2 Structuur van de Nederlandse economie

3 Energiebeleid

Gebundeld in één publicatie (1974)

4 Milieubeleid (1974)

5 Bevolkingsgroei (1974)

6 De organisatie van het openbaar bestuur (1975)

7 Buitenlandse invloeden op Nederland: Internationale migratie (1976)

8 Buitenlandse invloeden op Nederland: Beschikbaarheid van wetenschappelijke en technische kennis (1976)

9 Commentaar op de Discussienota Sectorraden (1976)

10 Commentaar op de nota Contouren van een toekomstig onderwijsbestel (1976)

11 Overzicht externe adviesorganen van de centrale overheid (1976)

12 Externe adviesorganen van de centrale overheid (1976)

13 Maken wij er werk van? Verkenningen omtrent de verhouding tussen actieven en niet-actieven (1977)

14 Interne adviesorganen van de centrale overheid (1977)

15 De komende vijfentwintig jaar - Een toekomstverkenning voor Nederland (1977)

16 Over sociale ongelijkheid - Een beleidsgerichte probleemverkenning (1977)

\section{Tweede raadsperiode (1978-1982)}

17 Etnische minderheden (1979)

A. Rapport aan de Regering

B. Naar een algemeen etnisch minderhedenbeleid?

18 Plaats en toekomst van de Nederlandse industrie (1980)

19 Beleidsgerichte toekomstverkenning

Deel 1: Een poging tot uitlokking (1980)

20 Democratie en geweld. Probleemanalyse naar aanleiding van de gebeurtenissen in Amsterdam op 30 april 1980

21 Vernieuwingen in het arbeidsbestel (1981)

22 Herwaardering van welzijnsbeleid (1982)

23 Onder invloed van Duitsland. Een onderzoek naar gevoeligheid en kwetsbaarheid in de betrekkingen tussen Nederland en de Bondsrepubliek (1982)

24 Samenhangend mediabeleid (1982)

\section{Derde raadsperiode (1983-1987)}

25 Beleidsgerichte toekomstverkenning Deel 2: Een verruiming van perspectief (1983)

26 Waarborgen voor zekerheid. Een nieuw stelsel van sociale zekerheid in hoofdlijnen (1985)

27 Basisvorming in het onderwijs (1986)

28 De onvoltooide Europese integratie (1986)

29 Ruimte voor groei. Kansen en bedreigingen voor de Nederlandse economie in de komende tien jaar (1987)

30 Op maat van het midden- en kleinbedrijf (1987) 
Deel 1: Rapport aan de Regering

Deel 2: Pre-adviezen

31 Cultuur zonder grenzen (1987)

32 De financiering van de Europese Gemeenschap. Een interimrapport (1987)

33 Activerend arbeidsmarktbeleid (1987)

34 Overheid en toekomstonderzoek. Een inventarisatie (1988)

\section{Vierde raadsperiode (1988-1992)}

35 Rechtshandhaving (1988)

36 Allochtonenbeleid (1989)

37 Van de stad en de rand (1990)

38 Een werkend perspectief. Arbeidsparticipatie in de jaren '90 (1990)

39 Technologie en overheid (1990)

40 De onderwijsverzorging in de toekomst (1991)

41 Milieubeleid. Strategie, instrumenten en handhaafbaarheid (1992)

42 Grond voor keuzen. Vier perspectieven voor de landelijke gebieden in de Europese Gemeenschap (1992)

43 Ouderen voor ouderen. Demografische ontwikkelingen en beleid (1993)

\section{Vijfde raadsperiode (1993-1997)}

45 Belang en beleid. Naar een verantwoorde uitvoering van de werknemersverzekeringen (1994)

46 Besluiten over grote projecten (1994)

47 Hoger onderwijs in fasen (1995)

48 Stabiliteit en veiligheid in Europa. Het veranderende krachtenveld voor het buitenlands beleid (1995)

49 Orde in het binnenlands bestuur (1995)

50 Tweedeling in perspectief (1996)

51 Van verdelen naar verdienen. Afwegingen voor de sociale zekerheid in de 21e eeuw (1997)

52 Volksgezondheidszorg (1997)

53 Ruimtelijke-ontwikkelingspolitiek (1998)

54 Staat zonder land. Een verkenning van bestuurlijke gevolgen van informatie- en communicatietechnologie (1998)

\section{Zesde raadsperiode (1998-2002)}

55 Generatiebewust beleid (1999)

56 Het borgen van publiek belang (2000)

57 Doorgroei van arbeidsparticipatie (2000)

58 Ontwikkelingsbeleid en goed bestuur (2001)

59 Naar een Europabrede Unie (2001)

60 Nederland als immigratiesamenleving (2001)

61 Van oude en nieuwe kennis. De gevolgen van ICT voor het kennisbeleid (2002)

62 Duurzame ontwikkeling. Bestuurlijke voorwaarden voor een mobiliserend beleid (2002)

63 De toekomst van de nationale rechtsstaat (2002)

64 Beslissen over biotechnologie (2003)

65 Slagvaardigheid in de Europabrede Unie (2003) 
66 Nederland handelsland. Het perspectief van de transactiekosten (2003)

67 Naar nieuwe wegen in het milieubeleid (2003)

\section{Zevende raadsperiode (2003-2007)}

68 Waarden, normen en de last van het gedrag (2003)

69 De Europese Unie, Turkije en de islam (2004)

70 Bewijzen van goede dienstverlening (2004)

71 Focus op functies. Uitdagingen voor een toekomstbestendig mediabeleid (2005)

72 Vertrouwen in de buurt (2005)

73 Dynamiek in islamitisch activisme. Aanknopingspunten voor democratisering en mensenrechten (2006)

74 Klimaatstrategie - tussen ambitie en realisme (2006)

75 Lerende overheid. Een pleidooi voor probleemgerichte politiek (2006)

76 De verzorgingsstaat herwogen. Over verzorgen, verzekeren, verheffen en verbinden (2006)

77 Investeren in werkzekerheid (2007)

78 Europa in Nederland (2007)

79 Identificatie met Nederland (2007)

80 Innovatie vernieuwd. Opening in viervoud (2008)

81 Infrastructures. Time to Invest (2008)

\section{Achtste raadsperiode (2008-2012)}

82 Onzekere veiligheid. Verantwoordelijkheden rond fysieke veiligheid (2008)

83 Vertrouwen in de school. Over de uitval van 'overbelaste' jongeren (2009)

84 Minder pretentie, meer ambitie. Ontwikkelingshulp die verschil maakt (2009)

Rapporten aan de Regering nrs. $1 \mathrm{t} / \mathrm{m} 67$ en publicaties in de reeks Voorstudies en achtergronden zijn niet meer leverbaar. Alle studies van de WRR zijn beschikbaar via de website www.wrr.nl.

Rapporten aan de Regering nrs. 68 t/m 84 zijn verkrijgbaar in de boekhandel of via Amsterdam University Press, Herengracht 221, 1016 BG Amsterdam (www.aup.nl). 


\section{VERKENNINGEN}

\section{Zevende raadsperiode (2003-2007)}

1 J. Pelkmans, M. Sie Dhian Ho en B. Limonard (red.) (2003) Nederland en de Europese grondwet

2 P.T. de Beer en C.J.M. Schuyt (red.) (2004) Bijdragen aan waarden en normen

3 G. van den Brink (2004) Schets van een beschavingsoffensief. Over normen, normaliteit en normalisatie in Nederland

4 E.R. Engelen en M. Sie Dhian Ho (red.) (2004) De staat van de democratie. Democratie voorbij de staat

5 P.A. van der Duin, C.A. Hazeu, P. Rademaker en I.J. Schoonenboom (red.) (2004) Vijfentwintig jaar later. De Toekomstverkenning van de WRR uit 1977 als leerproces

6 H. Dijstelbloem, P.L. Meurs en E.K. Schrijvers (red.) (2004) Maatschappelijke dienstverlening. Een onderzoek naar vijf sectoren

7 W.B.H.J. van de Donk, D.W.J. Broeders en F.J.P. Hoefnagel (red.) (2005) Trends in het medialandschap. Vier verkenningen

8 G. Engbersen, E. Snel en A. Weltevrede (2005) Sociale herovering in Amsterdam en Rotterdam. Eén verhaal over twee wijken

9 D.J. Wolfson (2005) Transactie als bestuurlijke vernieuwing. Op zoek naar samenhang in beleid en uitvoering

10 Nasr Abu Zayd (2006) Reformation of Islamic Thought. A Critical Historical Analysis

11 J.M. Otto (2006) Sharia en nationaal recht. Rechtssystemen in moslimlanden tusssen traditie, politiek en rechtsstaat

12 P.L. Meurs, E.K. Schrijvers en G.H. de Vries (red.) (2006) Leren van de praktijk. Gebruik van lokale kennis en ervaring voor beleid

13 W.B.H.J. van de Donk, A.P. Jonkers en G.J. Kronjee (red.) (2006) Geloven in het publieke domein. Verkenningen van een dubbele transformatie

14 D. Scheele, J.J.M. Theeuwes, G.J.M. de Vries (red.) (2007) Arbeidsflexibiliteit en ontslagrecht

15 P.A.H. van Lieshout, M.S.S. van der Meij en J.C.I. de Pree (red.) (2007) Bouwstenen voor betrokken jeugdbeleid

16 J.J.C. Voorhoeve (2007) From War to the Rule of Law. Peace Building after Violent Conflicts

17 M. Grever en K. Ribbens (2007) Nationale identiteit en meervoudig verleden

18 B. Nooteboom and E. Stam (eds.) (2008) Micro-foundations for Innovation Policy

19 G. Arts, W. Dicke and L. Hancher (eds.) (2008) New Perspectives on Investments in Infrastructures

\section{Achtste raadsperiode (2008-2012)}

20 D. Scheele, R. van Gaalen en J. van Rooijen (2008) Werk en inkomsten na massaontslag: de zekerheid is niet van de baan

21 Monique Kremer, Peter van Lieshout and Robert Went (eds.) (2009) Doing Good or Doing Better. Development Policies in a Globalizing World

22 W.L. Tiemeijer, C.A. Thomas en H.M. Prast (red.) (2009) De menselijke beslisser. Over de psychologie van keuze en gedrag

Alle Verkenningen zijn verkrijgbaar in de boekhandel of via Amsterdam University Press, Herengracht 221, 1016 BG Amsterdam (www.aup.nl). 


\section{WEBPUBLICATIES}

\section{Zevende raadsperiode (2003-2007)}

WP 01

WP 02

WP 03

WP 04

WP 05

WP 06

WP 07

WP 08

WP 09

WP 10

WP 11

WP 13 Sharia en nationaal recht in twaalf moslimlanden

WP 14

WP 16 Europe in law, law in Europe

WP 17 Faces of Europe: Searching for leadership in a new political style

WP 18 The psychology and economics of attitudes in the Netherlands

WP 19 Citizens and the legitimacy of the European Union

WP 20 No news is bad news! The role of the media and news framing in embedding Europe

WP 21 Actor paper subnational governments: Their role in bridging the gap between the EU and its citizens

WP 22 The Dutch third sector and the European Union: Connecting citizens to Brussels

WP 23 Europe in parliament: Towards targeted politicization

WP 24 Europe in the Netherlands: Political parties

WP 25 The EU Constitutional Treaty in the Netherlands: Could a better embedding have made a difference?

WP 26 How to solve the riddle of belated Euro contestation in the Netherlands?

WP 27 Connection, consumer, citizen: Liberalising the European Union gas market

WP 28 Dutch EU-policies with regard to legal migration - The directive on family reunification

WP 29 The accession of Turkey to the European Union: The political decision-making process on Turkey in The Netherlands

WP 30 The Habitats Directive: A case of contested Europeanization

WP 31 Encapsulating services in the 'polder': Processing the Bolkestein Directive in Dutch Politics

WP 33 De casus Inburgering en Nationaliteitswetgeving: iconen van nationale identiteit

WP 34 In debat over Nederland

\section{Achtste raadsperiode (2008-2012)}

WP 35 Veel voorkomende criminaliteit

WP 36 Gevaarlijke stoffen 
WP 37 ICT en internet

WP 38 Voedsel en geneesmiddelen

WP 39 Waterbeheer en waterveiligheid

WP 40 Verschuivende vensters: veranderingen in het institutionele landschap van de Nederlandse ontwikkelingssamenwerking

WP 41 Internationale publieke goederen: karakteristieken en typologie

WP 42 Het Nederlandse veiligheidsbeleid in een veranderende wereld

WP 43 Internationalisering en Europeanisering van strafrechtelijke rechtshandhaving in Nederland 


\section{Het gezicht van de publieke zaak}

Het openbaar bestuur is veelvuldig inzet van debat. Zowel in de publieke meningsvorming als in de politieke discussie worden zijn taak, rol en positie nadrukkelijk tegen het licht gehouden. Dat mag geen verbazing wekken: openbaar bestuur is per definitie een publieke zaak. Hoe komt het publieke karakter in dat bestuur zelf tot uitdrukking en wie bewaakt dit? Het zijn vragen die geregeld worden gesteld, maar zelden worden beantwoord.

Europeanisering, juridisering, decentralisering, deregulering, privatisering, verzelfstandiging en bevordering van marktwerking hebben het bestuur de afgelopen decennia een ander gezicht gegeven. De vraag is hoe dat zich tot zijn 'openbare' karakter verhoudt.

Het gezicht van de publieke zaak: openbaar bestuur onder ogen bevat bijdragen van verschillende auteurs, onder wie Luuk van Middelaar, Maarten Hajer, Philip van Praag en Luuk Boelens. Ze gaan in op actuele vraagstukken rond bestuurlijke versnippering, de verhouding tot Europa, gezag, de media en verantwoording. Tezamen biedt dit een gevarieerde beschouwing van de problemen en de uitdagingen van het hedendaagse bestuur en een perspectief op zijn publieke karakter.

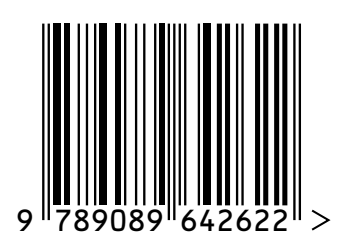

ISBN 9789089642622 